\title{
SUMÁRIO
}

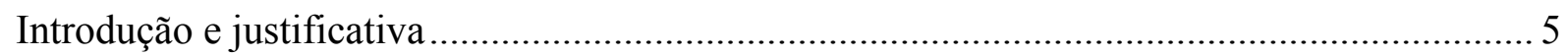

Capítulo 1 - Ciclos eleitorais e partidários nos municípios brasileiros .................................. 8

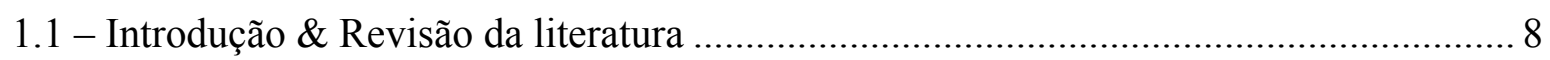

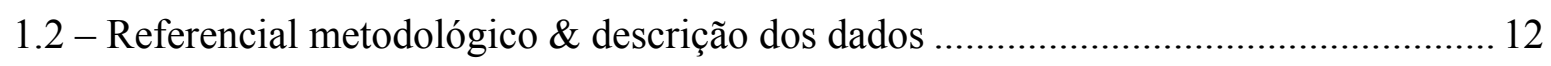

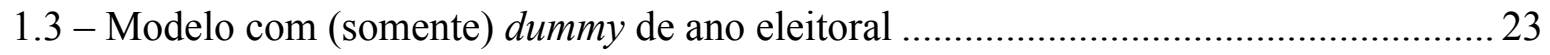

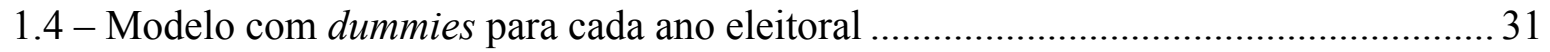

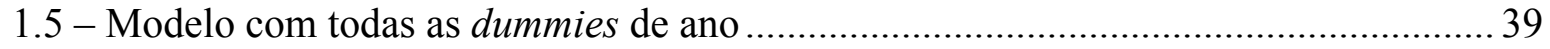

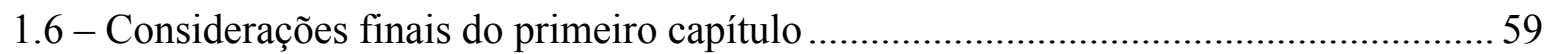

Capítulo 2 - Reeleição nos municípios brasileiros ................................................................ 63

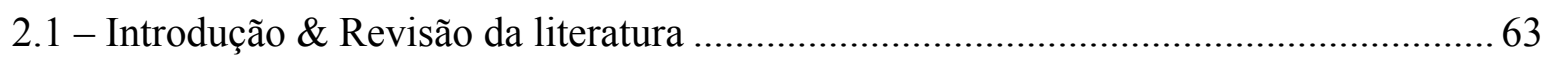

2.2 - Referencial metodológico \& descrição dos dados .................................................... 69

2.3 - Despesa total (despesa orçamentária total dos quatro anos de governo) .................... 72

2.4 - Despesa do ano eleitoral \& despesa média dos anos não eleitorais ........................... 77

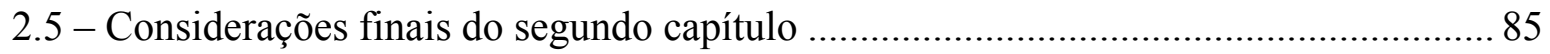

Capitulo 3 - Déficit e ajuste fiscal nos municípios paulistas ................................................. 88

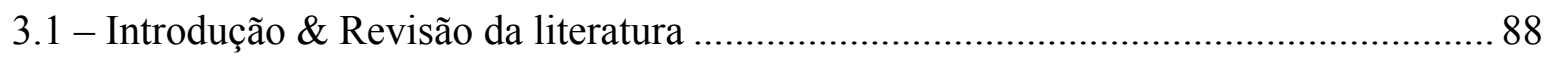

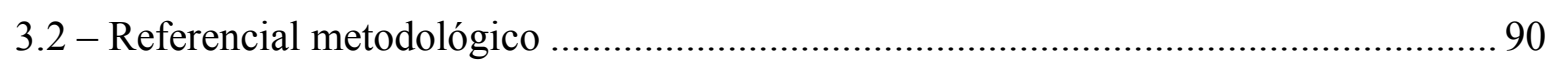

3.3 - Descrevendo o procedimento de Wooldridge (1995) ................................................ 93

3.31 - Procedimento do teste de viés de seleção.............................................................. 98

3.32 - Procedimento de correção do viés de seleção ....................................................... 99

3.4 - Descrição dos dados, modelo estimado e resultados obtidos ..................................... 103

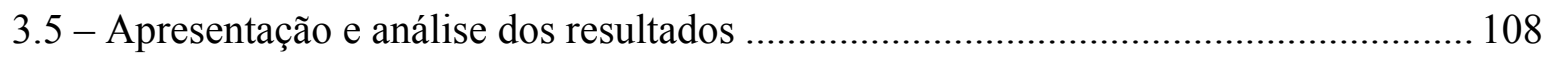

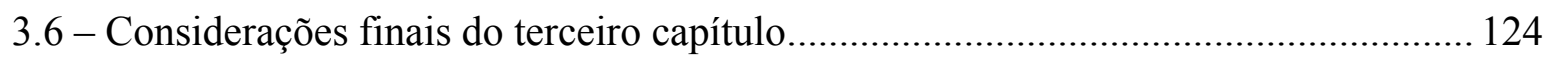

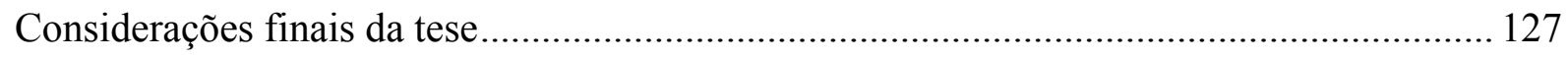

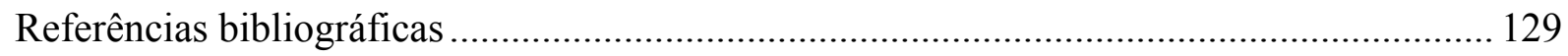

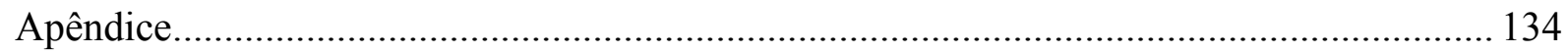

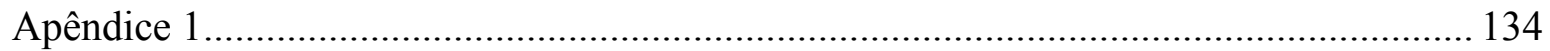

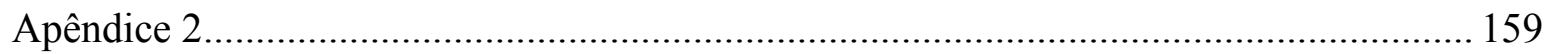

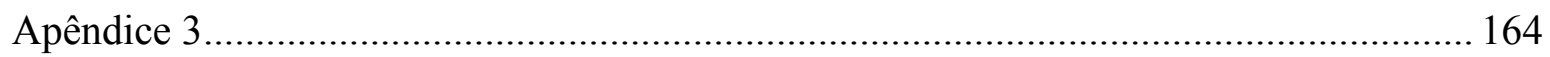




\section{ÍNDICE DE TABELAS}

Tabela 1.1 - Municípios presentes na amostra, por ano e por unidade da federação...............18

Tabela 1.2 - Freqüência dos partidos políticos na amostra...................................................18

Tabela 1.3 - Despesa orçamentária - efeitos fixos.............................................................24

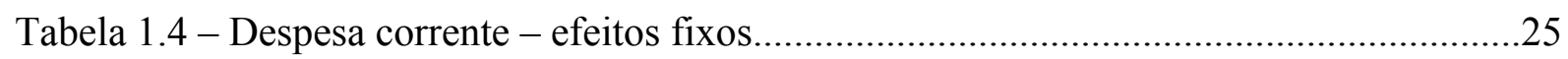

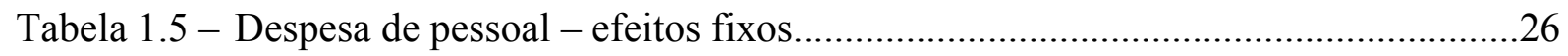

Tabela 1.6 - Transferências correntes - efeitos fixos..........................................................27

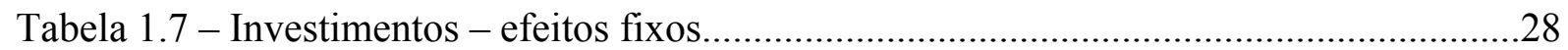

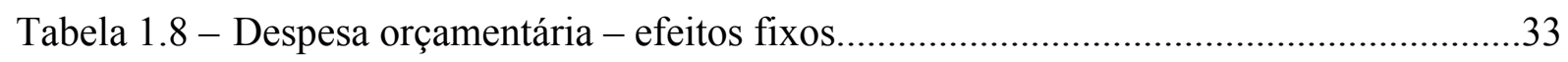

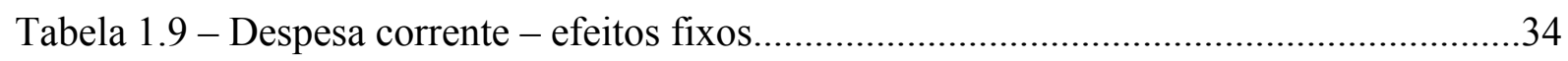

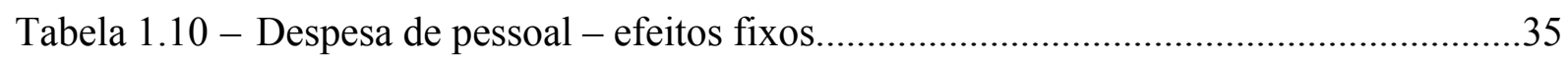

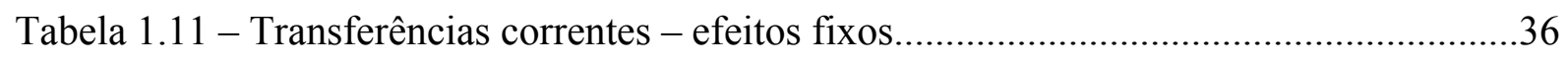

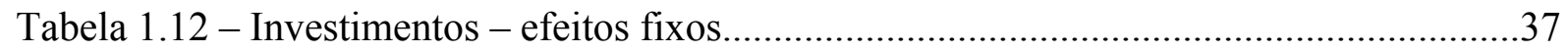

Tabela 1.13 - Despesa orçamentária - efeitos fixos.............................................................. 40

Tabela 1.14 - Despesa corrente - efeitos fixos.....................................................................44

Tabela 1.15 - Despesa de pessoal - efeitos fixos.............................................................. 48

Tabela 1.16 - Transferências correntes - efeitos fixos...........................................................52

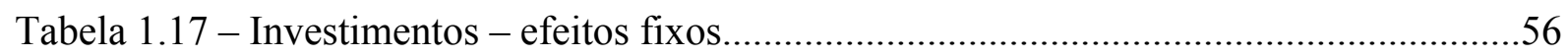

Tabela 2.1 - Probabilidade de reeleição em função da despesa total (total dos quatro anos)

- modelo logit - efeitos fixos......

Tabela 2.2 - Probabilidade de reeleição em função da despesa do ano eleitoral e da média dos três anos anteriores à eleição - modelo logit - efeitos fixos

Tabela 3.1 - Categorias de solvência - Lei Complementar nº 089/97 do Ministério

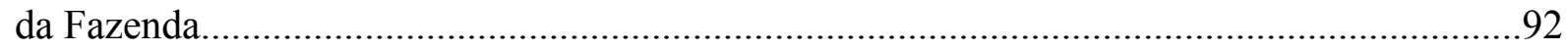

Tabela 3.2 - Distribuição dos municípios, conforme resultado primário...............................104

Tabela 3.3 - Freqüência dos partidos políticos na amostra (em \%)....................................107

Tabela 3.4 - Regressões do resultado primário - efeitos fixos..............................................108

Tabela 3.5 - Viés de seleção em OLS .................................................................................111

Tabela 3.6 - Equação do teste do viés de seleção.................................................................114

Tabela 3.7 - Resultados das equações de seleção (1989 a 2001) - I $^{\mathrm{o}}$ estágio.........................116

Tabela 3.8 - Resultado da equação do superávit primário - II ${ }^{\mathbf{0}}$ estágio................................118

Tabela 3.9 - Resultado da equação do déficit primário - II $^{\mathrm{o}}$ estágio....................................123 


\section{ÍNDICE DE FIGURAS}

Organograma 1 - Organização dos componentes da despesa municipal.

Gráfico 1.1 - Despesa orçamentária per capita.

Gráfico 1.2 - Despesa corrente per capita.

Gráfico 1.3 - Despesa de pessoal per capita.. 20

Gráfico 1.4 - Transferências correntes per capita. .20

Gráfico 1.5 - Despesa de investimento per capita... 21

Gráfico 1.6 - Receita tributária per capita. 21

Gráfico 1.7 - Receita de transferências correntes per capita..... 21

Gráfico 1.8 - Despesa orçamentária - dummies de ano - painel não balanceado.

Gráfico 1.9 - Despesa orçamentária - dummies de ano - painel balanceado.

Gráfico 1.10 - Despesa orçamentária - dummies de partido - painel não balanceado.

Gráfico 1.11 - Despesa orçamentária - dummies de partido - painel balanceado. 41

Gráfico 1.12 - Despesa corrente - dummies de ano - painel não balanceado. 45

Gráfico 1.13 - Despesa corrente - dummies de ano - painel balanceado. 45

Gráfico 1.14 - Despesa corrente - dummies de partido - painel não balanceado. . .45

Gráfico 1.15 - Despesa corrente - dummies de partido - painel balanceado.

Gráfico 1.16 - Despesa de pessoal - dummies de ano - painel não balanceado. .49

Gráfico 1.17 - Despesa de pessoal - dummies de ano - painel balanceado.

Gráfico 1.18 - Despesa de pessoal - dummies de partido - painel não balanceado.

Gráfico 1.19 - Despesa de pessoal - dummies de partido - painel balanceado. . .49

Gráfico 1.20 - Transferências correntes-dummies de ano - painel não balanceado. .53

Gráfico 1.21 - Transferências correntes-dummies de ano - painel balanceado. . .53

Gráfico 1.22 - Transferências correntes-dummies de partido - painel não balanceado..........53

Gráfico 1.23 - Transferências correntes-dummies de partido - painel balanceado.................53

Gráfico 1.24 - Investimentos - dummies de ano - painel não balanceado..............................57

Gráfico 1.25 - Investimentos - dummies de ano - painel balanceado.....................................57

Gráfico 1.26 - Investimentos - dummies de partido - painel não balanceado..........................57

Gráfico 1.27 - Investimentos - dummies de partido - painel balanceado.

Gráfico 2.1 - Prefeituras administradas pelos partidos políticos, por período de governo (em \%). 
Gráfico 2.2 - Taxa de reeleição dos partidos políticos, por ano eleitoral (em \%)....................71

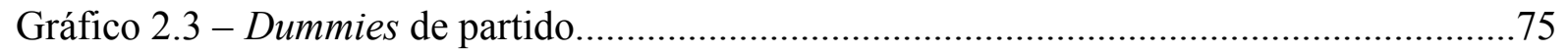

Gráfico 2.4 - Interações entre dummies de partido \& despesa total.......................................75

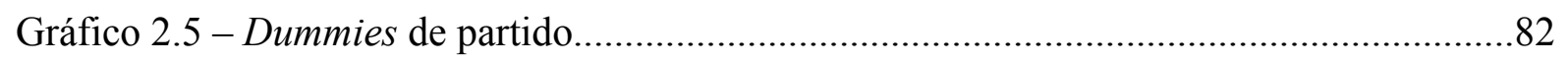

Gráfico 2.6 - Interações entre dummies de partido \& despesa do ano eleitoral.......................82

Gráfico 2.7 - Interações entre dummies de partido \& despesa média dos anos não

eleitorais.

Gráfico 3.1 - Distribuição dos municípios, conforme resultado primário (em \%).................104

Gráfico 3.2 - Dummies de partido - superávit fiscal.........................................................120

Gráfico 3.3 - Razões de Mills invertidas - superávit fiscal...............................................120

Gráfico 3.4 - Dummies de partido - déficit fiscal............................................................ 124

Gráfico 3.5 - Razões de Mills invertidas - déficit fiscal.....................................................124 


\section{Introdução e justificativa}

A percepção de que o comportamento da economia influencia e é influenciado pelo comportamento dos agentes políticos é bastante difundida e, de fato, evidências que corroboram tal hipótese não raramente são observadas. Tufte (1978) pode ser considerado um dos primeiros estudos em que tal relação é analisada de maneira mais formal e criteriosa, embora esta seja apenas uma das várias referências que procuram argumentar sobre a relevância desta interação.

Muitos dos modelos macroeconômicos básicos consideram a hipótese de que policymakers benevolentes visam prioritariamente obter o melhor resultado para a sociedade e certos modelos e instrumentos de política econômica são derivados tomando implicitamente esta característica. Entretanto, quando estes policymakers têm outros objetivos em mente, existe uma probabilidade potencial de que suas decisões possam não ser as ideais do ponto de vista das preferências da coletividade e levando em consideração a existência de dois grupos de indivíduos, quais sejam, eleitores e políticos, é razoável considerar que tanto a divergência de interesses entre grupos como intra-grupos pode alterar o processo de decisão política e por conseqüência gerar uma potencial ineficiência ou distorção alocativa dos recursos públicos.

Neste contexto, a análise do comportamento fiscal ${ }^{1}$ dos municípios brasileiros torna-se especialmente relevante, tanto pela importância que estas instâncias do poder político desempenham no bem-estar dos indivíduos como pela relativa ausência, na literatura brasileira, de estudos que promovam a análise da interação entre elementos de ordem econômica e elementos de ordem política em tais localidades.

Explicitamente, um primeiro elemento que demonstra a relevância da análise dos municípios está no fato de que, dada a maior proximidade dos indivíduos em relação a estas esferas do poder político (comparativamente ao governo estadual e federal) é razoável considerar a hipótese de que a demanda da sociedade por recursos públicos recaia principalmente sobre administração municipal, uma vez que é nos municípios que os indivíduos vivem seu dia-a-dia e portanto, desejam melhorar sua qualidade de vida.

Este argumento é notadamente relevante dado que a Constituição de 1988 efetivamente alterou a posição dos municípios brasileiros dentro do arranjo federativo, ao fazer com que a provisão de um conjunto relevante de serviços públicos passasse a ser feita

\footnotetext{
${ }^{1}$ Como bem aponta Drazen (2002), a importância das políticas fiscais neste contexto político se faz presente dado que as mesmas sempre geram resultados econômicos de ordem real, descartando assim qualquer discussão a respeito da efetividade da política monetária como forma de alterar o comportamento das variáveis reais da economia.
} 
pela administração municipal - fenômeno comumente denominado como descentralização dos serviços públicos. É também a partir desta data que o número de municípios brasileiros sofre um aumento significativo em praticamente todas as regiões do país, o que significa um número mais elevado de prefeituras e câmaras legislativas distribuídas ao longo do Brasil. Complementarmente, a análise dos municípios torna-se mais importante ainda caso seja considerada a idéia de que políticas de caráter nacional ou macroeconômico têm pouco impacto na avaliação que os indivíduos realizam a respeito dos governantes das esferas menos agregadas do poder político [Cossio (2001)], pois em regimes descentralizados do poder político (que vem a ser o caso brasileiro), a maior parte dos bens públicos é ofertada justamente pelos estados e municípios.

Por fim, uma justificativa adicional para o estudo dos municípios reside na percepção de que, particularmente no caso dos policymakers, é razoável considerar também que seu sucesso e ascensão no cenário político muitas vezes estão condicionados ao sucesso que estes obtêm na administração de instâncias menos agregadas do poder político. Deste modo, se tais percepções são realistas e condizentes, a probabilidade de que o comportamento destes níveis menos agregados do poder político esteja relacionado a fatores de natureza política tende a ser não desprezível.

Tendo tais elementos em mente, o objetivo geral desta tese é procurar analisar algumas características da interação entre variáveis de natureza fiscal e variáveis de natureza política e os resultados advindos a partir deste fenômeno no caso dos municípios brasileiros. O estudo está dividido basicamente em três capítulos, todos de natureza empírica, e que podem ser resumidos de acordo com a descrição que se segue.

O primeiro capítulo procura analisar qual o comportamento das finanças públicas dos municípios brasileiros frente ao calendário eleitoral e frente às diferenças partidárias dos prefeitos municipais. A realização desta análise pode ser vista como um exercício introdutório básico a respeito da teoria dos ciclos políticos de forma geral, e consiste em uma extensão natural do trabalho de Sakurai (2004), aludindo aos conceitos tradicionais dos ciclos oportunistas e ciclos partidários, agora aplicados à totalidade dos municípios brasileiros. Assim, a intenção é procurar verificar se em anos eleitorais existem evidências de maiores execuções fiscais (tanto em termos do orçamento agregado como em categorias específicas do mesmo - investimentos municipais, por exemplo) e se a postura política (partidária) do Executivo municipal apresenta influência sobre a composição dos gastos municipais.

O segundo capítulo representa uma extensão natural da análise realizada no primeiro capítulo e parte do pressuposto de que um eventual comportamento distinto das despesas 
municipais em anos eleitorais teria como fundamento, influenciar a avaliação recebida pela classe política por parte dos eleitores. Assim, no caso da validade desta percepção, deveria haver alguma relação entre o comportamento das despesas municipais - variável em alguma medida sujeita ao controle dos políticos - e o desempenho eleitoral dos partidos políticos, ou mais especificamente, sobre a reeleição do prefeito municipal ou de algum candidato de seu partido, uma vez que o primeiro seria um dos instrumentos disponíveis para influenciar o desempenho do segundo. Este argumento é a motivação básica para o estudo realizado, que procura estimar o impacto da despesa orçamentária municipal sobre a reeleição dos prefeitos brasileiros nas eleições de 1992, 1996 e 2000, levando explicitamente em consideração a existência dos diferentes partidos políticos e a influência desta diferenciação sobre o fenômeno de interesse.

O terceiro capítulo pode ser visto como um estudo particular, ao realizar uma análise relativamente distinta dos dois anteriores e procurar avaliar se (e quais) fatores políticos podem influenciar a obtenção de superávits ou déficits fiscais, bem como o montante dos mesmos. Em termos mais específicos, tal capítulo tem como motivação a questão do "viés de seleção", mas agora considerando um conjunto de informações em formato de panel data. Mensurar a magnitude do superávit (ou do déficit) fiscal com base em uma amostra que contemple somente aqueles municípios que resolveram fazê-lo pode não ser visto como um procedimento adequado, uma vez que fatores não observáveis dos municípios podem afetar tanto a decisão de se realizar ajustes orçamentários, como a sua magnitude. Assim, o objetivo é estimar a probabilidade de um município realizar o ajuste (ou desajuste) fiscal e, em optando por fazê-lo, verificar qual seria o montante financeiro deste ajuste, tendo em mente agora a existência de efeitos não observáveis (efeitos fixos) intrínsecos a cada unidade contemplada. Ressalta-se que este tal estudo contempla apenas os municípios paulistas, por motivos a serem posteriormente expostos no respectivo capítulo.

Em cada um dos capítulos, é apresentada uma breve revisão da literatura específica para cada caso, bem como a descrição dos dados e dos métodos empregados. Embora cada um dos capítulos supracitados tenha propósitos distintos, todos utilizam técnicas econométricas para dados em painel, uma vez que a amostra avaliada contempla informações tanto seccionais (municípios) como temporais (anos). Cada capítulo também contempla discussões a respeito dos resultados obtidos em cada um dos mesmos e, ao final da tese, também é apresentada uma conclusão geral, na qual se discute de forma geral todos os resultados obtidos. 


\section{Capítulo 1 - Ciclos eleitorais e partidários nos municípios brasileiros}

\section{1 - Introdução \& Revisão da literatura}

Definindo genericamente como ciclos políticos a possibilidade de fatores políticos (num sentido amplo) afetarem o comportamento das variáveis econômicas, a literatura pode ser dividida em basicamente duas partes. A escola de análise relacionada à existência de incentivos oportunistas pode ser caracterizada basicamente por considerar o pressuposto de que policymakers, independentemente de ideologia partidária, visam implícita e fundamentalmente manter-se no poder. Assim sendo, os denominados ciclos eleitorais podem ser vistos como sendo resultados de ações promovidas pelo governante com vistas a obter uma maior probabilidade de permanência no poder. Esta corrente analítica pode ser dividida em duas abordagens, uma considerando eleitores "irracionais" [expectativas adaptativas Nordhaus (1975)] e outra considerando indivíduos racionais [Rogoff \& Sibert (1988) e Rogoff (1990)], mas ambas procurando justificar a existência de ciclos econômicos em função do calendário eleitoral. De acordo com Nordhaus (1975), em um ambiente em que os demais agentes econômicos formam suas expectativas de forma adaptativa, políticos conseguem determinar um determinado padrão cíclico no comportamento da economia em função do calendário eleitoral, ao passo que Rogoff \& Sibert (1988) e Rogoff (1990) consideram que a existência dos ciclos econômicos como função do calendário eleitoral é determinada não pela "irracionalidade" dos agentes econômicos, mas fundamentalmente pela questão da assimetria de informações entre policymakers e eleitores, ou seja, os eleitores são influenciados pelos políticos uma vez que, ao menos momentaneamente, não possuem todas as informações disponíveis para avaliar a competência de um candidato à permanência no poder.

Paralelamente ao desenvolvimento da abordagem teórica que analisa elementos de ordem oportunista na determinação de ciclos econômicos, a segunda vertente teórica procura enfatizar as diferenças ideológicas ou, mais explicitamente, partidárias, e a possibilidade deste fator afetar o comportamento da economia. Neste caso, as referências básicas são os trabalhos de Hibbs (1977), também considerando o pressuposto de expectativas adaptativas, e Alesina (1987), no caso dos modelos pressupondo expectativas racionais. De acordo com esta abordagem, os partidos políticos apresentariam preferências diferentes em relação à conduta de suas respectivas políticas econômicas e assim, existiria um comportamento distinto da economia em função de uma consistência ideológica por parte dos partidos políticos, uma vez estando no poder. De acordo com Hibbs (1977), a simples diferenciação existente entre os 
partidos políticos seria condição suficiente para gerar os denominados ciclos partidários, enquanto que para Alesina (1987), os ciclos partidários seriam mais contundentes em situações em que os resultados eleitorais fossem mais incertos, ou seja, em que a incerteza sobre o partido a assumir o poder é maior. Conforme tal incerteza diminui ou conforme o comportamento partidário é internalizado pelos indivíduos, menores tendem a ser tais flutuações.

Em termos empíricos, as evidências sugerem resultados distintos sobre a possibilidade dos ciclos eleitorais e dos ciclos partidários. Em Berger \& Woitek (1997), por exemplo, são encontradas evidências de expansões do produto agregado nos períodos anteriores às eleições alemãs. Já em Alesina, Roubini e Cohen (1997), os resultados sugerem a ausência dos ciclos eleitorais nos países da OCDE sugerindo, por outro lado, a influência das diferenças partidárias sobre o comportamento destas economias, ou seja, os resultados corroboram apenas os ciclos partidários. Por sua vez, a literatura mais recente tem procurando analisar o comportamento fiscal através da análise de bases de dados que contemplam países de diferentes graus de desenvolvimento econômico, como ocorre em Shi \& Svensson (2002), por exemplo, que encontram evidências de deterioração fiscal em períodos pré-eleitorais, ao passo que em Persson \& Tabellini (2003) são observadas evidências de redução da carga tributária antes das eleições. Contudo, Brender \& Drazen (2003) demonstram que tal resultado é observado devido basicamente ao comportamento dos países em que o regime democrático ainda é recente uma vez que nos países com regimes democráticos mais sólidos, o fenômeno do ciclo eleitoral tende a ser inexistente.

Para o caso brasileiro, da mesma forma que na literatura internacional, as primeiras referências literárias enfatizavam a possibilidade dos ciclos políticos em variáveis de natureza macroeconômica, principalmente aquelas associadas ao nível de produção agregada (PIB e desemprego, por exemplo), ao comportamento do nível de preços (inflação) e da oferta agregada de moeda, entre outros, sendo a estimação de modelos econométricos autoregressivos o procedimento normalmente implementado. Neste caso, podem ser considerados os trabalhos de Fialho (1997) e Ogura (2002), cujos resultados corroboram a hipótese de expansão do produto agregado anteriormente à realização das eleições presidenciais, conforme teorizado pelo modelo de Nordhaus (1975). Por fim, em Bonomo \& Terra (1999), os resultados sugerem que em períodos anteriores às eleições, são observadas valorizações da moeda doméstica, ao passo que desvalorizações são normalmente observadas após as realizações das eleições. 
No que diz respeito aos estudos aplicados em níveis menos concentrados de governo, as referências da literatura brasileira são relativamente mais recentes. Um estudo que pode ser considerado relevante neste contexto é o trabalho realizado por Cossio (2001), ao promover uma análise das características do sistema político brasileiro e seus impactos no comportamento fiscal dos governos estaduais. Neste trabalho, no qual é constituído um painel para variáveis fiscais para o período que compreende os anos de 1985 a 1997, são encontradas evidências que sugerem a existência de impulsos positivos de despesa em anos eleitorais, bem como indícios de que um maior grau de participação da sociedade no processo político (mais especificamente, nas eleições) levaria a uma maior disciplina fiscal dos governadores brasileiros. Adicionalmente, são obtidas evidências de que uma maior dificuldade em formar maiorias de governo nos Legislativos de cada estado brasileiro está relacionada de forma positiva com o volume de gastos, ou seja, assembléias legislativas mais fragmentadas (em termos partidários) tendem a gerar uma maior dificuldade em realizar programas de ajuste fiscal. Neste estudo, não é encontrada nenhuma evidência de distinção fiscal devido aos partidos políticos dos governadores, ou seja, não há nenhuma caracterização mais contundente dos ciclos partidários. Finalmente, a coincidência do partido do governador e do partido do presidente da República sugere um maior ajuste fiscal observado nos estados brasileiros.

Um segundo trabalho que aborda o caso brasileiro é Sakurai (2004), no qual é analisado o comportamento fiscal dos municípios paulistas entre 1989 e 2001. Tal estudo procura avaliar se o calendário eleitoral e os diferentes partidos políticos dos prefeitos de tais unidades apresentam algum tipo de influência sobre o comportamento de cinco categorias de despesa pública, quais sejam: (i) despesa orçamentária, (ii) despesa corrente, (iii) despesa de pessoal, (iv) despesa de transferências correntes e finalmente (v) despesa de investimentos. Os resultados do estudo, obtidos através de estimações econométricas para dados em painel, sugerem que para a despesa orçamentária e para a despesa corrente são observados impulsos de gastos nos anos eleitorais de 1992 e 1996, embora tal comportamento não seja observado no caso da despesa de pessoal, transferências correntes e despesa de investimento. No que diz respeito ao teste para os partidos políticos, os resultados obtidos demonstram que (i) o PT é o partido que menos gasta em transferências correntes; (ii) as maiores despesas agregadas do PFL têm como origem seus maiores gastos em investimentos públicos; (iii) os maiores gastos agregados observados para o PTB e para o PPB / PDS têm como origem seus maiores gastos em despesas de pessoal e (iv) o PSDB também se destaca por despender maiores recursos em despesas de pessoal. Por fim, os resultados também sugerem que o alinhamento partidário 
entre os prefeitos e o governador estadual não influencia o comportamento das variáveis supracitadas dentro do período analisado.

Por fim, uma referência adicional é o trabalho de Nakaguma (2006), no qual são investigados componentes específicos do orçamento dos estados brasileiros durante o período 1986 - 2004. Em termos mais específicos, procura-se analisar também a influência do calendário eleitoral sobre o comportamento das receitas e das despesas estaduais através da utilização de painéis dinâmicos (autoregressivos).

Os resultados obtidos indicam que a receita orçamentária dos estados brasileiros sofre elevação nos anos eleitorais, sendo que a mesma também sofre influência positiva caso o governador tenha se candidatado à reeleição. Um resultado curioso diz respeito ao fato de que com a Lei de Responsabilidade Fiscal houve uma queda nas receitas de transferências correntes, nas receitas de capital, nas receitas de operação de crédito, e um aumento na receita tributária, sugerindo portanto uma recomposição do total de recursos em benefício de uma maior sustentabilidade intertemporal do orçamento público. No tocante as despesas, os resultados indicam um aumento da despesa orçamentária (via aumentos da despesa corrente e de custeio) nos anos eleitorais, sendo observada uma queda da despesa de capital no ano posterior ao ano eleitoral, sugerindo assim a existência de um ajuste fiscal pós-eleição através da redução dos investimentos públicos. Por sua vez, e de forma oposta à obtida por Meneguin \& Bugarin (2001), é observado um aumento da despesa orçamentária (também via aumentos da despesa corrente e da despesa de custeio) no caso do governador concorrer à reeleição, o que indica que a possibilidade de permanência no poder gera estímulos para manipulações fiscais. Finalmente, a Lei de Responsabilidade Fiscal provocou redução significativa da despesa de custeio dos estados brasileiros.

Os resultados de Nakaguma (2006) permitem ainda observar que partidos de esquerda apresentam efetivamente um maior grau de intervenção na economia, através tanto de uma maior arrecadação de recursos como também através de uma maior execução fiscal. Um outro resultado bastante relevante diz respeito ao fato de que a ocorrência dos ciclos eleitorais sofre redução ao longo do tempo, sugerindo assim que o aprendizado e a experiência obtida com a continuidade do processo eleitoral reduz a possibilidade de manipulações por parte dos políticos, conforme obtido em Brender \& Drazen (2005). 


\section{2 - Referencial metodológico \& descrição dos dados}

O objetivo da análise empírica a ser aqui realizada consiste em analisar o comportamento temporal da despesa agregada e de quatro categorias distintas de despesas públicas dos municípios brasileiros, tanto com base na probabilidade da existência de um comportamento distinto destas variáveis nos anos eleitorais, como também na possibilidade de um comportamento distinto em funções das diferenças partidárias. Assim, o teste procura encontrar evidências dos denominados ciclos eleitorais e ciclos partidários, conforme analisado na revisão da literatura.

Antes de realizar propriamente a descrição dos dados e do método implementado, um fator relevante a ser considerado no caso brasileiro é o caráter exógeno do calendário eleitoral. No caso brasileiro, todas as eleições (para os governos federal, estadual e municipal, tanto para o Executivo como para o Legislativo) são realizadas periodicamente em datas (anos) prédefinidas sendo, portanto, previamente conhecida pelos agentes. Esta é uma característica significativamente diferente daquela vigente nos sistemas eleitorais de países de regimes de governo parlamentaristas ${ }^{2}$, cuja data das eleições não é conhecida a priori e com plena antecedência pelos agentes. No caso do contexto brasileiro, esta característica pode permitir à classe política ajustar o timing das políticas implementadas, de modo que os resultados obtidos possam ser posteriormente vinculados a uma maior popularidade das mesmas e conseqüentemente, a uma maior probabilidade de permanência no poder. Isto é especialmente provável no caso brasileiro uma vez que (i) as eleições são normalmente realizadas somente em outubro de um dado ano eleitoral e (ii) o ano-calendário da execução fiscal coincide com o ano-calendário civil. Desta forma, existe a possibilidade de que a despesa municipal executada entre janeiro e outubro possa efetivamente influenciar as escolhas dos eleitores.

A amostra considerada inclui informações dos municípios brasileiros entre 1989 e 2003, período a respeito do qual existem informações das eleições municipais de 1988, 1992, 1996 e 2000. Assim, uma vez que a amostra contempla unidades seccionais (municípios) ao longo do tempo, as regressões utilizam os métodos de estimação econométrica para dados em painel, sendo realizadas estimações tanto para o painel não balanceado (em que, para algumas unidades seccionais, inexistem informações para alguns anos) como para o painel balanceado

\footnotetext{
${ }^{2}$ Para uma análise mais profunda deste contexto, uma referência importante é o trabalho de Ito (1989), no qual o autor analisa o comportamento da economia japonesa frente às convocações de eleições por parte do parlamento do país. A evidência apresentada neste trabalho sugere que em regimes parlamentares, a relação causal é do desempenho econômico definir a ocorrência das eleições, ou seja, em períodos de expansão econômica, o líder do governo convoca as eleições para o parlamento, uma vez que é maior a possibilidade de sucesso político. Assim, o calendário eleitoral passa a ser endógeno em relação ao comportamento da economia.
} 
(em que são consideradas somente as unidades seccionais para as quais existem informações para todos os anos abordados).

O teste realizado segue o mesmo padrão presente em Sakurai (2004), e consiste em realizar cinco estimações em que as variáveis dependentes são cada uma das cinco categorias de despesa pública consideradas (ilustradas no organograma 1), quais sejam:

1. Despesa orçamentária (despesa total do município)

2. Despesa corrente

3. Despesa de pessoal

4. Despesa com transferências correntes

5. Despesa de investimentos

\section{Organograma $1^{3}$ - Organização dos componentes da despesa municipal}

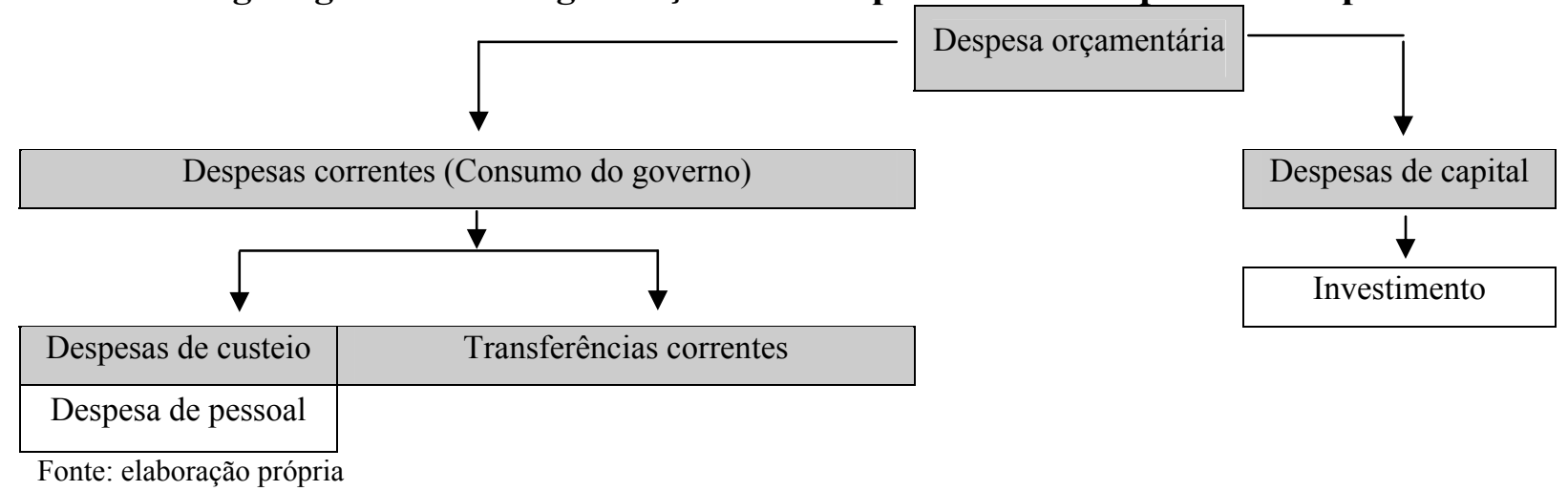

Tais categorias de despesa pública foram selecionadas uma vez que a despesa corrente seria uma medida de consumo do governo (cujo componente de maior peso financeiro são as despesas de pessoal), existindo por outro lado as despesas de capital, que incluem os gastos com investimento público, variável relevante neste estudo uma vez que a realização de obras públicas pode ser (e normalmente é) vista como uma forma de expor o desempenho dos políticos aos eleitores. Por sua vez, a despesa com transferências correntes (que podem ser entendidas como sendo dotações destinadas a terceiros sem a correspondente prestação/contrapartida de serviços ou bens) pode ser considerada de importância relevante neste contexto, pois é um dos mecanismos mais rápidos de transmissão dos recursos públicos

\footnotetext{
${ }^{3} \mathrm{O}$ orçamento municipal envolve certamente outros componentes de despesa. No organograma foram ilustrados somente os componentes utilizados neste trabalho.
} 
aos indivíduos (eleitores) e deste modo, seria um instrumento relevante de ação para o policymaker (candidatos).

Considerando os objetivos primários deste capítulo, são inseridas dummies para cada um dos quinze anos da amostra ${ }^{4}$, procedimento que permite analisar o comportamento das despesas ao longo do tempo e, portanto, avaliar a possibilidade dos ciclos políticos. Por sua vez, são inseridas dummies para cada um dos oito partidos mais freqüentes na amostra ${ }^{5,6}$, sejam eles PMDB, PFL, PSDB, PT, PTB, PDT, PDS / PPB $^{7}$ e PL. Os demais partidos da amostra são incluídos num único grupo, denominado genericamente de "outros partidos"8. Através deste procedimento, as estimações procuram identificar se diferenças partidárias causam alguma influência no comportamento das categorias de despesa a serem analisadas, em alusão ao fenômeno dos ciclos partidários.

Com respeito ao tratamento dos partidos políticos, observa-se que a opção aqui implementada é distinta daquela utilizada em outros estudos, como por exemplo, Nakaguma (2006), Bittencourt (2002) e Cossio (1998), nos quais os partidos políticos são classificados em partidos de esquerda, direita e centro. Neste sentido, os trabalhos de Kinzo (1993) e Rodrigues (2002) procuram justamente classificar os partidos políticos brasileiros conforme as três categorias mencionadas e poderiam, portanto, servir de referência para os testes desta tese. Contudo, como os dois trabalhos supracitados levam predominantemente em consideração a atuação dos deputados federais brasileiros e a composição partidária da Câmara Federal como forma de definir tal classificação, percebe-se que há uma diferença significativa em relação a esta tese, uma vez que nesta são considerados os partidos políticos dos prefeitos brasileiros. Assim, decidiu-se por aplicar uma metodologia mais flexível, na qual não é considerada nenhuma categorização prévia dos partidos políticos até mesmo como forma de prover resultados particulares sobre a atuação dos mesmos especificamente nos municípios brasileiros - sobre esta questão, eventuais contribuições à literatura podem ser providas a partir dos resultados obtidos nesta tese.

As variáveis de controle consideradas são (i) receita tributária, (ii) receita de transferências correntes (da União e dos respectivos governos estaduais), (iii) proporção de

\footnotetext{
4 Desta forma, a dummy associada ao ano de 1989 assume 1 em tal ano (0 caso contrário), e assim sucessivamente para cada um dos demais anos.

5 Assim, a dummy associada ao PMDB assume o valor 1 nos quatro anos da administração em que o prefeito é deste partido (0 caso contrário), e assim sucessivamente para cada um dos demais partidos.

${ }^{6}$ Tais freqüências são expostas na seção da descrição dos dados e do método implementado.

${ }^{7}$ A unificação dos partidos PDS e PPB em uma só dummy reflete apenas a evolução temporal do primeiro, que passou a se chamar PPB a partir de 1995 (a partir de 2003, passa a se chamar PP).

${ }^{8}$ Inclui os seguintes partidos: PC do B, PCDN, PDC, PHS, PLT, PMB, PMC, PMN, PMSD, PPR, PPS, PRN, PRONA, PRP, PRTB, PSB, PSC, PSD, PSDC, PSL, PST, PT do B, PTD, PTN, PTR, PTRB, PV.
} 
jovens e (iv) proporção de idosos residindo no município, (v) grau de urbanização e (vi) população total (em logaritmo natural) do município e finalmente, duas dummies políticas: (vii) uma dummy que assume o valor 1 caso o partido do prefeito e do governador sejam os mesmos ( 0 caso contrário) e (viii) uma dummy que assume o valor 1 caso o partido do prefeito e do presidente da República sejam os mesmos (0 caso contrário). Desta forma, subentende-se que independentemente de razões políticas, um município tende a ter um maior ou menor volume de despesa pública executada a depender de como se comportam tais variáveis. No caso das duas categorias de receitas em especial, torna-se natural considerar que o volume das despesas municipais esteja condicionado ao volume de recursos disponíveis pelos municípios, ao passo que o alinhamento político com o poder Executivo estadual e/ou com o poder Executivo federal pode eventualmente ser fator determinante sobre a administração dos recursos por parte dos prefeitos.

A decomposição da receita municipal em dois componentes procura mensurar como a despesa municipal se comporta em relação a duas fontes bastante distintas de recursos financeiros para as administrações municipais, quais sejam, a utilização de mecanismos tributários sob controle do próprio governo local e a obtenção de recursos a partir dos mecanismos de transferências a partir do governo estadual e federal. Entre outras possibilidades, é possível através deste procedimento observar um maior ou menor conservadorismo fiscal em relação a cada uma destas fontes de receita.

Especificamente para a análise dos ciclos eleitorais, três formas funcionais diferentes são estimadas. A primeira forma funcional a ser estimada, cujos resultados estão apresentados na seção 1.3, consiste em considerar explicitamente nas estimações apenas uma dummy que assume o valor 1 (um) nos anos eleitorais e zero nos demais. Neste caso, embora possa ser dito que a ênfase incide sobre a análise dos anos eleitorais, pressupõe-se que um eventual comportamento distinto nos mesmos vem a ser exatamente igual, tendo como referência a média dos demais anos (não eleitorais). Na estimação desta primeira forma funcional são consideradas também as interações entre dummies de partido e dummy de ano eleitoral, no intuito de procurar verificar como se comportam as despesas públicas em anos eleitorais em funções de eventuais diferenças partidárias.

Procurando tornar mais específica a análise dos ciclos eleitorais, a segunda forma funcional avaliada, cujos resultados são apresentados na seção 1.4, consiste em considerar explicitamente nas estimações dummies para cada um dos anos eleitorais de 1992, 1996 e 2000. Neste caso, permite-se uma análise específica para cada um destes anos, tomando novamente como referência a média dos anos não eleitorais. 
Finalmente, como último passo para o objetivo que aqui se apresenta, são apresentados na seção 1.5 os resultados de um modelo que consiste em inserir explicitamente nas estimações todas as dummies de ano (ou seja, uma dummy para cada ano da amostra) e, no sentido de verificar se nos anos eleitorais são, de fato, observadas alterações estatisticamente significantes nas despesas municipais - relativamente ao ano anterior e posterior - são apresentados os seguintes testes de hipótese ${ }^{9}$ :

$$
\begin{aligned}
& \text { dummy } 1991=\text { dummy } 1992 ; \\
& \text { dummy } 1992=\text { dummy } 1993 ; \\
& \text { dummy } 1995=\text { dummy } 1996 ; \\
& \text { dummy } 1996=\text { dummy } 1997, \\
& \text { dummy } 1999=\text { dummy } 2000 ; \\
& \text { dummy } 2000=\text { dummy } 2001 .
\end{aligned}
$$

Em se tratando do modelo mais abrangente deste capítulo, somente neste ponto é realizada de forma mais profunda a análise dos demais coeficientes obtidos através das estimações, especialmente as dummies de partido. Desta forma, considerando todos os modelos estimados, estima-se inicialmente um modelo particular, com apenas uma dummy de ano eleitoral, partindo-se progressivamente para um modelo geral, em que todas as dummies de ano são inseridas nas estimações.

Ao longo das três análises sugeridas, são apresentados os resultados associados ao estimador de efeitos fixos para dados em painel, considerados consistentes de acordo com a estatística do teste de Hausman ${ }^{10}$, enquanto que os resultados obtidos através dos métodos de efeitos aleatórios e os resultados associados à estimação para dados agrupados (pooled OLS) são apresentados no apêndice desta tese. No caso da análise dos ciclos partidários, em todas as estimações é retirada a dummy associada ao PMDB sendo, portanto, o partido de referência de todos os exames.

As análises apresentadas neste capítulo consideram informações associadas ao comportamento fiscal dos municípios brasileiros, bem como informações de natureza política

\footnotetext{
${ }^{9}$ Resultados expostos no apêndice 1.e.

${ }^{10} \mathrm{O}$ teste de Hausman foi implementado como forma de avaliar qual o método mais adequado entre o método de efeitos fixos e o método de efeitos aleatórios. As hipóteses nula e alternativa do teste são, respectivamente:

$\mathrm{H}_{0}=$ os estimadores de efeitos fixos e de efeitos aleatórios são ambos consistentes, mas o de efeitos aleatórios é eficiente;

$\mathrm{H}_{\mathrm{a}}=$ só o estimador de efeitos fixos é consistente.

$\mathrm{O}$ teste é distribuído através de uma $\chi^{2}$ com $\mathrm{N}$ (número de coeficientes estimados) graus de liberdade.
} 
e de natureza demográfica destas unidades (em 1988 os municípios brasileiros totalizavam 4200 e hoje totalizam 5560, distribuídos entre os 26 estados da federação). O primeiro destes conjuntos de dados foi obtido junto ao Tesouro Nacional, através do banco de dados FINBRA, cujas informações estão disponíveis para os anos de 1989 a 2003. Por sua vez, os dados sobre as eleições municipais (1989, 1992, 1996 e 2000) e estaduais (1990, 1994, 1998 e 2002) brasileiras foram obtidas junto ao Tribunal Superior Eleitoral (TSE) e junto ao Tribunal Regional Eleitoral (TRE) de cada estado brasileiro ${ }^{11}$. Finalmente, as informações demográficas dos municípios brasileiros (população total, proporção de jovens e idosos e grau de urbanização) foram obtidas junto ao Instituto Brasileiro de Geografia e Estatística (IBGE). É importante ressaltar neste momento que para alguns estados não foi possível obter todas as informações políticas para todos os períodos avaliados. Conforme apresentado na tabela 1.1, este é o caso dos estados do Acre, Maranhão e Roraima, por exemplo. A tabela 1.2 também apresenta a freqüência relativa dos partidos analisados neste trabalho, conforme descrito anteriormente.

\footnotetext{
${ }^{11}$ Ressalta-se que um detalhamento mais específico das informações eleitorais encontra-se disponível somente para as eleições realizadas a partir de 1994, o que impede, ex ante, a avaliação de algumas características eleitorais relevantes, como a questão das coligações partidárias municipais e os microdados a respeito dos candidatos a prefeito e a vereador, por exemplo.
} 
Tabela 1.1 - Municípios presentes na amostra, por ano e por unidade da federação

\begin{tabular}{|c|c|c|c|c|c|c|c|c|c|c|c|c|c|c|c|}
\hline$J F \backslash$ Ano & 989 & 1990 & 1991 & 1992 & 1993 & 1994 & 1995 & 1996 & 1997 & 1998 & 1999 & 2000 & 2001 & 2002 & 2003 \\
\hline$A C$ & - & - & - & - & - & - & - & - & 22 & 21 & 21 & 22 & 22 & 22 & 21 \\
\hline$A L$ & 96 & 6 & 96 & 96 & 100 & 100 & 98 & 97 & 91 & 64 & 64 & 97 & 100 & 99 & 99 \\
\hline AM & 41 & 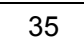 & 31 & 23 & 0 & $2 \varepsilon$ & ve & 5 & 11 & 35 & 38 & 49 & 56 & 7 & 57 \\
\hline AP & V & 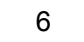 & 0 & V & 12 & 11 & 12 & 12 & 10 & 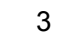 & 2 & 10 & 14 & 1 & 8 \\
\hline BA & 363 & 406 & 379 & 401 & 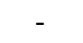 & - & 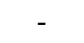 & - & 413 & 309 & 317 & 393 & 393 & 366 & 343 \\
\hline CE & 173 & 146 & 174 & 173 & 179 & 176 & 176 & 170 & 166 & 112 & 118 & 164 & 184 & 173 & 181 \\
\hline ES & o & o & 65 & 65 & 0 & 38 & 0 & 38 & 77 & 65 & 65 & 10 & 75 & 76 & 76 \\
\hline GO & 139 & 165 & 144 & 165 & 210 & 213 & 214 & 212 & 233 & 181 & 187 & 231 & 234 & 233 & 218 \\
\hline 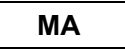 & 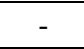 & - & - & - & - & - & - & - & 81 & 1 & 43 & 102 & 165 & די & 7 \\
\hline MG & 721 & 720 & 716 & 721 & 739 & 739 & 714 & 735 & 795 & 755 & 764 & 835 & 828 & 807 & 785 \\
\hline MS & 7 & 6 & 71 & 66 & 77 & 6 & 7 & 72 & 77 & 57 & 57 & 77 & 77 & 77 & 75 \\
\hline$N$ & 9 & 9 & 93 & 93 & 1 & 11 & 1 & 116 & 126 & 9 & 92 & 114 & 117 & 106 & 95 \\
\hline PA & 91 & 97 & 92 & 93 & 110 & 99 & 108 & 67 & 102 & 27 & 26 & 90 & 127 & 121 & 98 \\
\hline PB & 169 & 166 & 169 & 169 & 170 & 171 & 171 & 171 & 219 & 138 & 139 & 201 & 208 & 209 & 200 \\
\hline PE & 165 & 162 & 165 & 163 & 173 & 104 & 121 & 176 & 179 & 134 & 143 & 166 & 177 & 168 & 165 \\
\hline $\mathbf{P}$ & 117 & 115 & 117 & 112 & 112 & 113 & 121 & 70 & 212 & 136 & 138 & 196 & 216 & 205 & 194 \\
\hline PR & 317 & 313 & 317 & 315 & 329 & 371 & 369 & 370 & 396 & 387 & 388 & 396 & 399 & 383 & 378 \\
\hline RJ & 62 & 61 & 62 & 60 & 81 & 81 & 80 & 80 & 91 & 75 & 77 & 90 & 87 & 86 & 82 \\
\hline RN & 147 & 146 & 147 & 145 & 139 & 147 & 146 & 123 & 141 & 90 & 90 & 149 & 152 & 154 & 152 \\
\hline RO & 22 & 22 & 22 & - & 11 & - & 21 & 29 & 51 & 33 & 33 & 51 & 49 & 47 & 46 \\
\hline RR & - & - & - & - & - & - & - & - & 1 & 1 & 2 & 5 & 12 & 12 & 14 \\
\hline RS & 332 & 331 & 332 & 332 & 426 & 425 & 391 & 425 & 454 & 447 & 449 & 467 & 464 & 461 & 462 \\
\hline SC & 205 & 205 & 152 & 205 & 260 & 259 & 260 & 260 & 292 & 281 & 282 & 293 & 292 & 285 & 285 \\
\hline SE & 73 & 72 & 73 & 72 & 34 & 34 & 34 & 32 & 75 & 66 & 65 & 68 & 70 & 73 & 70 \\
\hline SP & 571 & 565 & 571 & 571 & 623 & 623 & 623 & 622 & 641 & 590 & 592 & 635 & 631 & 589 & 589 \\
\hline TO & 17 & 39 & 33 & 29 & 87 & 85 & 108 & 109 & 132 & 95 & 91 & 114 & 133 & 132 & 123 \\
\hline Total & 4056 & 4094 & 4029 & 4075 & 4056 & 3999 & 4026 & 3991 & 5100 & 4235 & 4283 & 5090 & 5282 & 5106 & 4963 \\
\hline
\end{tabular}

Fonte: construção própria

Tabela 1.2 - Freqüência dos partidos politicos na amostra

\begin{tabular}{|c|c|c|}
\hline Partido & Amostra não balanceada (\%) & Amostra balanceada (\%) \\
\hline PT & 1,93 & 2,23 \\
\hline PL & 4,55 & 4,17 \\
\hline PDT & 6,67 & 7,12 \\
\hline PTB & 6,81 & 7,27 \\
\hline PSDB & 10,63 & 10,72 \\
\hline PDS / PPB & 10,66 & 10,96 \\
\hline PFL & 19,28 & 17,14 \\
\hline PMDB & 29,41 & 31,35 \\
\hline
\end{tabular}

Fonte: construção própria

Todas as variáveis de natureza financeira estão avaliadas em reais de 2004, através da utilização do IGP-DI como índice deflacionador das séries. As mesmas encontram-se também avaliadas em termos per capita, sendo os Censos de 1991 e 2000 bem como a Contagem Populacional de 1996 as referências para tal transformação. Em termos específicos, o procedimento utilizado para transformar todas as variáveis financeiras em valores per capita inclui o cálculo da população entre os anos em que existiram Censos e Contagens 
Populacionais. Assim, entre 1991 e 1996 a população de cada município brasileiro foi obtida através de interpolação exponencial entre o Censo de 1991 e a Contagem Populacional de 1996, e a população de cada município brasileiro entre 1996 e 2000 também foi obtida através de interpolação exponencial entre a Contagem Populacional de 1996 e o Censo de 2000. Por sua vez, no que diz respeito aos dados de finanças municipais, ressalta-se que as informações não estão perfeitamente decompostas entre receita e despesa por natureza e por função e suas respectivas categorias para todos os anos abordados, o que antecipadamente restringe a execução de determinadas avaliações e testes empíricos.

Os gráficos em seqüência ilustram o comportamento das cinco categorias da despesa municipal cujos comportamentos são avaliados nesta primeira análise empírica, tendo em mente as transformações anteriormente consideradas. As tabelas que contém as informações ilustradas nos gráficos, estão dispostas no apêndice 1a desta tese e apresentam também as médias e desvios-padrão das variáveis, por ano e por partido político analisado. Tanto as tabelas como os gráficos consideram as informações da amostra não balanceada.

\section{Gráfico 1.1 - Despesa orçamentária per capita}

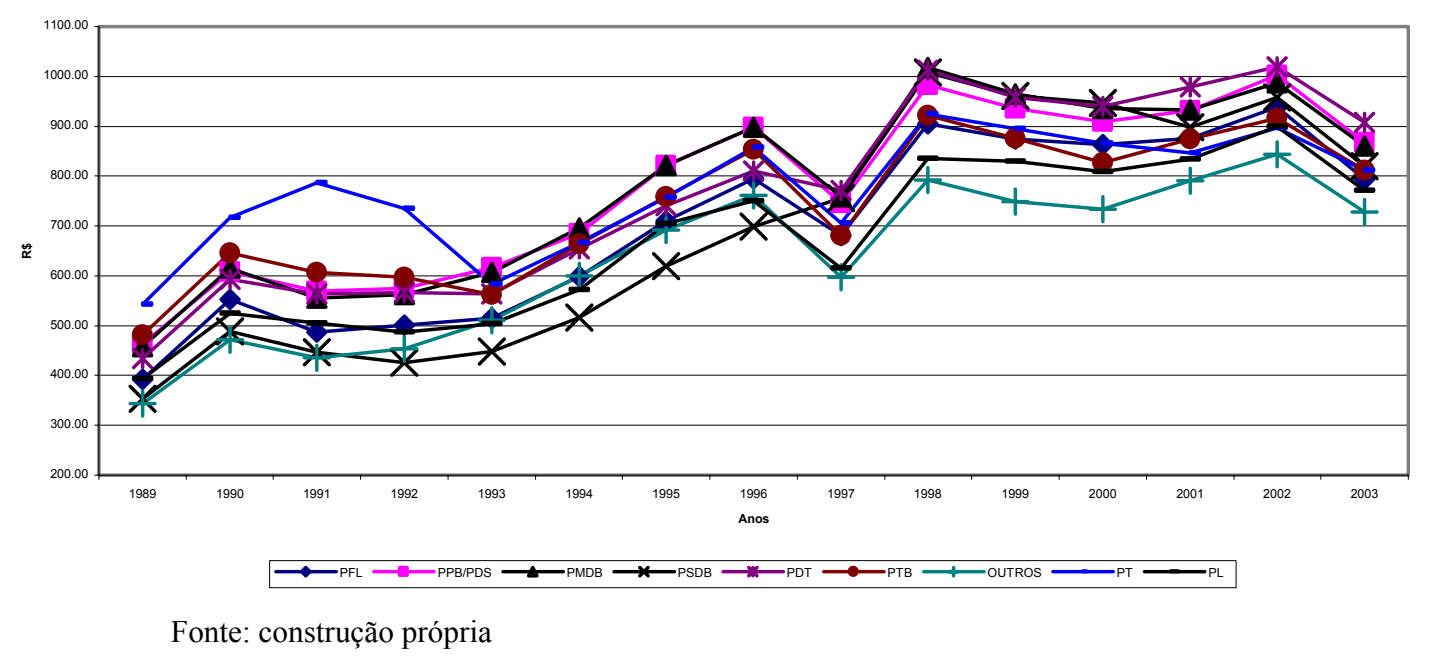


Gráfico 1.2-Despesa corrente per capita

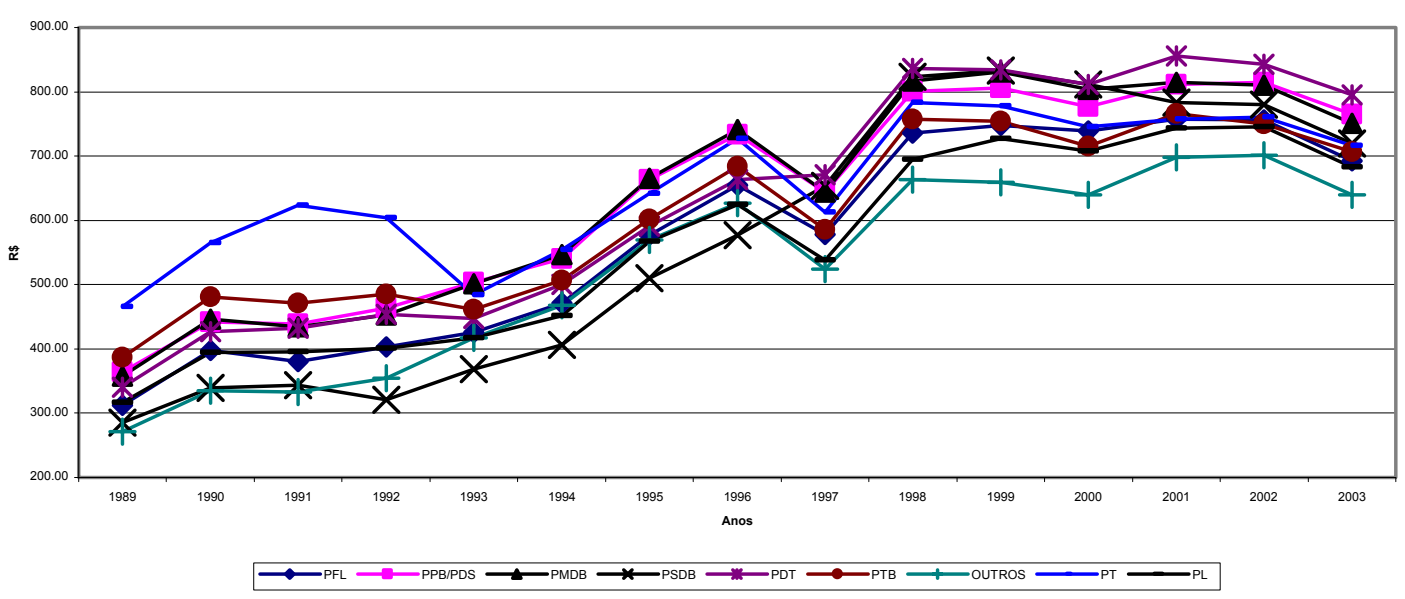

Fonte: construção própria

Gráfico 1.3 - Despesa de pessoal per capita

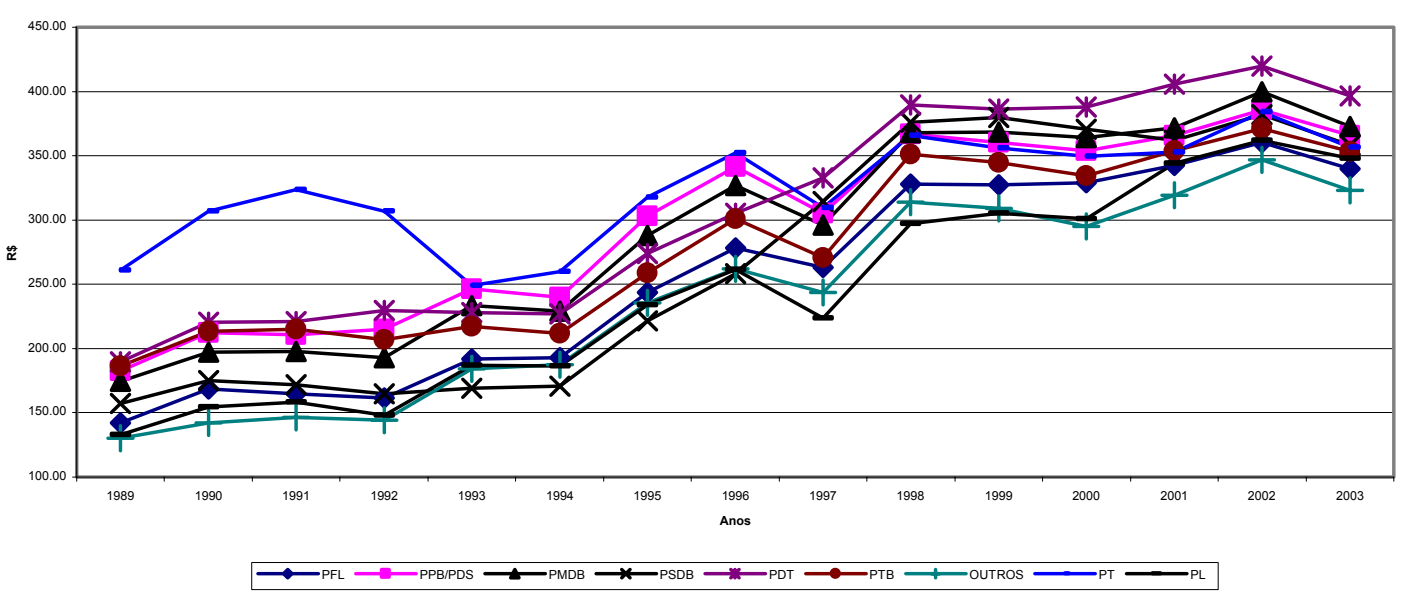

Fonte: construção própria

Gráfico 1.4-Transferências correntes per capita

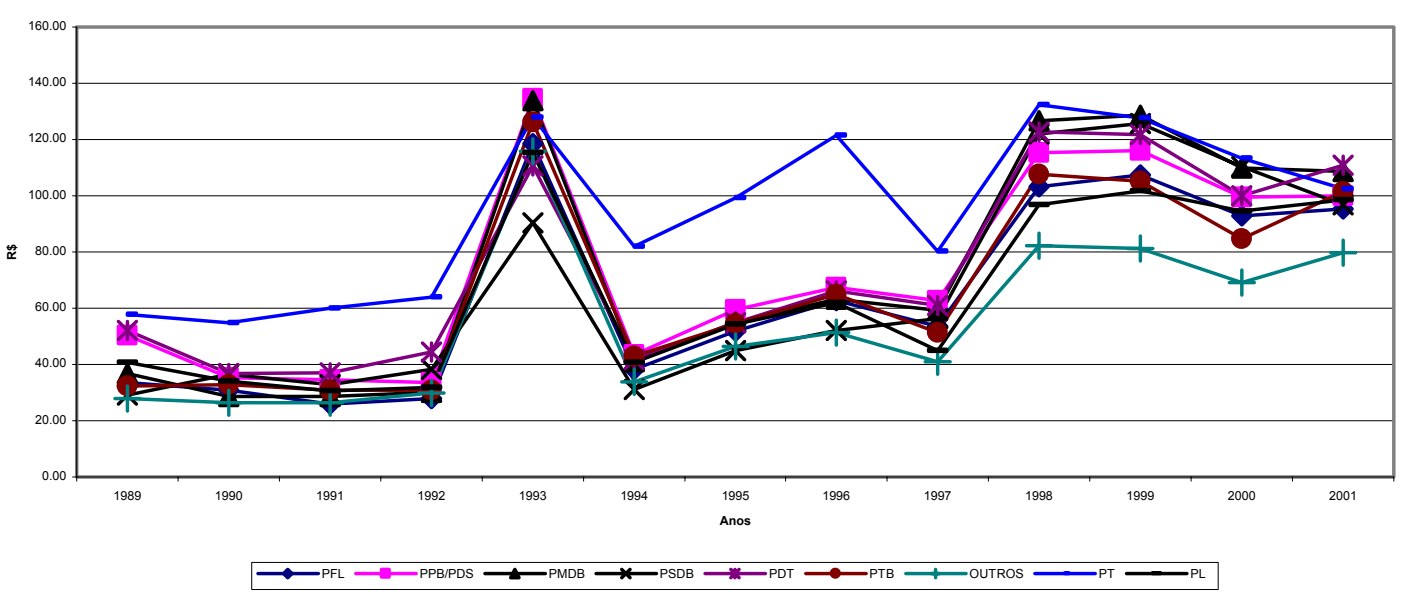

Fonte: construção própria 
Gráfico 1.5 - Despesa de investimento per capita

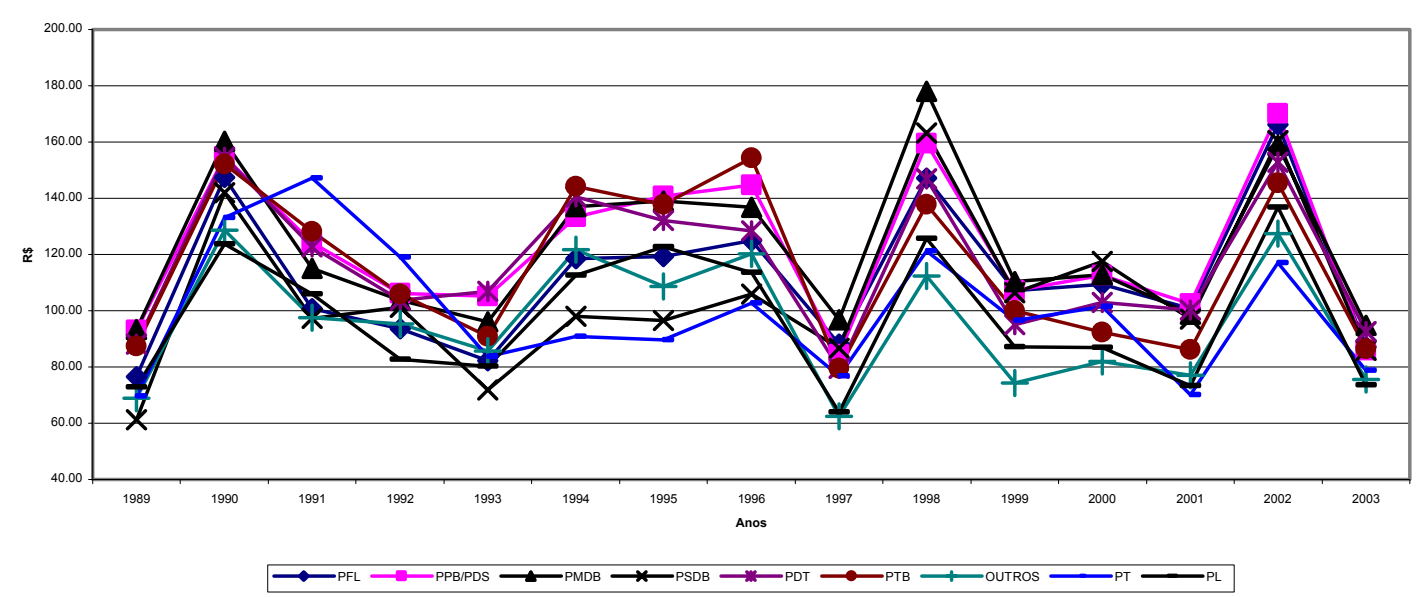

Fonte: construção própria

Gráfico 1.6 - Receita tributária per capita

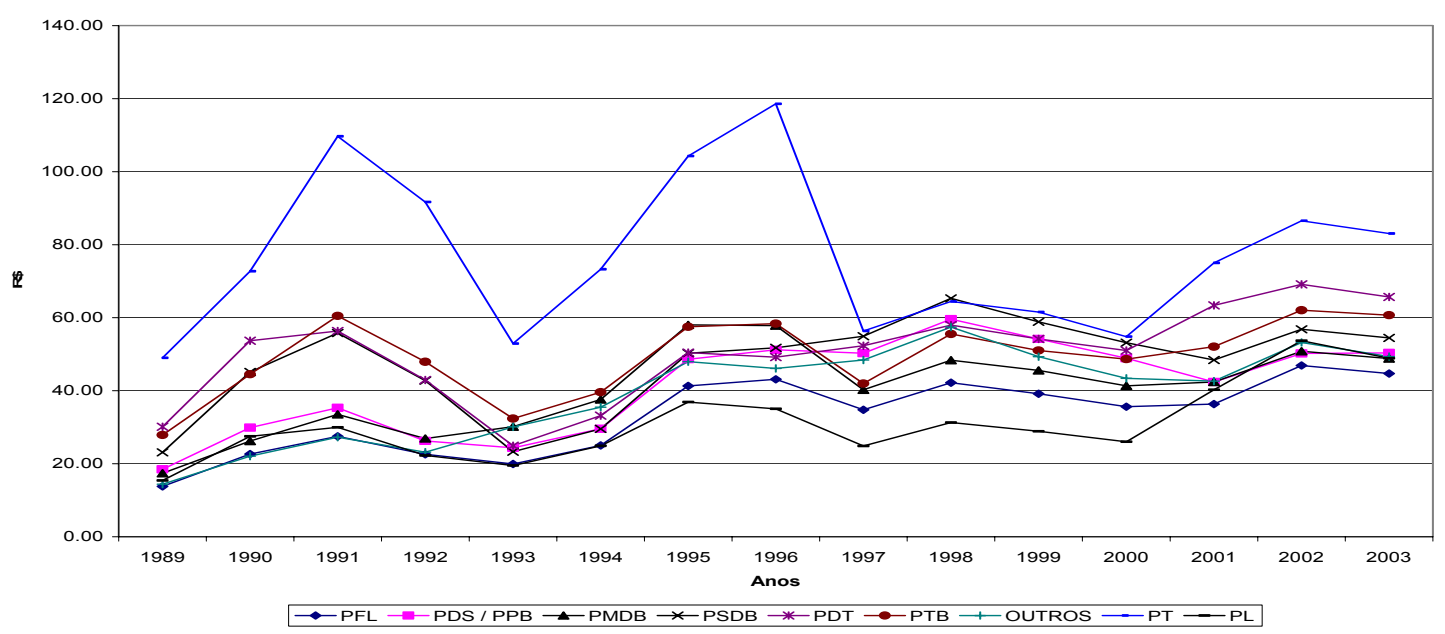

Fonte: construção própria

Gráfico 1.7 - Receita de transferências correntes per capita

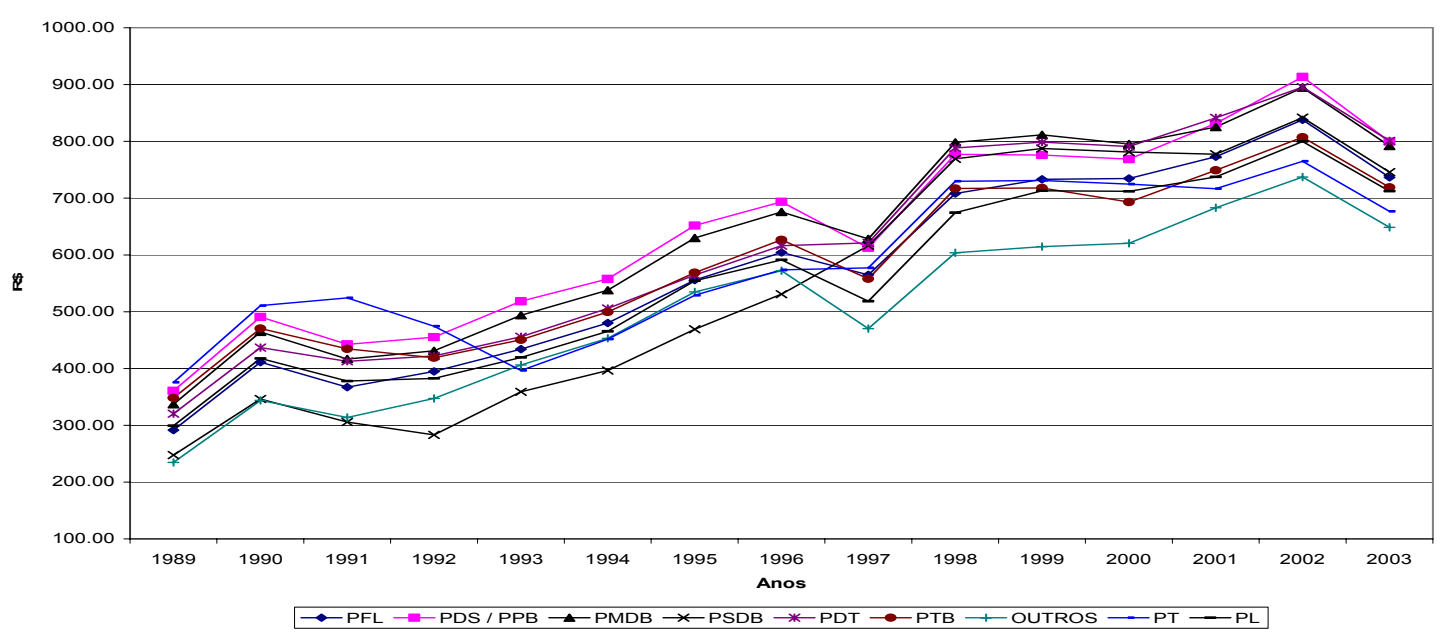

Fonte: construção própria 
Os gráficos permitem observar algumas características em comum entre as variáveis consideradas, como por exemplo, a tendência de crescimento ao longo do período avaliado, mesmo tendo em mente que todas se encontram em valores reais per capita. A exceção fica por conta da despesa de investimento, variável que aparentemente apresenta oscilações significantes, mas cuja média tende a ser constante (igual à $\mathrm{R} \$ 109,55$ per capita) ao longo do período avaliado. Considerando tal elemento, observa-se que enquanto as despesas correntes (e as suas respectivas sub-categorias despesa de pessoal e transferências correntes ${ }^{12}$ ) acompanham a tendência de crescimento associada à despesa orçamentária, as despesas de investimento não parecem seguir o mesmo padrão, sinalizando assim uma queda da participação dos investimentos públicos em relação ao total da despesa municipal. Por sua vez, observa-se também que o crescimento da receita tributária ocorre a uma taxa relativamente menor que a observada para as transferências recebidas da União e dos respectivos governos estaduais pelos governos municipais, o que sinaliza também uma crescente participação da segunda fonte de recursos sobre o total de receitas disponíveis pelos municípios ao longo do tempo.

As ilustrações também permitem notar que algum grau de diferenciação partidária parece existir em cada uma das cinco categorias de despesa, como por exemplo o caso do PT, cujas despesas estão, em média, entre as mais elevadas em todos os casos, principalmente no caso das transferências correntes (média igual à $\mathrm{R} \$ 94,10$, sendo a média do PDT, segunda mais elevada, é igual à $\mathrm{R} \$ 73,40)$. A exceção é observada no caso dos investimentos, cujos valores mais elevados são observados para o PMDB e PDS / PPB - neste caso, o PT é justamente um dos partidos que menos aloca recursos nesta categoria. Por outro lado, o grupo formado pelos "outros partidos" é aparentemente mais conservador que os demais partidos apreciados, uma vez que em média suas despesas são as menores para todas as categorias consideradas. Assim, estas informações vêm a sugerir que algum grau de distinção na conduta do orçamento municipal entre as agremiações partidárias parece ser efetivamente observado. De qualquer forma, deve-se ressaltar que esta é uma análise preliminar e que apenas apresenta o comportamento das variáveis sem considerar nenhuma espécie de controle mais rigoroso. Os resultados das estimações apresentadas em seqüência permitem realizar uma avaliação mais apurada do problema aqui analisado, qual seja, a possibilidade de flutuações em função do calendário eleitoral e das diferenças partidárias dos prefeitos dos municípios brasileiros.

\footnotetext{
${ }^{12}$ Para esta variável, não há disponibilidade de dados para os anos de 2002 e 2003.
} 
A seqüência deste capítulo traz os resultados das estimações dos modelos previamente apresentados, sendo uma análise particular realizada para cada estimação e, ao final dos três procedimentos implementados, uma análise geral vem a ser apresentada.

\section{3 - Modelo com (somente) dummy de ano eleitoral}

Conforme descrito anteriormente, esta seção 1.3 apresenta os resultados das estimações do modelo mais restrito entre os três sugeridos, em que somente uma dummy de ano eleitoral é inserida nas estimações, ou seja, a mesma assume o valor 1 (um) nos anos de 1992, 1996 e 2000 e zero caso contrário. Assim, o resultado deste coeficiente representa a média de um eventual comportamento distinto das cinco categorias de despesa pública em tais anos. Também são apresentadas estimações em que são inseridas interações entre a dummy de ano eleitoral e as dummies de partido, com o propósito de verificar como os partidos políticos conduzem, especificamente nos anos eleitorais, o orçamento dos municípios que administram.

Ressalta-se novamente que, para efeito de simplificação, somente os resultados obtidos através do método de efeitos fixos são expostos, uma vez que o teste de Hausman aponta para a consistência destes. Os resultados obtidos através dos demais procedimentos estão expostos no apêndice $1 b$ desta tese. Finalmente, é importante ressaltar a inclusão, tanto nesta seção 1.3 como também na seção 1.4 , de uma tendência linear e de uma tendência quadrática, no intuito de controlar as estimações por eventuais efeitos temporais que sejam persistentes ao longo do período avaliado ${ }^{13}$. Ressalta-se novamente a exclusão da dummy associada ao PMDB com vistas a evitar multicolinearidade perfeita nas regressões.

No que diz respeito à significância estatística dos coeficientes, foi considerada a seguinte notação, também válida para todos os testes apresentados nesta tese:

*** : coeficiente estatisticamente significante a no máximo $1 \%$;

** : coeficiente estatisticamente significante a no máximo 5\%;

* : coeficiente estatisticamente significante a no máximo $10 \%$.

\footnotetext{
${ }^{13}$ Conforme resultados das estimações da seção 1.5 (modelo geral) a serem apresentados em seqüência, justificase em alguns casos (despesa orçamentária, despesa corrente e investimentos, por exemplo) a inclusão dos termos de tendência.
} 
Tabela 1.3-Despesa orçamentária - efeitos fixos

\begin{tabular}{|c|c|c|c|c|}
\hline $\begin{array}{l}\text { Regressor } \\
\text { (Erro nadrão) }\end{array}$ & \multicolumn{2}{|c|}{ Painel não balanceado } & \multicolumn{2}{|c|}{ Painel balanceado } \\
\hline Receita tributária & $\begin{array}{l}1.212^{* * *} \\
(0.015)\end{array}$ & $\begin{array}{l}1.212^{* * *} \\
(0.015)\end{array}$ & $\begin{array}{l}1.166^{* * *} \\
(0.018)\end{array}$ & $\begin{array}{l}1.166^{\star \star *} \\
(0.018)\end{array}$ \\
\hline Receita de transferências & $\begin{array}{c}0.917^{* * *} \\
(0.004)\end{array}$ & $\begin{array}{c}0.917^{* * *} \\
(0.004)\end{array}$ & $\begin{array}{c}0.885^{* * *} \\
(0.006)\end{array}$ & $\begin{array}{c}0.885^{\star * *} \\
(0.006)\end{array}$ \\
\hline Dummy ano eleitoral & $\begin{array}{c}13.917^{\star \star \star} \\
(1.450)\end{array}$ & $\begin{array}{c}13.708^{* \star \star} \\
(2.638) \\
\end{array}$ & $\begin{array}{c}18.136^{\star * \star} \\
(1.824)\end{array}$ & $\begin{array}{c}18.479^{\star * \star} \\
(3.231)\end{array}$ \\
\hline PFL & $\begin{array}{c}-5.542^{* *} \\
(2.197)\end{array}$ & $\begin{array}{l}-4.513^{\star} \\
(2.386)\end{array}$ & $\begin{array}{l}-4.394 \\
(2.762)\end{array}$ & $\begin{array}{c}-3.071 \\
(3.019)\end{array}$ \\
\hline PSDB & $\begin{array}{l}6.000^{* *} \\
(2.927)\end{array}$ & $\begin{array}{c}4.573 \\
(2.998)\end{array}$ & $\begin{array}{c}4.426 \\
(3.512)\end{array}$ & $\begin{array}{c}3.665 \\
(3.604)\end{array}$ \\
\hline PT & $\begin{array}{c}-17.144^{* * *} \\
(5.477)\end{array}$ & $\begin{array}{c}-17.819^{* * *} \\
(5.724)\end{array}$ & $\begin{array}{c}-19.192^{\star * *} \\
(6.181)\end{array}$ & $\begin{array}{c}-20.784^{* * *} \\
(6.500)\end{array}$ \\
\hline PTB & $\begin{array}{l}-5.335^{\star} \\
(3.059)\end{array}$ & $\begin{array}{l}-6.165^{*} \\
(3.305)\end{array}$ & $\begin{array}{l}-3.465 \\
(3.650)\end{array}$ & $\begin{array}{l}-4.139 \\
(3.963)\end{array}$ \\
\hline PDT & $\begin{array}{l}-2.256 \\
(3.094) \\
\end{array}$ & $\begin{array}{l}-2.368 \\
(3.363) \\
\end{array}$ & $\begin{array}{l}-2.603 \\
(3.618) \\
\end{array}$ & $\begin{array}{l}-1.352 \\
(3.958) \\
\end{array}$ \\
\hline PDS / PPB & $\begin{array}{l}-6.750^{\star *} \\
(2.645)\end{array}$ & $\begin{array}{c}-7.503^{* * *} \\
(2.866)\end{array}$ & $\begin{array}{c}-4.990 \\
(3.233)\end{array}$ & $\begin{array}{c}-5.330 \\
(3.517)\end{array}$ \\
\hline PL & $\begin{array}{c}-16.694^{* * *} \\
(3.594)\end{array}$ & $\begin{array}{c}-15.683^{* * *} \\
(3.888)\end{array}$ & $\begin{array}{c}-12.647^{* \star \star} \\
(4.512)\end{array}$ & $\begin{array}{c}-11.717^{* *} \\
(4.911) \\
\end{array}$ \\
\hline Outros & $\begin{array}{l}-4.245 \\
(2.635)\end{array}$ & $\begin{array}{l}-4.030 \\
(2.863)\end{array}$ & $\begin{array}{l}-4.934 \\
(3.350)\end{array}$ & $\begin{array}{c}-5.618 \\
(3.641)\end{array}$ \\
\hline PFL \& ano eleitoral & & $\begin{array}{c}-5.594 \\
(4.109)\end{array}$ & & $\begin{array}{l}-6.489 \\
(5.289)\end{array}$ \\
\hline PSDB \& ano eleitoral & & $\begin{array}{c}10.722^{\star *} \\
(5.441)\end{array}$ & & $\begin{array}{c}5.089 \\
(6.698)\end{array}$ \\
\hline PT \& ano eleitoral & & $\begin{array}{c}5.366 \\
(11.673) \\
\end{array}$ & & $\begin{array}{c}11.612 \\
(13.646)\end{array}$ \\
\hline PTB \& ano eleitoral & & $\begin{array}{c}3.684 \\
(5.974) \\
\end{array}$ & & $\begin{array}{c}3.500 \\
(7.371) \\
\end{array}$ \\
\hline PDT \& ano eleitoral & & $\begin{array}{c}0.004 \\
(5.890) \\
\end{array}$ & & $\begin{array}{l}-6.030 \\
(7.161) \\
\end{array}$ \\
\hline PDS / PPB \& ano eleitoral & & $\begin{array}{c}3.486 \\
(5.039)\end{array}$ & & $\begin{array}{c}1.732 \\
(6.280)\end{array}$ \\
\hline PL \& ano eleitoral & & $\begin{array}{l}-5.597 \\
(6.987) \\
\end{array}$ & & $\begin{array}{l}-4.572 \\
(9.128) \\
\end{array}$ \\
\hline Outros \& ano eleitoral & & $\begin{array}{l}-1.470 \\
(5.108)\end{array}$ & & $\begin{array}{c}3.536 \\
(6.720) \\
\end{array}$ \\
\hline Prefeito \& Governador & $\begin{array}{c}1.569 \\
(1.322)\end{array}$ & $\begin{array}{c}1.771 \\
(1.327)\end{array}$ & $\begin{array}{c}6.283^{* * *} \\
(1.686)\end{array}$ & $\begin{array}{c}6.352^{* * *} \\
(1.691)\end{array}$ \\
\hline Prefeito \& Presidente & $\begin{array}{c}-7.361^{* * *} \\
(2.224)\end{array}$ & $\begin{array}{c}-7.910^{\star \star \star} \\
(2.298)\end{array}$ & $\begin{array}{l}-6.043^{\star \star} \\
(2.682)\end{array}$ & $\begin{array}{l}-6.142^{\star \star} \\
(2.775)\end{array}$ \\
\hline Idosos & $\begin{array}{c}-10.020^{* * *} \\
(1.032)\end{array}$ & $\begin{array}{c}-9.994^{* * *} \\
(1.033) \\
\end{array}$ & $\begin{array}{c}-9.887^{* * *} \\
(1.361) \\
\end{array}$ & $\begin{array}{c}-9.860^{\star * *} \\
(1.362) \\
\end{array}$ \\
\hline Urbanização & $\begin{array}{l}0.262^{* *} \\
(0.129)\end{array}$ & $\begin{array}{l}0.263^{* *} \\
(0.129)\end{array}$ & $\begin{array}{l}0.442^{* *} \\
(0.182)\end{array}$ & $\begin{array}{l}0.441^{* *} \\
(0.182)\end{array}$ \\
\hline Jovens & $\begin{array}{l}-0.511 \\
(0.585) \\
\end{array}$ & $\begin{array}{c}-0.517 \\
(0.585) \\
\end{array}$ & $\begin{array}{c}-0.976 \\
(0.849) \\
\end{array}$ & $\begin{array}{l}-0.965 \\
(0.849) \\
\end{array}$ \\
\hline População & $\begin{array}{c}-81.488^{* * *} \\
(5.590)\end{array}$ & $\begin{array}{c}-81.463^{* * *} \\
(5.590)\end{array}$ & $\begin{array}{c}-98.991^{* * *} \\
(7.568)\end{array}$ & $\begin{array}{c}-99.016^{* * *} \\
(7.569)\end{array}$ \\
\hline Tendência linear & $\begin{array}{c}16.139^{* * *} \\
(0.787)\end{array}$ & $\begin{array}{c}16.178^{* * *} \\
(0.787)\end{array}$ & $\begin{array}{c}19.482^{\star * \star} \\
(1.016) \\
\end{array}$ & $\begin{array}{c}19.508^{* * *} \\
(1.017)\end{array}$ \\
\hline Tendência quadrática & $\begin{array}{c}-1.121^{* * *} \\
(0.039)\end{array}$ & $\begin{array}{c}-1.123^{* * *} \\
(0.039)\end{array}$ & $\begin{array}{c}-1.300^{* * *} \\
(0.050)\end{array}$ & $\begin{array}{c}-1.301^{* \star *} \\
(0.050)\end{array}$ \\
\hline Constante & $\begin{array}{c}922.983^{* * *} \\
(56.043)\end{array}$ & $\begin{array}{c}922.855^{* * *} \\
(56.047)\end{array}$ & $\begin{array}{c}116.434^{* * *} \\
(77.258)\end{array}$ & $\begin{array}{c}1116.121^{* * *} \\
(77.277)\end{array}$ \\
\hline $\mathrm{R}^{2}$ & 0,8575 & 0,8575 & 0,8441 & 0,8440 \\
\hline Observações & 66384 & 66384 & 33525 & 33525 \\
\hline Teste de Hausman & $\begin{array}{c}\chi^{2}=1390,96 \\
\text { Prob }=0,00\end{array}$ & $\begin{array}{c}\chi^{2}=1380,60 \\
\text { Prob }=0,00\end{array}$ & $\begin{array}{c}\chi^{2}=1157,02 \\
\text { Prob }=0,00\end{array}$ & $\begin{array}{l}\chi^{2}=1151,79 \\
\text { Prob }=0,00\end{array}$ \\
\hline
\end{tabular}

Fonte: elaboração própria 
Tabela 1.4-Despesa corrente - efeitos fixos

\begin{tabular}{|c|c|c|c|c|}
\hline $\begin{array}{c}\text { Regressor } \\
\text { (Erro padrão) }\end{array}$ & \multicolumn{2}{|c|}{ Painel não balanceado } & \multicolumn{2}{|c|}{ Painel balanceado } \\
\hline Receita tributária & $\begin{array}{c}0.837^{* * *} \\
(0.010)\end{array}$ & $\begin{array}{c}0.837^{\star \star *} \\
(0.010)\end{array}$ & $\begin{array}{c}0.793^{* * *} \\
(0.014)\end{array}$ & $\begin{array}{c}0.793^{* * *} \\
(0.014)\end{array}$ \\
\hline Receita de transferências & $\begin{array}{c}0.715^{* * *} \\
(0.003)\end{array}$ & $\begin{array}{c}0.715^{\star * *} \\
(0.003)\end{array}$ & $\begin{array}{c}0.693^{* * *} \\
(0.004)\end{array}$ & $\begin{array}{c}0.693^{* * *} \\
(0.004)\end{array}$ \\
\hline Dummy ano eleitoral & $\begin{array}{c}15.343^{* * *} \\
(1.016) \\
\end{array}$ & $\begin{array}{c}17.525^{\star * *} \\
(1.847) \\
\end{array}$ & $\begin{array}{c}16.194^{\star * *} \\
(1.423) \\
\end{array}$ & $\begin{array}{c}20.264^{\star * \star} \\
(2.521) \\
\end{array}$ \\
\hline PFL & $\begin{array}{c}-4.627^{* \star *} \\
(1.538)\end{array}$ & $\begin{array}{c}-3.371^{* \star} \\
(1.671)\end{array}$ & $\begin{array}{c}-5.781^{* \star *} \\
(2.155)\end{array}$ & $\begin{array}{c}-3.721 \\
(2.355)\end{array}$ \\
\hline PSDB & $\begin{array}{c}6.524^{* * *} \\
(2.050)\end{array}$ & $\begin{array}{c}5.935^{\star * \star} \\
(2.100)\end{array}$ & $\begin{array}{c}1.855 \\
(2.740) \\
\end{array}$ & $\begin{array}{c}1.819 \\
(2.812) \\
\end{array}$ \\
\hline PT & $\begin{array}{c}-3.462 \\
(3.836)\end{array}$ & $\begin{array}{c}-2.652 \\
(4.009)\end{array}$ & $\begin{array}{c}-0.481 \\
(4.822)\end{array}$ & $\begin{array}{c}-0.257 \\
(5.071)\end{array}$ \\
\hline PTB & $\begin{array}{l}-2.973 \\
(2.143) \\
\end{array}$ & $\begin{array}{c}-3.141 \\
(2.315) \\
\end{array}$ & $\begin{array}{c}-1.073 \\
(2.847) \\
\end{array}$ & $\begin{array}{l}-0.419 \\
(3.091) \\
\end{array}$ \\
\hline PDT & $\begin{array}{c}-0.099 \\
(2.167) \\
\end{array}$ & $\begin{array}{c}0.523 \\
(2.355) \\
\end{array}$ & $\begin{array}{l}5.212^{*} \\
(2.822) \\
\end{array}$ & $\begin{array}{c}8.150^{* * *} \\
(3.087)\end{array}$ \\
\hline PDS / PPB & $\begin{array}{l}-3.198^{*} \\
(1.853)\end{array}$ & $\begin{array}{c}-3.087 \\
(2.007) \\
\end{array}$ & $\begin{array}{c}0.885 \\
(2.523) \\
\end{array}$ & $\begin{array}{c}2.490 \\
(2.744) \\
\end{array}$ \\
\hline PL & $\begin{array}{c}-7.943^{* * *} \\
(2.517)\end{array}$ & $\begin{array}{c}-6.341^{* \star} \\
(2.723)\end{array}$ & $\begin{array}{c}-1.705 \\
(3.521)\end{array}$ & $\begin{array}{c}0.031 \\
(3.831)\end{array}$ \\
\hline Outros & $\begin{array}{c}-7.010^{* * *} \\
(1.845) \\
\end{array}$ & $\begin{array}{c}-5.249^{* * *} \\
(2.006) \\
\end{array}$ & $\begin{array}{c}-7.698^{* * *} \\
(2.613) \\
\end{array}$ & $\begin{array}{c}-6.957^{* *} \\
(2.841)\end{array}$ \\
\hline PFL \& ano eleitoral & & $\begin{array}{c}-5.833^{\star \star} \\
(2.878) \\
\end{array}$ & & $\begin{array}{c}-8.783^{* *} \\
(4.126)\end{array}$ \\
\hline PSDB \& ano eleitoral & & $\begin{array}{c}3.593 \\
(3.811) \\
\end{array}$ & & $\begin{array}{c}-1.814 \\
(5.225) \\
\end{array}$ \\
\hline PT \& ano eleitoral & & $\begin{array}{c}-4.099 \\
(8.175)\end{array}$ & & $\begin{array}{c}1.121 \\
(10.645)\end{array}$ \\
\hline PTB \& ano eleitoral & & $\begin{array}{c}1.297 \\
(4.184) \\
\end{array}$ & & $\begin{array}{l}-1.849 \\
(5.750) \\
\end{array}$ \\
\hline PDT \& ano eleitoral & & $\begin{array}{c}-2.726 \\
(4.125) \\
\end{array}$ & & $\begin{array}{c}-12.817^{\star *} \\
(5.587)\end{array}$ \\
\hline PDS / PPB \& ano eleitoral & & $\begin{array}{c}0.046 \\
(3.529) \\
\end{array}$ & & $\begin{array}{c}-6.498 \\
(4.899) \\
\end{array}$ \\
\hline PL \& ano eleitoral & & $\begin{array}{c}-7.585 \\
(4.893) \\
\end{array}$ & & $\begin{array}{c}-7.326 \\
(7.121) \\
\end{array}$ \\
\hline Outros \& ano eleitoral & & $\begin{array}{c}-8.258^{* *} \\
(3.578)\end{array}$ & & $\begin{array}{c}-2.085 \\
(5.242) \\
\end{array}$ \\
\hline Prefeito \& Governador & $\begin{array}{c}-4.196^{\star * *} \\
(0.926)\end{array}$ & $\begin{array}{c}-4.028^{* * *} \\
(0.929)\end{array}$ & $\begin{array}{l}2.986^{\star *} \\
(1.315)\end{array}$ & $\begin{array}{l}3.173^{* *} \\
(1.319)\end{array}$ \\
\hline Prefeito \& Presidente & $\begin{array}{c}-3.800^{\star *} \\
(1.558)\end{array}$ & $\begin{array}{c}-3.622^{* *} \\
(1.609)\end{array}$ & $\begin{array}{c}0.544 \\
(2.093) \\
\end{array}$ & $\begin{array}{c}1.395 \\
(2.165) \\
\end{array}$ \\
\hline Idosos & $\begin{array}{c}-2.681^{* * *} \\
(0.723)\end{array}$ & $\begin{array}{c}-2.659^{\star * *} \\
(0.723)\end{array}$ & $\begin{array}{c}2.722^{* \star *} \\
(1.062)\end{array}$ & $\begin{array}{c}-2.692^{\star *} \\
(1.062)\end{array}$ \\
\hline Urbanização & $\begin{array}{l}0.206^{\star *} \\
(0.090)\end{array}$ & $\begin{array}{l}0.206^{\star \star} \\
(0.090)\end{array}$ & $\begin{array}{c}0.173 \\
(0.142) \\
\end{array}$ & $\begin{array}{c}0.173 \\
(0.142) \\
\end{array}$ \\
\hline Jovens & $\begin{array}{c}2.572^{* * *} \\
(0.410)\end{array}$ & $\begin{array}{c}2.564^{* * *} \\
(0.410)\end{array}$ & $\begin{array}{l}1.346^{\star *} \\
(0.662)\end{array}$ & $\begin{array}{l}1.363^{* *} \\
(0.662)\end{array}$ \\
\hline População & $\begin{array}{c}-55.007^{* * *} \\
(3.916)\end{array}$ & $\begin{array}{c}-54.980^{* \star *} \\
(3.915)\end{array}$ & $\begin{array}{c}-61.319^{* * *} \\
(5.904)\end{array}$ & $\begin{array}{c}-61.336 * * * \\
(5.905)\end{array}$ \\
\hline Tendência linear & $\begin{array}{c}23.389^{* * *} \\
(0.551) \\
\end{array}$ & $\begin{array}{c}23.403^{* * *} \\
(0.551)\end{array}$ & $\begin{array}{c}27.284^{\star \star \star} \\
(0.793) \\
\end{array}$ & $\begin{array}{c}27.273^{\star * *} \\
(0.793) \\
\end{array}$ \\
\hline Tendência quadrática & $\begin{array}{c}-0.972^{* * *} \\
(0.027)\end{array}$ & $\begin{array}{c}-0.973^{\star \star *} \\
(0.027)\end{array}$ & $\begin{array}{c}-1.214^{* * *} \\
(0.039)\end{array}$ & $\begin{array}{c}-1.212^{\star \star \star} \\
(0.039)\end{array}$ \\
\hline Constante & $\begin{array}{c}472.898^{* * *} \\
(39.253)\end{array}$ & $\begin{array}{c}472.161^{* * *} \\
(39.255)\end{array}$ & $\begin{array}{c}600.306^{\star * *} \\
(60.275)\end{array}$ & $\begin{array}{c}598.499^{* * *} \\
(60.286)\end{array}$ \\
\hline $\mathrm{R}^{2}$ & 0,8741 & 0,8741 & 0,8582 & 0,8581 \\
\hline Observações & 66384 & 66384 & 33525 & 33525 \\
\hline Teste de Hausman & $\begin{array}{c}\chi^{2}=2120,73 \\
\text { Prob }=0,00\end{array}$ & $\begin{array}{c}\chi^{2}=2113,73 \\
\text { Prob }=0,00\end{array}$ & $\begin{array}{c}\chi^{2}=1194,50 \\
\text { Prob }=0,00\end{array}$ & $\begin{array}{c}\chi^{2}=1191,69 \\
\text { Prob }=0,00\end{array}$ \\
\hline
\end{tabular}

Fonte: elaboração própria 
Tabela 1.5 - Despesa de pessoal - efeitos fixos

\begin{tabular}{|c|c|c|c|c|}
\hline \multirow{2}{*}{$\begin{array}{c}\begin{array}{c}\text { Regressor } \\
\text { (Erro padrão) }\end{array} \\
\text { Receita tributária }\end{array}$} & \multicolumn{2}{|c|}{ Painel não balanceado } & \multicolumn{2}{|c|}{ Painel balanceado } \\
\hline & $\begin{array}{c}0.296^{\star \star *} \\
(0.007)\end{array}$ & $\begin{array}{c}0.296^{\star * *} \\
(0.007)\end{array}$ & $\begin{array}{c}0.269^{\star \star \star} \\
(0.009)\end{array}$ & $\begin{array}{c}0.270^{\star \star *} \\
(0.009)\end{array}$ \\
\hline Receita de transferências & $\begin{array}{c}0.295^{\star * *} \\
(0.002)\end{array}$ & $\begin{array}{c}0.295^{* * *} \\
(0.002)\end{array}$ & $\begin{array}{c}0.308^{* * *} \\
(0.003)\end{array}$ & $\begin{array}{c}0.309^{* * *} \\
(0.003)\end{array}$ \\
\hline Dummy ano eleitoral & $\begin{array}{c}0.388 \\
(0.696) \\
\end{array}$ & $\begin{array}{c}1.620 \\
(1.266) \\
\end{array}$ & $\begin{array}{l}2.069^{\star *} \\
(0.954) \\
\end{array}$ & $\begin{array}{c}5.352^{\star \star \star} \\
(1.690) \\
\end{array}$ \\
\hline PFL & $\begin{array}{c}-2.367^{* *} \\
(1.055)\end{array}$ & $\begin{array}{l}-1.108 \\
(1.146)\end{array}$ & $\begin{array}{l}-2.457^{*} \\
(1.445)\end{array}$ & $\begin{array}{c}-0.279 \\
(1.579)\end{array}$ \\
\hline PSDB & $\begin{array}{c}10.619^{* * *} \\
(1.405)\end{array}$ & $\begin{array}{c}10.738^{* * *} \\
(1.440)\end{array}$ & $\begin{array}{c}7.153^{* * *} \\
(1.837)\end{array}$ & $\begin{array}{c}7.728^{* * *} \\
(1.885)\end{array}$ \\
\hline PT & $\begin{array}{l}-4.931^{*} \\
(2.630)\end{array}$ & $\begin{array}{l}-5.230^{*} \\
(2.748)\end{array}$ & $\begin{array}{l}-5.639^{*} \\
(3.234)\end{array}$ & $\begin{array}{l}-5.527 \\
(3.400)\end{array}$ \\
\hline PTB & $\begin{array}{l}-1.167 \\
(1.469)\end{array}$ & $\begin{array}{l}-1.460 \\
(1.587)\end{array}$ & $\begin{array}{l}-0.460 \\
(1.909)\end{array}$ & $\begin{array}{c}0.369 \\
(2.073)\end{array}$ \\
\hline PDT & $\begin{array}{c}1.955 \\
(1.486)\end{array}$ & $\begin{array}{c}1.096 \\
(1.615)\end{array}$ & $\begin{array}{c}3.067 \\
(1.893)\end{array}$ & $\begin{array}{l}3.808^{*} \\
(2.070)\end{array}$ \\
\hline PDS / PPB & $\begin{array}{c}-3.602^{* * *} \\
(1.270)\end{array}$ & $\begin{array}{c}-4.300^{\star * *} \\
(1.376)\end{array}$ & $\begin{array}{l}-2.418 \\
(1.692)\end{array}$ & $\begin{array}{l}-2.459 \\
(1.840)\end{array}$ \\
\hline PL & $\begin{array}{c}-7.985^{\star * *} \\
(1.726)\end{array}$ & $\begin{array}{c}-6.452^{* * *} \\
(1.867)\end{array}$ & $\begin{array}{c}0.189 \\
(2.361)\end{array}$ & $\begin{array}{c}2.616 \\
(2.569)\end{array}$ \\
\hline Outros & $\begin{array}{c}-2.884^{* *} \\
(1.265)\end{array}$ & $\begin{array}{l}-1.825 \\
(1.375) \\
\end{array}$ & $\begin{array}{l}-0.936 \\
(1.752) \\
\end{array}$ & $\begin{array}{c}0.119 \\
(1.905)\end{array}$ \\
\hline PFL \& ano eleitoral & & $\begin{array}{c}-5.864^{\star \star *} \\
(1.973)\end{array}$ & & $\begin{array}{c}-9.451^{* * *} \\
(2.766)\end{array}$ \\
\hline PSDB \& ano eleitoral & & $\begin{array}{l}-1.583 \\
(2.612)\end{array}$ & & $\begin{array}{l}-6.017^{*} \\
(3.503)\end{array}$ \\
\hline PT \& ano eleitoral & & $\begin{array}{c}2.991 \\
(5.604)\end{array}$ & & $\begin{array}{c}1.412 \\
(7.137)\end{array}$ \\
\hline PTB \& ano eleitoral & & $\begin{array}{c}1.886 \\
(2.868)\end{array}$ & & $\begin{array}{l}-2.898 \\
(3.855)\end{array}$ \\
\hline PDT \& ano eleitoral & & $\begin{array}{c}4.297 \\
(2.828)\end{array}$ & & $\begin{array}{l}-2.383 \\
(3.746)\end{array}$ \\
\hline PDS / PPB \& ano eleitoral & & $\begin{array}{c}3.966 \\
(2.419)\end{array}$ & & $\begin{array}{c}1.805 \\
(3.285)\end{array}$ \\
\hline PL \& ano eleitoral & & $\begin{array}{c}-7.214^{* *} \\
(3.354)\end{array}$ & & $\begin{array}{c}-10.834^{* *} \\
(4.774)\end{array}$ \\
\hline Outros \& ano eleitoral & & $\begin{array}{c}-4.923^{\star \star} \\
(2.453)\end{array}$ & & $\begin{array}{l}-3.939 \\
(3.515) \\
\end{array}$ \\
\hline Prefeito \& Governador & $\begin{array}{c}-1.766^{\star \star \star} \\
(0.635)\end{array}$ & $\begin{array}{c}-1.760^{\star * *} \\
(0.637)\end{array}$ & $\begin{array}{c}0.288 \\
(0.882)\end{array}$ & $\begin{array}{c}0.422 \\
(0.884)\end{array}$ \\
\hline Prefeito \& Presidente & $\begin{array}{c}-2.422^{* *} \\
(1.068)\end{array}$ & $\begin{array}{l}-2.111^{*} \\
(1.103)\end{array}$ & $\begin{array}{c}0.352 \\
(1.403)\end{array}$ & $\begin{array}{c}1.243 \\
(1.451)\end{array}$ \\
\hline Idosos & $\begin{array}{l}-0.504 \\
(0.496)\end{array}$ & $\begin{array}{l}-0.501 \\
(0.496)\end{array}$ & $\begin{array}{c}0.142 \\
(0.712)\end{array}$ & $\begin{array}{c}0.164 \\
(0.712)\end{array}$ \\
\hline Urbanização & $\begin{array}{l}-0.095 \\
(0.062) \\
\end{array}$ & $\begin{array}{c}-0.096 \\
(0.062) \\
\end{array}$ & $\begin{array}{c}-0.250^{* * *} \\
(0.095) \\
\end{array}$ & $\begin{array}{c}-0.251^{* * *} \\
(0.095)\end{array}$ \\
\hline Jovens & $\begin{array}{c}0.986^{\star \star *} \\
(0.281)\end{array}$ & $\begin{array}{c}0.980^{\star \star \star} \\
(0.281)\end{array}$ & $\begin{array}{l}-0.309 \\
(0.444) \\
\end{array}$ & $\begin{array}{l}-0.306 \\
(0.444) \\
\end{array}$ \\
\hline População & $\begin{array}{c}-30.807^{* * *} \\
(2.684)\end{array}$ & $\begin{array}{c}-30.761^{* * *} \\
(2.684)\end{array}$ & $\begin{array}{c}-30.193^{* * *} \\
(3.959)\end{array}$ & $\begin{array}{c}-30.074^{* * *} \\
(3.959)\end{array}$ \\
\hline Tendência linear & $\begin{array}{c}5.771^{* * *} \\
(0.378)\end{array}$ & $\begin{array}{c}5.788^{* * *} \\
(0.378)\end{array}$ & $\begin{array}{c}5.966^{* * *} \\
(0.532)\end{array}$ & $\begin{array}{c}5.957^{* \star *} \\
(0.532)\end{array}$ \\
\hline Tendência quadrática & $\begin{array}{c}0.055^{\star \star \star *} \\
(0.019)\end{array}$ & $\begin{array}{c}0.053^{\star \star \star *} \\
(0.019)\end{array}$ & $\begin{array}{l}-0.022 \\
(0.026) \\
\end{array}$ & $\begin{array}{l}-0.021 \\
(0.026) \\
\end{array}$ \\
\hline Constante & $\begin{array}{c}303.809^{\star * *} \\
(26.911)\end{array}$ & $\begin{array}{c}303.216^{* * *} \\
(26.909)\end{array}$ & $\begin{array}{c}364.184^{\star * *} \\
(40.417)\end{array}$ & $\begin{array}{c}361.806^{* * *} \\
(40.418)\end{array}$ \\
\hline $\mathrm{R}^{2}$ & 0,6999 & 0,7002 & 0,7001 & 0,7005 \\
\hline Observações & 66384 & 66384 & 33525 & 33525 \\
\hline Teste de Hausman & $\begin{array}{l}\chi^{2}=1777,03 \\
\text { Prob }=0,00\end{array}$ & $\begin{array}{c}\chi^{2}=1762,86 \\
\text { Prob }=0,00\end{array}$ & $\begin{array}{l}\chi^{2}=907,01 \\
\text { Prob }=0,00\end{array}$ & $\begin{array}{l}\chi^{2}=903,73 \\
\text { Prob }=0,00\end{array}$ \\
\hline
\end{tabular}

Fonte: elaboração própria 
Tabela 1.6 - Transferências correntes - efeitos fixos

\begin{tabular}{|c|c|c|c|c|}
\hline \multirow{2}{*}{$\begin{array}{c}\text { Regressor } \\
\text { (Erro padrão) }\end{array}$} & \multicolumn{2}{|c|}{ Painel não balanceado } & \multicolumn{2}{|c|}{ Painel balanceado } \\
\hline & $\begin{array}{c}0.068^{* * *} \\
(0.007)\end{array}$ & $\begin{array}{c}0.068^{* * *} \\
(0.007)\end{array}$ & $\begin{array}{c}0.032^{* * *} \\
(0.009)\end{array}$ & $\begin{array}{c}0.032^{* * *} \\
(0.009)\end{array}$ \\
\hline Receita de transferências & $\begin{array}{l}0.121^{* * *} \\
(0.002)\end{array}$ & $\begin{array}{c}0.121^{* * *} \\
(0.002)\end{array}$ & $\begin{array}{c}0.092^{* * *} \\
(0.003)\end{array}$ & $\begin{array}{c}0.093^{* * *} \\
(0.003) \\
\end{array}$ \\
\hline Dummy ano eleitoral & $\begin{array}{c}-10.801^{\star * *} \\
(0.624)\end{array}$ & $\begin{array}{c}-7.164^{* * *} \\
(1.151) \\
\end{array}$ & $\begin{array}{c}-13.317^{* * *} \\
(0.845)\end{array}$ & $\begin{array}{c}-9.232^{* \star *} \\
(1.519) \\
\end{array}$ \\
\hline PFL & $\begin{array}{c}7.815^{\star \star \star} \\
(1.045)\end{array}$ & $\begin{array}{c}9.281^{* * *} \\
(1.148)\end{array}$ & $\begin{array}{c}7.629^{* * *} \\
(1.396)\end{array}$ & $\begin{array}{c}9.238^{* * *} \\
(1.543)\end{array}$ \\
\hline PSDB & $\begin{array}{c}-10.980^{\star * *} \\
(1.460)\end{array}$ & $\begin{array}{c}-11.792^{* * \star} \\
(1.506)\end{array}$ & $\begin{array}{c}-11.451^{\star \star \star} \\
(1.864)\end{array}$ & $\begin{array}{c}-12.051^{\star \star *} \\
(1.926)\end{array}$ \\
\hline PT & $\begin{array}{l}4.568^{*} \\
(2.774)\end{array}$ & $\begin{array}{c}3.893 \\
(2.948) \\
\end{array}$ & $\begin{array}{c}3.919 \\
(3.332) \\
\end{array}$ & $\begin{array}{c}3.645 \\
(3.572) \\
\end{array}$ \\
\hline PTB & $\begin{array}{c}5.088^{* * *} \\
(1.453)\end{array}$ & $\begin{array}{c}6.674^{* * *} \\
(1.584) \\
\end{array}$ & $\begin{array}{c}7.421^{* * *} \\
(1.852)\end{array}$ & $\begin{array}{c}10.094^{\star * *} \\
(2.032) \\
\end{array}$ \\
\hline PDT & $\begin{array}{c}9.270^{\star \star \star} \\
(1.445)\end{array}$ & $\begin{array}{c}11.216^{* * *} \\
(1.581) \\
\end{array}$ & $\begin{array}{c}11.132^{\star * *} \\
(1.798) \\
\end{array}$ & $\begin{array}{c}13.438^{* * *} \\
(1.983) \\
\end{array}$ \\
\hline PDS / PPB & $\begin{array}{l}6.446^{\star \star *} \\
(1.255)\end{array}$ & $\begin{array}{c}8.489^{* * *} \\
(1.374) \\
\end{array}$ & $\begin{array}{c}8.533^{* * *} \\
(1.630)\end{array}$ & $\begin{array}{c}11.134^{\star * *} \\
(1.793) \\
\end{array}$ \\
\hline PL & $\begin{array}{c}6.837^{* * *} \\
(1.690)\end{array}$ & $\begin{array}{c}7.668^{* * *} \\
(1.843)\end{array}$ & $\begin{array}{c}9.456^{* * *} \\
(2.259)\end{array}$ & $\begin{array}{c}10.411^{* * *} \\
(2.479)\end{array}$ \\
\hline Outros & $\begin{array}{c}7.982^{* * *} \\
(1.248)\end{array}$ & $\begin{array}{c}10.405^{\star \star \star} \\
(1.370) \\
\end{array}$ & $\begin{array}{c}6.508^{* * *} \\
(1.700)\end{array}$ & $\begin{array}{c}8.201^{* * *} \\
(1.871)\end{array}$ \\
\hline PFL \& ano eleitoral & & $\begin{array}{c}-5.136^{\star * \star} \\
(1.790)\end{array}$ & & $\begin{array}{c}-5.488^{* *} \\
(2.479)\end{array}$ \\
\hline PSDB \& ano eleitoral & & $\begin{array}{c}1.242 \\
(2.374) \\
\end{array}$ & & $\begin{array}{c}-0.231 \\
(3.148) \\
\end{array}$ \\
\hline PT \& ano eleitoral & & $\begin{array}{c}6.024 \\
(5.110) \\
\end{array}$ & & $\begin{array}{c}4.118 \\
(6.440) \\
\end{array}$ \\
\hline PTB \& ano eleitoral & & $\begin{array}{l}-5.767^{* *} \\
(2.596)\end{array}$ & & $\begin{array}{c}-10.355^{\star * *} \\
(3.447)\end{array}$ \\
\hline PDT \& ano eleitoral & & $\begin{array}{c}-7.262^{* \star *} \\
(2.550) \\
\end{array}$ & & $\begin{array}{c}-8.634^{* * *} \\
(3.341) \\
\end{array}$ \\
\hline PDS / PPB \& ano eleitoral & & $\begin{array}{c}-7.506^{\star * *} \\
(2.191) \\
\end{array}$ & & $\begin{array}{c}-9.804^{* * *} \\
(2.941) \\
\end{array}$ \\
\hline PL \& ano eleitoral & & $\begin{array}{l}-2.523 \\
(3.026) \\
\end{array}$ & & $\begin{array}{l}-2.852 \\
(4.257) \\
\end{array}$ \\
\hline Outros \& ano eleitoral & & $\begin{array}{c}-9.197^{* * *} \\
(2.221)\end{array}$ & & $\begin{array}{l}-5.861^{*} \\
(3.147) \\
\end{array}$ \\
\hline Prefeito \& Governador & $\begin{array}{c}-0.683 \\
(0.625) \\
\end{array}$ & $\begin{array}{l}-0.416 \\
(0.627) \\
\end{array}$ & $\begin{array}{c}0.781 \\
(0.849) \\
\end{array}$ & $\begin{array}{c}0.985 \\
(0.851) \\
\end{array}$ \\
\hline Prefeito \& Presidente & $\begin{array}{c}24.095^{\star \star \star} \\
(1.071) \\
\end{array}$ & $\begin{array}{c}25.007^{* * *} \\
(1.114) \\
\end{array}$ & $\begin{array}{c}23.612^{* * *} \\
(1.373) \\
\end{array}$ & $\begin{array}{c}24.715^{\star \star \star} \\
(1.430) \\
\end{array}$ \\
\hline Idosos & $\begin{array}{c}10.921^{* * *} \\
(0.594)\end{array}$ & $\begin{array}{c}10.926^{\star * *} \\
(0.594) \\
\end{array}$ & $\begin{array}{c}8.749 * * * \\
(0.839)\end{array}$ & $\begin{array}{c}8.755^{\star * *} \\
(0.838) \\
\end{array}$ \\
\hline Urbanização & $\begin{array}{c}-0.216^{* * *} \\
(0.076)\end{array}$ & $\begin{array}{c}-0.214^{* * *} \\
(0.076)\end{array}$ & $\begin{array}{c}-0.223^{* *} \\
(0.112)\end{array}$ & $\begin{array}{l}-0.220^{* *} \\
(0.112)\end{array}$ \\
\hline Jovens & $\begin{array}{c}4.249^{* * *} \\
(0.304)\end{array}$ & $\begin{array}{c}4.250^{* * *} \\
(0.304) \\
\end{array}$ & $\begin{array}{c}2.554^{* * *} \\
(0.476)\end{array}$ & $\begin{array}{c}2.584^{\star * *} \\
(0.476)\end{array}$ \\
\hline População & $\begin{array}{c}4.870 \\
(2.978) \\
\end{array}$ & $\begin{array}{l}4.904^{*} \\
(2.977) \\
\end{array}$ & $\begin{array}{l}-0.300 \\
(4.304) \\
\end{array}$ & $\begin{array}{c}-0.434 \\
(4.304) \\
\end{array}$ \\
\hline Tendência linear & $\begin{array}{l}1.787^{* * *} \\
(0.421)\end{array}$ & $\begin{array}{l}1.826^{* * *} \\
(0.421)\end{array}$ & $\begin{array}{c}4.454^{* * *} \\
(0.582)\end{array}$ & $\begin{array}{c}4.505^{\star * *} \\
(0.583)\end{array}$ \\
\hline Tendência quadrática & $\begin{array}{l}0.227^{* \star \star} \\
(0.024)\end{array}$ & $\begin{array}{c}0.225^{* * *} \\
(0.024)\end{array}$ & $\begin{array}{c}0.130^{\star * *} \\
(0.033)\end{array}$ & $\begin{array}{l}0.127^{* * *} \\
(0.033)\end{array}$ \\
\hline Constante & $\begin{array}{c}-272.003^{* * *} \\
(30.242)\end{array}$ & $\begin{array}{c}-273.923^{* * *} \\
(30.235)\end{array}$ & $\begin{array}{c}-136.065^{* * *} \\
(44.347)\end{array}$ & $\begin{array}{c}-137.627^{* * *} \\
(44.340)\end{array}$ \\
\hline $\mathrm{R}^{2}$ & 0,2454 & 0,2460 & 0,2570 & 0,2568 \\
\hline Observações & 56315 & 56315 & 29055 & 29055 \\
\hline Teste de Hausman & $\begin{array}{l}\chi^{2}=674,38 \\
\text { Prob }=0,00\end{array}$ & $\begin{array}{l}\chi^{2}=659,74 \\
\text { Prob }=0,00\end{array}$ & $\begin{array}{l}\chi^{2}=261,21 \\
\text { Prob }=0,00\end{array}$ & $\begin{array}{l}\chi^{2}=261,57 \\
\text { Prob }=0,00\end{array}$ \\
\hline
\end{tabular}

Fonte: elaboração própria 
Tabela 1.7 - Investimentos - efeitos fixos

\begin{tabular}{|c|c|c|c|c|}
\hline $\begin{array}{l}\text { Regressor } \\
\text { (Erro }\end{array}$ & \multicolumn{2}{|c|}{ Painel não balanceado } & \multicolumn{2}{|c|}{ Painel balanceado } \\
\hline Receita tributária & $\begin{array}{l}0.350^{* * *} \\
(0.011)\end{array}$ & $\begin{array}{c}0.350 * * * \\
(0.011)\end{array}$ & $\begin{array}{c}0.350 * * * \\
(0.012)\end{array}$ & $\begin{array}{c}0.350^{\star * *} \\
(0.012)\end{array}$ \\
\hline Receita de transferências & $\begin{array}{c}0.184^{* * *} \\
(0.003)\end{array}$ & $\begin{array}{c}0.184^{* * *} \\
(0.003)\end{array}$ & $\begin{array}{c}0.172^{* * *} \\
(0.004)\end{array}$ & $\begin{array}{c}0.172^{* * *} \\
(0.004)\end{array}$ \\
\hline Dummy ano eleitoral & $\begin{array}{c}0.189 \\
(1.108) \\
\end{array}$ & $\begin{array}{l}-2.455 \\
(2.016) \\
\end{array}$ & $\begin{array}{c}3.765^{\star \star \star} \\
(1.221)\end{array}$ & $\begin{array}{l}-0.412 \\
(2.164) \\
\end{array}$ \\
\hline PFL & $\begin{array}{l}-1.300 \\
(1.679)\end{array}$ & $\begin{array}{c}-1.694 \\
(1.823)\end{array}$ & $\begin{array}{c}0.617 \\
(1.850)\end{array}$ & $\begin{array}{l}-0.339 \\
(2.022)\end{array}$ \\
\hline PSDB & $\begin{array}{l}-1.269 \\
(2.236)\end{array}$ & $\begin{array}{l}-1.985 \\
(2.291)\end{array}$ & $\begin{array}{c}1.365 \\
(2.352)\end{array}$ & $\begin{array}{c}0.686 \\
(2.414)\end{array}$ \\
\hline PT & $\begin{array}{c}-11.816^{\star * *} \\
(4.186)\end{array}$ & $\begin{array}{c}-12.904^{* * *} \\
(4.374)\end{array}$ & $\begin{array}{c}-17.605^{\star \star *} \\
(4.140)\end{array}$ & $\begin{array}{c}-19.269^{* * *} \\
(4.353)\end{array}$ \\
\hline PTB & $\begin{array}{l}-2.515 \\
(2.338) \\
\end{array}$ & $\begin{array}{l}-3.609 \\
(2.526) \\
\end{array}$ & $\begin{array}{l}-3.204 \\
(2.444) \\
\end{array}$ & $\begin{array}{l}-5.051^{*} \\
(2.654) \\
\end{array}$ \\
\hline PDT & $\begin{array}{l}-2.922 \\
(2.364) \\
\end{array}$ & $\begin{array}{l}-3.544 \\
(2.570) \\
\end{array}$ & $\begin{array}{c}-9.030^{\star * *} \\
(2.423) \\
\end{array}$ & $\begin{array}{c}-10.932^{* * *} \\
(2.650)\end{array}$ \\
\hline PDS / PPB & $\begin{array}{l}-3.535^{*} \\
(2.021)\end{array}$ & $\begin{array}{c}-4.468^{* *} \\
(2.190) \\
\end{array}$ & $\begin{array}{c}-5.897^{* \star *} \\
(2.166) \\
\end{array}$ & $\begin{array}{c}-7.826^{\star \star *} \\
(2.356) \\
\end{array}$ \\
\hline PL & $\begin{array}{c}-8.767^{* * *} \\
(2.746)\end{array}$ & $\begin{array}{c}-9.626 * * * \\
(2.972) \\
\end{array}$ & $\begin{array}{c}-11.629 * * * \\
(3.022)\end{array}$ & $\begin{array}{c}-12.935^{\star * *} \\
(3.289)\end{array}$ \\
\hline Outros & $\begin{array}{c}2.870 \\
(2.013) \\
\end{array}$ & $\begin{array}{c}1.286 \\
(2.188) \\
\end{array}$ & $\begin{array}{c}2.977 \\
(2.243) \\
\end{array}$ & $\begin{array}{c}1.508 \\
(2.439) \\
\end{array}$ \\
\hline PFL \& ano eleitoral & & $\begin{array}{c}1.025 \\
(3.140) \\
\end{array}$ & & $\begin{array}{c}3.215 \\
(3.542) \\
\end{array}$ \\
\hline PSDB \& ano eleitoral & & $\begin{array}{c}6.391 \\
(4.158) \\
\end{array}$ & & $\begin{array}{c}6.817 \\
(4.486) \\
\end{array}$ \\
\hline PT \& ano eleitoral & & $\begin{array}{c}6.396 \\
(8.920) \\
\end{array}$ & & $\begin{array}{c}9.070 \\
(9.139) \\
\end{array}$ \\
\hline PTB \& ano eleitoral & & $\begin{array}{c}4.540 \\
(4.566) \\
\end{array}$ & & $\begin{array}{c}7.855 \\
(4.936) \\
\end{array}$ \\
\hline PDT \& ano eleitoral & & $\begin{array}{c}2.180 \\
(4.501) \\
\end{array}$ & & $\begin{array}{c}7.700 \\
(4.796) \\
\end{array}$ \\
\hline PDS / PPB \& ano eleitoral & & $\begin{array}{c}3.729 \\
(3.851) \\
\end{array}$ & & $\begin{array}{l}7.922^{*} \\
(4.206)\end{array}$ \\
\hline PL \& ano eleitoral & & $\begin{array}{c}3.270 \\
(5.339) \\
\end{array}$ & & $\begin{array}{c}5.074 \\
(6.113) \\
\end{array}$ \\
\hline Outros \& ano eleitoral & & $\begin{array}{l}6.924^{*} \\
(3.904)\end{array}$ & & $\begin{array}{c}5.662 \\
(4.500) \\
\end{array}$ \\
\hline Prefeito \& Governador & $\begin{array}{l}5.802^{* * *} \\
(1.010)\end{array}$ & $\begin{array}{c}5.815^{\star \star \star} \\
(1.014)\end{array}$ & $\begin{array}{c}3.775^{\star \star \star} \\
(1.129)\end{array}$ & $\begin{array}{c}3.624^{* \star *} \\
(1.132)\end{array}$ \\
\hline Prefeito \& Presidente & $\begin{array}{c}-3.674^{* *} \\
(1.700)\end{array}$ & $\begin{array}{c}-4.422^{* *} \\
(1.756)\end{array}$ & $\begin{array}{c}-6.818^{* * *} \\
(1.797) \\
\end{array}$ & $\begin{array}{c}-7.853^{\star * *} \\
(1.858) \\
\end{array}$ \\
\hline Idosos & $\begin{array}{c}-8.133^{\star * \star} \\
(0.789) \\
\end{array}$ & $\begin{array}{c}-8.129^{\star \star \star} \\
(0.789) \\
\end{array}$ & $\begin{array}{c}-8.115^{\star \star *} \\
(0.912) \\
\end{array}$ & $\begin{array}{c}-8.120^{* * *} \\
(0.912) \\
\end{array}$ \\
\hline Urbanização & $\begin{array}{c}0.033 \\
(0.098) \\
\end{array}$ & $\begin{array}{c}0.033 \\
(0.098) \\
\end{array}$ & $\begin{array}{c}0.209^{*} \\
(0.122)\end{array}$ & $\begin{array}{c}0.208^{*} \\
(0.122)\end{array}$ \\
\hline Jovens & $\begin{array}{c}-3.841^{* \star *} \\
(0.447) \\
\end{array}$ & $\begin{array}{c}-3.839^{* * *} \\
(0.447) \\
\end{array}$ & $\begin{array}{c}-3.419^{\star \star *} \\
(0.569) \\
\end{array}$ & $\begin{array}{c}-3.426^{\star * *} \\
(0.569) \\
\end{array}$ \\
\hline População & $\begin{array}{c}-19.607^{* * *} \\
(4.272)\end{array}$ & $\begin{array}{c}-19.598^{* \star \star} \\
(4.272)\end{array}$ & $\begin{array}{c}-25.835^{\star \star \star} \\
(5.068)\end{array}$ & $\begin{array}{c}-25.837^{* \star *} \\
(5.069)\end{array}$ \\
\hline Tendência linear & $\begin{array}{c}-9.778^{* * *} \\
(0.601) \\
\end{array}$ & $\begin{array}{c}-9.758^{* * *} \\
(0.602) \\
\end{array}$ & $\begin{array}{c}-10.650^{* * *} \\
(0.681)\end{array}$ & $\begin{array}{c}-10.619^{* * *} \\
(0.681)\end{array}$ \\
\hline Tendência quadrática & $\begin{array}{l}-0.050^{*} \\
(0.030)\end{array}$ & $\begin{array}{l}-0.051^{*} \\
(0.030)\end{array}$ & $\begin{array}{c}0.021 \\
(0.033) \\
\end{array}$ & $\begin{array}{c}0.019 \\
(0.033) \\
\end{array}$ \\
\hline Constante & $\begin{array}{c}426.137^{* * *} \\
(42.827)\end{array}$ & $\begin{array}{c}426.712^{* * *} \\
(42.831)\end{array}$ & $\begin{array}{c}457.766^{* * *} \\
(51.742)\end{array}$ & $\begin{array}{c}459.387^{* * *} \\
(51.754)\end{array}$ \\
\hline $\mathrm{R}^{2}$ & 0,2892 & 0,2893 & 0,3395 & 0,3396 \\
\hline Observações & 66384 & 66384 & 33525 & 33525 \\
\hline Teste de Hausman & $\begin{array}{l}\chi^{2}=316,63 \\
\text { Prob }=0,00\end{array}$ & $\begin{array}{l}\chi^{2}=303,64 \\
\text { Prob }=0,00\end{array}$ & $\begin{array}{l}\chi^{2}=191,60 \\
\text { Prob }=0,00\end{array}$ & $\begin{array}{l}\chi^{2}=181,09 \\
\text { Prob }=0,00\end{array}$ \\
\hline
\end{tabular}

Fonte: elaboração própria 
Considerando os resultados apresentados na tabela 1.3, em ambas as amostras, o resultado da dummy de ano eleitoral corrobora a hipótese dos impulsos de despesa observados em tais anos, uma vez que o referido coeficiente assume valor positivo e estatisticamente significante em todas as estimações. As diferenças são observadas somente na magnitude destes coeficientes, uma vez que os valores do painel balanceado são mais elevados que na amostra não balanceada, tanto nas estimações sem interações como nas estimações com interações. É curioso notar também que em ambas as amostras e nos dois métodos de estimação, PT e PL tendem a executar relativamente menos recursos que o PMDB, o partido de referência na análise, na média de todo o período amostral, ao passo que em particular para a amostra não balanceada, observam-se coeficientes negativos e estatisticamente significativos para o PFL, PTB e PDS / PPB.

Especificamente em relação ao ano eleitoral, o único caso de distinção partidária é observado para o PSDB no painel não balanceado, sendo seu coeficiente positivo $(10,72)$ e estatisticamente significante a $5 \%$.

No caso da despesa corrente (tabela 1.4), o resultado deste primeiro procedimento de estimação permite observar um impulso de despesa nos anos eleitorais em relação à média do período com as mesmas características observadas no caso da despesa orçamentária, ou seja, coeficientes numericamente mais elevados para o painel balanceado. Neste caso, observa-se também que as estimações com interações apresentam coeficientes numericamente maiores que as estimações sem interações (no caso do painel balanceado, por exemplo, tal coeficiente assume valor igual a 16,19 na estimação sem as interações e valor igual a 20,26 no caso da estimação com as interações).

No que diz respeito às dummies de partido, os resultados comuns às duas amostras sinalizam que PFL e outros partidos apresentam coeficientes negativos e estatisticamente significantes a, no máximo $10 \%$. Particularmente no caso da amostra não balanceada, observam-se também coeficientes positivos e significativos para o PSDB e negativos para o PL, ao passo que na amostra balanceada, os resultados indicam que o PDT despende mais recursos que o partido de referência.

Em comum às duas amostras, as interações com a dummy de ano eleitoral sugerem que PFL executa relativamente menos recursos nos anos eleitorais comparativamente ao PMDB, uma vez que tais coeficientes assumem valores negativos e estatisticamente significantes a, no máximo, $10 \%$. Por sua vez, o grupo “outros partidos" no caso do painel não balanceado e o PDT no caso do painel balanceado também se distinguem também por possuírem coeficientes estatisticamente significantes a 5\% e negativos, iguais à $-8,2$ e $-12,81$ respectivamente. 
No que diz respeito aos resultados apresentados na tabela 1.5, somente no caso do painel balanceado os coeficientes das dummies de ano eleitoral parecem indicar algum comportamento distinto (e positivo) da despesa de pessoal em tais anos comparativamente aos demais, uma vez que a dummy de ano eleitoral do painel não balanceado (para as duas equações estimadas) assume valor estatisticamente nulo. De qualquer forma, os resultados associados ao painel não balanceado podem ser vistos como mais adequados uma vez que a amostra balanceada, por conter somente os municípios existentes em todo o período amostral, sofre um problema de viés de "permanência" ou de seleção.

Quanto aos partidos políticos, o único resultado comum às duas amostras está associado ao PSDB, que executa um maior volume de recursos nesta categoria do orçamento público. Em particular para a amostra não balanceada, observam-se coeficientes negativos para o PT, para o PDS / PPB e para o $\mathrm{PL}^{14}$.

Em relação às interações entre dummy de ano eleitoral e dummies de partido os resultados indicam que, para ambas as amostras, PFL e PL são agremiações que executam relativamente menos recursos nesta categoria do orçamento público nos anos eleitorais, novamente em relação ao partido de referência PMDB, uma vez que tais coeficientes assumem valores negativos e estatisticamente significantes a, no máximo, 5\%. No caso do painel não balanceado, o mesmo resultado também é observado para o grupo "outros partidos", cujo coeficiente é igual à $-4,92$ e estatisticamente significante a $5 \%$, e para o caso do painel balanceado, o coeficiente associado ao PSDB também assume valor negativo ($6,01)$ e estatisticamente significante a $10 \%$. Assim, os resultados sugerem que eventuais distinções partidárias especificamente nos anos eleitorais estão associadas a menores níveis de despesa de pessoal em relação ao partido de referência.

Conforme observado nos resultados da tabela 1.6, o caso das transferências correntes é relativamente distinto das demais variáveis uma vez que o volume de recursos despendidos nesta categoria em anos eleitorais é relativamente menor que na média dos demais anos - a título de ilustração, tais coeficientes assumem os valores -10,80 e -13,31 na amostra não balanceada e na amostra balanceada, respectivamente, considerando o caso sem interações com as dummies de partido.

No que diz respeito aos partidos políticos, é possível observar resultados interessantes uma vez que praticamente todas as dummies de partido (exceção feita ao PT no caso do painel não balanceado e na estimação sem interações) possuem significância estatística sendo que

\footnotetext{
${ }^{14}$ Os demais resultados variam entre as estimações com e sem interações.
} 
somente para o PSDB os coeficientes assumem valores negativos - para os demais partidos, os resultados indicam uma maior volume de transferências correntes realizadas comparativamente ao PMDB.

Particularmente quanto às interações entre dummies de partido e dummy de ano eleitoral, os resultados permitem também observar que PFL, PTB, PDT, PDS / PPB e o grupo formado pelos outros partidos são, em ambas as amostras, os únicos que parecem se diferenciar em relação ao PMDB, sendo seus coeficientes negativos e estatisticamente significantes a, no máximo, 10\%, sugerindo assim menores recursos destinados a esta categoria da despesa pública em tais anos. As dummies associadas ao PSDB, ao PT e ao PL são estatisticamente nulas.

Finalizando a análise das cinco categorias de despesa pública aqui consideradas, o comportamento distinto nos anos eleitorais nas despesas de investimento (tabela 1.7) é observado somente no caso sem interações da amostra balanceada, na qual o coeficiente da estimação apresenta sinal positivo (igual a 3,76) e significância estatística a 1\%. Deste modo, apenas neste caso são observadas evidências de execuções fiscais mais elevadas na média dos anos eleitorais, comparativamente aos demais anos.

Em relação às dummies de partido, os resultados comuns às duas amostras permitem observar coeficientes estatisticamente significantes e negativos para o PT, para o PDS / PPB e para o PL, sendo também observados coeficientes negativos para o PDT somente no caso do painel balanceado (nas estimações com e sem interações). Quanto às dummies de interações, somente os coeficientes associados grupo "outros partidos" $(6,92)$ no caso do painel não balanceado e ao PDS / PPB no caso do painel balanceado $(7,92)$ apresentam significância estatística, sugerindo em ambos os casos maiores investimentos em anos eleitorais novamente relativamente ao PMDB.

\section{4 - Modelo com dummies para cada ano eleitoral}

Nesta seção 1.4, são apresentados e discutidos os resultados das estimações em que são consideradas apenas as dummies de 1992, 1996 e 2000, novamente considerando as cinco variáveis dependentes anteriores. Em todos os casos, observa-se a consistência do estimador de efeitos fixos, cujos resultados norteiam as análises de cada estimação - os resultados obtidos através do procedimento de efeitos aleatórios e de dados agrupados (pooled - OLS) estão expostos no apêndice 1.c desta tese. Desta forma, realiza-se uma breve discussão dos 
coeficientes anteriormente mencionados, para cada categoria de despesa selecionada. Como esta forma funcional alternativa é estimada com vistas a analisar especificamente a questão dos ciclos eleitorais, ainda não é realizada uma análise mais profunda das variáveis partidárias e dos demais coeficientes, uma vez que esta avaliação é apresentada somente na seção 1.5, em que são apresentados os resultados do modelo mais abrangente entre os três estimados neste capítulo. Novamente, ressalta-se também a presença do termo de tendência linear e de tendência quadrática, conforme justificado na seção 1.3. 
Tabela 1.8-Despesa orçamentária-efeitos fixos

\begin{tabular}{|c|c|c|}
\hline $\begin{array}{c}\text { Regressor } \\
\text { (Erro padrão) }\end{array}$ & Painel não balanceado & Painel balanceado \\
\hline Receita tributária & $\begin{array}{l}1.205^{\star \star *} \\
(0.015)\end{array}$ & $\begin{array}{l}1.157^{* \star \star} \\
(0.018)\end{array}$ \\
\hline Receita de transferências & $\begin{array}{c}0.915^{* * *} \\
(0.004)\end{array}$ & $\begin{array}{l}0.881^{* * *} \\
(0.006)\end{array}$ \\
\hline Dummy 1992 & $\begin{array}{c}-11.831^{* * *} \\
(2.427)\end{array}$ & $\begin{array}{l}-5.474^{*} \\
(2.962)\end{array}$ \\
\hline Dummy 1996 & $\begin{array}{c}37.622^{* * *} \\
(2.485)\end{array}$ & $\begin{array}{c}40.016^{* * *} \\
(3.009)\end{array}$ \\
\hline Dummy 2000 & $\begin{array}{c}18.164^{* * *} \\
(2.190)\end{array}$ & $\begin{array}{c}22.064^{\star \star *} \\
(2.919)\end{array}$ \\
\hline PFL & $\begin{array}{l}-5.483^{\star *} \\
(2.193)\end{array}$ & $\begin{array}{l}-4.192 \\
(2.758)\end{array}$ \\
\hline PSDB & $\begin{array}{c}7.735^{\star * *} \\
(2.923) \\
\end{array}$ & $\begin{array}{l}6.314^{*} \\
(3.509) \\
\end{array}$ \\
\hline PT & $\begin{array}{c}-16.011^{* * *} \\
(5.468)\end{array}$ & $\begin{array}{c}-17.968^{* * *} \\
(6.170)\end{array}$ \\
\hline PTB & $\begin{array}{l}-5.517^{*} \\
(3.054)\end{array}$ & $\begin{array}{l}-3.283 \\
(3.643) \\
\end{array}$ \\
\hline PDT & $\begin{array}{l}-2.970 \\
(3.091)\end{array}$ & $\begin{array}{l}-2.911 \\
(3.616)\end{array}$ \\
\hline PDS / PPB & $\begin{array}{l}-6.215^{\star *} \\
(2.641) \\
\end{array}$ & $\begin{array}{l}-4.499 \\
(3.229) \\
\end{array}$ \\
\hline PL & $\begin{array}{c}-16.962^{* \star \star} \\
(3.588)\end{array}$ & $\begin{array}{c}-12.527^{\star \star *} \\
(4.504)\end{array}$ \\
\hline Outros & $\begin{array}{l}-5.544^{\star *} \\
(2.631) \\
\end{array}$ & $\begin{array}{l}-6.096^{*} \\
(3.344) \\
\end{array}$ \\
\hline Prefeito \& Governador & $\begin{array}{l}2.614^{* *} \\
(1.329) \\
\end{array}$ & $\begin{array}{c}6.980^{* \star *} \\
(1.684)\end{array}$ \\
\hline Prefeito \& Presidente & $\begin{array}{c}-9.580^{* * *} \\
(2.240)\end{array}$ & $\begin{array}{c}-8.157^{* * *} \\
(2.701)\end{array}$ \\
\hline Idosos & $\begin{array}{c}-11.334^{* * *} \\
(1.038)\end{array}$ & $\begin{array}{c}-11.546^{* \star *} \\
(1.371) \\
\end{array}$ \\
\hline Urbanização & $\begin{array}{l}0.260^{\star *} \\
(0.128) \\
\end{array}$ & $\begin{array}{l}0.426^{* *} \\
(0.182)\end{array}$ \\
\hline Jovens & $\begin{array}{l}-0.557 \\
(0.584) \\
\end{array}$ & $\begin{array}{l}-1.092 \\
(0.847) \\
\end{array}$ \\
\hline População & $\begin{array}{c}-82.906^{* * *} \\
(5.581)\end{array}$ & $\begin{array}{c}-101.906^{* * *} \\
(7.557)\end{array}$ \\
\hline Tendência linear & $\begin{array}{c}14.763^{* * *} \\
(0.791)\end{array}$ & $\begin{array}{c}18.323^{* * *} \\
(1.020)\end{array}$ \\
\hline Tendência quadrática & $\begin{array}{c}-1.058^{* * *} \\
(0.039) \\
\end{array}$ & $\begin{array}{c}-1.246^{\star * *} \\
(0.050)\end{array}$ \\
\hline Constante & $\begin{array}{c}952.569^{\star * *} \\
(55.978)\end{array}$ & $\begin{array}{c}1165.817^{* * *} \\
(77.225) \\
\end{array}$ \\
\hline $\mathrm{R}^{2}$ & 0,8567 & 0,8414 \\
\hline Observações & 66384 & 33525 \\
\hline Teste de Hausman & $\begin{array}{l}\chi^{2}=1436,41 \\
\text { Prob }=0,00\end{array}$ & $\begin{array}{l}\chi^{2}=1217,42 \\
\text { Prob }=0,00\end{array}$ \\
\hline
\end{tabular}

Fonte: elaboração própria 
Tabela 1.9-Despesa corrente - efeitos fixos

\begin{tabular}{|c|c|c|}
\hline $\begin{array}{c}\text { Regressor } \\
\text { (Erro padrão) }\end{array}$ & Painel não balanceado & Painel balanceado \\
\hline Receita tributária & $\begin{array}{c}0.834^{* * *} \\
(0.010)\end{array}$ & $\begin{array}{c}0.789^{* \star *} \\
(0.014)\end{array}$ \\
\hline Receita de transferências & $\begin{array}{c}0.713^{* * *} \\
(0.003)\end{array}$ & $\begin{array}{c}0.690^{* * *} \\
(0.004)\end{array}$ \\
\hline Dummy 1992 & $\begin{array}{c}-4.285^{\star \star} \\
(1.700)\end{array}$ & $\begin{array}{l}-1.077 \\
(2.313)\end{array}$ \\
\hline Dummy 1996 & $\begin{array}{c}24.561^{* * *} \\
(1.741)\end{array}$ & $\begin{array}{c}24.406^{* \star *} \\
(2.349)\end{array}$ \\
\hline Dummy 2000 & $\begin{array}{c}24.702^{\star \star \star} \\
(1.534)\end{array}$ & $\begin{array}{c}25.702^{* \star *} \\
(2.279)\end{array}$ \\
\hline PFL & $\begin{array}{c}-4.812^{* * *} \\
(1.536)\end{array}$ & $\begin{array}{c}-5.953^{* * *} \\
(2.153)\end{array}$ \\
\hline PSDB & $\begin{array}{l}7.631^{\star \star \star} \\
(2.048) \\
\end{array}$ & $\begin{array}{c}2.922 \\
(2.739) \\
\end{array}$ \\
\hline PT & $\begin{array}{l}-2.745 \\
(3.830) \\
\end{array}$ & $\begin{array}{c}0.037 \\
(4.816)\end{array}$ \\
\hline РTB & $\begin{array}{l}-3.415 \\
(2.140)\end{array}$ & $\begin{array}{l}-1.231 \\
(2.844)\end{array}$ \\
\hline PDT & $\begin{array}{l}-1.066 \\
(2.165)\end{array}$ & $\begin{array}{c}4.399 \\
(2.823)\end{array}$ \\
\hline PDS / PPB & $\begin{array}{l}-3.079^{*} \\
(1.850) \\
\end{array}$ & $\begin{array}{c}0.802 \\
(2.521) \\
\end{array}$ \\
\hline PL & $\begin{array}{c}-8.363^{\star \star *} \\
(2.513)\end{array}$ & $\begin{array}{l}-1.797 \\
(3.516) \\
\end{array}$ \\
\hline Outros & $\begin{array}{c}-7.759^{* * *} \\
(1.843)\end{array}$ & $\begin{array}{c}-8.428^{* * *} \\
(2.611)\end{array}$ \\
\hline Prefeito \& Governador & $\begin{array}{c}-2.942^{\star \star \star} \\
(0.931)\end{array}$ & $\begin{array}{c}3.513^{\star \star \star} \\
(1.315)\end{array}$ \\
\hline Prefeito \& Presidente & $\begin{array}{c}-6.247^{\star \star \star} \\
(1.569)\end{array}$ & $\begin{array}{l}-1.673 \\
(2.109)\end{array}$ \\
\hline Idosos & $\begin{array}{c}-3.142^{* * *} \\
(0.727)\end{array}$ & $\begin{array}{c}-3.346^{* * *} \\
(1.070)\end{array}$ \\
\hline Urbanização & $\begin{array}{l}0.210^{* *} \\
(0.090)\end{array}$ & $\begin{array}{c}0.168 \\
(0.142)\end{array}$ \\
\hline Jovens & $\begin{array}{c}2.558^{* * *} \\
(0.409)\end{array}$ & $\begin{array}{l}1.293^{*} \\
(0.661)\end{array}$ \\
\hline População & $\begin{array}{c}-55.783^{* * *} \\
(3.910)\end{array}$ & $\begin{array}{c}-62.959^{* * *} \\
(5.899)\end{array}$ \\
\hline Tendência linear & $\begin{array}{c}22.600^{* * *} \\
(0.554)\end{array}$ & $\begin{array}{c}26.683^{* * *} \\
(0.796)\end{array}$ \\
\hline Tendência quadrática & $\begin{array}{c}-0.945^{\star \star \star} \\
(0.027)\end{array}$ & $\begin{array}{c}-1.196^{\star * *} \\
(0.039)\end{array}$ \\
\hline Constante & $\begin{array}{c}488.422^{* * *} \\
(39.213)\end{array}$ & $\begin{array}{c}627.036^{\star * *} \\
(60.288)\end{array}$ \\
\hline$R^{2}$ & 0,8734 & 0,8565 \\
\hline Observações & 66384 & 33525 \\
\hline Teste de Hausman & $\begin{array}{l}\chi^{2}=2174,07 \\
\text { Prob }=0,00\end{array}$ & $\begin{array}{l}\chi^{2}=1232,12 \\
\text { Prob }=0,00\end{array}$ \\
\hline
\end{tabular}

Fonte: elaboração própria 
Tabela 1.10 - Despesa de pessoal - efeitos fixos

\begin{tabular}{|c|c|c|}
\hline $\begin{array}{c}\text { Regressor } \\
\text { (Erro padrão) }\end{array}$ & Painel não balanceado & Painel balanceado \\
\hline Receita tributária & $\begin{array}{c}0.295^{\star * * *} \\
(0.007)\end{array}$ & $\begin{array}{c}0.266^{* \star *} \\
(0.009)\end{array}$ \\
\hline Receita de transferências & $\begin{array}{c}0.294^{* * *} \\
(0.002)\end{array}$ & $\begin{array}{c}0.307^{* * *} \\
(0.003)\end{array}$ \\
\hline Dummy 1992 & $\begin{array}{c}-10.710^{\star \star \star} \\
(1.166) \\
\end{array}$ & $\begin{array}{c}-7.290^{\star \star \star} \\
(1.551) \\
\end{array}$ \\
\hline Dummy 1996 & $\begin{array}{c}6.245^{\star * *} \\
(1.194) \\
\end{array}$ & $\begin{array}{c}10.261^{* * *} \\
(1.575) \\
\end{array}$ \\
\hline Dummy 2000 & $\begin{array}{c}5.232^{* \star *} \\
(1.052)\end{array}$ & $\begin{array}{c}4.035^{\star \star \star} \\
(1.529)\end{array}$ \\
\hline PFL & $\begin{array}{l}-2.455^{\star *} \\
(1.054)\end{array}$ & $\begin{array}{l}-2.397^{*} \\
(1.444) \\
\end{array}$ \\
\hline PSDB & $\begin{array}{c}11.260^{\star \star \star} \\
(1.405)\end{array}$ & $\begin{array}{c}7.882^{\star \star \star *} \\
(1.837) \\
\end{array}$ \\
\hline PT & $\begin{array}{l}-4.515^{*} \\
(2.627) \\
\end{array}$ & $\begin{array}{l}-5.177 \\
(3.231) \\
\end{array}$ \\
\hline РTB & $\begin{array}{l}-1.395 \\
(1.468) \\
\end{array}$ & $\begin{array}{l}-0.406 \\
(1.908) \\
\end{array}$ \\
\hline PDT & $\begin{array}{c}1.440 \\
(1.485)\end{array}$ & $\begin{array}{c}2.909 \\
(1.893)\end{array}$ \\
\hline PDS / PPB & $\begin{array}{c}-3.513^{\star \star \star *} \\
(1.269) \\
\end{array}$ & $\begin{array}{l}-2.251 \\
(1.691) \\
\end{array}$ \\
\hline PL & $\begin{array}{c}-8.206^{\star * *} \\
(1.724)\end{array}$ & $\begin{array}{c}0.225 \\
(2.358) \\
\end{array}$ \\
\hline Outros & $\begin{array}{c}-3.325^{\star * *} \\
(1.264)\end{array}$ & $\begin{array}{l}-1.389 \\
(1.751) \\
\end{array}$ \\
\hline Prefeito \& Governador & $\begin{array}{l}-1.090^{*} \\
(0.639)\end{array}$ & $\begin{array}{c}0.565 \\
(0.882)\end{array}$ \\
\hline Prefeito \& Presidente & $\begin{array}{c}-3.751^{* * *} \\
(1.077) \\
\end{array}$ & $\begin{array}{l}-0.527 \\
(1.414) \\
\end{array}$ \\
\hline Idosos & $\begin{array}{l}-0.804 \\
(0.499) \\
\end{array}$ & $\begin{array}{l}-0.479 \\
(0.718) \\
\end{array}$ \\
\hline Urbanização & $\begin{array}{l}-0.093 \\
(0.062) \\
\end{array}$ & $\begin{array}{c}-0.256^{\star \star *} \\
(0.095)\end{array}$ \\
\hline Jovens & $\begin{array}{c}0.976^{* * *} \\
(0.280)\end{array}$ & $\begin{array}{l}-0.353 \\
(0.444)\end{array}$ \\
\hline População & $\begin{array}{c}-31.267^{* * *} \\
(2.682)\end{array}$ & $\begin{array}{c}-31.318^{* * *} \\
(3.957)\end{array}$ \\
\hline Tendência linear & $\begin{array}{c}5.305^{\star \star \star *} \\
(0.380)\end{array}$ & $\begin{array}{c}5.522^{* \star *} \\
(0.534)\end{array}$ \\
\hline Tendência quadrática & $\begin{array}{c}0.071^{* * *} \\
(0.019)\end{array}$ & $\begin{array}{l}-0.002 \\
(0.026) \\
\end{array}$ \\
\hline Constante & $\begin{array}{c}313.100^{* * *} \\
(26.898)\end{array}$ & $\begin{array}{c}383.180^{* \star *} \\
(40.437)\end{array}$ \\
\hline $\mathrm{R}^{2}$ & 0,6987 & 0,6967 \\
\hline Observações & 66384 & 33525 \\
\hline Teste de Hausman & $\begin{array}{l}\chi^{2}=1796,37 \\
\text { Prob }=0,00\end{array}$ & $\begin{array}{l}\chi^{2}=931,43 \\
\text { Prob }=0,00\end{array}$ \\
\hline
\end{tabular}

Fonte: elaboração própria 
Tabela 1.11 - Transferências correntes - efeitos fixos

\begin{tabular}{|c|c|c|}
\hline $\begin{array}{c}\text { Regressor } \\
\text { (Erro padrão) }\end{array}$ & Painel não balanceado & Painel balanceado \\
\hline Receita tributária & $\begin{array}{c}0.072^{* * *} \\
(0.007)\end{array}$ & $\begin{array}{c}0.035^{\star * *} \\
(0.009)\end{array}$ \\
\hline Receita de transferências & $\begin{array}{c}0.122^{* * *} \\
(0.002)\end{array}$ & $\begin{array}{c}0.094^{* * *} \\
(0.003)\end{array}$ \\
\hline Dummy 1992 & $\begin{array}{c}-12.395^{\star * \star} \\
(1.045) \\
\end{array}$ & $\begin{array}{c}-14.997^{* * *} \\
(1.378) \\
\end{array}$ \\
\hline Dummy 1996 & $\begin{array}{c}-22.984^{\star \star *} \\
(1.070) \\
\end{array}$ & $\begin{array}{c}-22.338^{* * *} \\
(1.399) \\
\end{array}$ \\
\hline Dummy 2000 & $\begin{array}{c}0.061 \\
(1.015) \\
\end{array}$ & $\begin{array}{c}-2.991^{\star *} \\
(1.467) \\
\end{array}$ \\
\hline PFL & $\begin{array}{c}7.556^{* * *} \\
(1.042) \\
\end{array}$ & $\begin{array}{c}7.317^{\star * *} \\
(1.394)\end{array}$ \\
\hline PSDB & $\begin{array}{c}-11.188^{* * *} \\
(1.458) \\
\end{array}$ & $\begin{array}{c}-11.702^{* * *} \\
(1.864) \\
\end{array}$ \\
\hline PT & $\begin{array}{c}4.458 \\
(2.768) \\
\end{array}$ & $\begin{array}{c}3.690 \\
(3.326) \\
\end{array}$ \\
\hline PTB & $\begin{array}{c}4.720^{* * *} \\
(1.450) \\
\end{array}$ & $\begin{array}{c}7.159^{* * \star} \\
(1.849) \\
\end{array}$ \\
\hline PDT & $\begin{array}{c}8.518^{* * *} \\
(1.443)\end{array}$ & $\begin{array}{c}10.383^{* * *} \\
(1.797)\end{array}$ \\
\hline PDS / PPB & $\begin{array}{c}6.079^{* * *} \\
(1.252) \\
\end{array}$ & $\begin{array}{c}8.105^{\star * *} \\
(1.628) \\
\end{array}$ \\
\hline PL & $\begin{array}{c}6.557^{* * *} \\
(1.686) \\
\end{array}$ & $\begin{array}{c}9.267^{* * *} \\
(2.255) \\
\end{array}$ \\
\hline Outros & $\begin{array}{c}8.277^{* * *} \\
(1.246) \\
\end{array}$ & $\begin{array}{c}6.606^{* * *} \\
(1.699) \\
\end{array}$ \\
\hline Prefeito \& Governador & $\begin{array}{l}-0.066 \\
(0.626) \\
\end{array}$ & $\begin{array}{c}0.887 \\
(0.848) \\
\end{array}$ \\
\hline Prefeito \& Presidente & $\begin{array}{c}23.086^{* * *} \\
(1.076)\end{array}$ & $\begin{array}{c}22.796^{* * *} \\
(1.381)\end{array}$ \\
\hline Idosos & $\begin{array}{c}12.041^{* * *} \\
(0.598) \\
\end{array}$ & $\begin{array}{c}9.702^{* * *} \\
(0.848) \\
\end{array}$ \\
\hline Urbanização & $\begin{array}{c}-0.206^{* * *} \\
(0.076) \\
\end{array}$ & $\begin{array}{l}-0.213^{*} \\
(0.112) \\
\end{array}$ \\
\hline Jovens & $\begin{array}{c}4.308^{* \star *} \\
(0.304) \\
\end{array}$ & $\begin{array}{c}2.602^{* \star *} \\
(0.475) \\
\end{array}$ \\
\hline População & $\begin{array}{l}6.336^{\star *} \\
(2.972) \\
\end{array}$ & $\begin{array}{c}1.135 \\
(4.302) \\
\end{array}$ \\
\hline Tendência linear & $\begin{array}{c}3.058^{* \star *} \\
(0.427)\end{array}$ & $\begin{array}{c}5.530^{* \star *} \\
(0.591)\end{array}$ \\
\hline Tendência quadrática & $\begin{array}{c}0.114^{\star \star *} \\
(0.025) \\
\end{array}$ & $\begin{array}{c}0.028 \\
(0.034) \\
\end{array}$ \\
\hline Constante & $\begin{array}{c}-296.997^{* * *} \\
(30.221) \\
\end{array}$ & $\begin{array}{c}-159.195^{\star * *} \\
(44.401) \\
\end{array}$ \\
\hline $\mathrm{R}^{2}$ & 0,2507 & 0,2641 \\
\hline Observações & 56315 & 29055 \\
\hline Teste de Hausman & $\begin{array}{l}\chi^{2}=715,81 \\
\text { Prob }=0,00\end{array}$ & $\begin{array}{l}\chi^{2}=265,06 \\
\text { Prob }=0,00\end{array}$ \\
\hline
\end{tabular}

Fonte: elaboração própria 
Tabela 1.12 - Investimentos - efeitos fixos

\begin{tabular}{|c|c|c|}
\hline $\begin{array}{c}\text { Regressor } \\
\text { (Erro padrão) }\end{array}$ & Painel não balanceado & Painel balanceado \\
\hline Receita tributária & $\begin{array}{c}0.346^{* * *} \\
(0.011)\end{array}$ & $\begin{array}{c}0.345^{\star \star \star *} \\
(0.012)\end{array}$ \\
\hline Receita de transferências & $\begin{array}{l}0.184^{* * *} \\
(0.003)\end{array}$ & $\begin{array}{l}0.172^{* * *} \\
(0.004)\end{array}$ \\
\hline Dummy 1992 & $\begin{array}{l}-2.955 \\
(1.857) \\
\end{array}$ & $\begin{array}{c}0.330 \\
(1.986) \\
\end{array}$ \\
\hline Dummy 1996 & $\begin{array}{c}13.443^{* * *} \\
(1.901)\end{array}$ & $\begin{array}{c}15.886^{* \star *} \\
(2.017)\end{array}$ \\
\hline Dummy 2000 & $\begin{array}{c}-6.458^{* \star \star} \\
(1.675)\end{array}$ & $\begin{array}{l}-3.270^{*} \\
(1.958)\end{array}$ \\
\hline PFL & $\begin{array}{l}-1.023 \\
(1.678)\end{array}$ & $\begin{array}{l}1.014 \\
(1.849)\end{array}$ \\
\hline PSDB & $\begin{array}{l}-0.805 \\
(2.237) \\
\end{array}$ & $\begin{array}{l}2.000 \\
(2.352)\end{array}$ \\
\hline PT & $\begin{array}{c}-11.507^{* * *} \\
(4.183)\end{array}$ & $\begin{array}{c}-16.994^{* * *} \\
(4.137)\end{array}$ \\
\hline РTB & $\begin{array}{l}-2.182 \\
(2.337)\end{array}$ & $\begin{array}{l}-2.844 \\
(2.443)\end{array}$ \\
\hline PDT & $\begin{array}{l}-2.514 \\
(2.365)\end{array}$ & $\begin{array}{c}-8.400^{\star \star *} \\
(2.424)\end{array}$ \\
\hline PDS / PPB & $\begin{array}{l}-3.132 \\
(2.021)\end{array}$ & $\begin{array}{c}-5.319^{\star \star} \\
(2.165)\end{array}$ \\
\hline $\mathrm{PL}$ & $\begin{array}{c}-8.547^{* * \star} \\
(2.745)\end{array}$ & $\begin{array}{c}-11.405^{\text {*** }} \\
(3.020)\end{array}$ \\
\hline Outros & $\begin{array}{l}2.430 \\
(2.013)\end{array}$ & $\begin{array}{c}2.671 \\
(2.242)\end{array}$ \\
\hline Prefeito \& Governador & $\begin{array}{c}5.395^{\star \star \star *} \\
(1.017)\end{array}$ & $\begin{array}{c}3.858^{* \star \star} \\
(1.129)\end{array}$ \\
\hline Prefeito \& Presidente & $\begin{array}{l}-3.060^{*} \\
(1.714)\end{array}$ & $\begin{array}{c}-6.356^{\star \star *} \\
(1.811)\end{array}$ \\
\hline Idosos & $\begin{array}{c}-8.926^{* * *} \\
(0.794)\end{array}$ & $\begin{array}{c}-9.032^{* * *} \\
(0.919)\end{array}$ \\
\hline Urbanização & $\begin{array}{c}0.027 \\
(0.098)\end{array}$ & $\begin{array}{c}0.199 \\
(0.122)\end{array}$ \\
\hline Jovens & $\begin{array}{c}-3.872^{\star \star *} \\
(0.447)\end{array}$ & $\begin{array}{c}-3.472^{\star \star \star} \\
(0.568)\end{array}$ \\
\hline População & $\begin{array}{c}-20.137^{* * *} \\
(4.270)\end{array}$ & $\begin{array}{c}-26.824^{* * *} \\
(5.067)\end{array}$ \\
\hline Tendência linear & $\begin{array}{c}-10.250^{* * *} \\
(0.605)\end{array}$ & $\begin{array}{c}-11.103^{* * *} \\
(0.684)\end{array}$ \\
\hline Tendência quadrática & $\begin{array}{l}-0.018 \\
(0.030)\end{array}$ & $\begin{array}{c}0.054 \\
(0.033)\end{array}$ \\
\hline Constante & $\begin{array}{c}437.976^{* * *} \\
(42.830)\end{array}$ & $\begin{array}{c}475.724^{* * *} \\
(51.779)\end{array}$ \\
\hline$R^{2}$ & 0,2900 & 0,3389 \\
\hline Observações & 66384 & 33525 \\
\hline Teste de Hausman & $\begin{array}{l}\chi^{2}=258,30 \\
\text { Prob }=0,00\end{array}$ & $\begin{array}{l}\chi^{2}=197,31 \\
\text { Prob }=0,00\end{array}$ \\
\hline
\end{tabular}

Fonte: elaboração própria 
No caso da despesa orçamentária (tabela 1.8), os resultados das dummies de anos eleitorais permitem observar a presença dos impulsos positivos de gastos nos anos de 1996 e 2000, ao passo que em 1992 o resultado é distinto dos demais, uma vez que o coeficiente negativo parece indicar um comportamento fiscal relativamente conservador em relação à média dos demais anos. Os resultados entre as duas amostras são bastante similares, diferindo apenas nos valores dos coeficientes (os coeficientes da amostra balanceada são numericamente maiores), mas mantendo sempre o sinal e a significância estatística. Desta forma, os resultados deste procedimento permitem, em alguma medida (ou seja, nos dois últimos dos três anos de eleições municipais contemplados na amostra), corroborar a percepção dos impulsos de gastos em anos eleitorais na despesa orçamentária dos municípios brasileiros.

Quanto ao caso das despesas correntes (tabela 1.9), os resultados permitem observar novamente o impulso positivo nos dois últimos dos três anos eleitorais existentes na amostra relativamente, à média dos demais anos, ao passo que em 1992, o coeficiente da dummy é negativo no painel não balanceado e estatisticamente nulo no painel balanceado. Assim, em termos gerais, os resultados indicam a presença dos impulsos em anos eleitorais no caso das despesas correntes sendo os efeitos observados em 1996 e 2000 bastante semelhantes tendo em mente a magnitude dos coeficientes em ambas as amostras. Por sua vez, no caso da despesa de pessoal (tabela 1.10), todas as dummies de anos eleitorais apresentam significância estatística e, de forma semelhante à observada no caso da despesa orçamentária, observam-se impulsos positivos de despesa nos anos de 1996 e 2000 e um impulso negativo no ano de 1992, em ambas as amostras.

O caso das transferências correntes (tabela 1.11) novamente demonstra ser um caso distinto dos demais, uma vez que os coeficientes das dummies dos anos eleitorais são negativos, sugerindo deste modo menores volumes de transferências realizadas em tais anos, comparativamente à média dos demais anos do período amostral aqui analisado - somente no caso do ano de 2000 no painel não balanceado a dummy assume valor estatisticamente nulo.

Por fim, no caso das despesas de investimento (tabela 1.12), alguma influência positiva do calendário eleitoral sobre as execuções orçamentárias parece ser verdadeira especialmente no ano de 1996, novamente tendo como referência a média dos anos não eleitorais - observa-se que os coeficientes são estatisticamente significantes a $1 \%$ e iguais a 13,44 e 15,88 no painel não balanceado e no painel balanceado, respectivamente. Para o ano de 1992 observa-se que as dummies são estatisticamente nulas em ambas as amostras, não indicando assim nenhum comportamento distinto dos investimentos públicos, ao passo que 
em 2000 os coeficientes assumem valores negativos (e estatisticamente significantes a no máximo 10\%) em ambas as amostras, sugerindo assim contrações dos investimentos públicos em tal ano - novamente, a diferença entre as duas amostras tendem a ser relativamente restrita, sendo observados coeficientes numericamente maiores para o painel balanceado, mas mantendo as características em comum.

\section{5 - Modelo com todas as dummies de ano}

Finalmente, nesta seção 1.5, são apresentados os resultados em que todas as dummies de ano são inseridas explicitamente nas estimações. Os gráficos apresentados na seqüência das tabelas de regressões contém os resultados das dummies de ano e das dummies de partidos, tanto para a amostra não balanceada como para a amostra balanceada, tendo em mente os resultados obtidos através do procedimento de estimação consistente (que em todos os casos, vem a ser o método de efeitos fixos).

Conforme esclarecido anteriormente, apresentam-se somente os resultados obtidos através do procedimento de efeitos fixos, sendo os resultados obtidos através do procedimento de efeitos aleatórios e dados agrupados (pooled - OLS) expostos no apêndice 1.d desta tese. Adicionalmente, para este modelo mais geral, são realizados testes de igualdade entre as dummies de partido (entre todos os pares possíveis - vide apêndice 1e), com vistas a captar as diferenças relativas entre os grupos políticos avaliados. Por sua vez, é retirada das estimações a dummy associada ao ano de 1989 sendo este, portanto, o ano de referência na análise. Finalmente, ressalta-se a exclusão da dummy associada ao PMDB com vistas a evitar multicolinearidade perfeita nas regressões ressaltando-se também, com vistas a facilitar a interpretação dos resultados.

Feitas estas considerações, seguem-se as análises de cada um dos cinco componentes da despesa pública analisadas neste estudo. 
Tabela 1.13-Despesa orçamentária - efeitos fixos

\begin{tabular}{|c|c|c|}
\hline $\begin{array}{c}\text { Regressor } \\
\text { (Erro padrão) }\end{array}$ & Painel não balanceado & Painel balanceado \\
\hline Receita tributária & $\begin{array}{l}1.167^{* * *} \\
(0.015)\end{array}$ & $\begin{array}{l}1.104^{* * *} \\
(0.018)\end{array}$ \\
\hline Receita de transferências & $\begin{array}{l}0.868^{\star * *} \\
(0.004)\end{array}$ & $\begin{array}{l}0.827^{\star \star \star} \\
(0.006)\end{array}$ \\
\hline Dummy 1990 & $\begin{array}{c}35.809^{* * *} \\
(3.306)\end{array}$ & $\begin{array}{c}44.167^{* \star *} \\
(4.067)\end{array}$ \\
\hline Dummy 1991 & $\begin{array}{c}14.856^{\star \star \star} \\
(3.384)\end{array}$ & $\begin{array}{c}20.359^{\star \star \star} \\
(4.163)\end{array}$ \\
\hline Dummy 1992 & $\begin{array}{c}16.809^{* * *} \\
(3.517)\end{array}$ & $\begin{array}{c}33.558^{* * *} \\
(4.347)\end{array}$ \\
\hline Dummy 1993 & $\begin{array}{c}-13.711^{* * *} \\
(3.608)\end{array}$ & $\begin{array}{l}-0.023 \\
(2.300)\end{array}$ \\
\hline Dummy 1994 & $\begin{array}{c}21.540^{* * *} \\
(3.853)\end{array}$ & $\begin{array}{c}34.770^{* \star *} \\
(4.816)\end{array}$ \\
\hline Dummy 1995 & $\begin{array}{c}45.007^{\star * \star} \\
(4.258)\end{array}$ & $\begin{array}{c}65.052^{\star \star *} \\
(5.426)\end{array}$ \\
\hline Dummy 1996 & $\begin{array}{c}80.667^{* * *} \\
(4.552)\end{array}$ & $\begin{array}{c}102.251^{* * *} \\
(5.856)\end{array}$ \\
\hline Dummy 1997 & $\begin{array}{c}16.399^{* * *} \\
(4.646)\end{array}$ & $\begin{array}{c}36.025^{\star \star \star} \\
(6.148)\end{array}$ \\
\hline Dummy 1998 & $\begin{array}{c}100.029^{* * *} \\
(5.127)\end{array}$ & $\begin{array}{c}115.907^{* * *} \\
(6.700)\end{array}$ \\
\hline Dummy 1999 & $\begin{array}{c}47.845^{\star * *} \\
(5.388)\end{array}$ & $\begin{array}{c}69.849^{* * *} \\
(7.077)\end{array}$ \\
\hline Dummy 2000 & $\begin{array}{c}43.466^{* * \star} \\
(5.616)\end{array}$ & $\begin{array}{c}65.865^{\star * \star} \\
(7.468)\end{array}$ \\
\hline Dummy 2001 & $\begin{array}{c}18.630^{* * *} \\
(5.933)\end{array}$ & $\begin{array}{c}32.642^{\star \star *} \\
(7.904)\end{array}$ \\
\hline Dummy 2002 & $\begin{array}{c}7.301 \\
(6.349)\end{array}$ & $\begin{array}{c}19.289^{* *} \\
(8.423)\end{array}$ \\
\hline Dummy 2003 & $\begin{array}{c}-33.964^{* * *} \\
(6.532)\end{array}$ & $\begin{array}{c}-17.541^{* *} \\
(8.727)\end{array}$ \\
\hline PFL & $\begin{array}{l}-3.839^{*} \\
(2.169) \\
\end{array}$ & $\begin{array}{l}-2.729 \\
(2.729) \\
\end{array}$ \\
\hline PSDB & $\begin{array}{l}-0.181 \\
(3.017)\end{array}$ & $\begin{array}{l}-3.833 \\
(3.517)\end{array}$ \\
\hline PT & $\begin{array}{c}-17.273^{* * *} \\
(5.398)\end{array}$ & $\begin{array}{c}-20.982^{* * *} \\
(6.082)\end{array}$ \\
\hline PTB & $\begin{array}{l}-3.995 \\
(3.027)\end{array}$ & $\begin{array}{l}-1.633 \\
(3.629)\end{array}$ \\
\hline PDT & $\begin{array}{l}-1.582 \\
(3.042)\end{array}$ & $\begin{array}{l}-2.051 \\
(3.598)\end{array}$ \\
\hline PDS / PPB & $\begin{array}{l}-5.715^{\star \star} \\
(2.622)\end{array}$ & $\begin{array}{l}-4.075 \\
(3.184) \\
\end{array}$ \\
\hline PL & $\begin{array}{c}-14.989^{* * *} \\
(3.543)\end{array}$ & $\begin{array}{l}-9.434^{\star *} \\
(4.429)\end{array}$ \\
\hline Outros & $\begin{array}{l}-0.853 \\
(2.585)\end{array}$ & $\begin{array}{l}-0.606 \\
(3.367)\end{array}$ \\
\hline Prefeito \& Governador & $\begin{array}{l}3.028^{* *} \\
(1.317)\end{array}$ & $\begin{array}{c}6.259^{\star * *} \\
(1.660)\end{array}$ \\
\hline Prefeito \& Presidente & $\begin{array}{c}0.185 \\
(2.313)\end{array}$ & $\begin{array}{c}4.192 \\
(2.931)\end{array}$ \\
\hline Idosos & $\begin{array}{c}-10.917^{* * *} \\
(1.029)\end{array}$ & $\begin{array}{c}-11.009^{* * *} \\
(1.356)\end{array}$ \\
\hline Urbanização & $\begin{array}{l}0.292^{* *} \\
(0.126)\end{array}$ & $\begin{array}{c}0.479^{* * *} \\
(0.179)\end{array}$ \\
\hline Jovens & $\begin{array}{l}-0.724 \\
(0.575)\end{array}$ & $\begin{array}{l}-1.007 \\
(0.832)\end{array}$ \\
\hline População & $\begin{array}{c}-100.112^{* \star *} \\
(5.528) \\
\end{array}$ & $\begin{array}{c}-120.820^{* * *} \\
(7.463) \\
\end{array}$ \\
\hline Constante & $\begin{array}{c}1150.187^{* * *} \\
(55.484)\end{array}$ & $\begin{array}{c}1376.513^{* * \star} \\
(76.388)\end{array}$ \\
\hline $\mathrm{R}^{2}$ & 0,8445 & 0,8195 \\
\hline Observações & 66384 & 33525 \\
\hline Teste de Hausman & $\begin{array}{c}\chi^{2}=2088,57 \\
\text { Prob }=0,00\end{array}$ & $\begin{array}{l}\chi^{2}=1586,96 \\
\text { Prob }=0,00\end{array}$ \\
\hline
\end{tabular}

Fonte: elaboração própria 
Gráfico 1.8 - Despesa orçamentária

dummies de ano - painel não balanceado

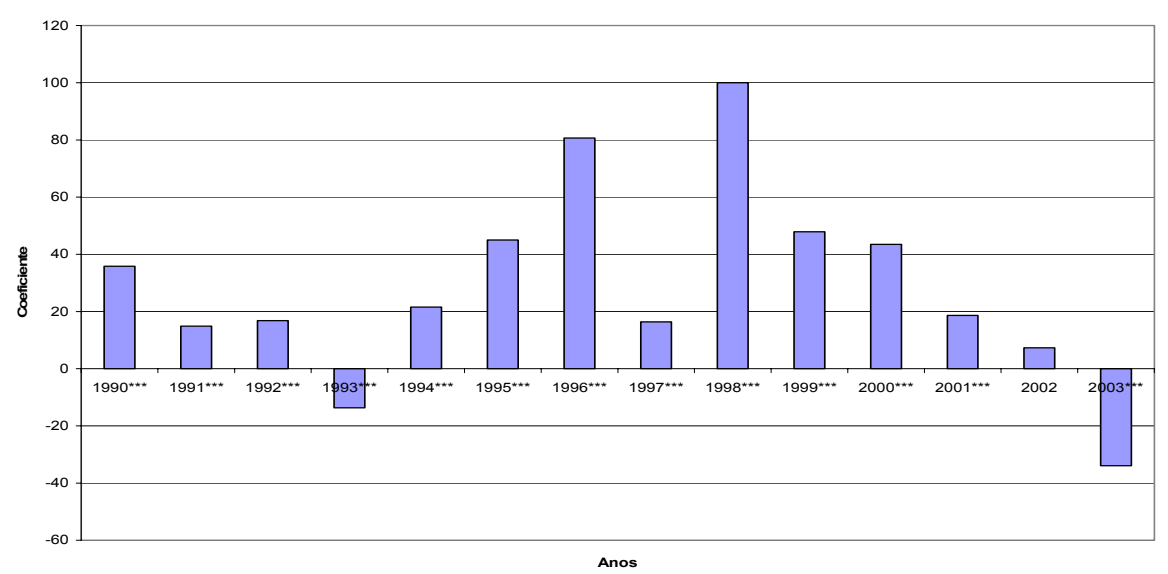

Fonte: elaboração própria

Gráfico 1.10 - Despesa orçamentária dummies de partido - painel não balanceado

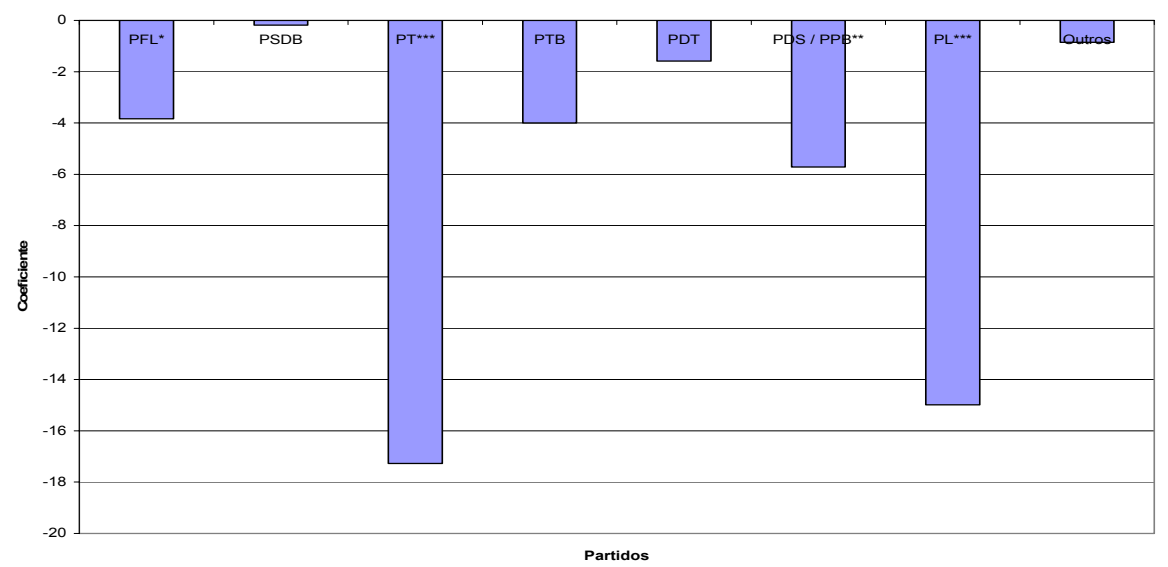

Fonte: elaboração própria
Gráfico 1.9 - Despesa orçamentária

dummies de ano-painel balanceado

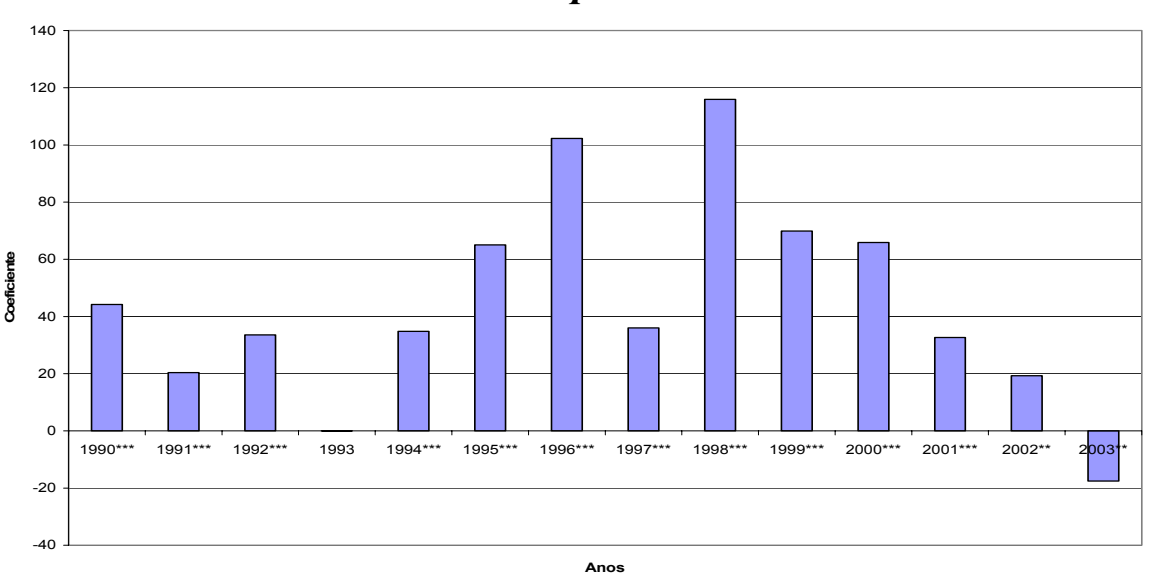

Fonte: elaboração própria

Gráfico 1.11 - Despesa orçamentária dummies de partido-painel balanceado

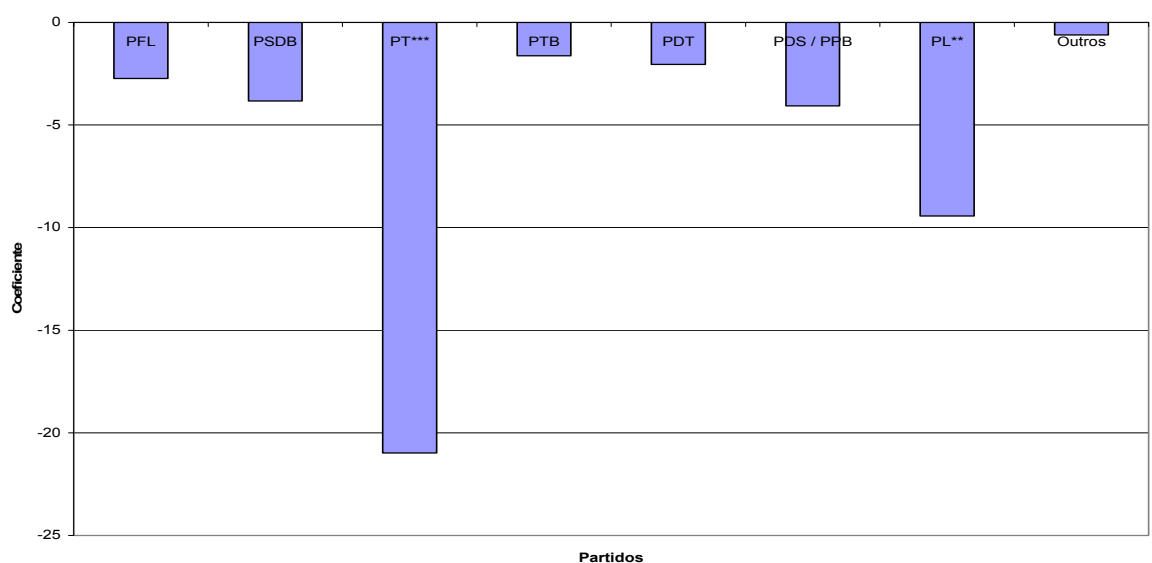

Fonte: elaboração própria 


\section{Despesa orçamentária}

Tanto no painel balanceado como no painel não balanceado, o teste de Hausman indica a consistência do estimador de efeitos fixos. Considerando a título de ilustração os resultados obtidos por tal procedimento para o painel não balanceado, os coeficientes indicam que para cada real de receita tributária e de receita de transferências obtida pelos municípios, $\mathrm{R} \$ 1,16$ e R \$ 0,86 são respectivamente destinados ao total das despesas municipais (note que os coeficientes obtidos para o painel balanceado são bastante semelhantes). Assim, estes resultados sugerem que os municípios tendem a ser mais conservadores na gestão dos recursos transferidos pela União e pelos governos estaduais comparativamente aos recursos oriundos de tributação local, o que pode ser explicado pela significativa preponderância que a primeira destas fontes de recursos exerce sobre o total de recursos disponíveis pelas prefeituras. Em outros termos, a pequena (e muitas vezes residual) participação da receita tributária sobre a receita total dos municípios pode fazer com que os mesmos sejam administrados de forma menos conservadora.

Em ambas as amostras consideradas, as dummies de tempo apresentam a princípio uma tendência positiva dentro do período considerado. Especificamente a respeito dos anos eleitorais, os testes de hipótese (apêndice 1e.1) indicam que em 1992 o impulso positivo de gastos (comparativamente a 1991 e 1993) é observado somente para o painel balanceado. Por sua vez, em 1996 o impulso positivo (comparativamente a 1995 e 1997) é observado para ambas as amostras e a diferença parece residir na magnitude destes efeitos, uma vez que na amostra balanceada tais impulsos são aparentemente maiores do que na amostra não balanceada - a dummy de 1996 é aproximadamente igual a 80 no painel não balanceado e aproximadamente igual a 102 no painel balanceado. Finalmente, em 2000, os resultados dos testes estatísticos não permitem descartar a hipótese de que a dummy de tal ano (para ambas as amostras) seja estatisticamente igual à dummy de 1999, além do fato da dummy de 2000 ser estatisticamente superior a dummy de 2001 (também para ambas as amostras) - em termos gerais, entre 1998 e 2001 as dummies têm comportamento sistematicamente descendente, o que descaracteriza o ano de 2000 como sendo um ano eleitoral nos padrões aqui considerados.

Os testes de igualdade das dummies de partido indicam alguns resultados comuns às duas amostras, sendo que o PT é o partido que mais se diferencia em relação a todos os demais (à exceção do PL), despendendo ceteris paribus relativamente menos recursos no total da despesa municipal, conforme o próprio gráfico das dummies de partido sugere - em ambas as amostras, a dummy associada ao partido mencionado apresenta magnitude relativamente 
semelhante. Por sua vez, o PL (que como visto, não apresenta distinção estatisticamente significante em relação ao PT) também se caracteriza por ser conservador na gestão da despesa orçamentária, relativamente ao PMDB e ao grupo outros partidos ${ }^{15}$. De qualquer forma, os resultados obtidos não evidenciam nenhuma diferenciação mais significativa entre os partidos políticos brasileiros, ao menos no que diz respeito ao montante (nível) total de recursos executados nesta categoria de despesa.

Em ambas as amostras o alinhamento político entre prefeito municipal e governador estadual parece influenciar o comportamento dos gastos municipais, sugerindo que tal efeito eleva o total de recursos executados pela prefeitura (elevações da ordem de R 33 per capita no painel não balanceado e $\mathrm{R} \$ 6,26$ per capita no painel balanceado). Já em relação ao alinhamento partidário com o governo federal, não há aparentemente nenhuma influência sobre a despesa orçamentária municipal. Por fim, todos os indicadores demográficos utilizados como variáveis de controle nas regressões apresentam significância estatística nas duas amostras, a exceção da proporção de jovens: os resultados indicam que uma maior proporção de idosos nos municípios e uma maior população tendem a afetar negativamente o total dos gastos realizados, ao passo que um maior grau de urbanização afeta positivamente a despesa orçamentária. Assim, tais resultados podem estar associados ao fato de que a participação relativa (per capita) do setor público diminui à medida que o porte populacional dos municípios aumenta e à medida que a composição etária da população é composta por indivíduos mais velhos. Por fim, o último destes resultados pode ser considerado natural, indicando que municípios com uma maior taxa de urbanização tendem a ter uma maior atuação relativa do setor público.

\footnotetext{
${ }^{15}$ Em particular para a amostra não balanceada, os resultados ainda indicam que o PL despende menos recursos relativamente ao PFL, PDS / PPB, PSDB, PDT e PTB, sugerindo adicionalmente que PMDB despende relativamente mais recursos que PFL e PDS / PPB.
} 
Tabela 1.14 - Despesa corrente - efeitos fixos

\begin{tabular}{|c|c|c|}
\hline $\begin{array}{c}\text { Regressor } \\
\text { (Erro padrão) }\end{array}$ & Painel não balanceado & Painel balanceado \\
\hline Receita tributária & $\begin{array}{l}0.825^{\star \star \star} \\
(0.010)\end{array}$ & $\begin{array}{c}0.771^{\star * *} \\
(0.014)\end{array}$ \\
\hline Receita de transferências & $\begin{array}{c}0.693^{* * *} \\
(0.003)\end{array}$ & $\begin{array}{c}0.664^{\star * *} \\
(0.005)\end{array}$ \\
\hline Dummy 1990 & $\begin{array}{c}-8.401^{* * *} \\
(2.295)\end{array}$ & $\begin{array}{l}-5.767^{*} \\
(3.151) \\
\end{array}$ \\
\hline Dummy 1991 & $\begin{array}{l}8.338^{\star \star \star} \\
(2.349)\end{array}$ & $\begin{array}{l}7.360^{\star \star} \\
(3.228)\end{array}$ \\
\hline Dummy 1992 & $\begin{array}{c}24.009^{* * *} \\
(2.437)\end{array}$ & $\begin{array}{c}34.345^{* * *} \\
(3.370)\end{array}$ \\
\hline Dummy 1993 & $\begin{array}{c}12.873^{\star \star \star} \\
(2.504)\end{array}$ & $\begin{array}{c}30.519^{\star \star \star} \\
(3.460)\end{array}$ \\
\hline Dummy 1994 & $\begin{array}{c}20.996^{\star \star \star} \\
(2.675)\end{array}$ & $\begin{array}{c}32.340^{\star \star \star} \\
(3.734)\end{array}$ \\
\hline Dummy 1995 & $\begin{array}{c}60.518^{\star * *} \\
(2.954)\end{array}$ & $\begin{array}{c}71.026^{\star * *} \\
(4.208)\end{array}$ \\
\hline Dummy 1996 & $\begin{array}{c}99.968^{\star * *} \\
(3.159)\end{array}$ & $\begin{array}{c}113.801^{* \star *} \\
(4.539)\end{array}$ \\
\hline Dummy 1997 & $\begin{array}{c}80.901^{\star \star \star *} \\
(3.219)\end{array}$ & $\begin{array}{c}99.104^{\star \star \star} \\
(4.769)\end{array}$ \\
\hline Dummy 1998 & $\begin{array}{c}123.029^{* * *} \\
(3.557)\end{array}$ & $\begin{array}{c}139.162^{* * *} \\
(5.195)\end{array}$ \\
\hline Dummy 1999 & $\begin{array}{c}126.369^{* * \star} \\
(3.738)\end{array}$ & $\begin{array}{c}137.299^{* * *} \\
(5.485)\end{array}$ \\
\hline Dummy 2000 & $\begin{array}{c}120.060^{* * *} \\
(3.897) \\
\end{array}$ & $\begin{array}{c}131.264^{* * *} \\
(5.788)\end{array}$ \\
\hline Dummy 2001 & $\begin{array}{c}116.738^{\star * *} \\
(4.115)\end{array}$ & $\begin{array}{c}122.814^{* * *} \\
(6.135)\end{array}$ \\
\hline Dummy 2002 & $\begin{array}{c}63.345^{* * *} \\
(4.393)\end{array}$ & $\begin{array}{c}68.505^{\star * *} \\
(6.537)\end{array}$ \\
\hline Dummy 2003 & $\begin{array}{c}75.840^{\star * *} \\
(4.536)\end{array}$ & $\begin{array}{c}77.096^{\star * \star} \\
(6.763)\end{array}$ \\
\hline PFL & $\begin{array}{c}-4.707^{\star \star \star} \\
(1.509)\end{array}$ & $\begin{array}{c}-7.259^{\star * \star} \\
(2.116)\end{array}$ \\
\hline PSDB & $\begin{array}{c}0.909 \\
(2.020) \\
\end{array}$ & $\begin{array}{l}-4.624^{*} \\
(2.736) \\
\end{array}$ \\
\hline PT & $\begin{array}{l}-4.599 \\
(3.739) \\
\end{array}$ & $\begin{array}{l}-4.877 \\
(4.689) \\
\end{array}$ \\
\hline PTB & $\begin{array}{l}-4.050^{*} \\
(2.098)\end{array}$ & $\begin{array}{l}-2.787 \\
(2.787)\end{array}$ \\
\hline PDT & $\begin{array}{l}-2.039 \\
(2.124) \\
\end{array}$ & $\begin{array}{c}1.032 \\
(2.789) \\
\end{array}$ \\
\hline PDS / PPB & $\begin{array}{l}-4.228^{* *} \\
(1.815) \\
\end{array}$ & $\begin{array}{l}-2.108 \\
(2.480) \\
\end{array}$ \\
\hline PL & $\begin{array}{c}-8.293^{* * *} \\
(2.461)\end{array}$ & $\begin{array}{l}-1.588 \\
(3.452)\end{array}$ \\
\hline Outros & $\begin{array}{l}-3.457^{*} \\
(1.810)\end{array}$ & $\begin{array}{c}-5.123^{\star *} \\
(2.562)\end{array}$ \\
\hline Prefeito \& Governador & $\begin{array}{l}-0.434 \\
(0.923)\end{array}$ & $\begin{array}{c}3.677^{* * *} \\
(1.290) \\
\end{array}$ \\
\hline Prefeito \& Presidente & $\begin{array}{l}-3.316^{\star *} \\
(1.675)\end{array}$ & $\begin{array}{l}-0.612 \\
(2.267)\end{array}$ \\
\hline Idosos & $\begin{array}{c}-3.094^{* * *} \\
(0.713)\end{array}$ & $\begin{array}{c}-2.970^{* * *} \\
(1.053)\end{array}$ \\
\hline Urbanização & $\begin{array}{l}0.238^{\star \star *} \\
(0.088)\end{array}$ & $\begin{array}{c}0.200 \\
(0.139)\end{array}$ \\
\hline Jovens & $\begin{array}{c}2.366^{\star * *} \\
(0.400)\end{array}$ & $\begin{array}{l}1.326^{* *} \\
(0.647)\end{array}$ \\
\hline População & $\begin{array}{c}-64.062^{* * *} \\
(3.834)\end{array}$ & $\begin{array}{c}-71.522^{* * *} \\
(5.787)\end{array}$ \\
\hline Constante & $\begin{array}{c}626.463^{* * *} \\
(38.504) \\
\end{array}$ & $\begin{array}{c}768.490^{* * *} \\
(59.206) \\
\end{array}$ \\
\hline $\mathrm{R}^{2}$ & 0,8689 & 0,8481 \\
\hline Observações & 66384 & 33525 \\
\hline Teste de Hausman & $\begin{array}{l}\chi^{2}=2522,44 \\
\text { Prob }=0,00\end{array}$ & $\begin{array}{l}\chi^{2}=1511,39 \\
\text { Prob }=0,00\end{array}$ \\
\hline
\end{tabular}

Fonte: elaboração própria 
Gráfico 1.12 - Despesa corrente

dummies de ano-painel não balanceado

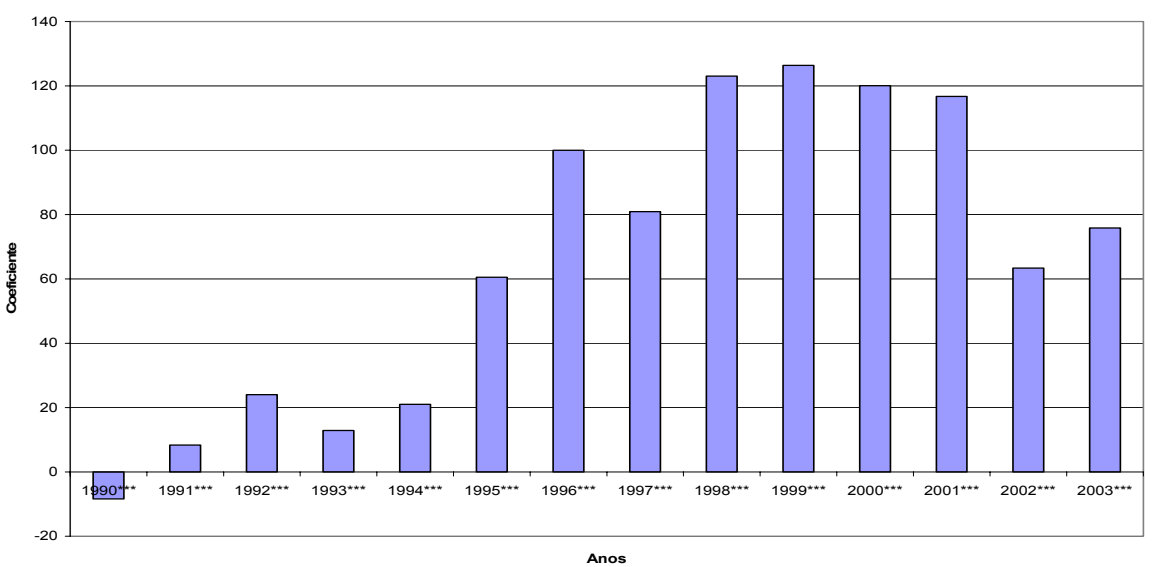

Fonte: elaboração própria

Gráfico 1.14 - Despesa corrente dummies de partido - painel não balanceado

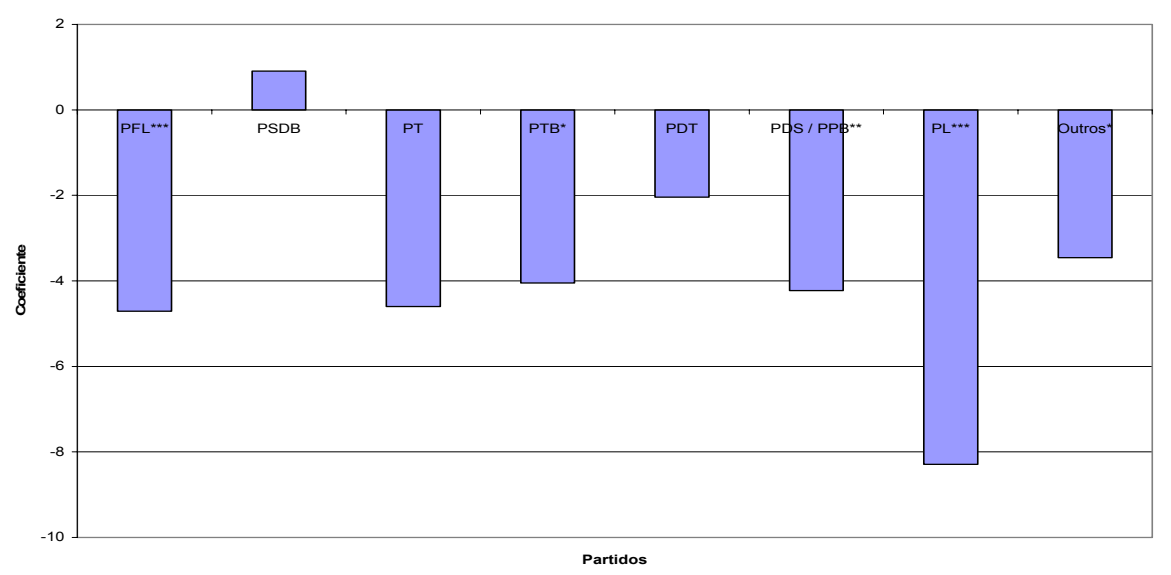

Fonte: elaboração própria
Gráfico 1.13-Despesa corrente

dummies de ano-painel balanceado

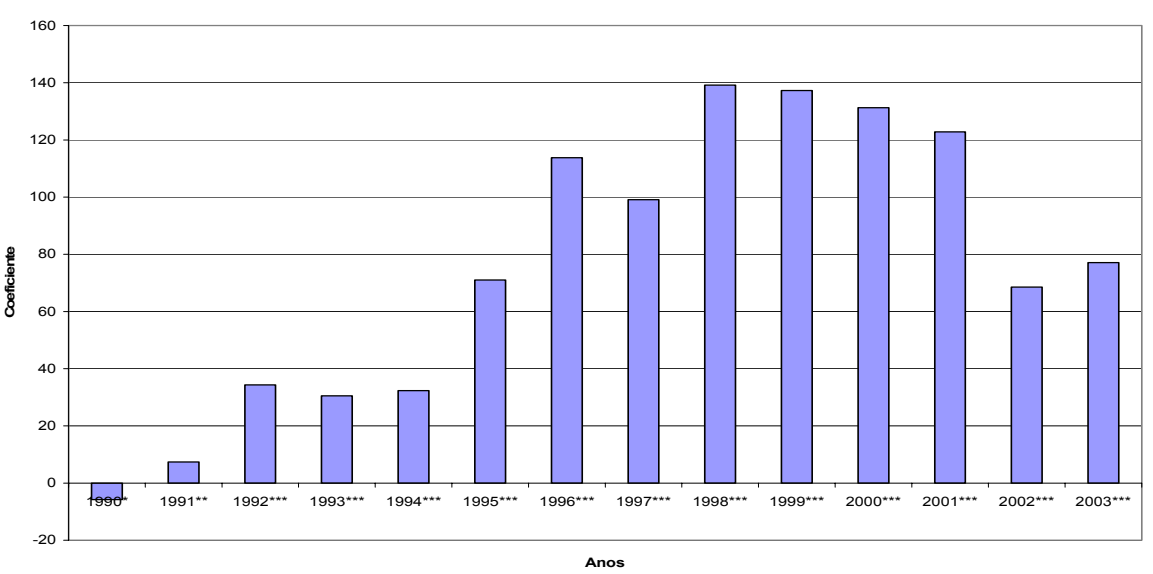

Fonte: elaboração própria

Gráfico 1.15-Despesa corrente dummies de partido-painel balanceado

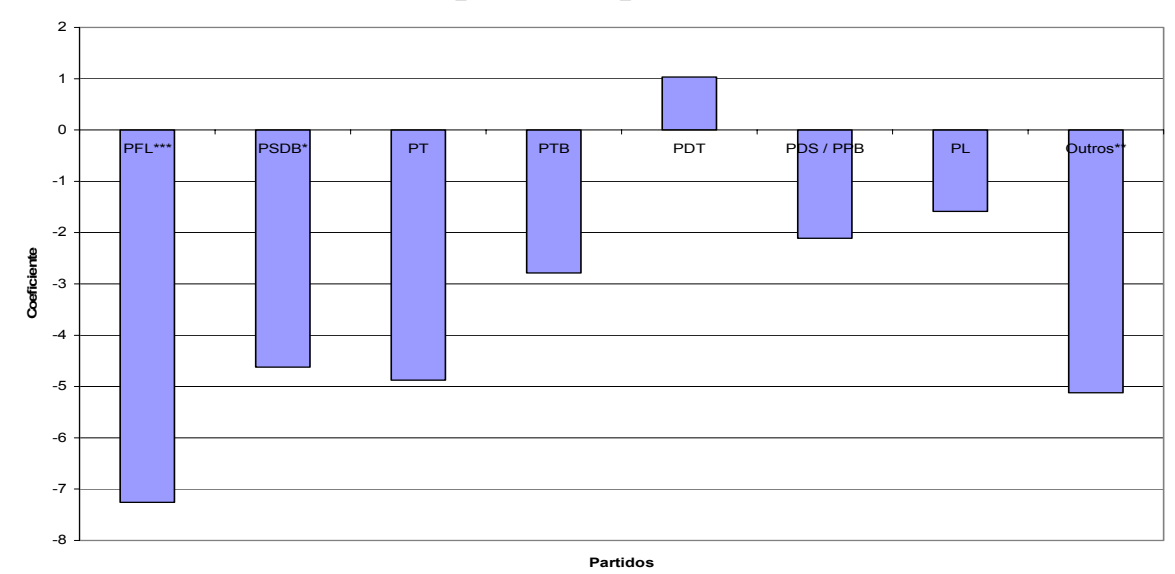

Fonte: elaboração própria 


\section{Despesa corrente}

Tomando como base os coeficientes obtidos pelo método de efeitos fixos, estimador considerado consistente de acordo com o teste de Hausman, e considerando os resultados do painel não balanceado como referência, os resultados associados à receita tributária e as receitas de transferências assumem valores iguais a, respectivamente, 0,82 e 0,69 sugerindo um maior conservadorismo das despesas correntes em relação à segunda fonte de recursos dos municípios brasileiros, da mesma forma que a observada no caso da despesa orçamentária (novamente, os coeficientes para o painel balanceado são relativamente semelhantes aos obtidos para o painel não balanceado).

O comportamento das dummies de tempo no caso das despesas correntes parece indicar uma tendência ascendente ao longo do período aqui considerado, sugerindo um volume crescente de recursos financeiros alocados nesta categoria do orçamento municipal. Tendo como referência o ano de 1989, no caso do painel não balanceado por exemplo, a dummy de 1990 assume valor igual a -8,40 e em 2003, passa a assumir valor igual a 75,84.

Especificamente a respeito dos anos eleitorais, o ano de 1992 apresenta alteração positiva no volume de despesas correntes (relativamente a 1991 e 1993) somente no caso do painel não balanceado (vide apêndice 1e.2), uma vez que no painel balanceado, não é possível descartar a hipótese de que as dummies de 1992 e 1993 sejam estatisticamente iguais. No que diz respeito à dummy de 1996, em ambas as amostras é possível observar uma elevação do nível de despesas correntes relativamente ao ano anterior e posterior, sendo novamente distinto o nível destes efeitos entre a amostra não balanceada (coeficiente aproximadamente igual a 100) e a amostra balanceada (coeficiente aproximadamente igual a 114). Finalmente, no que diz respeito ao ano eleitoral de 2000, embora a dummy de tal ano seja estatisticamente diferente das dummies de 1999 e 2001 em ambas as amostras, observa-se na realidade uma queda sistemática da despesa corrente ao longo deste período, o que novamente descaracteriza o comportamento associado a um ano eleitoral.

No que diz respeito às dummies de partido, o caso das despesas correntes é relativamente distinto do caso das despesas orçamentárias, uma vez que uma maior ou menor distinção entre os partidos políticos parece variar entre a amostra balanceada e a amostra não balanceada - em comum à ambas, observa-se que PFL e o grupo "outros partidos" executa menores despesas correntes relativamente ao PMDB. Particularmente no caso do painel não balanceado, a diferença mais significativa é observada para o PSDB, que despende relativamente mais recursos que o PFL, PDS / PPB, PTB, PL e o grupo “outros partidos". 
Ainda para esta amostra, observa-se também que o PL efetua menores despesas correntes relativamente ao PDT e ao grupo "outros partidos". Já no que diz respeito ao painel balanceado, os resultados indicam que o PFL despende relativamente menos recursos que o PDS / PPB, ao passo que o PDT despende relativamente mais recursos que PFL e o grupo "outros partidos".

$\mathrm{O}$ indicador de similaridade partidária entre o Executivo municipal e os Executivos estadual e federal apresenta resultados distintos entre os painéis estimados. Para o painel não balanceado, somente o alinhamento partidário com o governo federal influencia (negativamente - coeficiente igual a $-3,31$ ) a despesa corrente per capita dos municípios brasileiros. Por sua vez, para o painel balanceado, somente o alinhamento com o governo estadual influencia (positivamente - coeficiente igual a 3,67) a variável dependente em questão.

No que diz respeito às variáveis demográficas, para ambas as amostras uma menor proporção de idosos e uma menor população fazem com que a despesa corrente per capita dos municípios brasileiros sofra elevação, da mesma forma que a observada no caso da despesa orçamentária. Já uma maior proporção de jovens pode fazer com que haja uma maior participação do setor público nos municípios através da provisão de serviços de educação e saúde básica por exemplo, o que pode justificar o sinal positivo para tal coeficiente. Por fim, o coeficiente associado ao grau de urbanização é estatisticamente significante (e positivo) somente no caso do painel não balanceado. 
Tabela 1.15 - Despesa de pessoal - efeitos fixos

\begin{tabular}{|c|c|c|}
\hline $\begin{array}{c}\text { Regressor } \\
\text { (Erro padrão) }\end{array}$ & Painel não balanceado & Painel balanceado \\
\hline Receita tributária & $\begin{array}{l}0.286^{* * *} \\
(0.007)\end{array}$ & $\begin{array}{l}0.255^{\star \star *} \\
(0.009)\end{array}$ \\
\hline Receita de transferências & $\begin{array}{c}0.287^{* * *} \\
(0.002)\end{array}$ & $\begin{array}{l}0.302^{* * *} \\
(0.003)\end{array}$ \\
\hline Dummy 1990 & $\begin{array}{c}-13.592^{* * *} \\
(1.592) \\
\end{array}$ & $\begin{array}{c}-16.161^{* * *} \\
(2.135) \\
\end{array}$ \\
\hline Dummy 1991 & $\begin{array}{l}-2.671 \\
(1.629)\end{array}$ & $\begin{array}{c}-6.670^{\star \star \star} \\
(2.187)\end{array}$ \\
\hline Dummy 1992 & $\begin{array}{c}-7.378^{\star * *} \\
(1.692)\end{array}$ & $\begin{array}{c}-5.259^{* *} \\
(2.287)\end{array}$ \\
\hline Dummy 1993 & $\begin{array}{l}4.586^{* * *} \\
(1.737)\end{array}$ & $\begin{array}{c}10.087^{\star \star \star} \\
(2.340)\end{array}$ \\
\hline Dummy 1994 & $\begin{array}{c}-11.690^{* * *} \\
(1.856) \\
\end{array}$ & $\begin{array}{c}-13.334^{* * *} \\
(2.530) \\
\end{array}$ \\
\hline Dummy 1995 & $\begin{array}{c}14.027^{* * *} \\
(2.048)\end{array}$ & $\begin{array}{c}12.817^{* * *} \\
(2.848)\end{array}$ \\
\hline Dummy 1996 & $\begin{array}{c}34.904^{\star \star *} \\
(2.191)\end{array}$ & $\begin{array}{c}3.749^{\star * \star} \\
(3.071)\end{array}$ \\
\hline Dummy 1997 & $\begin{array}{c}47.895^{\star * *} \\
(2.233) \\
\end{array}$ & $\begin{array}{c}50.996^{* * *} \\
(3.228)\end{array}$ \\
\hline Dummy 1998 & $\begin{array}{c}61.375^{\star * *} \\
(2.468)\end{array}$ & $\begin{array}{c}54.554^{\star * *} \\
(3.515)\end{array}$ \\
\hline Dummy 1999 & $\begin{array}{c}58.392^{\star \star \star} \\
(2.593)\end{array}$ & $\begin{array}{c}46.120^{* \star *} \\
(3.713)\end{array}$ \\
\hline Dummy 2000 & $\begin{array}{c}62.848^{\star \star \star} \\
(2.703)\end{array}$ & $\begin{array}{c}52.704^{\star * *} \\
(3.916)\end{array}$ \\
\hline Dummy 2001 & $\begin{array}{c}65.488^{* * *} \\
(2.855)\end{array}$ & $\begin{array}{c}47.821^{* * *} \\
(4.151)\end{array}$ \\
\hline Dummy 2002 & $\begin{array}{c}68.072^{\star \star \star} \\
(3.048)\end{array}$ & $\begin{array}{c}58.868^{\star \star \star} \\
(4.423)\end{array}$ \\
\hline Dummy 2003 & $\begin{array}{c}73.295^{\star * *} \\
(3.146)\end{array}$ & $\begin{array}{c}60.271^{\star * *} \\
(4.576)\end{array}$ \\
\hline PFL & $\begin{array}{c}-2.717^{* \star *} \\
(1.045)\end{array}$ & $\begin{array}{c}-3.318^{* *} \\
(1.430)\end{array}$ \\
\hline PSDB & $\begin{array}{c}7.187^{* \star *} \\
(1.415) \\
\end{array}$ & $\begin{array}{l}3.689^{\star *} \\
(1.854) \\
\end{array}$ \\
\hline PT & $\begin{array}{l}-6.366^{\star \star} \\
(2.598)\end{array}$ & $\begin{array}{c}-8.166^{\star \star \star} \\
(3.190)\end{array}$ \\
\hline PTB & $\begin{array}{l}-2.178 \\
(1.452) \\
\end{array}$ & $\begin{array}{l}-1.622 \\
(1.886) \\
\end{array}$ \\
\hline PDT & $\begin{array}{c}0.242 \\
(1.513) \\
\end{array}$ & $\begin{array}{c}0.436 \\
(1.896) \\
\end{array}$ \\
\hline PDS / PPB & $\begin{array}{c}-5.061^{\star \star \star} \\
(1.259)\end{array}$ & $\begin{array}{c}-4.386^{\star \star \star} \\
(1.674) \\
\end{array}$ \\
\hline PL & $\begin{array}{c}-8.436^{\star * *} \\
(1.708)\end{array}$ & $\begin{array}{c}0.087 \\
(2.175)\end{array}$ \\
\hline Outros & $\begin{array}{l}-1.499 \\
(1.260) \\
\end{array}$ & $\begin{array}{l}-0.206 \\
(1.717) \\
\end{array}$ \\
\hline Prefeito \& Governador & $\begin{array}{l}-0.961 \\
(0.632) \\
\end{array}$ & $\begin{array}{c}0.127 \\
(0.847) \\
\end{array}$ \\
\hline Prefeito \& Presidente & $\begin{array}{l}-2.765^{\star *} \\
(1.162)\end{array}$ & $\begin{array}{l}-0.924 \\
(1.540) \\
\end{array}$ \\
\hline Idosos & $\begin{array}{c}-1.133^{* *} \\
(0.495)\end{array}$ & $\begin{array}{l}-0.997 \\
(0.712)\end{array}$ \\
\hline Urbanização & $\begin{array}{l}-0.080 \\
(0.061) \\
\end{array}$ & $\begin{array}{c}-0.255^{\star * *} \\
(0.094)\end{array}$ \\
\hline Jovens & $\begin{array}{c}0.892^{* * *} \\
(0.277)\end{array}$ & $\begin{array}{l}-0.380 \\
(0.437)\end{array}$ \\
\hline População & $\begin{array}{c}-34.478^{\star \star *} \\
(2.660)\end{array}$ & $\begin{array}{c}-33.230^{* \star *} \\
(3.914)\end{array}$ \\
\hline Constante & $\begin{array}{c}369.931^{* * *} \\
(26.710)\end{array}$ & $\begin{array}{c}428.630^{* * *} \\
(40.096)\end{array}$ \\
\hline $\mathrm{R}^{2}$ & 0,6914 & 0,6918 \\
\hline Observações & 66384 & 33525 \\
\hline Teste de Hausman & $\begin{array}{l}\chi^{2}=2027,42 \\
\text { Prob }=0,00\end{array}$ & $\begin{array}{l}\chi^{2}=994,08 \\
\text { Prob }=0,00\end{array}$ \\
\hline
\end{tabular}

Fonte: elaboração própria 
Gráfico 1.16 - Despesa de pessoal

dummies de ano - painel não balanceado

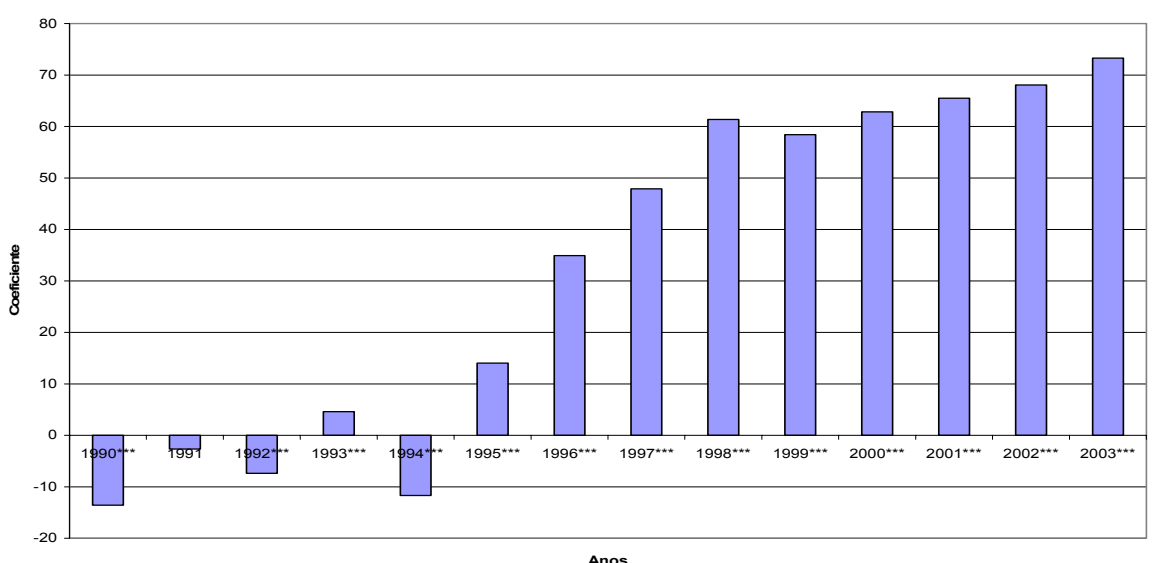

Fonte: elaboração própria

Gráfico 1.18 - Despesa pessoal dummies de partido - painel não balanceado

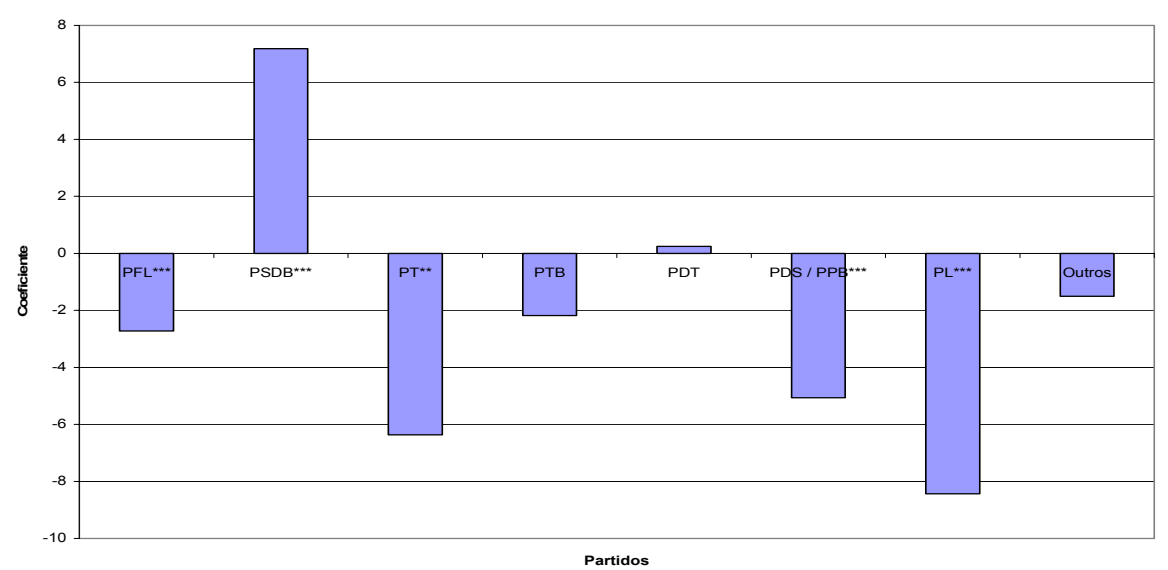

Fonte: elaboração própria
Gráfico 1.17 - Despesa pessoal

dummies de ano-painel balanceado

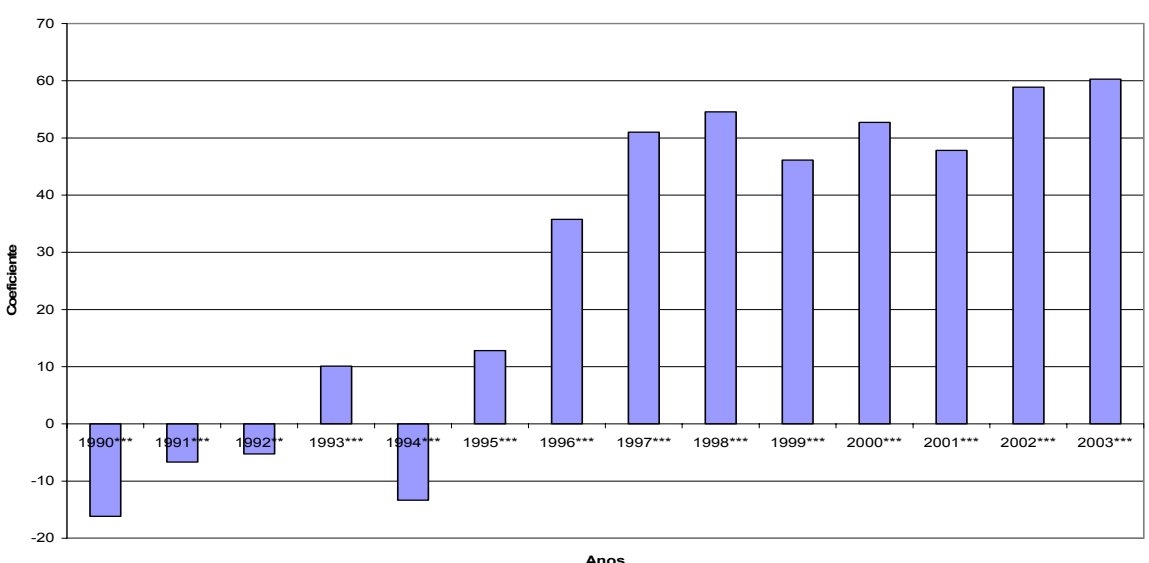

Fonte: elaboração própria

Gráfico 1.19-Despesa pessoal dummies de partido-painel balanceado

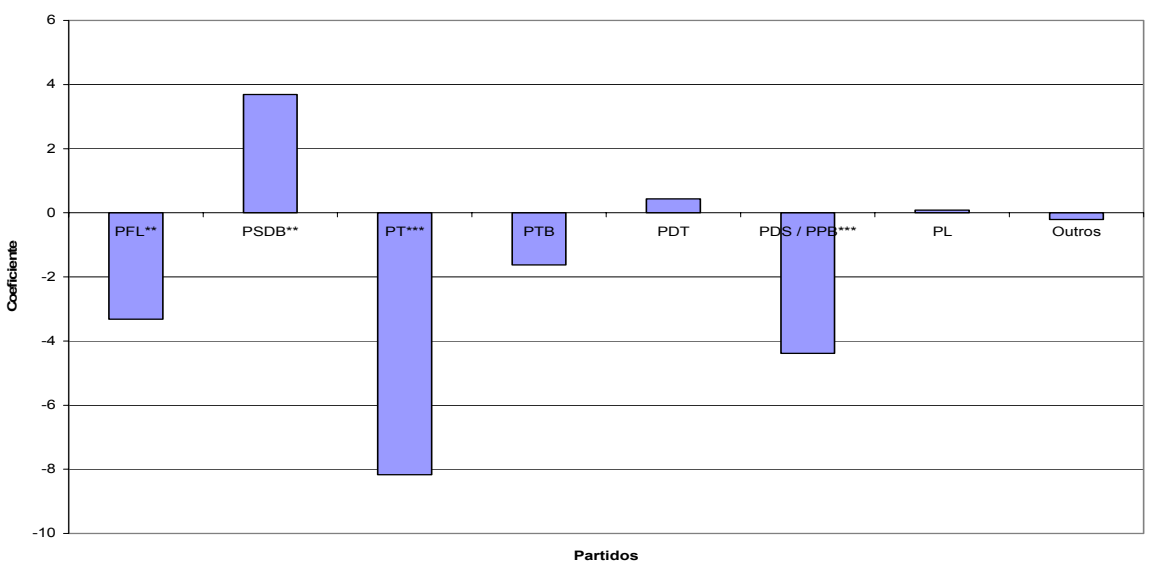

Fonte: elaboração própria 


\section{Despesa de pessoal}

Para o caso da despesa de pessoal, tendo em mente os resultados obtidos através do método de efeitos fixos, mais uma vez considerados consistente pelo teste de Hausman, a análise do coeficiente associado à receita tributária per capita é bastante similar entre as duas amostras consideradas: assume o valor 0,28 no caso do painel não balanceado e 0,25 no caso do painel balanceado. No caso da receita de transferências, os coeficientes são iguais a 0,28 no painel não balanceado e 0,30 no painel balanceado. Como nas estimações anteriormente analisadas, tais coeficientes vêm a ser estatisticamente significantes a $1 \%$.

A análise das dummies de ano permite observar a existência de uma tendência positiva nos gastos com pessoal, de forma semelhante à apontada anteriormente no caso das despesas correntes. A diferença entre os coeficientes do painel balanceado e do painel não balanceado parece residir apenas em suas magnitudes, uma vez que as dummies de ano da primeira amostra são em média inferiores às dummies da segunda amostra. Por sua vez, deve ser enfatizado que a categoria de despesa aqui analisada não apresenta em nenhum dos anos eleitorais o comportamento esperado caso fosse válida a percepção dos ciclos eleitorais, qual seja, a dummy do ano eleitoral ser estatisticamente maior que a dummy do ano anterior e posterior - a exceção ocorre no ano de 2000 no painel balanceado, que apresenta impulso positivo relativamente ao ano de 1999 e 2001. Logo, os resultados parecem sugerir que tal categoria de despesa não estaria significativamente sujeita ao fenômeno aqui considerado, de forma contrária à obtida em Ames, Hiroi \& Renno (2005), no qual são apresentados resultados que demonstram um aumento da despesa de pessoal nos anos eleitorais nos estados brasileiros.

Se as dummies de ano não permitem corroborar nenhuma distinção mais contundente nos anos eleitorais, as dummies de partido permitem observar uma diferenciação mais evidente entre os partidos políticos quando analisado o comportamento dos gastos com pessoal. Embora no painel não balanceado tais diferenças sejam observadas com maior freqüência (vide testes de hipótese do apêndice 1e.3), o fato de (i) o PSDB despender mais recursos comparativamente ao PMDB, PDS / PPB, PFL, PTB, PT e "outros partidos", (ii) o PT despender relativamente menos recursos que PMDB, PDT o grupo “outros partidos" e (iii) o PDS / PPB despender relativamente menos recursos que PMDB, PDT e o grupo "outros partidos" podem ser vistos como resultados comuns a ambas as amostras ${ }^{16}$.

\footnotetext{
${ }^{16}$ Em comum às duas amostras, observa-se também que o PDT despende comparativamente mais recursos que o PFL, e que este, por sua vez, despende menos recursos que o PMDB. Especificamente no caso da amostra não
} 
O único caso em que a similaridade partidária entre os municípios e instâncias de governo superiores apresenta significância estatística (a 5\%) ocorre no painel não balanceado, sinalizando um comportamento conservador da despesa de pessoal quando ocorre o alinhamento partidário entre prefeito e presidente da República, indicando um dispêndio R\$ 2,76 menor (per capita) em tal circunstância. Já no caso dos indicadores demográficos, para ambas as amostras, a despesa de pessoal é negativamente influenciada à medida que cresce o tamanho da população total, fato que pode sugerir um eventual ganho de escala nos custos de atuação do setor público. Para as demais variáveis demográficas, os resultados variam de amostra para amostra: no caso do painel não balanceado, uma menor proporção de idosos e uma maior proporção de jovens residindo nos municípios brasileiros faz com que cresça a despesa de pessoal per capita. Já no caso do painel balanceado, (somente) uma maior taxa de urbanização influencia negativamente tal categoria de despesa pública.

balanceada, os resultados também indicam que o PL despende relativamente menos recursos que o PMDB, PDT, PTB, PSDB, PFL e o grupo formado pelos "outros partidos", além do fato do PDS / PPB despender comparativamente menos recursos que o PFL e o PTB e o PDT despender menos recursos que o PSDB. Já especificamente no caso da amostra balanceada, observa-se que o PT executa comparativamente menos recursos que PTB e PL, e que o PFL executa menos recursos que o grupo "outros partidos". 
Tabela 1.16 - Transferências correntes - efeitos fixos

\begin{tabular}{|c|c|c|}
\hline $\begin{array}{c}\text { Regressor } \\
\text { (Erro padrão) }\end{array}$ & Painel não balanceado & Painel balanceado \\
\hline Receita tributária & $\begin{array}{l}0.111^{* * *} \\
(0.006)\end{array}$ & $\begin{array}{l}0.081^{* * *} \\
(0.008)\end{array}$ \\
\hline Receita de transferências & $\begin{array}{l}0.125^{\star \star \star} \\
(0.002)\end{array}$ & $\begin{array}{l}0.103^{\star \star *} \\
(0.003)\end{array}$ \\
\hline Dummy 1990 & $\begin{array}{c}-19.726^{\star \star *} \\
(1.338)\end{array}$ & $\begin{array}{c}-19.729^{* * *} \\
(1.771)\end{array}$ \\
\hline Dummy 1991 & $\begin{array}{c}-15.526^{* \star *} \\
(1.386)\end{array}$ & $\begin{array}{c}-16.762^{\star \star *} \\
(1.834)\end{array}$ \\
\hline Dummy 1992 & $\begin{array}{c}-13.959^{* * *} \\
(1.465)\end{array}$ & $\begin{array}{c}-13.711^{* * *} \\
(1.950)\end{array}$ \\
\hline Dummy 1993 & $\begin{array}{c}73.927^{* * *} \\
(1.525)\end{array}$ & $\begin{array}{c}76.241^{* * *} \\
(2.035)\end{array}$ \\
\hline Dummy 1994 & $\begin{array}{c}-15.127^{\star \star \star} \\
(1.662)\end{array}$ & $\begin{array}{c}-11.151^{* * *} \\
(2.248)\end{array}$ \\
\hline Dummy 1995 & $\begin{array}{c}-11.425^{\star * *} \\
(1.879) \\
\end{array}$ & $\begin{array}{c}-5.542^{* *} \\
(2.590) \\
\end{array}$ \\
\hline Dummy 1996 & $\begin{array}{c}-8.751^{* * *} \\
(2.040)\end{array}$ & $\begin{array}{l}-1.663 \\
(2.819) \\
\end{array}$ \\
\hline Dummy 1997 & $\begin{array}{c}0.207 \\
(2.070) \\
\end{array}$ & $\begin{array}{l}5.324^{*} \\
(2.991)\end{array}$ \\
\hline Dummy 1998 & $\begin{array}{c}41.606^{\star * *} \\
(2.340)\end{array}$ & $\begin{array}{c}52.938^{* * *} \\
(3.286)\end{array}$ \\
\hline Dummy 1999 & $\begin{array}{c}46.537^{\star * *} \\
(2.477) \\
\end{array}$ & $\begin{array}{c}57.091^{* * *} \\
(3.492)\end{array}$ \\
\hline Dummy 2000 & $\begin{array}{c}37.137^{* * *} \\
(2.608)\end{array}$ & $\begin{array}{c}43.768^{* * *} \\
(3.706)\end{array}$ \\
\hline Dummy 2001 & $\begin{array}{c}38.553^{* * *} \\
(2.774)\end{array}$ & $\begin{array}{c}44.092^{* * *} \\
(3.947)\end{array}$ \\
\hline PFL & $\begin{array}{c}2.829^{* \star *} \\
(0.966) \\
\end{array}$ & $\begin{array}{l}2.581^{\star *} \\
(1.278)\end{array}$ \\
\hline PSDB & $\begin{array}{l}-0.943 \\
(1.387)\end{array}$ & $\begin{array}{l}-2.007 \\
(1.745)\end{array}$ \\
\hline PT & $\begin{array}{l}-0.912 \\
(2.533)\end{array}$ & $\begin{array}{l}-0.426 \\
(3.043)\end{array}$ \\
\hline PTB & $\begin{array}{l}-0.041 \\
(1.367)\end{array}$ & $\begin{array}{c}2.585 \\
(1.690)\end{array}$ \\
\hline PDT & $\begin{array}{c}1.457 \\
(1.337)\end{array}$ & $\begin{array}{l}3.707^{\star *} \\
(1.648)\end{array}$ \\
\hline PDS / PPB & $\begin{array}{c}1.153 \\
(1.153) \\
\end{array}$ & $\begin{array}{l}3.563^{\star *} \\
(1.491)\end{array}$ \\
\hline PL & $\begin{array}{c}2.071 \\
(1.557) \\
\end{array}$ & $\begin{array}{l}4.803^{\star *} \\
(2.061)\end{array}$ \\
\hline Outros & $\begin{array}{l}2.181^{*} \\
(1.154)\end{array}$ & $\begin{array}{c}0.832 \\
(1.570) \\
\end{array}$ \\
\hline Prefeito \& Governador & $\begin{array}{l}-0.501 \\
(0.576)\end{array}$ & $\begin{array}{c}2.214^{\star \star *} \\
(0.774)\end{array}$ \\
\hline Prefeito \& Presidente & $\begin{array}{l}4.503^{\star * \star} \\
(1.096)\end{array}$ & $\begin{array}{l}3.312^{\star *} \\
(1.403)\end{array}$ \\
\hline Idosos & $\begin{array}{c}14.985^{\star * *} \\
(0.554)\end{array}$ & $\begin{array}{c}13.042^{* * *} \\
(0.779) \\
\end{array}$ \\
\hline Urbanização & $\begin{array}{c}-0.160^{* *} \\
(0.070)\end{array}$ & $\begin{array}{l}-0.170^{*} \\
(0.102)\end{array}$ \\
\hline Jovens & $\begin{array}{c}4.336^{\star * \star} \\
(0.279)\end{array}$ & $\begin{array}{c}2.647^{* \star *} \\
(0.433)\end{array}$ \\
\hline População & $\begin{array}{c}11.532^{\star * *} \\
(2.739) \\
\end{array}$ & $\begin{array}{l}6.913^{*} \\
(3.928)\end{array}$ \\
\hline Constante & $\begin{array}{c}-349.140 * * * \\
(27.887)\end{array}$ & $\begin{array}{c}-218.989 * * * \\
(40.554)\end{array}$ \\
\hline $\mathrm{R}^{2}$ & 0,3429 & 0,3760 \\
\hline Observações & 56315 & 29055 \\
\hline Teste de Hausman & $\begin{array}{l}\chi^{2}=761,45 \\
\text { Prob }=0,00\end{array}$ & $\begin{array}{l}\chi^{2}=286,67 \\
\text { Prob }=0,00\end{array}$ \\
\hline
\end{tabular}

Fonte: elaboração própria 
Gráfico 1.20 - Transferências Correntes

dummies de ano-painel não balanceado

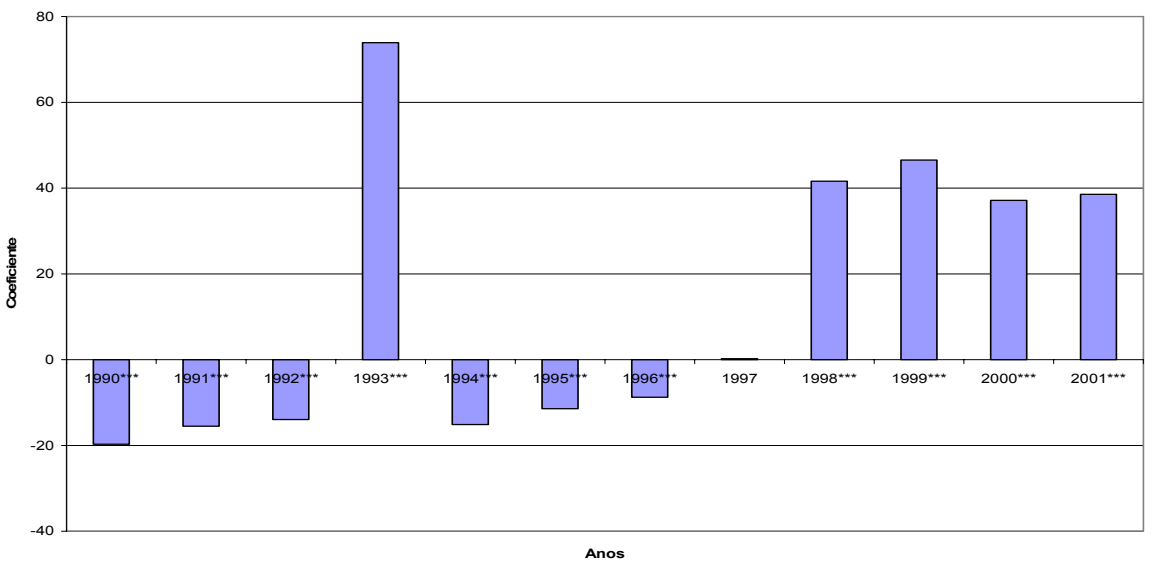

Fonte: elaboração própria

Gráfico 1.22 - Transferências Correntes dummies de partido - painel não balanceado

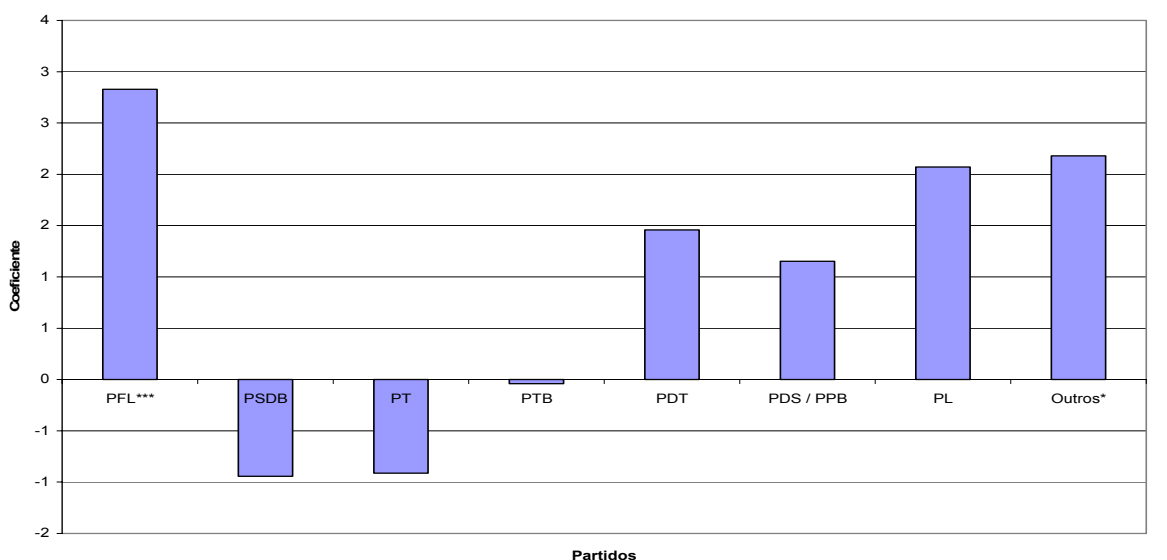

Fonte: elaboração própria
Gráfico 1.21 - Transferências Correntes

dummies de ano-painel balanceado

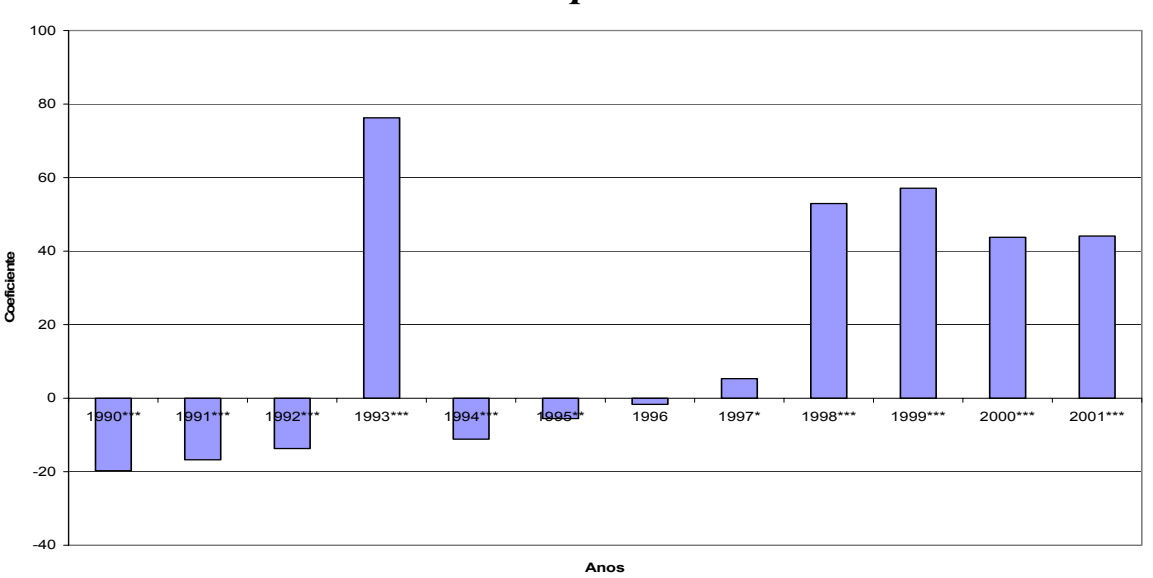

Fonte: elaboração própria

Gráfico 1.23 - Transferências Correntes dummies de partido - painel balanceado

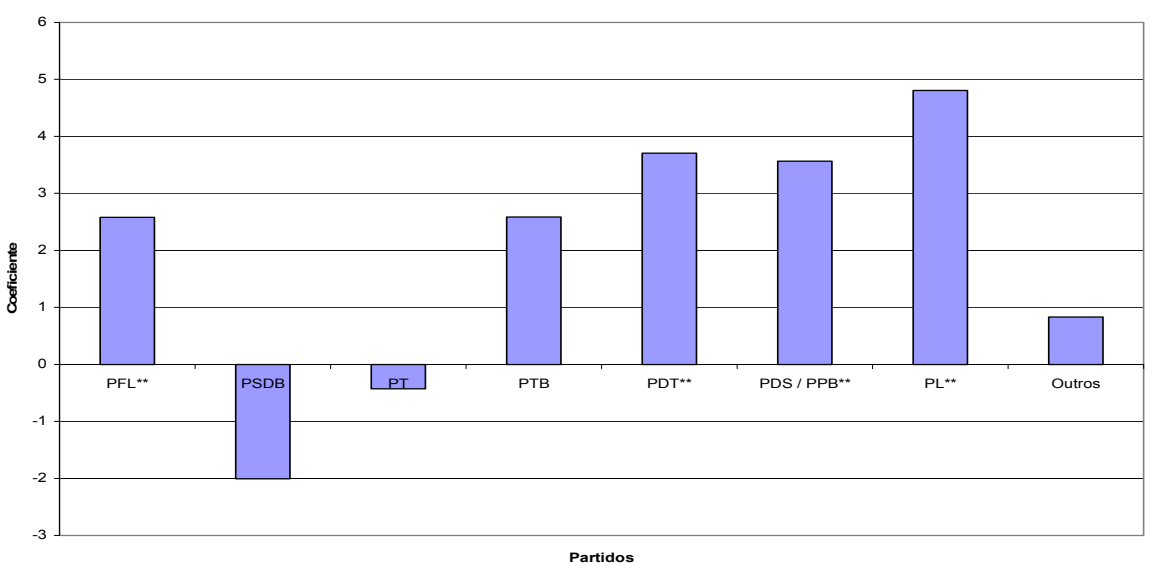

Fonte: elaboração própria 


\section{Transferências correntes}

Os resultados obtidos para o caso das transferências correntes indicam que, no caso do painel não balanceado, a cada Real de receita tributária obtida pelo município, $\mathrm{R} \$ 0,11$ são destinados às transferências correntes, ao passo que para cada Real de transferências da União e dos governos estaduais, $\mathrm{R} \$ 0,12$ são destinados a tal categoria de orçamento municipal. Ambos os coeficientes foram obtidos pelo método de efeitos fixos, novamente consistentes com base na estatística do teste de Hausman. Novamente, a diferença destes coeficientes para os obtidos na amostra balanceada são relativamente discretas, sendo estes últimos iguais a, respectivamente, 0,08 e 0,10 .

Da mesma forma que a observada no caso da despesa de pessoal, o caso das transferências correntes parece não apresentar evidência mais contundente de impulso de gastos nos anos eleitorais. Os gráficos 1.20 e 1.21 bem como os testes de hipótese realizados (apêndice 1e.4) permitem observar que para ambas as amostras a dummy de 1993 e a dummy de 1997 são estatisticamente superiores as dummies de 1992 e 1996, respectivamente, ao passo que a dummy de 1999 é estatisticamente superior a dummy de 2000, o que descaracteriza a análise do ciclo eleitoral ao menos nos padrões aqui propostos. Assim, esta parece ser também uma variável que a princípio não apresenta nenhum tipo de correlação mais contundente com algum interesse oportunista nos anos eleitorais.

O caso das transferências correntes apresenta evidências de ser um caso particular das despesas municipais, uma vez que nenhuma distinção mais significativa é observada entre os partidos políticos. Em comum às duas amostras consideradas, observa-se apenas que o PFL destina mais recursos às transferências correntes comparativamente ao PMDB e ao PSDB. Para a amostra não balanceada, observa-se que o grupo "outros partidos" aloca relativamente mais recursos que o PMDB e o PSDB, sendo observado adicionalmente que o PFL aloca mais recursos que o PTB. Já especificamente para a amostra balanceada, os resultados indicam que o PMDB e o PSDB realizam menores transferências correntes que o PDT, PDS / PPB o PL, sendo que este último também realiza maiores transferências correntes que o grupo "outros partidos”. Deve-se ressaltar que nenhuma distinção especial é observada para o PT, conforme sugeria o gráfico 1.4, ressaltando assim a influência das variáveis de controle.

$\mathrm{O}$ alinhamento político do prefeito com o governo federal influencia positivamente as transferências correntes em ambas as amostras (coeficiente igual a 4,50 para o painel não balanceado e igual a 3,31 para o painel balanceado, ambos estatisticamente significantes a no máximo 5\%), ao passo que o alinhamento com o governo estadual influencia (positivamente) 
as transferências correntes somente no caso do painel balanceado. Com respeito aos indicadores demográficos, estes são bastante semelhantes quando comparadas as duas amostras analisadas e indicam a significância estatística de todas as variáveis consideradas: os coeficientes associados à proporção de idosos, de proporção de jovens e de população municipal são positivos e estatisticamente significantes a no máximo $5 \%$, indicando um maior volume de recursos financeiros despendidos nesta categoria do orçamento público quando tais variáveis apresentam crescimento. Em particular para a proporção de jovens e de idosos, estes resultados indicam que conforme crescem tais proporções, provavelmente cresce também a demanda por assistência social pública, o que pode justificar em partes tal resultado. Por sua vez, o grau de urbanização apresenta coeficiente estatisticamente significante e negativo, indicando assim que municípios com uma maior proporção de indivíduos residindo na zona urbana despendem menos recursos em transferências correntes. 
Tabela 1.17 - Investimentos - efeitos fixos

\begin{tabular}{|c|c|c|}
\hline $\begin{array}{c}\text { Regressor } \\
\text { (Erro padrão) }\end{array}$ & Painel não balanceado & Painel balanceado \\
\hline Receita tributária & $\begin{array}{c}0.319^{* * *} \\
(0.011)\end{array}$ & $\begin{array}{c}0.314^{* * *} \\
(0.012)\end{array}$ \\
\hline Receita de transferências & $\begin{array}{l}0.161^{* \star *} \\
(0.003)\end{array}$ & $\begin{array}{c}0.147^{\star \star *} \\
(0.004)\end{array}$ \\
\hline Dummy 1990 & $\begin{array}{c}41.733^{\star * *} \\
(2.523)\end{array}$ & $\begin{array}{c}46.672^{* \star *} \\
(2.706)\end{array}$ \\
\hline Dummy 1991 & $\begin{array}{l}6.220^{* *} \\
(2.581) \\
\end{array}$ & $\begin{array}{c}12.080^{* * *} \\
(2.771)\end{array}$ \\
\hline Dummy 1992 & $\begin{array}{c}-6.969^{* * *} \\
(2.680)\end{array}$ & $\begin{array}{l}-1.392 \\
(2.900)\end{array}$ \\
\hline Dummy 1993 & $\begin{array}{c}-29.485^{\star \star \star} \\
(2.756)\end{array}$ & $\begin{array}{c}-34.362^{* * *} \\
(2.967)\end{array}$ \\
\hline Dummy 1994 & $\begin{array}{l}-4.304 \\
(2.948)\end{array}$ & $\begin{array}{l}-4.246 \\
(3.192)\end{array}$ \\
\hline Dummy 1995 & $\begin{array}{c}-24.164^{\star * *} \\
(3.252)\end{array}$ & $\begin{array}{c}-16.311^{* * *} \\
(3.609)\end{array}$ \\
\hline Dummy 1996 & $\begin{array}{c}-28.676^{* * *} \\
(3.476)\end{array}$ & $\begin{array}{c}-23.295^{\star * *} \\
(3.895)\end{array}$ \\
\hline Dummy 1997 & $\begin{array}{c}-75.371^{* * *} \\
(3.542)\end{array}$ & $\begin{array}{c}-76.319^{* \star *} \\
(4.090)\end{array}$ \\
\hline Dummy 1998 & $\begin{array}{c}-37.722^{* * *} \\
(3.913)\end{array}$ & $\begin{array}{c}-41.013^{* * *} \\
(4.453)\end{array}$ \\
\hline Dummy 1999 & $\begin{array}{c}-92.766^{* * *} \\
(4.114)\end{array}$ & $\begin{array}{c}-84.957^{* * *} \\
(4.704)\end{array}$ \\
\hline Dummy 2000 & $\begin{array}{c}-88.755^{\star \star *} \\
(4.288)\end{array}$ & $\begin{array}{c}-80.323^{* * *} \\
(4.964)\end{array}$ \\
\hline Dummy 2001 & $\begin{array}{c}-110.841^{\star \star \star} \\
(4.528)\end{array}$ & $\begin{array}{c}-106.495^{\star \star *} \\
(5.259)\end{array}$ \\
\hline Dummy 2002 & $\begin{array}{c}-66.950^{* * *} \\
(4.837)\end{array}$ & $\begin{array}{c}-63.399^{* * *} \\
(5.606)\end{array}$ \\
\hline Dummy 2003 & $\begin{array}{c}-120.751^{* * \star} \\
(4.992)\end{array}$ & $\begin{array}{c}-108.359^{* * \star} \\
(5.798)\end{array}$ \\
\hline PFL & $\begin{array}{c}0.443 \\
(1.641) \\
\end{array}$ & $\begin{array}{l}3.808^{* *} \\
(1.813) \\
\end{array}$ \\
\hline PSDB & $\begin{array}{l}-1.277 \\
(2.240)\end{array}$ & $\begin{array}{c}0.275 \\
(2.292)\end{array}$ \\
\hline PT & $\begin{array}{c}-10.754^{* * *} \\
(4.120)\end{array}$ & $\begin{array}{c}-14.660^{* * *} \\
(4.039)\end{array}$ \\
\hline PTB & $\begin{array}{l}-0.022 \\
(2.200)\end{array}$ & $\begin{array}{c}0.399 \\
(2.347)\end{array}$ \\
\hline PDT & $\begin{array}{l}-0.076 \\
(2.533)\end{array}$ & $\begin{array}{l}-3.971^{*} \\
(2.378)\end{array}$ \\
\hline PDS / PPB & $\begin{array}{l}-1.405 \\
(2.007) \\
\end{array}$ & $\begin{array}{l}-1.808 \\
(2.127) \\
\end{array}$ \\
\hline PL & $\begin{array}{l}-6.720^{* *} \\
(2.710)\end{array}$ & $\begin{array}{c}-8.658^{* * *} \\
(2.955)\end{array}$ \\
\hline Outros & $\begin{array}{l}2.466 \\
(1.989)\end{array}$ & $\begin{array}{l}4.476^{\star \star} \\
(2.205)\end{array}$ \\
\hline Prefeito \& Governador & $\begin{array}{c}3.184^{\star * *} \\
(1.008)\end{array}$ & $\begin{array}{c}3.002^{* * *} \\
(1.104)\end{array}$ \\
\hline Prefeito \& Presidente & $\begin{array}{l}3.281^{*} \\
(1.843)\end{array}$ & $\begin{array}{l}4.416^{* *} \\
(1.945)\end{array}$ \\
\hline Idosos & $\begin{array}{c}-8.499^{* * *} \\
(0.785)\end{array}$ & $\begin{array}{c}-8.863^{* * *} \\
(0.902)\end{array}$ \\
\hline Urbanização & $\begin{array}{c}0.027 \\
(0.096)\end{array}$ & $\begin{array}{l}0.216^{*} \\
(0.119) \\
\end{array}$ \\
\hline Jovens & $\begin{array}{c}-3.829^{\star \star \star} \\
(0.440)\end{array}$ & $\begin{array}{c}-3.422^{\star \star \star} \\
(0.555)\end{array}$ \\
\hline População & $\begin{array}{c}-28.097^{* * *} \\
(4.219) \\
\end{array}$ & $\begin{array}{c}-35.827^{* * *} \\
(4.962)\end{array}$ \\
\hline Constante & $\begin{array}{c}482.899^{\star * \star} \\
(42.360)\end{array}$ & $\begin{array}{c}526.547^{\star \star *} \\
(50.776)\end{array}$ \\
\hline $\mathrm{R}^{2}$ & 0,2931 & 0,3322 \\
\hline Observações & 66384 & 33525 \\
\hline Teste de Hausman & $\begin{array}{c}\chi^{2}=41,96 \\
\text { Prob }=0,056\end{array}$ & $\begin{array}{l}\chi^{2}=300,25 \\
\text { Prob }=0,00\end{array}$ \\
\hline
\end{tabular}

Fonte: elaboração própria 
Gráfico 1.24 - Investimentos

dummies de ano - painel não balanceado

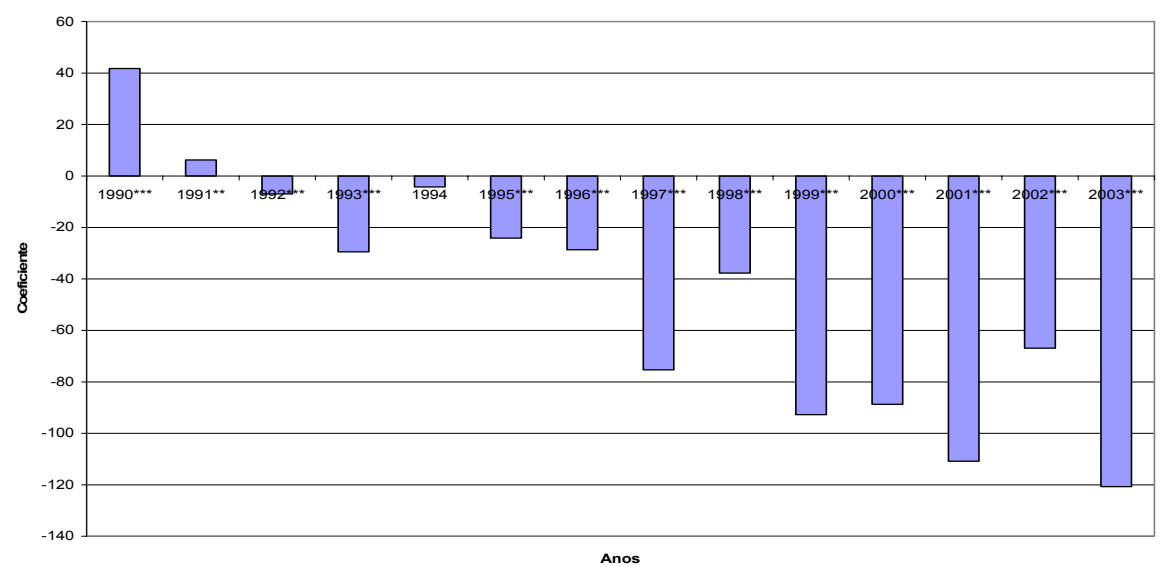

Fonte: elaboração própria

Gráfico 1.26 - Investimentos dummies de partido - painel não balanceado

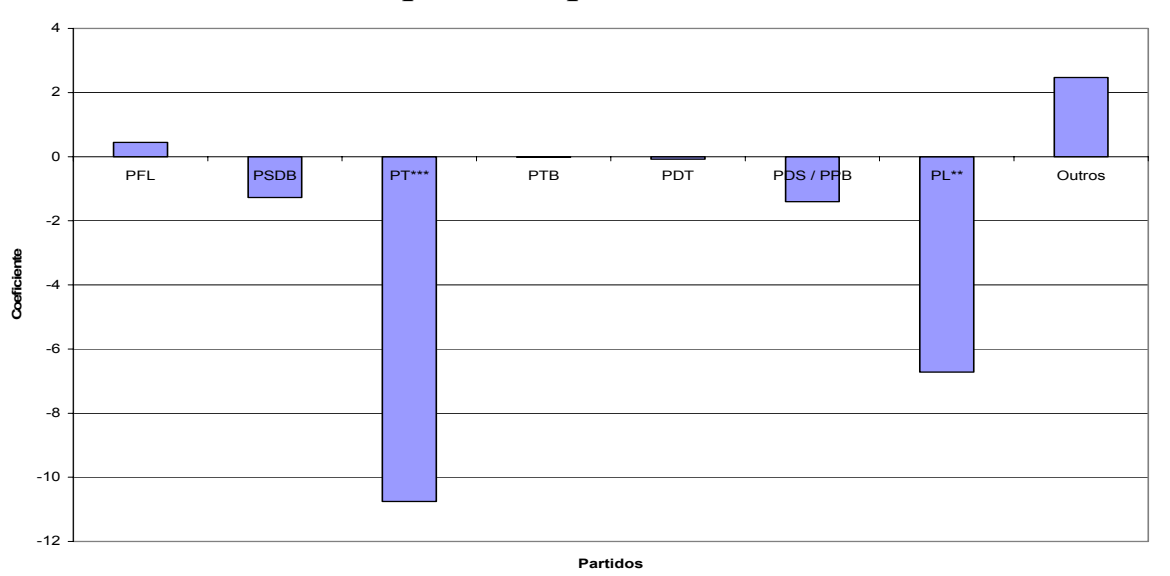

Fonte: elaboração própria
Gráfico 1.25 - Investimentos

dummies de ano-painel balanceado

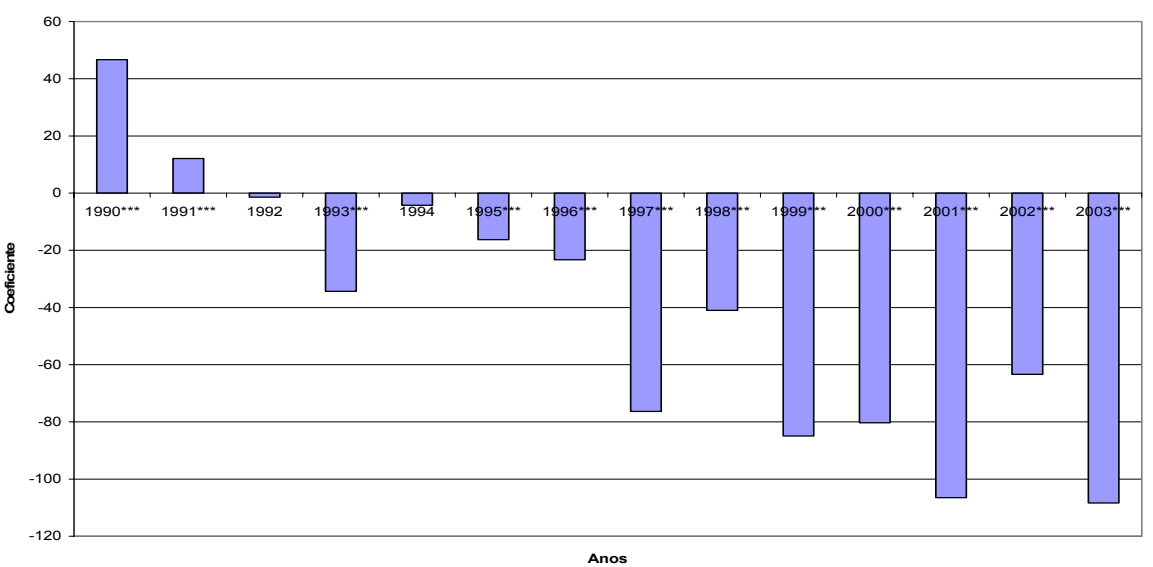

Fonte: elaboração própria

Gráfico 1.27 - Investimentos dummies de partido-painel balanceado

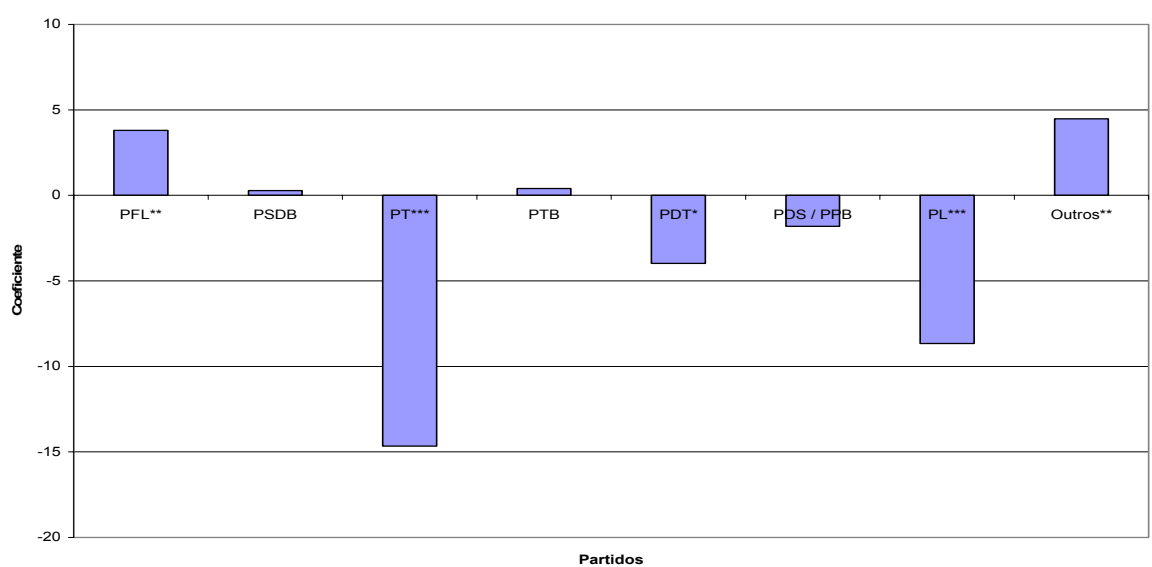

Fonte: elaboração própria 


\section{Despesa de investimento}

Analisando as despesas de investimento, novamente com base nos coeficientes obtidos através do método de efeitos fixos, os coeficientes associados às receitas tributária e de transferências são novamente bastante semelhantes quando comparados o painel balanceado e o painel não balanceado. No caso do painel não balanceado por exemplo, o coeficiente da receita tributária apresenta valor igual a 0,31 ao passo que o coeficiente associado à receita de transferências assume valor igual a 0,16. Já no caso do painel balanceado, tais coeficientes são iguais a 0,31 e 0,14, respectivamente. Em ambas as amostras, os coeficientes são estatisticamente significantes a $1 \%$, como ocorre nos casos anteriormente analisados, e novamente sugerem uma gestão mais conservadora da receita de transferências na realização de investimentos públicos.

Os resultados das dummies de ano permitem observar um fenômeno interessante para o caso das despesas de investimento, uma vez que uma tendência descendente é verificada ao longo do período considerado. Este é justamente o fenômeno oposto do observado no caso das despesas correntes e despesa de pessoal, o que pode sinalizar uma realocação de recursos dentro do orçamento municipal, ao menos nos anos aqui considerados ${ }^{17}$. Tendo como referência o ano de 1989 e considerando o painel não balanceado como exemplo, a dummy de 1990 assume 41,73 e a dummy de 2003 assume valor igual a -120,75, sinalizando tal tendência.

Em termos dos anos eleitorais, as despesas de investimento também parecem não estar significativamente sujeitas ao calendário eleitoral, uma vez que entre 1991 e 1993 e entre 1995 e 1997 são observadas tendências negativas desta categoria de despesa para as duas amostras. A exceção é observada para o ano eleitoral de 2000, uma vez que em tal ano é observado um impulso positivo de investimentos relativamente ao ano imediatamente anterior e posterior, para ambas as amostras (vide apêndice 1e.5).

No que diz respeito às dummies de partido, o caso das despesas de investimento parece ser uma variável cujo comportamento está efetivamente associado à filiação partidária dos prefeitos municipais. Em comum às duas amostras e como observado em boa parte dos casos anteriores, o PT novamente se destaca por alocar menos recursos per capita nesta categoria do orçamento municipal, sendo adicionalmente observado um comportamento também conservador dos investimentos públicos por parte do PL. Para ambos os partidos, as

\footnotetext{
${ }^{17}$ Esta conclusão é factível dado que para todos os casos utilizam-se variáveis de receitas dos municípios brasileiros como controles das regressões.
} 
diferenças (para menos) mais significativas ocorrem em relação ao PMDB, PFL, PDS / PPB, PSDB, PTB e o grupo “outros partidos". Observa-se também que o grupo outros partidos realiza maiores investimentos que o PDS / PPB e que o PDT realiza maiores investimentos que o $\mathrm{PT}^{18}$.

Por fim, em ambas as amostras, tanto a similaridade partidária do poder Executivo municipal com o poder Executivo estadual como com o poder Executivo federal parecem influenciar de forma positiva e estatisticamente significante o comportamento dos investimentos municipais - no caso do painel não balanceado por exemplo, tais coeficientes (estatisticamente significantes a no máximo 10\%) são iguais a 3,18 e 3,28, respectivamente. Assim, estes resultados são particularmente relevantes por sinalizar a importância do alinhamento político com instâncias governamentais superiores como eventual forma de obtenção de recursos adicionais para a realização de investimentos municipais - isto é especialmente provável uma vez que boa parte dos recursos disponíveis pelas prefeituras é obtida através das transferências governamentais dos estados e da União, sendo estes predominante e previamente vinculados à manutenção corrente de serviços públicos (educação e saúde, por exemplo).

Complementarmente, observa-se também que todos os indicadores demográficos parecem influenciar sobremaneira o comportamento dos investimentos municipais, à exceção do grau de urbanização no painel não balanceado: menores níveis de investimento per capita são observados em municípios com uma maior proporção de idosos e com uma maior proporção de jovens residentes, bem como nos municípios de maior porte populacional.

\section{6 - Considerações finais do primeiro capítulo}

Em termos gerais, os três procedimentos implementados permitem observar que no agregado da despesa municipal (despesa orçamentária), o comportamento distinto nos anos eleitorais parece ser verdadeiro. Considerando o resultado do modelo geral, com todas as dummies de ano, tal fenômeno tende a ser observado somente nos anos de 1992 e 1996, sendo que em 2000 o comportamento fiscal dos municípios brasileiros tende a ser relativamente

\footnotetext{
${ }^{18}$ Particularmente para o painel não balanceado, observa-se o PDT executa mais investimentos que o PL. Por sua vez, particularmente para o painel balanceado, os resultados indicam que ao PDT estão associados menores investimentos comparativamente ao PFL, "outros partidos" e PMDB. Ao PMDB estão associados menores investimentos relativamente ao grupo "outros partidos" e ao PFL e finalmente, o PFL realiza maiores investimentos que o PDS / PPB.
} 
conservador. Algumas razões podem ser enumeradas para justificar essa mudança neste ano em particular, sendo que em 2000 (i) passa a vigorar a Lei de Responsabilidade Fiscal e (ii) passa a ser permitida a reeleição dos prefeitos municipais. Ambos os fatores tendem a gerar o mesmo resultado, uma vez que o primeiro tende a originar incentivos a uma gestão relativamente mais conservadora dos recursos públicos dada a possibilidade de punições legais aos administradores públicos. Conforme Nunes \& Nunes (2003), ainda que se considere que no primeiro ano da referida lei o ajuste fiscal foi parcial porque as administrações já trabalhavam com orçamentos aprovados no ano anterior, muitos ajustes que não dependiam dos orçamentos foram efetivamente realizados. Logo, são observadas ações de conservadorismo fiscal já no próprio ano de aprovação da lei. Por sua vez, para o segundo fator, uma eventual permanência no poder de um partido político ou (e principalmente) de um prefeito acarretaria uma menor probabilidade de ocorrência de desajustes fiscais ou orçamentos mal administrados. De todo modo, estas são apenas hipóteses que podem explicar o comportamento fiscal distinto no ano eleitoral de 2000.

O comportamento distinto da despesa orçamentária nos anos eleitorais parece ter como origem o comportamento da despesa corrente, uma vez que estas duas variáveis apresentam oscilações bastante semelhantes ao longo do período aqui considerado. Para as demais categorias da despesa pública analisadas, quais sejam, despesa de pessoal, transferências correntes e despesa de investimento, os resultados são mais discretos e corroboram em apenas alguns casos o fenômeno do ciclo eleitoral (casos da despesa de pessoal e dos investimentos no ano de 2000, por exemplo), nos padrões aqui considerados. Assim, em termos gerais, o fenômeno do ciclo eleitoral tende a ser marginal quando se consideram os efeitos de tendência que parecem predominar em alguns casos.

No que diz respeito aos partidos políticos, os resultados permitem observar a existência de uma relativa distinção entre os mesmos na condução dos orçamentos dos municípios brasileiros. O caso do PT representa um dos casos mais particulares, uma vez que o comportamento fiscal mais conservador ${ }^{19}$ observado no agregado da despesa orçamentária é aparentemente originado de execuções fiscais relativamente mais restritas na despesa de pessoal e nos investimentos. Em outras palavras, pode ser afirmar que este partido despende menos recursos tanto em despesas de natureza corrente como também em investimentos, implicando assim em um menor dispêndio agregado. Para os demais partidos, os resultados tendem a variar de acordo com a categoria da despesa apreciada: considerando os casos do

\footnotetext{
${ }^{19}$ Note que tal resultado vai de encontro ao resultado observado na análise dos gráficos apresentada na descrição dos dados deste capítulo, quando nenhum tipo de controle era considerado nas avaliações.
} 
PFL e do grupo "outros partidos" como exemplos, os resultados parecem sugerir um maior conservadorismo nas despesas correntes (também na despesa de pessoal, no caso do PFL) sendo a contrapartida observada em maiores transferências correntes e em investimentos públicos. Por sua vez, o PSDB destaca-se por ser um dos partidos que mais recursos despende na categoria despesa de pessoal. Finalmente, observa-se que o PL é um caso particular por despender menos recursos no agregado da despesa municipal e na despesa de investimentos, mas também se destacam por ser um dos partidos que mais recursos aloca nas transferências correntes.

Em relação ao comportamento dos partidos selecionados especificamente nos anos eleitorais, os procedimentos permitem constatar que a diferença mais contundente está associada ao PMDB, que pode ser visto como um dos principais partidos que promovem variações positivas nas execuções das despesas municipais em tais anos. Deste modo, considerando estes elementos e os também avaliados no parágrafo anterior, embora a existência da diferenciação partidária e sua eventual influência sobre a administração físcal dos municípios brasileiros não possa ser generalizada a todas as variáveis, algum grau relativo de heterogeneidade é corroborado pelas estimações. Este é um resultado peculiar, uma vez que revela algumas características do comportamento dos partidos políticos brasileiros nos municípios, unidades para as quais poucos resultados encontram-se disponíveis na literatura.

$\mathrm{O}$ alinhamento partidário entre o poder Executivo estadual e federal e o poder Executivo municipal exerce influência discreta sobre o comportamento da despesa dos municípios brasileiros. De todo modo, tal relação parece ser observada com mais contundência fundamentalmente no caso dos investimentos, sendo que a ocorrência do fenômeno em questão tende a influenciar positivamente o volume de recursos executados nesta categoria do orçamento municipal. Nos demais casos, esta influência tende a ocorrer somente em uma das duas amostras consideradas, como no caso da despesa orçamentária do painel balanceado, em que o alinhamento partidário com o Executivo estadual influencia positivamente seus valores e a influência do alinhamento com o governo federal é nula. Este é um resultado distinto do obtido por Cossio (2001) em que, conforme visto na revisão da literatura, há um comportamento fiscal conservador caso o partido do presidente da República e o partido do governador estadual sejam os mesmos. No caso da análise aqui realizada, tal diferença pode ocorrer simplesmente porque as amostras são efetivamente distintas, mas pode ser justificada também pela possibilidade de que os municípios estão menos sujeitos a alguma espécie de influência conservadora advinda do governo estadual e federal. 
Um fato interessante a ser também observado diz respeito ao comportamento das despesas corrente e da despesa de investimento, uma vez que mesmo considerando as distinções partidárias e mesmo tendo em mente o comportamento da receita municipal, as estimações parecem efetivamente corroborar a percepção já apresentada na descrição dos dados presente neste capítulo, ou seja, uma tendência crescente da participação da despesa corrente (em relação à receita disponível) em contrapartida da queda da participação dos investimentos públicos. Assim, estes resultados parecem sinalizar um aumento das despesas administrativas dos municípios brasileiros e uma queda justamente em execuções que poderiam propiciar uma maior possibilidade de desenvolvimento e crescimento sustentável ou de longo prazo a tais unidades. Este é um resultado também observado no caso dos municípios paulistas, conforme descrito em Sakurai (2004), ou seja, trata-se aparentemente de um fenômeno observado no conjunto dos municípios brasileiros e que merece, portanto, tal ponderação. Adicionalmente, os resultados sugerem que municípios com maiores proporções de idosos residentes e com maiores portes populacionais despendem menos recursos tanto em despesas correntes como em investimentos públicos. Já a proporção de jovens parece gerar um efeito alocador no orçamento municipal, ao fazer com que as despesas correntes aumentem em função da queda dos investimentos públicos. 


\section{Capítulo 2 - Reeleição nos municípios brasileiros}

\section{1 - Introdução \& Revisão da literatura}

O primeiro capítulo desta tese teve como propósito básico procurar evidências de um comportamento distinto da despesa municipal em anos eleitorais e, conforme observado, maiores execuções de recursos tendem a ser observadas em tais momentos. Por sua vez, observa-se também algum grau de diferenciação partidária na conduta do orçamento dos municípios brasileiros, ou seja, a filiação partidária dos prefeitos per se tende a influenciar o comportamento fiscal destas unidades. Deste modo, dando prosseguimento à tese, uma análise natural vem a ser como tais distorções de despesas tendem a afetar as chances de permanência no poder dos partidos políticos ou mesmo da própria figura do prefeito municipal, pressupondo-se que tal manipulação fiscal tende a ser realizada com algum objetivo oportunista.

Uma das principais referências que abordam a questão das despesas governamentais sobre o desempenho político é o trabalho de Peltzman (1992), no qual se procura verificar qual a influência das despesas públicas não só sobre o resultado das eleições americanas para presidente da República, mas também sobre os resultados das eleições para o cargo de governador dos estados e para o cargo de senador, entre os anos de 1950 e 1988.

Em termos mais específicos, Peltzman (1992) procura avaliar como despesas públicas mais elevadas influenciam a proporção de votos recebidos por um candidato, procurando controlar as regressões tanto através do uso de variáveis de caráter macroeconômico (inflação e PIB) como também de natureza política (partidos diferentes e o alinhamento partidário com o poder Executivo federal). Adicionalmente, o estudo promove também um estudo mais detalhado do comportamento de diferentes categorias de despesa pública sobre a variável de interesse, procurando avaliar divisões como despesas militares e despesas não militares, despesas com transferência e não-transferências e despesas de natureza pública ou despesas de natureza privada. Os resultados obtidos em tal estudo são característicos justamente por evidenciar um resultado bastante sistemático e robusto, e que pode ser sumarizado na afirmação de que os eleitores americanos são especialmente avessos a despesas mais elevadas, penalizando os candidatos através de uma menor proporção de votos recebidos nas eleições, independentemente do cargo político disputado. Os eleitores parecem considerar também o timing com que tais despesas são executadas, ou seja, quanto mais próximos das eleições estão despesas mais elevadas, maior é a punição recebida pelos candidatos. 
De forma complementar, os resultados sugerem também que, especificamente paras as eleições presidenciais, a composição da despesa pública parece não influenciar a forma com que os eleitores americanos avaliam despesas adicionais, ou seja, independentemente de onde estas despesas estejam sendo executadas, elas são sistematicamente punidas nas urnas. Por outro lado, tal composição parece influenciar as eleições para governador dos estados, sinalizando que maiores despesas com bem-estar (saúde e educação, entre outros) são justamente as mais indesejadas pelos eleitores, com a conseqüente redução na proporção de votos recebidos pelo candidato à reeleição.

Finalmente, duas considerações especiais devem ainda ser apresentadas: a primeira diz respeito aos resultados que envolvem o alinhamento partidário entre governador e presidente da República, uma vez que caso tal fenômeno aconteça, despesas mais elevadas realizadas na esfera federal têm impactos negativos sobre a proporção de votos recebida pelos candidatos aos governos estaduais. O segundo fenômeno está associado à existência dos dois principais partidos políticos americanos e ao resultado que demonstra que nas eleições para governador, despesas mais elevadas são especialmente punidas caso o candidato seja democrata, partido tradicionalmente defensor de uma maior participação pública no funcionamento da economia e que, conforme os resultados sugerem, fazem com que os eleitores desenvolvam uma "restrição" a tal tendência.

Ainda em relação à literatura internacional, um segundo estudo relevante diz respeito à análise da reeleição nos municípios israelenses realizado por Brender (2003), no qual são investigados quais fatores influenciam a probabilidade de permanência no poder nas eleições dos anos de 1989, 1993 e 1998. A relevância deste estudo está na ênfase sobre as mudanças institucionais que ocorrem ao longo do período analisado, como um maior rigor do governo central israelense em auditar as contas dos governos locais e o desenvolvimento de mecanismos efetivos de controle do orçamento público destas unidades. Com base neste elemento, os testes realizados pelo autor permitem observar que somente na eleição de 1998, ou seja, após a implementação das reformas, há alguma influência de fatores fiscais sobre a reeleição dos governantes locais - assim, este resultado parece sugerir que o comportamento do eleitorado sofre mudanças ao longo do tempo, principalmente ao permitir que os mesmos tenham uma maior experiência com o processo eleitoral e em avaliar informações relevantes para suas decisões eleitorais, que por sua vez foram sistematizadas devido às reforma institucionais.

Em relação às questões fiscais, os resultados indicam que os eleitores israelenses são avessos à deterioração das contas públicas ao longo do mandato. Um resultado 
particularmente importante é que deteriorações fiscais ocorridas especificamente nos anos eleitorais não influenciam de forma significante as chances de permanência no poder. Adicionalmente, três resultados particulares são providos pelos resultados deste estudo: (i) a melhora da qualidade dos serviços prestados pelos governos locais (mensurada pela qualidade da educação pública) é um fator preponderante para os eleitores israelenses, gerando uma maior probabilidade de manter um governo no poder; (ii) o volume de recursos obtidos pelos governos locais através de transferências do governo central não apresenta influência significante sobre a reeleição, ou seja, os eleitores israelenses parecem ser indiferentes a um maior esforço da administração local em obter maiores receitas junto a instâncias superiores do poder político e (iii) os eleitores de tais unidades tendem a avaliar positivamente governos que executam maiores despesas em projetos de desenvolvimento local (investimentos públicos), propiciando aos mesmos uma maior probabilidade de reeleição.

Finalmente, um terceiro trabalho da literatura internacional considerado relevante neste contexto é o realizado por Brender \& Drazen (2005), no qual é avaliado como a probabilidade de reeleição dos chefes do poder Executivo é afetada pelo comportamento fiscal em uma amostra de 74 países ao longo do período 1960 - 2003. Apesar de relativamente pequeno em termos das unidades seccionais, este conjunto inclui uma gama bastante variada de países, tanto em termos de desenvolvimento econômico como em termos de anos de existência e características políticas, entre outros fatores, o que ratifica a relevância desta referência.

Em termos mais específicos, os autores procuram avaliar como o déficit público (orçamentário) decomposto em déficit do ano eleitoral e déficit dos demais anos de um dado período de governo (ambos avaliados como proporção do PIB) e como as taxas de crescimento do PIB, também decompostas em crescimento do ano eleitoral e crescimento médio do período de governo, influenciam as possibilidades de reeleição do chefe do Executivo ou então, de seu partido político. Com vistas a promover uma análise mais específica conforme as informações disponíveis pelos autores, as estimações econométricas realizadas pelos mesmos são controladas por variáveis de natureza política que, de fato, podem afetar o comportamento do evento da reeleição, a saber: regime de governo (presidencialista ou parlamentarista), grau de desenvolvimento econômico (desenvolvidos ou em desenvolvimento), sistema eleitoral (proporcional ou majoritário) e finalmente, o período em que o regime democrático prevalece nos países (divididos em duas categorias, quais sejam, novas e velhas democracias). 
Os resultados obtidos pelos autores são especialmente relevantes uma vez que mesmo controlando por todos os fatores mencionados, é possível observar de forma robusta que os eleitores não recompensam os políticos que promovem desajustes fiscais (déficits elevados) em anos eleitorais. Especialmente nos países desenvolvidos e com democracias consolidadas, o resultado é justamente o oposto e sugere que seus eleitores avaliam de forma positiva a realização de gestões fiscais conservadoras, propiciando aos seus chefes de Executivos maiores probabilidades de permanência no poder caso sejam observadas reduções na relação déficit público sobre o PIB. Desta forma, além de corroborar, em alguma medida pequena que seja, os resultados observados em Peltzman (1992), os resultados de Brender \& Drazen (2005) também indicam que a percepção dos eleitores acerca dos resultados econômicos depende das características dos países em que vivem, o que em certa medida sugere a relevância das características institucionais e as restrições e incentivos que as mesmas geram para o comportamento da classe política.

Especificamente para o caso brasileiro, Libânio (2003) analisa o fenômeno da reeleição nas eleições brasileiras para o cargo de governador, entre os anos de 1982 a $1998^{20}$, procurando enfatizar a influência de indicadores sócio-econômicos sobre a variável de interesse. A permanência no poder (variável binária que assume 1 caso o governador ou seu partido tenha sido reeleito, 0 caso contrário) é regredida, através de um modelo logit em painel (uma vez que existem informações sobre os estados brasileiros ao longo do tempo), em função de variáveis que mensuram o bem-estar dos eleitores, quais sejam, (i) Pobreza (número de pessoas vivendo abaixo da linha de pobreza), (ii) Desigualdade [diferença entre a menor renda entre os $25 \%$ chefes de família mais ricas (de maior rendimento) e a maior renda entre os $25 \%$ chefes de família mais pobres (de menor rendimento)], (iii) Renda (mediana da renda familiar per capita), (iv) Infra-estrutura (qualidade das moradias das famílias), (v) Ativos (geladeira, fogão e cômodos médios nas residências), (vi) Agricultura (porcentagem de indivíduos trabalhando neste setor), (vii) Educação (escolaridade entre jovens de 10 e 15 anos) e finalmente (viii) Desemprego (\% de indivíduos procurando emprego), por região metropolitana brasileira ${ }^{21}$.

Os resultados obtidos permitem observar que o aumento da pobreza influencia negativamente a permanência no poder, embora nenhuma influência seja exercida pela desigualdade de renda - tal resultado seria um indício de que os eleitores parecem não se

\footnotetext{
${ }^{20} \mathrm{O}$ trabalho exclui o estado do Tocantins bem como o Distrito Federal, pela indisponibilidade de informações. Por sua vez, como a reeleição do candidato é permitida somente a partir da eleição de 1998, o estudo trata a permanência do partido político como reeleição.

${ }^{21}$ Variáveis extraídas das PNAD's.
} 
importar com a dispersão de renda, mas predominantemente com a pobreza. Adicionalmente, maiores chances de reeleição seriam observadas nos estados com uma maior proporção de indivíduos trabalhando no setor agrícola, sugerindo que nestes casos haveria uma maior dificuldade em conhecer novos postulantes ao cargo (opositores ao incumbente), bem como nos estados em que exista uma maior quantidade de ativos domésticos possuídos pelas famílias. De qualquer forma, os resultados sugerem uma percepção generalizada de que a melhora dos indicadores sociais seria sinalizadora da qualidade da administração pública e que, conseqüentemente, seria recompensada pelos eleitores através de uma maior probabilidade de manter um candidato/partido no poder.

Também analisando os estados brasileiros, Nakaguma (2006) pode ser novamente considerado $^{22}$ como uma referência relevante neste contexto, ao avaliar o sucesso eleitoral dos governadores brasileiros (ou de seus respectivos partidos políticos, mensurado pela proporção de votos recebidos nas tentativas de reeleição) em função do comportamento das receitas e das despesas estaduais. O tratamento sugerido pelo autor decompõe estes dois elementos em três componentes, a saber, (i) uma fração exógena, independente de questões políticas, (ii) uma fração oportunista, em função do calendário eleitoral e (iii) a fração residual, que seria uma proxy para avaliar a competência do candidato à permanência no poder.

De acordo com os resultados, manipulações com caráter oportunista (eleitoral) tanto na receita como na despesa afetam positivamente a proporção de votos obtidos nas eleições, resultado que pode indicar uma falta de controle dos eleitores sobre os políticos. De todo modo, o estudo evidencia que tal influência tende a ser declinante no tempo - conforme já citado anteriormente, este parece ser um indício de que a interação e a experiência dos eleitores com o processo eleitoral reduz as possibilidades de exploração de instrumentos fiscais com vistas à obtenção de benefícios políticos. Por sua vez, de forma contra-intuitiva, a fração das receitas e das despesas estaduais associadas à competência do candidato não influencia de forma preponderante o sucesso político dos governadores ${ }^{23}$.

Finalmente, três resultados relevantes ainda podem ser analisados. O primeiro sugere que há uma queda na proporção de votos recebidos pelo governador caso este e o presidente da República sejam pertencentes ao mesmo partido político, fenômeno que, segundo o autor, pode ser justificado pelo desgaste político ao qual o presidente da República está sujeito ao longo do seu mandato, gerando assim conseqüências para políticos a ele ligados. O segundo aponta para um acirramento das eleições estaduais, uma vez que a fragmentação das

\footnotetext{
${ }^{22}$ Referência já citada no primeiro capítulo desta tese.

${ }^{23}$ Nos casos em que ocorre, tal influência é observada somente no período final da amostra.
} 
preferências políticas do eleitorado tem apresentado influencia negativa e crescente sobre a variável dependente. Por fim, o terceiro resultado é intuitivo e indica que candidatos à reeleição possuem inerentemente uma significativa e maior chance de sucesso político, decorrente do simples fato de já estar no poder.

Especificamente sobre a questão da reeleição nos municípios brasileiros, Mendes e Rocha (2004) e Mendes (2004) analisam, de forma bastante semelhante, o resultado das eleições municipais de 2000 através dos procedimentos econométricos de modelo de seleção e modelo de Heckman com vistas a identificar quais fatores influenciam a decisão de um prefeito brasileiro em tentar a reeleição ( $1^{\circ}$ estágio) e uma vez feita a escolha, quais fatores determinariam a sua efetiva reeleição ( $2^{\circ}$ estágio - caso do modelo de seleção) ou então, quais fatores determinariam a proporção de votos recebida nos pleitos $\left(2^{\circ}\right.$ estágio - caso do modelo de Heckman).

Os estudos abrangem um conjunto bastante significante de variáveis explicativas, que podem ser categorizadas em quatro grupos básicos, quais sejam, (i) variáveis associadas à performance do candidato, (ii) variáveis associadas à condição política do candidato, (iii) variáveis associadas às características locais do município e finalmente, (iv) variáveis associadas às características pessoais do candidato ${ }^{24}$.

Alguns dos resultados são comuns aos dois trabalhos, entre os quais destaca-se o fato de que municípios criados entre 1993 e 1996 apresentam maiores probabilidades de tentativa e de obtenção efetiva da reeleição, sinalizando que municípios mais novos praticamente não possuem endividamento e, portanto, possuem um orçamento com menores restrições à execução orçamentária. O alinhamento partidário com o presidente da República e o desempenho na eleição de 1996 também tendem a afetar positivamente as chances de um prefeito manter-se no poder. Particularmente ao primeiro dos estudos, encontram-se evidências de que denúncias de crimes graves parecem afetar (negativamente) somente os candidatos da região Sul e Sudeste do país, ao passo que parece não ter influência sobre o desempenho político dos candidatos do Norte e Nordeste, sendo assim uma alusão indireta às diferenças educacionais e institucionais entre tais regiões. Já em relação aos resultados específicos do segundo estudo, o desempenho fiscal dos prefeitos influencia expressivamente

\footnotetext{
${ }^{24}$ Para (i), pode se considerar como exemplos a evolução de indicadores sociais e fiscais durante o período de governo, bem como o histórico de crimes pessoais ou de irregularidades administrativas. Para (ii), o desempenho na eleição de 1996 e alinhamento partidário com o governador do respectivo estado e com o presidente da República. Para (iii), características demográficas como analfabetismo, grau de urbanização e o fato do município ter sido criado entre 1993 e 1996, entre outros, e finalmente, para (iv) é considerada a idade do prefeito.
} 
sua performance política, uma vez que as chances de reeleição estão fortemente associadas à execução de maiores despesas correntes, bem como à maior obtenção de transferências correntes e de transferências de capital a partir da União e do (respectivo) governo estadual. Assim, os resultados parecem sugerir que dentro do federalismo fiscal brasileiro, seria ideal ao prefeito procurar canalizar o máximo de recursos possíveis ao seu município, em detrimento de um equilibro agregado na gestão dos orçamentos dos municípios brasileiros.

\section{2 - Referencial metodológico \& descrição dos dados ${ }^{25}$}

O segundo capítulo desta tese tem como propósito básico avaliar como a probabilidade de permanência dos prefeitos brasileiros é influenciada por fatores de natureza fiscal ou, em outras palavras, como o comportamento da despesa municipal tende a afetar a expectativa de reeleição, procurando considerar explicitamente a existência dos diferentes partidos políticos brasileiros e como este fator tende a afetar o comportamento do fenômeno de interesse.

O método aqui utilizado consiste em utilizar o modelo de estimação logit considerando, no entanto, que a amostra aqui avaliada é um conjunto de dados em painel, ou seja, conforme descrito no primeiro capítulo desta tese, existem informações a respeito dos municípios brasileiros para os anos eleitorais de 1988, 1992, 1996 e 2000, o que permite estudar a reeleição nos três últimos dos quatro supracitados. Não obstante, diferentemente do exercício econométrico realizado no primeiro capítulo, em que eram consideradas tanto a amostra não balanceada como a amostra balanceada nas análises, este segundo capítulo enfatizará apenas a amostra balanceada dos municípios brasileiros, que contempla 2235 prefeituras.

Para cada método de estimação implementado (efeitos fixos, efeitos aleatórios e pooled - dados agrupados), são consideradas três estimações de interesse. A variável dependente das estimações assume 1 quando o prefeito municipal ou seu partido é reeleito (0 caso contrário $)^{26}$, ao passo que as variáveis de controle são basicamente as mesmas consideradas no primeiro capítulo desta tese, quais sejam, (i) receita tributária per capita, (ii)

\footnotetext{
${ }^{25}$ Para as estimações, considere novamente que:

$* * *$ : coeficiente estatisticamente significante a $1 \%$

**: coeficiente estatisticamente significante a $5 \%$

*: coeficiente estatisticamente significante a $10 \%$

${ }^{26}$ Note que a variável dependente aqui avaliada é distinta da considerada em Peltzman (1992), uma vez que a proporção de votos recebida pelos candidatos a prefeito é uma informação não disponível para todas as eleições realizadas no período.
} 
receita de transferências per capita; (iii) proporção de idosos e (iv) proporção de jovens residentes em cada município considerado, bem como (v) taxa de urbanização e (vi) a população total (em logaritmo) de cada município e finalmente (vii) uma dummy que assume o valor 1 caso o partido do prefeito municipal e o partido do governador do estado sejam iguais ( 0 caso contrário) e (viii) uma dummy que assume o valor 1 caso o partido do prefeito municipal e o partido do presidente da República sejam iguais ( 0 caso contrário). Considerase também que o alinhamento partidário com o governo estadual e federal pode, a princípio, influenciar as oportunidades dos prefeitos que procuram permanecer no poder através de outras formas que não aquelas associadas à questão orçamentária. Já a receita municipal, novamente dividida entre receita tributária e receita de transferências, é incluída na regressão com o propósito de permitir avaliar como a despesa municipal afeta a variável dependente efetiva e isoladamente, uma vez que um município pode eventualmente vir a ter uma probabilidade elevada de reeleição devido a uma despesa municipal mais elevada mas que, por sua vez, ocorre devido à existência de recursos mais elevados para tal.

Neste ponto do trabalho, torna-se importante ressaltar que, dada a indisponibilidade de dados, não foi possível considerar mudanças nos Executivos municipais brasileiros que acontecem ao longo de um dado período de governo. Mais especificamente, não foi possível captar a possibilidade de um prefeito mudar de partido político ao longo do mandato ou de abandonar o cargo para a disputa de outro (principalmente devido à possibilidade do viceprefeito, que assumiria o cargo neste caso, ser de outro partido político), fatos que não raramente acontecem no cenário político nacional. Assim, uma ressalva importante deste capítulo reside no pressuposto de que uma vez iniciado um mandato, o prefeito termina o mesmo, sem qualquer tipo de alteração semelhante às discutidas anteriormente. Esclarece-se também que especificamente para o ano eleitoral de 2000, primeiro ano em que passa a ser permitida a reeleição dos prefeitos eleitos em 1996, o evento reeleição do prefeito é tratado como a efetiva permanência do mesmo, independente de alterações partidárias que possam ter ocorrido ao longo do período ${ }^{27}$.

O gráfico 2.1 em seqüência apresenta a proporção de prefeituras administradas por cada um dos partidos políticos durante cada um dos períodos administrativos abordados nesta análise, ao passo que o gráfico 2.2 apresenta as suas respectivas taxas de reeleição. Em 1992 e 1996 somente a reeleição dos partidos políticos era permitida, ao passo que em 2000 tanto o partido como o próprio prefeito municipal poderia concorrer à permanência no poder. Isso

\footnotetext{
${ }^{27}$ Em outros termos, controla-se pelo nome do prefeito efetivamente.
} 
pode ser uma justificativa do porquê das taxas de reeleições em 2000 serem mais elevadas que nos demais anos - em 1992, a taxa média de reeleição é da ordem de $22,42 \%$, ao passo que em 1996 é igual a 18,52\% e em 2000, passa a ser igual a 42,45\%. Especificamente focalizando os partidos, o caso do PL é um dos mais interessantes, uma vez que em 1992 sua taxa de reeleição foi da ordem de $12,60 \%$, passando a sofrer significativo aumento e vindo a ser igual a 50,00\% em 2000. Ao grupo "outros partidos" tal fenômeno também é observado, ou seja, um crescimento expressivo da proporção da ocorrência da reeleição. Em 2000, observa-se também uma menor disparidade entre-partidos das taxas de reeleição, ou seja, as chances de permanência no poder são mais elevadas e mais homogêneas para todas as agremiações.

Gráfico 2.1 - Prefeituras administradas pelos partidos políticos, por período de governo (em \%)

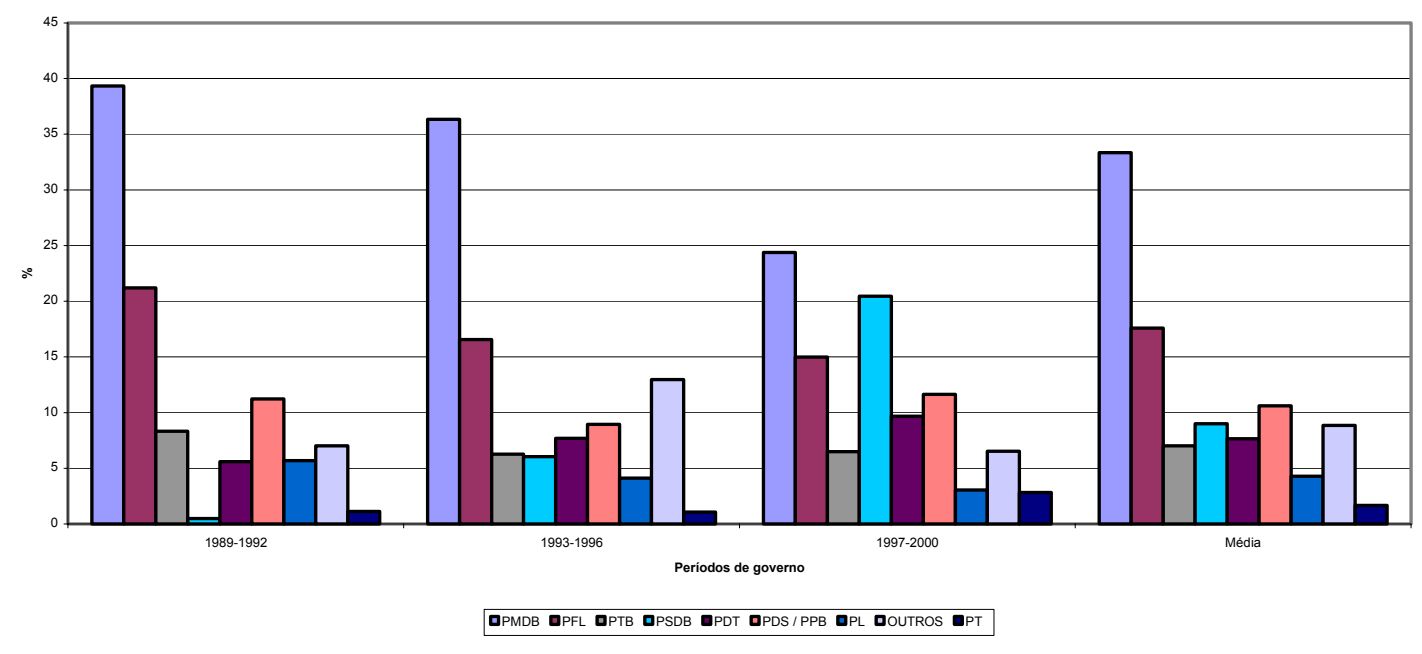

Fonte: construção própria, com base nos dados do TSE e TRE's

Gráfico 2.2 - Taxa de reeleição dos partidos políticos, por ano eleitoral (em \%)

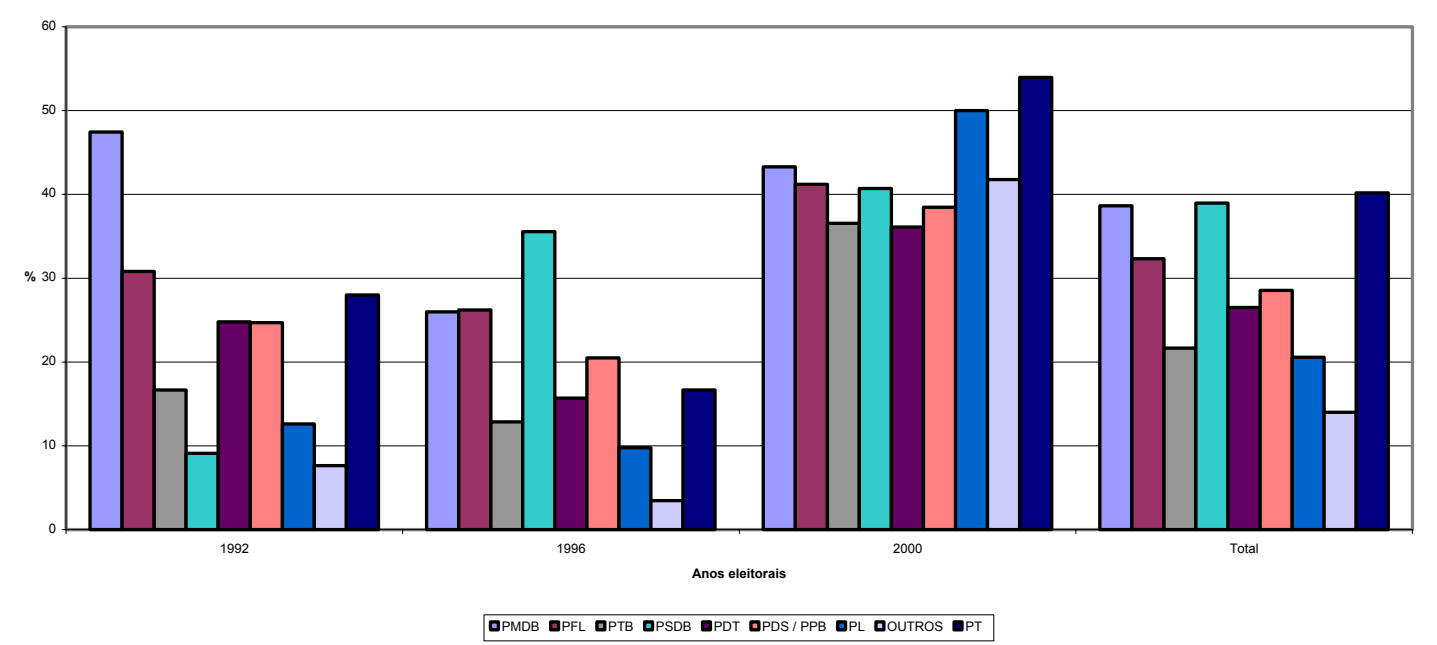

Fonte: construção própria, com base nos dados do TSE e TRE's 
Uma análise conjunta das duas ilustrações anteriores também permite observar alguns resultados importantes dentro da amostra, como por exemplo o caso do PT, que em termos proporcionais administra poucos municípios, mas que apresenta taxas de permanência no poder relativamente elevadas quando comparadas à média geral - durante o período 1997 2000 por exemplo, o partido administrou apenas 2,82\% dos municípios da amostra, mas obteve uma taxa de reeleição da ordem de 53,97\% na eleição do ano de 2000. Os casos do PFL e do PMDB tendem a apresentar característica relativamente oposta comparativamente ao PT, uma vez que a proporção de prefeituras administradas pelos mesmos e suas respectivas taxas de reeleição não apresenta disparidades tão elevadas entre si. No caso do PFL, cuja participação média na amostra total é da ordem de 17,58\%, sua taxa média de reeleição é da ordem de 32,32\%, ao passo que para o PMDB tais valores são iguais a 33,35\% e 38,64, respectivamente.

Tendo em mente tais elementos, dois exercícios econométricos são realizados neste capítulo, cujas descrições e resultados são apresentados em seqüência.

\section{3 - Despesa total (despesa orçamentária total dos quatro anos de governo)}

A tabela 2.1 apresenta os resultados das regressões do primeiro teste econométrico, que associa a (dummy de) reeleição dos prefeitos ou dos partidos dos municípios brasileiros em função da despesa orçamentária realizada durante os quatro anos do respectivo período administrativo. Assim, o propósito é procurar encontrar alguma evidência de que maiores despesas sejam eventualmente convertidas em maior ou menor sucesso político (aqui entendido como a permanência no poder) do prefeito ou do partido incumbente. Desta forma, para cada um dos três métodos de estimação:

- A primeira estimação (primeira coluna - A) considera apenas a despesa orçamentária (per capita e em logaritmo natural) e as variáveis de controle como regressores;

- A segunda regressão (segunda coluna - B) considera além das variáveis já inclusas na primeira regressão, dummies para cada um dos nove partidos considerados neste trabalho (os mesmos considerados no primeiro capítulo), ressaltando-se que a dummy associada ao PMDB foi retirada da regressão para evitar multicolinearidade perfeita entre tais variáveis (procedimento já considerado no primeiro capítulo deste estudo). Desta forma, a consideração das dummies de partido procura avaliar se partidos diferentes possuem, inerentemente, probabilidades diferentes de reeleição; 
- A terceira regressão (terceira coluna - C) avalia todos os regressores considerados na segunda regressão, além das interações entre despesa orçamentária total (em logaritmo natural) e as dummies de partido. Desta forma, além de avaliar a influência particular de cada partido sobre a probabilidade de permanência no poder, existe o propósito adicional de procurar avaliar como as despesas realizadas por cada um dos partidos políticos afetam a variável dependente de interesse. Os resultados desta estimação estão ilustrados nos gráficos 2.3 e 2.4. Para esta última estimação, são realizados os testes de hipótese de igualdade entre os coeficientes das dummies de partido (partido a partido), bem como testes de hipótese de igualdade entre os coeficientes das interações entre dummy de partido e despesa orçamentária (interação a interação), cujos resultados encontram-se expostos no apêndice 2.3. Deve ser ressaltado que as tabelas com os resultados das estimações apresentam os coeficientes das estimações propriamente, e não os efeitos marginais das variáveis independentes sobre a reeleição. Por sua vez, ressalta-se também que são expostos somente os resultados obtidos através do procedimento de efeitos fixos, considerados consistentes de acordo com o teste de Hausman. Os coeficientes obtidos através dos métodos de dados agrupados (pooled) e de efeitos aleatórios são apresentados no apêndice 2.1 desta tese. 
Tabela 2.1 - Probabilidade de reeleição em função da despesa total (total dos quatro anos) - modelo logit - efeitos fixos

\begin{tabular}{|c|c|c|c|}
\hline $\begin{array}{c}\text { Coeficiente } \\
\text { (desvio-padrão) }\end{array}$ & (A) & (B) & (C) \\
\hline Despesa Total & $\begin{array}{l}0.881^{* *} \\
(0.368)\end{array}$ & $\begin{array}{l}0.816^{\star *} \\
(0.370)\end{array}$ & $\begin{array}{l}0.713^{*} \\
(0.386)\end{array}$ \\
\hline PFL & & $\begin{array}{l}-0.209^{*} \\
(0.113)\end{array}$ & $\begin{array}{c}0.611 \\
(1.686)\end{array}$ \\
\hline PTB & & $\begin{array}{c}-0.438^{\star * *} \\
(0.171)\end{array}$ & $\begin{array}{l}-4.434 \\
(2.922)\end{array}$ \\
\hline PSDB & & $\begin{array}{l}-1.938 \\
(1.237)\end{array}$ & $\begin{array}{l}-1.355 \\
(2.379)\end{array}$ \\
\hline PDT & & $\begin{array}{l}-0.094 \\
(0.150) \\
\end{array}$ & $\begin{array}{l}-3.268 \\
(2.595) \\
\end{array}$ \\
\hline PDS / PPB & & $\begin{array}{l}-0.099 \\
(0.134)\end{array}$ & $\begin{array}{c}-4.508^{* *} \\
(2.298)\end{array}$ \\
\hline PL & & $\begin{array}{c}-0.574^{* * *} \\
(0.207) \\
\end{array}$ & $\begin{array}{c}-10.091^{\text {*** }} \\
(3.301) \\
\end{array}$ \\
\hline OUTROS & & $\begin{array}{c}-0.532^{* * *} \\
(0.170)\end{array}$ & $\begin{array}{c}-6.023)^{* *} \\
(2.503)\end{array}$ \\
\hline PT & & $\begin{array}{l}0.547^{* *} \\
(0.277) \\
\end{array}$ & $\begin{array}{l}-3.365 \\
(5.048) \\
\end{array}$ \\
\hline Despesa Total \& PFL & & & $\begin{array}{l}-0.107 \\
(0.216)\end{array}$ \\
\hline Despesa Total \& PTB & & & $\begin{array}{c}0.507 \\
(0.369)\end{array}$ \\
\hline Despesa Total \& PSDB & & & $\begin{array}{l}-0.126 \\
(0.270)\end{array}$ \\
\hline Despesa Total \& PDT & & & $\begin{array}{c}0.403 \\
(0.327)\end{array}$ \\
\hline Despesa Total \& PDS / PPB & & & $\begin{array}{l}0.558^{*} \\
(0.290)\end{array}$ \\
\hline Despesa Total \& PL & & & $\begin{array}{l}1.223^{\star \star *} \\
(0.422)\end{array}$ \\
\hline Despesa Total \& Outros & & & $\begin{array}{l}0.710^{* *} \\
(0.321)\end{array}$ \\
\hline Despe*sa Total \& PT & & & $\begin{array}{c}0.497 \\
(0.636) \\
\end{array}$ \\
\hline Receita tributária & $\begin{array}{l}0.203^{\star *} \\
(0.083)\end{array}$ & $\begin{array}{c}0.215^{\star * * *} \\
(0.084)\end{array}$ & $\begin{array}{l}0.206^{* *} \\
(0.085)\end{array}$ \\
\hline Receita de Transferências & $\begin{array}{l}0.570^{*} \\
(0.341)\end{array}$ & $\begin{array}{l}0.594^{*} \\
(0.344)\end{array}$ & $\begin{array}{c}0.534 \\
(0.347) \\
\end{array}$ \\
\hline Prefeito \& Governador & $\begin{array}{l}0.182^{* *} \\
(0.075)\end{array}$ & $\begin{array}{l}0.192^{* *} \\
(0.078)\end{array}$ & $\begin{array}{l}0.193^{* *} \\
(0.079) \\
\end{array}$ \\
\hline Prefeito \& Presidente & $\begin{array}{c}0.574^{* \star *} \\
(0.132)\end{array}$ & $\begin{array}{l}2.352^{*} \\
(1.237) \\
\end{array}$ & $\begin{array}{l}2.836^{* *} \\
(1.257)\end{array}$ \\
\hline Idosos & $\begin{array}{c}-0.417^{\star \star *} \\
(0.060) \\
\end{array}$ & $\begin{array}{c}-0.424^{* * *} \\
(0.060) \\
\end{array}$ & $\begin{array}{c}-0.419^{\star \star \star} \\
(0.060) \\
\end{array}$ \\
\hline Urbanização & $\begin{array}{l}-0.009 \\
(0.009) \\
\end{array}$ & $\begin{array}{l}-0.007 \\
(0.009)\end{array}$ & $\begin{array}{l}-0.010 \\
(0.009) \\
\end{array}$ \\
\hline Jovens & $\begin{array}{c}0.084^{* * *} \\
(0.030)\end{array}$ & $\begin{array}{c}0.084^{* \star *} \\
(0.030)\end{array}$ & $\begin{array}{c}0.083^{\star * *} \\
(0.031)\end{array}$ \\
\hline População Total & $\begin{array}{c}0.504 \\
(0.360) \\
\end{array}$ & $\begin{array}{c}0.415 \\
(0.362) \\
\end{array}$ & $\begin{array}{c}0.395 \\
(0.364) \\
\end{array}$ \\
\hline Constante & - & - & - \\
\hline Observações & 4085 & 4085 & 4085 \\
\hline Teste de Hausman & $\begin{array}{l}\chi^{2}=147,15 \\
\text { Prob }=0,00\end{array}$ & $\begin{array}{l}\chi^{2}=262,47 \\
\text { Prob }=0,00\end{array}$ & $\begin{array}{l}\chi^{2}=278,37 \\
\text { Prob }=0,00\end{array}$ \\
\hline
\end{tabular}

Fonte: elaboração própria 
Gráfico 2.3 - Dummies de partido

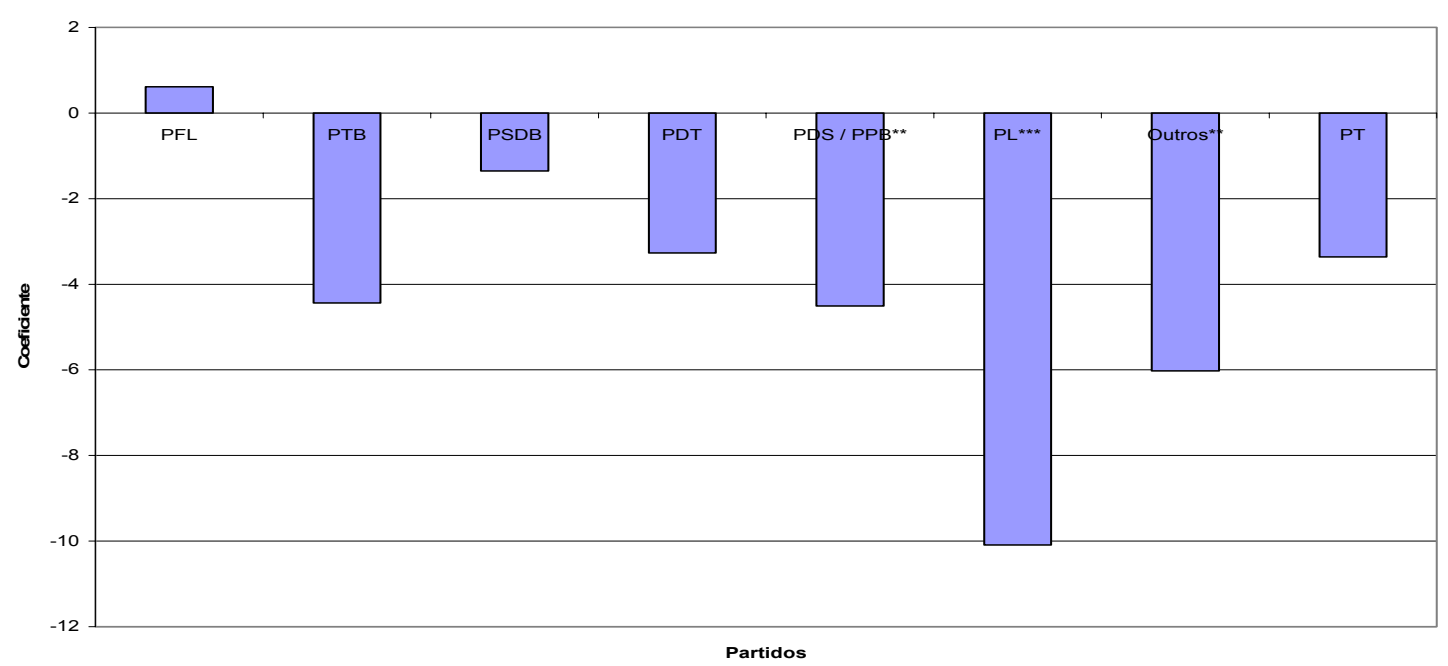

Fonte: elaboração própria

Gráfico 2.4 - Interações entre dummies de partido \& despesa total

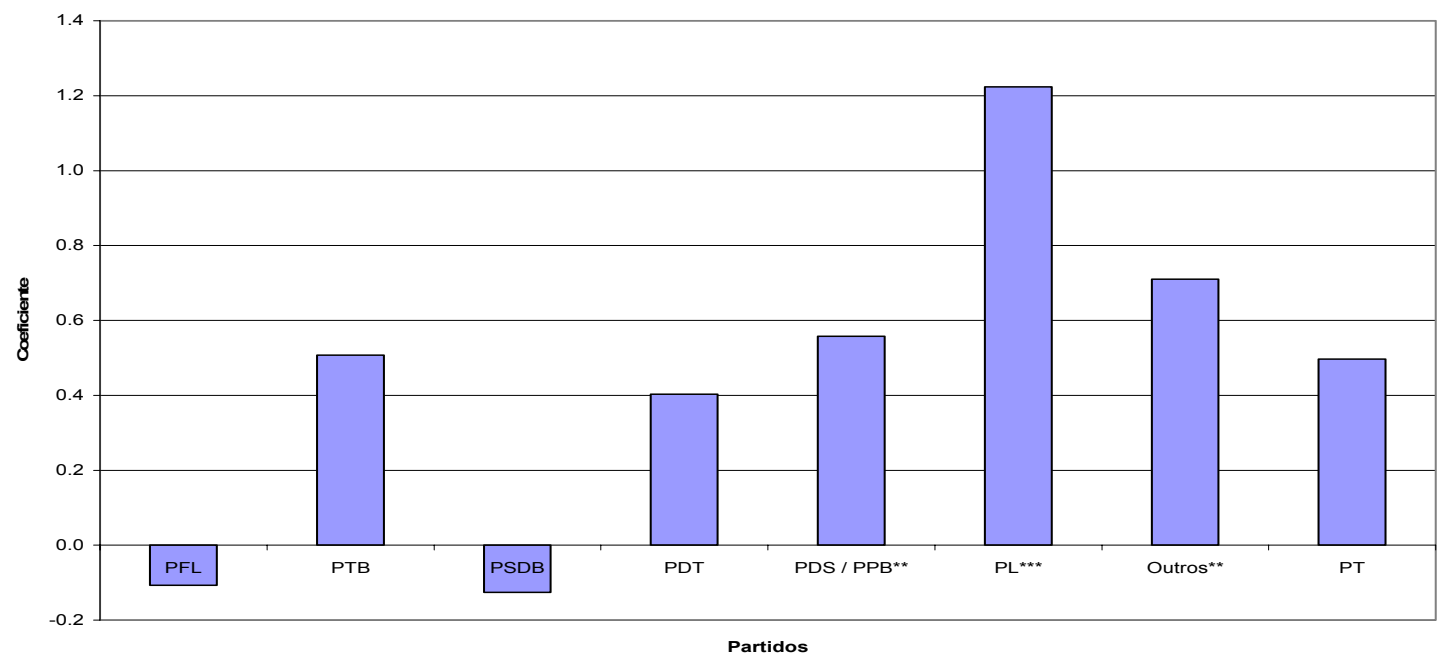

Fonte: elaboração própria

Considerando os resultados obtidos através do método de efeitos fixos (vide teste de Hausman), o resultado obtido na primeira regressão (coluna A) permite observar que um maior nível de despesa realizada pelas prefeituras, ao longo dos quatros anos de governo, é convertido em maior probabilidade de reeleição. Em relação às variáveis de controle, estas parecem indicar que municípios com menores proporções de idosos e com maiores proporções de jovens tendem a ter maiores chances de reeleição, ao passo que maiores chances de reeleição também são observadas quando existe o alinhamento partidário do prefeito municipal com o governador do estado e com o presidente da República. Os coeficientes associados à taxa de urbanização e à população total são estatisticamente não 
significantes e finalmente, o montante de receitas tributária e de transferências influencia positivamente a probabilidade de reeleição.

Os resultados obtidos pela segunda regressão (coluna B) são relativamente robustos quando comparados aos resultados obtidos na primeira regressão, ou seja, despesas mais elevadas continuam influenciando positivamente a probabilidade de reeleição, ao passo que uma maior receita tributária per capita, uma maior receita de transferências per capita, uma menor proporção de idosos e uma maior proporção de jovens continuam influenciando positivamente a probabilidade de permanência no poder. Adicionalmente, a reeleição continua sendo positivamente influenciada pelo alinhamento político do prefeito com o Executivo estadual e federal. Por fim, as dummies de partido parecem indicar que o PMDB se diferencia em relação aos demais partidos por possuir uma probabilidade de reeleição inerentemente maior que PFL, PTB, PL e outros partidos, mas menor que a observada para o PT. Quanto ao PSDB, PDT e PDS / PPB não há nenhuma diferenciação mais significante.

No que diz respeito aos resultados obtidos na terceira regressão (coluna C), observa-se a permanência dos resultados associados às variáveis de controle relativamente às estimações das colunas A e B, ou seja, municípios com uma maior receita tributária per capita, uma maior proporção de jovens, menor proporção de idosos e com prefeitos politicamente alinhados com o governo estadual e federal apresentam maiores probabilidades de reeleição (coeficientes estatisticamente significantes a, no máximo, 10\%). Nesta regressão, contudo, o coeficiente associado às transferências governamentais é significante somente a $13 \%$. De todo modo, observa-se que o coeficiente associado à despesa total continua sendo positivo $(0,71)$ e estatisticamente significante a $1 \%$, sugerindo que maiores despesas executadas ao longo de um período de governo prejudicam as chances de permanência de um prefeito ou de um candidato de seu partido.

Com respeito às dummies de partido, cujos coeficientes estão ilustrados no gráfico 2.3, os resultados indicam que o PMDB apresenta uma maior probabilidade de permanência no poder, principalmente em relação ao PDS / PPB, PL e o grupo formado pelos outros partidos - note que este é inclusive um resultado que corrobora as informações contidas no gráfico 2.2. Adicionalmente, os resultados dos testes de hipóteses (vide apêndice 2.3) parecem indicar que o PMDB e o PFL apresentam posições privilegiadas, uma vez que apresentam inerentemente maiores probabilidades de reeleição em relação ao PDS / PPB, PL e grupo formado pelos outros partidos. Os testes permitem ainda observar que o PL possui uma menor probabilidade de reeleição relativamente ao PDT e PSDB e finalmente, o PFL possui uma probabilidade de reeleição superior à do PTB. 
Os resultados mais específicos ficam por conta das interações entre os partidos políticos e o total da despesa executada nos quatro anos de governo, cujos resultados (ilustrados no gráfico 2.4) apresentam coeficientes positivos e estatisticamente significantes (a, no máximo, 10\%) para o PDS / PPB, PL e outros partidos (iguais a 0,558, 1,223 e 0,710 respectivamente). Considerando como referência a soma numérica entre estes valores e o coeficiente associado à despesa total $(0,71$, conforme visto anteriormente), tem-se que os coeficientes associados à PDS / PPB, PL e o grupo formado pelos outros partidos passam a ser igual a 1,271, 1,936 e 1,423 respectivamente, indicando que nestes casos despesas orçamentárias mais elevadas ao longo do mandato tendem a ser benéficas à permanência no poder, em comparação com o PMDB.

Os testes de hipótese (vide apêndice 2.3) parecem demonstrar que maiores despesas apresentam uma maior ou menor efetividade (sobre a probabilidade de reeleição) quando são comparados entre si dois partidos: assim, as despesas realizadas pelo PDS / PPB, PL e pelo grupo formado pelos outros partidos parecem ser politicamente mais favoráveis que as realizadas pelo PMDB, PFL e PSDB, dado que os coeficientes são estatisticamente maiores para aqueles (relativamente a estes). Por fim, os testes de hipótese permitem observar que as despesas efetuadas pelo PL são relativamente politicamente mais efetivas que as efetuadas pelo PDT.

\section{4 - Despesa do ano eleitoral \& despesa média dos anos não eleitorais}

O segundo teste a ser realizado consiste em modificar a despesa orçamentária considerada no teste anteriormente realizado. Neste último, tal variável consistia no seu somatório para cada um dos períodos de governo existentes na amostra, ou seja, consistia na despesa orçamentária realizada em um dado período administrativo (quatro anos), e os resultados permitiram observar que despesas municipais mais elevadas tendem a ser recebidas de forma favorável pelos eleitores, através de uma maior possibilidade de manter um prefeito (ou um partido) no poder, existindo também algum grau de diferenciação partidária na efetividade destas despesas.

Os resultados obtidos no primeiro capítulo permitiram observar que para a despesa orçamentária, o ano eleitoral pode normalmente ser visto como distinto dos demais e o argumento de que estas despesas tenham especial influência na escolha política dos eleitores pode ser considerada uma possível explicação. De qualquer forma, se estes anos se 
distinguem dos demais, então um estudo detalhado destes pode ser considerado relevante, principalmente no que diz respeito à influência destes sobre os resultados dos pleitos. Em Meneguin \& Bugarin (2001), no qual é analisado o comportamento fiscal dos estados brasileiros no ano de 1994, são apresentados resultados que demonstram uma maior contenção das despesas caso a possibilidade de reeleição do partido do governador seja elevada (uma vez que a possibilidade de reeleição ainda era inexistente na eleição de 1994). Em Meneguin, Bugarin \& Carvalho (2005), numa reavaliação de Meneguin \& Bugarin (2001), são apresentados resultados de testes econométrico que enfatizam justamente a influência mútua entre comportamento fiscal e a ocorrência reeleição (agora, aplicados aos municípios brasileiros na eleição de 2000), sugerindo que maiores as chances de reeleição levam a um maior conservadorismo fiscal e que os eleitores são avessos à despesas de custeio, atribuindo menores chances de reeleição aos prefeitos que executam maiores níveis desta despesa e atribuindo maiores chances de reeleição aos prefeitos que executam maiores investimentos públicos. Para os autores:

Por um lado, o governante é consciente de que pode influir em sua probabilidade de reeleição por meio de sua política fiscal, o que cria um incentivo ao gasto excessivo em anos eleitorais. Por outro lado, os eleitores percebem esse incentivo e, além disso, o próprio governante, percebe o custo futuro desse comportamento, caso seja eleito. Finalmente, o governante com freqüência, tem uma percepção bastante acurada de suas chances finais de reeleição muito antes do fím da campanha eleitoral, o que pode fazer com que, nesses últimos meses do mandato, ele adote como fixa sua probabilidade de reeleição independentemente de suas últimas escolhas de política fiscal. Os novos incentivos vigentes nesse último período da campanha eleitoral podem, de fato, explicar a legislação atual no Brasil, que muito limita os gastos públicos nos últimos seis meses de mandato, por exemplo. (MENEGUIN, BUGARIN \& CARVALHO (2005), p. 25)

Analisando o problema de forma ampla, é razoável considerar a necessidade de ações governamentais (do policymaker) ex ante que façam com quem avaliações positivas por parte do eleitorado sejam obtidas, o que geraria tal (elevada) probabilidade de permanência no poder em seu último período de governo. Desta forma, abre-se novamente espaço para a possibilidade de alterações de ordem fiscal em anos anteriores ao ano eleitoral no sentido de ampliar esta probabilidade de permanência do policymaker no governo, ou seja, volta a existir a possibilidade de manipulações eleitorais ao longo de um dado período administrativo, seja no ano eleitoral especificamente, seja nos demais anos anteriores. Tal raciocínio pode ser considerado válido justamente pelo fato de que em Meneguin \& Bugarin (2001) e em 
Meneguin, Bugarin \& Carvalho (2005) são consideradas as despesas realizadas exclusivamente no ano eleitoral, ou seja, abre-se espaço para que se possa avaliar a influência do comportamento fiscal dos anos anteriores ao eleitoral sobre a reeleição.

O novo estudo a ser realizado, cujo resultado está exposto na tabela 2.2, consiste em tentar avaliar, de forma mais específica, qual o impacto das despesas realizadas nos anos eleitorais sobre a probabilidade de reeleição de um prefeito ou então, novamente, de um correligionário de seu partido. Assim, a despesa orçamentária (novamente, per capita e em logaritmo natural) a ser considerada nas regressões passa a ser dividida em (i) a despesa realizada especificamente no ano eleitoral e (ii) a média da despesa realizada nos três anos anteriores ao ano eleitoral. O procedimento de estimação é basicamente o mesmo considerado no teste econométrico anterior, ou seja, as mesmas variáveis de controle e as mesmas dummies de partido continuam sendo consideradas, entretanto, a modificação passa a ocorrer na análise das interações entre despesa orçamentária e dummies de partido, considerando agora:

i) As interações entre a despesa do ano eleitoral e as dummies de partido;

ii) As interações entre a média da despesa dos três anos anteriores ao ano eleitoral e as dummies de partido.

Desta forma, reconsiderando as análises:

- A primeira estimação (primeira coluna - D) considera apenas a despesa do ano eleitoral e a despesa média dos três anos anteriores (não eleitorais), além das variáveis de controle como regressores;

- A segunda regressão (segunda coluna - E) considera, além das variáveis já inclusas na primeira regressão, as dummies para cada um dos nove partidos considerados neste trabalho, sendo o PMDB novamente excluído para evitar o problema anteriormente discutido;

- Por fim, a terceira regressão (terceira coluna - F) utiliza todos os regressores considerados na segunda regressão, além das interações entre despesa orçamentária do ano eleitoral e as dummies de partido, bem como as interações entre a despesa orçamentária média dos três anos não eleitorais e as dummies de partido (novamente excluindo-se o PMDB). Para esta estimação, o gráficos 2.5 apresenta os coeficientes das dummies de partido, ao passo que o gráfico 2.6 apresenta os coeficientes das interações entre dummies de partido e a despesa do ano eleitoral e finalmente, o gráfico 2.7 apresenta os coeficientes das interações entre dummies de partido e despesa média dos anos não eleitorais. Também são realizados os testes de hipótese de igualdade entre os coeficientes das dummies de partido e os testes de hipótese 
de igualdade entre os coeficientes das interações, cujos resultados encontram-se expostos no apêndice 2.4. Novamente, ressalta-se que são expostos somente os resultados obtidos através do procedimento de efeitos fixos, considerados consistentes de acordo com o teste de Hausman. Os coeficientes obtidos através dos métodos de dados agrupados (pooled) e de efeitos aleatórios são apresentados no apêndice 2.2 desta tese. 
Tabela 2.2 - Probabilidade de reeleição em função da despesa do ano eleitoral e da média dos três anos anteriores à eleição - modelo logit - efeitos fixos

\begin{tabular}{|c|c|c|c|}
\hline $\begin{array}{c}\text { Coeficiente } \\
\text { (desvio-padrão) }\end{array}$ & (D) & (E) & $(\mathrm{F})$ \\
\hline Despesa ano eleitoral & $\begin{array}{c}-0.762^{\star \star \star} \\
(0.227)\end{array}$ & $\begin{array}{c}-0.813^{\star \star *} \\
(0.229)\end{array}$ & $\begin{array}{c}-1.204^{\star \star *} \\
(0.329)\end{array}$ \\
\hline Despesa média 3 anos & $\begin{array}{c}1.460^{* * *} \\
(0.328)\end{array}$ & $\begin{array}{l}1.433^{* * *} \\
(0.330)\end{array}$ & $\begin{array}{l}1.848^{* * *} \\
(0.425)\end{array}$ \\
\hline PFL & & $\begin{array}{l}-0.228^{* *} \\
(0.114)\end{array}$ & $\begin{array}{c}0.325 \\
(1.402)\end{array}$ \\
\hline PTB & & $\begin{array}{c}-0.477^{* \star *} \\
(0.171)\end{array}$ & $\begin{array}{l}-3.517 \\
(2.465)\end{array}$ \\
\hline PSDB & & $\begin{array}{l}-2.103^{*} \\
(1.231)\end{array}$ & $\begin{array}{l}-1.594 \\
(2.101)\end{array}$ \\
\hline PDT & & $\begin{array}{l}-0.137 \\
(0.152) \\
\end{array}$ & $\begin{array}{l}-2.500 \\
(2.179) \\
\end{array}$ \\
\hline PDS / PPB & & $\begin{array}{l}-0.128 \\
(0.135)\end{array}$ & $\begin{array}{l}-3.691^{*} \\
(1.911)\end{array}$ \\
\hline PL & & $\begin{array}{c}-0.590^{\star * *} \\
(0.208)\end{array}$ & $\begin{array}{c}-8.908^{* * *} \\
(2.735) \\
\end{array}$ \\
\hline OUTROS & & $\begin{array}{c}-0.541^{\star \star *} \\
(0.171) \\
\end{array}$ & $\begin{array}{c}-5.019^{\star \star} \\
(2.055) \\
\end{array}$ \\
\hline PT & & $\begin{array}{l}0.504^{*} \\
(0.278) \\
\end{array}$ & $\begin{array}{c}0.390 \\
(4.614)\end{array}$ \\
\hline Despesa ano eleitoral \& PFL & & & $\begin{array}{c}0.554 \\
(0.517)\end{array}$ \\
\hline Despesa ano eleitoral \& PTB & & & $\begin{array}{c}0.510 \\
(0.929)\end{array}$ \\
\hline Despesa ano eleitoral \& PSDB & & & $\begin{array}{l}1.575^{\star *} \\
(0.793)\end{array}$ \\
\hline Despesa ano eleitoral \& PDT & & & $\begin{array}{c}1.271 \\
(0.844)\end{array}$ \\
\hline Despesa ano eleitoral \& PDS / PPB & & & $\begin{array}{l}1.298^{*} \\
(0.739)\end{array}$ \\
\hline Despesa ano eleitoral \& PL & & & $\begin{array}{l}2.223^{*} \\
(1.181)\end{array}$ \\
\hline Despesa ano eleitoral \& Outros & & & $\begin{array}{l}-1.398 \\
(0.976) \\
\end{array}$ \\
\hline Despesa ano eleitoral \& PT & & & $\begin{array}{l}-2.438 \\
(1.977) \\
\end{array}$ \\
\hline Despesa média 3 anos \& PFL & & & $\begin{array}{l}-0.650 \\
(0.524)\end{array}$ \\
\hline Despesa média 3 anos \& PTB & & & $\begin{array}{l}-0.050 \\
(0.897)\end{array}$ \\
\hline Despesa média 3 anos \& PSDB & & & $\begin{array}{c}-1.717^{* *} \\
(0.764) \\
\end{array}$ \\
\hline Despesa média 3 anos \& PDT & & & $\begin{array}{l}-0.925 \\
(0.830) \\
\end{array}$ \\
\hline Despesa média 3 anos \& PDS / PPB & & & $\begin{array}{l}-0.767 \\
(0.749)\end{array}$ \\
\hline Despesa média 3 anos \& PL & & & $\begin{array}{l}-0.947 \\
(1.175)\end{array}$ \\
\hline Despesa média 3 anos \& Outros & & & $\begin{array}{l}2.128^{* *} \\
(1.009) \\
\end{array}$ \\
\hline Despesa média 3 anos \& PT & & & $\begin{array}{c}2.485 \\
(1.804)\end{array}$ \\
\hline Receita tributária & $\begin{array}{l}0.251^{\star \star *} \\
(0.084)\end{array}$ & $\begin{array}{l}0.264^{\star \star *} \\
(0.085)\end{array}$ & $\begin{array}{c}0.252^{\star \star *} \\
(0.086)\end{array}$ \\
\hline Receita de transferências & $\begin{array}{c}0.551 \\
(0.349)\end{array}$ & $\begin{array}{l}0.587^{*} \\
(0.353)\end{array}$ & $\begin{array}{c}0.450 \\
(0.359)\end{array}$ \\
\hline Prefeito $=$ Governador & $\begin{array}{l}0.179^{* *} \\
(0.075)\end{array}$ & $\begin{array}{l}0.187^{* *} \\
(0.078)\end{array}$ & $\begin{array}{l}0.184^{\star *} \\
(0.080)\end{array}$ \\
\hline
\end{tabular}




\begin{tabular}{|c|c|c|c|}
\hline Prefeito = Presidente & $\begin{array}{c}0.576^{\star \star *} \\
(0.133)\end{array}$ & $\begin{array}{c}2.503^{* *} \\
(1.230)\end{array}$ & $\begin{array}{c}2.819^{* *} \\
(1.261)\end{array}$ \\
\hline Idosos & $\begin{array}{c}-0.337^{* * *} \\
(0.061)\end{array}$ & $\begin{array}{c}-0.341^{\star * *} \\
(0.062)\end{array}$ & $\begin{array}{c}-0.339^{* * *} \\
(0.063)\end{array}$ \\
\hline \multirow{2}{*}{ Urbanização } & $\begin{array}{c}-0.009 \\
(0.009)\end{array}$ & $\begin{array}{c}-0.007 \\
(0.009)\end{array}$ & $\begin{array}{c}-0.009 \\
(0.009)\end{array}$ \\
\hline Jovens & $\begin{array}{c}0.073^{\star *} \\
(0.030)\end{array}$ & $\begin{array}{c}0.073^{\star *} \\
(0.030)\end{array}$ & $\begin{array}{c}0.072^{\star *} \\
(0.031)\end{array}$ \\
\hline População Total & 0.486 & 0.398 & 0.393 \\
$(0.357)$ & $(0.359)$ & $(0.365)$ \\
\hline Constante & - & - & - \\
\hline Observações & 4085 & 4085 & 4085 \\
\hline \multirow{2}{*}{ Teste de Hausman } & $\chi^{2}=143,76$ & $\chi^{2}=269,39$ & $\chi^{2}=283,96$ \\
& Prob $=0,00$ & Prob $=0,00$ & Prob $=0,00$ \\
\hline
\end{tabular}

Fonte: elaboração própria

Gráfico 2.5-Dummies de partido

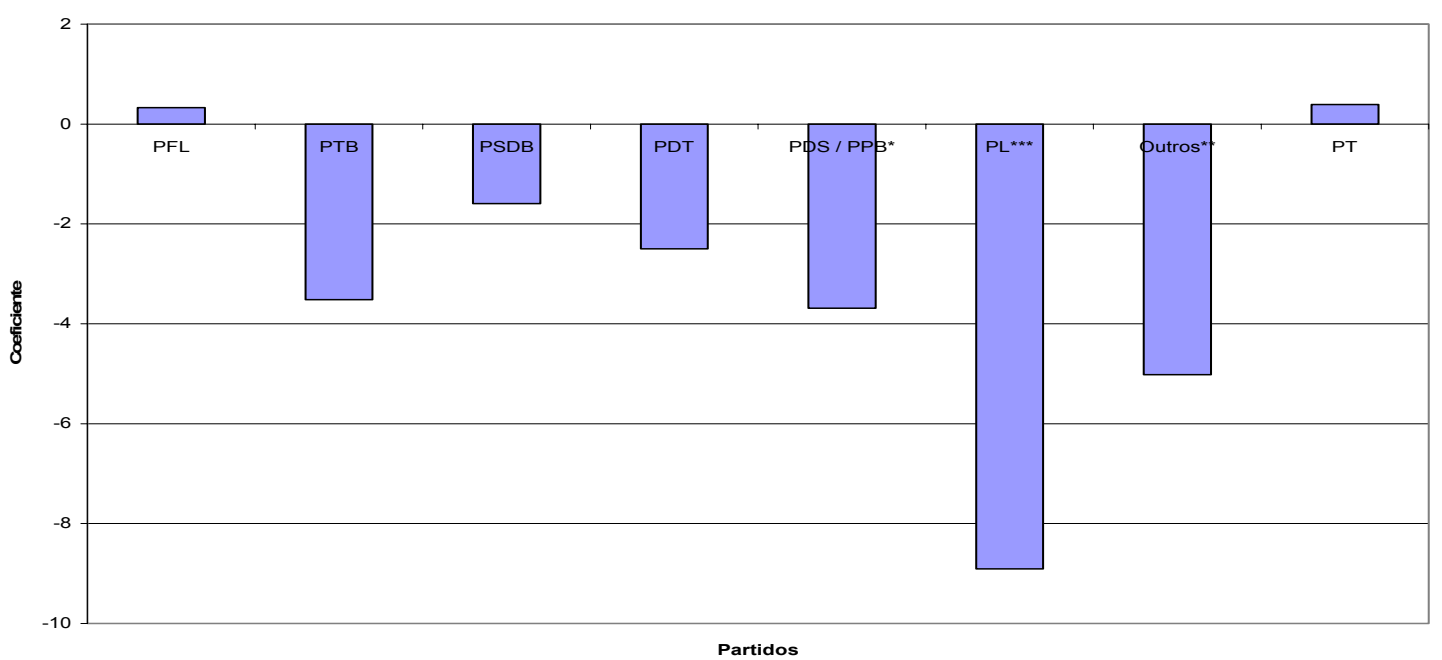

Fonte: elaboração própria

Gráfico 2.6 - Interações entre dummies de partido \& despesa do ano eleitoral

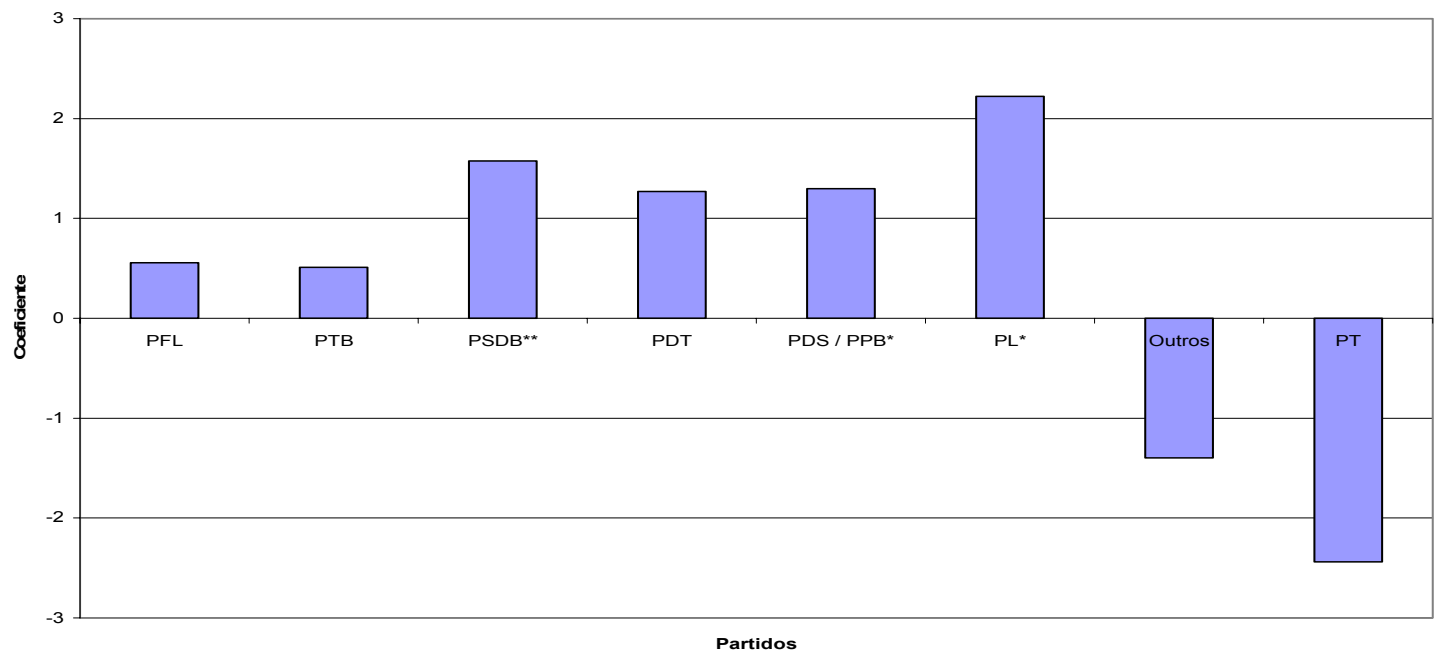

Fonte: elaboração própria 
Gráfico 2.7 - Interações entre dummies de partido \& despesa média dos anos não eleitorais

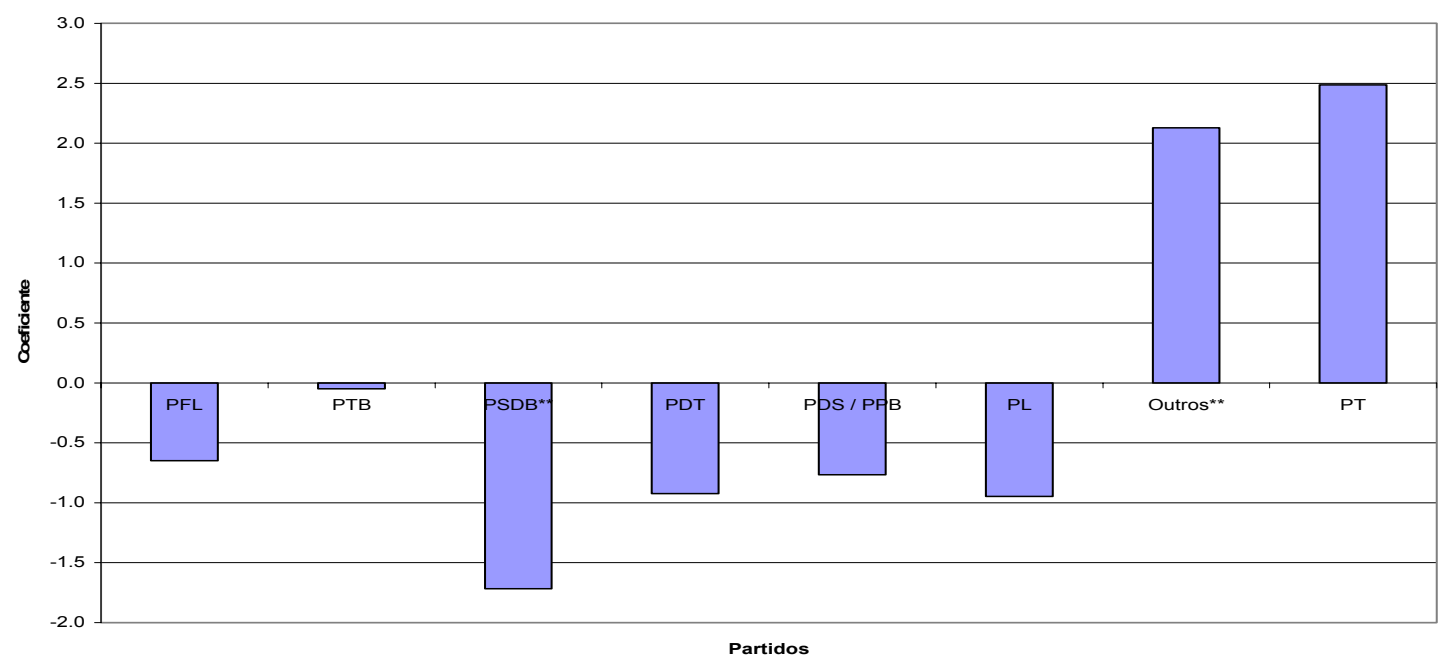

Fonte: elaboração própria

Novamente, considerando os resultados obtidos pelo método de efeitos fixos (vide teste de Hausman), a primeira estimação (coluna D) sugere que a despesa orçamentária decomposta em despesa realizada no ano eleitoral e realizada nos anos não eleitorais apresenta resultados distintos sobre a probabilidade de reeleição: o coeficiente associado à primeira destas variáveis é negativo $(-0,762)$ e estatisticamente significante a $1 \%$, sugerindo que maiores despesas realizadas nos anos eleitorais reduzem a probabilidade de permanência no poder, ao passo que maiores despesas realizadas ao longo dos três anos não eleitorais influenciam positivamente tal probabilidade (coeficiente estatisticamente significante a \% e igual a 1,460). Em relação às variáveis de controle, os resultados obtidos são relativamente semelhantes aos obtidos no teste anterior, em que era considerado o total da despesa orçamentária: maior receita tributária, a ocorrência do alinhamento político do prefeito com o governo estadual e federal, uma menor proporção de idosos e uma maior proporção de jovens (coeficientes estatisticamente significantes a 1\%) elevam a probabilidade de permanência no poder. Neste caso, as receitas de transferências apresentam significância estatística somente a $12 \%$, ao passo que a população total e grau de urbanização não apresentam influência significante sobre a variável dependente em questão.

$\mathrm{O}$ segundo teste (coluna $\mathrm{E}$ ), em que são inseridas as dummies de partido, permite observar que em relação ao PMDB, os partidos PFL, PTB, PSDB, PL e o grupo formado pelos outros partidos apresentam menores probabilidades de reeleição (coeficientes estatisticamente significantes a, no máximo, 10\%), ao passo que o PT possui maior 
probabilidade (coeficiente estatisticamente significante a 10\%). Os resultados associados às variáveis de controle, à despesa do ano eleitoral e à despesa média dos anos não eleitorais são robustos quando comparados à regressão anterior, permanecendo praticamente os mesmos neste caso, a receita de transferências correntes volta a apresentar significância estatística quando considerado o limite estatístico de $10 \%$.

Por fim, analisando os resultados obtidos na terceira estimação (coluna F), em que são consideradas as interações entre partidos e despesas, as dummies de partido permitem observar que PDS / PPB, PL e o grupo formado pelos outros partidos apresentam menores probabilidades de reeleição relativamente ao PMDB (conforme gráfico 2.5), resultado este que também é corroborado em boa parte pelas informações contidas no gráfico 2.2 e pelos resultados obtidos na regressão da seção 2.3 , em que fora considerada a despesa total do período administrativo. Adicionalmente, os testes de igualdade de tais coeficientes (vide apêndice 2.4) permitem observar diferenças adicionais principalmente para o PL, que possui inerentemente menores chances de reeleição em relação ao PMDB, PFL, PSDB, PDT, PDS / PPB e PT. Por fim, os testes ainda permitem observar que o PFL possui uma maior chance de reeleição relativamente ao PDS / PPB e ao grupo “outros partidos”. Já quanto às variáveis de controle, a robustez dos coeficientes permanece sugerindo os mesmos resultados obtidos nas estimações das colunas D e E.

Os principais resultados ficam por conta dos coeficientes associados à despesa do ano eleitoral, à despesa média dos anos não eleitorais e às interações, conforme segue:

- considerando as informações ilustradas no gráfico 2.6 e o coeficiente associado à despesa do ano eleitoral (igual à -1,204 e estatisticamente significante a 1\%) como referência, observa-se que especialmente para o PSDB (coeficiente igual a 1,575, diferença numérica igual a 0,371), para o PDS / PPB (coeficiente igual a 1,298 e diferença numérica igual a 0,094) e para o PL (coeficiente igual a 2,223 e diferença numérica igual a 1,019) despesas mais elevadas especificamente no ano eleitoral tendem a ser benéficas à reeleição relativamente ao PMDB. A efetividade destas despesas também parece variar entre os partidos, ou seja, em termos relativos, despesas mais elevados no ano eleitoral tendem a gerar menores benefícios políticos ao PT e ao grupo outros partidos em relação ao PSDB, PDS / PPB e PL e PDT ${ }^{28}$;

- em relação às despesas médias dos anos anteriores ao ano eleitoral (resultados ilustrados no gráfico 2.7) e considerando o coeficiente associado à despesa média dos anos

\footnotetext{
${ }^{28}$ Complementarmente, o PFL apresenta ganhos relativos comparativamente ao grupo "outros partidos".
} 
não eleitorais $(1,848)$ como referência, os resultados sugerem que somente para o PSDB (coeficiente igual a $-1,717$ e diferença numérica igual a 0,131) tal manipulação significa menores benefícios políticos, ao passo que para o grupo outros partidos (coeficiente igual a 2,128 e soma numérica igual a 3,976), despesas mais elevadas são relativamente mais favoráveis à probabilidade de permanência no poder comparativamente ao partido de referência. Em termos relativos, os testes de hipótese (conforme terceira coluna do apêndice 2.4) sugerem adicionalmente que as despesas realizadas pelo PT e pelo grupo dos outros partidos são as mais favoráveis à reeleição, principalmente em relação ao PFL, PSDB, PDT, PDS / PPB e PL ${ }^{29}$.

\section{5 - Considerações finais do segundo capítulo}

Em termos gerais, os resultados obtidos pelo primeiro procedimento econométrico implementado neste capítulo sugerem que um maior volume de despesa orçamentária executada ao longo de um dado mandato é avaliado de forma positiva pelos eleitores, ao propiciar ao incumbente uma maior probabilidade de permanência no poder (conforme discutido anteriormente, tais ganhos tendem a ser mais significativos para o PDS / PPB, PL e para o grupo "outros partidos"). Por sua vez, os resultados obtidos pelos testes também indicam que os eleitores avaliam de maneira efetivamente distinta, em termos políticos, a forma com que os gestores das finanças públicas municipais brasileiras distribuem as execuções orçamentárias ao longo de um dado período administrativo. Em termos gerais, o resultado obtido pelo último procedimento de estimação apresentado neste capítulo sugere que maiores desajustes fiscais especificamente nos anos eleitorais podem ser vistos como prejudiciais às pretensões de reeleição de praticamente todos os partidos políticos aqui considerados, exceção feita ao PSDB, PDS / PPB e o PL, conforme visto anteriormente. Por outro lado, um maior volume de despesa orçamentária executada ao longo dos três anos anteriores ao ano eleitoral pode ser avaliado como benéfico às pretensões eleitorais dos prefeitos brasileiros (exceção feita ao PSDB, conforme também visto). De qualquer forma, em ambos os procedimentos econométricos aqui realizados, os resultados parecem apresentar algum grau de diferenciação entre as agremiações partidárias.

\footnotetext{
${ }^{29}$ Adicionalmente, as despesas efetuadas pelo grupo outros partidos também parece ser relativamente mais comparativamente ao PTB.
} 
De forma resumida, tais resultados sugerem que os eleitores brasileiros são especialmente avessos à manipulações fiscais nos anos eleitorais, resultado relativamente semelhante ao obtido por Peltzman (1992) e por Brender \& Drazen (2005), conforme visto na revisão da literatura. Outro fato interessante dos resultados aqui obtidos é que, para certos partidos políticos (PFL, PTB, PDT e PT), maiores despesas não acarretam nenhuma alteração de suas chances de sucesso político (tanto positivamente e nem negativamente), enquanto que somente para o PSDB observa-se influência das distorções realizadas em ambos os períodos (quais sejam, ano eleitoral e anos pré-eleitorais). Para o PDS / PPB e PL a influência está associada somente às distorções fiscais executadas especificamente no ano eleitoral, enquanto que para o grupo "outros partidos", tal influência ocorre somente com as distorções realizadas na média dos três anos anteriores às eleições.

Outro resultado do trabalho aqui realizado reflete um fenômeno relativamente esperado, que é a influência positiva do alinhamento partidário do prefeito com o governador estadual e com o presidente da República sobre a possibilidade de permanência no poder dado o sistema de transferências de recursos entre União, estados e municípios, tal característica pode significa uma maior facilidade de captação de recursos e uma posterior maior execução financeira, fenômeno em alguma medida corroborado pelos resultados obtidos no primeiro capítulo, em que o alinhamento partidário com o governo estadual significava, de fato, uma despesa orçamentária mais elevada (predominantemente no caso do painel balanceado, que é justamente a amostra considerada neste segundo capítulo - vide tabela 1.13). Adicionalmente, não devem ser negligenciadas também formas de apoio político que um prefeito pode receber a partir do governador estadual e federal e que não necessariamente envolvam questões financeiras, como o apoio em campanhas eleitorais, por exemplo. Desta forma, tanto no caso da análise dos ciclos eleitorais e partidários como no caso da questão da reeleição, a ocorrência de tal fenômeno parece apresentar efetivamente algum impacto sobre o comportamento da classe política.

Finalmente, resultados adicionais são providos pelos resultados associados às variáveis de controle: em praticamente todos os modelos estimados, observa-se a significância estatística e influência positiva da receita tributária e da receita de transferências correntes sobre a probabilidade de reeleição. O primeiro destes pode estar associado ao fato de que administrações bem sucedidas podem gerar estímulos significativos ao pagamento de tributos, ou seja, tal resultado pode ser visto como uma espécie de avaliação da população sobre a qualidade da administração municipal, uma vez que os cidadãos podem se sentir mais dispostos a arcar com os impostos locais caso os mesmos estejam sendo administrados de 
forma adequada (Meneguin, Bugarin \& Carvalho (2005)). Já o segundo resultado é bastante semelhante ao obtido por Mendes (2004) [mas diferente do obtido por Brender (2003)], segundo o qual um maior volume de recursos obtidos pela prefeitura municipal através de transferências do governo estadual e federal é avaliado de forma positiva pelos eleitores, sinalizando a competência da gestão municipal em canalizar recursos para o seu território. Outro resultado interessante está associado à perspectiva de que elementos de natureza intergeracional estejam influenciando a ocorrência da reeleição, dado que a proporção de idosos residente nos municípios brasileiros influencia negativamente tal fenômeno, resultado justamente oposto ao associado à proporção de jovens residentes em tais unidades. Tal resultado pode sugerir que a perspectiva de longo prazo por parte destes últimos indivíduos tende a gerar algum critério de longo prazo para a avaliação de uma dada administração municipal, propiciando ao incumbente uma maior chance de permanência no poder para, por exemplo, a execução de projetos para os quais um único mandato seja insuficiente. 


\section{Capitulo 3 - Déficit e ajuste fiscal nos municípios paulistas}

\section{1 - Introdução \& Revisão da literatura}

Nos últimos anos, tem sido observado um significativo esforço do governo federal brasileiro com o objetivo de elevar ou ao menos manter nos atuais valores o superávit fiscal. A título de ilustração, a Necessidade de Financiamento do Setor Público ${ }^{30}$ do governo federal (como porcentagem do PIB) tem decrescido sistematicamente a partir de 2000, passando de $1,86 \%$ para $-2,97 \%$ ao final de 2004, sinalizando assim tal empenho. A mesma tendência é observada para o caso dos estados brasileiros (-0,42\% do PIB em 2000 e $-0,91 \%$ do PIB em 2004) mas o caso dos municípios não é semelhante, ocorrendo períodos de maior ou menor esforço fiscal ao longo dos últimos anos. De qualquer forma, o que justifica a ocorrência de déficits fiscais ou, por outro lado, o que levaria um governo a gerar superávits fiscais? Estariam estes resultados associados somente a condicionantes econômicos, ou outros elementos poderiam também influenciá-los? Em particular para os estados e municípios, estariam estes menos propensos a realizar ajustes fiscais comparativamente ao governo federal? Embora o comportamento fiscal deste último seja o mais significativo e portanto, considerado o mais importante, não se pode negligenciar os resultados orçamentários advindos das demais esferas administrativas, o que justifica uma investigação mais detalhada, notadamente dos municípios, uma vez que as mesmas são ainda pouco analisadas pela literatura referente.

A literatura econômica considera uma série de elementos que justificam o comportamento dos déficits fiscais. Para a teoria clássica por exemplo, os superávits fiscais obtidos em períodos de expansão econômica podem ser utilizados como forma de financiar déficits fiscais em períodos recessivos, de modo a garantir um padrão de consumo estável ao longo do tempo [originando o conceito tradicional de tax-smoothing de Barro (1979) e Lucas \& Stokey (1983)]. A análise sugere que os déficits fiscais não são necessariamente indesejados, desde que o governo tenha um orçamento intertemporal equilibrado, ou seja, inserir um mecanismo que garanta um orçamento equilibrado em cada período de tempo não seria uma estratégia ótima para o governante, ao restringir as possibilidades de consumo em períodos recessivos.

\footnotetext{
${ }^{30}$ De acordo com dados do Banco Central do Brasil - Necessidades sem desvalorização cambial.
} 
Um detalhe importante a ser adicionalmente considerado na teoria clássica diz respeito à existência ou não de garantias de que o orçamento intertemporal do governo esteja, de fato, sendo respeitado (equivalência ricardiana). Este resultado pode não ocorrer caso, por exemplo, os eleitores não tenham pleno entendimento da restrição intertemporal do governo (irracionalidade), menosprezando o custo futuro de um déficit corrente [o fenômeno da “ilusão fiscal” de Buchanan \& Wagner (1977)]. Uma outra possibilidade ainda concernente ao comportamento dos indivíduos é discutida em Tabellini \& Alesina (1990), em que défícits fiscais tenderiam a ocorrer não devido à "miopia" dos agentes, mas sim devido a uma maior dispersão de preferências políticas entre os eleitores com respeito à forma como o orçamento público deveria ser gerido ao longo do tempo (incerteza quanto às preferências das gerações futuras). Desta forma, conforme apontam os autores, uma análise empírica seria testar se à coletividades com preferências políticas mais divergentes (politicamente mais instáveis) estariam associados maiores níveis de endividamento. Finalmente, em Alesina \& Tabellini (1990), fatores políticos são explicitamente considerados como fatores determinantes do déficit público - mais especificamente, a divergência de preferências entre os postulantes aos cargos públicos (policymakers) pode fazer com que um governante decida elevar o estoque de endividamento de modo a restringir as possibilidades de consumo de um governo opositor que possa estar futuramente no poder. Logo, quanto menores as chances de um governante ser reeleito e quanto mais divergentes as preferências entre os políticos, maiores tendem a ser os níveis de endividamento.

Em uma situação em que exista a substituição regular de governantes, como ocorre em regimes democráticos, a disputa política inerente a este processo pode fazer com que os instrumentos de política econômica sejam utilizados como forma de propiciar maior sucesso político. Neste caso, se as instituições fiscalizadoras existentes não têm a efetividade esperada, déficits podem ser gerados sem a respectiva capacidade de solvência futura, o que pode gerar montantes de endividamento com sustentabilidade restrita. Assim sendo, o embate político pode fazer com que não sejam garantidos resultados associados a um modelo clássico de horizonte infinito, por exemplo, mas sim associados a um modelo de gerações sobrepostas, em que os custos associados a um maior endividamento na data atual seriam pagos somente pelas gerações futuras [como derivado em Tabellini (1991), por exemplo], gerando significativo estímulo a uma gestão orçamentária menos conservadora. Seria necessário então, nesta situação, o desenvolvimento de mecanismos formais como forma de coibir o surgimento e a persistência de resultados fiscais negativos? 
Abordando especificamente a questão dos déficits públicos para o caso brasileiro, um trabalho importante a ser considerado é Botelho (2002), em que é analisado o comportamento fiscal dos estados brasileiros entre 1986 e 2000 através de um modelo logit multinomial, utilizando os critérios institucionalizados pela Lei Complementar $n^{\circ}$ 089/97 do Ministério da Fazenda - tal critério classifica a capacidade de solvência dos estados e municípios brasileiros, conforme será demonstrado na seqüência deste capítulo.

Os resultados obtidos em tal estudo são relevantes por permitir um entendimento abrangente da questão fiscal dos estados brasileiros, considerando tanto condicionantes de natureza política como fatores de natureza econômica. Estados com um maior comprometimento da receita corrente em relação à despesa de pessoal apresentam maiores dificuldades em realizar ajustes fiscais, assim como ocorre em estados com uma maior participação da receita tributária em relação à receita corrente. Este último resultado sugere que uma maior independência fiscal dos estados em relação às transferências da União pode ampliar as possibilidades de endividamento, dada a maior possibilidade de pagamento futura. Adicionalmente os resultados ainda indicam, da mesma forma que a observada em Cossio $(2001)^{31}$, a existência de menores esforços fiscais nos anos eleitorais, conforme sugerido pela teoria dos ciclos eleitorais. Por fim, estados que apresentam preferências eleitorais mais heterogêneas (esta mensurada pela dispersão dos votos obtidos pelos candidatos ao Executivo estadual) são justamente aqueles com maiores dificuldades em realizar ajustes fiscais, sugerindo portanto que o próprio padrão de preferência dos eleitores pode, em alguma medida, influenciar a forma com que as administrações estaduais regem seus respectivos orçamentos.

\section{2 - Referencial metodológico}

O objetivo deste terceiro capítulo consiste em analisar o comportamento fiscal dos municípios paulistas, mensurado especificamente através do resultado primário orçamentário. Em termos mais específicos, tal análise toma como referência básica o trabalho de Botelho (2002), procurando analisar quais fatores de natureza econômica e política determinam a probabilidade de um município paulista obter resultados fiscais primários positivos ou negativos e, no caso da ocorrência de cada um destes, quais elementos afetam sua magnitude.

\footnotetext{
${ }^{31}$ Referência considerada no primeiro capítulo desta tese.
} 
Em última instância, o estudo procura implementar o modelo de seleção [Heckman (1976), (1979)], mas considerando, contudo, uma estrutura de dados em painel, conforme considerado nos dois primeiros capítulos desta tese. Ressalta-se que este capítulo compreende apenas os municípios paulistas durante o período 1989 - 2001, uma vez que informações específicas do orçamento dos demais municípios brasileiros e mesmo um período mais extenso para as cidades do estado de São Paulo ainda não se encontram disponíveis.

Em termos específicos, a Lei Complementar $n^{\circ}$ 089/97 do Ministério da Fazenda estabelece uma metodologia que classifica a capacidade de solvência dos estados e municípios brasileiros com base nas suas respectivas execuções fiscais - entre outros, tal categorização serve como referência para que a União conceda garantias às operações de crédito realizadas pelos estados e municípios brasileiros. A Lei Complementar em questão define o conceito de resultado primário, através da seguinte relação:

Resultado Primário - é igual às receitas arrecadadas (RA), excluídas as receitas financeiras (RF), as operações de crédito (OC) e as alienações de bens (AB), menos as despesas liquidadas (DL) e restos a pagar não processados (NP), excluídos os serviços (SV) encargos e amortizações - das dívidas mobiliária e contratual, interna e externa. Assim, o resultado primário (RP) é dado por:

$$
R P=R A-(R F+O C+A B)-(D L+N P-S V)
$$

Assim, tendo em mente o parágrafo anterior, os estados e municípios brasileiros são classificados como:

a) categoria "A", quando o resultado primário for positivo e suficiente para saldar todos os serviços das dívidas mobiliária, contratual e flutuante, de origem interna e externa, que competem ao período, dado o limite de comprometimento contratualmente assumido;

b) categoria "B", quando o resultado primário for positivo e suficiente para saldar todos os encargos das dívidas mobiliária, contratual e flutuante, de origem interna e externa, porém insuficiente para cumprir com o total da amortização programada, dado o limite de comprometimento contratualmente assumido;

c) categoria "C", quando o resultado primário for positivo, porém insuficiente para saldar todos os encargos devidos das dívidas mobiliária, contratual e flutuante, de origem interna e externa, dado o limite de comprometimento contratualmente assumido; 
d) categoria "D", quando o resultado primário for negativo.

Em termos gerais, tal classificação pode ser ilustrada conforme a tabela $1 \mathrm{em}$ seqüência.

\section{Tabela 3.1}

Categorias de solvência - Lei Complementar n ${ }^{\circ 089 / 97}$ do Ministério da Fazenda

\begin{tabular}{|l|l|}
\hline A & $\begin{array}{l}\text { O município apresenta resultado primário positivo e suficiente para arcar (tanto) com } \\
\text { as despesas de amortização (como) e com os encargos da dívida }\end{array}$ \\
\hline B & $\begin{array}{l}\text { O município apresenta resultado primário positivo e suficiente para arcar (somente) } \\
\text { com os encargos da dívida }\end{array}$ \\
\hline C & $\begin{array}{l}\text { O município apresenta resultado primário positivo, porém insuficiente para arcar com } \\
\text { os encargos da dívida }\end{array}$ \\
\hline D & O município apresenta resultado primário negativo \\
\hline
\end{tabular}

Considerando as quatro categorias de solvência determinadas pela portaria em questão, observa-se que as categorias A, B e C podem ser agregadas em uma única categoria, em que o resultado primário observado assume valor positivo, ao passo que a categoria D é composta pelos casos em que o resultado primário assume valor negativo. Assim, pode-se afirmar que estes dois eventos estão, em alguma medida, sob controle das administrações dos municípios brasileiros e portanto, consiste em uma variável de decisão preliminar. A partir de então, restaria uma segunda variável de escolha das prefeituras, que consistiria em determinar o tamanho do esforço fiscal, ou seja, o tamanho do superávit primário, uma vez que a decisão de obtê-lo tenha sido anteriormente feita - mesmo raciocínio é válido no caso do déficit fiscal primário. Assim, em termos da metodologia do modelo de seleção, no primeiro estágio seria tomada a decisão entre obter um resultado primário positivo ou negativo e, uma vez tomada a decisão afirmativa, decidir qual o montante do resultado fiscal.

Neste ponto, cabe questionar a validade de uma análise baseada no modelo de seleção para o caso em questão. Em termos gerais, para que haja o problema aqui sugerido o processo de seleção deve ser aleatório “condicional nas variáveis explicativas", ou seja, após o controle pelas variáveis observadas. Em outras palavras, deve restar um processo de seleção baseado em características não observáveis pois caso contrário, o controle pelas características observáveis seria suficiente para extinguir o problema. 
Partindo do pressuposto de que a obtenção de um resultado primário positivo ou negativo seja um evento aleatório, ou seja, independente de qualquer decisão por parte das prefeituras, não haveria nenhuma justificativa para implementar tal metodologia (viés de seleção) e a única decisão de tais unidades seria a respeito do montante do superávit ou déficit. Neste caso, não haveria problemas significativos em implementar um procedimento de regressão clássico para avaliar quais fatores determinam o montante do esforço fiscal das prefeituras paulistas. Contudo, imaginar que a observação de um resultado primário positivo ou negativo seja um evento randômico pode ser considerada inapropriada uma vez que tal decisão está certamente condicionada às condições fiscais e até mesmo outras variáveis relevantes que venham a influenciar o comportamento do orçamento das prefeituras. Não se pode descartar inclusive a possibilidade de que o próprio padrão de preferências da população e da administração pública de um determinado município (que em última instância é função das preferências do Executivo e do Legislativo municipal), variáveis dificilmente mensuráveis (ou seja, tendem a ser não observáveis), sejam elementos determinantes sobre o problema em xeque. Assim, seria mais considerável considerar que a decisão preliminar da realização ou não do esforço fiscal não seja meramente um acontecimento fortuito, o que justificaria a implementação do modelo de estimação aqui efetivamente utilizado. Em outras palavras, municípios que apresentam superávit primário e municípios que apresentam déficit primário fariam parte de amostras não aleatórias, o que tornaria inapropriada qualquer conclusão obtida exclusivamente com base nas observações superavitárias ou exclusivamente com base nas observações deficitárias.

A partir deste ponto, cabe uma descrição detalhada do procedimento implementado com vistas a corrigir o fenômeno do viés de seleção. A análise econométrica aqui realizada segue o procedimento sugerido em Wooldridge (1995), conforme segue.

\section{3 - Descrevendo o procedimento de Wooldridge (1995)}

O procedimento descrito em Wooldridge (1995) tem como motivação fundamental o desenvolvimento de um referencial econométrico que corrija o viés de seleção em uma amostra de dados em painel, ou seja, quando existem informações sobre unidades seccionais ao longo de um determinado período de tempo. Em termos mais específicos, o procedimento sugerido em tal estudo trata de um modelo de efeitos fixos, no sentido de que a característica não observada intrínseca a cada unidade seccional pode apresentar correlação diferente de 
zero com os regressores da variável dependente. No sentido de facilitar a estimação da equação de seleção, pressupõe-se que seus erros apresentam distribuição normal, permitindo contudo que os mesmos apresentem correlação serial e heteroscedasticidade não condicional, conforme descrito em seqüência.

O procedimento originalmente descrito em Wooldridge (1995) com vistas a corrigir o problema de viés de seleção em painel toma como referência o trabalho de Chamberlain (1980). Contudo, o procedimento implementado neste capítulo, apesar de apresentar o mesmo propósito, toma como referência o trabalho de Mundlak (1978). Tais tratamentos são também detalhados em seqüência.

Considere, para uma observação associada a uma unidade seccional i (i $\in \mathrm{N}$ ) em um dado instante de tempo $t(t \in T)$ :

$$
y_{i t}=\alpha_{i}+x_{i t .} \beta+u_{i t}, i=1, \ldots, N \text { e } t=1, \ldots T
$$

Em que $\mathrm{x}_{\mathrm{it}}$ é um vetor de dimensão $[1 \mathrm{x}(1+\mathrm{K})]$, em que $\mathrm{K}$ é número de regressores e $\beta$ é um vetor de dimensão $[(1+K) \times 1]-o$ elemento 1 do termo $(1+K)$ refere-se à constante da regressão.

Considere, também, a seguinte hipótese:

Hipótese 1: $\mathrm{E}\left(\mathrm{u}_{\mathrm{it}} \mid \alpha_{\mathrm{i}}, \mathrm{x}_{\mathrm{i} 1}, \mathrm{x}_{\mathrm{i} 2}, \ldots \mathrm{x}_{\mathrm{iT}}\right)=0$

$\mathrm{Na}$ validade da hipótese 1 (exogeneidade estrita), o estimador de efeitos fixos é consistente e $\sqrt{N}$ assintoticamente normal, conforme demonstrado em Wooldridge (1995) e em Wooldridge (2002).

Considere também uma variável indicadora $s_{\text {it }}$ que assume valor 1 quando o valor de $\mathrm{y}_{\text {it }}$ é observado e assume o valor 0 caso contrário. Assim, para uma dada unidade seccional i, o vetor $\mathrm{s}_{\mathrm{i}}$ é dado por:

$$
s_{i}=\left(s_{i 1}, s_{i 2}, \ldots s_{i T}\right)^{\prime}
$$


Considerando (1) e (2) e a validade da hipótese 1, o estimador de efeitos fixos para $\beta$ pode ser escrito como:

$$
\hat{\beta}=\left(N^{-1} \cdot \sum_{t=1}^{T} \sum_{i=1}^{N} s_{i t} \cdot \ddot{x}_{i t}^{\prime} \cdot \ddot{x}_{i t}\right)^{-1} \cdot\left(\sum_{t=1}^{T} \sum_{i=1}^{N} s_{i t} \cdot \ddot{x}_{i t}^{\prime} \cdot \ddot{y}_{i t}\right)
$$

Em que, para $s_{i t}=1$

$$
\begin{gathered}
\ddot{x}_{i t}=x_{i t}-T_{i}^{-1} \cdot \sum_{r=1}^{T} s_{i r} x_{i r} \\
\ddot{y}_{i t}=y_{i t}-T_{i}^{-1} \cdot \sum_{r=1}^{T} s_{i r} y_{i r} \\
T_{i}=\sum_{t=1}^{T} s_{i t}
\end{gathered}
$$

Assim, considerando o estimador de efeitos fixos descrito em (3), sua consistência é garantida (com $\mathrm{N} \rightarrow \infty$ ) caso seja válida a seguinte hipótese:

Hipótese 1': $\mathrm{E}\left(\mathrm{u}_{\mathrm{it}} \mid \alpha_{\mathrm{i}}, \mathrm{x}_{\mathrm{i}}, \mathrm{s}_{\mathrm{i}}\right)=0$

Note que como existem observações tais que $s_{i t}=0$ ou $s_{i t}=1$, a hipótese 1' atesta que $\mathrm{u}_{\mathrm{it}}$ deve estar condicionado não só ao conjunto de regressores $\mathrm{x}_{\mathrm{i}}$ [em que $\mathrm{x}_{\mathrm{i}}=\left(\mathrm{x}_{\mathrm{i} 1}, \mathrm{x}_{\mathrm{i} 2}, \ldots, \mathrm{x}_{\mathrm{iT}}\right)$ ], mas também à $\mathrm{s}_{\mathrm{i}}$. Assim, na validade da hipótese 1', o processo de seleção é estritamente exógeno condicional à $\alpha_{i}$ e $x_{i}$. e neste caso, não ocorreria o fenômeno do viés de seleção.

Considere agora uma variável latente $\mathrm{h}_{\mathrm{it}}{ }^{*}$ definida por:

$$
h_{i t}^{*}=\xi_{i}+x_{i t} \delta+a_{i t}
$$

Em que, por hipótese, $\left(\xi_{i}, a_{i t}\right)$ é distribuído (de forma conjunta) via distribuição normal, $\mathrm{E}\left(a_{i t}\right)=0$ e $a_{i t}$ independente do conjunto de regressores $\mathrm{x}_{\mathrm{i}}$.

Defina também uma variável binária indicadora da seleção tal que:

$$
s_{i t} \equiv 1\left[h_{i t} *>0\right]
$$


Note que a equação (4) envolve um efeito fixo $\xi_{i}$ a respeito do qual formas funcionais específicas podem ser consideradas na sua estimação de modo a permitir que o mesmo tenha correlação não nula com o conjunto de regressores. Caso fosse considerado o procedimento sugerido por Chamberlain (1980), para uma dada unidade seccional, a variável dependente seria regredida em função dos regressores defasados, contemporâneos e futuros e assim, considerando um caso com $\mathrm{K}$ regressores, o vetor $\mathrm{x}_{\mathrm{i}}$ teria dimensão $[1 \mathrm{x}(1+\mathrm{TK})]$ (já considerando que o primeiro valor do vetor seja o valor 1 associado à constante do modelo). Neste caso:

$$
x_{i}=\left(x_{i 1}, x_{i 2}, \ldots x_{i T}\right)
$$

Assim, considerando tal procedimento como exemplo, o efeito fixo $\xi_{i}$ da equação (4) seleção seria função linear do conjunto de regressores $x_{i}$ e assumiria especificamente a seguinte forma:

$$
\xi_{i}=\eta_{0}+x_{i 1} . \eta_{1}+x_{i 2 .} \eta_{2}+\ldots+x_{i t} . \eta_{t}+\ldots+x_{i T} . \eta_{T}+c_{i}
$$

Assim, considerando (4) e (7), e obter-se-ia a seguinte forma funcional:

$$
h_{i t}^{*}=\eta_{0}+x_{i 1 .} \eta_{1}+x_{i 2 .} \eta_{2}+\ldots+x_{i t .}\left(\eta_{t}+\delta\right)+x_{i T} . \eta_{T}+\left(c_{i}+a_{i t}\right)
$$

Por hipótese, $\mathrm{c}_{\mathrm{i}}$ é independente de $\mathrm{x}_{\mathrm{i}}$, o que permite constituir um novo elemento tal que $\left(c_{i}+a_{i t}\right)=v_{i t}$, sendo que $v_{i t}$ é, por hipótese, independente de $\left(\alpha_{i}, x_{i}\right)$ e $v_{i t} \sim \operatorname{Normal}\left(0, \tau_{t}^{2}\right)$. Assim, observa-se que $\mathrm{c}_{\mathrm{i}}$ é tratado como uma espécie de efeito aleatório e portanto, $v_{i t}$ apresenta autocorrelação serial ao longo de uma dada unidade seccional i.

É possível argumentar que o procedimento descrito no parágrafo anterior seja inadequado no que diz respeito aos graus de liberdade e até mesmo em relação à implementação de um número elevado de regressores, conforme descrito. Assim, novamente com vistas à controlar as estimações pelo efeito fixo de cada uma das unidades seccionais da amostra e também considerando uma forma funcional linear entre os termos $\xi_{i} e \mathrm{x}_{\mathrm{i}}$, o tratamento alternativo sugerido por Mundlak (1978) considera que o vetor $\mathrm{x}_{\mathrm{i}}$ seria composto pelos seguintes elementos, conforme segue: 


$$
\begin{aligned}
& x_{i}=\left(x_{i t}, \bar{x}_{i}\right) \\
& \bar{x}_{i}=\left(\sum_{t=1}^{T} t\right)^{-1} \cdot\left(\sum_{t=1}^{T} x_{i t}\right)
\end{aligned}
$$

Assim, considerando novamente como exemplo um caso com $\mathrm{K}$ regressores, o vetor $\mathrm{x}_{\mathrm{i}}$ teria agora dimensão $(1 \mathrm{x}(1+\mathrm{K}+\mathrm{K}))$. Note que neste caso, para uma dada unidade seccional, uma variável dependente $\mathrm{y}_{\mathrm{it}}$ seria regredida em função de $\mathrm{x}_{\mathrm{it}} \mathrm{e}$ da média temporal $\bar{x}_{i}$, tratamento que permite preservar graus de liberdade e simplificar o procedimento de estimação.

Considerando Mundlak (1978) como exemplo, (7) assumiria a seguinte forma:

$$
\xi_{i}=\eta_{0}+x_{i t} \cdot \eta+\bar{x}_{i} \cdot \psi+c_{i}
$$

$$
\text { sendo } \eta=(K \times 1), \psi=(K \times 1) \text { e }\left[\eta_{0}^{\prime} \eta^{\prime} \psi^{\prime}\right]^{\prime}=((1+K+K) \times 1)
$$

Assim, considerando (4) e (10), e obter-se-ia a seguinte equação:

$$
h_{i t}{ }^{*}=\eta_{0}+x_{i t} \cdot(\eta+\delta)+\bar{x}_{i} \cdot \psi+\left(c_{i}+a_{i t}\right)
$$

Sendo novamente $\left(c_{i}+a_{i t}\right)=v_{i t}$, conforme anteriormente considerado. Ressalta-se que o teste empírico aqui realizado segue o padrão sugerido por Mundlak (1978), sendo ressaltado também que em Wooldridge (1995) é descrito o procedimento de correção do viés de seleção em painel considerando o procedimento sugerido por Chamberlain (1980). Em todo caso, ambos os tratamentos têm a mesma finalidade, variando apenas no tratamento do conjunto de regressores com vistas a controlar pela característica não observada de cada unidade seccional.

Note que no caso da hipótese 1' ser válida e considerando que $s_{i}=s_{i}\left(x_{i}, v_{i}\right)$, em que $x_{i}$ pode ser dado tanto por dado tanto por (6.a) como por (6.b), a condição suficiente para que o estimador de efeitos fixos continuasse a ser consistente seria:

$$
E\left(u_{i t} \mid \alpha_{i}, x_{i}, v_{i}\right)=0
$$


A equação anterior pode ser modificada de modo a sugerir a ocorrência do viés de seleção. A alternativa mais básica seria considerar que:

$$
E\left(u_{i t} \mid \alpha_{i}, x_{i}, v_{i}\right)=\rho . v_{i t}
$$

Note que tal hipótese pressupõe que $\mathrm{u}_{\mathrm{i}}$, condicional à $\mathrm{v}_{\mathrm{it}}$, tenha média independente dos elementos $\left(\alpha_{i}, x_{i},\left(v_{i 1}, v_{i 2}, \ldots v_{i t-1}, v_{i t+1}, \ldots, v_{i T}\right)\right)$ - portanto, a correlação entre $u$ e v ocorre apenas contemporaneamente. Assim, pressupondo a validade de tal hipótese:

$$
E\left[y_{i t} \mid \alpha_{i}, x_{i}, v_{i}, s_{i}\right]=E\left[y_{i t} \mid \alpha_{i}, x_{i}, v_{i}\right]=\alpha_{i}+x_{i t} \beta+\rho . v_{i t}
$$

Neste caso, seria possível estimar o viés de seleção através do procedimento tradicional de efeitos fixos, em que o termo $v_{i t}$ seria estimado para as observações tais que $s_{i t}$ $=1$, através da estimação de um probit e o posterior cálculo da razão de Mills invertida, dado pelo elemento $\lambda($.$) , conforme segue.$

$$
\begin{gathered}
E\left[y_{i t} \mid \alpha_{i}, x_{i}, s_{i}\right]=\alpha_{i}+x_{i t} \beta+\rho . E\left[v_{i t} \mid \alpha_{i}, x_{i}, s_{i}\right]=\alpha_{i}+x_{i t} \cdot \beta+\rho . E\left[v_{i t} \mid x_{i}, s_{i}\right] \\
E\left[v_{i t} \mid x_{i}, s_{i t}=1\right]=E\left[v_{i t} \mid x_{i}, v_{i t}>-x_{i} . \delta\right] \\
E\left[v_{i t} \mid x_{i}, v_{i t}>-x_{i} . \delta\right]=\lambda\left(x_{i} . \delta\right)
\end{gathered}
$$

Note que a equação 15 considera que $v_{i}$ seja independente de $\left(\alpha_{i}, x_{i}\right)$, conforme anteriormente descrito.

\subsection{1 - Procedimento do teste de viés de seleção}

O procedimento sugerido com vistas à testar a presença ou não do viés de seleção em uma amostra de dados em painel consiste basicamente em um método de efeitos fixos, no sentido de que é estimado um modelo de diferenças em relação à média de cada unidade seccional i, sendo a variável dependente (contínua) regredida em função do conjunto de regressores de interesse, bem como em função da razão de Mills invertida, obtida através de probits estimados ano a ano em que a variável dependente é o indicador da ocorrência do 
superávit primário $\left(\mathrm{s}_{\mathrm{it}}=1\right)$ ou da não ocorrência do superávit primário $\left(\mathrm{s}_{\mathrm{it}}=0\right)$. Assim, $\mathrm{o}$ procedimento é realizado com base nos seguintes passos:

(i) Para cada período t da amostra existente, estima-se a equação via probit.

$$
P\left(s_{i t}=1 \mid x_{i}\right)=\Phi\left(x_{i} \delta\right)
$$

(ii) Para as observações tais que $\mathrm{s}_{\mathrm{it}}=1$, calcula-se $\hat{\lambda}_{i t} \equiv \lambda\left(x_{i} \cdot \hat{\delta}\right)$

(iii) Para as observações tais que $\mathrm{s}_{\mathrm{it}}=1$, calcula-se $\ddot{\lambda}_{i t} \equiv \hat{\lambda}_{i t}-T_{i}^{-1} \sum_{r=1}^{T} s_{i r} \cdot \hat{\lambda}_{i t}$

(iv) Com base apenas nas observações em que $\mathrm{s}_{\mathrm{it}}=1$, estima-se a equação:

$$
\ddot{y}_{i t}=\ddot{x}_{i t} \cdot \beta+\rho \cdot \ddot{\lambda}_{i t}+\omega_{i t}
$$

em que $\omega_{i t}$ é o resíduo da regressão

(v) Testa-se $\rho=0$ através da estatística t para o coeficiente $\rho$.

Observe novamente que o cálculo dos desvios em relação à média, para cada unidade seccional, e a posterior estimação de um OLS nas variáveis transformadas consiste justamente no procedimento de efeitos fixos para dados em painel. No caso da validade da hipótese de que $\rho=0$, inexiste o viés de seleção e assim, inexiste o problema de viés de variável omitida associado à influência de efeitos não observáveis sobre a variável de interesse.

\subsection{2 - Procedimento de correção do viés de seleção}

O procedimento de correção do viés de seleção é um procedimento relativamente mais complexo que a realização do teste de sua presença, principalmente no que diz respeito à correção dos desvios-padrão dos coeficientes da equação de interesse (segundo estágio) - isto é necessário uma vez que parte dos regressores utilizados no segundo estágio é obtida num estágio preliminar, com base no conjunto de regressores pré-existentes (ou seja, as razões de Mills invertidas, utilizadas no segundo estágio, são obtidas com base nos valores de x, em um primeiro estágio da análise). Assim, considere a seguinte forma funcional, com base no tratamento de Mundlak (1978): 


$$
E\left[y_{i t} \mid x_{i}, s_{i t}=1\right]=\bar{x}_{i} \cdot \psi+x_{i t .} \beta+\gamma_{t}\left[\lambda\left(x_{i} . \delta\right)\right]
$$

Note, pela equação (19), que os vieses de seleção são separados ano a ano via $t$ coeficientes $\gamma$, ou seja, o procedimento permite analisar a influência de tal variável sobre a variável de interesse de forma isolada em cada período de tempo existente na amostra.

O procedimento de correção do viés de seleção é implementado conforme segue.

(i) Para cada $t=1,2, \ldots \mathrm{T}$, estima-se a equação (18) através de um probit tradicional. Para as informações tais que $\mathrm{s}_{\mathrm{it}}=1$, calcula-se a razão de Mills invertida $\hat{\lambda}_{i t} \equiv \lambda\left(x_{i} \cdot \hat{\delta}_{t}\right)$.

(ii) Para cada $\mathrm{s}_{\mathrm{it}}=1$, defina o vetor $\hat{w}_{i t} \equiv\left(1, \bar{x}_{i}, x_{i t}, 0, \ldots, 0, \hat{\lambda}_{i t}, 0, \ldots, 0\right)$.

Em termos de exemplificação, para uma dada unidade seccional i nos instantes de tempo 1 e 2, ter-se-ia os seguintes vetores:

$$
\begin{aligned}
\hat{w}_{i 1} & \equiv\left(1, \bar{x}_{i}, x_{i 1}, 0,0, \ldots, 0, \hat{\lambda}_{i 1}, 0,0, \ldots, 0\right) \\
\hat{w}_{i 2} & \equiv\left(1, \bar{x}_{i}, 0, x_{i 2}, 0, \ldots, 0,0, \hat{\lambda}_{i 2}, 0, \ldots, 0\right)
\end{aligned}
$$

e assim sucessivamente, para cada t.

(iii) Para cada uma destas $t$ estimações dos probits, obtém-se a inversa da matriz hessiana bem como a matriz de scores para cada observação i, esta última definida como a contribuição marginal de cada variável para o $\log$ da verossimilhança de cada um dos t probits estimados. Em termos mais específicos, conforme descrito em Wooldridge (2002), seja $l_{i}(\theta)$ a função de log-verossimilhança em função de um conjunto de parâmetros $\theta=\left(\theta_{1}, \theta_{2}, \ldots, \theta_{p}\right)$ de interesse, o score da log-verossimilhança para uma cada observação i é dada por:

$$
\nabla_{\theta} l_{i}(\theta)^{\prime}=\left(\frac{\partial l_{i}}{\partial \theta_{1}}(\theta), \frac{\partial l_{i}}{\partial \theta_{2}}(\theta), \ldots, \frac{\partial l_{i}}{\partial \theta_{p}}(\theta)\right)^{\prime}
$$


Tanto a inversa da matriz hessiana como o vetor de scores da função logverossimilhança não são utilizados no procedimento do teste em si, embora sejam na correção dos desvios-padrão dos coeficientes associados ao segundo estágio da metodologia.

(iv) Calcula-se $\hat{\theta} \equiv\left(\hat{\psi}^{\prime}, \hat{\beta^{\prime}}, \gamma^{\prime}\right)^{\prime}$ através de um OLS agrupado (pooled OLS), sendo $\hat{\theta}$ $=((1+\mathrm{K}+\mathrm{K}+\mathrm{T}) \times 1)$;

(v) Estima-se a variância assintótica de $\hat{\theta}$.

O passo (v) do procedimento de correção do viés de seleção pode ser considerado como a execução mais complexa dentro de toda a metodologia e portanto, merece uma apreciação mais detalhada. Assim, o procedimento pode ser sumarizado a partir dos seguintes passos:

(v.1) Estima-se os resíduos da equação (19) para as observações tais que $s_{i t}=1$, ou $\operatorname{seja}, \hat{e}_{i t}=y_{i t}-\hat{w}_{i t} . \theta, \mathrm{s}_{\mathrm{it}}=1$;

(v.2) Define-se os valores $\hat{v}_{i t}=\lambda^{\prime}\left(x_{i} . \delta\right)$. Cada valor de $\hat{v}_{i t}$ vem a ser, desta forma, um escalar, definido como o valor da derivada da razão de Mills invertida avaliada no ponto $\mathrm{x}_{\mathrm{i}} . \delta$, sendo este último justamente o valor previsto (linear) por cada um dos t probits estimados no passo (i);

(v.3) Define-se os valores $\left[\left(\hat{v}_{i t}\right) \cdot\left(x_{i}\right)\right]=\left[\lambda^{\prime}\left(x_{i} \cdot \delta\right)\right] .\left(x_{i}\right)$. Note que $\left(v_{i t}\right) .\left(x_{i}\right)$ vem a ser uma matriz (vetor) de dimensão $[1 \times(1+\mathrm{K}+\mathrm{K})]$;

(v.4) Defina a matriz $\mathrm{Z}_{\mathrm{it}}=\left[\begin{array}{llll}0^{\prime} & 0^{\prime} & \left(v_{i} t\right) .\left(x_{i}\right)^{\prime} & 0^{\prime} \ldots 0^{\prime}\end{array}\right]^{\prime}$, em que o termo $\left(v_{i} t\right) \cdot\left(x_{i}\right)^{\prime}$ está situado na t-ésima coluna da matriz $\mathrm{Z}_{i t}$. Note que tal matriz contém $\mathrm{T}$ elementos e que cada elemento da matriz $Z_{\text {it }}$ tem dimensão $[(1+K+K) \times 1]$, o que torna $Z_{i t}$ uma matriz de dimensão igual à $[\mathrm{T}$ x $(1+\mathrm{K}+\mathrm{K})]$ - cada elemento 0 vem a ser uma matriz nula. 
(v.5) Defina a matriz $G_{i t}=\left|\begin{array}{ccccccc}0 & \ldots & 0 & 0 & 0 & \ldots & 0 \\ 0 & \ldots & 0 & 0 & Z_{i t} & \ldots & 0\end{array}\right|$

Em que cada elemento 0 da linha superior da matriz $\mathrm{G}_{\text {it }}$ é novamente uma matriz nula, de dimensão $[(1+K+K) \times(1+K+K)]$, e cada elemento 0 da linha inferior da matriz $G_{i t}$ é uma matriz nula de dimensão [ T x $(1+\mathrm{K}+\mathrm{K})$ ]. Cada linha da matriz $\mathrm{G}_{\text {it }}$ possui $\mathrm{T}$ elementos, o que a torna uma matriz de dimensão total $[(1+\mathrm{K}+\mathrm{K}+\mathrm{T})] \mathrm{x}[((1+\mathrm{K}+\mathrm{K}) \mathrm{x} \mathrm{T})]$. $\mathrm{O}$ elemento $Z_{i t}$ está na t-ésima coluna da segunda linha da matriz $G_{i t}$.

(v.6) Defina a matriz $\mathrm{w}_{\mathrm{it}}{ }^{\prime} . \hat{\theta}{ }^{\prime}$, de dimensão total $[(1+\mathrm{K}+\mathrm{K}+\mathrm{T}) \mathrm{x}(1+\mathrm{K}+\mathrm{K}+\mathrm{T})]$;

(v.7) Defina a matriz $\mathrm{w}_{\mathrm{it}}{ }^{\prime} \cdot \hat{\theta}^{\prime} \cdot \mathrm{G}_{\mathrm{it}}$, de dimensão total $[(1+\mathrm{K}+\mathrm{K}+\mathrm{T})] \times[((1+\mathrm{K}+\mathrm{K})$ x T)];

(v.8) Defina a matriz $\mathrm{D}=N^{-1} \cdot \sum_{i=1}^{N} \sum_{t=1}^{T} s_{i t} \cdot w_{i t}{ }^{\prime} \cdot \hat{\theta^{\prime}} \cdot G_{i t}$, de dimensão total $[(1+\mathrm{K}+\mathrm{K}+$ $\mathrm{T})] \times[((1+\mathrm{K}+\mathrm{K}) \times \mathrm{T})]$

(v.9) Considerando cada uma das t matrizes hessianas obtidas em cada um dos $\mathrm{t}$ probits estimados no procedimento (iii) bem como cada uma das matrizes de scores para cada observação i e para cada um dos t probits estimados, define-se:

$$
r_{i t}=\left(\text { hessiana }_{t}\right) .\left(\text { score }_{i t}\right)
$$

que resulta em uma matriz de dimensão $[(1+K+K) \times 1]$

(v.10) Calcula-se a matriz $r_{i}$, que consiste no empilhamento, para cada unidade seccional $i$, de suas respectivas matrizes $r_{i t}$. Assim, por exemplo, a matriz $r$ da unidade seccional 1 pode ser definida como $r_{1}=\left[\begin{array}{llll}r_{11} & r_{12} & \ldots & r_{1 T}\end{array}\right]^{\prime}$. Logo, a matriz $r_{i}$ tem dimensão [T x $(1+\mathrm{K}+\mathrm{K})]$

(v.11) Para cada unidade seccional i, calcula-se a matriz D. $r_{i}$, de dimensão [(1 $+\mathrm{K}+\mathrm{K}$ $+\mathrm{T}) \mathrm{x} 1]$ 
(v.12) Para cada unidade seccional i, define-se a matriz $\hat{q}_{i}=\sum_{t=1}^{T} s_{i t} \cdot \hat{w}_{i t}{ }^{\prime} \cdot \hat{e}_{i t}$, de dimensão $[(1+K+K+T) \times 1]$

(v.13) Para cada unidade seccional i, define-se a matriz $\hat{p}_{i}=\hat{q}_{i}-D . r_{i}$, de dimensão [(1 $+\mathrm{K}+\mathrm{K}+\mathrm{T}) \times 1]$

(v.14) Define-se a matriz (quadrada) $A=N^{-1} \cdot \sum_{i=1}^{N} \sum_{t=1}^{T} s_{i t} \cdot w_{i t}{ }^{\prime} \cdot w_{i t}$, de dimensão $[(1+\mathrm{K}+$ $\mathrm{K}+\mathrm{T}) \mathrm{x}(1+\mathrm{K}+\mathrm{K}+\mathrm{T})]$

(v.15) Define-se a matriz (quadrada) $B=N^{-1} \cdot \sum_{i=1}^{N} \hat{p_{i}} \cdot \hat{p_{i}}{ }^{\prime}$, de dimensão $[(1+\mathrm{K}+\mathrm{K}+\mathrm{T})$ $\mathrm{x}(1+\mathrm{K}+\mathrm{K}+\mathrm{T})]$

(v.16) Define-se a matriz $\operatorname{avar}(\hat{\theta})=\left(\mathrm{A}^{-1} \cdot \mathrm{B} \cdot \mathrm{A}^{-1}\right) / \mathrm{N}$

Conforme descrito em Wooldridge (1995), $\sqrt{N}(\hat{\theta}-\theta) \stackrel{d}{\longrightarrow} \operatorname{Normal}\left(0, \mathrm{~A}^{-1} \mathrm{BA}^{-1}\right)$

(v.17) Calculando a raiz quadrada dos elementos da diagonal principal da matriz $\operatorname{avar}(\theta)$, obtém-se os desvios-padrão corrigidos dos elementos da matriz $\hat{\theta} \equiv\left(\hat{\psi^{\prime},}, \hat{\beta}^{\prime}, \gamma^{\prime}\right)$ '.

\section{4 - Descrição dos dados, modelo estimado e resultados obtidos}

Conforme anteriormente descrito, este capítulo considera apenas os municípios paulistas dentro do período 1989 - 2001. Efetivamente, nem todos os atuais 645 municípios existentes no estado puderam ser considerados devido à inexistência de todas as informações utilizadas para todas estas unidades e para todos os anos. A tabela 3.2 em seqüência apresenta a distribuição dos municípios dentro da amostra, considerando a ocorrência ou não do resultado primário positivo: 
Tabela 3.2 - Distribuição dos municípios, conforme resultado primário

\begin{tabular}{|c|c|c|c|}
\hline Ano & $\begin{array}{c}\text { Resultado primário } \\
\text { negativo }\end{array}$ & $\begin{array}{c}\text { Resultado primário } \\
\text { positivo }\end{array}$ & Total \\
\hline $\mathbf{1 9 8 9}$ & 95 & 121 & 216 \\
\hline $\mathbf{1 9 9 0}$ & 164 & 49 & 213 \\
\hline $\mathbf{1 9 9 1}$ & 155 & 43 & 198 \\
\hline $\mathbf{1 9 9 2}$ & 177 & 17 & 194 \\
\hline $\mathbf{1 9 9 3}$ & 94 & 106 & 200 \\
\hline $\mathbf{1 9 9 4}$ & 152 & 59 & 211 \\
\hline $\mathbf{1 9 9 5}$ & 188 & 40 & 228 \\
\hline $\mathbf{1 9 9 6}$ & 196 & 48 & 244 \\
\hline $\mathbf{1 9 9 7}$ & 122 & 116 & 238 \\
\hline $\mathbf{1 9 9 8}$ & 109 & 127 & 236 \\
\hline $\mathbf{1 9 9 9}$ & 72 & 167 & 239 \\
\hline $\mathbf{2 0 0 0}$ & 52 & 158 & 210 \\
\hline $\mathbf{2 0 0 1}$ & 17 & 184 & 201 \\
\hline Total & 1593 & 1235 & 2828 \\
\hline
\end{tabular}

Fonte: construção própria, com base dados do SEADE

Gráfico 3.1 - Distribuição dos municípios, conforme resultado primário (em \%)

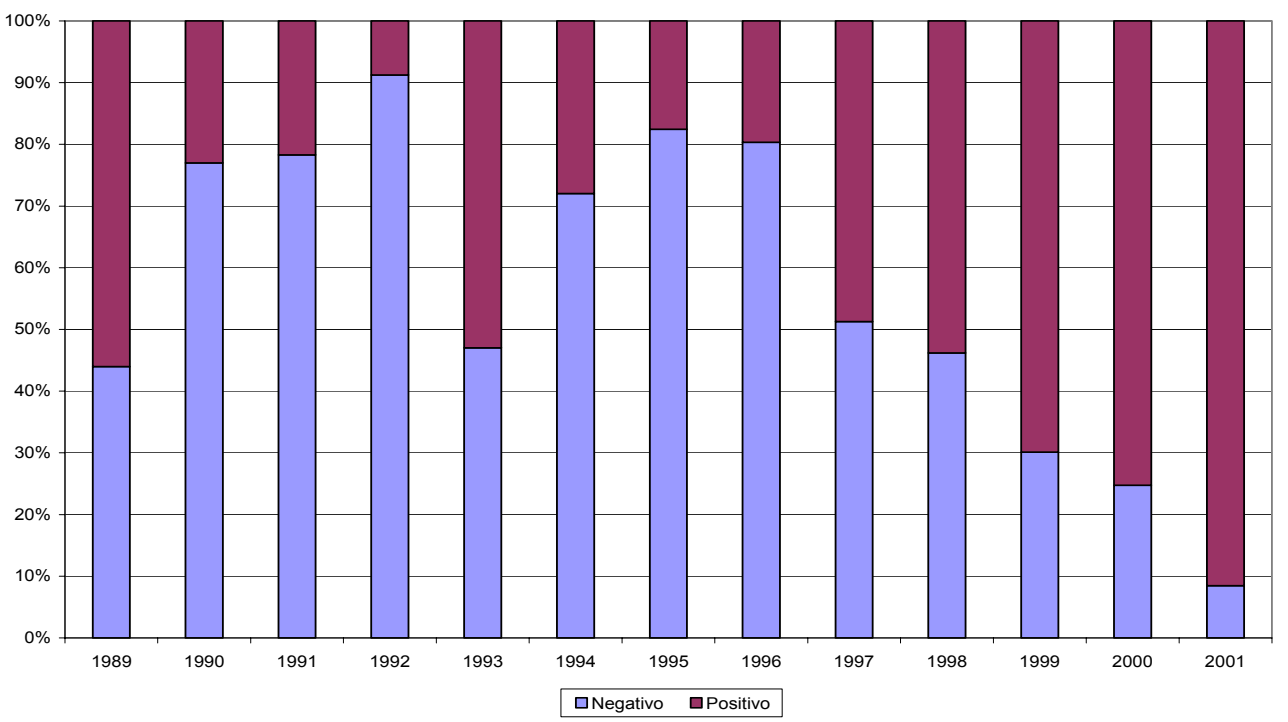

Fonte: construção própria, com base dados do SEADE

A tabela 3.2 e o gráfico 3.1 apresentam a distribuição dos municípios paulistas por ano e pelo resultado primário observado. Embora tais proporções devam ser analisadas com cautela, uma vez que o número total de municípios varia ano a ano, é possível observar que após 1996 a proporção de prefeituras com déficit primário sofre significativa redução, principalmente quando se considera que até então, o fenômeno inverso parece ser predominante. Em 1989, os municípios que apresentaram resultado primário positivo e resultado primário negativo representavam 56,02\% e 43,98\% respectivamente. Em 1997 estas proporções tornam-se próximas, indicando que 48,74\% dos municípios paulistas obtiveram 
superávit primário e 51,26\% obtiveram déficit. Já em 2001, ano final da amostra aqui considerada, estes valores passam a ser iguais a $91,54 \%$ e $8,46 \%$ respectivamente. Assim, tais valores indicam que a disciplina fiscal dos municípios paulistas parece sofrer significativa alteração ao longo do período considerado, dado que o número de municípios com resultado primário positivo apresenta elevação significativa a partir de 1996, fato que pode servir como indício da influência da portaria estipulada pelo Ministério da Fazenda.

No que diz respeito ao modelo estimado, Botelho (2002) sugere uma modificação do cálculo do resultado primário em que, do total de receitas disponíveis pelo município, não é subtraída a receita oriunda de alienação de bens. Deste modo, considera-se que os recursos obtidos pela prefeitura através deste procedimento também podem ser considerados instrumentos de realização de ajustes fiscais e assim, o resultado primário efetivamente considerado nas estimações pode ser descrita através da seguinte formulação:

\section{Resultado Primário}

\section{$=$}

(Receita Total - Receitas Financeiras - Receitas de Operações de Crédito)

(Despesa Total-Despesas de Juros e Encargos - Despesas de Amortizações)

Os regressores podem ser divididos em dois grupos, sejam eles, variáveis fiscais e variáveis políticas. No primeiro caso, os regressores selecionados são os mesmos sugeridos por Botelho (2002), quais sejam:

i) a razão Despesa de pessoal / Receita corrente: esta seria uma medida de rigidez orçamentária dos municípios, ou seja, um maior comprometimento dos gastos municipais com a folha de pagamento tornaria mais difícil a obtenção de resultados fiscais positivos, sendo razoável portanto esperar que tal coeficiente apresente sinal negativo nas estimações;

ii) a razão Receita tributária / Receita corrente: esta seria uma medida de independência do município em relação às receitas oriundas de transferências constitucionais (da União e dos estados). Para esta variável em particular, um sinal estatisticamente negativo poderia sugerir que os municípios com menor dependência das transferências seriam aqueles com maior autonomia fiscal e portanto, com maiores possibilidades de endividamento. Por outro lado, um sinal estatisticamente positivo poderia sugerir que o maior esforço arrecadatório dos municípios estivesse associado a um comportamento fiscal mais conservador, ocasionando assim uma maior disciplina fiscal. Logo, não é possível determinar 
a priori qual destas duas possibilidades seria a mais condizente com a amostra analisada não sendo possível, deste modo, esperar um determinado sinal para tal variável.

No tocante às variáveis políticas, foram consideradas:

i) índice de fracionalização das preferências do eleitorado para o cargo Executivo: tal índice, calculado para cada município e para cada período de governo, é obtido com base na fórmula fracionalização de preferências $=1-\sum_{j}^{J} v_{j}{ }^{2}$, em que $v_{j}$ é a proporção de votos obtida por cada candidato $\mathrm{j}$ a prefeito - tal índice é calculado para os resultados eleitorais de 1988, 1992, 1996 e 2000. Tal indicador, também presente em Botelho (2002) e inspirado em Tabellini \& Alesina (1990), tem como objetivo mensurar a dispersão / concentração das preferências do eleitorado para o cargo Executivo, sendo esperado um sinal negativo para o mesmo: uma maior dispersão das preferências (maior índice de fracionalização) estaria associada a uma maior heterogeneidade das preferências dos eleitores, dificultando a realização de ajustes fiscais;

ii) índice de fracionalização partidária do Legislativo: de forma semelhante ao índice anterior, este coeficiente, também calculado para cada município e para cada período de governo, é obtido com base na fórmula fracionalização do Legislativo $=1-\sum_{j}^{J} v_{w}{ }^{2}$, em que $v_{w}$ é a proporção de cadeiras ocupada por cada partido w na câmara de vereadores - tal índice também é calculado para cada um dos resultados eleitorais de 1988, 1992, 1996 e 2000 . Tal indicador, presente em Cossio (2001), tem como finalidade mensurar a influência da dispersão das preferências dos partidos políticos sobre o desempenho fiscal.

Ressalta-se que tais indicadores podem ser considerados peculiares, uma vez que poucos trabalhos da literatura nacional contemplam a influência de tais variáveis sobre o desempenho fiscal dos entes da federação brasileira (até pela própria dificuldade em obter tais informações), especialmente no que diz respeito ao comportamento dos municípios brasileiros. Assim, a inclusão destes índices pode promover um entendimento mais profundo a respeito do tema aqui abordado.

iii) partido do prefeito municipal: seguindo o padrão estabelecido nos dois primeiros capítulos desta tese, foram criadas dummies para cada um dos nove partidos de prefeitos municipais com maior freqüência na amostra (conforme tabela 3.3 em seqüencia), quais sejam, PSDB, PMDB, PFL, PTB, PT e PDS / PPB - novamente, os demais partidos foram incluídos no grupo "outros partidos". A inclusão destas variáveis continua sendo verificar se 
os diferentes partidos dos prefeitos municipais influenciam a probabilidade de obtenção de resultados primários positivos / negativos;

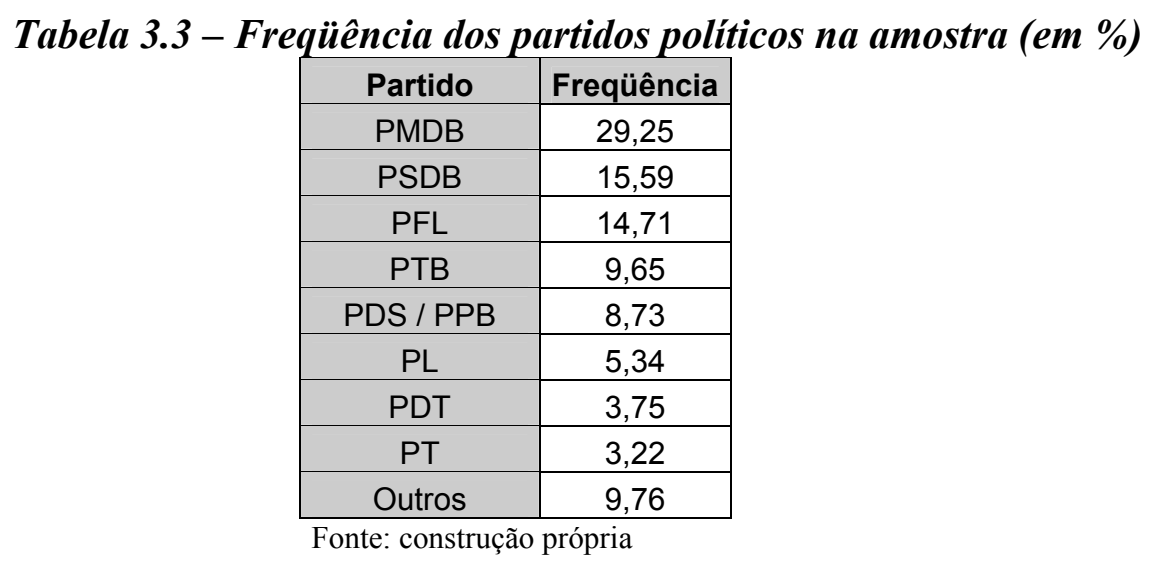

iv) similaridade: novamente, foi criada uma dummy assumindo o valor 1 caso o partido do prefeito municipal e do governador do estado sejam os mesmos, procurando verificar se o alinhamento partidário entre estas duas instâncias influencia a probabilidade do resultado primário positivo / negativo obtido pelos municípios. É importante ressaltar que neste capítulo, diferentemente do procedimento implementado nos dois primeiros, não é inserida nas estimações a dummy de similaridade partidária entre prefeito e presidente da República. Tal procedimento é implementado uma vez que por serem analisados somente os municípios do estado de São Paulo, as dummies de similaridade com o Executivo estadual e federal são praticamente as mesmas, variando apenas durante os anos (1990 a 1992) em que o governo federal esteve sob controle do PRN, no governo de Fernando Collor de Mello, e o governo estadual paulista esteve sob controle do PMDB, no governo de Luiz Antônio Fleury Filho. Assim, uma eventual significância estatística deste coeficiente estaria mensurando o efeito da influência do alinhamento político com os dois níveis de governo, e não somente com o Executivo estadual.

Adicionalmente, foram consideradas nas estimações as mesmas variáveis demográficas consideradas nos capítulos anteriores, ou seja, a população total (em logaritmo natural), a proporção de jovens e idosos e a taxa de urbanização. Também conforme considerado nos dois primeiros capítulos desta tese, a dummy associada ao PMDB foi retirada da amostra com vistas a evitar o problema de multicolinearidade perfeita entre as dummies de partido e portanto, vem a ser o partido de referência das análises. 


\section{5 - Apresentação e análise dos resultados}

Tabela 3.4 - Regressões do resultado primário - efeitos fixos

\begin{tabular}{|c|c|c|c|}
\hline & $\begin{array}{l}\text { Positivo e } \\
\text { negativo }\end{array}$ & Positivo & Negativo \\
\hline Pessoal / Receitas & $\begin{array}{c}-478.506^{* * *} \\
(36.285) \\
\end{array}$ & $\begin{array}{c}-422.432^{* * *} \\
(50.703) \\
\end{array}$ & $\begin{array}{c}195.765^{* * *} \\
(38.974) \\
\end{array}$ \\
\hline Tributária / Receitas & $\begin{array}{c}-413.769^{* * *} \\
(74.216) \\
\end{array}$ & $\begin{array}{l}-15.543 \\
(89.201) \\
\end{array}$ & $\begin{array}{l}111.922 \\
(83.633) \\
\end{array}$ \\
\hline PDS / PPB & $\begin{array}{c}33.393^{* *} \\
(15.312)\end{array}$ & $\begin{array}{c}-5.759 \\
(18.614)\end{array}$ & $\begin{array}{c}-38.913^{* *} \\
(18.580)\end{array}$ \\
\hline PDT & $\begin{array}{c}4.012 \\
(19.742)\end{array}$ & $\begin{array}{c}21.277 \\
(24.652)\end{array}$ & $\begin{array}{l}-14.749 \\
(21.903)\end{array}$ \\
\hline PL & $\begin{array}{c}57.156^{* \star *} \\
(17.753)\end{array}$ & $\begin{array}{c}8.656 \\
(22.453)\end{array}$ & $\begin{array}{l}-22.374 \\
(20.557)\end{array}$ \\
\hline PSDB & $\begin{array}{l}-15.943 \\
(12.913) \\
\end{array}$ & $\begin{array}{l}-21.981 \\
(16.139) \\
\end{array}$ & $\begin{array}{l}-20.379 \\
(14.625) \\
\end{array}$ \\
\hline PFL & $\begin{array}{c}11.190 \\
(12.935)\end{array}$ & $\begin{array}{c}12.406 \\
(15.442)\end{array}$ & $\begin{array}{c}3.956 \\
(15.188)\end{array}$ \\
\hline PTB & $\begin{array}{c}22.738 \\
(14.708) \\
\end{array}$ & $\begin{array}{c}-6.766 \\
(18.211) \\
\end{array}$ & $\begin{array}{l}-11.094 \\
(16.380) \\
\end{array}$ \\
\hline PT & $\begin{array}{l}36.109^{*} \\
(22.476)\end{array}$ & $\begin{array}{c}-9.517 \\
(26.834)\end{array}$ & $\begin{array}{l}-37.016 \\
(25.190)\end{array}$ \\
\hline OUTROS & $\begin{array}{l}-12.034 \\
(14.431) \\
\end{array}$ & $\begin{array}{c}5.118 \\
(18.688)\end{array}$ & $\begin{array}{c}12.153 \\
(15.840)\end{array}$ \\
\hline Frac. Câmara & $\begin{array}{c}101.390 \text { ** } \\
(43.135)\end{array}$ & $\begin{array}{c}19.070 \\
(50.316)\end{array}$ & $\begin{array}{c}-98.455^{\star *} \\
(51.138)\end{array}$ \\
\hline Frac. Executivo & $\begin{array}{c}-186.748^{* * *} \\
(49.013) \\
\end{array}$ & $\begin{array}{l}-50.734 \\
(58.171) \\
\end{array}$ & $\begin{array}{c}112.841^{* *} \\
(56.576)\end{array}$ \\
\hline Prefeito \& Governador & $\begin{array}{c}30.062 \text { *** } \\
(11.142)\end{array}$ & $\begin{array}{l}29.786^{*} \\
(15.871)\end{array}$ & $\begin{array}{c}2.913 \\
(11.443)\end{array}$ \\
\hline Idosos & $\begin{array}{c}-19.888^{* *} \\
(7.796)\end{array}$ & $\begin{array}{c}-25.004^{* * *} \\
(8.329)\end{array}$ & $\begin{array}{c}0.769 \\
(11.487)\end{array}$ \\
\hline Urbanização & $\begin{array}{c}2.987^{* \star *} \\
(1.033)\end{array}$ & $\begin{array}{c}5.091^{* \star *} \\
(1.291)\end{array}$ & $\begin{array}{l}-0.047 \\
(1.162)\end{array}$ \\
\hline Jovens & $\begin{array}{c}-17.455^{* * *} \\
(2.345) \\
\end{array}$ & $\begin{array}{l}-0.829 \\
(2.624) \\
\end{array}$ & $\begin{array}{l}6.645^{* *} \\
(3.368) \\
\end{array}$ \\
\hline População & $\begin{array}{c}19.367 \\
(41.603)\end{array}$ & $\begin{array}{c}-135.038^{* * *} \\
(43.356) \\
\end{array}$ & $\begin{array}{c}-5.066 \\
(57.115) \\
\end{array}$ \\
\hline Constante & $\begin{array}{c}453.487 \\
(487.152)\end{array}$ & $\begin{array}{c}1347.839 * * * \\
(495.806)\end{array}$ & $\begin{array}{l}-142.733 \\
(685.907)\end{array}$ \\
\hline $\mathrm{R}^{2}$ & 0,0409 & 0,0438 & 0,0244 \\
\hline Observações & 2828 & 1235 & 1593 \\
\hline Teste de Hausman & $\begin{array}{l}\chi^{2}=150,29 \\
\text { Prob }=0,00\end{array}$ & $\begin{array}{c}\chi^{2}=65,01 \\
\text { Prob }=0,00\end{array}$ & $\begin{array}{c}\chi^{2}=33,49 \\
\text { Prob }=0,00\end{array}$ \\
\hline
\end{tabular}

Fonte: construção própria

A tabela 3.4 apresenta os resultados das estimações em que o resultado primário é regredido em função das variáveis explicativas analisadas anteriormente sem considerar a possibilidade do viés de seleção - em última instância, pressupõe-se portanto que a ocorrência do superávit ou do déficit é um evento aleatório e portanto, seria permitido estimar uma regressão tradicional em painel sem incorrer no problema de viés de variável omitida. São estimadas três regressões, diferenciadas entre si pela amostra considerada: no primeiro caso (primeira coluna da tabela 3.4) considera-se todos os municípios paulistas durante o período, sem nenhuma distinção quanto sinal do resultado primário, ao passo que na segunda 
estimação (segunda coluna da tabela 3.4), são considerados apenas os municípios que apresentam resultado primário positivo. Por fim, a terceira coluna apresenta o resultado das estimações em que são considerados apenas os municípios com déficit - é importante ressaltar que, com vistas a facilitar o entendimento dos resultados associados às observações com déficit fiscal, foi utilizado o valor absoluto do mesmo (e não seu valor negativo), alteração que permite interpretar coeficientes positivos como elementos que influenciam positivamente o aumento do déficit - tal raciocínio é válido para todos os testes deste capítulo. É apresentada também a estatística referente ao teste de Hausman, que indica a consistência dos resultados obtidos através do método de efeitos fixos - os resultados obtidos através dos procedimentos de OLS e efeitos aleatórios encontram-se nos apêndices 3.2 e 3.3, respectivamente.

Os resultados obtidos podem ser considerados particulares uma vez que a significância dos coeficientes varia significativamente entre as amostras. No caso do primeiro teste (primeira coluna), observa-se que uma maior relação despesa de pessoal sobre receitas correntes afeta negativamente o resultado primário (coeficiente igual a $-478,50$, significante a $1 \%$ ), sugerindo portanto que municípios com um maior comprometimento da receita em função de tal categoria de despesa possuem efetivamente uma maior dificuldade em gerar saldos fiscais positivos. Por sua vez, municípios com uma maior participação das receitas tributárias sobre o total da receita corrente também apresentam tendência a resultados primários negativos (coeficiente igual à $-413,77$, estatisticamente significante a 11\%). Assim, considerando a totalidade dos municípios presentes na amostra, observa-se uma maior tendência a desajustes fiscais quando há um maior comprometimento da receita corrente com a despesa de pessoal, bem como quando há uma maior autonomia fiscal dos estados em relação aos recursos vindos a partir da União. Estes são exatamente os mesmos resultados por Botelho (2002) para os estados brasileiros, conforme visto na revisão da literatura.

No que diz respeito aos partidos políticos, somente os coeficientes associados ao PDS / PPB (33,39), PL $(57,15)$ e PT $(36,10)$ apresentam significância estatística, indicando maiores superávits primários por parte destes partidos relativamente ao PMDB. Adicionalmente, resultados importantes são os sugeridos pelas variáveis fracionalização de preferências ao Executivo e fracionalização do Legislativo: no caso do primeiro destes, cujo coeficiente é negativo e estatisticamente significante $(-186,74)$, observa-se que disputas mais acirradas ao Executivo (em termos da proporção de votos obtidos pelos candidatos) tendem a negativamente o resultado primário, ao passo que câmaras de vereadores partidariamente mais fragmentadas tendem a influenciar positivamente o montante do resultado fiscal (coeficiente igual a 101,39). Finalmente, ainda sobre questões de natureza política, o alinhamento com o 
governo estadual (e, em alguma medida, com o governo federal também, conforme discutido anteriormente) afeta positivamente o resultado primário, significando assim um maior conservadorismo fiscal.

Considerando os resultados associados (somente) aos municípios com superávit primário (segunda coluna da tabela 3.4), os únicos coeficientes estatisticamente significantes são os associados à razão despesa de pessoal sobre receita corrente, que permanece negativo mas passa a assumir valor igual a $-422,43$, e ao alinhamento partidário com o Executivo estadual, que indica a ocorrência de maiores superávits primários (coeficiente igual a 29,78) na ocorrência deste fenômeno. Por fim, considerando a terceira coluna da tabela 3.4, na qual são consideradas somente as observações com (o valor absoluto do) déficit, observa-se novamente que uma maior relação despesa de pessoal sobre a receita corrente tende a gerar maiores déficits fiscais, ao passo que somente para o PDS / PPB é observado significância estatística, indicando menores déficits comparativamente ao PMDB. Quanto às demais variáveis, uma maior fracionalização partidária do poder Legislativo tende a minimizar o tamanho do déficit (coeficiente igual a -98,45) ao passo que disputas ao Executivo municipal mais acirradas tendem a gerar maiores déficits (coeficiente igual a 112,84).

Sobre as variáveis demográficas, são observados resultados particulares variantes entre as amostras: no caso da proporção de idosos, observa-se que a sua influência negativa sobre o montante do resultado fiscal (primeira coluna) se origina basicamente da sua influência negativa sobre o montante do superávit fiscal (segunda coluna), pois no caso dos municípios deficitários (terceira coluna), o resultado fiscal negativo não é influenciado por tal variável. Tal resultado também é observado para o grau de urbanização, embora tal variável influencie positivamente o montante do superávit fiscal. No que diz respeito à proporção de jovens, por sua vez, observa-se que a sua influência negativa sobre o resultado fiscal advém basicamente da sua influência sobre os resultados deficitários, fazendo com que tais saldos negativos sejam cada vez maiores. Por fim, observa-se que a população total apresenta significância estatística somente na segunda coluna (coeficiente igual a $-135,03$ ), influenciando negativamente o tamanho do superávit fiscal. 
Tabela 3.5 - Viés de seleção em OLS

\begin{tabular}{|c|c|c|c|}
\hline $\begin{array}{c}\text { Coeficiente } \\
\text { (desvio-padrão) }\end{array}$ & $\begin{array}{c}\text { Equação de seleção } \\
\text { (Iºstágio) }\end{array}$ & $\begin{array}{c}\text { Equação de variável contínua } \\
\text { (II estágio) } \\
\text { observações superavitárias }\end{array}$ & $\begin{array}{c}\text { Equação de variável contínua } \\
\text { (II estágio) } \\
\text { observações deficitárias }\end{array}$ \\
\hline $\begin{array}{l}\text { Pessoal / } \\
\text { Receitas }\end{array}$ & $\begin{array}{c}-2.866^{* * *} \\
(0.262)\end{array}$ & $\begin{array}{l}-202.259 \\
(144.414)\end{array}$ & $\begin{array}{l}528.093^{* * *} \\
(149.217)\end{array}$ \\
\hline $\begin{array}{l}\text { Tributária / } \\
\text { Receitas }\end{array}$ & $\begin{array}{l}-1.465^{\star * *} \\
(0.371)\end{array}$ & $\begin{array}{c}130.162 \\
(212.448)\end{array}$ & $\begin{array}{l}293.437^{\star * *} \\
(98.824)\end{array}$ \\
\hline PDS / PPB & $\begin{array}{l}0.203^{*} \\
(0.107)\end{array}$ & $\begin{array}{c}15.457 \\
(16.725)\end{array}$ & $\begin{array}{l}-57.905^{\star * *} \\
(17.742)\end{array}$ \\
\hline PDT & $\begin{array}{c}0.223 \\
(0.143)\end{array}$ & $\begin{array}{c}8.881 \\
(17.237)\end{array}$ & $\begin{array}{l}-60.149^{* * *} \\
(21.309)\end{array}$ \\
\hline PL & $\begin{array}{l}0.272^{* *} \\
(0.124)\end{array}$ & $\begin{array}{c}4.603 \\
(20.612)\end{array}$ & $\begin{array}{c}-42.415^{* *} \\
(19.754)\end{array}$ \\
\hline PSDB & $\begin{array}{l}0.128 \\
(0.09)\end{array}$ & $\begin{array}{l}-20.698 \\
(15.983)\end{array}$ & $\begin{array}{c}-74.982^{* * *} \\
(13.499)\end{array}$ \\
\hline PFL & $\begin{array}{l}0.207^{* *} \\
(0.092)\end{array}$ & $\begin{array}{c}8.963 \\
(15.974)\end{array}$ & $\begin{array}{l}-47.796^{* *} \\
(19.084)\end{array}$ \\
\hline PTB & $\begin{array}{l}0.175^{*} \\
(0.102)\end{array}$ & $\begin{array}{l}-19.215^{*} \\
(11.593)\end{array}$ & $\begin{array}{l}-31.095^{*} \\
(16.586)\end{array}$ \\
\hline PT & $\begin{array}{l}0.271^{*} \\
(0.152)\end{array}$ & $\begin{array}{c}2.111 \\
(17.129)\end{array}$ & $\begin{array}{l}-101.906^{* * *} \\
(22.035)\end{array}$ \\
\hline OUTROS & $\begin{array}{l}-0.072 \\
(0.103)\end{array}$ & $\begin{array}{c}-0.043 \\
(12.062)\end{array}$ & $\begin{array}{c}25.678 \\
(20.851)\end{array}$ \\
\hline Frac. Câmara & $\begin{array}{l}1.405^{\star * *} \\
(0.277)\end{array}$ & $\begin{array}{c}-48.656 \\
(114.129)\end{array}$ & $\begin{array}{c}-281.107^{* * *} \\
(84.766)\end{array}$ \\
\hline Frac. Executivo & $\begin{array}{c}-1.786^{\star \star *} \\
(0.306)\end{array}$ & $\begin{array}{c}-3.122 \\
(121.374)\end{array}$ & $\begin{array}{c}320.361^{\star * *} \\
(114.596)\end{array}$ \\
\hline $\begin{array}{l}\text { Prefeito \& } \\
\text { Governador }\end{array}$ & $\begin{array}{l}0.166^{*} \\
(0.089)\end{array}$ & $\begin{array}{c}16.74 \\
(11.929)\end{array}$ & $\begin{array}{l}-16.289 \\
(16.677)\end{array}$ \\
\hline Idosos & $\begin{array}{c}-0.217^{\star \star \star *} \\
(0.027)\end{array}$ & $\begin{array}{c}-6.94 \\
(12.209)\end{array}$ & $\begin{array}{c}6.666 \\
(14.305) \\
\end{array}$ \\
\hline Urbanização & $\begin{array}{c}-0.008^{* * *} \\
(0.002)\end{array}$ & $\begin{array}{l}0.777^{*} \\
(0.456)\end{array}$ & $\begin{array}{l}1.777^{\star * *} \\
(0.478)\end{array}$ \\
\hline Jovens & $\begin{array}{c}-0.130^{* * *} \\
(0.012)\end{array}$ & $\begin{array}{c}0.120 \\
(7.244)\end{array}$ & $\begin{array}{l}14.334^{*} \\
(7.466)\end{array}$ \\
\hline População & $\begin{array}{l}-0.002 \\
(0.034)\end{array}$ & $\begin{array}{c}-18.849^{* *} \\
(7.454)\end{array}$ & $\begin{array}{c}-11.162^{* *} \\
(4.377)\end{array}$ \\
\hline Razão de Mills & - & $\begin{array}{l}-47.919 \\
(92.149) \\
\end{array}$ & $\begin{array}{c}279.826^{\star \star *} \\
(97.012) \\
\end{array}$ \\
\hline Constante & $\begin{array}{c}6.963^{* * *} \\
(0.639) \\
\end{array}$ & $\begin{array}{c}382.954 \\
271.869)\end{array}$ & $\begin{array}{l}-821.864^{*} \\
(480.405)\end{array}$ \\
\hline $\mathbf{R}^{2}$ & 0,1120 (Pseudo $R^{2}$ ) & 0,0926 & 0,0804 \\
\hline Observações & 2828 & 1235 & 1593 \\
\hline
\end{tabular}

Fonte: construção própria

A título de comparação, os resultados da tabela 3.5 foram obtidos através da implementação do modelo de seleção tradicional, em que todos os dados foram agrupados e tratados como se fossem elementos de uma amostra do tipo cross-section. A primeira coluna apresenta os resultados da regressão do primeiro estágio do procedimento de Heckman, em que a variável binária indicadora da observação $(\mathrm{y}=1)$ ou não $(\mathrm{y}=0)$ do superávit primário é 
regredida em função dos regressores considerados. Por sua vez, a segunda coluna da tabela apresenta os resultados do segundo estágio do procedimento, em que o superávit primário (variável contínua) é regredido em função em função dos regressores de interesse e também em função da razão de Mills invertida, obtida no primeiro estágio. Finalmente, a estimação na qual o (valor absoluto) do déficit é regredido em função dos regressores de interesse e da razão de Mills invertida ${ }^{32}$ é apresentada na terceira coluna.

No caso da equação de seleção, observa-se que tanto uma maior relação despesa de pessoal sobre receitas correntes como uma maior relação receita tributária sobre receitas correntes afetam negativamente a probabilidade de ocorrência do superávit primário (coeficientes iguais à $-2,86$ e $-1,46$, respectivamente, e estatisticamente significantes a 1\%). De forma complementar, os resultados sugerem também PDS / PPB, PL PFL, PTB e PT apresentam maiores probabilidades de esforços fiscais relativamente ao PMDB, a passo que preferências mais fragmentadas para os Executivos municipais (coeficiente igual à $-1,78$, significante a 1\%) e câmaras de vereadores mais fragmentadas (coeficiente igual a 1,40, significante a 1\%) afetam as chances de ocorrência do resultado primário positivo de forma negativa e positiva, respectivamente. Por fim, observa-se que a ocorrência do alinhamento partidário entre prefeituras e governo estadual, bem como municípios com menores proporções de idosos e jovens e menores taxas de urbanização apresentam maiores chances de obtenção de resultados primários positivos.

Em relação ao segundo estágio do procedimento, é interessante notar que apenas o grau e urbanização e a população total parecem influenciar (de forma positiva e negativa, respectivamente) a magnitude do superávit obtido pelas prefeituras paulistas. Em termos partidários, observa-se também que ao PTB estariam associados menores superávits fiscais. Assim, é interessante notar que os coeficientes tendem à ter maior influência na probabilidade de obtenção do superávit primário, e não no montante do resultado em si. Já em relação aos municípios deficitários (terceira coluna) boa parte dos coeficientes apresenta significância estatística e os resultados podem ser sumarizados da seguinte forma: em relação aos indicadores de natureza fiscal, uma maior relação despesa de pessoal sob receitas correntes e uma maior relação receitas tributárias sobre receita corrente tendem a elevar a magnitude do déficit fiscal. Em relação aos partidos políticos, observam-se coeficientes negativos para todas

\footnotetext{
${ }^{32}$ É extremamente importante ressaltar que embora os valores linearmente previstos pela equação de seleção sejam (em módulo) os mesmos para a amostra negativa e positiva (variando naturalmente apenas o sinal), o mesmo não pode ser dito para a razão de Mills invertida. Assim, é necessário estimar as razões de Mills invertida separadamente para a amostra com resultado primário positivo e para a amostra com resultado primário negativo, ou seja, os valores da razão de Mills invertida não são perfeitamente simétricos entre as duas amostras.
} 
as agremiações (exceto para o grupo "outros partidos”), indicando assim menores déficits comparativamente ao PMDB. Observa-se também que menores déficits estariam associados a municípios com câmaras legislativas mais fragmentadas e à eleições para o Executivo municipal menos acirradas em termos de proporção de votos. Finalmente, em relação aos elementos de natureza demográfica, observa-se que municípios mais urbanizados, com maiores proporções de jovens residentes e menores portes populacionais tendem a possuir maiores déficits fiscais.

O principal resultado provido pela tabela 3.5 reside na significância estatística dos coeficientes associados às razões de Mills invertidas: note que para os municípios com resultado primário positivo, tal coeficiente não é estatisticamente diferente de zero, o que sugere a inexistência do fenômeno do viés de seleção quando se ignora a característica de painel da amostra. Resultado distinto passa a ser observado quando são analisados os municípios deficitários, dado que a razão de Mills invertida, neste caso, assume valor positivo $(279,82)$ e estatisticamente significante a $1 \%$.

A tabela 3.6 apresenta os resultados associados ao teste da presença do viés de seleção dentro da amostra avaliada, ou seja, considerando-se que a estrutura dos dados disponíveis é do tipo panel data e considerando a possibilidade de que a ocorrência (ou não ocorrência) do superávit ou do déficit primário não seja um evento de natureza estocástica, implementa-se o procedimento sugerido em Wooldridge (1995) com vistas a saber se, de fato, o problema aqui analisado merece um tratamento mais específico. A primeira coluna apresenta os resultados do teste do viés de seleção para as observações superavitárias, ao passo que a segunda coluna realiza o mesmo teste, mas somente para as observações cujo resultado primário é negativo. Ressalta-se que toda as variáveis são transformadas, de modo que para cada uma das unidades seccionais, são calculados desvios em relação à média temporal de cada variável, de modo a obter uma regressão via método de efeitos fixos. 
Tabela 3.6 - Equação do teste do viés de seleção

\begin{tabular}{|c|c|c|}
\hline $\begin{array}{c}\text { Coeficiente } \\
\text { (desvio-padrão) }\end{array}$ & $\begin{array}{l}\text { Amostra } \\
\text { positiva }\end{array}$ & $\begin{array}{l}\text { Amostra } \\
\text { negativa }\end{array}$ \\
\hline Pessoal / Receitas & $\begin{array}{c}-333.737^{\star} \\
(75.610) \\
\end{array}$ & $\begin{array}{c}128.073^{* *} \\
(63.121)\end{array}$ \\
\hline Tributária / Receitas & $\begin{array}{c}21.824 \\
(262.537)\end{array}$ & $\begin{array}{c}34.854 \\
(122.738)\end{array}$ \\
\hline PDS / PPB & $\begin{array}{c}6.978 \\
(21.224)\end{array}$ & $\begin{array}{l}-33.447^{*} \\
(18.307) \\
\end{array}$ \\
\hline PDT & $\begin{array}{c}15.608 \\
(11.728)\end{array}$ & $\begin{array}{c}-8.382 \\
(16.673)\end{array}$ \\
\hline PL & $\begin{array}{c}-6.270 \\
(13.889)\end{array}$ & $\begin{array}{l}-19.404 \\
(13.924)\end{array}$ \\
\hline PSDB & $\begin{array}{l}-15.195 \\
(16.755)\end{array}$ & $\begin{array}{l}-22.353^{*} \\
(12.941)\end{array}$ \\
\hline PFL & $\begin{array}{c}5.689 \\
(10.884) \\
\end{array}$ & $\begin{array}{c}7.022 \\
(16.931) \\
\end{array}$ \\
\hline PTB & $\begin{array}{c}-9.108 \\
(11.458)\end{array}$ & $\begin{array}{c}-0.442 \\
(13.570)\end{array}$ \\
\hline PT & $\begin{array}{l}-21.050 \\
(19.409) \\
\end{array}$ & $\begin{array}{l}-41.109^{* *} \\
(16.871) \\
\end{array}$ \\
\hline OUTROS & $\begin{array}{c}5.416 \\
(11.264) \\
\end{array}$ & $\begin{array}{c}12.765 \\
(20.292)\end{array}$ \\
\hline Frac. Câmara & $\begin{array}{c}32.980 \\
(35.119)\end{array}$ & $\begin{array}{l}-65.718 \\
(48.905)\end{array}$ \\
\hline Frac. Executivo & $\begin{array}{l}-26.043 \\
(50.095)\end{array}$ & $\begin{array}{c}65.537 \\
(55.246) \\
\end{array}$ \\
\hline Prefeito \& Governador & $\begin{array}{l}23.311^{*} \\
(13.400)\end{array}$ & $\begin{array}{c}9.440 \\
(10.854)\end{array}$ \\
\hline Idosos & $\begin{array}{c}-14.031^{*} \\
(7.851) \\
\end{array}$ & $\begin{array}{l}-10.144 \\
(9.411) \\
\end{array}$ \\
\hline Urbanização & $\begin{array}{l}4.615^{\star \star \star} \\
(1.128)\end{array}$ & $\begin{array}{c}0.362 \\
(0.797)\end{array}$ \\
\hline Jovens & $\begin{array}{l}4.294^{*} \\
(2.336)\end{array}$ & $\begin{array}{c}1.297 \\
(4.215)\end{array}$ \\
\hline População & $\begin{array}{l}-105.674^{* *} \\
(46.735)\end{array}$ & $\begin{array}{l}-23.804 \\
(74.957)\end{array}$ \\
\hline Razão de Mills & $\begin{array}{c}-40.162^{* * *} \\
(8.632) \\
\end{array}$ & $\begin{array}{c}-50.886^{* * *} \\
(9.804) \\
\end{array}$ \\
\hline Constante & $\begin{array}{l}-0.652 \\
(2.440) \\
\end{array}$ & $\begin{array}{l}-0.828 \\
(2.515) \\
\end{array}$ \\
\hline $\mathrm{R}^{2}$ & 0,1266 & 0,0716 \\
\hline Observações & 1170 & 1540 \\
\hline
\end{tabular}

Fonte: construção própria

Em termos da significância estatística dos coeficientes, os resultados da primeira coluna indiciam que municípios com uma maior proporção da receita corrente alocada na despesa de pessoal (coeficiente igual à $-333,37$, estatisticamente significante a 1\%) possuem uma maior dificuldade em gerar superávits fiscais. Adicionalmente, observa-se que a ocorrência do alinhamento partidário entre prefeito e governador, bem como uma menor proporção de idosos, uma maior taxa de urbanização, uma maior proporção de jovens residentes e uma menor população total afetam positivamente a magnitude do superávit primário dos municípios paulistas. De todo modo, o principal resultado é o associado à razão 
de Mills invertida, que assume valor negativo $(-40,16)$ e estatisticamente significante a $1 \%$, sugerindo portanto a presença do viés de seleção caso seja (corretamente) considerada a estrutura de dados em painel da amostra - neste caso, o resultado sugere que os termos de erro da equação de seleção ( $\mathrm{I}^{\mathrm{o}}$ estágio) e da equação de variável contínua (II ${ }^{\circ}$ estágio) são negativamente correlacionados.

No que diz respeito à segunda coluna da tabela 3.6, os resultados evidenciam o fato de que municípios com uma maior proporção da receita corrente alocada nas despesas de pessoal tendem a ter maiores déficits fiscais, resultado já corroborado pela análise da tabela 3.4, sendo observados também coeficientes negativos para o PDS / PPB, PSDB e para o PT. De todo modo, como também ocorre no caso da amostra com observações superavitárias, o coeficiente da razão de Mills invertida apresenta significância estatística a 1\%, sugerindo novamente a existência do problema do viés de seleção nesta parte da amostra - neste caso, observa-se que os termos de erro das equações de seleção e da equação do déficit primário são negativamente correlacionados.

Dados estes resultados, justifica-se o prosseguimento do procedimento de correção conforme descrito no referencial metodológico deste capítulo. 
Tabela 3.7 - Resultados das equações de seleção (1989 a 2001) - I estágio

\begin{tabular}{|c|c|c|c|c|c|c|c|c|c|c|c|c|c|c|}
\hline & \multicolumn{2}{|c|}{1989} & \multicolumn{2}{|c|}{1990} & \multicolumn{2}{|c|}{1991} & \multicolumn{2}{|c|}{1992} & \multicolumn{2}{|c|}{1993} & \multicolumn{2}{|c|}{1994} & \multicolumn{2}{|c|}{1995} \\
\hline & Coef & Prob & Coef & Prob & Coef & Prob & Coef & Prob & Coef & Prob & Coef & Prob & Coef & Prob \\
\hline Pessoal / Receitas & -8.983 & 0.000 & -6.335 & 0.001 & -4.584 & 0.005 & -8.557 & 0.000 & -16.570 & 0.000 & -4.609 & 0.018 & -5.059 & 0.026 \\
\hline Tributária / Receitas & -5.942 & 0.057 & -1.965 & 0.520 & 0.310 & 0.933 & 10.351 & 0.017 & -11.738 & 0.002 & 2.128 & 0.549 & -4.629 & 0.271 \\
\hline PDS / PPB & 0.378 & 0.672 & -1.853 & 0.055 & 0.982 & 0.315 & 0.651 & 0.584 & -1.884 & 0.141 & -0.704 & 0.468 & 0.301 & 0.576 \\
\hline PDT & -2.162 & 0.053 & -2.203 & 0.018 & - & - & -0.963 & 0.448 & - & - & - & - & - & - \\
\hline PL & 0.105 & 0.906 & -0.423 & 0.636 & 1.390 & 0.171 & -0.097 & 0.932 & 0.739 & 0.642 & - & - & -0.474 & 0.561 \\
\hline PSDB & -0.520 & 0.593 & -2.944 & 0.011 & - & - & - & - & -1.581 & 0.199 & -2.048 & 0.032 & -0.253 & 0.647 \\
\hline PFL & -0.404 & 0.616 & -2.465 & 0.009 & 0.404 & 0.646 & -0.401 & 0.702 & 0.804 & 0.520 & 0.005 & 0.996 & -1.363 & 0.015 \\
\hline PTB & -0.355 & 0.685 & -1.882 & 0.017 & 0.652 & 0.491 & 1.761 & 0.067 & -0.452 & 0.727 & 0.139 & 0.878 & 0.027 & 0.966 \\
\hline PT & 0.104 & 0.918 & - & - & 0.279 & 0.805 & - & - & - & - & - & - & - & - \\
\hline OUTROS & - & - & - & - & -0.038 & 0.970 & - & - & -0.509 & 0.676 & -0.598 & 0.479 & -0.532 & 0.345 \\
\hline Frac. Câmara & -2.172 & 0.288 & 1.108 & 0.592 & 4.317 & 0.050 & 2.881 & 0.200 & -2.606 & 0.231 & -1.212 & 0.479 & 1.628 & 0.353 \\
\hline Frac. Executivo & 1.746 & 0.437 & -1.481 & 0.569 & 1.986 & 0.385 & 1.646 & 0.610 & 3.990 & 0.081 & 1.274 & 0.562 & -0.104 & 0.960 \\
\hline Prefeito \& Governador & 0.889 & 0.275 & -1.860 & 0.035 & 1.133 & 0.238 & -0.640 & 0.557 & -0.229 & 0.843 & -0.419 & 0.608 & - & - \\
\hline Idosos & -0.733 & 0.034 & -0.291 & 0.520 & 0.548 & 0.358 & -0.283 & 0.607 & -0.648 & 0.405 & 0.160 & 0.702 & 0.067 & 0.862 \\
\hline Urbanização & 0.112 & 0.001 & 0.012 & 0.690 & 0.139 & 0.021 & 0.092 & 0.177 & -0.033 & 0.560 & 0.032 & 0.672 & -0.003 & 0.967 \\
\hline Jovens & -0.212 & 0.048 & -0.336 & 0.025 & -0.241 & 0.150 & 0.300 & 0.258 & -0.298 & 0.177 & 0.177 & 0.348 & 0.063 & 0.697 \\
\hline População & 1.768 & 0.230 & -3.373 & 0.107 & 1.401 & 0.631 & -1.196 & 0.626 & -2.496 & 0.438 & -1.486 & 0.735 & -0.568 & 0.900 \\
\hline Média Pessoal / Receitas & 5.417 & 0.014 & 4.716 & 0.037 & 6.342 & 0.015 & 11.123 & 0.000 & 13.186 & 0.000 & 3.569 & 0.196 & 4.229 & 0.173 \\
\hline Média Tributária / Receitas & 4.786 & 0.105 & 1.748 & 0.591 & -5.574 & 0.269 & -12.390 & 0.020 & 5.802 & 0.072 & 0.803 & 0.850 & 4.015 & 0.457 \\
\hline Média PDS / PPB & -0.768 & 0.445 & -1.638 & 0.092 & -1.568 & 0.202 & 1.577 & 0.404 & 1.983 & 0.125 & 0.240 & 0.818 & 2.455 & 0.036 \\
\hline Média PDT & 2.183 & 0.142 & -2.476 & 0.028 & 1.608 & 0.401 & 2.412 & 0.257 & 2.919 & 0.062 & 1.370 & 0.293 & 0.925 & 0.491 \\
\hline Média PL & -1.233 & 0.292 & -4.650 & 0.002 & -1.812 & 0.258 & 1.465 & 0.342 & 0.056 & 0.966 & -0.760 & 0.545 & 2.390 & 0.090 \\
\hline Média PSDB & 1.699 & 0.022 & 0.926 & 0.315 & 2.972 & 0.002 & 0.682 & 0.589 & -0.117 & 0.912 & 1.604 & 0.061 & -0.524 & 0.632 \\
\hline Média PFL & -0.104 & 0.898 & -1.417 & 0.138 & -0.655 & 0.480 & 2.026 & 0.115 & -0.142 & 0.903 & -0.783 & 0.388 & 2.618 & 0.012 \\
\hline Média PTB & -0.069 & 0.953 & -2.373 & 0.034 & -0.659 & 0.564 & -3.300 & 0.078 & 0.201 & 0.856 & -1.313 & 0.163 & 1.232 & 0.305 \\
\hline Média PT & 0.317 & 0.832 & -3.443 & 0.009 & -0.759 & 0.641 & -0.368 & 0.854 & -1.631 & 0.338 & - & - & 3.022 & 0.033 \\
\hline Média OUTROS & -1.136 & 0.188 & -0.564 & 0.512 & -0.279 & 0.778 & 0.439 & 0.748 & -1.281 & 0.313 & -1.240 & 0.338 & 1.596 & 0.305 \\
\hline Média Frac. Câmara & 4.217 & 0.122 & -3.197 & 0.226 & -1.145 & 0.675 & -3.619 & 0.253 & 3.437 & 0.288 & -0.098 & 0.974 & -3.496 & 0.258 \\
\hline Média Frac. Executivo & -2.154 & 0.404 & 3.759 & 0.244 & -5.027 & 0.087 & 1.033 & 0.723 & -8.308 & 0.015 & 0.565 & 0.860 & -3.638 & 0.235 \\
\hline Média Prefeito \& Governador & -1.918 & 0.047 & -3.040 & 0.004 & -1.360 & 0.190 & 1.025 & 0.561 & 1.017 & 0.378 & -0.445 & 0.636 & 2.256 & 0.049 \\
\hline Média Idosos & 0.597 & 0.080 & 0.141 & 0.762 & -0.775 & 0.209 & 0.668 & 0.236 & 0.535 & 0.498 & -0.054 & 0.897 & -0.290 & 0.482 \\
\hline Média Urbanização & -0.137 & 0.000 & -0.013 & 0.691 & -0.149 & 0.016 & -0.090 & 0.163 & 0.008 & 0.896 & -0.012 & 0.870 & 0.010 & 0.879 \\
\hline Média Jovens & 0.228 & 0.042 & 0.314 & 0.050 & 0.174 & 0.329 & -0.007 & 0.979 & 0.216 & 0.358 & -0.041 & 0.833 & -0.143 & 0.393 \\
\hline Média População & -1.745 & 0.249 & 3.030 & 0.150 & -1.308 & 0.657 & 1.703 & 0.486 & 2.728 & 0.404 & 0.992 & 0.822 & 0.662 & 0.884 \\
\hline Constante & 3.564 & 0.324 & 8.939 & 0.029 & 2.483 & 0.518 & -21.103 & 0.002 & 7.144 & 0.061 & -1.625 & 0.626 & 3.805 & 0.267 \\
\hline
\end{tabular}

Fonte: construção própria 
Tabela 3.7 - Resultados das equações de seleção (1989 a 2001) - Io estágio - continuação

\begin{tabular}{|c|c|c|c|c|c|c|c|c|c|c|c|c|}
\hline & \multicolumn{2}{|c|}{1996} & \multicolumn{2}{|c|}{1997} & \multicolumn{2}{|c|}{1998} & \multicolumn{2}{|c|}{1999} & \multicolumn{2}{|c|}{2000} & \multicolumn{2}{|c|}{2001} \\
\hline & Coef & Prob & Coef & Prob & Coef & Prob & Coef & Prob & Coef & Prob & Coef & Prob \\
\hline Pessoal / Receitas & -5.481 & 0.007 & -10.300 & 0.000 & -6.389 & 0.000 & -8.276 & 0.001 & -4.236 & 0.009 & -5.580 & 0.015 \\
\hline Tributária / Receitas & -4.824 & 0.163 & 6.939 & 0.070 & -4.718 & 0.146 & 6.728 & 0.059 & 3.311 & 0.391 & -1.049 & 0.865 \\
\hline PDS / PPB & 0.048 & 0.924 & 0.380 & 0.464 & -0.970 & 0.064 & 0.456 & 0.423 & -0.385 & 0.525 & - & - \\
\hline PDT & - & - & 0.337 & 0.672 & -0.140 & 0.845 & -0.346 & 0.633 & -2.484 & 0.017 & -1.786 & 0.009 \\
\hline PL & 0.425 & 0.601 & 2.186 & 0.002 & 0.292 & 0.697 & -0.135 & 0.861 & -1.680 & 0.033 & - & - \\
\hline PSDB & 0.091 & 0.839 & 1.155 & 0.015 & -0.209 & 0.659 & 0.221 & 0.672 & -0.807 & 0.195 & 0.083 & 0.871 \\
\hline PFL & -0.193 & 0.652 & 0.847 & 0.096 & 0.029 & 0.955 & 0.760 & 0.165 & 0.052 & 0.938 & -1.440 & 0.032 \\
\hline PTB & 0.507 & 0.390 & 0.669 & 0.265 & 0.100 & 0.866 & 0.182 & 0.777 & 0.060 & 0.936 & - & - \\
\hline PT & -0.473 & 0.589 & 0.803 & 0.304 & 0.922 & 0.295 & -0.001 & 0.999 & -0.098 & 0.905 & -1.830 & 0.031 \\
\hline OUTROS & -0.470 & 0.342 & 0.510 & 0.341 & 0.210 & 0.693 & 0.351 & 0.544 & 0.764 & 0.301 & -1.399 & 0.036 \\
\hline Frac. Câmara & -1.900 & 0.328 & 0.761 & 0.650 & -2.367 & 0.160 & -0.675 & 0.706 & -0.648 & 0.723 & -3.867 & 0.313 \\
\hline Frac. Executivo & 1.465 & 0.517 & -3.352 & 0.083 & -0.414 & 0.819 & -0.049 & 0.980 & -3.738 & 0.105 & 4.071 & 0.170 \\
\hline Prefeito \& Governador & - & - & - & - & - & - & - & - & - & - & - & - \\
\hline Idosos & 0.458 & 0.117 & -0.303 & 0.503 & 0.086 & 0.868 & -0.399 & 0.235 & -0.257 & 0.338 & 0.704 & 0.048 \\
\hline Urbanização & -0.002 & 0.968 & -0.008 & 0.874 & -0.010 & 0.830 & -0.051 & 0.169 & 0.020 & 0.665 & -0.134 & 0.054 \\
\hline Jovens & 0.325 & 0.027 & -0.035 & 0.835 & -0.024 & 0.867 & -0.450 & 0.000 & 0.002 & 0.986 & -0.073 & 0.616 \\
\hline População & 2.401 & 0.195 & -1.627 & 0.539 & -2.228 & 0.338 & 0.183 & 0.913 & 0.263 & 0.842 & 0.546 & 0.858 \\
\hline Média Pessoal / Receitas & 5.240 & 0.039 & 6.524 & 0.002 & 2.162 & 0.229 & 3.410 & 0.098 & -0.909 & 0.645 & -1.151 & 0.623 \\
\hline Média Tributária / Receitas & 7.024 & 0.110 & -6.892 & 0.114 & 4.279 & 0.252 & -10.711 & 0.005 & -2.237 & 0.585 & 13.586 & 0.123 \\
\hline Média PDS / PPB & -0.277 & 0.761 & -0.263 & 0.743 & 0.500 & 0.564 & -0.587 & 0.525 & 0.614 & 0.532 & - & - \\
\hline Média PDT & -2.144 & 0.094 & -1.098 & 0.525 & -0.331 & 0.831 & 1.025 & 0.468 & 6.926 & 0.004 & 1.425 & 0.492 \\
\hline Média PL & -1.120 & 0.388 & -2.042 & 0.070 & 0.167 & 0.883 & -0.073 & 0.948 & 0.866 & 0.461 & -2.884 & 0.067 \\
\hline Média PSDB & 0.908 & 0.369 & -0.845 & 0.226 & 0.199 & 0.793 & 0.670 & 0.424 & 0.427 & 0.626 & -0.467 & 0.672 \\
\hline Média PFL & 0.721 & 0.385 & -1.198 & 0.166 & -0.323 & 0.709 & -1.054 & 0.248 & 0.679 & 0.501 & 4.675 & 0.004 \\
\hline Média PTB & -0.610 & 0.502 & -2.148 & 0.015 & -0.511 & 0.581 & -0.009 & 0.993 & 0.738 & 0.499 & 3.807 & 0.031 \\
\hline Média PT & 2.313 & 0.070 & -0.899 & 0.451 & -1.623 & 0.245 & 0.234 & 0.881 & 1.328 & 0.335 & 1.359 & 0.455 \\
\hline Média OUTROS & 0.596 & 0.512 & -0.863 & 0.321 & 0.604 & 0.486 & -1.289 & 0.178 & 1.460 & 0.178 & 1.325 & 0.321 \\
\hline Média Frac. Câmara & 1.319 & 0.677 & 0.918 & 0.600 & 0.671 & 0.733 & 2.168 & 0.241 & 0.123 & 0.952 & 3.544 & 0.230 \\
\hline Média Frac. Executivo & -0.936 & 0.764 & 5.529 & 0.039 & -1.726 & 0.483 & -1.770 & 0.489 & 3.197 & 0.307 & 8.547 & 0.015 \\
\hline Média Prefeito \& Governador & -0.982 & 0.349 & -1.678 & 0.073 & -1.151 & 0.235 & -0.787 & 0.479 & 1.609 & 0.123 & -0.153 & 0.906 \\
\hline Média Idosos & -0.291 & 0.371 & 0.323 & 0.500 & -0.104 & 0.844 & 0.342 & 0.315 & 0.208 & 0.489 & -0.967 & 0.019 \\
\hline Média Urbanização & -0.016 & 0.755 & -0.001 & 0.985 & 0.007 & 0.885 & 0.057 & 0.134 & -0.045 & 0.330 & 0.114 & 0.087 \\
\hline Média Jovens & -0.287 & 0.069 & -0.016 & 0.921 & 0.015 & 0.915 & 0.424 & 0.001 & -0.132 & 0.314 & -0.002 & 0.992 \\
\hline Média População & -2.469 & 0.180 & 1.439 & 0.585 & 2.362 & 0.306 & -0.315 & 0.852 & -0.188 & 0.886 & -1.665 & 0.579 \\
\hline Constante & -0.775 & 0.804 & 3.818 & 0.184 & 4.611 & 0.090 & 4.617 & 0.094 & 8.183 & 0.010 & 12.610 & 0.025 \\
\hline
\end{tabular}

Fonte: construção própria 
Tabela 3.8 - Resultado da equação do superávit primário - II estágio

\begin{tabular}{|c|c|c|c|c|c|c|c|}
\hline & coeficiente & $\begin{array}{c}\text { Desvio-padrão } \\
\text { corrigido }\end{array}$ & $t$ & prob & $\begin{array}{l}\text { Desvio-padrão } \\
\text { sem correção }\end{array}$ & $t$ & prob \\
\hline Pessoal / Receitas & -442.460 & 100.800 & -4.389 & 0.000 & 58.324 & -7.590 & 0.000 \\
\hline Tributária / Receitas & 45.403 & 345.780 & 0.131 & 0.896 & 94.067 & 0.480 & 0.629 \\
\hline PDS / PPB & -7.639 & 20.093 & -0.380 & 0.704 & 19.265 & -0.400 & 0.692 \\
\hline PDT & -10.324 & 13.321 & -0.775 & 0.439 & 24.389 & -0.420 & 0.672 \\
\hline PL & -16.754 & 15.124 & -1.108 & 0.268 & 23.350 & -0.720 & 0.473 \\
\hline PSDB & -20.321 & 20.928 & -0.971 & 0.332 & 16.860 & -1.210 & 0.228 \\
\hline PFL & -7.381 & 13.507 & -0.546 & 0.585 & 15.588 & -0.470 & 0.636 \\
\hline PTB & -14.957 & 12.372 & -1.209 & 0.227 & 20.259 & -0.740 & 0.461 \\
\hline PT & -44.188 & 16.589 & -2.664 & 0.008 & 27.296 & -1.620 & 0.106 \\
\hline OUTROS & -4.925 & 16.081 & -0.306 & 0.759 & 18.104 & -0.270 & 0.786 \\
\hline Frac. Câmara & 27.734 & 33.782 & 0.821 & 0.412 & 50.821 & 0.550 & 0.585 \\
\hline Frac. Executivo & -6.916 & 55.232 & -0.125 & 0.900 & 61.613 & -0.110 & 0.911 \\
\hline Prefeito \& Governador & 10.357 & 20.415 & 0.507 & 0.612 & 16.318 & 0.630 & 0.526 \\
\hline Idosos & -6.881 & 81.297 & -0.085 & 0.933 & 9.332 & -0.740 & 0.461 \\
\hline Urbanização & 3.070 & 12.224 & 0.251 & 0.802 & 1.373 & 2.240 & 0.026 \\
\hline Jovens & 2.885 & 33.521 & 0.086 & 0.931 & 3.119 & 0.930 & 0.355 \\
\hline População & -54.076 & 59.667 & -0.906 & 0.365 & 50.247 & -1.080 & 0.282 \\
\hline Média Pessoal / Receitas & 258.410 & 73.928 & 3.495 & 0.000 & 67.416 & 3.830 & 0.000 \\
\hline Média Tributária / Receitas & 165.200 & 246.190 & 0.671 & 0.502 & 106.180 & 1.560 & 0.120 \\
\hline Média PDS / PPB & 60.032 & 26.662 & 2.252 & 0.025 & 29.824 & 2.010 & 0.044 \\
\hline Média PDT & 48.017 & 32.865 & 1.461 & 0.144 & 43.436 & 1.110 & 0.269 \\
\hline Média PL & 25.148 & 30.328 & 0.829 & 0.407 & 36.377 & 0.690 & 0.490 \\
\hline Média PSDB & 14.791 & 30.253 & 0.489 & 0.625 & 24.691 & 0.600 & 0.549 \\
\hline Média PFL & 44.332 & 27.019 & 1.641 & 0.101 & 24.859 & 1.780 & 0.075 \\
\hline Média PTB & 7.436 & 21.573 & 0.345 & 0.730 & 29.829 & 0.250 & 0.803 \\
\hline Média PT & 102.700 & 33.894 & 3.030 & 0.003 & 43.927 & 2.340 & 0.020 \\
\hline Média OUTROS & 8.629 & 22.094 & 0.391 & 0.696 & 28.319 & 0.300 & 0.761 \\
\hline Média Frac. Câmara & -99.142 & 74.691 & -1.327 & 0.185 & 68.473 & -1.450 & 0.148 \\
\hline Média Frac. Executivo & -43.977 & 61.660 & -0.713 & 0.476 & 82.216 & -0.530 & 0.593 \\
\hline Média Prefeito \& Governador & 17.676 & 26.808 & 0.659 & 0.510 & 27.823 & 0.640 & 0.525 \\
\hline Média Idosos & -10.135 & 83.235 & -0.122 & 0.903 & 10.257 & -0.990 & 0.323 \\
\hline Média Urbanização & -2.750 & 1.182 & -2.327 & 0.020 & 1.414 & -1.940 & 0.052 \\
\hline Média Jovens & -7.734 & 43.348 & -0.178 & 0.858 & 3.555 & -2.180 & 0.030 \\
\hline Média População & 31.857 & 57.266 & 0.556 & 0.578 & 50.464 & 0.630 & 0.528 \\
\hline Mills 1989 & -14.937 & 19.954 & -0.749 & 0.454 & 22.063 & -0.680 & 0.499 \\
\hline Mills 1990 & -29.842 & 16.131 & -1.850 & 0.065 & 16.624 & -1.800 & 0.073 \\
\hline Mills 1991 & -23.980 & 19.757 & -1.214 & 0.225 & 16.822 & -1.430 & 0.154 \\
\hline Mills 1992 & -15.443 & 16.463 & -0.938 & 0.348 & 21.656 & -0.710 & 0.476 \\
\hline Mills 1993 & -0.297 & 13.094 & -0.023 & 0.982 & 20.754 & -0.010 & 0.989 \\
\hline Mills 1994 & -48.108 & 14.041 & -3.426 & 0.001 & 15.864 & -3.030 & 0.002 \\
\hline Mills 1995 & -44.346 & 13.692 & -3.239 & 0.001 & 15.612 & -2.840 & 0.005 \\
\hline Mills 1996 & -19.274 & 11.140 & -1.730 & 0.084 & 15.219 & -1.270 & 0.206 \\
\hline Mills 1997 & 6.977 & 15.730 & 0.444 & 0.657 & 18.163 & 0.380 & 0.701 \\
\hline Mills 1998 & -11.778 & 12.041 & -0.978 & 0.328 & 17.348 & -0.680 & 0.497 \\
\hline Mills 1999 & -17.828 & 18.486 & -0.964 & 0.335 & 21.027 & -0.850 & 0.397 \\
\hline Mills 2000 & 37.404 & 22.109 & 1.692 & 0.091 & 25.198 & 1.480 & 0.138 \\
\hline Mills 2001 & -1.730 & 23.863 & -0.072 & 0.942 & 40.339 & -0.040 & 0.966 \\
\hline Constante & 635.540 & 143.540 & 4.428 & 0.000 & 98.446 & 6.460 & 0.000 \\
\hline $\mathbf{R}^{2}$ & \multicolumn{7}{|c|}{0,1119} \\
\hline Observações & \multicolumn{7}{|c|}{1170} \\
\hline
\end{tabular}

Fonte: construção própria 
A tabela 3.7 apresenta os resultados das treze equações de seleção (probits - ressalta-se que a variável dependente assume o valor 1 no caso do resultado primário positivo e assume 0 no caso do resultado primário negativo), regredidas no primeiro estágio do procedimento de correção do viés de seleção em painel com base no procedimento de Mundlak (1978), o que justifica a presença dos coeficientes associados às variáveis transformadas em média temporal para cada unidade seccional presente na amostra. São apresentados apenas os valores dos coeficientes e as suas respectivas significâncias estatísticas, sendo os resultados completos apresentados no apêndice 3.4 desta tese. Além da retirada da dummy associada ao PMDB para evitar o problema de multicolinearidade perfeita entre as dummies de partido, observa-se que em algumas estimações dummies adicionais também são retiradas, como no caso da dummy associada à similaridade entre partido do prefeito e do governador entre os anos de 1995 a 2001, uma vez que esta acaba assumindo exatamente o mesmo valor da dummy associada ao PSDB, partido que esteve no comando do governo paulista entre 1995 e 2001. Em outros casos, a variável dependente não sofre variação para alguns partidos como ocorre em 1990 com o PDT, por exemplo, em que todos os municípios sob sua administração obtêm resultados primários negativos.

É interessante notar que em todas as estimações, o coeficiente associado à razão despesa de pessoal sobre receitas correntes assume valor negativo e estatisticamente negativo, o que realmente indica que municípios com maiores proporções da receita alocada nesta categoria da despesa municipal realmente apresentam dificuldades contundentes em obter um resultado primário superavitário. Os demais coeficientes apresentam significância estatística variando de estimação a estimação, ou seja, não há uma significância sistemática para os mesmos.

Por sua vez, a tabela 3.8 apresenta os resultados do segundo estágio do procedimento de Wooldridge (1995), já sendo apresentados, para efeito de comparação, tanto os desviospadrão sem correção bem como os desvios-padrão já corrigidos de acordo com a metodologia descrita. Os resultados sugerem a persistência de um resultado obtido em todos os testes apresentados até o momento, qual seja, a influência negativa e estatisticamente significante da relação despesa de pessoal sobre receitas correntes. Assim sendo, a robustez de tal fenômeno sugere que prefeituras que comprometem parcelas mais significativas de sua receita corrente com esta categoria de despesa pública são efetivamente as que possuem maiores dificuldades em realizar ajustes fiscais. Este pode ser considerado um resultado intuitivo, uma vez que realizar contenções fiscais em tal categoria é algo normalmente restrito não só devido a questões inerentes à legislação trabalhista, mas também devido à impopularidade política a ser 
associada à administração municipal. Finalmente, diferentemente dos demais testes, somente o PT se diferencia em relação ao partido de referência PMDB, ao apresentar coeficiente estatisticamente significante a $1 \%$ e igual à $-44,18$.

Gráfico 3.2 - Dummies de partido - superávit fiscal

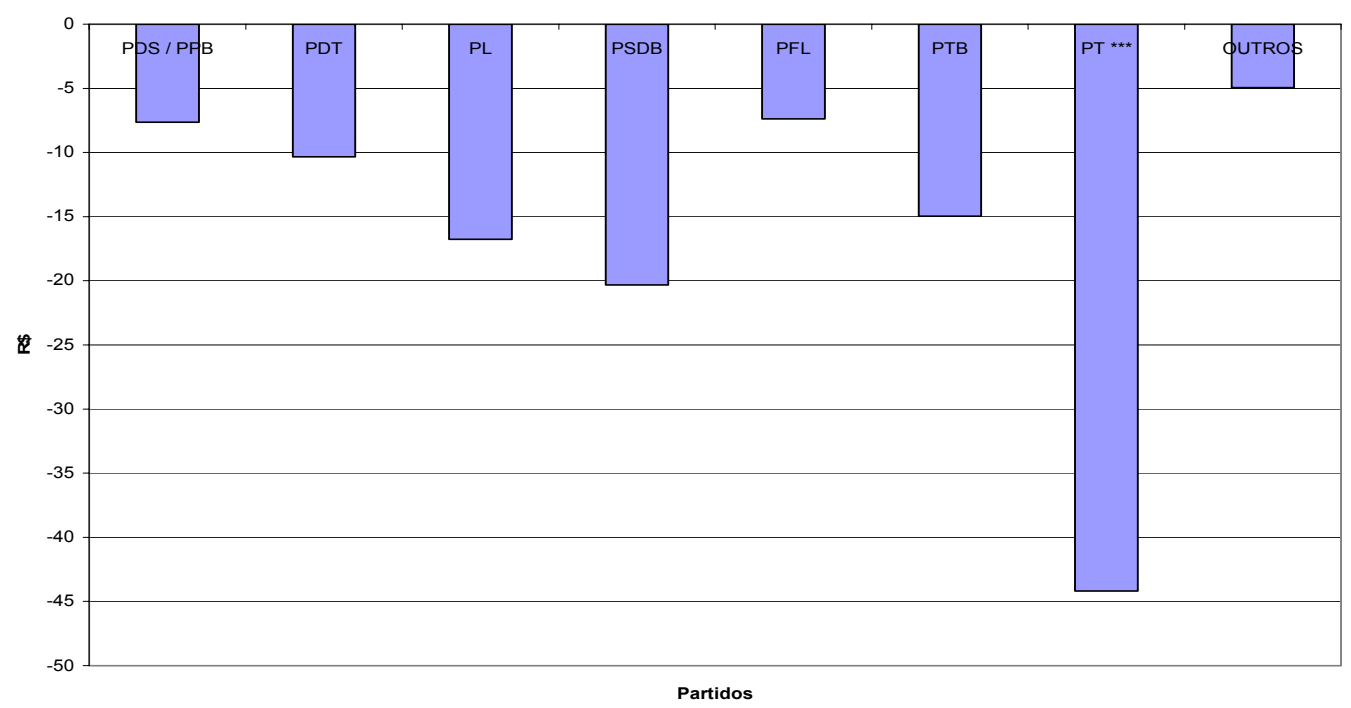

Fonte: construção própria

Gráfico 3.3 - Razões de Mills invertidas - superávit fiscal

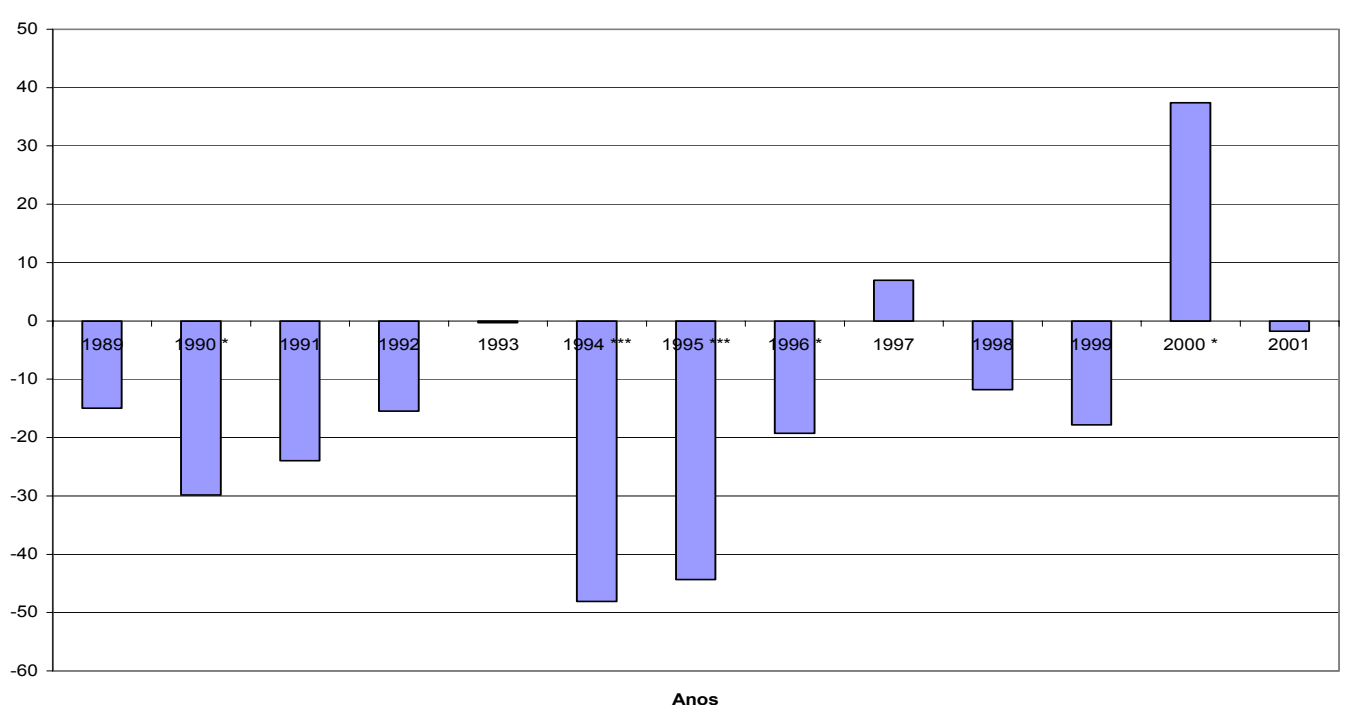

Fonte: construção própria

Por fim, resultados interessantes ficam por conta das razões de Mills invertidas decompostas ano a ano, conforme ilustradas no gráfico 3.3: considerando $10 \%$ como 
significância estatística limítrofe, é possível notar que em 1990, 1994, 1995 e 1996 os coeficientes assumem valores negativos, sugerindo a ocorrência de déficits fiscais nos mesmos, ao passo que em 2000 o coeficiente assume valor positivo. Este último resultado é particularmente interessante uma vez que, conforme já discutido anteriormente, 2000 não é somente o ano em que a Lei de Responsabilidade Fiscal entra em vigor, mas também o primeiro ano (dentro do período amostral) em que um prefeito (eleito em 1996) poderia concorrer à reeleição. Estes dois fatores podem, em alguma medida, influenciar a conduta das administrações municipais especificamente no que diz respeito ao comportamento do orçamento público, conduzindo a uma maior conservadorismo fiscal conforme sugerido pelos resultados.

A tabela 3.9 em seqüência apresenta os resultados associados à regressão do segundo estágio do procedimento de Wooldridge (1995) para as observações com resultado primário negativo, sendo novamente apresentados, para comparação, os desvios-padrão corrigidos e os desvios-padrão sem correção. Novamente, conforme já observado em todos os testes preliminares deste capitulo, uma maior proporção da receita corrente alocada nas despesas de pessoal elevam o montante do déficit fiscal dos municípios paulistas. Por sua vez, quanto aos partidos políticos, observam-se coeficientes estatisticamente significantes somente para o PT, indicando que prefeituras sob sua gestão apresentariam menores déficits fiscais relativamente ao PMDB. Assim, considerando o resultado obtido para este partido no caso dos municípios superavitários, observa-se que as prefeituras paulistas sob sua gestão convergem para um equilíbrio fiscal, ou seja, um superávit menor, mas um déficit também menor.

Dois coeficientes adicionais também apresentam significância estatística na regressão das unidades em déficit primário: primeiro, uma maior proporção de idosos residindo nos municípios paulistas tende a acarretar um menor déficit municipal; segundo, conforme sugerido por Tabellini \& Alesina (1990), uma maior divergência de preferências para o Executivo, mensurada pela dispersão dos votos dos candidatos à prefeitura dos municípios paulistas, tende a gerar maiores déficits fiscais.

No que diz respeito às razões de Mills invertidas, os coeficientes associados aos anos de 1989, 1990, 1993, 1997, 1998, 1999 e 2000 são estatisticamente significantes e negativos (sugerindo assim que os termos de erro da equação de seleção e da equação do déficit primário são negativamente correlacionados). Por outro lado, para o ano de 1996, o coeficiente é também estatisticamente significante, mas positivo. Assim, considerando os anos em que a razão de Mills apresenta significância estatística nas duas amostras, é possível observar que em 1990 a razão de Mills invertida influencia os resultados fiscais de modo a 
diminuir o montante do superávit, mas também de modo a diminuir o tamanho do déficit. Em 1996, justamente o anterior à instituição da lei complementar $n^{\circ} 089 / 97$, observa-se que a referida variável tende a gerar tanto um menor superávit como um maior déficit primário. Finalmente, em 2000, ano de eventos políticos relevantes e já previamente discutidos, a razão de Mills invertida parece atuar de tal forma a elevar o conservadorismo fiscal, ao minimizar o tamanho do déficit e ao elevar o montante do superávit fiscal. 
Tabela 3.9 - Resultado da equação do déficit primário - II estágio

\begin{tabular}{|c|c|c|c|c|c|c|c|}
\hline & coeficiente & $\begin{array}{c}\text { Desvio-padrão } \\
\text { corrigido }\end{array}$ & $t$ & prob & $\begin{array}{l}\text { Desvio-padrão } \\
\text { sem correção }\end{array}$ & $t$ & prob \\
\hline Pessoal / Receitas & 153.011 & 70.095 & -2.183 & 0.029 & 52.051 & -2.940 & 0.003 \\
\hline Tributária / Receitas & -35.521 & 98.598 & 0.360 & 0.719 & 106.113 & 0.335 & 0.738 \\
\hline PDS / PPB & -33.209 & 23.939 & 1.387 & 0.166 & 20.644 & 1.609 & 0.108 \\
\hline PDT & 8.255 & 16.084 & -0.513 & 0.608 & 26.957 & -0.306 & 0.759 \\
\hline PL & -28.833 & 18.727 & 1.540 & 0.124 & 23.453 & 1.229 & 0.219 \\
\hline PSDB & -12.085 & 13.507 & 0.895 & 0.371 & 17.848 & 0.677 & 0.498 \\
\hline PFL & 18.071 & 11.856 & -1.524 & 0.128 & 17.489 & -1.033 & 0.302 \\
\hline PTB & -0.971 & 14.462 & 0.067 & 0.946 & 19.433 & 0.050 & 0.960 \\
\hline PT & -37.411 & 19.325 & 1.936 & 0.053 & 32.529 & 1.150 & 0.250 \\
\hline OUTROS & 4.514 & 16.389 & -0.275 & 0.783 & 18.694 & -0.241 & 0.809 \\
\hline Frac. Câmara & -39.239 & 53.625 & 0.732 & 0.464 & 59.216 & 0.663 & 0.508 \\
\hline Frac. Executivo & 108.645 & 62.800 & -1.730 & 0.084 & 67.330 & -1.614 & 0.107 \\
\hline Prefeito \& Governador & 15.871 & 11.096 & -1.430 & 0.153 & 14.436 & -1.099 & 0.272 \\
\hline Idosos & -32.276 & 12.443 & 2.594 & 0.010 & 13.219 & 2.442 & 0.015 \\
\hline Urbanização & -0.251 & 1.040 & 0.241 & 0.809 & 1.352 & 0.185 & 0.853 \\
\hline Jovens & -0.380 & 3.388 & 0.112 & 0.911 & 4.153 & 0.091 & 0.927 \\
\hline População & -80.015 & 79.702 & 1.004 & 0.316 & 64.685 & 1.237 & 0.216 \\
\hline Média Pessoal / Receitas & -44.481 & 94.723 & 0.470 & 0.639 & 72.523 & 0.613 & 0.540 \\
\hline Média Tributária / Receitas & 114.010 & 134.940 & -0.845 & 0.398 & 122.192 & -0.933 & 0.351 \\
\hline Média PDS / PPB & 12.479 & 77.326 & -0.161 & 0.872 & 33.506 & -0.372 & 0.710 \\
\hline Média PDT & -59.078 & 75.271 & 0.785 & 0.433 & 43.907 & 1.346 & 0.179 \\
\hline Média PL & 50.809 & 66.209 & -0.767 & 0.443 & 40.115 & -1.267 & 0.206 \\
\hline Média PSDB & -66.559 & 34.855 & 1.910 & 0.056 & 28.455 & 2.339 & 0.019 \\
\hline Média PFL & -65.088 & 59.148 & 1.100 & 0.271 & 29.283 & 2.223 & 0.026 \\
\hline Média PTB & -16.104 & 67.015 & 0.240 & 0.810 & 32.551 & 0.495 & 0.621 \\
\hline Média PT & -72.927 & 77.783 & 0.938 & 0.349 & 48.448 & 1.505 & 0.132 \\
\hline Média OUTROS & -19.989 & 36.976 & 0.541 & 0.589 & 31.720 & 0.630 & 0.529 \\
\hline Média Frac. Câmara & 140.525 & 100.580 & -1.397 & 0.163 & 85.808 & -1.638 & 0.102 \\
\hline Média Frac. Executivo & -191.166 & 137.290 & 1.392 & 0.164 & 91.084 & 2.099 & 0.036 \\
\hline Média Prefeito \& Governador & 2.265 & 57.784 & -0.039 & 0.969 & 31.062 & -0.073 & 0.942 \\
\hline Média Idosos & -8.502 & 15.265 & 0.557 & 0.578 & 13.829 & 0.615 & 0.539 \\
\hline Média Urbanização & 0.525 & 1.116 & -0.470 & 0.638 & 1.415 & -0.371 & 0.711 \\
\hline Média Jovens & -13.080 & 4.893 & 2.673 & 0.008 & 4.537 & 2.883 & 0.004 \\
\hline Média População & 63.322 & 81.021 & -0.782 & 0.435 & 64.931 & -0.975 & 0.330 \\
\hline Mills 1989 & -59.008 & 15.645 & 3.772 & 0.000 & 21.933 & 2.690 & 0.007 \\
\hline Mills 1990 & -41.970 & 21.421 & 1.959 & 0.050 & 31.411 & 1.336 & 0.182 \\
\hline Mills 1991 & -29.630 & 26.428 & 1.121 & 0.262 & 33.714 & 0.879 & 0.380 \\
\hline Mills 1992 & 52.872 & 46.390 & -1.140 & 0.255 & 50.404 & -1.049 & 0.294 \\
\hline Mills 1993 & -71.627 & 20.334 & 3.523 & 0.000 & 25.200 & 2.842 & 0.005 \\
\hline Mills 1994 & -14.967 & 20.823 & 0.719 & 0.472 & 29.042 & 0.515 & 0.606 \\
\hline Mills 1995 & 32.056 & 34.302 & -0.935 & 0.350 & 36.184 & -0.886 & 0.376 \\
\hline Mills 1996 & 56.238 & 30.596 & -1.838 & 0.066 & 33.441 & -1.682 & 0.093 \\
\hline Mills 1997 & -33.998 & 11.778 & 2.887 & 0.004 & 20.706 & 1.642 & 0.101 \\
\hline Mills 1998 & -53.177 & 11.177 & 4.758 & 0.000 & 20.099 & 2.646 & 0.008 \\
\hline Mills 1999 & -43.148 & 11.782 & 3.662 & 0.000 & 18.784 & 2.297 & 0.022 \\
\hline Mills 2000 & -47.416 & 12.026 & 3.943 & 0.000 & 20.576 & 2.304 & 0.021 \\
\hline Mills 2001 & -23.205 & 28.231 & 0.822 & 0.411 & 31.884 & 0.728 & 0.467 \\
\hline Constante & 839.823 & 219.630 & -3.824 & 0.000 & 113.911 & -7.373 & 0.000 \\
\hline $\mathbf{R}^{2}$ & \multicolumn{7}{|c|}{0,1040} \\
\hline Observações & \multicolumn{7}{|c|}{1540} \\
\hline
\end{tabular}

Fonte: construção própria 
Gráfico 3.4 - Dummies de partido - déficit fiscal

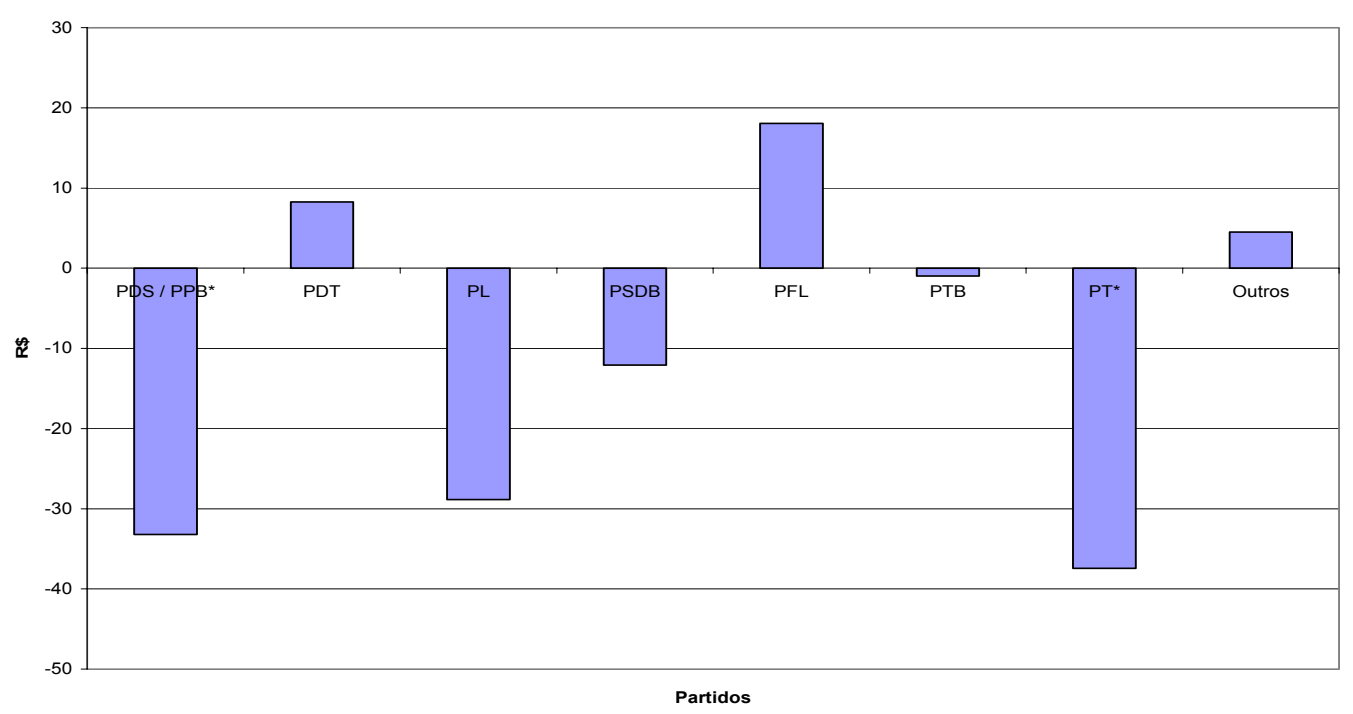

Fonte: construção própria

Gráfico 3.5 - Razões de Mills invertidas - déficit fiscal

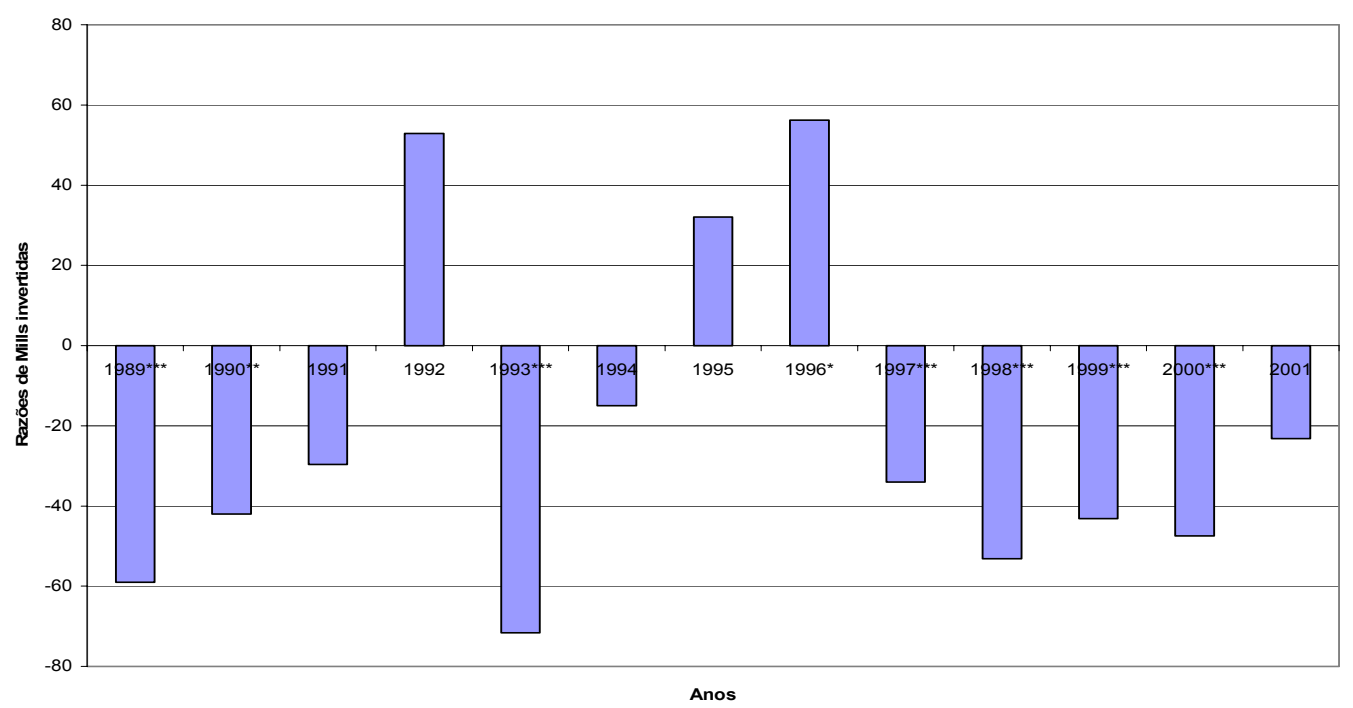

Fonte: construção própria

\section{6 - Considerações finais do terceiro capítulo}

O terceiro capítulo desta tese que aqui se finaliza teve como propósito fundamental testar a presença do viés de seleção na análise do déficit e do ajuste fiscal dos municípios paulistas durante os anos de 1989 a 2001. Em suma, a percepção motivadora desta discussão reside na possibilidade de que fatores não observáveis podem influenciar a decisão de um município ou, mais especificamente, dos gestores de um dado município, em realizar 
administrações fiscais conservadoras na busca de um resultado orçamentário que controle a possibilidade de aumento do endividamento municipal. Para tal, a estratégia de análise considera um referencial metodológico ainda não aplicado pela literatura para a análise de fenômenos presentes na economia brasileira.

Os resultados sugerem que de fato, elementos a princípio não perceptíveis ou ao menos não mensuráveis tendem a gerar algum tipo de influência sobre a decisão das administrações municipais paulistas em realizar ou não programas de contenção fiscal, ou seja, anteriormente à decisão da magnitude do ajuste a ser realizado, existe uma decisão preliminar a respeito da obtenção do mesmo ou não. Por sua vez, estes mesmos elementos não observáveis também tendem a influenciar a decisão das prefeituras paulistas em obter um resultado primário negativo anteriormente à decisão do montante do déficit a ser incorrido. De todo modo, observa-se que as variáveis explicativas aqui consideradas tendem a influenciar de forma mais significativa a decisão de obter resultados primários positivos, tendo menor influência sobre o volume do superávit obtido - em especial, observa-se que municípios com um orçamento mais comprometido com despesas de custeio (de pessoal, especificamente) tendem a ter dificuldades expressivas para realizar tais ajustes. Tal resultado parece sugerir que a predisposição de se realizar uma gestão orçamentária mais conservadora não é suficiente para garantir resultados fiscais positivos, envolvendo ainda a necessidade de restringir ou até mesmo diminuir execuções fiscais justamente em uma das categorias de despesa pública de mais difícil alteração, seja por restrições de natureza institucional / legal, seja por razões políticas. Em outras palavras, além de ser legalmente restrita a possibilidade de reduzir salários ou mesmo diminuir o número de servidores públicos, existe um custo político não desprezível em realizar tais contenções principalmente em municípios, em que a proximidade do cidadão e do administrador público tende a ser maior.

Um outro resultado interessante vem a ser, de forma relativamente semelhante ao primeiro capítulo, a não significância do coeficiente associado ao alinhamento partidário entre os prefeitos e o governador do estado de São Paulo. Assim, todas estas evidências sugerem que tal um eventual conservadorismo fiscal do governo estadual parece não ser transmitido às gestões municipais. Os demais fatores de natureza política aqui considerados, quais sejam, os partidos políticos e a fracionalização das preferências dos eleitores e do poder Legislativo municipal também tendem a ter influência nula sobre o superávit fiscal dos municípios paulistas durante o período avaliado - a exceção reside no caso do PT, partido ao qual estão associados menores superávits primários. Por sua vez, na amostra com observações 
deficitária, tais fatores políticos passam a gerar alguma influência, conforme discutido anteriormente.

Por fim, observa-se também que institucionalização de um critério formal de classificação da dívida dos entes da federação brasileira - mais especificamente estados e municípios - pode representar um efetivo controle sobre a possibilidade de ocorrência de resultados orçamentários deficitários em tais unidades, ressaltando a relevância da portaria $\mathrm{n}^{\mathrm{o}}$ 089/97 do Ministério da Fazenda. 


\section{Considerações finais da tese}

A tese que aqui se finaliza teve como propósito fundamental analisar o comportamento fiscal dos municípios brasileiros e sua relação com fatores de natureza política, considerando tanto a possibilidade de que o primeiro seja influenciado pelo segundo (primeiro e terceiro capítulo, quais sejam, a análise dos ciclos eleitorais e partidários e a análise dos superávits e déficits fiscais) como a possibilidade de que o primeiro influencie o segundo (segundo capítulo, que analisa a questão da reeleição nos municípios brasileiros). Entende-se que as principais contribuições desta tese residem justamente na tentativa de se investigar entes da federação ainda pouco abordados pela literatura a partir de um ponto de vista teórico positivo, ou seja, que procure considerar fatores que efetivamente influenciam o comportamento fiscal dos municípios brasileiros e que não tenham conotação exclusivamente associada à teoria econômica tradicional. Em termos mais específicos quanto à metodologia implementada, uma segunda contribuição deste trabalho pode ser vista no procedimento econométrico implementado e na base de dados disponível, qual seja, uma amostra de dados em painel, fato que permite realizar uma avaliação mais profunda do problema em xeque.

De modo simplificado, os resultados parecem sugerir a presença de ciclos eleitorais nos municípios brasileiros, mas de modo relativo e não generalizado. Em outras palavras, a influência do calendário eleitoral não é observada em todas as categorias de despesa pública e nem mesmo em todos os anos eleitorais - se a lei de Responsabilidade Fiscal e a possibilidade de reeleição dos prefeitos podem ser vistas como potenciais justificativas para a inibição de tal acontecimento, então a tendência é de que os mesmos venham a ser cada vez mais discretos. Este é justamente o resultado provido por Brender e Drazen (2003) e por Nakaguma (2006), qual seja, de que os ciclos eleitorais tendem a ser cada vez menores ao longo do tempo. Por sua vez, distinções associadas às diferenças partidárias entre os prefeitos brasileiros parecem apresentar alguma influência sobre a forma como os mesmos administram os recursos das cidades sob seus respectivos controles. Desta forma, independentemente de qualquer critério normativo para julgar a otimalidade deste último resultado, o mesmo pode ser considerado um critério (informação) adicional aos eleitores nos períodos que antecedem as eleições municipais, ou seja, no momento de decisão do voto.

No que diz respeito à questão da reeleição, os resultados parecem negar o senso comum de que despesas mais elevadas tendem a atrair mais eleitores. Os resultados sugerem que os eleitores são basicamente avessos à expansões fiscais ocorridas especificamente no ano eleitoral e que as perdas (em termos de chances de reeleição) decorrentes de desajustes físcais 
também apresentam distinções entre os partidos políticos. Este último pode ser visto como um resultado relativamente natural, considerando as diferenças de gestão do orçamento municipal existentes entre os partidos políticos, conforme obtidas no primeiro capítulo. Por sua vez, os eleitores são aparentemente receptivos à expansões fiscais ocorridas ao longo dos anos anteriores às eleições, provendo ao ocupante do Executivo municipal maiores chances de permanência no cargo.

Finalmente, quanto à questão dos déficits municipais, uma extensão natural deste estudo residiria na exploração de dados orçamentários para a totalidade dos municípios brasileiros a partir do momento em que tais informações estejam disponíveis, ou seja, a abordagem realizada neste estudo é apenas uma aproximação preliminar, que permite um entendimento a respeito das finanças dos municípios do estado de São Paulo. De todo modo, pode-se considerar que a apreciação atingiu o objetivo proposto, de procurar demonstrar que a obtenção de resultados fiscais superavitários e deficitários é uma questão complexa e que envolve fatores que vão além das capacidades financeiras de uma determinada administração municipal.

Finalizando esta tese, os resultados parecem efetivamente sugerir que a inclusão de variáveis de natureza política podem ampliar as possibilidades de entendimento de alguns fenômenos econômicos observados empiricamente e que, somente à luz da teoria econômica, poderiam ser de interpretação incompleta ou até mesmo incorreta. Tais elementos podem ser considerados relevantes como forma de explicar a existência de resultados economicamente considerados sub-ótimos e principalmente, a persistência destes resultados ao longo do tempo. 


\section{Referências bibliográficas}

ALESINA, Alberto. Macroeconomic policy in a two-party system as a repeated game. Quarterly Journal of Economics: nº 102, páginas 651-678, 1987.

ALESINA, Alberto, ROUBINI, Nouriel \& COHEN, Gerald D. Political cycles and the macroeconomy. Cambridge: the MIT Press, 1997.

ALESINA, Alberto \& TABELLINI, Guido. A positive theory of fiscal deficits and government debt. The Review of Economic Studies: volume 57, nº 3, páginas 403 - 414, 1990.

AMES, Barry, HIROI, Taeko \& RENNO, Lucio. The political economy of personnel expenditures: Brazilian states, 1965-1994. Revista de Economia Política: volume 25, $\mathrm{n}^{\mathrm{o}} 1$ (97), páginas 50-69, 2005.

AVELINO Filho, George. Clientelismo e política no Brasil. Novos Estudos: $n^{\circ} 38$, páginas 225-240, 1994.

BARRO, Robert. On the determination of the public debt. Journal of Political Economy: $\mathrm{n}^{\circ}$ 87, páginas 940-947, 1979.

BERGER, Helge \& WOITEK, Ulrich. Searching for political business cycle in Germany. Public Choice: $\mathrm{n}^{\circ}$ 91, páginas 179-197, 1997.

BITTENCOURT, Jeferson Luís. Evidências de ciclo político na economia brasileira: um teste para a execução orçamentária dos governos estaduais - 1983/2000. Dissertação de mestrado - Programa de pós-graduação em Economia - Faculdade de Ciências Econômicas Universidade Federal do Rio Grande do Sul, 2002.

BONOMO, Marco \& TERRA, Cristina. The political economy of exchange rate policy in Brazil: 1964 - 1997. Textos para discussão EPGE-FGV $\mathrm{n}^{\circ}$ 341. Disponível em < http://econpapers.repec.org/paper/fgvepgewp/341.htm>. Acesso em 13 de Junho de 2003.

BOTELHO, Ricardo. Determinantes do comportamento fiscal dos estados brasileiros. Dissertação de mestrado - Instituto de Pesquisas Econômicas - Faculdade de Economia, Administração e Contabilidade - Universidade de São Paulo, 2002.

BRENDER, Adi \& DRAZEN, Allan. How do budget deficits and economic growth affect reelection prospects? Evidence from a large cross-section of countries. NBER Working paper series, $\mathrm{n}^{\mathrm{o}} 11862,2005$.

BRENDER, Adi \& DRAZEN, Allan. Where does the political budget cycle really come from? CEPR Discussion Papers, no 4049, 2003.

BRENDER, Adi. The effect of fiscal performance on local government election results in Israel: 1989-1998. Journal of Public Economics: no 87, páginas 2187-2205, 2003. 
BUCHANAN, James \& WAGNER. Democracy in deficit: the political legacy of Lord Keynes. New York: Academic press, 1977.

BUGARIN, Maurício Soares. Subnational debt renegotiation and elections: experimentation and reputation in the Brazilian fiscal federalism. Brazilian Review of Econometrics: volume 26, no $1,2006$.

CHAMBERLAIN, Gary. Analysis of covariance with qualitative data. Review of Economic Studies: nº 47, páginas 225-238, 1980.

COSSIO, Fernando Andrés Blanco. O comportamento fiscal dos estados brasileiros e seus determinantes políticos. Economia: volume 2, nº 1, páginas 207-258, 2001.

DRAZEN, Allan. Political economy and macroeconomics. New Jersey: Princeton University Press, 2002.

FERREIRA, Ivan Fecury Sydrião \& BUGARIN, Maurício Soares. Ciclo políticoorçamentário no federalismo fiscal brasileiro: o papel das transferências voluntárias no resultado das eleições municipais. XXVI ${ }^{\circ}$ Encontro da Sociedade Brasileira de Econometria, João Pessoa (PB), 2004.

FIALHO, Tânia Marta Maia. Ciclos políticos: uma resenha. Revista de Economia Política: volume 19, no 2 (74), páginas 131 - 149, abril - junho, 1999.

FIALHO, Tânia Marta Maia. Testando a evidência de ciclos políticos no Brasil. Revista Brasileira de Economia: volume 51, nº 3, páginas 379-389, 1997.

HECKMAN, James J. Sample selection bias as a specification error. Econometrica: volume 47, páginas $153-161,1979$.

HECKMAN, James J. The common structure of statistical models of truncation, sample selection and limited dependent variables and a simples estimator for such models. Annals of Economic and Social Measurement, 5, páginas 475 - 492, 1976.

HIBBS, Douglas A. Jr. Political parties and macroeconomic policy. American Political Science Review: $\mathrm{n}^{\circ}$ 71, 1977.

HSIAO, Cheng. Analysis of panel data. Cambridge: Editora Cambridge University Press, 1986.

ITO, Takatoshi. The timing of elections and political business cycles in Japan. Journal of Asian Economics: volume 1, páginas 135-156, 1990.

KINZO, Maria D’alva Gil. Radiografia do quadro partidário brasileiro. Fundação Konrad Adenauer, 1993.

KYRIAZIDOU, Ekaterini. Estimation of a panel data sample selection model. Econometrica: volume 65, no 6, 1997. 
LIBANIO, Rita de Cássia. Indicadores sociais e desempenho nas eleições estaduais. Dissertação de Mestrado (não publicada) - Instituto de Pesquisas Econômicas - Faculdade de Economia, Administração e Contabilidade - Universidade de São Paulo, 2003.

LUCAS Jr, Robert \& STOKEY, Nancy. Optimal fiscal and monetary policy in an economy without capital. Journal of Monetary Economics: nº 12, páginas 55-94, 1983.

MAINWARING, Scott. Políticos, partidos e sistemas eleitorais. Novos Estudos: $\mathrm{n}^{\mathbf{0}}$ 29, páginas 34-58, 1991.

MENDES, Marcos \& ROCHA, Carlos Alexandre Amorim. O que reelege um prefeito? Consultoria Legislativa do Senado Federal: Textos para discussão, nº 7, 2004.

MENDES, Marcos. Federalismo fiscal e crescimento do governo: evidências eleitorais para o Brasil. XXXII ${ }^{\circ}$ Encontro Nacional da Associação Nacional de Centros de pós-graduação em Economia (Anpec). João Pessoa (PB), 2004.

MENEGUIN, Fernando B. \& BUGARIN, Mauricio Soares. Reeleição e política fiscal: um estudo dos efeitos da reeleição nos gastos públicos. Economia Aplicada: volume 5, $\mathrm{n}^{\mathbf{o}}$ 3, 2001 .

MENEGUIN, Fernando B.; BUGARIN, Mauricio Soares \& CARVALHO, Alexandre X. de. $\mathrm{O}$ que leva um governante à reeleição? Textos para discussão - Instituto de Pesquisa Econômica Aplicada - IPEA - no 1135, 2005.

MUNDLAK, Yair. On the pooling of time series and cross section data. Econometrica: $\mathrm{n}^{\circ} 46$, páginas $69-85,1978$.

NAKAGUMA, Marcos Yamada. Ciclos políticos e resultados eleitorais: um estudo sobre o comportamento do eleitor brasileiro. Dissertação de mestrado - Instituto de Pesquisas Econômicas - Faculdade de Economia, Administração e Contabilidade - Universidade de São Paulo, 2006.

NICKELL, Stephen. Biases in dynamic models with fixed effects. Econometrica: $\mathrm{n}^{\mathrm{o}}$ 6, volume 49, páginas 1417-1426, 1981.

NORDHAUS, William. The political business cycle. Review of Economic Studies: ${ }^{\circ} 42$, páginas 169-190, 1975.

NUNES, Selene P. \& NUNES, Ricardo da C. (2003) Dois anos da Lei de Responsabilidade Fiscal do Brasil: uma avaliação dos resultados à luz do modelo do fundo comum. Série Textos para discussão, $\mathrm{n}^{\circ}$ 276. Departamento de Economia - Universidade de Brasília.

OGURA, Laudo Massaharu. Ciclos Eleitorais na Economia Brasileira: 1980 - 1998. Disponível em $<$ http://www.unb.br/ih/eco/ecosum.htm>. Junho 10, 2002.

PELTZMAN, Sam. Voters as fiscal conservatives. The Quarterly Journal of Economics: volume 107, páginas 327-361, 1992. 
PERSSON, Torsten \& TABELLINI, Guido. Do electoral cycles differ across political systems? IGIER Working Paper, no 232, 2003.

PETTERSON - LIDBOM, Per. A test of the rational electoral-cycle hypothesis. Research Workshop in Political Economy. Faculty of Arts and Sciences. Harvard University. Disponível em <http://www.courses.fas.harvard.edu/ gov3007/Electoralcycle.doc $>$. Acesso em 20 de setembro de 2002.

ROCHINA - BARRACHINA, Maria Engracia. A new estimator for panel data sample selection models. Annales d'Économie et de Statistique: $n^{0} 55-56,1999$.

RODRIGUES, Leôncio Martins. Partidos, ideologia e composição social: um estudo das bancadas partidárias na Câmara dos Deputados. São Paulo: Editora Edusp, 2002.

ROGOFF, Kenneth \& SIBERT, Anne. Elections and macroeconomic policy cycles. Review of Economic Studies: $n^{\circ}$ 55, páginas 1-16, 1988.

ROGOFF, Kenneth. Equilibrium political budget cycles. The American Economic Review: volume 80, nº 1, páginas 21-36, 1990.

SAKURAI, Sergio Naruhiko. Political business cycles: procurando evidências empíricas para os municípios paulistas. Dissertação de mestrado - Instituto de Pesquisas Econômicas Faculdade de Economia, Administração e Contabilidade - Universidade de São Paulo, 2004.

SAKURAI, Sergio Naruhiko. Déficit e ajuste fiscal dos municípios paulistas: uma análise para o período 1989-2001 via dados em painel. Economia: volume 6, nº 2, 2005.

SAKURAI, Sergio Naruhiko. Testando a hipótese de ciclos eleitorais racionais nas eleições dos municípios paulistas. Estudos Econômicos: volume 35, nº 2, 2005.

SAMUELS, David. Determinantes do Voto Partidário em Sistemas Eleitorais Centrados no Candidato: Evidências sobre o Brasil. Dados: volume 40, nº 3, 1997.

SHI, Min \& SVENSSON, Jakob. Political business cycles in developed and developing countries. Institute for International Economic Studies, 2002. Disponível em $<$ http://www.iies.su.se/ svenssoj/pbc1.pdf $>$. Acesso em 15 de outubro de 2003.

SHI, Min \& SVENSSON, Jakob. Political budget cycles: a review of recent developments. Nordic Journal of Political Economy, volume 29 (1), páginas 67-76, 2003.

TABELLINI, Guido \& ALESINA, Alberto. Voting on the budget deficit. The American Economic Review: volume 80, nº 1, págs 37 - 49, março de 1990.

TABELLINI, Guido. The politics of intergenerational redistribution. Journal of Political Economy: no 99, páginas 335 - 357, 1991.

TERRA, Maria Cristina \& BONOMO, Marco Antônio. Elections and exchange rate policy cycles. Economics and Politics: volume 17, nº 2, páginas, 151-176, 2005 
TUFTE, Edward. Political control of the Economy. New Jersey: Princeton University Press, 1978

WOOLDRIDGE, Jeffrey. Econometric analysis of cross section and panel data. Boston: The MIT Press, 2002.

WOOLDRIDGE, Jeffrey. Selection corrections for panel data models under conditional mean independence assumptions. Journal of Econometrics: volume 68, páginas 115 - 132, 1995. 
Apêndice

Apêndice 1

Apêndice 1a - Tabelas com médias e desvios-padrão das variáveis orçamentárias selecionadas (amostra não balanceada)

Apêndice 1a.1-Despesa orçamentária per capita

\begin{tabular}{|c|c|c|c|c|c|c|c|c|c|c|c|}
\hline & PFL & $\begin{array}{c}\text { PPB I } \\
\text { PDS }\end{array}$ & PMDB & PSDB & PDT & PTB & OUTROS & PT & PL & Média & $\begin{array}{c}\text { Desvio } \\
\text { padrão }\end{array}$ \\
\hline 1989 & 392,43 & 463,00 & 457,34 & 353,03 & 434,52 & 480,94 & 343,48 & 543,18 & 393,78 & 429,08 & 64,60 \\
\hline 1990 & 552,61 & 608,53 & 614,98 & 488,14 & 592,34 & 645,38 & 471,08 & 716,49 & 524,74 & 579,37 & 78,42 \\
\hline 1991 & 486,31 & 569,84 & 555,94 & 446,73 & 564,21 & 606,97 & 435,48 & 786,39 & 505,48 & 550,82 & 105,81 \\
\hline 1992 & 501,44 & 574,93 & 561,70 & 425,57 & 566,91 & 597,23 & 454,17 & 734,54 & 486,66 & 544,80 & 92,28 \\
\hline 1993 & 514,77 & 617,17 & 606,87 & 447,86 & 563,80 & 562,69 & 510,42 & 582,82 & 503,89 & 545,59 & 55,19 \\
\hline 1994 & 598,78 & 685,34 & 696,17 & 515,65 & 654,02 & 663,28 & 599,23 & 666,92 & 571,85 & 627,91 & 60,03 \\
\hline 1995 & 710,45 & 821,53 & 821,96 & 619,84 & 740,02 & 758,56 & 692,06 & 756,98 & 703,82 & 736,13 & 64,01 \\
\hline 1996 & 794,49 & 897,56 & 898,42 & 699,35 & 810,20 & 853,26 & 761,23 & 856,92 & 750,77 & 813,58 & 68,75 \\
\hline 1997 & 680,29 & 746,46 & 758,09 & 756,51 & 771,66 & 681,00 & 597,04 & 705,19 & 614,95 & 701,24 & 63,70 \\
\hline 1998 & 904,46 & 983,04 & 1017,58 & 1007,91 & 1012,83 & 921,14 & 792,06 & 923,83 & 835,97 & 933,20 & 80,59 \\
\hline 1999 & 873,74 & 934,95 & 964,16 & 960,87 & 958,43 & 875,91 & 749,54 & 894,59 & 830,29 & 893,61 & 71,49 \\
\hline 2000 & 863,42 & 908,47 & 936,17 & 946,93 & 939,71 & 827,13 & 733,53 & 866,06 & 808,58 & 870,00 & 71,53 \\
\hline 2001 & 875,10 & 932,06 & 932,43 & 897,65 & 978,48 & 874,61 & 791,23 & 846,61 & 834,48 & 884,74 & 57,43 \\
\hline 2002 & 937,72 & 1002,91 & 986,90 & 957,31 & 1018,56 & 915,87 & 843,71 & 896,44 & 899,51 & 939,88 & 57,04 \\
\hline 2003 & 793,43 & 867,50 & 860,60 & 819,89 & 907,57 & 811,76 & 728,50 & 811,95 & 771,52 & 819,19 & 53,77 \\
\hline & & & & & & & & & & & \\
\hline Média & 698,63 & 774,22 & 777,95 & 689,55 & 767,55 & 738,38 & 633,52 & 772,59 & 669,09 & & \\
\hline $\begin{array}{l}\text { Desvio } \\
\text { padrão }\end{array}$ & 179,28 & 175,25 & 183,17 & 232,03 & 195,22 & 141,71 & 157,20 & 115,06 & 162,23 & & \\
\hline
\end{tabular}

Fonte: construção própria

Apêndice 1a.2 - Despesa corrente per capita

\begin{tabular}{|c|c|c|c|c|c|c|c|c|c|c|c|c|}
\hline & PFL & $\begin{array}{c}\text { PPB / } \\
\text { PDS }\end{array}$ & PMDB & PSDB & PDT & PTB & OUTROS & PT & PL & Média & $\begin{array}{c}\text { Desvio } \\
\text { padrão }\end{array}$ \\
\hline 1989 & 311,93 & 364,51 & 358,22 & 285,18 & 340,67 & 386,68 & 270,88 & 466,14 & 316,90 & 344,57 & 59,10 \\
\hline 1990 & 397,74 & 442,23 & 445,76 & 339,65 & 427,30 & 480,87 & 335,26 & 564,85 & 394,56 & 425,36 & 71,08 \\
\hline 1991 & 380,88 & 438,69 & 434,45 & 343,33 & 432,62 & 470,78 & 333,34 & 623,14 & 395,51 & 428,08 & 86,24 \\
\hline 1992 & 403,53 & 463,36 & 452,57 & 320,69 & 453,67 & 485,16 & 354,58 & 603,77 & 400,40 & 437,53 & 82,25 \\
\hline 1993 & 426,13 & 503,26 & 500,98 & 368,25 & 447,58 & 461,53 & 416,97 & 484,46 & 417,65 & 447,42 & 44,85 \\
\hline 1994 & 471,57 & 539,88 & 546,69 & 406,41 & 500,21 & 506,77 & 467,86 & 554,31 & 451,58 & 493,92 & 49,22 \\
\hline 1995 & 576,91 & 663,06 & 665,79 & 510,01 & 590,96 & 601,98 & 569,64 & 642,03 & 567,67 & 598,67 & 50,92 \\
\hline 1996 & 654,77 & 733,18 & 741,64 & 577,18 & 663,29 & 683,65 & 626,56 & 727,16 & 624,94 & 670,26 & 56,33 \\
\hline 1997 & 578,62 & 643,83 & 644,05 & 653,89 & 671,47 & 585,96 & 523,98 & 613,06 & 538,02 & 605,88 & 52,45 \\
\hline 1998 & 736,33 & 801,05 & 816,40 & 822,77 & 835,95 & 757,23 & 663,74 & 783,08 & 694,33 & 767,88 & 59,89 \\
\hline 1999 & 748,01 & 805,91 & 830,82 & 832,82 & 834,29 & 753,63 & 659,10 & 777,46 & 726,83 & 774,32 & 59,02 \\
\hline 2000 & 738,62 & 776,89 & 804,13 & 811,66 & 811,54 & 715,72 & 639,37 & 745,34 & 707,82 & 750,12 & 57,65 \\
\hline 2001 & 757,92 & 811,58 & 814,44 & 783,36 & 855,46 & 765,64 & 698,27 & 757,84 & 743,49 & 776,45 & 46,06 \\
\hline 2002 & 756,03 & 814,93 & 810,67 & 780,39 & 843,15 & 750,35 & 700,72 & 760,37 & 745,71 & 773,59 & 43,42 \\
\hline 2003 & 692,24 & 764,91 & 750,86 & 720,09 & 794,85 & 707,04 & 639,36 & 716,56 & 682,60 & 718,72 & 46,65 \\
\hline & & & & & & & & & & & & \\
\hline Média & 575,41 & 637,82 & 641,17 & 570,38 & 633,53 & 607,53 & 526,64 & 654,64 & 560,53 & & \\
\hline $\begin{array}{l}\text { Desvio } \\
\text { padrão }\end{array}$ & 162,49 & 163,11 & 169,00 & 212,06 & 187,02 & 132,83 & 150,68 & 106,51 & 152,76 & & & \\
\hline
\end{tabular}


Apêndice 1a.3 - Despesa de pessoal per capita

\begin{tabular}{|c|c|c|c|c|c|c|c|c|c|c|c|}
\hline & PFL & $\begin{array}{l}\text { PPB / } \\
\text { PDS }\end{array}$ & PMDB & PSDB & PDT & PTB & OUTROS & PT & PL & Média & $\begin{array}{l}\text { Desvio } \\
\text { padrão }\end{array}$ \\
\hline 1989 & 142,20 & 182,71 & 174,61 & 157,43 & 189,70 & 186,63 & 130,17 & 260,71 & 133,01 & 173,02 & 40,12 \\
\hline 1990 & 168,41 & 212,16 & 197,25 & 175,25 & 220,27 & 213,21 & 142,03 & 306,88 & 154,64 & 198,90 & 48,97 \\
\hline 1991 & 164,65 & 210,47 & 197,86 & 171,99 & 221,09 & 215,27 & 146,60 & 323,65 & 158,13 & 201,08 & 53,28 \\
\hline 1992 & 161,71 & 214,82 & 192,69 & 164,80 & 229,84 & 206,95 & 144,33 & 306,76 & 148,23 & 196,68 & 51,23 \\
\hline 1993 & 192,01 & 246,64 & 233,66 & 169,26 & 228,09 & 217,41 & 184,26 & 249,26 & 186,92 & 211,95 & 29,52 \\
\hline 1994 & 192,83 & 239,69 & 229,08 & 170,73 & 226,94 & 212,01 & 187,76 & 259,63 & 186,28 & 211,66 & 29,30 \\
\hline 1995 & 243,54 & 302,85 & 287,87 & 221,54 & 274,15 & 259,05 & 235,40 & 317,64 & 234,02 & 264,01 & 33,58 \\
\hline 1996 & 278,44 & 341,35 & 326,93 & 258,17 & 305,42 & 300,85 & 262,30 & 352,14 & 261,27 & 298,54 & 35,88 \\
\hline 1997 & 262,92 & 305,02 & 296,23 & 314,67 & 332,58 & 270,57 & 243,92 & 309,36 & 223,43 & 284,30 & 36,11 \\
\hline 1998 & 327,81 & 366,70 & 367,96 & 375,75 & 389,39 & 351,14 & 314,00 & 365,78 & 297,02 & 350,62 & 30,94 \\
\hline 1999 & 327,31 & 360,44 & 368,36 & 379,63 & 386,38 & 344,86 & 308,96 & 356,13 & 305,02 & 348,57 & 29,40 \\
\hline 2000 & 329,19 & 353,66 & 364,29 & 370,66 & 388,12 & 334,68 & 294,91 & 349,34 & 300,67 & 342,84 & 31,17 \\
\hline 2001 & 342,32 & 365,76 & 371,92 & 361,96 & 405,85 & 353,88 & 319,51 & 352,52 & 344,10 & 357,53 & 23,78 \\
\hline 2002 & 360,58 & 385,98 & 399,77 & 382,12 & 419,67 & 371,10 & 346,76 & 384,18 & 361,92 & 379,12 & 22,09 \\
\hline 2003 & 339,87 & 365,73 & 372,82 & 357,92 & 396,34 & 353,23 & 322,80 & 356,75 & 347,95 & 357,05 & 20,72 \\
\hline Média & 255,59 & 296,93 & 292,09 & 268,79 & 307,59 & 279,39 & 238,91 & 323,38 & 242,84 & & \\
\hline $\begin{array}{l}\text { Desvio } \\
\text { padrão }\end{array}$ & 19,13 & 7,64 & 3 & $y$ & 84,13 & 61,39 & 11,33 & 66 & 9,00 & & \\
\hline
\end{tabular}

Fonte: construção própria

Apêndice 1a.4 - Transferências correntes per capita

\begin{tabular}{|c|c|c|c|c|c|c|c|c|c|c|c|c|}
\hline & PFL & $\begin{array}{c}\text { PPB / } \\
\text { PDS }\end{array}$ & PMDB & PSDB & PDT & PTB & OUTROS & PT & PL & Média & $\begin{array}{c}\text { Desvio } \\
\text { padrão }\end{array}$ \\
\hline 1989 & 33,66 & 50,35 & 36,76 & 29,25 & 52,03 & 32,24 & 27,89 & 57,80 & 40,82 & 40,09 & 10,85 \\
\hline 1990 & 30,91 & 35,33 & 28,60 & 36,58 & 36,71 & 32,90 & 26,30 & 54,74 & 34,13 & 35,13 & 8,17 \\
\hline 1991 & 25,92 & 34,46 & 28,52 & 32,77 & 37,11 & 30,91 & 26,45 & 59,98 & 30,65 & 34,09 & 10,37 \\
\hline 1992 & 27,85 & 33,46 & 30,16 & 38,29 & 44,49 & 30,83 & 29,82 & 63,99 & 31,74 & 36,74 & 11,43 \\
\hline 1993 & 118,54 & 134,46 & 133,90 & 90,33 & 110,66 & 126,17 & 115,87 & 127,93 & 115,27 & 119,24 & 13,73 \\
\hline 1994 & 38,28 & 43,42 & 40,99 & 31,14 & 41,75 & 43,01 & 33,76 & 81,91 & 40,83 & 43,90 & 14,85 \\
\hline 1995 & 51,95 & 59,39 & 54,95 & 44,87 & 54,88 & 54,51 & 46,30 & 99,23 & 54,42 & 57,83 & 16,17 \\
\hline 1996 & 62,60 & 67,33 & 63,15 & 52,21 & 66,18 & 64,87 & 51,28 & 121,47 & 61,87 & 67,88 & 20,89 \\
\hline 1997 & 53,54 & 62,83 & 59,30 & 56,40 & 61,08 & 51,47 & 40,90 & 80,35 & 45,06 & 56,77 & 11,43 \\
\hline 1998 & 103,21 & 115,40 & 126,73 & 121,88 & 122,84 & 107,77 & 82,19 & 132,34 & 96,73 & 112,12 & 16,10 \\
\hline 1999 & 107,48 & 116,17 & 128,57 & 125,57 & 121,70 & 105,16 & 81,24 & 127,71 & 101,80 & 112,82 & 15,53 \\
\hline 2000 & 92,79 & 99,53 & 109,98 & 110,31 & 100,10 & 84,67 & 69,12 & 113,31 & 94,65 & 97,16 & 14,05 \\
\hline 2001 & 95,41 & 99,91 & 108,59 & 96,80 & 110,91 & 101,45 & 79,75 & 102,44 & 98,40 & 99,30 & 8,95 \\
\hline & & & & & & & & & & & & \\
\hline Média & 64,78 & 73,23 & 73,09 & 66,64 & 73,88 & 66,61 & 54,68 & 94,09 & 65,11 & & \\
\hline $\begin{array}{l}\text { Desvio } \\
\text { padrão }\end{array}$ & 34,04 & 35,40 & 41,88 & 36,74 & 33,89 & 34,25 & 28,42 & 29,19 & 31,37 & & \\
\hline
\end{tabular}

Fonte: construção própria 
Apêndice 1a.5 - Despesa de investimentos per capita

\begin{tabular}{|c|c|c|c|c|c|c|c|c|c|c|c|}
\hline & PFL & $\begin{array}{c}\text { PPB / } \\
\text { PDS }\end{array}$ & PMDB & PSDB & PDT & PTB & OUTROS & PT & PL & Média & $\begin{array}{c}\text { Desvio } \\
\text { padrão }\end{array}$ \\
\hline 1989 & 76,49 & 93,11 & 93,25 & 61,21 & 88,17 & 87,43 & 68,95 & 69,71 & 72,89 & 79,02 & 11,75 \\
\hline 1990 & 147,28 & 154,77 & 160,17 & 141,98 & 154,54 & 152,07 & 128,65 & 133,01 & 123,59 & 144,01 & 12,95 \\
\hline 1991 & 100,64 & 124,08 & 115,09 & 97,35 & 122,65 & 128,27 & 97,58 & 147,19 & 105,82 & 115,41 & 16,80 \\
\hline 1992 & 93,63 & 106,26 & 103,74 & 101,26 & 103,74 & 106,04 & 95,29 & 118,94 & 82,77 & 101,30 & 10,05 \\
\hline 1993 & 82,27 & 105,10 & 95,96 & 71,82 & 106,88 & 90,94 & 85,74 & 83,73 & 80,29 & 89,19 & 11,65 \\
\hline 1994 & 118,48 & 133,25 & 136,93 & 97,92 & 140,46 & 144,31 & 121,72 & 90,98 & 112,59 & 121,85 & 18,81 \\
\hline 1995 & 119,24 & 140,73 & 138,95 & 96,63 & 132,01 & 137,87 & 108,60 & 89,68 & 122,62 & 120,70 & 18,88 \\
\hline 1996 & 125,04 & 144,80 & 136,90 & 106,01 & 128,49 & 154,29 & 120,20 & 102,84 & 113,57 & 125,79 & 17,33 \\
\hline 1997 & 88,09 & 84,43 & 96,90 & 86,55 & 79,40 & 79,59 & 62,36 & 76,78 & 63,96 & 79,78 & 11,14 \\
\hline 1998 & 147,27 & 159,57 & 178,01 & 163,10 & 146,92 & 137,85 & 112,25 & 121,24 & 125,62 & 143,54 & 21,46 \\
\hline 1999 & 107,25 & 107,28 & 110,48 & 106,51 & 95,17 & 99,90 & 74,34 & 96,58 & 87,24 & 98,30 & 11,66 \\
\hline 2000 & 109,42 & 112,70 & 112,93 & 117,63 & 103,07 & 92,25 & 81,99 & 101,45 & 86,80 & 102,03 & 12,56 \\
\hline 2001 & 100,83 & 102,41 & 98,65 & 97,15 & 100,16 & 86,10 & 76,92 & 70,06 & 73,27 & 89,51 & 13,05 \\
\hline 2002 & 166,06 & 170,25 & 158,77 & 160,54 & 152,80 & 145,47 & 127,50 & 117,06 & 136,74 & 148,35 & 18,12 \\
\hline 2003 & 87,05 & 85,84 & 94,74 & 85,96 & 92,52 & 86,31 & 75,62 & 78,76 & 73,63 & 84,49 & 7,18 \\
\hline & & & & & & & & & & & \\
\hline Média & 111,27 & 121,64 & 122,10 & 106,11 & 116,47 & 115,25 & 95,85 & 99,87 & 97,43 & & \\
\hline $\begin{array}{l}\text { Desvio } \\
\text { padrão }\end{array}$ & 26,22 & 27,50 & 27,64 & 29,21 & 24,78 & 28,03 & 22,59 & 23,44 & 23,63 & & \\
\hline
\end{tabular}

Fonte: construção própria

Apêndice 1a.6 - Receita tributária per capita

\begin{tabular}{|c|c|c|c|c|c|c|c|c|c|c|c|c|}
\hline & PFL & $\begin{array}{c}\text { PPB / } \\
\text { PDS }\end{array}$ & PMDB & PSDB & PDT & PTB & OUTROS & PT & PL & Média & $\begin{array}{c}\text { Desvio } \\
\text { padrão }\end{array}$ \\
\hline 1989 & 13.77 & 18.45 & 17.36 & 23.09 & 30.09 & 27.88 & 14.38 & 48.99 & 15.39 & 23.27 & 11.28 \\
\hline 1990 & 22.62 & 29.87 & 26.21 & 45.12 & 53.67 & 44.50 & 22.04 & 72.69 & 27.48 & 38.24 & 17.13 \\
\hline 1991 & 27.47 & 35.30 & 33.53 & 55.79 & 56.34 & 60.50 & 27.24 & 109.67 & 29.94 & 48.42 & 26.55 \\
\hline 1992 & 22.55 & 26.23 & 26.91 & 42.77 & 42.92 & 47.91 & 23.15 & 91.66 & 22.24 & 38.48 & 22.34 \\
\hline 1993 & 19.94 & 24.33 & 30.15 & 23.31 & 24.92 & 32.33 & 30.06 & 52.90 & 19.49 & 28.60 & 10.17 \\
\hline 1994 & 24.98 & 29.58 & 37.59 & 29.51 & 33.15 & 39.57 & 35.48 & 73.25 & 24.88 & 36.44 & 14.74 \\
\hline 1995 & 41.27 & 48.61 & 58.01 & 50.27 & 50.41 & 57.51 & 47.93 & 104.25 & 36.87 & 55.01 & 19.66 \\
\hline 1996 & 43.09 & 51.18 & 57.81 & 51.73 & 49.18 & 58.37 & 46.09 & 118.57 & 35.04 & 56.78 & 24.27 \\
\hline 1997 & 34.75 & 50.28 & 40.25 & 54.91 & 52.33 & 41.95 & 48.39 & 56.33 & 24.84 & 44.89 & 10.39 \\
\hline 1998 & 42.17 & 59.59 & 48.34 & 65.27 & 57.98 & 55.52 & 57.41 & 64.44 & 31.28 & 53.56 & 11.09 \\
\hline 1999 & 39.16 & 54.18 & 45.55 & 58.85 & 54.19 & 50.99 & 49.30 & 61.51 & 28.88 & 49.18 & 10.15 \\
\hline 2000 & 35.60 & 48.86 & 41.31 & 53.12 & 51.00 & 48.63 & 43.40 & 54.79 & 25.99 & 44.75 & 9.29 \\
\hline 2001 & 36.35 & 42.37 & 42.37 & 48.43 & 63.33 & 52.05 & 42.60 & 75.01 & 40.26 & 49.20 & 12.53 \\
\hline 2002 & 46.91 & 50.19 & 50.79 & 56.81 & 69.12 & 62.04 & 53.19 & 86.52 & 53.65 & 58.80 & 12.38 \\
\hline 2003 & 44.70 & 50.32 & 48.79 & 54.44 & 65.65 & 60.68 & 49.33 & 83.06 & 48.87 & 56.21 & 12.02 \\
\hline & & & & & & & & & & & & \\
\hline Média & 33.02 & 41.29 & 40.33 & 47.56 & 50.29 & 49.36 & 39.33 & 76.91 & 31.01 & & \\
\hline $\begin{array}{l}\text { Desvio } \\
\text { padrão }\end{array}$ & 10.34 & 12.80 & 11.83 & 12.80 & 12.79 & 10.48 & 13.03 & 21.71 & 10.49 & & & \\
\hline
\end{tabular}

Fonte: construção própria 
Apêndice 1a.7-Receita de transferências per capita

\begin{tabular}{|c|c|c|c|c|c|c|c|c|c|c|c|}
\hline & PFL & $\begin{array}{l}\text { PPB / } \\
\text { PDS }\end{array}$ & PMDB & PSDB & PDT & РTB & OUTROS & PT & PL & Média & $\begin{array}{l}\text { Desvio } \\
\text { padrão }\end{array}$ \\
\hline 1989 & 291.66 & 360.61 & 336.98 & 247.57 & 320.33 & 348.24 & 234.63 & 375.74 & 299.38 & 312.79 & 48.91 \\
\hline 1990 & 411.25 & 490.87 & 464.50 & 346.15 & 436.92 & 470.49 & 343.84 & 510.58 & 417.65 & 432.47 & 59.14 \\
\hline 1991 & 367.29 & 442.66 & 416.72 & 305.73 & 412.63 & 434.60 & 313.61 & 524.41 & 377.75 & 399.49 & 67.87 \\
\hline 1992 & 394.73 & 455.25 & 431.09 & 283.13 & 422.18 & 418.99 & 347.32 & 474.36 & 382.64 & 401.08 & 58.26 \\
\hline 1993 & 434.01 & 518.29 & 493.86 & 358.88 & 455.89 & 450.52 & 406.29 & 396.62 & 419.36 & 437.08 & 49.21 \\
\hline 1994 & 480.13 & 557.68 & 537.79 & 396.45 & 505.76 & 499.53 & 453.21 & 451.84 & 465.46 & 483.09 & 48.78 \\
\hline 1995 & 555.81 & 651.66 & 629.73 & 469.03 & 564.37 & 568.62 & 534.77 & 528.88 & 554.42 & 561.92 & 53.91 \\
\hline 1996 & 604.18 & 693.61 & 675.73 & 530.93 & 616.11 & 626.51 & 572.23 & 573.55 & 591.32 & 609.35 & 51.25 \\
\hline 1997 & 564.91 & 612.39 & 628.06 & 616.20 & 621.26 & 557.88 & 470.18 & 577.13 & 518.40 & 574.05 & 53.19 \\
\hline 1998 & 708.23 & 777.19 & 798.03 & 769.05 & 788.29 & 716.82 & 603.76 & 729.49 & 674.38 & 729.47 & 62.70 \\
\hline 1999 & 733.20 & 775.91 & 811.51 & 787.25 & 798.54 & 717.93 & 614.60 & 731.04 & 712.86 & 742.54 & 60.29 \\
\hline 2000 & 734.63 & 768.59 & 795.23 & 781.14 & 790.71 & 692.94 & 620.52 & 724.64 & 711.84 & 735.58 & 56.46 \\
\hline 2001 & 772.77 & 831.51 & 825.04 & 777.25 & 841.37 & 748.94 & 683.11 & 716.60 & 737.25 & 770.43 & 54.64 \\
\hline 2002 & 837.82 & 913.46 & 894.55 & 841.83 & 895.41 & 807.31 & 737.13 & 764.81 & 799.67 & 832.44 & 61.10 \\
\hline 2003 & 736.54 & 799.59 & 791.88 & 745.83 & 800.79 & 718.97 & 648.59 & 676.72 & 712.10 & 736.78 & 54.17 \\
\hline Média & 575.14 & 643.29 & 635.38 & 550.43 & 618.04 & 585.22 & 505.59 & 583.76 & 558.30 & & \\
\hline $\begin{array}{l}\text { Desvio } \\
\text { padrão }\end{array}$ & 172.27 & 166.76 & 179.23 & 218.46 & 188.11 & 143.53 & 151.41 & 131.35 & 159.41 & & \\
\hline
\end{tabular}

Fonte: construção própria 


\section{Apêndice $1 b$-Regressões com dummy de ano eleitoral-OLS e efeitos aleatórios}

Apêndice 1b.1 - Despesa orçamentária

\begin{tabular}{|c|c|c|c|c|c|c|c|c|}
\hline \multirow[b]{3}{*}{ Receita tributária } & \multicolumn{4}{|c|}{ Painel não balanceado } & \multicolumn{4}{|c|}{ Painel balanceado } \\
\hline & \multicolumn{2}{|c|}{ OLS } & \multicolumn{2}{|c|}{ Efeitos aleatórios } & \multicolumn{2}{|c|}{ OLS } & \multicolumn{2}{|c|}{ Efeitos aleatórios } \\
\hline & $\begin{array}{c}1.428^{* * *} \\
(0.024)\end{array}$ & $\begin{array}{c}1.428^{* * *} \\
(0.024)\end{array}$ & $\begin{array}{l}1.354^{* * *} \\
(0.011)\end{array}$ & $\begin{array}{c}1.354^{* * *} \\
(0.011)\end{array}$ & $\begin{array}{c}1.426^{* * *} \\
(0.032)\end{array}$ & $\begin{array}{c}1.426^{* * *} \\
(0.032)\end{array}$ & $\begin{array}{c}1.342^{* * *} \\
(0.014)\end{array}$ & $\begin{array}{c}1.342^{* * *} \\
(0.014)\end{array}$ \\
\hline Receita de transferências & $\begin{array}{l}1.079^{* * *} \\
(0.010)\end{array}$ & $\begin{array}{l}1.079^{* * *} \\
(0.010)\end{array}$ & $\begin{array}{l}1.009^{* * *} \\
(0.003)\end{array}$ & $\begin{array}{l}1.009^{* * *} \\
(0.003)\end{array}$ & $\begin{array}{c}1.062^{* * *} \\
(0.011)\end{array}$ & $\begin{array}{c}1.062^{* * *} \\
(0.011)\end{array}$ & $\begin{array}{c}0.999^{* * *} \\
(0.004)\end{array}$ & $\begin{array}{c}0.999^{* * *} \\
(0.004)\end{array}$ \\
\hline Dummy ano eleitoral & \begin{tabular}{|c|}
$12.620^{* \star *}$ \\
$(1.511)$ \\
\end{tabular} & $\begin{array}{c}13.594^{\star \star *} \\
(3.035)\end{array}$ & $\begin{array}{c}13.504^{\star \star *} \\
(1.462)\end{array}$ & $\begin{array}{c}13.962^{* * *} \\
(2.656)\end{array}$ & $\begin{array}{c}19.232^{* * *} \\
(1.781) \\
\end{array}$ & $\begin{array}{c}22.036^{* * *} \\
(3.463) \\
\end{array}$ & $\begin{array}{c}18.809^{* * *} \\
(1.851)\end{array}$ & $\begin{array}{c}20.651^{* * *} \\
(3.273) \\
\end{array}$ \\
\hline PFL & $\begin{array}{c}0.462 \\
(2.100) \\
\end{array}$ & $\begin{array}{c}1.610 \\
(2.473) \\
\end{array}$ & $\begin{array}{c}-4.224^{* *} \\
(2.064) \\
\end{array}$ & $\begin{array}{l}-3.069 \\
(2.264) \\
\end{array}$ & $\begin{array}{l}2.950 \\
(2.902) \\
\end{array}$ & $\begin{array}{c}4.956 \\
(3.420) \\
\end{array}$ & $\begin{array}{l}-1.918 \\
(2.620) \\
\end{array}$ & $\begin{array}{c}-0.170 \\
(2.896) \\
\end{array}$ \\
\hline PSDB & $\begin{array}{l}-0.668 \\
(2.720)\end{array}$ & $\begin{array}{l}-1.440 \\
(2.839) \\
\end{array}$ & $\begin{array}{c}1.927 \\
(2.812)\end{array}$ & $\begin{array}{c}0.867 \\
(2.887)\end{array}$ & $\begin{array}{l}-0.865 \\
(2.959) \\
\end{array}$ & $\begin{array}{l}-0.761 \\
(3.036)\end{array}$ & $\begin{array}{l}-0.164 \\
(3.401)\end{array}$ & $\begin{array}{c}-0.307 \\
(3.502) \\
\end{array}$ \\
\hline PT & $\begin{array}{c}-11.657^{\star \star \star} \\
(3.622)\end{array}$ & $\begin{array}{c}-11.969^{* * \star} \\
(3.996)\end{array}$ & $\begin{array}{c}-12.561^{* *} \\
(5.137)\end{array}$ & $\begin{array}{c}-12.969^{\star *} \\
(5.412)\end{array}$ & $\begin{array}{l}-7.198^{*} \\
(3.985)\end{array}$ & $\begin{array}{l}-7.714^{*} \\
(4.325)\end{array}$ & $\begin{array}{c}-11.771^{\star *} \\
(5.878)\end{array}$ & $\begin{array}{c}-12.823^{* *} \\
(6.234)\end{array}$ \\
\hline PTB & $\begin{array}{c}0.529 \\
(2.392) \\
\end{array}$ & $\begin{array}{c}0.129 \\
(2.753) \\
\end{array}$ & $\begin{array}{l}-3.856 \\
(2.893) \\
\end{array}$ & $\begin{array}{l}-4.557 \\
(3.153) \\
\end{array}$ & $\begin{array}{c}3.411 \\
(2.940) \\
\end{array}$ & $\begin{array}{c}3.092 \\
(3.341) \\
\end{array}$ & $\begin{array}{l}-0.675 \\
(3.489) \\
\end{array}$ & $\begin{array}{l}-1.207 \\
(3.827) \\
\end{array}$ \\
\hline PDT & $\begin{array}{l}-4.733^{*} \\
(2.760) \\
\end{array}$ & $\begin{array}{l}-4.784 \\
(3.181) \\
\end{array}$ & $\begin{array}{l}-1.987 \\
(2.932) \\
\end{array}$ & $\begin{array}{l}-2.007 \\
(3.216) \\
\end{array}$ & $\begin{array}{c}-5.859^{* *} \\
(2.646) \\
\end{array}$ & $\begin{array}{l}-3.573 \\
(3.117) \\
\end{array}$ & $\begin{array}{l}-3.294 \\
(3.464) \\
\end{array}$ & $\begin{array}{c}-1.529 \\
(3.827) \\
\end{array}$ \\
\hline PDS / PPB & $\begin{array}{c}-13.472^{* * *} \\
(2.215) \\
\end{array}$ & $\begin{array}{c}-14.085^{\star * *} \\
(2.649)\end{array}$ & $\begin{array}{c}-8.832^{* * *} \\
(2.506)\end{array}$ & $\begin{array}{c}-9.536^{* * *} \\
(2.739)\end{array}$ & $\begin{array}{c}-7.628^{* *} \\
(3.086)\end{array}$ & $\begin{array}{c}-7.308^{* *} \\
(3.705)\end{array}$ & $\begin{array}{c}-6.119^{* *} \\
(3.088)\end{array}$ & $\begin{array}{l}-6.097^{*} \\
(3.392)\end{array}$ \\
\hline $\mathrm{PL}$ & $\begin{array}{c}-8.798^{\star \star *} \\
(2.542)\end{array}$ & $\begin{array}{c}-7.002^{\star *} \\
(2.942)\end{array}$ & $\begin{array}{c}-15.325^{\star \star \star} \\
(3.410)\end{array}$ & $\begin{array}{c}-14.044^{\star * *} \\
(3.722)\end{array}$ & $\begin{array}{l}-0.281 \\
(3.600)\end{array}$ & $\begin{array}{c}1.582 \\
(4.107)\end{array}$ & $\begin{array}{c}-9.220^{* *} \\
(4.326)\end{array}$ & $\begin{array}{l}-7.833^{*} \\
(4.752)\end{array}$ \\
\hline Outros & $\begin{array}{l}-0.024 \\
(2.358)\end{array}$ & $\begin{array}{c}0.981 \\
(2.787)\end{array}$ & $\begin{array}{l}-3.000 \\
(2.506)\end{array}$ & $\begin{array}{l}-2.315 \\
(2.745)\end{array}$ & $\begin{array}{c}8.078^{\star * *} \\
(2.780)\end{array}$ & $\begin{array}{c}8.462^{\star * *} \\
(3.155)\end{array}$ & $\begin{array}{l}-0.108 \\
(3.211)\end{array}$ & $\begin{array}{c}-0.003 \\
(3.523)\end{array}$ \\
\hline PFL \& ano eleitoral & & $\begin{array}{l}-5.731 \\
(4.681)\end{array}$ & & $\begin{array}{l}-5.984 \\
(4.137)\end{array}$ & & $\begin{array}{l}-8.894 \\
(6.233)\end{array}$ & & $\begin{array}{l}-7.967 \\
(5.360)\end{array}$ \\
\hline PSDB \& ano eleitoral & & $\begin{array}{l}5.477 \\
(6.530) \\
\end{array}$ & & $\begin{array}{c}7.796 \\
(5.475) \\
\end{array}$ & & $\begin{array}{l}-2.239 \\
(6.273) \\
\end{array}$ & & $\begin{array}{l}-0.188 \\
(6.781) \\
\end{array}$ \\
\hline PT \& ano eleitoral & & $\begin{array}{l}2.817 \\
(8.278)\end{array}$ & & $\begin{array}{c}3.602 \\
(11.745)\end{array}$ & & $\begin{array}{l}5.027 \\
(9.847)\end{array}$ & & $\begin{array}{c}8.437 \\
(13.816)\end{array}$ \\
\hline PTB \& ano eleitoral & & $\begin{array}{l}2.057 \\
(5.747)\end{array}$ & & $\begin{array}{c}3.349 \\
(6.014)\end{array}$ & & $\begin{array}{c}2.623 \\
(7.231)\end{array}$ & & $\begin{array}{c}3.413 \\
(7.469)\end{array}$ \\
\hline PDT \& ano eleitoral & & $\begin{array}{c}0.204 \\
(6.325) \\
\end{array}$ & & $\begin{array}{l}-0.154 \\
(5.936) \\
\end{array}$ & & $\begin{array}{c}-10.072^{*} \\
(5.742) \\
\end{array}$ & & $\begin{array}{c}-7.864 \\
(7.260) \\
\end{array}$ \\
\hline PDS / PPB \& ano eleitoral & & $\begin{array}{c}3.308 \\
(4.528) \\
\end{array}$ & & $\begin{array}{c}3.565 \\
(5.075) \\
\end{array}$ & & $\begin{array}{l}-0.499 \\
(6.005) \\
\end{array}$ & & $\begin{array}{c}0.626 \\
(6.364)\end{array}$ \\
\hline PL \& ano eleitoral & & $\begin{array}{l}-8.884 \\
(6.023)\end{array}$ & & $\begin{array}{l}-6.634 \\
(7.041)\end{array}$ & & $\begin{array}{l}-8.264 \\
(8.624)\end{array}$ & & $\begin{array}{l}-6.274 \\
(9.252)\end{array}$ \\
\hline Outros \& ano eleitoral & & $\begin{array}{l}-4.930 \\
(5.246)\end{array}$ & & $\begin{array}{l}-3.545 \\
(5.140)\end{array}$ & & $\begin{array}{l}-0.868 \\
(6.792)\end{array}$ & & $\begin{array}{c}0.184 \\
(6.809)\end{array}$ \\
\hline Prefeito $=$ Governador & $\begin{array}{l}-1.969 \\
(1.410) \\
\end{array}$ & $\begin{array}{l}-1.868 \\
(1.410) \\
\end{array}$ & $\begin{array}{c}0.880 \\
(1.307)\end{array}$ & $\begin{array}{c}1.038 \\
(1.312)\end{array}$ & $\begin{array}{c}2.721 \\
(1.792) \\
\end{array}$ & $\begin{array}{c}2.819 \\
(1.789) \\
\end{array}$ & $\begin{array}{c}5.206^{* * *} \\
(1.676)\end{array}$ & $\begin{array}{c}5.288^{* * *} \\
(1.680)\end{array}$ \\
\hline Prefeito $=$ Presidente & $\begin{array}{c}0.810 \\
(2.504) \\
\end{array}$ & $\begin{array}{c}0.701 \\
(2.654) \\
\end{array}$ & $\begin{array}{c}-3.472 \\
(2.228) \\
\end{array}$ & $\begin{array}{l}-3.769 \\
(2.299) \\
\end{array}$ & $\begin{array}{c}3.930 \\
(2.804) \\
\end{array}$ & \begin{tabular}{|c|}
4.545 \\
$(2.981)$ \\
\end{tabular} & $\begin{array}{l}-0.536 \\
(2.699) \\
\end{array}$ & $\begin{array}{c}-0.137 \\
(2.788) \\
\end{array}$ \\
\hline Idosos & $\begin{array}{c}-5.542^{* * *} \\
(0.622)\end{array}$ & $\begin{array}{c}-5.541^{* * *} \\
(0.623)\end{array}$ & $\begin{array}{c}-8.692^{\star * *} \\
(0.703)\end{array}$ & $\begin{array}{c}-8.685^{\star \star *} \\
(0.703)\end{array}$ & $\begin{array}{c}-6.091^{* * *} \\
(0.779)\end{array}$ & $\begin{array}{c}-6.086^{* * *} \\
(0.779)\end{array}$ & $\begin{array}{c}-8.213^{\star * *} \\
(0.917)\end{array}$ & $\begin{array}{c}-8.200^{\star * *} \\
(0.917)\end{array}$ \\
\hline Urbanização & $\begin{array}{c}0.313^{\star * *} \\
(0.034)\end{array}$ & $\begin{array}{c}0.313^{* \star *} \\
(0.034) \\
\end{array}$ & $\begin{array}{c}0.530^{\star \star *} \\
(0.057)\end{array}$ & $\begin{array}{c}0.530^{\star * *} \\
(0.057)\end{array}$ & $\begin{array}{c}0.379^{* * *} \\
(0.046)\end{array}$ & $\begin{array}{c}0.379^{\star * *} \\
(0.046)\end{array}$ & $\begin{array}{c}0.675^{\star \star *} \\
(0.074) \\
\end{array}$ & $\begin{array}{c}0.675^{\star * *} \\
(0.074)\end{array}$ \\
\hline Jovens & $\begin{array}{c}-2.591^{\text {*** }} \\
(0.265)\end{array}$ & $\begin{array}{c}-2.592^{* * *} \\
(0.265)\end{array}$ & $\begin{array}{c}-3.908^{\star * *} \\
(0.262)\end{array}$ & $\begin{array}{c}-3.912^{* * *} \\
(0.262)\end{array}$ & $\begin{array}{c}-4.033^{* * *} \\
(0.362)\end{array}$ & $\begin{array}{c}-4.032^{* * *} \\
(0.362)\end{array}$ & $\begin{array}{c}-5.117^{\star * \star} \\
(0.377)\end{array}$ & $\begin{array}{c}-5.114^{\star * *} \\
(0.377)\end{array}$ \\
\hline População & $\begin{array}{l}-3.107 \\
(1.994) \\
\end{array}$ & $\begin{array}{l}-3.119 \\
(1.994) \\
\end{array}$ & \begin{tabular}{|c|}
$-17.207^{* * *}$ \\
$(1.389)$ \\
\end{tabular} & $\begin{array}{c}-17.232^{* * *} \\
(1.389) \\
\end{array}$ & $\begin{array}{c}-6.784^{* * *} \\
(2.315) \\
\end{array}$ & $\begin{array}{c}-6.779^{* * *} \\
(2.317) \\
\end{array}$ & $\begin{array}{c}-18.457^{* * *} \\
(1.691) \\
\end{array}$ & $\begin{array}{c}-18.459^{* * \star} \\
(1.692) \\
\end{array}$ \\
\hline Tendência linear & $\begin{array}{c}8.315^{\star * *} \\
(0.738)\end{array}$ & $\begin{array}{c}8.350^{* * *} \\
(0.739)\end{array}$ & $\begin{array}{c}10.090^{* * *} \\
(0.624)\end{array}$ & $\begin{array}{c}10.129^{* * *} \\
(0.624)\end{array}$ & $\begin{array}{c}9.064^{* * *} \\
(0.917)\end{array}$ & $\begin{array}{c}9.054^{* * *} \\
(0.915)\end{array}$ & $\begin{array}{c}11.352^{* * *} \\
(0.789)\end{array}$ & $\begin{array}{c}11.352^{* * *} \\
(0.790)\end{array}$ \\
\hline Tendência quadrática & $\begin{array}{c}-1.079^{* * *} \\
(0.044)\end{array}$ & $\begin{array}{c}-1.081^{* * *} \\
(0.044)\end{array}$ & $\begin{array}{c}-1.107^{\star * *} \\
(0.037)\end{array}$ & $\begin{array}{c}-1.110^{* * *} \\
(0.037)\end{array}$ & $\begin{array}{c}-1.169^{* \star *} \\
(0.051)\end{array}$ & $\begin{array}{c}-1.168^{* * *} \\
(0.051)\end{array}$ & $\begin{array}{c}-1.227^{\star \star \star} \\
(0.047)\end{array}$ & $\begin{array}{c}-1.227^{\star * *} \\
(0.047)\end{array}$ \\
\hline Constante & $\begin{array}{c}181.923^{\star \star \star} \\
(30.181)\end{array}$ & $\begin{array}{c}181.751^{* \star *} \\
(30.194)\end{array}$ & $\begin{array}{c}396.877^{* \star \star} \\
(18.761)\end{array}$ & $\begin{array}{c}397.016^{\star * \star} \\
(18.782)\end{array}$ & $\begin{array}{c}266.390^{\star * \star} \\
(35.840)\end{array}$ & $\begin{array}{c}265.450^{\star * *} \\
(35.918)\end{array}$ & $\begin{array}{c}435.205^{\star \star \star} \\
(24.027)\end{array}$ & $\begin{array}{c}434.493^{\text {*** }}(24.060) \\
\end{array}$ \\
\hline $\mathrm{R}^{2}$ & 0,8881 & 0.8881 & 0,8872 & 0.8872 & 0.8967 & 0.8967 & 0.8958 & 0.8958 \\
\hline Observações & 66384 & 66384 & 66384 & 66384 & 33525 & 33525 & 33525 & 33525 \\
\hline
\end{tabular}


Apêndice 1b.2 - Despesa corrente

\begin{tabular}{|c|c|c|c|c|c|c|c|c|}
\hline \multirow[b]{3}{*}{ Receita tributária } & \multicolumn{4}{|c|}{ Painel não balanceado } & \multicolumn{4}{|c|}{ Painel balanceado } \\
\hline & \multicolumn{2}{|c|}{ OLS } & \multicolumn{2}{|c|}{ Efeitos aleatórios } & \multicolumn{2}{|c|}{ OLS } & \multicolumn{2}{|c|}{ Efeitos aleatórios } \\
\hline & $\begin{array}{l}1.100^{* * *} \\
(0.024)\end{array}$ & $\begin{array}{c}1.100^{* * *} \\
(0.024)\end{array}$ & $\begin{array}{c}0.996^{* * *} \\
(0.008)\end{array}$ & $\begin{array}{c}0.995^{\star * *} \\
(0.008)\end{array}$ & $\begin{array}{c}1.036^{* * *} \\
(0.031)\end{array}$ & $\begin{array}{l}1.036^{* * *} \\
(0.031)\end{array}$ & $\begin{array}{c}0.938^{* * *} \\
(0.012)\end{array}$ & $\begin{array}{c}0.937^{\star * *} \\
(0.012)\end{array}$ \\
\hline Receita de transferências & $\begin{array}{c}0.838^{\star * *} \\
(0.007)\end{array}$ & $\begin{array}{c}0.838^{\star * *} \\
(0.007)\end{array}$ & $\begin{array}{c}0.779^{* * *} \\
(0.002)\end{array}$ & $\begin{array}{c}0.779^{* * *} \\
(0.002)\end{array}$ & $\begin{array}{c}0.838^{* * *} \\
(0.010)\end{array}$ & $\begin{array}{c}0.838^{\star * *} \\
(0.010)\end{array}$ & $\begin{array}{c}0.773^{\star * *} \\
(0.003)\end{array}$ & $\begin{array}{c}0.774^{* * *} \\
(0.003)\end{array}$ \\
\hline Dummy ano eleitoral & $\begin{array}{c}16.281^{* * *} \\
(1.141)\end{array}$ & $\begin{array}{c}20.532^{* * *} \\
(2.144)\end{array}$ & $\begin{array}{c}15.570^{* * *} \\
(1.029)\end{array}$ & $\begin{array}{c}18.522^{* * *} \\
(1.869) \\
\end{array}$ & $\begin{array}{c}17.683^{* * *} \\
(1.517) \\
\end{array}$ & $\begin{array}{c}24.163^{* * *} \\
(2.872)\end{array}$ & $\begin{array}{c}16.835^{* * *} \\
(1.445) \\
\end{array}$ & $\begin{array}{c}22.081^{* * *} \\
(2.557) \\
\end{array}$ \\
\hline PFL & $\begin{array}{c}-0.864 \\
(1.552) \\
\end{array}$ & $\begin{array}{c}0.776 \\
(1.784)\end{array}$ & $\begin{array}{c}-4.619^{\star \star *} \\
(1.468)\end{array}$ & $\begin{array}{c}-3.217^{\star *} \\
(1.608)\end{array}$ & $\begin{array}{c}0.289 \\
(2.271)\end{array}$ & $\begin{array}{c}3.065 \\
(2.655) \\
\end{array}$ & $\begin{array}{c}-4.807^{* *} \\
(2.081)\end{array}$ & $\begin{array}{l}-2.432 \\
(2.293) \\
\end{array}$ \\
\hline PSDB & $\begin{array}{c}1.926 \\
(1.961)\end{array}$ & $\begin{array}{c}1.924 \\
(2.036) \\
\end{array}$ & $\begin{array}{l}3.844^{*} \\
(1.994)\end{array}$ & $\begin{array}{l}3.537^{*} \\
(2.046)\end{array}$ & $\begin{array}{c}0.994 \\
(2.358) \\
\end{array}$ & $\begin{array}{c}1.661 \\
(2.429) \\
\end{array}$ & $\begin{array}{c}-0.749 \\
(2.687) \\
\end{array}$ & $\begin{array}{c}-0.346 \\
(2.764) \\
\end{array}$ \\
\hline PT & $\begin{array}{c}11.393^{* * *} \\
(3.043)\end{array}$ & $\begin{array}{c}12.865^{\star * *} \\
(3.322)\end{array}$ & $\begin{array}{c}2.866 \\
(3.656)\end{array}$ & $\begin{array}{c}4.064 \\
(3.846)\end{array}$ & $\begin{array}{c}21.696^{\star * *} \\
(3.684)\end{array}$ & $\begin{array}{c}22.818^{* * *} \\
(3.988)\end{array}$ & $\begin{array}{l}8.338^{*} \\
(4.666)\end{array}$ & $\begin{array}{l}9.032^{*} \\
(4.937)\end{array}$ \\
\hline PTB & $\begin{array}{c}2.667 \\
(1.856)\end{array}$ & $\begin{array}{c}3.396 \\
(2.113) \\
\end{array}$ & $\begin{array}{l}-2.014 \\
(2.056) \\
\end{array}$ & $\begin{array}{l}-1.923 \\
(2.238) \\
\end{array}$ & $\begin{array}{c}7.863^{* * *} \\
(2.552) \\
\end{array}$ & $\begin{array}{c}9.161^{* * *} \\
(2.899) \\
\end{array}$ & $\begin{array}{c}1.718 \\
(2.766)\end{array}$ & $\begin{array}{c}2.566 \\
(3.026) \\
\end{array}$ \\
\hline PDT & $\begin{array}{c}0.523 \\
(2.058) \\
\end{array}$ & $\begin{array}{c}1.597 \\
(2.342)\end{array}$ & $\begin{array}{c}1.007 \\
(2.083) \\
\end{array}$ & $\begin{array}{c}1.808 \\
(2.281)\end{array}$ & $\begin{array}{l}5.555^{* *} \\
(2.310)\end{array}$ & $\begin{array}{c}9.430^{* * *} \\
(2.712)\end{array}$ & $\begin{array}{l}5.249^{*} \\
(2.745)\end{array}$ & $\begin{array}{c}8.588^{* * *} \\
(3.025)\end{array}$ \\
\hline PDS / PPB & $\begin{array}{c}-10.281^{* * *} \\
(1.711)\end{array}$ & $\begin{array}{c}-9.552^{* * *} \\
(1.999) \\
\end{array}$ & $\begin{array}{c}-5.350^{* * *} \\
(1.781) \\
\end{array}$ & $\begin{array}{c}-5.125^{\star * *} \\
(1.943) \\
\end{array}$ & $\begin{array}{c}-3.283 \\
(2.540) \\
\end{array}$ & $\begin{array}{l}-1.066 \\
(2.995) \\
\end{array}$ & $\begin{array}{l}-0.729 \\
(2.448) \\
\end{array}$ & $\begin{array}{c}1.144 \\
(2.682) \\
\end{array}$ \\
\hline PL & $\begin{array}{l}-1.095 \\
(1.996)\end{array}$ & $\begin{array}{c}1.168 \\
(2.231)\end{array}$ & $\begin{array}{c}-7.167^{* \star *} \\
(2.423)\end{array}$ & $\begin{array}{c}-5.349^{* *} \\
(2.641)\end{array}$ & $\begin{array}{c}2.931 \\
(2.922)\end{array}$ & $\begin{array}{c}5.156 \\
(3.279)\end{array}$ & $\begin{array}{l}-1.288 \\
(3.427)\end{array}$ & $\begin{array}{c}0.746 \\
(3.755)\end{array}$ \\
\hline Outros & $\begin{array}{c}2.522 \\
(1.605)\end{array}$ & $\begin{array}{c}5.403^{\star * *} \\
(1.821)\end{array}$ & $\begin{array}{c}-5.095^{\star \star \star} \\
(1.779)\end{array}$ & $\begin{array}{l}-2.845 \\
(1.947)\end{array}$ & $\begin{array}{c}8.537^{\star \star *} \\
(2.309)\end{array}$ & $\begin{array}{c}10.520^{\star * \star} \\
(2.542)\end{array}$ & $\begin{array}{l}-3.701 \\
(2.544)\end{array}$ & $\begin{array}{l}-2.281 \\
(2.784)\end{array}$ \\
\hline PFL \& ano eleitoral & & $\begin{array}{c}-7.205^{* *} \\
(3.549) \\
\end{array}$ & & $\begin{array}{c}-6.336^{* *} \\
(2.912) \\
\end{array}$ & & $\begin{array}{c}-11.514^{* *} \\
(4.975)\end{array}$ & & $\begin{array}{c}-9.896^{* *} \\
(4.187) \\
\end{array}$ \\
\hline PSDB \& ano eleitoral & & $\begin{array}{l}-1.194 \\
(4.713) \\
\end{array}$ & & $\begin{array}{c}1.275 \\
(3.854) \\
\end{array}$ & & $\begin{array}{l}-7.461 \\
(5.301) \\
\end{array}$ & & $\begin{array}{c}-5.497 \\
(5.299) \\
\end{array}$ \\
\hline PT \& ano eleitoral & & $\begin{array}{l}-7.631 \\
(7.599) \\
\end{array}$ & & $\begin{array}{l}-6.518 \\
(8.268) \\
\end{array}$ & & $\begin{array}{l}-3.767 \\
(9.572) \\
\end{array}$ & & $\begin{array}{c}-1.581 \\
(10.795)\end{array}$ \\
\hline PTB \& ano eleitoral & & $\begin{array}{l}-2.632 \\
(4.479)\end{array}$ & & $\begin{array}{c}0.252 \\
(4.233)\end{array}$ & & $\begin{array}{l}-4.275 \\
(6.228) \\
\end{array}$ & & $\begin{array}{l}-2.358 \\
(5.835) \\
\end{array}$ \\
\hline PDT \& ano eleitoral & & $\begin{array}{l}-4.338 \\
(4.853) \\
\end{array}$ & & $\begin{array}{l}-3.346 \\
(4.178) \\
\end{array}$ & & $\begin{array}{c}-16.600^{* * *} \\
(4.984)\end{array}$ & & $\begin{array}{c}-14.297^{* *} \\
(5.671)\end{array}$ \\
\hline PDS / PPB \& ano eleitoral & & $\begin{array}{l}-2.462 \\
(3.665) \\
\end{array}$ & & $\begin{array}{c}-0.252 \\
(3.572) \\
\end{array}$ & & $\begin{array}{l}-8.690 \\
(5.312) \\
\end{array}$ & & $\begin{array}{l}-7.321 \\
(4.971) \\
\end{array}$ \\
\hline PL \& ano eleitoral & & $\begin{array}{c}-10.261^{* *} \\
(5.043)\end{array}$ & & $\begin{array}{l}-8.404^{*} \\
(4.955)\end{array}$ & & $\begin{array}{c}-8.964 \\
(7.305) \\
\end{array}$ & & $\begin{array}{l}-8.384 \\
(7.227) \\
\end{array}$ \\
\hline Outros \& ano eleitoral & & $\begin{array}{c}-13.272^{* * *} \\
(3.839)\end{array}$ & & $\begin{array}{c}-10.479^{* * *} \\
(3.618)\end{array}$ & & $\begin{array}{l}-7.619 \\
(6.007) \\
\end{array}$ & & $\begin{array}{l}-5.098 \\
(5.319) \\
\end{array}$ \\
\hline Prefeito $=$ Governador & $\begin{array}{c}-4.030^{* * *} \\
(1.022)\end{array}$ & $\begin{array}{c}-3.912^{* * *} \\
(1.025)\end{array}$ & $\begin{array}{c}-4.266^{* * *} \\
(0.923)\end{array}$ & $\begin{array}{c}-4.124^{* * *} \\
(0.926)\end{array}$ & $\begin{array}{l}3.099^{* \star} \\
(1.446)\end{array}$ & $\begin{array}{l}3.285^{\star *} \\
(1.444)\end{array}$ & $\begin{array}{l}2.885^{\star *} \\
(1.316)\end{array}$ & $\begin{array}{l}3.077^{* *} \\
(1.319)\end{array}$ \\
\hline Prefeito $=$ Presidente & $\begin{array}{c}4.969^{* * *} \\
(1.756)\end{array}$ & $\begin{array}{c}5.628^{* * *} \\
(1.831)\end{array}$ & $\begin{array}{l}-0.486 \\
(1.569) \\
\end{array}$ & $\begin{array}{c}-0.085 \\
(1.620) \\
\end{array}$ & $\begin{array}{c}10.351^{* * *} \\
(2.221)\end{array}$ & $\begin{array}{c}11.760^{* * *} \\
(2.363)\end{array}$ & $\begin{array}{l}4.840^{\star *} \\
(2.112) \\
\end{array}$ & $\begin{array}{c}6.043^{* * *} \\
(2.183) \\
\end{array}$ \\
\hline Idosos & $\begin{array}{l}-0.243 \\
(0.450) \\
\end{array}$ & $\begin{array}{l}-0.240 \\
(0.451) \\
\end{array}$ & $\begin{array}{c}-2.054^{* * *} \\
(0.516) \\
\end{array}$ & $\begin{array}{c}-2.045^{\star * *} \\
(0.516) \\
\end{array}$ & $\begin{array}{l}-0.414 \\
(0.666) \\
\end{array}$ & $\begin{array}{l}-0.407 \\
(0.667) \\
\end{array}$ & $\begin{array}{c}-2.272^{* * *} \\
(0.770) \\
\end{array}$ & $\begin{array}{c}-2.251^{* * *} \\
(0.771)\end{array}$ \\
\hline Urbanização & $\begin{array}{c}0.620^{* * *} \\
(0.028)\end{array}$ & $\begin{array}{c}0.619^{* * *} \\
(0.028)\end{array}$ & $\begin{array}{c}0.769^{* * *} \\
(0.042)\end{array}$ & $\begin{array}{c}0.768^{* * *} \\
(0.042)\end{array}$ & $\begin{array}{c}0.640^{* * *} \\
(0.042)\end{array}$ & $\begin{array}{c}0.640^{* * *} \\
(0.042)\end{array}$ & $\begin{array}{c}0.820^{* * *} \\
(0.064)\end{array}$ & $\begin{array}{c}0.820^{* * *} \\
(0.064)\end{array}$ \\
\hline Jovens & $\begin{array}{c}-2.797^{* * *} \\
(0.201)\end{array}$ & $\begin{array}{c}-2.796^{* * *} \\
(0.201)\end{array}$ & $\begin{array}{c}-3.493^{* * *} \\
(0.195)\end{array}$ & $\begin{array}{c}-3.493^{* * *} \\
(0.195)\end{array}$ & $\begin{array}{c}-3.386^{* * *} \\
(0.311)\end{array}$ & $\begin{array}{c}-3.384^{* * *} \\
(0.311)\end{array}$ & $\begin{array}{c}-4.125^{\star * *} \\
(0.326)\end{array}$ & $\begin{array}{c}-4.117^{\star * *} \\
(0.326)\end{array}$ \\
\hline População & $\begin{array}{c}-11.325^{\star * *} \\
(1.488)\end{array}$ & $\begin{array}{c}-11.324^{* * *} \\
(1.488)\end{array}$ & $\begin{array}{c}-19.488^{* * *} \\
(1.049)\end{array}$ & $\begin{array}{c}-19.486^{\star * *} \\
(1.049)\end{array}$ & $\begin{array}{c}-12.975^{\star \star *} \\
(2.114)\end{array}$ & $\begin{array}{c}-12.955^{* \star *} \\
(2.114) \\
\end{array}$ & $\begin{array}{c}-22.025^{\star \star *} \\
(1.485)\end{array}$ & $\begin{array}{c}-21.997^{* * *} \\
(1.486)\end{array}$ \\
\hline Tendência linear & $\begin{array}{c}13.340^{\star * *} \\
(0.540)\end{array}$ & $\begin{array}{c}13.356^{\star * *} \\
(0.540)\end{array}$ & $\begin{array}{c}15.872^{* * *} \\
(0.442) \\
\end{array}$ & $\begin{array}{c}15.890^{\star * *} \\
(0.443)\end{array}$ & $\begin{array}{c}16.701^{* * *} \\
(0.754) \\
\end{array}$ & $\begin{array}{c}16.668^{* * *} \\
(0.753) \\
\end{array}$ & $\begin{array}{c}19.522^{\star * *} \\
(0.626)\end{array}$ & $\begin{array}{c}19.495^{\star * *} \\
(0.626)\end{array}$ \\
\hline Tendência quadrática & $\begin{array}{c}-0.898^{* * *} \\
(0.030)\end{array}$ & $\begin{array}{c}-0.898^{* * *} \\
(0.030)\end{array}$ & $\begin{array}{c}-0.939^{* * *} \\
(0.026)\end{array}$ & $\begin{array}{c}-0.939^{* * *} \\
(0.026)\end{array}$ & $\begin{array}{c}-1.096^{* * *} \\
(0.041)\end{array}$ & $\begin{array}{c}-1.093^{* * *} \\
(0.041)\end{array}$ & $\begin{array}{c}-1.158^{* * *} \\
(0.037) \\
\end{array}$ & $\begin{array}{c}-1.156^{* * *} \\
(0.037)\end{array}$ \\
\hline Constante & $\begin{array}{c}191.763^{* * *} \\
(22.051)\end{array}$ & $\begin{array}{c}190.533^{* * *} \\
(22.060)\end{array}$ & $\begin{array}{c}316.452^{* * *} \\
(13.936)\end{array}$ & $\begin{array}{c}315.549^{* * *} \\
(13.949)\end{array}$ & $\begin{array}{c}215.275^{* * *} \\
(31.728)\end{array}$ & $\begin{array}{c}213.164^{\star * *} \\
(31.775)\end{array}$ & $\begin{array}{c}354.310^{* * *} \\
(20.582)\end{array}$ & $\begin{array}{c}352.131^{\star * *} \\
(20.608)\end{array}$ \\
\hline $\mathrm{R}^{2}$ & 0.9088 & 0.9088 & 0.9077 & 0.9077 & 0.8985 & 0.8986 & 0.8972 & 0.8972 \\
\hline Observações & 66384 & 66384 & 66384 & 66384 & 33525 & 33525 & 33525 & 33525 \\
\hline
\end{tabular}


Apêndice 1b.3-Despesa de pessoal

\begin{tabular}{|c|c|c|c|c|c|c|c|c|}
\hline \multirow[b]{3}{*}{ Receita tributária } & \multicolumn{4}{|c|}{ Painel não balanceado } & \multicolumn{4}{|c|}{ Painel não balanceado } \\
\hline & \multicolumn{2}{|c|}{ OLS } & \multicolumn{2}{|c|}{ Efeitos aleatórios } & \multicolumn{2}{|c|}{ OLS } & \multicolumn{2}{|c|}{ Efeitos aleatórios } \\
\hline & $\begin{array}{c}0.519^{\star \star *} \\
(0.018)\end{array}$ & $\begin{array}{c}0.519^{\star * *} \\
(0.018)\end{array}$ & $\begin{array}{c}0.403^{\star * *} \\
(0.006)\end{array}$ & $\begin{array}{c}0.403^{* * *} \\
(0.006)\end{array}$ & $\begin{array}{c}0.461^{* \star *} \\
(0.022)\end{array}$ & $\begin{array}{c}0.461^{* * *} \\
(0.022)\end{array}$ & $\begin{array}{c}0.356^{\star * *} \\
(0.008)\end{array}$ & $\begin{array}{c}0.356^{\star \star *} \\
(0.008)\end{array}$ \\
\hline Receita de transferências & $\begin{array}{c}0.371^{* * *} \\
(0.005)\end{array}$ & $\begin{array}{c}0.371^{* * *} \\
(0.005)\end{array}$ & $\begin{array}{c}0.329^{* * *} \\
(0.002)\end{array}$ & $\begin{array}{c}0.329^{* * *} \\
(0.002)\end{array}$ & $\begin{array}{c}0.393^{* * *} \\
(0.006)\end{array}$ & $\begin{array}{c}0.393^{* * *} \\
(0.006)\end{array}$ & $\begin{array}{c}0.348^{* * *} \\
(0.002)\end{array}$ & $\begin{array}{c}0.348^{* * *} \\
(0.002)\end{array}$ \\
\hline Dummy ano eleitoral & $\begin{array}{c}0.879 \\
(0.906) \\
\end{array}$ & $\begin{array}{c}2.483 \\
(1.638)\end{array}$ & $\begin{array}{c}0.473 \\
(0.705) \\
\end{array}$ & $\begin{array}{c}1.940 \\
(1.281)\end{array}$ & $\begin{array}{l}2.937^{* *} \\
(1.193)\end{array}$ & $\begin{array}{c}7.199^{* * *} \\
(2.070)\end{array}$ & $\begin{array}{l}2.378^{* *} \\
(0.966)\end{array}$ & $\begin{array}{c}6.141^{* * *} \\
(1.709)\end{array}$ \\
\hline PFL & $\begin{array}{c}-4.142^{* * *} \\
(1.043)\end{array}$ & $\begin{array}{c}-3.113^{* * *} \\
(1.177)\end{array}$ & $\begin{array}{c}-3.554^{* * *} \\
(1.023)\end{array}$ & $\begin{array}{c}-2.299^{\star *} \\
(1.118)\end{array}$ & $\begin{array}{l}-2.445 \\
(1.490) \\
\end{array}$ & $\begin{array}{c}-0.075 \\
(1.702) \\
\end{array}$ & $\begin{array}{c}-3.059^{* *} \\
(1.413)\end{array}$ & $\begin{array}{l}-0.775 \\
(1.553) \\
\end{array}$ \\
\hline PSDB & $\begin{array}{c}4.498^{\star * *} \\
(1.447) \\
\end{array}$ & $\begin{array}{c}4.788^{\star \star \star} \\
(1.505) \\
\end{array}$ & $\begin{array}{c}8.414^{* \star *} \\
(1.382) \\
\end{array}$ & $\begin{array}{c}8.640^{* \star *} \\
(1.417) \\
\end{array}$ & $\begin{array}{c}1.594 \\
(1.783) \\
\end{array}$ & $\begin{array}{c}2.543 \\
(1.854) \\
\end{array}$ & $\begin{array}{l}4.563^{* *} \\
(1.816) \\
\end{array}$ & $\begin{array}{c}5.360^{\star \star \star} \\
(1.866) \\
\end{array}$ \\
\hline PT & $\begin{array}{c}10.532^{* * *} \\
(2.395)\end{array}$ & $\begin{array}{c}10.131^{\star * *} \\
(2.548)\end{array}$ & $\begin{array}{c}0.124 \\
(2.549)\end{array}$ & $\begin{array}{c}0.000 \\
(2.676)\end{array}$ & $\begin{array}{c}12.197^{\star \star *} \\
(2.942)\end{array}$ & $\begin{array}{c}12.511^{* * *} \\
(3.107)\end{array}$ & $\begin{array}{l}-0.603 \\
(3.168) \\
\end{array}$ & $\begin{array}{l}-0.268 \\
(3.344)\end{array}$ \\
\hline PTB & $\begin{array}{c}2.021 \\
(1.529) \\
\end{array}$ & $\begin{array}{c}2.154 \\
(1.704)\end{array}$ & $\begin{array}{l}-0.747 \\
(1.431) \\
\end{array}$ & $\begin{array}{l}-0.914 \\
(1.553) \\
\end{array}$ & $\begin{array}{c}2.849 \\
(1.945) \\
\end{array}$ & $\begin{array}{l}4.049^{*} \\
(2.160) \\
\end{array}$ & $\begin{array}{c}0.456 \\
(1.876) \\
\end{array}$ & $\begin{array}{c}1.363 \\
(2.046) \\
\end{array}$ \\
\hline PDT & $\begin{array}{c}14.586^{* * *} \\
(1.500)\end{array}$ & $\begin{array}{c}14.066^{* * *} \\
(1.688)\end{array}$ & $\begin{array}{c}5.079^{* * *} \\
(1.449)\end{array}$ & $\begin{array}{c}4.313^{* * *} \\
(1.583)\end{array}$ & $\begin{array}{c}15.014^{* * *} \\
(1.886)\end{array}$ & $\begin{array}{c}16.162^{* * *} \\
(2.123)\end{array}$ & $\begin{array}{c}5.382^{* * *} \\
(1.861)\end{array}$ & $\begin{array}{c}6.278^{* * *} \\
(2.045)\end{array}$ \\
\hline PDS / PPB & $\begin{array}{l}-1.420 \\
(1.279) \\
\end{array}$ & $\begin{array}{l}-2.506^{*} \\
(1.431) \\
\end{array}$ & $\begin{array}{c}-3.452^{* * *} \\
(1.239) \\
\end{array}$ & $\begin{array}{c}-4.227^{* \star *} \\
(1.349) \\
\end{array}$ & $\begin{array}{c}0.805 \\
(1.744) \\
\end{array}$ & $\begin{array}{c}0.676 \\
(1.950) \\
\end{array}$ & $\begin{array}{l}-2.118 \\
(1.660) \\
\end{array}$ & $\begin{array}{l}-2.122 \\
(1.815) \\
\end{array}$ \\
\hline$P L$ & $\begin{array}{c}-11.703^{* * *} \\
(1.583)\end{array}$ & $\begin{array}{c}-9.272^{* \star *} \\
(1.754)\end{array}$ & $\begin{array}{c}-9.447^{* \star *} \\
(1.685)\end{array}$ & $\begin{array}{c}-7.765^{\star \star *} \\
(1.832)\end{array}$ & $\begin{array}{c}-9.034^{* * *} \\
(2.386)\end{array}$ & $\begin{array}{c}-5.986^{* *} \\
(2.660)\end{array}$ & $\begin{array}{l}-1.915 \\
(2.322) \\
\end{array}$ & $\begin{array}{c}0.701 \\
(2.538)\end{array}$ \\
\hline Outros & $\begin{array}{l}-0.750 \\
(1.226)\end{array}$ & $\begin{array}{c}0.868 \\
(1.375)\end{array}$ & $\begin{array}{c}-2.945^{\star *} \\
(1.236)\end{array}$ & $\begin{array}{l}-1.657 \\
(1.350) \\
\end{array}$ & $\begin{array}{c}2.234 \\
(1.731)\end{array}$ & $\begin{array}{l}4.081^{* *} \\
(1.935)\end{array}$ & $\begin{array}{c}-0.809 \\
(1.723) \\
\end{array}$ & $\begin{array}{c}0.592 \\
(1.882)\end{array}$ \\
\hline PFL \& ano eleitoral & & $\begin{array}{l}-4.640^{*} \\
(2.536) \\
\end{array}$ & & $\begin{array}{c}-5.789^{\star \star *} \\
(1.995) \\
\end{array}$ & & $\begin{array}{c}-10.025^{\star \star *} \\
(3.446) \\
\end{array}$ & & $\begin{array}{c}-9.765^{\star * *} \\
(2.799) \\
\end{array}$ \\
\hline PSDB \& ano eleitoral & & $\begin{array}{l}-2.868 \\
(3.646) \\
\end{array}$ & & $\begin{array}{l}-2.451 \\
(2.641) \\
\end{array}$ & & $\begin{array}{l}-8.648^{*} \\
(4.514) \\
\end{array}$ & & $\begin{array}{c}-7.791^{* *} \\
(3.543) \\
\end{array}$ \\
\hline PT \& ano eleitoral & & $\begin{array}{c}3.500 \\
(6.962)\end{array}$ & & $\begin{array}{c}1.817 \\
(5.666)\end{array}$ & & $\begin{array}{c}0.466 \\
(8.763) \\
\end{array}$ & & $\begin{array}{c}0.129 \\
(7.218)\end{array}$ \\
\hline PTB \& ano eleitoral & & $\begin{array}{l}-0.131 \\
(3.876) \\
\end{array}$ & & $\begin{array}{c}1.349 \\
(2.900)\end{array}$ & & $\begin{array}{l}-4.355 \\
(4.927) \\
\end{array}$ & & $\begin{array}{l}-3.064 \\
(3.901) \\
\end{array}$ \\
\hline PDT \& ano eleitoral & & $\begin{array}{c}2.815 \\
(3.591) \\
\end{array}$ & & $\begin{array}{c}3.958 \\
(2.862) \\
\end{array}$ & & $\begin{array}{l}-4.088 \\
(4.527) \\
\end{array}$ & & $\begin{array}{l}-2.932 \\
(3.791) \\
\end{array}$ \\
\hline PDS / PPB \& ano eleitoral & & $\begin{array}{l}6.005^{\star} \\
(3.134) \\
\end{array}$ & & $\begin{array}{l}4.445^{\star} \\
(2.447) \\
\end{array}$ & & $\begin{array}{c}2.502 \\
(4.229) \\
\end{array}$ & & $\begin{array}{c}1.830 \\
(3.323) \\
\end{array}$ \\
\hline PL \& ano eleitoral & & $\begin{array}{c}-11.437^{* * *} \\
(4.021)\end{array}$ & & $\begin{array}{c}-7.862^{\star *} \\
(3.394) \\
\end{array}$ & & $\begin{array}{c}-13.400^{\star *} \\
(5.876)\end{array}$ & & $\begin{array}{c}-11.574^{* *} \\
(4.831) \\
\end{array}$ \\
\hline Outros \& ano eleitoral & & $\begin{array}{c}-7.607^{\star *} \\
(2.988)\end{array}$ & & $\begin{array}{c}-5.992^{* *} \\
(2.479)\end{array}$ & & $\begin{array}{l}-7.594^{*} \\
(4.174)\end{array}$ & & $\begin{array}{c}-5.480 \\
(3.556)\end{array}$ \\
\hline Prefeito $=$ Governador & $\begin{array}{c}-4.397^{* * *} \\
(0.743)\end{array}$ & $\begin{array}{c}-4.452^{\star \star \star} \\
(0.743)\end{array}$ & $\begin{array}{c}-2.335^{\star \star \star} \\
(0.635)\end{array}$ & $\begin{array}{c}-2.349^{\star \star *} \\
(0.637)\end{array}$ & $\begin{array}{c}-2.732^{* \star \star} \\
(1.019)\end{array}$ & $\begin{array}{c}-2.619^{\star \star \star} \\
(1.019)\end{array}$ & $\begin{array}{l}-0.330 \\
(0.884) \\
\end{array}$ & $\begin{array}{l}-0.197 \\
(0.886) \\
\end{array}$ \\
\hline Prefeito $=$ Presidente & $\begin{array}{c}3.458^{\star \star *} \\
(1.238)\end{array}$ & $\begin{array}{c}3.877^{\star \star *} \\
(1.282)\end{array}$ & $\begin{array}{l}-0.617 \\
(1.077) \\
\end{array}$ & $\begin{array}{l}-0.229 \\
(1.112) \\
\end{array}$ & $\begin{array}{c}6.929^{* \star *} \\
(1.514)\end{array}$ & $\begin{array}{c}8.035^{\star \star \star *} \\
(1.579) \\
\end{array}$ & $\begin{array}{l}2.518^{*} \\
(1.414) \\
\end{array}$ & $\begin{array}{l}3.564^{* *} \\
(1.462) \\
\end{array}$ \\
\hline Idosos & $\begin{array}{c}-0.920^{\star * *} \\
(0.317)\end{array}$ & $\begin{array}{c}-0.916^{\star * *} \\
(0.317)\end{array}$ & $\begin{array}{c}-0.987^{* \star *} \\
(0.381)\end{array}$ & $\begin{array}{c}-0.986^{\star * *} \\
(0.381)\end{array}$ & $\begin{array}{c}-1.326^{* * *} \\
(0.438)\end{array}$ & $\begin{array}{c}-1.320^{* \star *} \\
(0.439)\end{array}$ & $\begin{array}{l}-0.823 \\
(0.559) \\
\end{array}$ & $\begin{array}{l}-0.809 \\
(0.558) \\
\end{array}$ \\
\hline Urbanização & $\begin{array}{c}0.332^{* * *} \\
(0.021)\end{array}$ & $\begin{array}{c}0.332^{* * *} \\
(0.021)\end{array}$ & $\begin{array}{c}0.453^{* * *} \\
(0.033)\end{array}$ & $\begin{array}{c}0.452^{* * *} \\
(0.033)\end{array}$ & $\begin{array}{c}0.237^{* * *} \\
(0.029)\end{array}$ & $\begin{array}{c}0.236^{* * *} \\
(0.029)\end{array}$ & $\begin{array}{c}0.346^{* * *} \\
(0.049)\end{array}$ & $\begin{array}{c}0.345^{\star \star *} \\
(0.049)\end{array}$ \\
\hline Jovens & $\begin{array}{c}-3.569^{* * *} \\
(0.140)\end{array}$ & $\begin{array}{c}-3.568^{* * *} \\
(0.140)\end{array}$ & $\begin{array}{c}-3.633^{* * *} \\
(0.149) \\
\end{array}$ & $\begin{array}{c}-3.635^{* * *} \\
(0.149)\end{array}$ & $\begin{array}{c}-4.053^{* * *} \\
(0.183)\end{array}$ & $\begin{array}{c}-4.050^{* * *} \\
(0.183)\end{array}$ & $\begin{array}{c}-4.265^{\star * *} \\
(0.247) \\
\end{array}$ & $\begin{array}{c}-4.260^{\star \star *} \\
(0.247) \\
\end{array}$ \\
\hline População & $\begin{array}{l}1.904^{*} \\
(1.024)\end{array}$ & $\begin{array}{l}1.906^{*} \\
(1.024)\end{array}$ & $\begin{array}{c}-3.286^{\star \star \star} \\
(0.827)\end{array}$ & $\begin{array}{c}-3.265^{\star \star *} \\
(0.826)\end{array}$ & $\begin{array}{c}3.554^{\star \star *} \\
(1.249)\end{array}$ & $\begin{array}{c}3.572^{\star \star \star} \\
(1.249)\end{array}$ & $\begin{array}{l}-1.153 \\
(1.156) \\
\end{array}$ & $\begin{array}{c}-1.103 \\
(1.155) \\
\end{array}$ \\
\hline Tendência linear & $\begin{array}{c}-1.464^{* * *} \\
(0.351)\end{array}$ & $\begin{array}{c}-1.444^{* * *} \\
(0.351)\end{array}$ & $\begin{array}{l}0.730^{* *} \\
(0.308)\end{array}$ & $\begin{array}{l}0.747^{* *} \\
(0.308)\end{array}$ & $\begin{array}{l}-0.619 \\
(0.483)\end{array}$ & $\begin{array}{l}-0.626 \\
(0.483)\end{array}$ & $\begin{array}{l}1.353^{* * *} \\
(0.428)\end{array}$ & $\begin{array}{l}1.341^{* * *} \\
(0.428)\end{array}$ \\
\hline Tendência quadrática & $\begin{array}{c}0.089^{* * *} \\
(0.021)\end{array}$ & $\begin{array}{c}0.088^{* * *} \\
(0.021)\end{array}$ & $\begin{array}{c}0.063^{* * *} \\
(0.018)\end{array}$ & $\begin{array}{c}0.062^{* * *} \\
(0.018)\end{array}$ & $\begin{array}{c}0.017 \\
(0.028)\end{array}$ & $\begin{array}{c}0.018 \\
(0.028)\end{array}$ & $\begin{array}{l}-0.010 \\
(0.025)\end{array}$ & $\begin{array}{c}-0.009 \\
(0.025)\end{array}$ \\
\hline Constante & $\begin{array}{c}126.243^{* * *} \\
(15.047)\end{array}$ & $\begin{array}{c}125.672^{* * *} \\
(15.063)\end{array}$ & $\begin{array}{c}184.218^{* * *} \\
(10.626)\end{array}$ & $\begin{array}{c}183.652^{* * *} \\
(10.626)\end{array}$ & $\begin{array}{c}125.273^{* * *} \\
(17.609)\end{array}$ & $\begin{array}{c}123.698^{* * *} \\
(17.646)\end{array}$ & $\begin{array}{c}187.149^{* * *} \\
(15.468)\end{array}$ & $\begin{array}{c}185.260^{* * *} \\
(15.473)\end{array}$ \\
\hline $\mathrm{R}^{2}$ & 0.7979 & 0.7980 & 0.7940 & 0.7941 & 0.7960 & 0.7961 & 0.7922 & 0.7923 \\
\hline Observações & 66384 & 66384 & 66384 & 66384 & 33525 & 33525 & 33525 & 33525 \\
\hline
\end{tabular}


Apêndice 1b.4-Transferências correntes

\begin{tabular}{|c|c|c|c|c|c|c|c|c|}
\hline \multirow[b]{3}{*}{ Receita tributária } & \multicolumn{4}{|c|}{ Painel não balanceado } & \multicolumn{4}{|c|}{ Painel não balanceado } \\
\hline & \multicolumn{2}{|c|}{ OLS } & \multicolumn{2}{|c|}{ Efeitos aleatórios } & \multicolumn{2}{|c|}{ OLS } & \multicolumn{2}{|c|}{ Efeitos aleatórios } \\
\hline & $\begin{array}{c}0.080^{* * *} \\
(0.011)\end{array}$ & $\begin{array}{c}0.080^{\star * *} \\
(0.011)\end{array}$ & $\begin{array}{c}0.081^{* \star * *} \\
(0.005)\end{array}$ & $\begin{array}{c}0.081^{* * *} \\
(0.005)\end{array}$ & $\begin{array}{c}0.090^{* * *} \\
(0.015)\end{array}$ & $\begin{array}{c}0.090^{* * *} \\
(0.015)\end{array}$ & $\begin{array}{c}0.071^{* * *} \\
(0.007)\end{array}$ & $\begin{array}{c}0.071^{* * *} \\
(0.007)\end{array}$ \\
\hline Receita de transferências & $\begin{array}{c}0.122^{* \star *} \\
(0.005)\end{array}$ & $\begin{array}{c}0.122^{\star * \star} \\
(0.005)\end{array}$ & $\begin{array}{c}0.125^{\star * *} \\
(0.001)\end{array}$ & $\begin{array}{c}0.125^{\star \star *} \\
(0.001)\end{array}$ & $\begin{array}{c}0.113^{* * *} \\
(0.005)\end{array}$ & $\begin{array}{c}0.113^{* * *} \\
(0.005)\end{array}$ & $\begin{array}{c}0.109^{* * *} \\
(0.002)\end{array}$ & $\begin{array}{c}0.109^{* * *} \\
(0.002)\end{array}$ \\
\hline Dummy ano eleitoral & $\begin{array}{c}-11.191^{* * *} \\
(0.651)\end{array}$ & $\begin{array}{c}-8.659^{* * *} \\
(1.200)\end{array}$ & $\begin{array}{c}-10.890^{* * *} \\
(0.625)\end{array}$ & $\begin{array}{c}-7.524^{\star * *} \\
(1.153)\end{array}$ & $\begin{array}{c}-13.260^{\star * *} \\
(0.877)\end{array}$ & $\begin{array}{c}-9.989^{* * *} \\
(1.512)\end{array}$ & $\begin{array}{c}-13.139^{* * *} \\
(0.848)\end{array}$ & $\begin{array}{c}-9.109^{* * *} \\
(1.522)\end{array}$ \\
\hline PFL & $\begin{array}{c}6.144^{* * *} \\
(0.899)\end{array}$ & $\begin{array}{c}7.211^{* * *} \\
(1.069)\end{array}$ & $\begin{array}{c}6.828^{* * *} \\
(0.944)\end{array}$ & $\begin{array}{c}8.239^{\star * *} \\
(1.058)\end{array}$ & $\begin{array}{c}8.861^{* * *} \\
(1.265)\end{array}$ & $\begin{array}{c}10.191^{* * *} \\
(1.518)\end{array}$ & $\begin{array}{c}8.131^{* * *} \\
(1.298)\end{array}$ & $\begin{array}{c}9.757^{\star * *} \\
(1.457)\end{array}$ \\
\hline PSDB & $\begin{array}{c}-13.047^{* * *} \\
(1.501)\end{array}$ & $\begin{array}{c}-14.012^{* * *} \\
(1.566)\end{array}$ & $\begin{array}{c}-12.114^{* * *} \\
(1.370)\end{array}$ & $\begin{array}{c}-12.968^{* * *} \\
(1.422)\end{array}$ & $\begin{array}{c}12.749^{* * *} \\
(1.892)\end{array}$ & $\begin{array}{c}-13.447^{* * *} \\
(2.005)\end{array}$ & \begin{tabular}{|c|}
$-12.699^{* \star *}$ \\
$(1.776)$
\end{tabular} & $\begin{array}{c}-13.274^{* * *} \\
(1.845)\end{array}$ \\
\hline PT & $\begin{array}{c}15.088^{* * *} \\
(2.756)\end{array}$ & $\begin{array}{c}13.597^{* * *} \\
(3.060)\end{array}$ & $\begin{array}{c}9.715^{* * *} \\
(2.507)\end{array}$ & $\begin{array}{c}8.787^{\star * *} \\
(2.713)\end{array}$ & $\begin{array}{c}17.265^{\star * *} \\
(3.679)\end{array}$ & $\begin{array}{c}16.210^{* * *} \\
(4.086)\end{array}$ & $\begin{array}{c}9.669^{* * *} \\
(3.119)\end{array}$ & $\begin{array}{c}9.272^{* * *} \\
(3.386)\end{array}$ \\
\hline PTB & $\begin{array}{c}1.598 \\
(1.198)\end{array}$ & $\begin{array}{l}2.906^{* *} \\
(1.441) \\
\end{array}$ & $\begin{array}{l}3.081^{* *} \\
(1.324)\end{array}$ & $\begin{array}{c}4.611^{* * *} \\
(1.470)\end{array}$ & $\begin{array}{c}6.624^{* * *} \\
(1.655) \\
\end{array}$ & $\begin{array}{c}8.839^{* * *} \\
(2.000) \\
\end{array}$ & $\begin{array}{c}7.522^{* * *} \\
(1.735) \\
\end{array}$ & $\begin{array}{c}10.095^{* * *} \\
(1.930)\end{array}$ \\
\hline PDT & $\begin{array}{c}4.488^{\star * \star} \\
(1.232)\end{array}$ & $\begin{array}{c}5.786^{\star \star \star *} \\
(1.414)\end{array}$ & $\begin{array}{c}7.805^{\star * *} \\
(1.317)\end{array}$ & $\begin{array}{c}9.503^{\star * \star} \\
(1.467)\end{array}$ & $\begin{array}{c}7.943^{* * *} \\
(1.576)\end{array}$ & $\begin{array}{c}9.955^{\star * *} \\
(1.849)\end{array}$ & $\begin{array}{c}10.263^{\star * *} \\
(1.690)\end{array}$ & $\begin{array}{c}12.515^{\star * *} \\
(1.888)\end{array}$ \\
\hline PDS / PPB & $\begin{array}{l}1.771^{*} \\
(1.065)\end{array}$ & $\begin{array}{l}3.184^{* *} \\
(1.253)\end{array}$ & $\begin{array}{c}4.364^{* * *} \\
(1.145)\end{array}$ & $\begin{array}{c}6.166^{* * *} \\
(1.277)\end{array}$ & $\begin{array}{c}6.214^{* * *} \\
(1.439)\end{array}$ & $\begin{array}{c}8.395^{\text {***}} \\
(1.700)\end{array}$ & $\begin{array}{c}7.786^{* * *} \\
(1.528)\end{array}$ & $\begin{array}{c}10.292^{* * *} \\
(1.704)\end{array}$ \\
\hline PL & $\begin{array}{c}7.301^{* * *} \\
(1.261)\end{array}$ & $\begin{array}{c}7.872^{\star * *} \\
(1.481)\end{array}$ & $\begin{array}{c}6.135^{\star * *} \\
(1.548)\end{array}$ & $\begin{array}{c}6.925^{\star * *} \\
(1.717)\end{array}$ & $\begin{array}{c}13.066^{\star * *} \\
(1.789)\end{array}$ & $\begin{array}{c}13.858^{* * *} \\
(2.118)\end{array}$ & $\begin{array}{c}10.628^{\star * *} \\
(2.125)\end{array}$ & $\begin{array}{c}11.635^{\star * *} \\
(2.362)\end{array}$ \\
\hline Outros & $\begin{array}{c}2.756^{* * *} \\
(1.001)\end{array}$ & $\begin{array}{c}4.872^{\star \star *} \\
(1.186)\end{array}$ & $\begin{array}{c}5.033^{* * *} \\
(1.147)\end{array}$ & $\begin{array}{c}7.452^{\star \star \star} \\
(1.281)\end{array}$ & $\begin{array}{c}6.928^{* * *} \\
(1.459)\end{array}$ & $\begin{array}{c}8.392^{* * *} \\
(1.714)\end{array}$ & $\begin{array}{c}6.458^{\star * *} \\
(1.600)\end{array}$ & $\begin{array}{c}8.219^{\star * *} \\
(1.783)\end{array}$ \\
\hline PFL \& ano eleitoral & & $\begin{array}{c}-3.813^{\star \star} \\
(1.921)\end{array}$ & & $\begin{array}{c}-5.010^{* * *} \\
(1.793)\end{array}$ & & $\begin{array}{l}-4.619^{*} \\
(2.587)\end{array}$ & & $\begin{array}{c}-5.584^{* *} \\
(2.487)\end{array}$ \\
\hline PSDB \& ano eleitoral & & $\begin{array}{l}2.987 \\
(2.676)\end{array}$ & & $\begin{array}{c}1.720 \\
(2.377) \\
\end{array}$ & & $\begin{array}{c}1.117 \\
(3.554) \\
\end{array}$ & & $\begin{array}{l}-0.248 \\
(3.156) \\
\end{array}$ \\
\hline PT \& ano eleitoral & & $\begin{array}{c}8.557 \\
(6.910) \\
\end{array}$ & & $\begin{array}{c}6.705 \\
(5.120) \\
\end{array}$ & & $\begin{array}{c}6.904 \\
(9.225) \\
\end{array}$ & & $\begin{array}{c}4.541 \\
(6.460) \\
\end{array}$ \\
\hline PTB \& ano eleitoral & & $\begin{array}{c}-4.900^{* *} \\
(2.479)\end{array}$ & & $\begin{array}{c}-5.601^{* *} \\
(2.599)\end{array}$ & & $\begin{array}{c}-8.523^{* * *} \\
(3.323)\end{array}$ & & $\begin{array}{c}-9.877^{* * *} \\
(3.458)\end{array}$ \\
\hline PDT \& ano eleitoral & & $\begin{array}{l}-4.813^{*} \\
(2.851)\end{array}$ & & $\begin{array}{c}-6.259^{* *} \\
(2.558)\end{array}$ & & $\begin{array}{c}-7.570^{* *} \\
(3.500)\end{array}$ & & $\begin{array}{c}-8.375^{\star *} \\
(3.353)\end{array}$ \\
\hline PDS / PPB \& ano eleitoral & & $\begin{array}{l}-5.137^{* *} \\
(2.292) \\
\end{array}$ & & $\begin{array}{c}-6.531^{\star \star \star} \\
(2.197) \\
\end{array}$ & & $\begin{array}{c}-8.228^{\star \star \star} \\
(2.992)\end{array}$ & & $\begin{array}{c}-9.367^{\star * \star} \\
(2.950)\end{array}$ \\
\hline PL \& ano eleitoral & & $\begin{array}{l}-1.834 \\
(2.804) \\
\end{array}$ & & $\begin{array}{l}-2.480 \\
(3.035) \\
\end{array}$ & & $\begin{array}{l}-2.422 \\
(3.863) \\
\end{array}$ & & $\begin{array}{l}-3.066 \\
(4.272) \\
\end{array}$ \\
\hline Outros \& ano eleitoral & & $\begin{array}{c}-8.181^{* * *} \\
(2.134)\end{array}$ & & $\begin{array}{c}-9.233^{* * *} \\
(2.223)\end{array}$ & & $\begin{array}{l}-5.215^{*} \\
(3.117) \\
\end{array}$ & & $\begin{array}{c}-6.194^{* *} \\
(3.156)\end{array}$ \\
\hline Prefeito $=$ Governador & $\begin{array}{c}-4.465^{\star \star \star} \\
(0.641)\end{array}$ & $\begin{array}{c}-4.275^{\star * *} \\
(0.646)\end{array}$ & $\begin{array}{c}-2.199^{* * *} \\
(0.608)\end{array}$ & $\begin{array}{c}-1.955^{\star * *} \\
(0.610)\end{array}$ & $\begin{array}{c}-2.014^{\star *} \\
(0.891)\end{array}$ & $\begin{array}{c}-1.876^{\star *} \\
(0.899)\end{array}$ & $\begin{array}{l}-0.289 \\
(0.831)\end{array}$ & $\begin{array}{l}-0.103 \\
(0.833)\end{array}$ \\
\hline Prefeito $=$ Presidente & $\begin{array}{c}21.508^{\star \star \star} \\
(1.268)\end{array}$ & $\begin{array}{c}22.035^{\star \star \star} \\
(1.306)\end{array}$ & $\begin{array}{c}23.360^{\star * \star} \\
(1.059)\end{array}$ & $\begin{array}{c}24.167^{\star \star \star} \\
(1.099)\end{array}$ & $\begin{array}{c}23.164^{* * *} \\
(1.487)\end{array}$ & $\begin{array}{c}23.956^{* \star *} \\
(1.537)\end{array}$ & $\begin{array}{c}24.268^{* * *} \\
(1.359)\end{array}$ & $\begin{array}{c}25.333^{\star * \star} \\
(1.414)\end{array}$ \\
\hline Idosos & $\begin{array}{c}3.524^{\star \star \star} \\
(0.284)\end{array}$ & $\begin{array}{c}3.524^{\star \star \star *} \\
(0.284)\end{array}$ & $\begin{array}{c}5.820^{\star * \star} \\
(0.310)\end{array}$ & $\begin{array}{c}5.827^{\star \star \star} \\
(0.310)\end{array}$ & $\begin{array}{c}2.690^{\star \star \star *} \\
(0.360)\end{array}$ & $\begin{array}{c}2.691^{\star \star \star} \\
(0.360)\end{array}$ & $\begin{array}{c}4.292^{\star \star \star} \\
(0.475)\end{array}$ & $\begin{array}{c}4.298^{\star \star \star} \\
(0.475)\end{array}$ \\
\hline Urbanização & $\begin{array}{c}0.057^{* * *} \\
(0.017)\end{array}$ & $\begin{array}{c}0.057^{* * *} \\
(0.017)\end{array}$ & $\begin{array}{c}0.091^{* * *} \\
(0.024)\end{array}$ & $\begin{array}{c}0.091^{\star * *} \\
(0.024)\end{array}$ & $\begin{array}{c}0.081^{* * *} \\
(0.024)\end{array}$ & $\begin{array}{c}0.081^{* * *} \\
(0.024)\end{array}$ & $\begin{array}{c}0.134^{* * *} \\
(0.037)\end{array}$ & $\begin{array}{c}0.134^{\star \star *} \\
(0.037)\end{array}$ \\
\hline Jovens & $\begin{array}{c}-1.256^{\star * *} \\
(0.134)\end{array}$ & $\begin{array}{c}-1.256^{\star * *} \\
(0.135)\end{array}$ & $\begin{array}{c}-0.559^{* * *} \\
(0.112)\end{array}$ & $\begin{array}{c}-0.556^{* * *} \\
(0.112)\end{array}$ & $\begin{array}{c}-1.229^{* * *} \\
(0.154)\end{array}$ & $\begin{array}{c}-1.228^{* \star *} \\
(0.154)\end{array}$ & $\begin{array}{c}-0.792^{\star * *} \\
(0.188)\end{array}$ & $\begin{array}{c}-0.787^{\star \star *} \\
(0.188)\end{array}$ \\
\hline População & $\begin{array}{c}10.003^{\star * *} \\
(0.918)\end{array}$ & $\begin{array}{c}10.009^{\star \star *} \\
(0.918)\end{array}$ & $\begin{array}{c}11.089^{\star * *} \\
(0.567)\end{array}$ & $\begin{array}{c}11.105^{\star \star *} \\
(0.568)\end{array}$ & $\begin{array}{c}8.423^{\star * *} \\
(1.053)\end{array}$ & $\begin{array}{c}8.427^{\star * * *} \\
(1.054)\end{array}$ & $\begin{array}{c}8.448^{* * *} \\
(0.831)\end{array}$ & $\begin{array}{c}8.459^{* * *} \\
(0.831)\end{array}$ \\
\hline Tendência linear & $\begin{array}{c}0.152 \\
(0.315)\end{array}$ & $\begin{array}{c}0.211 \\
(0.316)\end{array}$ & $\begin{array}{l}-0.291 \\
(0.320)\end{array}$ & $\begin{array}{c}-0.240 \\
(0.321)\end{array}$ & $\begin{array}{l}3.027^{\star \star \star *} \\
(0.440)\end{array}$ & $\begin{array}{c}3.078^{\star \star \star} \\
(0.441)\end{array}$ & $\begin{array}{c}2.937^{* * *} \\
(0.435)\end{array}$ & $\begin{array}{c}2.978^{* * *} \\
(0.437)\end{array}$ \\
\hline Tendência quadrática & $\begin{array}{c}0.073^{* * *} \\
(0.024)\end{array}$ & $\begin{array}{c}0.070^{* * *} \\
(0.024)\end{array}$ & $\begin{array}{c}0.128^{* * *} \\
(0.022)\end{array}$ & $\begin{array}{c}0.126^{\star * *} \\
(0.022)\end{array}$ & $\begin{array}{c}0.007 \\
(0.033)\end{array}$ & $\begin{array}{c}0.004 \\
(0.033)\end{array}$ & $\begin{array}{c}0.038 \\
(0.030)\end{array}$ & $\begin{array}{c}0.036 \\
(0.030)\end{array}$ \\
\hline Constante & $\begin{array}{c}-84.572^{\star \star \star} \\
(15.057)\end{array}$ & $\begin{array}{c}85.654^{\star * *} \\
(15.071)\end{array}$ & $\begin{array}{c}-138.417^{* * *} \\
(8.046)\end{array}$ & $\begin{array}{c}-140.030^{* * *} \\
(8.057)\end{array}$ & $\begin{array}{c}-78.392^{\star * \star} \\
(15.483)\end{array}$ & $\begin{array}{c}-79.675^{\star \star \star} \\
(15.493)\end{array}$ & $\begin{array}{c}-103.847^{* * *} \\
(12.108)\end{array}$ & $\begin{array}{c}-105.665^{\star \star \star} \\
(12.110)\end{array}$ \\
\hline $\mathrm{R}^{2}$ & 0.3719 & 0.3722 & 0.3699 & 0.3702 & 0.3624 & 0.3628 & 0.3607 & 0.3611 \\
\hline Observač̃es & 56315 & 56315 & 56315 & 56315 & 29055 & 29055 & 29055 & 29055 \\
\hline
\end{tabular}


Apêndice 1b.5 Investimentos

\begin{tabular}{|c|c|c|c|c|c|c|c|c|}
\hline \multirow[b]{3}{*}{ Receita tributária } & \multicolumn{4}{|c|}{ Painel não balanceado } & \multicolumn{4}{|c|}{ Painel não balanceado } \\
\hline & \multicolumn{2}{|c|}{ OLS } & \multicolumn{2}{|c|}{ Efeitos aleatórios } & \multicolumn{2}{|c|}{ OLS } & \multicolumn{2}{|c|}{ Efeitos aleatórios } \\
\hline & $\begin{array}{c}0.303^{* \star *} \\
(0.015)\end{array}$ & $\begin{array}{c}0.303^{\star \star *} \\
(0.015)\end{array}$ & $\begin{array}{c}0.315^{\star \star *} \\
(0.008)\end{array}$ & $\begin{array}{c}0.315^{\star \star *} \\
(0.008)\end{array}$ & $\begin{array}{c}0.366^{\star \star *} \\
(0.022)\end{array}$ & $\begin{array}{c}0.366^{\star \star *} \\
(0.022)\end{array}$ & $\begin{array}{c}0.357^{* * *} \\
(0.010)\end{array}$ & $\begin{array}{c}0.357^{\star \star *} \\
(0.010)\end{array}$ \\
\hline Receita de transferências & $\begin{array}{c}0.220^{* * *} \\
(0.007)\end{array}$ & $\begin{array}{c}0.219^{* * *} \\
(0.007)\end{array}$ & $\begin{array}{c}0.206^{\star * *} \\
(0.002)\end{array}$ & $\begin{array}{c}0.206^{* * *} \\
(0.002)\end{array}$ & $\begin{array}{c}0.203^{* \star *} \\
(0.009)\end{array}$ & $\begin{array}{c}0.203^{* * *} \\
(0.009)\end{array}$ & $\begin{array}{c}0.189^{* * *} \\
(0.003)\end{array}$ & $\begin{array}{c}0.189^{* * *} \\
(0.003)\end{array}$ \\
\hline Dummy ano eleitoral & $\begin{array}{l}-1.962^{*} \\
(1.130)\end{array}$ & $\begin{array}{c}-5.484^{\star *} \\
(2.270)\end{array}$ & $\begin{array}{l}-0.596 \\
(1.110)\end{array}$ & $\begin{array}{l}-3.485^{*} \\
(2.015)\end{array}$ & $\begin{array}{l}3.436^{* *} \\
(1.346)\end{array}$ & $\begin{array}{l}-0.641 \\
(2.421)\end{array}$ & $\begin{array}{c}3.704^{* * *} \\
(1.224)\end{array}$ & $\begin{array}{l}-0.339 \\
(2.165)\end{array}$ \\
\hline PFL & $\begin{array}{c}1.990 \\
(1.455)\end{array}$ & $\begin{array}{c}1.339 \\
(1.756)\end{array}$ & $\begin{array}{c}0.426 \\
(1.541)\end{array}$ & $\begin{array}{l}-0.014 \\
(1.695) \\
\end{array}$ & $\begin{array}{l}3.642^{* *} \\
(1.788) \\
\end{array}$ & $\begin{array}{c}2.637 \\
(2.060)\end{array}$ & $\begin{array}{c}2.087 \\
(1.751)\end{array}$ & $\begin{array}{c}1.180 \\
(1.931)\end{array}$ \\
\hline PSDB & \begin{tabular}{|l|}
-1.916 \\
$(1.878)$ \\
\end{tabular} & $\begin{array}{l}-2.616 \\
(1.974) \\
\end{array}$ & $\begin{array}{l}-1.934 \\
(2.111) \\
\end{array}$ & $\begin{array}{l}-2.607 \\
(2.168) \\
\end{array}$ & $\begin{array}{l}-1.775 \\
(2.121) \\
\end{array}$ & \begin{tabular}{|l|}
-2.358 \\
$(2.178)$ \\
\end{tabular} & $\begin{array}{c}0.174 \\
(2.265) \\
\end{array}$ & $\begin{array}{l}-0.428 \\
(2.331) \\
\end{array}$ \\
\hline PT & $\begin{array}{c}-22.440^{* * *} \\
(2.577)\end{array}$ & $\begin{array}{c}-23.921^{* * *} \\
(2.851)\end{array}$ & $\begin{array}{c}-15.467^{* * *} \\
(3.833)\end{array}$ & $\begin{array}{c}-16.745^{\star \star *} \\
(4.047)\end{array}$ & $\begin{array}{c}-28.819^{\star \star *} \\
(2.779)\end{array}$ & $\begin{array}{c}-30.345^{\star * \star} \\
(2.977)\end{array}$ & $\begin{array}{c}-20.800^{* * *} \\
(3.927)\end{array}$ & $\begin{array}{c}-22.480^{\star * *} \\
(4.158)\end{array}$ \\
\hline PTB & $\begin{array}{l}-3.637^{*} \\
(1.870)\end{array}$ & $\begin{array}{c}-5.223^{\star *} \\
(2.182)\end{array}$ & $\begin{array}{l}-2.676 \\
(2.163)\end{array}$ & $\begin{array}{l}-3.961^{*} \\
(2.363)\end{array}$ & $\begin{array}{c}-6.379^{* * *} \\
(2.064)\end{array}$ & $\begin{array}{c}-8.520^{* * *} \\
(2.302)\end{array}$ & $\begin{array}{l}-4.185^{*} \\
(2.329)\end{array}$ & $\begin{array}{c}-6.108^{* *} \\
(2.550)\end{array}$ \\
\hline PDT & $\begin{array}{c}-7.572^{* * *} \\
(2.137)\end{array}$ & $\begin{array}{c}-8.471^{* * *} \\
(2.512)\end{array}$ & $\begin{array}{c}-4.653^{* *} \\
(2.192)\end{array}$ & $\begin{array}{c}-5.367^{* *} \\
(2.410)\end{array}$ & $\begin{array}{c}-14.907^{* * *} \\
(1.893)\end{array}$ & $\begin{array}{c}-16.586^{* * *} \\
(2.160)\end{array}$ & $\begin{array}{c}-10.380^{* * *} \\
(2.312)\end{array}$ & $\begin{array}{c}-12.220^{* * *} \\
(2.550)\end{array}$ \\
\hline PDS / PPB & $\begin{array}{c}-2.282 \\
(1.604) \\
\end{array}$ & $\begin{array}{l}-3.615^{\star} \\
(1.902)\end{array}$ & $\begin{array}{l}-2.881 \\
(1.874) \\
\end{array}$ & $\begin{array}{l}-3.916^{*} \\
(2.053) \\
\end{array}$ & $\begin{array}{l}-3.148 \\
(2.012) \\
\end{array}$ & $\begin{array}{c}-4.941^{* *} \\
(2.273)\end{array}$ & $\begin{array}{c}-4.862^{\star *} \\
(2.061)\end{array}$ & $\begin{array}{c}-6.718^{* \star *} \\
(2.260)\end{array}$ \\
\hline PL & $\begin{array}{c}-6.449^{\star * *} \\
(1.966)\end{array}$ & $\begin{array}{c}-7.239^{\star * *} \\
(2.310)\end{array}$ & $\begin{array}{c}-7.883^{* * *} \\
(2.551)\end{array}$ & $\begin{array}{c}-8.722^{* \star *} \\
(2.790)\end{array}$ & $\begin{array}{l}-3.139 \\
(2.603) \\
\end{array}$ & $\begin{array}{l}-4.025 \\
(2.976) \\
\end{array}$ & $\begin{array}{c}-9.106^{\star \star *} \\
(2.886)\end{array}$ & $\begin{array}{c}-10.308^{* * *} \\
(3.166)\end{array}$ \\
\hline Outros & $\begin{array}{l}-1.621 \\
(1.797)\end{array}$ & $\begin{array}{l}-3.573^{*} \\
(2.092) \\
\end{array}$ & $\begin{array}{c}1.721 \\
(1.876)\end{array}$ & $\begin{array}{c}0.028 \\
(2.060)\end{array}$ & $\begin{array}{c}0.553 \\
(2.141) \\
\end{array}$ & $\begin{array}{l}-1.030 \\
(2.397) \\
\end{array}$ & $\begin{array}{c}2.929 \\
(2.142) \\
\end{array}$ & $\begin{array}{c}1.478 \\
(2.347)\end{array}$ \\
\hline PFL \& ano eleitoral & & $\begin{array}{c}2.220 \\
(3.155) \\
\end{array}$ & & $\begin{array}{c}1.240 \\
(3.140)\end{array}$ & & $\begin{array}{c}3.625 \\
(4.187) \\
\end{array}$ & & $\begin{array}{c}3.074 \\
(3.546) \\
\end{array}$ \\
\hline PSDB \& ano eleitoral & & $\begin{array}{c}6.275 \\
(4.144) \\
\end{array}$ & & $\begin{array}{c}6.113 \\
(4.155) \\
\end{array}$ & & $\begin{array}{c}5.566 \\
(4.646) \\
\end{array}$ & & $\begin{array}{c}6.027 \\
(4.487) \\
\end{array}$ \\
\hline PT \& ano eleitoral & & $\begin{array}{c}8.248 \\
(6.232) \\
\end{array}$ & & $\begin{array}{c}7.515 \\
(8.913) \\
\end{array}$ & & $\begin{array}{c}7.776 \\
(7.282) \\
\end{array}$ & & $\begin{array}{c}9.114 \\
(9.141) \\
\end{array}$ \\
\hline PTB \& ano eleitoral & & $\begin{array}{c}6.955 \\
(4.345) \\
\end{array}$ & & $\begin{array}{c}5.531 \\
(4.564)\end{array}$ & & $\begin{array}{l}9.400^{*} \\
(5.193)\end{array}$ & & $\begin{array}{l}8.306^{*} \\
(4.941)\end{array}$ \\
\hline PDT \& ano eleitoral & & $\begin{array}{c}3.439 \\
(4.681) \\
\end{array}$ & & $\begin{array}{c}2.634 \\
(4.506) \\
\end{array}$ & & $\begin{array}{c}6.832 \\
(4.431) \\
\end{array}$ & & $\begin{array}{c}7.489 \\
(4.802) \\
\end{array}$ \\
\hline PDS / PPB \& ano eleitoral & & $\begin{array}{c}5.650 \\
(3.630) \\
\end{array}$ & & $\begin{array}{c}4.249 \\
(3.852) \\
\end{array}$ & & $\begin{array}{c}7.476 \\
(4.781) \\
\end{array}$ & & $\begin{array}{l}7.671^{*} \\
(4.210) \\
\end{array}$ \\
\hline PL \& ano eleitoral & & $\begin{array}{c}2.922 \\
(4.426) \\
\end{array}$ & & $\begin{array}{c}3.198 \\
(5.344) \\
\end{array}$ & & $\begin{array}{c}3.130 \\
(6.153) \\
\end{array}$ & & $\begin{array}{c}4.630 \\
(6.120) \\
\end{array}$ \\
\hline Outros \& ano eleitoral & & $\begin{array}{l}8.680^{* *} \\
(4.290)\end{array}$ & & $\begin{array}{l}7.499^{\star} \\
(3.901)\end{array}$ & & $\begin{array}{c}6.495 \\
(5.272) \\
\end{array}$ & & $\begin{array}{c}5.699 \\
(4.504) \\
\end{array}$ \\
\hline Prefeito = Governador & $\begin{array}{c}3.251^{\star \star *} \\
(1.036)\end{array}$ & $\begin{array}{c}3.230^{\star \star *} \\
(1.032)\end{array}$ & $\begin{array}{c}5.299^{* \star *} \\
(0.988)\end{array}$ & $\begin{array}{c}5.299^{* \star \star} \\
(0.991)\end{array}$ & $\begin{array}{c}1.350 \\
(1.141)\end{array}$ & $\begin{array}{c}1.236 \\
(1.144)\end{array}$ & $\begin{array}{c}3.330^{\star \star \star} \\
(1.112)\end{array}$ & $\begin{array}{c}3.188^{\star * *} \\
(1.115)\end{array}$ \\
\hline Prefeito $=$ Presidente & $\begin{array}{c}-4.172^{\star *} \\
(1.861) \\
\end{array}$ & $\begin{array}{c}-4.970^{\star *} \\
(1.991) \\
\end{array}$ & $\begin{array}{c}-3.497^{\star *} \\
(1.688) \\
\end{array}$ & $\begin{array}{c}-4.246^{\star *} \\
(1.742) \\
\end{array}$ & $\begin{array}{c}-6.486^{\star \star *} \\
(1.918) \\
\end{array}$ & $\begin{array}{c}-7.368^{\star * *} \\
(1.990) \\
\end{array}$ & $\begin{array}{c}-6.403^{* * *} \\
(1.787) \\
\end{array}$ & $\begin{array}{c}-7.354^{\star \star *} \\
(1.847) \\
\end{array}$ \\
\hline Idosos & $\begin{array}{c}-5.582^{\star * *} \\
(0.453) \\
\end{array}$ & $\begin{array}{c}-5.583^{\star * *} \\
(0.454) \\
\end{array}$ & $\begin{array}{c}-7.275^{\star * \star} \\
(0.502) \\
\end{array}$ & $\begin{array}{c}-7.277^{* \star *} \\
(0.502) \\
\end{array}$ & $\begin{array}{c}-5.214^{* * *} \\
(0.541) \\
\end{array}$ & $\begin{array}{c}-5.215^{* * *} \\
(0.541)\end{array}$ & $\begin{array}{c}-6.600^{* * *} \\
(0.634)\end{array}$ & $\begin{array}{c}-6.605^{\star * *} \\
(0.634) \\
\end{array}$ \\
\hline Urbanização & $\begin{array}{c}-0.303^{\star \star *} \\
(0.025) \\
\end{array}$ & $\begin{array}{c}-0.302^{\star \star *} \\
(0.026) \\
\end{array}$ & $\begin{array}{c}-0.271^{* \star *} \\
(0.039)\end{array}$ & $\begin{array}{c}-0.271^{* * *} \\
(0.039)\end{array}$ & \begin{tabular}{|c|}
$-0.270^{* \star *}$ \\
$(0.036)$ \\
\end{tabular} & $\begin{array}{c}-0.269^{* \star \star} \\
(0.036)\end{array}$ & $\begin{array}{c}-0.146^{\star \star \star} \\
(0.052)\end{array}$ & $\begin{array}{c}-0.146^{\star \star \star} \\
(0.052)\end{array}$ \\
\hline Jovens & $\begin{array}{c}0.689^{\star * * *} \\
(0.176)\end{array}$ & $\begin{array}{c}0.687^{* * *} \\
(0.176)\end{array}$ & $\begin{array}{c}0.016 \\
(0.184)\end{array}$ & $\begin{array}{c}0.013 \\
(0.184)\end{array}$ & $\begin{array}{l}-0.153 \\
(0.248)\end{array}$ & $\begin{array}{l}-0.154 \\
(0.248)\end{array}$ & $\begin{array}{c}-0.957^{* * *} \\
(0.265)\end{array}$ & $\begin{array}{c}-0.961^{* * *} \\
(0.265)\end{array}$ \\
\hline População & $\begin{array}{c}5.904^{\star * *} \\
(1.331)\end{array}$ & $\begin{array}{c}5.893^{\star \star *} \\
(1.331)\end{array}$ & $\begin{array}{c}0.491 \\
(0.960)\end{array}$ & $\begin{array}{c}0.469 \\
(0.960)\end{array}$ & $\begin{array}{c}5.342^{\star \star \star} \\
(1.794)\end{array}$ & $\begin{array}{c}5.326^{\star \star \star} \\
(1.794)\end{array}$ & $\begin{array}{c}0.522 \\
(1.198) \\
\end{array}$ & $\begin{array}{c}0.498 \\
(1.198)\end{array}$ \\
\hline Tendência linear & $\begin{array}{c}-6.571^{\star * *} \\
(0.524) \\
\end{array}$ & $\begin{array}{c}-6.558^{\star * *} \\
(0.526) \\
\end{array}$ & $\begin{array}{c}-7.110^{* \star \star} \\
(0.469) \\
\end{array}$ & $\begin{array}{c}-7.096^{* \star *} \\
(0.470) \\
\end{array}$ & $\begin{array}{c}-9.896^{\star \star *} \\
(0.630) \\
\end{array}$ & $\begin{array}{c}-9.877^{\star \star *} \\
(0.630) \\
\end{array}$ & $\begin{array}{c}-9.749^{\star \star *} \\
(0.526) \\
\end{array}$ & $\begin{array}{c}-9.724^{\star \star *} \\
(0.527) \\
\end{array}$ \\
\hline Tendência quadrática & $\begin{array}{c}-0.082^{* *} \\
(0.033) \\
\end{array}$ & $\begin{array}{c}-0.083^{* *} \\
(0.033) \\
\end{array}$ & $\begin{array}{c}-0.076^{* * *} \\
(0.028)\end{array}$ & $\begin{array}{c}-0.077^{* \star *} \\
(0.028)\end{array}$ & $\begin{array}{c}0.054 \\
(0.034) \\
\end{array}$ & $\begin{array}{c}0.053 \\
(0.034) \\
\end{array}$ & $\begin{array}{c}0.035 \\
(0.031) \\
\end{array}$ & $\begin{array}{c}0.033 \\
(0.031) \\
\end{array}$ \\
\hline Constante & $\begin{array}{c}0.410 \\
1(9.894)\end{array}$ & $\begin{array}{c}1.511 \\
(19.840)\end{array}$ & $\begin{array}{c}93.139^{* * *} \\
(13.248)\end{array}$ & $\begin{array}{c}94.242^{* * *} \\
(13.265)\end{array}$ & $\begin{array}{l}45.571^{*} \\
(26.680)\end{array}$ & $\begin{array}{l}46.864^{*} \\
(26.621)\end{array}$ & $\begin{array}{c}124.623^{* * *} \\
(16.777)\end{array}$ & $\begin{array}{c}1^{126.171^{* * *}} \\
(16.791)\end{array}$ \\
\hline $\mathrm{R}^{2}$ & 0.3216 & 0.3216 & 0.3202 & 0.3202 & 0.3847 & 0.3849 & 0.3829 & 0.3830 \\
\hline Observações & 66384 & 66384 & 66384 & 66384 & 33525 & 33525 & 33525 & 33252 \\
\hline
\end{tabular}


Apêndice 1.c-Resultados das regressões com dummy para cada ano eleitoral OLS e efeitos aleatórios

Apêndice 1c.1 - Despesa orçamentária

\begin{tabular}{|c|c|c|c|c|}
\hline \multirow[b]{2}{*}{$\begin{array}{c}\text { Regressor } \\
\text { (Erro padrão) }\end{array}$} & \multicolumn{2}{|c|}{ Painel não balanceado } & \multicolumn{2}{|c|}{ Painel balanceado } \\
\hline & OLS & $\begin{array}{c}\text { Efeitos } \\
\text { Aleatórios }\end{array}$ & OLS & $\begin{array}{c}\text { Efeitos } \\
\text { Aleatórios }\end{array}$ \\
\hline Receita tributária & $\begin{array}{l}1.426^{* * *} \\
(0.024)\end{array}$ & $\begin{array}{c}1.350^{\star * *} \\
(0.011)\end{array}$ & $\begin{array}{l}1.424^{* * *} \\
(0.032)\end{array}$ & $\begin{array}{l}1.337^{\star * *} \\
(0.014)\end{array}$ \\
\hline Receita de transferências & $\begin{array}{c}1.078^{\star \star *} \\
(0.010)\end{array}$ & $\begin{array}{c}1.007^{\star * *} \\
(0.003)\end{array}$ & $\begin{array}{c}1.061^{* \star *} \\
(0.011)\end{array}$ & $\begin{array}{c}0.997^{* * *} \\
(0.004) \\
\end{array}$ \\
\hline Dummy 1992 & $\begin{array}{c}-8.024^{* * *} \\
(2.063)\end{array}$ & $\begin{array}{c}-9.697^{* * *} \\
(2.448)\end{array}$ & $\begin{array}{c}3.192 \\
(3.028)\end{array}$ & $\begin{array}{l}-0.125 \\
(3.003)\end{array}$ \\
\hline Dummy 1996 & $\begin{array}{c}32.853^{* * *} \\
(2.820)\end{array}$ & $\begin{array}{c}35.527^{* \star *} \\
(2.501)\end{array}$ & $\begin{array}{c}36.099^{* * *} \\
(3.123)\end{array}$ & $\begin{array}{c}37.777^{\star \star \star} \\
(3.045)\end{array}$ \\
\hline Dummy 2000 & $\begin{array}{c}15.185^{\star * *} \\
(2.421)\end{array}$ & $\begin{array}{c}16.875^{\star * *} \\
(2.205)\end{array}$ & $\begin{array}{c}20.224^{* * *} \\
(2.819)\end{array}$ & $\begin{array}{c}20.760^{* \star *} \\
(2.963)\end{array}$ \\
\hline PFL & $\begin{array}{c}0.545 \\
(2.098)\end{array}$ & $\begin{array}{c}-4.174^{* *} \\
(2.062)\end{array}$ & $\begin{array}{l}3.068 \\
(2.899)\end{array}$ & $\begin{array}{l}-1.753 \\
(2.619)\end{array}$ \\
\hline PSDB & $\begin{array}{c}0.466 \\
(2.726)\end{array}$ & $\begin{array}{c}3.382 \\
(2.810)\end{array}$ & $\begin{array}{c}0.180 \\
(2.976)\end{array}$ & $\begin{array}{c}1.254 \\
(3.400)\end{array}$ \\
\hline PT & $\begin{array}{c}-11.148^{* * *} \\
(3.626) \\
\end{array}$ & $\begin{array}{c}-11.724^{* *} \\
(5.130) \\
\end{array}$ & $\begin{array}{l}-6.554^{*} \\
(3.982) \\
\end{array}$ & $\begin{array}{c}-10.834^{*} \\
(5.872) \\
\end{array}$ \\
\hline РTB & $\begin{array}{c}0.607 \\
(2.396)\end{array}$ & $\begin{array}{l}-3.943 \\
(2.890)\end{array}$ & $\begin{array}{c}3.519 \\
(2.944)\end{array}$ & $\begin{array}{l}-0.523 \\
(3.486)\end{array}$ \\
\hline PDT & $\begin{array}{l}-5.250^{*} \\
(2.762)\end{array}$ & $\begin{array}{l}-2.619 \\
(2.930)\end{array}$ & $\begin{array}{c}-5.950^{* *} \\
(2.649)\end{array}$ & $\begin{array}{l}-3.444 \\
(3.465)\end{array}$ \\
\hline PDS / PPB & $\begin{array}{c}-13.185^{\star * *} \\
(2.215)\end{array}$ & $\begin{array}{c}-8.384^{* * *} \\
(2.504)\end{array}$ & $\begin{array}{c}-7.340^{* *} \\
(3.091)\end{array}$ & $\begin{array}{l}-5.700^{*} \\
(3.086)\end{array}$ \\
\hline PL & $\begin{array}{c}-8.820^{* * *} \\
(2.545) \\
\end{array}$ & $\begin{array}{c}-15.494^{* \star *} \\
(3.407)\end{array}$ & $\begin{array}{c}-0.210 \\
(3.605) \\
\end{array}$ & $\begin{array}{c}-9.103^{\star *} \\
(4.321) \\
\end{array}$ \\
\hline Outros & $\begin{array}{l}-0.727 \\
(2.355)\end{array}$ & $\begin{array}{l}-4.054 \\
(2.504)\end{array}$ & $\begin{array}{c}7.526^{\star * *} \\
(2.783)\end{array}$ & $\begin{array}{l}-0.963 \\
(3.209)\end{array}$ \\
\hline Prefeito \& Governador & $\begin{array}{l}-1.197 \\
(1.432) \\
\end{array}$ & $\begin{array}{c}1.801 \\
(1.315) \\
\end{array}$ & $\begin{array}{l}3.196^{*} \\
(1.806) \\
\end{array}$ & $\begin{array}{c}5.790^{\star \star \star} \\
(1.676) \\
\end{array}$ \\
\hline Prefeito \& Presidente & $\begin{array}{l}-0.689 \\
(2.532)\end{array}$ & $\begin{array}{c}-5.344^{* *} \\
(2.244)\end{array}$ & $\begin{array}{c}2.868 \\
(2.875)\end{array}$ & $\begin{array}{l}-2.008 \\
(2.718)\end{array}$ \\
\hline Idosos & $\begin{array}{c}-5.730^{\star \star \star *} \\
(0.622) \\
\end{array}$ & $\begin{array}{c}-9.289^{\star \star \star} \\
(0.705) \\
\end{array}$ & $\begin{array}{c}-6.363^{\star \star \star} \\
(0.783) \\
\end{array}$ & $\begin{array}{c}-8.927^{\star \star *} \\
(0.921) \\
\end{array}$ \\
\hline Urbanização & $\begin{array}{c}0.309^{* * *} \\
(0.034) \\
\end{array}$ & $\begin{array}{c}0.525^{\star * *} \\
(0.057) \\
\end{array}$ & $\begin{array}{c}0.376^{* \star *} \\
(0.046) \\
\end{array}$ & $\begin{array}{c}0.672^{\star \star *} \\
(0.074) \\
\end{array}$ \\
\hline Jovens & $\begin{array}{c}-2.629^{* * *} \\
(0.265)\end{array}$ & $\begin{array}{c}-4.028^{\star * *} \\
(0.262)\end{array}$ & $\begin{array}{c}-4.108^{* * *} \\
(0.362)\end{array}$ & $\begin{array}{c}-5.296^{\star \star *} \\
(0.378)\end{array}$ \\
\hline População & $\begin{array}{l}-3.145 \\
(1.993) \\
\end{array}$ & $\begin{array}{c}-17.487^{\star * *} \\
(1.388)\end{array}$ & $\begin{array}{c}-6.936^{* * *} \\
(2.315)\end{array}$ & $\begin{array}{c}-18.940^{\star * *} \\
(1.692)\end{array}$ \\
\hline Tendência linear & $\begin{array}{c}6.821^{* * *} \\
(0.750)\end{array}$ & $\begin{array}{c}8.573^{* * *} \\
(0.633)\end{array}$ & $\begin{array}{c}7.822^{\star * *} \\
(0.936)\end{array}$ & $\begin{array}{c}10.050^{* \star *} \\
(0.801)\end{array}$ \\
\hline Tendência quadrática & $\begin{array}{c}-1.007^{* * *} \\
(0.044)\end{array}$ & $\begin{array}{c}-1.037^{* * *} \\
(0.037)\end{array}$ & $\begin{array}{c}-1.109^{* * *} \\
(0.051)\end{array}$ & $\begin{array}{c}-1.167^{* * *} \\
(0.048)\end{array}$ \\
\hline Constante & $\begin{array}{c}191.027^{\text {*** }}(30.279) \\
\end{array}$ & $\begin{array}{c}414.411^{\text {*** }} \\
(18.792)\end{array}$ & $\begin{array}{c}277.053^{\star \star *} \\
(36.053)\end{array}$ & $\begin{array}{c}456.261^{* * *} \\
(24.123)\end{array}$ \\
\hline$R^{2}$ & 0,8883 & 0,8874 & 0,8968 & 0,8959 \\
\hline Observações & 66384 & 66384 & 33525 & 33525 \\
\hline
\end{tabular}


Apêndice 1c.2 - Despesa corrente

\begin{tabular}{|c|c|c|c|c|}
\hline \multirow[b]{2}{*}{$\begin{array}{c}\text { Regressor } \\
\text { (Erro padrão) }\end{array}$} & \multicolumn{2}{|c|}{ Painel não balanceado } & \multicolumn{2}{|c|}{ Painel balanceado } \\
\hline & OLS & $\begin{array}{c}\text { Efeitos } \\
\text { Aleatórios }\end{array}$ & OLS & $\begin{array}{c}\text { Efeitos } \\
\text { Aleatórios }\end{array}$ \\
\hline Receita tributária & 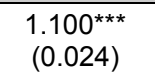 & $\begin{array}{c}0.994^{* * *} \\
(0.008)\end{array}$ & $\begin{array}{l}1.036^{* * *} \\
(0.031)\end{array}$ & $\begin{array}{c}0.936^{\text {*** }} \\
(0.012)\end{array}$ \\
\hline Receita de transferências & $\begin{array}{c}0.838^{\star \star *} \\
(0.007)\end{array}$ & $\begin{array}{c}0.778^{* * *} \\
(0.002)\end{array}$ & $\begin{array}{c}0.837^{* * *} \\
(0.010)\end{array}$ & $\begin{array}{c}0.772^{\star * *} \\
(0.003)\end{array}$ \\
\hline Dummy 1992 & $\begin{array}{c}1.139 \\
(1.762)\end{array}$ & $\begin{array}{l}-2.145 \\
(1.723)\end{array}$ & $\begin{array}{c}6.775^{\star * *} \\
(2.542)\end{array}$ & $\begin{array}{c}2.886 \\
(2.347)\end{array}$ \\
\hline Dummy 1996 & $\begin{array}{c}22.869^{\star * *} \\
(2.181)\end{array}$ & $\begin{array}{c}23.549^{* * *} \\
(1.760)\end{array}$ & $\begin{array}{c}22.019^{\star * *} \\
(2.688)\end{array}$ & $\begin{array}{c}23.102^{* * *} \\
(2.381)\end{array}$ \\
\hline Dummy 2000 & $\begin{array}{c}23.838^{\star \star *} \\
(1.757)\end{array}$ & $\begin{array}{c}24.235^{\star \star *} \\
(1.552)\end{array}$ & $\begin{array}{c}24.453^{\star * \star} \\
(2.384)\end{array}$ & $\begin{array}{c}24.838^{* \star *} \\
(2.315)\end{array}$ \\
\hline PFL & $\begin{array}{l}-1.002 \\
(1.552)\end{array}$ & $\begin{array}{c}-4.801^{\star * \star} \\
(1.467)\end{array}$ & $\begin{array}{c}0.124 \\
(2.271)\end{array}$ & $\begin{array}{c}-4.978^{\star *} \\
(2.080)\end{array}$ \\
\hline PSDB & $\begin{array}{c}2.789 \\
(1.965)\end{array}$ & $\begin{array}{l}4.833^{\star *} \\
(1.993)\end{array}$ & $\begin{array}{c}1.595 \\
(2.369)\end{array}$ & $\begin{array}{c}0.053 \\
(2.687)\end{array}$ \\
\hline PT & $\begin{array}{c}11.745^{\star \star *} \\
(3.047)\end{array}$ & $\begin{array}{c}3.433 \\
(3.651)\end{array}$ & $\begin{array}{c}21.914^{\star \star *} \\
(3.688)\end{array}$ & $\begin{array}{l}8.720^{*} \\
(4.663)\end{array}$ \\
\hline PTB & $\begin{array}{c}2.460 \\
(1.859)\end{array}$ & $\begin{array}{l}-2.384 \\
(2.054)\end{array}$ & $\begin{array}{c}7.716^{\star * *} \\
(2.555)\end{array}$ & $\begin{array}{c}1.564 \\
(2.765)\end{array}$ \\
\hline PDT & $\begin{array}{l}-0.072 \\
(2.060)\end{array}$ & $\begin{array}{c}0.169 \\
(2.083)\end{array}$ & $\begin{array}{l}5.096^{\star *} \\
(2.313)\end{array}$ & $\begin{array}{l}4.599^{*} \\
(2.747)\end{array}$ \\
\hline PDS / PPB & $\begin{array}{c}-10.253^{\star * *} \\
(1.710)\end{array}$ & $\begin{array}{c}-5.261^{* * *} \\
(1.779)\end{array}$ & $\begin{array}{l}-3.405 \\
(2.545)\end{array}$ & $\begin{array}{l}-0.824 \\
(2.448) \\
\end{array}$ \\
\hline PL & $\begin{array}{l}-1.358 \\
(1.998)\end{array}$ & $\begin{array}{c}-7.540^{\star * *} \\
(2.421)\end{array}$ & $\begin{array}{c}2.786 \\
(2.925)\end{array}$ & $\begin{array}{l}-1.393 \\
(3.425)\end{array}$ \\
\hline Outros & $\begin{array}{c}2.130 \\
(1.604)\end{array}$ & $\begin{array}{c}-5.709^{* * *} \\
(1.778)\end{array}$ & $\begin{array}{c}8.199^{* * *} \\
(2.310)\end{array}$ & $\begin{array}{l}-4.252^{*} \\
(2.543)\end{array}$ \\
\hline Prefeito \& Governador & $\begin{array}{c}3.144^{\star \star *} \\
(1.038)\end{array}$ & $\begin{array}{c}-3.141^{\star * *} \\
(0.928)\end{array}$ & $\begin{array}{l}3.408^{\star *} \\
(1.456)\end{array}$ & $\begin{array}{l}3.311^{* *} \\
(1.316)\end{array}$ \\
\hline Prefeito \& Presidente & $\begin{array}{l}3.192^{\star} \\
(1.776)\end{array}$ & $\begin{array}{l}-2.677^{*} \\
(1.581)\end{array}$ & $\begin{array}{c}9.023^{\star * *} \\
(2.272)\end{array}$ & $\begin{array}{c}3.077 \\
(2.128)\end{array}$ \\
\hline Idosos & $\begin{array}{l}-0.293 \\
(0.451)\end{array}$ & $\begin{array}{c}-2.263^{\star * \star} \\
(0.517)\end{array}$ & $\begin{array}{l}-0.496 \\
(0.670)\end{array}$ & $\begin{array}{c}-2.557^{\star \star \star} \\
(0.774)\end{array}$ \\
\hline Urbanização & $\begin{array}{c}0.619^{* * *} \\
(0.028)\end{array}$ & $\begin{array}{c}0.770^{* * *} \\
(0.042)\end{array}$ & $\begin{array}{c}0.640^{* * *} \\
(0.042)\end{array}$ & $\begin{array}{c}0.822^{* * *} \\
(0.064)\end{array}$ \\
\hline Jovens & $\begin{array}{c}-2.818^{\star * *} \\
(0.201)\end{array}$ & $\begin{array}{c}-3.548^{* * *} \\
(0.195) \\
\end{array}$ & $\begin{array}{c}-3.413^{\star \star *} \\
(0.312)\end{array}$ & $\begin{array}{c}-4.207^{* \star *} \\
(0.326) \\
\end{array}$ \\
\hline População & $\begin{array}{c}-11.365^{\star * *} \\
(1.487)\end{array}$ & $\begin{array}{c}-19.707^{\star \star *} \\
(1.049)\end{array}$ & $\begin{array}{c}-13.067^{* * *} \\
(2.114)\end{array}$ & $\begin{array}{c}-22.370^{\star \star *} \\
(1.486) \\
\end{array}$ \\
\hline Tendência linear & $\begin{array}{c}12.593^{* * *} \\
(0.548)\end{array}$ & $\begin{array}{c}15.064^{\star * *} \\
(0.449)\end{array}$ & $\begin{array}{c}16.206^{\star * *} \\
(0.767)\end{array}$ & $\begin{array}{c}18.924^{\star * *} \\
(0.635)\end{array}$ \\
\hline Tendência quadrática & $\begin{array}{c}-0.871^{* * *} \\
(0.030)\end{array}$ & $\begin{array}{c}-0.911^{* * *} \\
(0.026)\end{array}$ & $\begin{array}{c}-1.082^{* * *} \\
(0.042)\end{array}$ & $\begin{array}{c}-1.141^{* * *} \\
(0.038)\end{array}$ \\
\hline Constante & 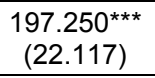 & $\begin{array}{c}326.522^{* * *} \\
(13.959)\end{array}$ & $\begin{array}{c}220.661^{* * *} \\
(31.920)\end{array}$ & $\begin{array}{c}366.264^{\star \star \star} \\
(20.665) \\
\end{array}$ \\
\hline $\mathrm{R}^{2}$ & 0,9089 & 0,9078 & 0,8986 & 0,8972 \\
\hline Observações & 66384 & 66384 & 33525 & 33525 \\
\hline
\end{tabular}


Apêndice 1c.3-Despesa de pessoal

\begin{tabular}{|c|c|c|c|c|}
\hline \multirow[b]{2}{*}{$\begin{array}{c}\text { Regressor } \\
\text { (Erro padrão) }\end{array}$} & \multicolumn{2}{|c|}{ Painel não balanceado } & \multicolumn{2}{|c|}{ Painel balanceado } \\
\hline & OLS & $\begin{array}{c}\text { Efeitos } \\
\text { Aleatórios }\end{array}$ & OLS & $\begin{array}{c}\text { Efeitos } \\
\text { Aleatórios }\end{array}$ \\
\hline Receita tributária & $\begin{array}{c}0.519^{* \star *} \\
(0.018)\end{array}$ & $\begin{array}{c}0.402^{\star * *} \\
(0.006)\end{array}$ & $\begin{array}{c}0.460^{* * *} \\
(0.022)\end{array}$ & $\begin{array}{c}0.354^{* * *} \\
(0.008)\end{array}$ \\
\hline Receita de transferências & $\begin{array}{c}0.371^{* * *} \\
(0.005)\end{array}$ & $\begin{array}{c}0.328^{* * *} \\
(0.002)\end{array}$ & $\begin{array}{c}0.393^{* * *} \\
(0.006)\end{array}$ & $\begin{array}{c}0.347^{* * *} \\
(0.002)\end{array}$ \\
\hline Dummy 1992 & $\begin{array}{c}-7.137^{* * *} \\
(1.290)\end{array}$ & $\begin{array}{c}-9.660^{* * *} \\
(1.180)\end{array}$ & $\begin{array}{l}-2.521 \\
(1.763)\end{array}$ & $\begin{array}{c}-5.384^{* * *} \\
(1.569)\end{array}$ \\
\hline Dummy 1996 & $\begin{array}{c}5.538^{* * *} \\
(1.594) \\
\end{array}$ & $\begin{array}{c}5.832^{* * *} \\
(1.207) \\
\end{array}$ & $\begin{array}{c}9.283^{* * *} \\
(2.002) \\
\end{array}$ & $\begin{array}{c}9.816^{* * *} \\
(1.592) \\
\end{array}$ \\
\hline Dummy 2000 & $\begin{array}{c}4.074^{* * *} \\
(1.485)\end{array}$ & $\begin{array}{c}4.883^{\star * *} \\
(1.064)\end{array}$ & $\begin{array}{c}2.755 \\
(2.054)\end{array}$ & $\begin{array}{l}3.462^{\star \star} \\
(1.547)\end{array}$ \\
\hline PFL & $\begin{array}{c}-4.187^{\star * *} \\
(1.041)\end{array}$ & $\begin{array}{c}-3.637^{* * *} \\
(1.023)\end{array}$ & $\begin{array}{l}-2.385 \\
(1.490)\end{array}$ & $\begin{array}{c}-2.995^{\star *} \\
(1.413)\end{array}$ \\
\hline PSDB & $\begin{array}{c}4.951^{* * *} \\
(1.449)\end{array}$ & $\begin{array}{c}8.993^{\star * *} \\
(1.381)\end{array}$ & $\begin{array}{c}1.959 \\
(1.784)\end{array}$ & $\begin{array}{c}5.157^{* * *} \\
(1.816)\end{array}$ \\
\hline PT & $\begin{array}{c}10.722^{* * *} \\
(2.395)\end{array}$ & $\begin{array}{c}0.465 \\
(2.547) \\
\end{array}$ & $\begin{array}{c}12.435^{* * *} \\
(2.941)\end{array}$ & $\begin{array}{c}-0.215 \\
(3.166) \\
\end{array}$ \\
\hline РTB & $\begin{array}{c}1.949 \\
(1.528) \\
\end{array}$ & $\begin{array}{c}-0.940 \\
(1.430) \\
\end{array}$ & $\begin{array}{c}2.904 \\
(1.945) \\
\end{array}$ & $\begin{array}{c}0.514 \\
(1.875) \\
\end{array}$ \\
\hline PDT & $\begin{array}{c}14.302^{* \star *} \\
(1.500)\end{array}$ & $\begin{array}{c}4.619^{\star \star *} \\
(1.449)\end{array}$ & $\begin{array}{c}15.017^{\star \star *} \\
(1.886)\end{array}$ & $\begin{array}{c}5.294^{\star * \star} \\
(1.862)\end{array}$ \\
\hline PDS / PPB & $\begin{array}{l}-1.380 \\
(1.278)\end{array}$ & $\begin{array}{c}-3.378^{* * *} \\
(1.238)\end{array}$ & $\begin{array}{c}0.930 \\
(1.743)\end{array}$ & $\begin{array}{c}-1.956 \\
(1.660)\end{array}$ \\
\hline $\mathrm{PL}$ & $\begin{array}{c}-11.807^{* * *} \\
(1.583)\end{array}$ & $\begin{array}{c}-9.639^{* * *} \\
(1.684)\end{array}$ & $\begin{array}{c}-8.994^{* * *} \\
(2.385)\end{array}$ & $\begin{array}{l}-1.860 \\
(2.321)\end{array}$ \\
\hline Outros & $\begin{array}{c}-0.975 \\
(1.228) \\
\end{array}$ & $\begin{array}{c}-3.323^{* * *} \\
(1.236) \\
\end{array}$ & $\begin{array}{c}2.043 \\
(1.732) \\
\end{array}$ & $\begin{array}{c}-1.174 \\
(1.723) \\
\end{array}$ \\
\hline Prefeito \& Governador & $\begin{array}{c}-3.973^{* * *} \\
(0.746)\end{array}$ & $\begin{array}{c}-1.726^{* * *} \\
(0.639)\end{array}$ & $\begin{array}{c}-2.569^{* *} \\
(1.021)\end{array}$ & $\begin{array}{l}-0.094 \\
(0.884)\end{array}$ \\
\hline Prefeito \& Presidente & $\begin{array}{l}2.614^{\star *} \\
(1.246)\end{array}$ & $\begin{array}{l}-1.810^{*} \\
(1.085)\end{array}$ & $\begin{array}{c}6.619^{* * *} \\
(1.529)\end{array}$ & $\begin{array}{c}1.869 \\
(1.425)\end{array}$ \\
\hline Idosos & $\begin{array}{c}-0.959^{\star \star *} \\
(0.317) \\
\end{array}$ & $\begin{array}{c}-1.152^{\star \star *} \\
(0.382)\end{array}$ & $\begin{array}{c}-1.428^{\star \star *} \\
(0.440)\end{array}$ & $\begin{array}{c}-1.187^{* *} \\
(0.562)\end{array}$ \\
\hline Urbanização & $\begin{array}{c}0.332^{* \star \star} \\
(0.021)\end{array}$ & $\begin{array}{c}0.453^{* \star *} \\
(0.033)\end{array}$ & $\begin{array}{c}0.236^{\star \star *} \\
(0.029)\end{array}$ & $\begin{array}{c}0.345^{\star \star \star} \\
(0.049)\end{array}$ \\
\hline Jovens & $\begin{array}{c}-3.581^{* * *} \\
(0.140)\end{array}$ & $\begin{array}{c}-3.669^{* * *} \\
(0.149)\end{array}$ & $\begin{array}{c}-4.081^{* * *} \\
(0.183)\end{array}$ & $\begin{array}{c}-4.347^{* * *} \\
(0.247)\end{array}$ \\
\hline População & $\begin{array}{l}1.885^{*} \\
(1.024)\end{array}$ & $\begin{array}{c}-3.433^{* * *} \\
(0.827)\end{array}$ & $\begin{array}{c}3.502^{* * *} \\
(1.248)\end{array}$ & $\begin{array}{c}-1.409 \\
(1.156)\end{array}$ \\
\hline Tendência linear & $\begin{array}{c}-1.909^{\star \star *} \\
(0.355) \\
\end{array}$ & $\begin{array}{c}0.246 \\
(0.313) \\
\end{array}$ & $\begin{array}{c}-1.071^{* *} \\
(0.491) \\
\end{array}$ & $\begin{array}{l}0.860^{\star *} \\
(0.434) \\
\end{array}$ \\
\hline Tendência quadrática & $\begin{array}{c}0.107^{* \star *} \\
(0.021)\end{array}$ & $\begin{array}{c}0.081^{* * *} \\
(0.018)\end{array}$ & $\begin{array}{c}0.040 \\
(0.029) \\
\end{array}$ & $\begin{array}{c}0.012 \\
(0.025) \\
\end{array}$ \\
\hline Constante & $\begin{array}{c}129.317^{* * *} \\
(15.085) \\
\end{array}$ & $\begin{array}{c}190.665^{\star * *} \\
(10.646)\end{array}$ & $\begin{array}{c}129.060^{* * *} \\
(17.680)\end{array}$ & $\begin{array}{c}197.040^{* * *} \\
(15.526) \\
\end{array}$ \\
\hline $\mathrm{R}^{2}$ & 0,7980 & 0,7940 & 0,7961 & 0,7922 \\
\hline Observações & 66384 & 66384 & 33525 & 33525 \\
\hline
\end{tabular}


Apêndice 1c.4 - Transferências correntes

\begin{tabular}{|c|c|c|c|c|}
\hline \multirow[b]{2}{*}{$\begin{array}{c}\text { Regressor } \\
\text { (Erro padrão) }\end{array}$} & \multicolumn{2}{|c|}{ Painel não balanceado } & \multicolumn{2}{|c|}{ Painel balanceado } \\
\hline & OLS & $\begin{array}{c}\text { Efeitos } \\
\text { Aleatórios }\end{array}$ & OLS & $\begin{array}{c}\text { Efeitos } \\
\text { Aleatórios }\end{array}$ \\
\hline Receita tributária & $\begin{array}{c}0.080^{* * *} \\
(0.011)\end{array}$ & $\begin{array}{c}0.083^{* * *} \\
(0.005)\end{array}$ & $\begin{array}{c}0.090^{* * *} \\
(0.015)\end{array}$ & $\begin{array}{c}0.073^{\star * *} \\
(0.007)\end{array}$ \\
\hline Receita de transferências & $\begin{array}{c}0.122^{* * *} \\
(0.005)\end{array}$ & $\begin{array}{c}0.126^{* * *} \\
(0.001)\end{array}$ & $\begin{array}{c}0.114^{* * *} \\
(0.005)\end{array}$ & $\begin{array}{c}0.110^{* * *} \\
(0.002)\end{array}$ \\
\hline Dummy 1992 & $\begin{array}{c}-14.187^{\star * *} \\
(0.693)\end{array}$ & $\begin{array}{c}-13.347^{* \star *} \\
(1.047)\end{array}$ & $\begin{array}{c}-15.379^{* \star *} \\
(0.985)\end{array}$ & $\begin{array}{c}-15.066^{* * *} \\
(1.379)\end{array}$ \\
\hline Dummy 1996 & $\begin{array}{c}-20.814^{\star * *} \\
(1.136)\end{array}$ & $\begin{array}{c}-21.535^{\star \star \star} \\
(1.067)\end{array}$ & $\begin{array}{c}-21.819^{* * *} \\
(1.471)\end{array}$ & $\begin{array}{c}-21.755^{\star * *} \\
(1.395)\end{array}$ \\
\hline Dummy 2000 & $\begin{array}{l}-1.093 \\
(1.290)\end{array}$ & $\begin{array}{l}-0.478 \\
(1.015)\end{array}$ & $\begin{array}{l}-2.866 \\
(1.834)\end{array}$ & $\begin{array}{c}-2.914^{* *} \\
(1.472)\end{array}$ \\
\hline PFL & $\begin{array}{c}5.928^{* * *} \\
(0.898)\end{array}$ & $\begin{array}{c}6.603^{* * *} \\
(0.943)\end{array}$ & $\begin{array}{c}8.584^{* * *} \\
(1.263)\end{array}$ & $\begin{array}{c}7.839^{* * *} \\
(1.297)\end{array}$ \\
\hline PSDB & $\begin{array}{c}-12.790^{* \star *} \\
(1.499)\end{array}$ & $\begin{array}{c}-12.037^{* \star \star} \\
(1.369)\end{array}$ & $\begin{array}{c}-12.694^{* * *} \\
(1.889)\end{array}$ & $\begin{array}{c}-12.800^{* \star \star} \\
(1.776)\end{array}$ \\
\hline PT & $\begin{array}{c}15.042^{\star * *} \\
(2.752)\end{array}$ & $\begin{array}{c}9.659^{* * *} \\
(2.503)\end{array}$ & $\begin{array}{c}17.044^{* \star *} \\
(3.674)\end{array}$ & $\begin{array}{c}9.433^{* * *} \\
(3.115) \\
\end{array}$ \\
\hline PTB & $\begin{array}{c}1.300 \\
(1.198)\end{array}$ & $\begin{array}{l}2.747^{* *} \\
(1.322)\end{array}$ & $\begin{array}{c}6.394^{* * *} \\
(1.654)\end{array}$ & $\begin{array}{c}7.284^{* \star \star} \\
(1.733)\end{array}$ \\
\hline PDT & $\begin{array}{c}4.053^{\star * *} \\
(1.234)\end{array}$ & $\begin{array}{c}7.235^{\star \star *} \\
(1.316)\end{array}$ & $\begin{array}{c}7.408^{\star * *} \\
(1.579)\end{array}$ & $\begin{array}{c}9.616^{\star \star \star} \\
(1.689)\end{array}$ \\
\hline PDS / PPB & $\begin{array}{c}1.550 \\
(1.063) \\
\end{array}$ & $\begin{array}{c}4.091^{* * *} \\
(1.144) \\
\end{array}$ & $\begin{array}{c}5.875^{\star * *} \\
(1.434) \\
\end{array}$ & $\begin{array}{c}7.406^{\star * *} \\
(1.527) \\
\end{array}$ \\
\hline PL & $\begin{array}{c}6.988^{* * *} \\
(1.260)\end{array}$ & $\begin{array}{c}5.826^{* * *} \\
(1.545)\end{array}$ & $\begin{array}{c}12.845^{\star * *} \\
(1.786)\end{array}$ & $\begin{array}{c}10.417^{* \star *} \\
(2.122)\end{array}$ \\
\hline Outros & $\begin{array}{l}2.781^{* * *} \\
(1.000)\end{array}$ & $\begin{array}{c}5.166^{* * *} \\
(1.146)\end{array}$ & $\begin{array}{c}6.874^{* * *} \\
(1.456)\end{array}$ & $\begin{array}{c}6.478^{\star \star *} \\
(1.599)\end{array}$ \\
\hline Prefeito \& Governador & $\begin{array}{c}-4.010^{* * *} \\
(0.642) \\
\end{array}$ & $\begin{array}{c}-1.655^{\star * *} \\
(0.610) \\
\end{array}$ & $\begin{array}{c}-1.963^{* *} \\
(0.892)\end{array}$ & $\begin{array}{l}-0.213 \\
(0.830) \\
\end{array}$ \\
\hline Prefeito \& Presidente & $\begin{array}{c}20.461^{* * *} \\
(1.269) \\
\end{array}$ & $\begin{array}{c}22.298^{* \star *} \\
(1.064) \\
\end{array}$ & $\begin{array}{c}22.280^{\star * *} \\
(1.488) \\
\end{array}$ & $\begin{array}{c}23.407^{\star * \star} \\
(1.366)\end{array}$ \\
\hline Idosos & $\begin{array}{c}3.636^{\star \star *} \\
(0.285)\end{array}$ & $\begin{array}{c}6.135^{\star \star *} \\
(0.311) \\
\end{array}$ & $\begin{array}{c}2.813^{\star \star *} \\
(0.362)\end{array}$ & $\begin{array}{c}4.624^{\star \star *} \\
(0.478)\end{array}$ \\
\hline Urbanização & $\begin{array}{c}0.059^{* * *} \\
(0.017)\end{array}$ & $\begin{array}{c}0.096^{* * *} \\
(0.024)\end{array}$ & $\begin{array}{l}0.082^{* * *} \\
(0.024)\end{array}$ & $\begin{array}{c}0.137^{* * *} \\
(0.037)\end{array}$ \\
\hline Jovens & $\begin{array}{c}-1.242^{* * *} \\
(0.135) \\
\end{array}$ & $\begin{array}{c}-0.498^{* * *} \\
(0.112) \\
\end{array}$ & $\begin{array}{c}-1.198^{* * *} \\
(0.155) \\
\end{array}$ & $\begin{array}{c}-0.714^{* * *} \\
(0.188) \\
\end{array}$ \\
\hline População & $\begin{array}{c}10.067^{* * *} \\
(0.919) \\
\end{array}$ & $\begin{array}{c}11.255^{\star * *} \\
(0.567) \\
\end{array}$ & $\begin{array}{c}8.500^{* * *} \\
(1.056) \\
\end{array}$ & $\begin{array}{l}8.642^{\star * *} \\
(0.832) \\
\end{array}$ \\
\hline Tendência linear & $\begin{array}{l}1.493^{* \star \star} \\
(0.335) \\
\end{array}$ & $\begin{array}{l}1.100^{* * *} \\
(0.334)\end{array}$ & $\begin{array}{c}4.358^{* \star *} \\
(0.468)\end{array}$ & $\begin{array}{c}4.213^{\star \star \star} \\
(0.455)\end{array}$ \\
\hline Tendência quadrática & $\begin{array}{l}-0.043^{*} \\
(0.026)\end{array}$ & $\begin{array}{c}0.010 \\
(0.023)\end{array}$ & $\begin{array}{c}-0.108^{* * *} \\
(0.036)\end{array}$ & $\begin{array}{c}-0.072^{* *} \\
(0.032)\end{array}$ \\
\hline Constante & $\begin{array}{c}-88.428^{* * *} \\
(15.115) \\
\end{array}$ & $\begin{array}{c}-146.579^{\star * \star} \\
(8.070) \\
\end{array}$ & $\begin{array}{c}-82.900^{\star * *} \\
(15.589) \\
\end{array}$ & $\begin{array}{c}-112.449^{\star \star *} \\
(12.174) \\
\end{array}$ \\
\hline $\mathrm{R}^{2}$ & 0,3736 & 0,3714 & 0,3641 & 0,3626 \\
\hline Observações & 56315 & 56315 & 29055 & 29055 \\
\hline
\end{tabular}


Apêndice 1c.5-Despesa de investimento

\begin{tabular}{|c|c|c|c|c|}
\hline \multirow[b]{2}{*}{$\begin{array}{c}\text { Regressor } \\
\text { (Erro padrão) }\end{array}$} & \multicolumn{2}{|c|}{ Painel não balanceado } & \multicolumn{2}{|c|}{ Painel balanceado } \\
\hline & OLS & $\begin{array}{c}\text { Efeitos } \\
\text { Aleatórios }\end{array}$ & OLS & $\begin{array}{c}\text { Efeitos } \\
\text { Aleatórios }\end{array}$ \\
\hline Receita tributária & $\begin{array}{c}0.302^{* * *} \\
(0.015)\end{array}$ & $\begin{array}{c}0.312^{* \star *} \\
(0.008)\end{array}$ & $\begin{array}{c}0.365^{\star * *} \\
(0.022)\end{array}$ & $\begin{array}{c}0.354^{* * *} \\
(0.010)\end{array}$ \\
\hline Receita de transferências & $\begin{array}{c}0.219^{\star \star *} \\
(0.007)\end{array}$ & $\begin{array}{c}0.206^{\star * *} \\
(0.002)\end{array}$ & $\begin{array}{c}0.203^{\star \star \star} \\
(0.009)\end{array}$ & $\begin{array}{c}0.189^{\star \star *} \\
(0.003)\end{array}$ \\
\hline Dummy 1992 & $\begin{array}{c}-4.790^{* * *} \\
(1.684)\end{array}$ & $\begin{array}{l}-3.389^{\star} \\
(1.861)\end{array}$ & $\begin{array}{c}1.259 \\
(2.404)\end{array}$ & $\begin{array}{c}0.989 \\
(1.988)\end{array}$ \\
\hline Dummy 1996 & $\begin{array}{c}10.053^{* * *} \\
(2.127)\end{array}$ & $\begin{array}{c}12.117^{* * *} \\
(1.900)\end{array}$ & $\begin{array}{c}14.100^{* * *} \\
(2.271)\end{array}$ & $\begin{array}{c}15.120^{* * *} \\
(2.016)\end{array}$ \\
\hline Dummy 2000 & $\begin{array}{c}-7.967^{\star \star *} \\
(1.556)\end{array}$ & $\begin{array}{c}-7.124^{\star * *} \\
(1.676)\end{array}$ & $\begin{array}{l}-3.586^{*} \\
(1.945)\end{array}$ & $\begin{array}{l}-3.427^{*} \\
(1.961)\end{array}$ \\
\hline PFL & $\begin{array}{c}2.225 \\
(1.456) \\
\end{array}$ & $\begin{array}{c}0.682 \\
(1.541) \\
\end{array}$ & $\begin{array}{l}3.945^{\star *} \\
(1.786) \\
\end{array}$ & $\begin{array}{c}2.449 \\
(1.750) \\
\end{array}$ \\
\hline PSDB & $\begin{array}{l}-1.795 \\
(1.882)\end{array}$ & $\begin{array}{l}-1.646 \\
(2.111)\end{array}$ & $\begin{array}{l}-1.504 \\
(2.130)\end{array}$ & $\begin{array}{c}0.668 \\
(2.266)\end{array}$ \\
\hline PT & $\begin{array}{c}-22.347^{\star * *} \\
(2.580)\end{array}$ & $\begin{array}{c}-15.290^{* * *} \\
(3.831)\end{array}$ & $\begin{array}{c}-28.473^{\star * *} \\
(2.785)\end{array}$ & $\begin{array}{c}-20.298^{* * *} \\
(3.925)\end{array}$ \\
\hline PTB & $\begin{array}{l}-3.331^{*} \\
(1.871)\end{array}$ & $\begin{array}{l}-2.349 \\
(2.162)\end{array}$ & $\begin{array}{c}-6.105^{\star * *} \\
(2.062)\end{array}$ & $\begin{array}{l}-3.855^{\star} \\
(2.328)\end{array}$ \\
\hline PDT & $\begin{array}{c}-7.401^{* * *} \\
(2.137)\end{array}$ & $\begin{array}{c}-4.352^{* *} \\
(2.193)\end{array}$ & $\begin{array}{c}-14.453^{* * *} \\
(1.893)\end{array}$ & $\begin{array}{c}-9.798^{* * *} \\
(2.313)\end{array}$ \\
\hline PDS / PPB & $\begin{array}{l}-2.040 \\
(1.606)\end{array}$ & $\begin{array}{l}-2.548 \\
(1.874)\end{array}$ & $\begin{array}{l}-2.736 \\
(2.013)\end{array}$ & $\begin{array}{c}-4.338^{* *} \\
(2.061)\end{array}$ \\
\hline PL & $\begin{array}{c}-6.175^{\star * *} \\
(1.968)\end{array}$ & $\begin{array}{c}-7.624^{* * *} \\
(2.550)\end{array}$ & $\begin{array}{l}-2.902 \\
(2.604)\end{array}$ & $\begin{array}{c}-8.858^{* * *} \\
(2.884)\end{array}$ \\
\hline Outros & $\begin{array}{l}-1.855 \\
(1.795)\end{array}$ & $\begin{array}{c}1.376 \\
(1.876)\end{array}$ & $\begin{array}{c}0.435 \\
(2.143)\end{array}$ & $\begin{array}{c}2.699 \\
(2.142)\end{array}$ \\
\hline Prefeito \& Governador & $\begin{array}{c}2.999^{* * *} \\
(1.046)\end{array}$ & $\begin{array}{c}4.942^{* \star *} \\
(0.994)\end{array}$ & $\begin{array}{c}1.433 \\
(1.146)\end{array}$ & $\begin{array}{c}3.416^{* * *} \\
(1.112)\end{array}$ \\
\hline Prefeito \& Presidente & $\begin{array}{l}-3.618^{*} \\
(1.875)\end{array}$ & $\begin{array}{l}-2.862^{*} \\
(1.702)\end{array}$ & $\begin{array}{c}-5.920^{* * *} \\
(1.942)\end{array}$ & $\begin{array}{c}-5.864^{* * *} \\
(1.801)\end{array}$ \\
\hline Idosos & $\begin{array}{c}-5.707^{\star \star *} \\
(0.454)\end{array}$ & $\begin{array}{c}-7.604^{* * *} \\
(0.503)\end{array}$ & $\begin{array}{c}-5.372^{* * *} \\
(0.545)\end{array}$ & $\begin{array}{c}-7.043^{\star * *} \\
(0.637)\end{array}$ \\
\hline Urbanização & $\begin{array}{c}-0.306^{* * *} \\
(0.026)\end{array}$ & $\begin{array}{c}-0.277^{* * *} \\
(0.039)\end{array}$ & $\begin{array}{c}-0.272^{\star * *} \\
(0.036)\end{array}$ & $\begin{array}{c}-0.151^{* * *} \\
(0.052)\end{array}$ \\
\hline Jovens & $\begin{array}{c}0.675^{\star * *} \\
(0.176)\end{array}$ & $\begin{array}{l}-0.034 \\
(0.184)\end{array}$ & $\begin{array}{l}-0.191 \\
(0.249)\end{array}$ & $\begin{array}{c}-1.052^{* * *} \\
(0.265)\end{array}$ \\
\hline População & $\begin{array}{c}5.912^{* * *} \\
(1.332)\end{array}$ & $\begin{array}{c}0.463 \\
(0.959)\end{array}$ & $\begin{array}{c}5.308^{* * *} \\
(1.798)\end{array}$ & $\begin{array}{c}0.394 \\
(1.198)\end{array}$ \\
\hline Tendência linear & $\begin{array}{c}-7.166^{* * *} \\
(0.533)\end{array}$ & $\begin{array}{c}-7.692^{* * *} \\
(0.477)\end{array}$ & $\begin{array}{c}-10.475^{\star * *} \\
(0.632)\end{array}$ & $\begin{array}{c}-10.324^{* * *} \\
(0.534)\end{array}$ \\
\hline Tendência quadrática & $\begin{array}{l}-0.042 \\
(0.033)\end{array}$ & $\begin{array}{l}-0.037 \\
(0.028)\end{array}$ & $\begin{array}{c}0.094^{* * *} \\
(0.035)\end{array}$ & $\begin{array}{l}0.073^{* *} \\
(0.032)\end{array}$ \\
\hline Constante & $\begin{array}{c}2.991 \\
(19.988) \\
\end{array}$ & $\begin{array}{c}98.687^{\star \star *} \\
(13.274) \\
\end{array}$ & $\begin{array}{l}49.206^{*} \\
(26.912) \\
\end{array}$ & $\begin{array}{c}132.941^{* \star *} \\
(16.842) \\
\end{array}$ \\
\hline $\mathrm{R}^{2}$ & 0,3221 & 0,3207 & 0,3854 & 0,3835 \\
\hline Observações & 66384 & 66384 & 33525 & 33525 \\
\hline
\end{tabular}


Apêndice 1.d-Resultados das regressões com todas as dummies de ano OLS e efeitos aleatórios

\section{Apêndice 1d.1 - Despesa orçamentária}

\begin{tabular}{|c|c|c|c|c|}
\hline & \multicolumn{2}{|c|}{ Painel não balanceado } & \multicolumn{2}{|c|}{ Painel balanceado } \\
\hline & OLS & Efeitos aleatórios & OLS & Efeitos aleatórios \\
\hline Receita tributária & $\begin{array}{c}1.425^{\star \star *} \\
(0.024)\end{array}$ & $\begin{array}{l}1.338^{* * *} \\
(0.011)\end{array}$ & $\begin{array}{l}1.422^{* * *} \\
(0.032)\end{array}$ & $\begin{array}{l}1.323^{* * *} \\
(0.014)\end{array}$ \\
\hline Receita de transferências & $\begin{array}{c}1.073^{* * *} \\
(0.010)\end{array}$ & $\begin{array}{c}0.987^{* * *} \\
(0.003)\end{array}$ & $\begin{array}{l}1.056^{* * *} \\
(0.011)\end{array}$ & $\begin{array}{c}0.978^{* * *} \\
(0.004)\end{array}$ \\
\hline Dummy 1990 & $\begin{array}{c}6.804 \\
(4.334) \\
\end{array}$ & $\begin{array}{c}16.536^{* * *} \\
(3.301)\end{array}$ & $\begin{array}{l}7.250 \\
(6.840)\end{array}$ & $\begin{array}{c}17.386^{* * *} \\
(4.062)\end{array}$ \\
\hline Dummy 1991 & $\begin{array}{c}-8.872^{\star * *} \\
(2.602)\end{array}$ & $\begin{array}{l}-3.482 \\
(3.316) \\
\end{array}$ & $\begin{array}{c}-11.986^{\star * *} \\
(3.505)\end{array}$ & $\begin{array}{l}-5.101 \\
(4.048) \\
\end{array}$ \\
\hline Dummy 1992 & $\begin{array}{c}-10.803^{* * *} \\
(2.714)\end{array}$ & $\begin{array}{l}-5.135 \\
(3.313)\end{array}$ & $\begin{array}{c}1.815 \\
(3.704)\end{array}$ & $\begin{array}{l}6.922^{*} \\
(4.072)\end{array}$ \\
\hline Dummy 1993 & $\begin{array}{c}-40.256^{\star * *} \\
(2.831)\end{array}$ & $\begin{array}{c}-36.210^{\star * *} \\
(3.248)\end{array}$ & $\begin{array}{c}-32.542^{* * *} \\
(3.400)\end{array}$ & $\begin{array}{c}-28.231^{* * *} \\
(3.954)\end{array}$ \\
\hline Dummy 1994 & $\begin{array}{c}-14.616^{* * *} \\
(3.150)\end{array}$ & $\begin{array}{c}-8.882^{* * *} \\
(3.290)\end{array}$ & $\begin{array}{c}-12.823^{\star * \star} \\
(3.717)\end{array}$ & $\begin{array}{l}-5.083 \\
(4.002) \\
\end{array}$ \\
\hline Dummy 1995 & $\begin{array}{c}-14.867^{* * *} \\
(3.184)\end{array}$ & $\begin{array}{l}-1.453 \\
(3.460)\end{array}$ & $\begin{array}{c}-11.956^{\star * *} \\
(3.959)\end{array}$ & $\begin{array}{c}3.724 \\
(4.232)\end{array}$ \\
\hline Dummy 1996 & $\begin{array}{c}9.725^{\star * *} \\
(3.712)\end{array}$ & $\begin{array}{c}26.388^{\star * *} \\
(3.509)\end{array}$ & $\begin{array}{c}13.377^{\star * *} \\
(4.459)\end{array}$ & $\begin{array}{c}31.509^{* * *} \\
(4.328)\end{array}$ \\
\hline Dummy 1997 & $\begin{array}{c}-50.319^{\star * *} \\
(3.153)\end{array}$ & $\begin{array}{c}-37.986^{\star * *} \\
(3.347)\end{array}$ & $\begin{array}{c}-51.293^{* * *} \\
(3.979)\end{array}$ & $\begin{array}{c}-35.934^{* * *} \\
(4.350)\end{array}$ \\
\hline Dummy 1998 & $\begin{array}{c}3.640 \\
(4.439)\end{array}$ & $\begin{array}{c}26.074^{* * *} \\
(3.601)\end{array}$ & $\begin{array}{l}-3.005 \\
(4.770)\end{array}$ & $\begin{array}{c}20.948^{* * *} \\
(4.505)\end{array}$ \\
\hline Dummy 1999 & $\begin{array}{c}-51.863^{* * *} \\
(3.929)\end{array}$ & $\begin{array}{c}-29.963^{\star \star *} \\
(3.650)\end{array}$ & $\begin{array}{c}-52.583^{* * *} \\
(4.596)\end{array}$ & $\begin{array}{c}-29.265^{\star \star *} \\
(4.573)\end{array}$ \\
\hline Dummy 2000 & $\begin{array}{c}-60.724^{* * *} \\
(3.910)\end{array}$ & $\begin{array}{c}-38.670^{* * *} \\
(3.597)\end{array}$ & $\begin{array}{c}-59.531^{* * *} \\
(4.629)\end{array}$ & $\begin{array}{c}-37.171^{* * *} \\
(4.652)\end{array}$ \\
\hline Dummy 2001 & $\begin{array}{c}-93.573^{* * *} \\
(3.965)\end{array}$ & $\begin{array}{c}-70.769^{* * *} \\
(3.654)\end{array}$ & $\begin{array}{c}-102.654^{* * *} \\
(4.815)\end{array}$ & $\begin{array}{c}-78.792^{* * *} \\
(4.769)\end{array}$ \\
\hline Dummy 2002 & $\begin{array}{c}-121.896^{* * *} \\
(4.459)\end{array}$ & $\begin{array}{c}-94.401^{* * *} \\
(3.797)\end{array}$ & $\begin{array}{c}-133.340^{* * *} \\
(5.215)\end{array}$ & $\begin{array}{c}-105.611^{* * *} \\
(4.914)\end{array}$ \\
\hline Dummy 2003 & $\begin{array}{c}-142.850^{\star * *} \\
(3.825)\end{array}$ & $\begin{array}{c}-125.623^{\star \star *} \\
(3.890)\end{array}$ & $\begin{array}{c}-148.110^{\star * *} \\
(4.792)\end{array}$ & $\begin{array}{c}-129.814^{\star * *} \\
(5.028)\end{array}$ \\
\hline PFL & $\begin{array}{c}1.057 \\
(2.114) \\
\end{array}$ & $\begin{array}{l}-3.308 \\
(2.055) \\
\end{array}$ & $\begin{array}{c}3.636 \\
(2.932) \\
\end{array}$ & $\begin{array}{l}-1.066 \\
(2.600) \\
\end{array}$ \\
\hline PSDB & $\begin{array}{l}-3.984 \\
(2.710) \\
\end{array}$ & $\begin{array}{l}-2.724 \\
(2.838) \\
\end{array}$ & $\begin{array}{l}-4.488 \\
(2.841) \\
\end{array}$ & $\begin{array}{l}-5.528 \\
(3.455) \\
\end{array}$ \\
\hline PT & $\begin{array}{c}-10.848^{* * *} \\
(3.640) \\
\end{array}$ & $\begin{array}{c}-11.736^{* *} \\
(5.081)\end{array}$ & $\begin{array}{l}-6.618^{*} \\
(3.963) \\
\end{array}$ & $\begin{array}{c}-11.710^{* *} \\
(5.826)\end{array}$ \\
\hline PTB & $\begin{array}{c}0.925 \\
(2.372) \\
\end{array}$ & $\begin{array}{l}-3.176 \\
(2.887) \\
\end{array}$ & $\begin{array}{c}4.143 \\
(2.918) \\
\end{array}$ & $\begin{array}{c}0.343 \\
(3.430) \\
\end{array}$ \\
\hline PDT & $\begin{array}{l}-4.413 \\
(2.775) \\
\end{array}$ & $\begin{array}{l}-1.612 \\
(2.931) \\
\end{array}$ & $\begin{array}{c}6.018^{* *} \\
(2.617)\end{array}$ & $\begin{array}{l}-3.306 \\
(3.444) \\
\end{array}$ \\
\hline PDS / PPB & $\begin{array}{c}-12.736^{\star * *} \\
(2.230)\end{array}$ & $\begin{array}{c}-8.058^{* \star *} \\
(2.495)\end{array}$ & $\begin{array}{c}-7.251^{* *} \\
(3.086)\end{array}$ & $\begin{array}{l}-5.634^{*} \\
(3.079) \\
\end{array}$ \\
\hline PL & $\begin{array}{c}-8.264^{\star * *} \\
(2.535)\end{array}$ & $\begin{array}{c}-14.533^{* * *} \\
(3.388)\end{array}$ & $\begin{array}{c}0.679 \\
(3.574)\end{array}$ & $\begin{array}{l}-7.733^{*} \\
(4.296)\end{array}$ \\
\hline Outros & $\begin{array}{c}1.762 \\
(2.349) \\
\end{array}$ & $\begin{array}{l}-0.649 \\
(2.496) \\
\end{array}$ & $\begin{array}{c}9.849^{* * *} \\
(2.759)\end{array}$ & $\begin{array}{c}2.330 \\
(3.192) \\
\end{array}$ \\
\hline Prefeito $=$ Governador & $\begin{array}{c}-0.849 \\
(1.415) \\
\end{array}$ & $\begin{array}{l}2.224^{*} \\
(1.308) \\
\end{array}$ & $\begin{array}{l}2.991^{*} \\
(1.759)\end{array}$ & $\begin{array}{c}5.421^{\star \star \star *} \\
(1.663)\end{array}$ \\
\hline Prefeito $=$ Presidente & $\begin{array}{l}4.568^{*} \\
(2.552)\end{array}$ & $\begin{array}{c}1.644 \\
(2.418) \\
\end{array}$ & $\begin{array}{c}7.632^{\star * \star} \\
(2.735)\end{array}$ & $\begin{array}{l}5.173^{*} \\
(2.973)\end{array}$ \\
\hline Idosos & $\begin{array}{c}-5.987^{* * *} \\
(0.622)\end{array}$ & $\begin{array}{c}-9.768^{* * *} \\
(0.703)\end{array}$ & $\begin{array}{c}-6.587^{* * *} \\
(0.778)\end{array}$ & $\begin{array}{c}-9.311^{* * *} \\
(0.922)\end{array}$ \\
\hline Urbanização & $\begin{array}{c}0.330^{* * *} \\
(0.034)\end{array}$ & $\begin{array}{c}0.591^{* * *} \\
(0.057)\end{array}$ & $\begin{array}{c}0.389^{* * *} \\
(0.046)\end{array}$ & $\begin{array}{c}0.738^{* * *} \\
(0.074)\end{array}$ \\
\hline Jovens & $\begin{array}{c}-2.734^{\star * *} \\
(0.267)\end{array}$ & $\begin{array}{c}-4.413^{\star \star *} \\
(0.262)\end{array}$ & $\begin{array}{c}-4.242^{\star \star \star} \\
(0.363)\end{array}$ & $\begin{array}{c}-5.652^{\star * *} \\
(0.379)\end{array}$ \\
\hline População & $\begin{array}{c}-4.424^{\star *} \\
(2.029)\end{array}$ & $\begin{array}{c}-21.760^{* * *} \\
(1.397) \\
\end{array}$ & $\begin{array}{c}-7.837^{* * \star} \\
(2.346)\end{array}$ & $\begin{array}{c}-22.287^{* * *} \\
(1.705)\end{array}$ \\
\hline Constante & $\begin{array}{c}222.919^{\star \star \star *} \\
(30.663)\end{array}$ & $\begin{array}{c}489.027^{* * *} \\
(18.896)\end{array}$ & $\begin{array}{c}307.681^{* * *} \\
(35.902)\end{array}$ & $\begin{array}{c}521.466^{* * *} \\
(24.322)\end{array}$ \\
\hline
\end{tabular}




\begin{tabular}{|c|c|c|c|c|c|}
\hline $\mathrm{R}^{2}$ & 0,8894 & 0,8881 & & 0,8981 & 0,8967 \\
\hline Observações & 66384 & 66384 & & 33525 & 33525 \\
\hline
\end{tabular}


Apêndice 1d.2 - Despesa corrente

\begin{tabular}{|c|c|c|c|c|}
\hline & \multicolumn{2}{|c|}{ Painel não balanceado } & \multicolumn{2}{|c|}{ Painel balanceado } \\
\hline & OLS & Efeitos aleatórios & OLS & Efeitos aleatórios \\
\hline Receita tributária & $\begin{array}{l}1.101^{* * *} \\
(0.024)\end{array}$ & $\begin{array}{c}0.991^{* \star *} \\
(0.008)\end{array}$ & $\begin{array}{l}1.037^{* * *} \\
(0.031)\end{array}$ & $\begin{array}{c}0.932^{* * \star} \\
(0.012)\end{array}$ \\
\hline Receita de transferências & $\begin{array}{c}0.836^{* * *} \\
(0.007)\end{array}$ & $\begin{array}{c}0.769^{* * *} \\
(0.002)\end{array}$ & $\begin{array}{c}0.837^{* * *} \\
(0.010)\end{array}$ & $\begin{array}{c}0.762^{* * *} \\
(0.003)\end{array}$ \\
\hline Dummy 1990 & $\begin{array}{c}-31.500^{* * *} \\
(3.302)\end{array}$ & $\begin{array}{c}-24.019 * * * \\
(2.296)\end{array}$ & $\begin{array}{c}-34.656^{* * *} \\
(5.267)\end{array}$ & $\begin{array}{c}-25.193^{* \star *} \\
(3.149)\end{array}$ \\
\hline Dummy 1991 & $\begin{array}{c}-14.809^{* * *} \\
(2.131)\end{array}$ & $\begin{array}{c}-10.030^{\star * *} \\
(2.306)\end{array}$ & $\begin{array}{c}-20.003^{* * *} \\
(3.040)\end{array}$ & $\begin{array}{c}-13.305^{\star \star *} \\
(3.145)\end{array}$ \\
\hline Dummy 1992 & $\begin{array}{l}-3.614 \\
(2.231)\end{array}$ & $\begin{array}{c}0.974 \\
(2.319)\end{array}$ & $\begin{array}{l}5.955^{\star} \\
(3.184)\end{array}$ & $\begin{array}{c}11.173^{\star \star *} \\
(3.165)\end{array}$ \\
\hline Dummy 1993 & $\begin{array}{c}-20.120^{\star * *} \\
(2.258)\end{array}$ & $\begin{array}{c}-13.808^{\star \star *} \\
(2.267)\end{array}$ & $\begin{array}{l}-1.686 \\
(2.858) \\
\end{array}$ & $\begin{array}{c}4.202 \\
(3.090) \\
\end{array}$ \\
\hline Dummy 1994 & $\begin{array}{c}-22.494^{* \star *} \\
(2.305)\end{array}$ & $\begin{array}{c}-13.900^{* * *} \\
(2.305)\end{array}$ & $\begin{array}{c}-13.125^{\star * *} \\
(3.010)\end{array}$ & $\begin{array}{l}-3.563 \\
(3.125)\end{array}$ \\
\hline Dummy 1995 & $\begin{array}{c}-2.358 \\
(2.482) \\
\end{array}$ & $\begin{array}{c}11.877^{* * *} \\
(2.414) \\
\end{array}$ & $\begin{array}{c}2.243 \\
(3.398) \\
\end{array}$ & $\begin{array}{c}19.104^{\star * *} \\
(3.334) \\
\end{array}$ \\
\hline Dummy 1996 & $\begin{array}{c}27.001^{* * *} \\
(2.848)\end{array}$ & $\begin{array}{c}43.827^{\star \star *} \\
(2.462) \\
\end{array}$ & $\begin{array}{c}34.394^{* * *} \\
(3.830)\end{array}$ & $\begin{array}{c}53.911^{* * *} \\
(3.410)\end{array}$ \\
\hline Dummy 1997 & $\begin{array}{l}4.19{ }^{*} \\
(2.354)\end{array}$ & $\begin{array}{c}20.880^{* * *} \\
(2.354) \\
\end{array}$ & $\begin{array}{c}17.714^{\star \star \star} \\
(3.440)\end{array}$ & $\begin{array}{c}6.078^{\star * *} \\
(3.439) \\
\end{array}$ \\
\hline Dummy 1998 & $\begin{array}{c}22.312^{* * *} \\
(3.007)\end{array}$ & $\begin{array}{c}47.735^{\star \star *} \\
(2.542) \\
\end{array}$ & $\begin{array}{c}32.047^{* * *} \\
(4.119)\end{array}$ & $\begin{array}{c}59.120^{\star * *} \\
(3.579) \\
\end{array}$ \\
\hline Dummy 1999 & $\begin{array}{c}21.354^{\star \star \star} \\
(2.933)\end{array}$ & $\begin{array}{c}46.314^{\star \star \star} \\
(2.579) \\
\end{array}$ & $\begin{array}{c}26.158^{* * *} \\
(4.049)\end{array}$ & $\begin{array}{c}52.736^{\star \star *} \\
(3.647) \\
\end{array}$ \\
\hline Dummy 2000 & $\begin{array}{c}9.508^{* \star *} \\
(2.881)\end{array}$ & $\begin{array}{c}34.586^{\star \star *} \\
(2.551)\end{array}$ & $\begin{array}{c}16.181^{\star \star *} \\
(4.045)\end{array}$ & $\begin{array}{c}42.242^{* * *} \\
(3.725)\end{array}$ \\
\hline Dummy 2001 & $\begin{array}{l}-3.141 \\
(2.908)\end{array}$ & $\begin{array}{c}23.687^{\star \star \star} \\
(2.597)\end{array}$ & $\begin{array}{l}-1.889 \\
(4.198)\end{array}$ & $\begin{array}{c}26.301^{* * *} \\
(3.828)\end{array}$ \\
\hline Dummy 2002 & $\begin{array}{c}-72.577^{* * *} \\
(3.180)\end{array}$ & $\begin{array}{c}-40.723^{* * *} \\
(2.706)\end{array}$ & $\begin{array}{c}-71.215^{\star * *} \\
(4.499)\end{array}$ & $\begin{array}{c}-38.821^{* * *} \\
(3.965)\end{array}$ \\
\hline Dummy 2003 & $\begin{array}{c}-47.472^{\star \star *} \\
(2.722)\end{array}$ & $\begin{array}{c}-23.937^{* * *} \\
(2.770)\end{array}$ & $\begin{array}{c}-47.137^{* * *} \\
(3.896)\end{array}$ & $\begin{array}{c}-23.757^{* \star *} \\
(4.054)\end{array}$ \\
\hline PFL & $\begin{array}{l}-1.565 \\
(1.550)\end{array}$ & $\begin{array}{c}-5.206^{\star * *} \\
(1.446)\end{array}$ & $\begin{array}{l}-1.537 \\
(2.260)\end{array}$ & $\begin{array}{c}-6.771^{* * *} \\
(2.052)\end{array}$ \\
\hline PSDB & $\begin{array}{l}-0.225 \\
(1.875)\end{array}$ & $\begin{array}{c}-0.128 \\
(2.133)\end{array}$ & $\begin{array}{l}-0.332 \\
(2.213)\end{array}$ & $\begin{array}{l}-4.725^{\star} \\
(2.700)\end{array}$ \\
\hline PT & $\begin{array}{c}11.188^{* * *} \\
(3.032)\end{array}$ & $\begin{array}{c}2.119 \\
(3.592)\end{array}$ & $\begin{array}{c}19.629^{* * *} \\
(3.655)\end{array}$ & $\begin{array}{c}4.943 \\
(4.577)\end{array}$ \\
\hline PTB & $\begin{array}{c}1.261 \\
(1.828) \\
\end{array}$ & $\begin{array}{l}-3.520^{*} \\
(2.023) \\
\end{array}$ & $\begin{array}{l}5.846^{\star \star} \\
(2.509)\end{array}$ & $\begin{array}{l}-0.500 \\
(2.778) \\
\end{array}$ \\
\hline PDT & $\begin{array}{l}-0.673 \\
(2.039) \\
\end{array}$ & $\begin{array}{l}-0.985 \\
(2.052)\end{array}$ & $\begin{array}{c}1.897 \\
(2.286) \\
\end{array}$ & $\begin{array}{c}0.881 \\
(2.670) \\
\end{array}$ \\
\hline PDS / PPB & $\begin{array}{c}-10.748^{\star * *} \\
(1.690)\end{array}$ & $\begin{array}{c}-6.321^{\star \star *} \\
(1.751) \\
\end{array}$ & $\begin{array}{c}-5.940^{\star *} \\
(2.517) \\
\end{array}$ & $\begin{array}{c}-3.811 \\
(2.412) \\
\end{array}$ \\
\hline PL & $\begin{array}{l}-1.999 \\
(1.960) \\
\end{array}$ & $\begin{array}{c}-8.080^{* * *} \\
(2.376) \\
\end{array}$ & $\begin{array}{c}1.642 \\
(2.831) \\
\end{array}$ & $\begin{array}{c}-2.162 \\
(3.378) \\
\end{array}$ \\
\hline Outros & $\begin{array}{c}4.386^{\star \star \star} \\
(1.589) \\
\end{array}$ & $\begin{array}{c}-2.490 \\
(1.754) \\
\end{array}$ & $\begin{array}{c}8.943^{* * *} \\
(2.276) \\
\end{array}$ & $\begin{array}{c}-2.581 \\
(2.506) \\
\end{array}$ \\
\hline Prefeito $=$ Governador & $\begin{array}{c}-1.054 \\
(1.033) \\
\end{array}$ & $\begin{array}{c}-0.711 \\
(0.912) \\
\end{array}$ & $\begin{array}{c}3.849^{* * *} \\
(1.420)\end{array}$ & $\begin{array}{c}3.670^{\star \star \star} \\
(1.297)\end{array}$ \\
\hline Prefeito $=$ Presidente & $\begin{array}{c}3.300^{*} \\
(1.765)\end{array}$ & $\begin{array}{l}-1.840 \\
(1.688)\end{array}$ & $\begin{array}{l}4.668^{\star *} \\
(2.151)\end{array}$ & $\begin{array}{c}0.502 \\
(2.282)\end{array}$ \\
\hline Idosos & $\begin{array}{c}-0.408 \\
(0.448) \\
\end{array}$ & $\begin{array}{c}-2.527^{\star \star \star} \\
(0.513) \\
\end{array}$ & $\begin{array}{c}-0.555 \\
(0.661) \\
\end{array}$ & $\begin{array}{c}-2.670^{\star * *} \\
(0.769) \\
\end{array}$ \\
\hline Urbanização & $\begin{array}{c}0.636^{* * *} \\
(0.028)\end{array}$ & $\begin{array}{c}0.811^{\star * *} \\
(0.042)\end{array}$ & $\begin{array}{l}0.641^{\star * *} \\
(0.042)\end{array}$ & $\begin{array}{c}0.850^{* * *} \\
(0.064)\end{array}$ \\
\hline Jovens & $\begin{array}{c}-2.873^{\star \star *} \\
(0.202)\end{array}$ & $\begin{array}{c}-3.744^{\star * *} \\
(0.194)\end{array}$ & $\begin{array}{c}-3.446^{\star \star *} \\
(0.312)\end{array}$ & $\begin{array}{c}-4.335^{\star \star *} \\
(0.325) \\
\end{array}$ \\
\hline População & $\begin{array}{c}-11.855^{\star * *} \\
(1.510)\end{array}$ & $\begin{array}{c}-21.727^{* \star *} \\
(1.051)\end{array}$ & $\begin{array}{c}-13.165^{\star * *} \\
(2.134)\end{array}$ & $\begin{array}{c}-23.899 * * * \\
(1.490)\end{array}$ \\
\hline Constante & $\begin{array}{c}244.703^{* * *} \\
(22.368)\end{array}$ & $\begin{array}{c}397.423^{\star * *} \\
(13.954)\end{array}$ & $\begin{array}{c}272.442^{\star * *} \\
(31.790)\end{array}$ & $\begin{array}{c}438.531^{\star * *} \\
(20.695)\end{array}$ \\
\hline $\mathrm{R}^{2}$ & 0,9113 & 0,9098 & 0,9013 & 0,8995 \\
\hline Observações & 66384 & 66384 & 33525 & 33525 \\
\hline
\end{tabular}


Apêndice 1d.3 - Despesa de pessoal

\begin{tabular}{|c|c|c|c|c|}
\hline & \multicolumn{2}{|c|}{ Painel não balanceado } & \multicolumn{2}{|c|}{ Painel balanceado } \\
\hline & OLS & Efeitos aleatórios & OLS & Efeitos aleatórios \\
\hline Receita tributária & $\begin{array}{c}0.518^{* * *} \\
(0.018)\end{array}$ & $\begin{array}{c}0.398^{* * *} \\
(0.006)\end{array}$ & $\begin{array}{c}0.459^{* * *} \\
(0.022)\end{array}$ & $\begin{array}{c}0.348^{* * *} \\
(0.008)\end{array}$ \\
\hline Receita de transferências & $\begin{array}{c}0.371^{* * *} \\
(0.005)\end{array}$ & $\begin{array}{c}0.326^{* * *} \\
(0.002)\end{array}$ & $\begin{array}{l}0.394^{* * *} \\
(0.006)\end{array}$ & $\begin{array}{c}0.347^{* * *} \\
(0.003)\end{array}$ \\
\hline Dummy 1990 & $\begin{array}{c}-28.946^{* \star *} \\
(1.877)\end{array}$ & $\begin{array}{c}-23.096 * * * \\
(1.592)\end{array}$ & $\begin{array}{c}-32.910^{* * *} \\
(2.879)\end{array}$ & $\begin{array}{c}-26.477^{* * *} \\
(2.123)\end{array}$ \\
\hline Dummy 1991 & $\begin{array}{c}-19.330^{\star \star *} \\
(1.496)\end{array}$ & $\begin{array}{c}-14.987^{* * *} \\
(1.598)\end{array}$ & $\begin{array}{c}-23.887^{* * *} \\
(2.152)\end{array}$ & $\begin{array}{c}-18.784^{\star * *} \\
(2.125)\end{array}$ \\
\hline Dummy 1992 & $\begin{array}{c}-27.455^{\star \star *} \\
(1.615)\end{array}$ & $\begin{array}{c}-23.157^{* * *} \\
(1.605)\end{array}$ & $\begin{array}{c}-23.112^{\star * \star} \\
(2.259)\end{array}$ & $\begin{array}{c}-19.385^{\star \star \star} \\
(2.142)\end{array}$ \\
\hline Dummy 1993 & $\begin{array}{c}-19.159^{* * *} \\
(1.657)\end{array}$ & $\begin{array}{c}-13.939^{\star * *} \\
(1.579)\end{array}$ & $\begin{array}{c}-10.296^{* * *} \\
(2.132)\end{array}$ & $\begin{array}{c}-6.330^{* * *} \\
(2.089) \\
\end{array}$ \\
\hline Dummy 1994 & $\begin{array}{c}-43.838^{* * *} \\
(1.569)\end{array}$ & $\begin{array}{c}-35.857^{* * *} \\
(1.609)\end{array}$ & $\begin{array}{c}-41.923^{* \star *} \\
(2.117)\end{array}$ & $\begin{array}{c}-35.332^{\star * \star} \\
(2.137)\end{array}$ \\
\hline Dummy 1995 & $\begin{array}{c}-32.047^{\star \star *} \\
(1.812)\end{array}$ & $\begin{array}{c}-18.899^{* * *} \\
(1.695)\end{array}$ & $\begin{array}{c}-30.334^{* \star *} \\
(2.427)\end{array}$ & $\begin{array}{c}-18.070^{\star * *} \\
(2.290)\end{array}$ \\
\hline Dummy 1996 & $\begin{array}{c}-17.379 * * * \\
(1.973)\end{array}$ & $\begin{array}{l}-2.882^{*} \\
(1.736)\end{array}$ & $\begin{array}{c}-13.720^{\star * \star} \\
(2.613)\end{array}$ & $\begin{array}{c}0.183 \\
(2.288)\end{array}$ \\
\hline Dummy 1997 & $\begin{array}{c}-8.565^{\star \star *} \\
(1.713)\end{array}$ & $\begin{array}{c}6.679^{* * *} \\
(1.666) \\
\end{array}$ & $\begin{array}{c}-0.844 \\
(2.482) \\
\end{array}$ & $\begin{array}{c}12.736^{\star * \star} \\
(2.385) \\
\end{array}$ \\
\hline Dummy 1998 & $\begin{array}{c}-9.973^{\star * *} \\
(2.206) \\
\end{array}$ & $\begin{array}{c}11.120^{\star * *} \\
(1.805)\end{array}$ & $\begin{array}{c}-12.605^{\star * \star} \\
(2.814)\end{array}$ & $\begin{array}{l}7.101^{\star * *} \\
(2.500)\end{array}$ \\
\hline Dummy 1999 & $\begin{array}{c}-16.738^{\star \star *} \\
(2.185)\end{array}$ & $\begin{array}{l}4.467^{* *} \\
(1.838)\end{array}$ & $\begin{array}{c}-24.389^{* * *} \\
(2.820)\end{array}$ & $\begin{array}{l}-4.615^{\star} \\
(2.564) \\
\end{array}$ \\
\hline Dummy 2000 & $\begin{array}{c}-17.704^{* * *} \\
(2.085)\end{array}$ & $\begin{array}{l}4.664^{\star *} \\
(1.829)\end{array}$ & $\begin{array}{c}-20.925^{* * *} \\
(2.832)\end{array}$ & $\begin{array}{l}-1.266 \\
(2.638) \\
\end{array}$ \\
\hline Dummy 2001 & $\begin{array}{c}-21.082^{\star \star *} \\
(2.077)\end{array}$ & $\begin{array}{c}2.239 \\
(1.866)\end{array}$ & $\begin{array}{c}-31.381^{* \star *} \\
(2.858)\end{array}$ & $\begin{array}{c}-10.680^{\star \star \star} \\
(2.711)\end{array}$ \\
\hline Dummy 2002 & $\begin{array}{c}-30.132^{* \star *} \\
(2.174)\end{array}$ & $\begin{array}{l}-2.436 \\
(1.965)\end{array}$ & $\begin{array}{c}-30.027^{* * *} \\
(2.961)\end{array}$ & $\begin{array}{c}-5.981^{* *} \\
(2.821)\end{array}$ \\
\hline Dummy 2003 & $\begin{array}{c}-18.283^{* * *} \\
(1.881)\end{array}$ & $\begin{array}{l}3.851^{*} \\
(2.006)\end{array}$ & $\begin{array}{c}-21.182^{\star \star *} \\
(2.615)\end{array}$ & $\begin{array}{l}-2.730 \\
(2.874) \\
\end{array}$ \\
\hline PFL & $\begin{array}{c}-4.865^{\star * *} \\
(1.048)\end{array}$ & $\begin{array}{c}-4.147^{\star * *} \\
(1.016)\end{array}$ & $\begin{array}{c}-3.637^{* *} \\
(1.503)\end{array}$ & $\begin{array}{c}-4.166^{* * *} \\
(1.403)\end{array}$ \\
\hline PSDB & $\begin{array}{l}3.535^{\star \star} \\
(1.408)\end{array}$ & $\begin{array}{c}5.954^{\star \star *} \\
(1.398)\end{array}$ & $\begin{array}{c}1.493 \\
(1.716)\end{array}$ & $\begin{array}{c}2.493 \\
(1.833)\end{array}$ \\
\hline PT & $\begin{array}{c}9.600^{* * *} \\
(2.394)\end{array}$ & $\begin{array}{l}-1.180 \\
(2.511)\end{array}$ & $\begin{array}{c}10.613^{* * *} \\
(2.924)\end{array}$ & $\begin{array}{l}-2.834 \\
(3.114)\end{array}$ \\
\hline PTB & $\begin{array}{c}0.859 \\
(1.507) \\
\end{array}$ & $\begin{array}{c}-1.983 \\
(1.416) \\
\end{array}$ & $\begin{array}{c}1.451 \\
(1.935) \\
\end{array}$ & $\begin{array}{l}-0.967 \\
(1.860) \\
\end{array}$ \\
\hline PDT & $\begin{array}{c}13.233^{* * *} \\
(1.502) \\
\end{array}$ & $\begin{array}{l}3.191^{\star *} \\
(1.437)\end{array}$ & $\begin{array}{c}12.623^{* * *} \\
(1.876)\end{array}$ & $\begin{array}{c}2.522 \\
(1.841) \\
\end{array}$ \\
\hline PDS / PPB & $\begin{array}{l}-2.482^{*} \\
(1.279) \\
\end{array}$ & $\begin{array}{c}-4.954^{* \star *} \\
(1.229) \\
\end{array}$ & $\begin{array}{l}-1.020 \\
(1.729) \\
\end{array}$ & $\begin{array}{c}-4.205^{\star *} \\
(1.649) \\
\end{array}$ \\
\hline PL & $\begin{array}{c}-12.424^{* \star *} \\
(1.583)\end{array}$ & $\begin{array}{c}-10.122^{* * *} \\
(1.670)\end{array}$ & $\begin{array}{c}-9.834^{\star * *} \\
(2.375) \\
\end{array}$ & $\begin{array}{l}-2.351 \\
(2.305) \\
\end{array}$ \\
\hline Outros & $\begin{array}{l}-0.341 \\
(1.218) \\
\end{array}$ & $\begin{array}{l}-2.025^{*} \\
(1.235) \\
\end{array}$ & $\begin{array}{c}1.728 \\
(1.728) \\
\end{array}$ & $\begin{array}{l}-0.739 \\
(1.719) \\
\end{array}$ \\
\hline Prefeito $=$ Governador & $\begin{array}{c}-3.919^{\star * \star} \\
(0.746) \\
\end{array}$ & $\begin{array}{c}-1.597^{* *} \\
(0.636) \\
\end{array}$ & $\begin{array}{c}-2.761^{* * *} \\
(1.008) \\
\end{array}$ & $\begin{array}{l}-0.395 \\
(0.878) \\
\end{array}$ \\
\hline Prefeito $=$ Presidente & $\begin{array}{c}1.522 \\
(1.268) \\
\end{array}$ & $\begin{array}{l}-2.080^{*} \\
(1.175) \\
\end{array}$ & $\begin{array}{l}2.708^{*} \\
(1.556) \\
\end{array}$ & $\begin{array}{l}-0.475 \\
(1.532) \\
\end{array}$ \\
\hline Idosos & $\begin{array}{c}-1.031^{\star * *} \\
(0.317) \\
\end{array}$ & $\begin{array}{c}-1.433^{\star * \star} \\
(0.381) \\
\end{array}$ & $\begin{array}{c}-1.526^{\star * \star} \\
(0.437) \\
\end{array}$ & $\begin{array}{c}-1.584^{\star \star *} \\
(0.560) \\
\end{array}$ \\
\hline Urbanização & $\begin{array}{c}0.339^{* * *} \\
(0.021)\end{array}$ & $\begin{array}{c}0.470^{* * *} \\
(0.033)\end{array}$ & $\begin{array}{c}0.230^{\star * *} \\
(0.029)\end{array}$ & $\begin{array}{c}0.339^{\star \star *} \\
(0.049)\end{array}$ \\
\hline Jovens & $\begin{array}{c}-3.607^{\star \star \star *} \\
(0.141)\end{array}$ & $\begin{array}{c}-3.773^{\star * *} \\
(0.149)\end{array}$ & $\begin{array}{c}-4.086^{\star * *} \\
(0.184)\end{array}$ & $\begin{array}{c}-4.411^{\star \star *} \\
(0.246)\end{array}$ \\
\hline População & $\begin{array}{c}1.887^{*} \\
(1.043) \\
\end{array}$ & $\begin{array}{c}-3.943^{* * *} \\
(0.830)\end{array}$ & $\begin{array}{c}3.859^{* * *} \\
(1.253)\end{array}$ & $\begin{array}{l}-1.259 \\
(1.155) \\
\end{array}$ \\
\hline Constante & $\begin{array}{c}144.859^{* * *} \\
(15.345)\end{array}$ & $\begin{array}{c}216.854^{\star \star *} \\
(10.667)\end{array}$ & $\begin{array}{c}143.826^{\star \star *} \\
(17.647)\end{array}$ & $\begin{array}{c}218.967^{* * *} \\
(15.552)\end{array}$ \\
\hline $\mathrm{R}^{2}$ & 0,8005 & 0,7961 & 0,7997 & 0,7954 \\
\hline Observações & 66384 & 66384 & 33525 & 33525 \\
\hline
\end{tabular}


Apêndice 1d.4 - Transferências correntes

\begin{tabular}{|c|c|c|c|c|}
\hline & \multicolumn{2}{|c|}{ Painel não balanceado } & \multicolumn{2}{|c|}{ Painel balanceado } \\
\hline & OLS & Efeitos aleatórios & OLS & Efeitos aleatórios \\
\hline Receita tributária & $\begin{array}{c}0.090^{* * *} \\
(0.011)\end{array}$ & $\begin{array}{c}0.105^{* * *} \\
(0.005)\end{array}$ & $\begin{array}{c}0.104^{* * *} \\
(0.015)\end{array}$ & $\begin{array}{c}0.099 * * * \\
(0.007)\end{array}$ \\
\hline Receita de transferências & $\begin{array}{c}0.122^{* * *} \\
(0.005)\end{array}$ & $\begin{array}{c}0.127^{* * *} \\
(0.001)\end{array}$ & $\begin{array}{c}0.115^{\star \star \star} \\
(0.005)\end{array}$ & $\begin{array}{c}0.114^{* * *} \\
(0.002)\end{array}$ \\
\hline Dummy 1990 & $\begin{array}{c}-22.609^{\star \star \star} \\
(1.255)\end{array}$ & $\begin{array}{c}-22.584^{\star \star \star} \\
(1.314)\end{array}$ & $\begin{array}{c}-23.448^{* * *} \\
(1.883)\end{array}$ & $\begin{array}{c}-22.771^{* \star *} \\
(1.722)\end{array}$ \\
\hline Dummy 1991 & $\begin{array}{c}-21.108^{* * *} \\
(1.041)\end{array}$ & $\begin{array}{c}-20.601^{* * *} \\
(1.317)\end{array}$ & $\begin{array}{c}-21.345^{\star * *} \\
(1.477)\end{array}$ & $\begin{array}{c}-20.627^{* * *} \\
(1.719)\end{array}$ \\
\hline Dummy 1992 & $\begin{array}{c}-21.986^{\star \star \star} \\
(1.012)\end{array}$ & $\begin{array}{c}-21.308^{\star \star \star} \\
(1.320)\end{array}$ & $\begin{array}{c}-19.102^{\star * *} \\
(1.419)\end{array}$ & $\begin{array}{c}-18.433^{\star \star \star} \\
(1.729)\end{array}$ \\
\hline Dummy 1993 & $\begin{array}{c}64.297^{* * *} \\
(1.420)\end{array}$ & $\begin{array}{c}64.718^{\star * *} \\
(1.282)\end{array}$ & $\begin{array}{c}70.587^{* * *} \\
(1.821)\end{array}$ & $\begin{array}{c}70.884^{\star * *} \\
(1.665)\end{array}$ \\
\hline Dummy 1994 & $\begin{array}{c}-26.166^{\star \star \star} \\
(1.060)\end{array}$ & $\begin{array}{c}-26.156^{\star * *} \\
(1.301)\end{array}$ & $\begin{array}{c}-18.388^{* * *} \\
(1.404)\end{array}$ & $\begin{array}{c}-18.045^{\star * \star} \\
(1.694)\end{array}$ \\
\hline Dummy 1995 & $\begin{array}{c}-25.185^{\star \star *} \\
(1.286)\end{array}$ & $\begin{array}{c}-24.902^{\star * *} \\
(1.377)\end{array}$ & $\begin{array}{c}-15.894^{* * *} \\
(1.754)\end{array}$ & $\begin{array}{c}-14.901^{* * *} \\
(1.826)\end{array}$ \\
\hline Dummy 1996 & $\begin{array}{c}-24.127^{\star \star \star} \\
(1.454)\end{array}$ & $\begin{array}{c}-23.968^{\star * *} \\
(1.402)\end{array}$ & $\begin{array}{c}-13.192^{\star * *} \\
(1.929)\end{array}$ & $\begin{array}{c}-12.254^{* \star *} \\
(1.868)\end{array}$ \\
\hline Dummy 1997 & $\begin{array}{c}-21.975^{\star * *} \\
(1.281)\end{array}$ & $\begin{array}{c}-19.771^{\star \star *} \\
(1.339)\end{array}$ & $\begin{array}{c}-9.433^{* * *} \\
(1.921)\end{array}$ & $\begin{array}{c}-7.983^{* \star *} \\
(1.883)\end{array}$ \\
\hline Dummy 1998 & $\begin{array}{c}14.956^{\star * *} \\
(1.731) \\
\end{array}$ & $\begin{array}{c}17.625^{\star \star \star} \\
(1.446) \\
\end{array}$ & $\begin{array}{c}32.780^{* * *} \\
(2.289)\end{array}$ & $\begin{array}{c}35.323^{* * *} \\
(1.963) \\
\end{array}$ \\
\hline Dummy 1999 & $\begin{array}{c}14.733^{* * *} \\
(1.741)\end{array}$ & $\begin{array}{c}18.581^{* * *} \\
(1.464) \\
\end{array}$ & $\begin{array}{c}32.937^{* * *} \\
(2.308)\end{array}$ & $\begin{array}{c}36.513^{* * *} \\
(1.999) \\
\end{array}$ \\
\hline Dummy 2000 & $\begin{array}{l}-0.633 \\
(1.666)\end{array}$ & $\begin{array}{c}4.709^{\star \star \star} \\
(1.444)\end{array}$ & $\begin{array}{c}16.070^{* * *} \\
(2.286)\end{array}$ & $\begin{array}{c}20.418^{* * *} \\
(2.040)\end{array}$ \\
\hline Dummy 2001 & $\begin{array}{c}-3.469^{* *} \\
(1.660)\end{array}$ & $\begin{array}{c}2.332 \\
(1.467)\end{array}$ & $\begin{array}{c}12.456^{* * *} \\
(2.302)\end{array}$ & $\begin{array}{c}17.706^{* * *} \\
(2.098)\end{array}$ \\
\hline PFL & $\begin{array}{l}1.616^{*} \\
(0.874)\end{array}$ & $\begin{array}{l}2.150^{* *} \\
(0.888)\end{array}$ & $\begin{array}{l}3.732^{* \star *} \\
(1.228)\end{array}$ & $\begin{array}{l}2.876^{\star *} \\
(1.203)\end{array}$ \\
\hline PSDB & $\begin{array}{l}-1.950 \\
(1.300)\end{array}$ & $\begin{array}{l}-1.071 \\
(1.306)\end{array}$ & $\begin{array}{c}-1.604 \\
(1.620)\end{array}$ & $\begin{array}{l}-2.026 \\
(1.688)\end{array}$ \\
\hline PT & $\begin{array}{c}10.125^{\star \star *} \\
(2.700)\end{array}$ & $\begin{array}{l}3.904^{*} \\
(2.338)\end{array}$ & $\begin{array}{c}12.271^{* * *} \\
(3.609)\end{array}$ & $\begin{array}{c}4.103 \\
(2.869)\end{array}$ \\
\hline PTB & $\begin{array}{c}-2.760^{* *} \\
(1.145)\end{array}$ & $\begin{array}{l}-1.545 \\
(1.236)\end{array}$ & $\begin{array}{c}1.634 \\
(1.556)\end{array}$ & $\begin{array}{c}2.546 \\
(1.601)\end{array}$ \\
\hline PDT & $\begin{array}{l}-1.803 \\
(1.194)\end{array}$ & $\begin{array}{c}0.882 \\
(1.242)\end{array}$ & $\begin{array}{c}1.362 \\
(1.513)\end{array}$ & $\begin{array}{l}3.189^{* *} \\
(1.563)\end{array}$ \\
\hline PDS / PPB & $\begin{array}{c}-3.107^{\star * *} \\
(1.015) \\
\end{array}$ & $\begin{array}{l}-0.510 \\
(1.063)\end{array}$ & $\begin{array}{c}1.129 \\
(1.344) \\
\end{array}$ & $\begin{array}{l}2.819^{* *} \\
(1.410)\end{array}$ \\
\hline PL & $\begin{array}{l}2.952^{\star *} \\
(1.190)\end{array}$ & $\begin{array}{c}1.469 \\
(1.440)\end{array}$ & $\begin{array}{l}8.056^{\star * *} \\
(1.675)\end{array}$ & $\begin{array}{c}5.532^{* * *} \\
(1.955)\end{array}$ \\
\hline Outros & $\begin{array}{c}-2.848^{\star * *} \\
(0.937) \\
\end{array}$ & $\begin{array}{l}-0.535 \\
(1.070) \\
\end{array}$ & $\begin{array}{c}1.055 \\
(1.353) \\
\end{array}$ & $\begin{array}{c}0.402 \\
(1.489) \\
\end{array}$ \\
\hline Prefeito $=$ Governador & $\begin{array}{c}-4.336^{\star * *} \\
(0.604)\end{array}$ & $\begin{array}{c}-1.885^{\star \star *} \\
(0.566) \\
\end{array}$ & $\begin{array}{l}-0.995 \\
(0.829)\end{array}$ & $\begin{array}{c}1.139 \\
(0.764)\end{array}$ \\
\hline Prefeito $=$ Presidente & $\begin{array}{l}2.326^{\star *} \\
(1.124)\end{array}$ & $\begin{array}{c}3.642^{* \star *} \\
(1.087)\end{array}$ & $\begin{array}{c}2.154 \\
(1.363) \\
\end{array}$ & $\begin{array}{l}2.957^{* *} \\
(1.395)\end{array}$ \\
\hline Idosos & $\begin{array}{c}4.071^{* * *} \\
(0.273)\end{array}$ & $\begin{array}{l}7.618^{* * *} \\
(0.304)\end{array}$ & $\begin{array}{l}3.288^{* * *} \\
(0.342)\end{array}$ & $\begin{array}{c}6.343^{* * *} \\
(0.462)\end{array}$ \\
\hline Urbanização & $\begin{array}{c}0.066^{\star * *} \\
(0.016) \\
\end{array}$ & $\begin{array}{c}0.106^{* * *} \\
(0.024)\end{array}$ & $\begin{array}{c}0.080^{* * *} \\
(0.022)\end{array}$ & $\begin{array}{c}0.137^{* * *} \\
(0.036)\end{array}$ \\
\hline Jovens & $\begin{array}{c}-1.043^{\star * \star} \\
(0.131)\end{array}$ & $\begin{array}{c}0.006 \\
(0.120)\end{array}$ & $\begin{array}{c}-1.046^{\star \star *} \\
(0.150)\end{array}$ & $\begin{array}{c}-0.226 \\
(0.184)\end{array}$ \\
\hline População & $\begin{array}{c}10.142^{* \star *} \\
(0.908)\end{array}$ & $\begin{array}{c}11.663^{\star \star *} \\
(0.563)\end{array}$ & $\begin{array}{c}8.690^{\star * \star} \\
(1.039)\end{array}$ & $\begin{array}{c}9.385^{\star * *} \\
(0.819) \\
\end{array}$ \\
\hline Constante & $\begin{array}{c}-83.322^{* \star *} \\
(14.773)\end{array}$ & $\begin{array}{c}-163.021^{* * *} \\
(7.891)\end{array}$ & $\begin{array}{c}-71.611^{* * *} \\
(15.140)\end{array}$ & $\begin{array}{c}-126.735^{* * *} \\
(11.844)\end{array}$ \\
\hline $\mathrm{R}^{2}$ & 0,4438 & 0,4398 & 0,4467 & 0,4438 \\
\hline Observações & 56315 & 56315 & 29055 & 29055 \\
\hline
\end{tabular}


Apêndice 1d.5 - Investimentos

\begin{tabular}{|c|c|c|c|c|}
\hline & \multicolumn{2}{|c|}{ Painel não balanceado } & \multicolumn{2}{|c|}{ Painel balanceado } \\
\hline & OLS & Efeitos aleatórios & OLS & Efeitos aleatórios \\
\hline Receita tributária & $\begin{array}{c}0.299^{* * *} \\
(0.015)\end{array}$ & $\begin{array}{c}0.304^{* * *} \\
(0.008)\end{array}$ & $\begin{array}{c}0.361^{* * *} \\
(0.021)\end{array}$ & $\begin{array}{c}0.341^{* * *} \\
(0.010)\end{array}$ \\
\hline Receita de transferências & $\begin{array}{c}0.216^{* * *} \\
(0.007)\end{array}$ & $\begin{array}{c}0.195^{* * *} \\
(0.002)\end{array}$ & $\begin{array}{c}0.199^{* * *} \\
(0.009)\end{array}$ & $\begin{array}{c}0.177^{* * *} \\
(0.003)\end{array}$ \\
\hline Dummy 1990 & $\begin{array}{c}37.554^{\star \star *} \\
(2.610)\end{array}$ & $\begin{array}{c}40.079^{* * *} \\
(2.491)\end{array}$ & $\begin{array}{c}40.206^{\star * *} \\
(3.754)\end{array}$ & $\begin{array}{c}43.412^{* * *} \\
(2.655)\end{array}$ \\
\hline Dummy 1991 & $\begin{array}{c}7.795^{* * *} \\
(2.227)\end{array}$ & $\begin{array}{c}8.867^{* * *} \\
(2.498)\end{array}$ & $\begin{array}{c}9.299^{* * *} \\
(3.110)\end{array}$ & $\begin{array}{c}11.265^{\star \star *} \\
(2.657) \\
\end{array}$ \\
\hline Dummy 1992 & $\begin{array}{l}-3.891^{*} \\
(2.275)\end{array}$ & $\begin{array}{l}-2.464 \\
(2.514)\end{array}$ & $\begin{array}{c}-1.851 \\
(3.191)\end{array}$ & $\begin{array}{l}-0.597 \\
(2.714)\end{array}$ \\
\hline Dummy 1993 & $\begin{array}{c}-19.052^{\star \star *} \\
(2.268)\end{array}$ & $\begin{array}{c}-20.861^{* * *} \\
(2.448)\end{array}$ & $\begin{array}{c}-31.178^{* \star \star} \\
(2.759)\end{array}$ & $\begin{array}{c}-31.627^{* \star *} \\
(2.592)\end{array}$ \\
\hline Dummy 1994 & $\begin{array}{l}7.735^{* * *} \\
(2.649)\end{array}$ & $\begin{array}{l}5.766^{\star *} \\
(2.475)\end{array}$ & $\begin{array}{c}-1.966 \\
(3.121)\end{array}$ & $\begin{array}{l}-1.771 \\
(2.643)\end{array}$ \\
\hline Dummy 1995 & $\begin{array}{c}-14.826^{\star \star \star} \\
(2.583)\end{array}$ & $\begin{array}{c}-14.612^{\star * *} \\
(2.586)\end{array}$ & $\begin{array}{c}-18.768^{* \star *} \\
(3.316)\end{array}$ & $\begin{array}{c}-16.029^{\star * *} \\
(2.797)\end{array}$ \\
\hline Dummy 1996 & $\begin{array}{c}-19.440^{\star \star *} \\
(2.871)\end{array}$ & $\begin{array}{c}-18.403^{\star * *} \\
(2.629)\end{array}$ & $\begin{array}{c}-26.193^{* \star *} \\
(3.753)\end{array}$ & $\begin{array}{c}-23.007^{\star \star *} \\
(2.858)\end{array}$ \\
\hline Dummy 1997 & $\begin{array}{c}-56.783^{\star * *} \\
(2.604)\end{array}$ & $\begin{array}{c}-59.950^{* * *} \\
(2.501)\end{array}$ & $\begin{array}{c}-74.767^{* * *} \\
(3.338)\end{array}$ & $\begin{array}{c}-73.732^{* * *} \\
(2.877)\end{array}$ \\
\hline Dummy 1998 & $\begin{array}{c}-23.247^{* \star *} \\
(3.661)\end{array}$ & $\begin{array}{c}-24.647^{* * *} \\
(2.685)\end{array}$ & $\begin{array}{c}-43.605^{\star \star \star} \\
(4.106)\end{array}$ & $\begin{array}{c}-40.738^{* \star *} \\
(2.987)\end{array}$ \\
\hline Dummy 1999 & $\begin{array}{c}-76.319^{\star * *} \\
(3.066)\end{array}$ & $\begin{array}{c}-77.946^{* \star *} \\
(2.715)\end{array}$ & $\begin{array}{c}-85.764^{* * *} \\
(3.974)\end{array}$ & $\begin{array}{c}-83.442^{\star * \star} \\
(3.041)\end{array}$ \\
\hline Dummy 2000 & $\begin{array}{c}-69.958^{\star \star *} \\
(2.958)\end{array}$ & $\begin{array}{c}-71.830^{* * *} \\
(2.668)\end{array}$ & $\begin{array}{c}-79.049^{* * *} \\
(3.984)\end{array}$ & $\begin{array}{c}-77.491^{* * *} \\
(3.101)\end{array}$ \\
\hline Dummy 2001 & $\begin{array}{c}-90.073^{* * *} \\
(3.061)\end{array}$ & $\begin{array}{c}-92.539^{* * *} \\
(2.700)\end{array}$ & $\begin{array}{c}-104.471^{* * *} \\
(4.092)\end{array}$ & $\begin{array}{c}-103.165^{* * *} \\
(3.184)\end{array}$ \\
\hline Dummy 2002 & $\begin{array}{c}-46.189^{\star * *} \\
(3.507)\end{array}$ & $\begin{array}{c}-48.465^{\star * *} \\
(2.798)\end{array}$ & $\begin{array}{c}-62.389^{* * *} \\
(4.488)\end{array}$ & $\begin{array}{c}-60.550^{\star * \star} \\
(3.291)\end{array}$ \\
\hline Dummy 2003 & $\begin{array}{c}-92.011^{* * *} \\
(2.955)\end{array}$ & $\begin{array}{c}-96.675^{\star * *} \\
(2.870)\end{array}$ & $\begin{array}{c}-100.168^{* * *} \\
(3.794)\end{array}$ & $\begin{array}{c}-101.095^{* * *} \\
(3.365)\end{array}$ \\
\hline PFL & $\begin{array}{l}3.283^{\star *} \\
(1.466)\end{array}$ & $\begin{array}{c}1.904 \\
(1.535)\end{array}$ & $\begin{array}{c}6.185^{* * *} \\
(1.777)\end{array}$ & $\begin{array}{c}4.991^{* * *} \\
(1.721)\end{array}$ \\
\hline PSDB & $\begin{array}{l}-2.774 \\
(1.862)\end{array}$ & $\begin{array}{l}-2.405 \\
(2.128)\end{array}$ & $\begin{array}{l}-3.564^{*} \\
(2.037)\end{array}$ & $\begin{array}{l}-1.042 \\
(2.265)\end{array}$ \\
\hline PT & $\begin{array}{c}-21.462^{* \star *} \\
(2.570)\end{array}$ & $\begin{array}{c}-13.977^{* * *} \\
(3.788)\end{array}$ & $\begin{array}{c}-26.081^{* * *} \\
(2.734)\end{array}$ & $\begin{array}{c}-17.340^{* * *} \\
(3.845)\end{array}$ \\
\hline PTB & $\begin{array}{c}-1.783 \\
(1.877)\end{array}$ & $\begin{array}{l}-0.430 \\
(2.150)\end{array}$ & $\begin{array}{l}-3.591^{*} \\
(2.017)\end{array}$ & $\begin{array}{c}-0.794 \\
(2.269)\end{array}$ \\
\hline PDT & $\begin{array}{c}-5.961^{* \star \star} \\
(2.137) \\
\end{array}$ & $\begin{array}{l}-2.195 \\
(2.173) \\
\end{array}$ & $\begin{array}{c}-11.184^{* * *} \\
(1.858)\end{array}$ & $\begin{array}{c}-5.636^{\star *} \\
(2.273)\end{array}$ \\
\hline PDS / PPB & $\begin{array}{c}-1.089 \\
(1.625)\end{array}$ & $\begin{array}{l}-1.168 \\
(1.854)\end{array}$ & $\begin{array}{c}-0.001 \\
(1.982)\end{array}$ & $\begin{array}{l}-1.126 \\
(2.011)\end{array}$ \\
\hline PL & $\begin{array}{c}-4.998^{* *} \\
(1.960)\end{array}$ & $\begin{array}{c}-6.197^{\star *} \\
(2.519)\end{array}$ & $\begin{array}{c}-0.922 \\
(2.561)\end{array}$ & $\begin{array}{c}-6.648^{* *} \\
(2.829)\end{array}$ \\
\hline Outros & $\begin{array}{l}-1.855 \\
(1.767) \\
\end{array}$ & $\begin{array}{c}1.352 \\
(1.852) \\
\end{array}$ & $\begin{array}{c}1.730 \\
(2.084) \\
\end{array}$ & $\begin{array}{l}4.231^{\star *} \\
(2.116)\end{array}$ \\
\hline Prefeito $=$ Governador & $\begin{array}{c}1.167 \\
(1.024) \\
\end{array}$ & $\begin{array}{c}2.867^{* \star *} \\
(0.985) \\
\end{array}$ & $\begin{array}{c}0.807 \\
(1.121) \\
\end{array}$ & $\begin{array}{l}2.659^{\star \star} \\
(1.090)\end{array}$ \\
\hline Prefeito $=$ Presidente & $\begin{array}{c}1.176 \\
(1.897) \\
\end{array}$ & $\begin{array}{c}2.926 \\
(1.829) \\
\end{array}$ & $\begin{array}{c}2.805 \\
(1.962) \\
\end{array}$ & $\begin{array}{l}4.088^{* *} \\
(1.937)\end{array}$ \\
\hline Idosos & $\begin{array}{c}-5.823^{\star \star \star} \\
(0.452) \\
\end{array}$ & $\begin{array}{c}-7.804^{* * *} \\
(0.501) \\
\end{array}$ & $\begin{array}{c}-5.505^{\star * *} \\
(0.538) \\
\end{array}$ & $\begin{array}{c}-7.265^{\star * \star} \\
(0.631) \\
\end{array}$ \\
\hline Urbanização & $\begin{array}{c}-0.303^{* * *} \\
(0.025)\end{array}$ & $\begin{array}{c}-0.256^{* * *} \\
(0.039)\end{array}$ & $\begin{array}{c}-0.262^{\star * *} \\
(0.035)\end{array}$ & $\begin{array}{c}-0.103^{* *} \\
(0.052)\end{array}$ \\
\hline Jovens & $\begin{array}{c}0.637^{* * *} \\
(0.177)\end{array}$ & $\begin{array}{l}-0.199 \\
(0.184)\end{array}$ & $\begin{array}{c}-0.274 \\
(0.249)\end{array}$ & $\begin{array}{c}-1.291^{\star * *} \\
(0.263) \\
\end{array}$ \\
\hline População & $\begin{array}{c}5.218^{* * *} \\
(1.355)\end{array}$ & $\begin{array}{l}-1.626^{*} \\
(0.962)\end{array}$ & $\begin{array}{l}4.622^{* *} \\
(1.827)\end{array}$ & $\begin{array}{l}-1.799 \\
(1.199)\end{array}$ \\
\hline Constante & $\begin{array}{c}-17.019 \\
(20.261)\end{array}$ & $\begin{array}{c}97.038^{* * *} \\
(13.311)\end{array}$ & $\begin{array}{c}22.069 \\
(27.246)\end{array}$ & $\begin{array}{c}126.172^{\star * \star} \\
(16.823)\end{array}$ \\
\hline $\mathrm{R}^{2}$ & 0,3364 & 0,3344 & 0,4057 & 0,4026 \\
\hline Observações & 66384 & 66384 & 33525 & 33525 \\
\hline
\end{tabular}


Apêndice 1e-Testes de hipótese

(com base nos resultados considerados consistentes via teste de Hausman)

Apêndice 1e.1 - Despesa orçamentária

\begin{tabular}{|c|c|c|c|c|c|}
\hline Hipótese & $\begin{array}{l}\text { Painel não } \\
\text { balanceado }\end{array}$ & $\begin{array}{c}\text { Painel } \\
\text { balanceado }\end{array}$ & Hipótese & $\begin{array}{c}\text { Painel } \\
\text { não balanceado }\end{array}$ & $\begin{array}{c}\text { Painel } \\
\text { balanceado }\end{array}$ \\
\hline $1991=1992$ & $\begin{array}{l}F(1,60868)=0.39 \\
\text { Prob }>F=0.5346\end{array}$ & $\begin{array}{c}F(1,31260)=11.98 \\
\text { Prob }>F=0.0005\end{array}$ & $\mathrm{PFL}=\mathrm{PDS} / \mathrm{PPB}$ & $\begin{array}{l}F(1,60868)=0.44 \\
\text { Prob }>F=0.5056\end{array}$ & $\begin{array}{l}F(1,31260)=0.15 \\
\text { Prob }>F=0.7018\end{array}$ \\
\hline $1992=1993$ & $\begin{array}{c}F(1,60868)=88.45 \\
P r o b>F=0.0000\end{array}$ & $\begin{array}{c}F(1,31260)=72.84 \\
\text { Prob }>F=0.0000\end{array}$ & $\mathrm{PFL}=\mathrm{PT}$ & $\begin{array}{l}F(1,60868)=5.94 \\
\text { Prob }>F=0.0148\end{array}$ & $\begin{array}{l}F(1,31260)=8.47 \\
\text { Prob }>F=0.0036\end{array}$ \\
\hline $1995=1996$ & $\begin{array}{c}F(1,60868)=127.10 \\
\text { Prob }>F=0.0000\end{array}$ & $\begin{array}{c}F(1,31260)=95.09 \\
\text { Prob }>F=0.0000\end{array}$ & $P F L=P S D B$ & $\begin{array}{l}F(1,60868)=1.18 \\
\text { Prob }>F=0.2771\end{array}$ & $\begin{array}{l}F(1,31260)=0.07 \\
\text { Prob }>F=0.7898\end{array}$ \\
\hline $1996=1997$ & $\begin{array}{c}F(1,60868)=447.19 \\
P r o b>F=0.0000\end{array}$ & $\begin{array}{c}F(1,31260)=296.65 \\
\text { Prob }>F=0.0000\end{array}$ & $\mathrm{PFL}=\mathrm{PTB}$ & $\begin{array}{l}F(1,60868)=0.00 \\
\text { Prob }>F=0.9600\end{array}$ & $\begin{array}{l}F(1,31260)=0.08 \\
\text { Prob }>F=0.7732\end{array}$ \\
\hline $1999=2000$ & $\begin{array}{l}F(1,60868)=2.18 \\
\text { Prob }>F=0.1395\end{array}$ & $\begin{array}{l}F(1,31260)=1.10 \\
\text { Prob }>F=0.2951\end{array}$ & PFL $=$ OUTROS & $\begin{array}{l}F(1,60868)=1.21 \\
\text { Prob }>F=0.2717\end{array}$ & $\begin{array}{l}F(1,31260)=0.37 \\
\text { Prob }>F=0.5431\end{array}$ \\
\hline \multirow[t]{23}{*}{$2000=2001$} & $\begin{array}{c}F(1,60868)=78.44 \\
P r o b>F=0.0000\end{array}$ & $\begin{array}{c}F(1,31260)=75.88 \\
\text { Prob }>F=0.0000\end{array}$ & $\mathrm{PFL}=\mathrm{PDT}$ & $\begin{array}{l}F(1,60868)=0.49 \\
\text { Prob }>F=0.4843\end{array}$ & $\begin{array}{l}F(1,31260)=0.03 \\
\text { Prob }>F=0.8603\end{array}$ \\
\hline & & & $P F L=P L$ & $\begin{array}{l}F(1,60868)=9.45 \\
\text { Prob }>F=0.0021\end{array}$ & $\begin{array}{l}F(1,31260)=2.13 \\
\text { Prob }>F=0.1447\end{array}$ \\
\hline & & & $\mathrm{PDS} / \mathrm{PPB}=\mathrm{PT}$ & $\begin{array}{l}F(1,60868)=4.17 \\
\text { Prob }>F=0.0411\end{array}$ & $\begin{array}{l}F(1,31260)=6.93 \\
P r o b>F=0.0085\end{array}$ \\
\hline & & & PDS $/$ PPB = PSDB & $\begin{array}{l}F(1,60868)=2.23 \\
\text { Prob }>F=0.1352\end{array}$ & $\begin{array}{l}F(1,31260)=0.00 \\
\text { Prob }>F=0.9575\end{array}$ \\
\hline & & & $\mathrm{PDS} / \mathrm{PPB}=\mathrm{PTB}$ & $\begin{array}{l}F(1,60868)=0.24 \\
\text { Prob }>F=0.6269\end{array}$ & $\begin{array}{l}F(1,31260)=0.33 \\
\text { Prob }>F=0.5677\end{array}$ \\
\hline & & & PDS / PPB = OUTROS & $\begin{array}{l}F(1,60868)=2.43 \\
\text { Prob }>F=0.1193\end{array}$ & $\begin{array}{l}F(1,31260)=0.78 \\
\text { Prob }>F=0.3772\end{array}$ \\
\hline & & & $\mathrm{PDS} / \mathrm{PPB}=\mathrm{PDT}$ & $\begin{array}{l}F(1,60868)=1.45 \\
\text { Prob }>F=0.2287\end{array}$ & $\begin{array}{l}F(1,31260)=0.25 \\
\text { Prob }>F=0.6188\end{array}$ \\
\hline & & & $\mathrm{PDS} / \mathrm{PPB}=\mathrm{PL}$ & $\begin{array}{l}F(1,60868)=5.36 \\
\text { Prob }>F=0.0206\end{array}$ & $\begin{array}{l}F(1,31260)=1.15 \\
\text { Prob }>F=0.2842\end{array}$ \\
\hline & & & $\mathrm{PT}=\mathrm{PSDB}$ & $\begin{array}{l}F(1,60868)=8.65 \\
\text { Prob }>F=0.0033\end{array}$ & $\begin{array}{l}F(1,31260)=6.74 \\
\text { Prob }>F=0.0094\end{array}$ \\
\hline & & & $\mathrm{PT}=\mathrm{PTB}$ & $\begin{array}{l}F(1,60868)=5.17 \\
\text { Prob }>F=0.0230\end{array}$ & $\begin{array}{l}F(1,31260)=8.56 \\
\text { Prob }>F=0.0034\end{array}$ \\
\hline & & & PT = OUTROS & $\begin{array}{l}F(1,60868)=8.40 \\
\text { Prob }>F=0.0038\end{array}$ & $\begin{array}{l}F(1,31260)=9.85 \\
\text { Prob }>F=0.0017\end{array}$ \\
\hline & & & $\mathrm{PT}=\mathrm{PDT}$ & $\begin{array}{l}F(1,60868)=7.14 \\
\text { Prob }>F=0.0075\end{array}$ & $\begin{array}{l}F(1,31260)=8.14 \\
\text { Prob }>F=0.0043\end{array}$ \\
\hline & & & $\mathrm{PT}=\mathrm{PL}$ & $\begin{array}{l}F(1,60868)=0.13 \\
\text { Prob }>F=0.7135\end{array}$ & $\begin{array}{l}F(1,31260)=2.56 \\
\text { Prob }>F=0.1093\end{array}$ \\
\hline & & & $\mathrm{PSDB}=\mathrm{PTB}$ & $\begin{array}{l}F(1,60868)=0.94 \\
\text { Prob }>F=0.3336\end{array}$ & $\begin{array}{l}F(1,31260)=0.22 \\
\text { Prob }>F=0.6429\end{array}$ \\
\hline & & & PSDB = OUTROS & $\begin{array}{l}F(1,60868)=0.03 \\
\text { Prob }>F=0.8527\end{array}$ & $\begin{array}{l}F(1,31260)=0.52 \\
\text { Prob }>F=0.4702\end{array}$ \\
\hline & & & PSDB = PDT & $\begin{array}{l}F(1,60868)=0.12 \\
\text { Prob }>F=0.7259\end{array}$ & $\begin{array}{l}F(1,31260)=0.14 \\
\text { Prob }>F=0.7085\end{array}$ \\
\hline & & & $P S D B=P L$ & $\begin{array}{c}F(1,60868)=11.40 \\
\text { Prob }>F=0.0007\end{array}$ & $\begin{array}{l}F(1,31260)=1.07 \\
\text { Prob }>F=0.3004\end{array}$ \\
\hline & & & $\mathrm{PDT}=\mathrm{PTB}$ & $\begin{array}{l}F(1,60868)=0.41 \\
\text { Prob }>F=0.5222\end{array}$ & $\begin{array}{l}F(1,31260)=0.01 \\
\text { Prob }>F=0.9248\end{array}$ \\
\hline & & & PDT $=$ OUTROS & $\begin{array}{l}F(1,60868)=0.04 \\
\text { Prob }>F=0.8341\end{array}$ & $\begin{array}{l}F(1,31260)=0.12 \\
\text { Prob }>F=0.7327\end{array}$ \\
\hline & & & $\mathrm{PDT}=\mathrm{PL}$ & $\begin{array}{l}F(1,60868)=9.70 \\
\text { Prob }>F=0.0018\end{array}$ & $\begin{array}{l}F(1,31260)=1.97 \\
\text { Prob }>F=0.1603\end{array}$ \\
\hline & & & PTB $=$ OUTROS & $\begin{array}{l}F(1,60868)=0.85 \\
\text { Prob }>F=0.3561\end{array}$ & $\begin{array}{l}F(1,31260)=0.06 \\
\text { Prob }>F=0.8077\end{array}$ \\
\hline & & & $\mathrm{PTB}=\mathrm{PL}$ & $\begin{array}{l}F(1,60868)=6.72 \\
\text { Prob }>F=0.0095\end{array}$ & $\begin{array}{l}F(1,31260)=2.23 \\
\text { Prob }>F=0.1355\end{array}$ \\
\hline & & & OUTROS = PL & $\begin{array}{c}F(1,60868)=13.17 \\
\text { Prob }>F=0.0003\end{array}$ & $\begin{array}{l}F(1,31260)=3.21 \\
\text { Prob }>F=0.0730\end{array}$ \\
\hline
\end{tabular}


Apêndice 1e.2-Despesa corrente

\begin{tabular}{|c|c|c|c|c|c|}
\hline Hipótese & $\begin{array}{l}\text { Painel não } \\
\text { balanceado }\end{array}$ & $\begin{array}{c}\text { Painel } \\
\text { balanceado }\end{array}$ & Hipótese & $\begin{array}{c}\text { Painel } \\
\text { não balanceado }\end{array}$ & $\begin{array}{c}\text { Painel } \\
\text { balanceado }\end{array}$ \\
\hline 1991 = 1992 & $\begin{array}{c}F(1,60868)=51.60 \\
\text { Prob }>F=0.0000\end{array}$ & $\begin{array}{c}F(1,31260)=83.29 \\
P r o b>F=0.0000\end{array}$ & $\mathrm{PFL}=\mathrm{PDS} / \mathrm{PPB}$ & $\begin{array}{l}F(1,60868)=0.06 \\
\text { Prob }>F=0.8065\end{array}$ & $\begin{array}{l}F(1,31260)=3.57 \\
\text { Prob }>F=0.0587\end{array}$ \\
\hline $1992=1993$ & $\begin{array}{c}F(1,60868)=24.47 \\
\text { Prob }>F=0.0000\end{array}$ & $\begin{array}{l}F(1,31260)=1.57 \\
\text { Prob }>F=0.2098\end{array}$ & $\mathrm{PFL}=\mathrm{PT}$ & $\begin{array}{l}F(1,60868)=0.00 \\
\text { Prob }>F=0.9776\end{array}$ & $\begin{array}{l}F(1,31260)=0.24 \\
\text { Prob }>F=0.6245\end{array}$ \\
\hline $1995=1996$ & $\begin{array}{c}F(1,60868)=323.22 \\
\text { Prob }>F=0.0000\end{array}$ & $\begin{array}{c}F(1,31260)=209.12 \\
\text { Prob }>F=0.0000\end{array}$ & $\mathrm{PFL}=\mathrm{PSDB}$ & $\begin{array}{l}F(1,60868)=5.79 \\
\text { Prob }>F=0.0161\end{array}$ & $\begin{array}{l}F(1,31260)=0.67 \\
\text { Prob }>F=0.4121\end{array}$ \\
\hline $1996=1997$ & $\begin{array}{c}F(1,60868)=81.79 \\
\text { Prob }>F=0.0000\end{array}$ & $\begin{array}{c}F(1,31260)=24.30 \\
\text { Prob }>F=0.0000\end{array}$ & $\mathrm{PFL}=\mathrm{PTB}$ & $\begin{array}{l}F(1,60868)=0.09 \\
\text { Prob }>F=0.7618\end{array}$ & $\begin{array}{l}F(1,31260)=2.30 \\
\text { Prob }>F=0.1297\end{array}$ \\
\hline $1999=2000$ & $\begin{array}{l}F(1,60868)=9.42 \\
\text { Prob }>F=0.0021\end{array}$ & $\begin{array}{l}F(1,31260)=4.18 \\
\text { Prob }>F=0.0408\end{array}$ & PFL $=$ OUTROS & $\begin{array}{l}F(1,60868)=0.44 \\
\text { Prob }>F=0.5073\end{array}$ & $\begin{array}{l}F(1,31260)=0.62 \\
\text { Prob }>F=0.4302\end{array}$ \\
\hline \multirow[t]{23}{*}{$2000=2001$} & $\begin{array}{l}F(1,60868)=2.92 \\
\text { Prob }>F=0.0877\end{array}$ & $\begin{array}{l}F(1,31260)=8.16 \\
\text { Prob }>F=0.0043\end{array}$ & $\mathrm{PFL}=\mathrm{PDT}$ & $\begin{array}{l}F(1,60868)=1.42 \\
\text { Prob }>F=0.2334\end{array}$ & $\begin{array}{l}F(1,31260)=7.70 \\
\text { Prob }>F=0.0055\end{array}$ \\
\hline & & & $P F L=P L$ & $\begin{array}{l}F(1,60868)=2.03 \\
\text { Prob }>F=0.1540\end{array}$ & $\begin{array}{l}F(1,31260)=2.53 \\
\text { Prob }>F=0.1117\end{array}$ \\
\hline & & & $\mathrm{PDS} / \mathrm{PPB}=\mathrm{PT}$ & $\begin{array}{l}F(1,60868)=0.01 \\
\text { Prob }>F=0.9246\end{array}$ & $\begin{array}{l}F(1,31260)=0.31 \\
\text { Prob }>F=0.5783\end{array}$ \\
\hline & & & PDS $/$ PPB = PSDB & $\begin{array}{l}F(1,60868)=4.00 \\
\text { Prob }>F=0.0456\end{array}$ & $\begin{array}{l}F(1,31260)=0.51 \\
\text { Prob }>F=0.4739\end{array}$ \\
\hline & & & PDS / PPB = PTB & $\begin{array}{l}F(1,60868)=0.01 \\
\text { Prob }>F=0.9422\end{array}$ & $\begin{array}{l}F(1,31260)=0.04 \\
\text { Prob }>F=0.8377\end{array}$ \\
\hline & & & PDS $/$ PPB $=$ OUTROS & $\begin{array}{l}F(1,60868)=0.13 \\
\text { Prob }>F=0.7218\end{array}$ & $\begin{array}{l}F(1,31260)=0.98 \\
\text { Prob }>F=0.3223\end{array}$ \\
\hline & & & PDS / PPB = PDT & $\begin{array}{l}F(1,60868)=0.84 \\
\text { Prob }>F=0.3582\end{array}$ & $\begin{array}{l}F(1,31260)=0.99 \\
\text { Prob }>F=0.3191\end{array}$ \\
\hline & & & $\mathrm{PDS} / \mathrm{PPB}=\mathrm{PL}$ & $\begin{array}{l}F(1,60868)=2.14 \\
\text { Prob }>F=0.1433\end{array}$ & $\begin{array}{l}F(1,31260)=0.02 \\
\text { Prob }>F=0.8934\end{array}$ \\
\hline & & & $\mathrm{PT}=\mathrm{PSDB}$ & $\begin{array}{l}F(1,60868)=1.87 \\
\text { Prob }>F=0.1718\end{array}$ & $\begin{array}{l}F(1,31260)=0.00 \\
\text { Prob }>F=0.9606\end{array}$ \\
\hline & & & $\mathrm{PT}=\mathrm{PTB}$ & $\begin{array}{l}F(1,60868)=0.02 \\
\text { Prob }>F=0.8921\end{array}$ & $\begin{array}{l}F(1,31260)=0.17 \\
\text { Prob }>F=0.6836\end{array}$ \\
\hline & & & PT $=$ OUTROS & $\begin{array}{l}F(1,60868)=0.08 \\
\text { Prob }>F=0.7714\end{array}$ & $\begin{array}{l}F(1,31260)=0.00 \\
\text { Prob }>F=0.9611\end{array}$ \\
\hline & & & $\mathrm{PT}=\mathrm{PDT}$ & $\begin{array}{l}F(1,60868)=0.39 \\
\text { Prob }>F=0.5298\end{array}$ & $\begin{array}{l}F(1,31260)=1.32 \\
\text { Prob }>F=0.2506\end{array}$ \\
\hline & & & $\mathrm{PT}=\mathrm{PL}$ & $\begin{array}{l}F(1,60868)=0.73 \\
\text { Prob }>F=0.3920\end{array}$ & $\begin{array}{l}F(1,31260)=0.35 \\
\text { Prob }>F=0.5564\end{array}$ \\
\hline & & & $\mathrm{PSDB}=\mathrm{PTB}$ & $\begin{array}{l}F(1,60868)=3.28 \\
\text { Prob }>F=0.0699\end{array}$ & $\begin{array}{l}F(1,31260)=0.25 \\
\text { Prob }>F=0.6177\end{array}$ \\
\hline & & & PSDB = OUTROS & $\begin{array}{l}F(1,60868)=3.03 \\
\text { Prob }>F=0.0817\end{array}$ & $\begin{array}{l}F(1,31260)=0.02 \\
\text { Prob }>F=0.8856\end{array}$ \\
\hline & & & PSDB = PDT & $\begin{array}{l}F(1,60868)=1.13 \\
\text { Prob }>F=0.2873\end{array}$ & $\begin{array}{l}F(1,31260)=2.34 \\
\text { Prob }>F=0.1258\end{array}$ \\
\hline & & & $\mathrm{PSDB}=\mathrm{PL}$ & $\begin{array}{l}F(1,60868)=9.15 \\
\text { Prob }>F=0.0025\end{array}$ & $\begin{array}{l}F(1,31260)=0.52 \\
\text { Prob }>F=0.4691\end{array}$ \\
\hline & & & $\mathrm{PDT}=\mathrm{PTB}$ & $\begin{array}{l}F(1,60868)=0.59 \\
\text { Prob }>F=0.4422\end{array}$ & $\begin{array}{l}F(1,31260)=1.23 \\
\text { Prob }>F=0.2667\end{array}$ \\
\hline & & & PDT $=$ OUTROS & $\begin{array}{l}F(1,60868)=0.34 \\
\text { Prob }>F=0.5573\end{array}$ & $\begin{array}{l}F(1,31260)=3.52 \\
\text { Prob }>F=0.0607\end{array}$ \\
\hline & & & $\mathrm{PDT}=\mathrm{PL}$ & $\begin{array}{l}F(1,60868)=4.39 \\
\text { Prob }>F=0.0362\end{array}$ & $\begin{array}{l}F(1,31260)=0.41 \\
\text { Prob }>F=0.5204\end{array}$ \\
\hline & & & PTB $=$ OUTROS & $\begin{array}{l}F(1,60868)=0.06 \\
\text { Prob }>F=0.8018\end{array}$ & $\begin{array}{l}F(1,31260)=0.51 \\
\text { Prob }>F=0.4753\end{array}$ \\
\hline & & & $\mathrm{PTB}=\mathrm{PL}$ & $\begin{array}{l}F(1,60868)=2.08 \\
\text { Prob }>F=0.1491\end{array}$ & $\begin{array}{l}F(1,31260)=0.09 \\
\text { Prob }>F=0.7673\end{array}$ \\
\hline & & & OUTROS = PL & $\begin{array}{l}F(1,60868)=3.20 \\
\text { Prob }>F=0.0735\end{array}$ & $\begin{array}{l}F(1,31260)=0.86 \\
\text { Prob }>F=0.3547\end{array}$ \\
\hline
\end{tabular}


Apêndice 1e.3-Despesa de pessoal

\begin{tabular}{|c|c|c|c|c|c|}
\hline Hipótese & $\begin{array}{l}\text { Painel não } \\
\text { balanceado }\end{array}$ & $\begin{array}{c}\text { Painel } \\
\text { balanceado }\end{array}$ & Hipótese & $\begin{array}{c}\text { Painel } \\
\text { não balanceado } \\
\end{array}$ & $\begin{array}{c}\text { Painel } \\
\text { balanceado }\end{array}$ \\
\hline 1991 = 1992 & $\begin{array}{l}F(1,60868)=9.67 \\
\text { Prob }>F=0.0019\end{array}$ & $\begin{array}{l}F(1,31260)=0.50 \\
\text { Prob }>F=0.4808\end{array}$ & $\mathrm{PFL}=\mathrm{PDS} / \mathrm{PPB}$ & $\begin{array}{l}F(1,60868)=2.99 \\
\text { Prob }>F=0.0840\end{array}$ & $\begin{array}{l}F(1,31260)=0.34 \\
\text { Prob }>F=0.5625\end{array}$ \\
\hline $1992=1993$ & $\begin{array}{c}F(1,60868)=58.67 \\
\text { Prob }>F=0.0000\end{array}$ & $\begin{array}{c}F(1,31260)=55.24 \\
\text { Prob }>F=0.0000\end{array}$ & $\mathrm{PFL}=\mathrm{PT}$ & $\begin{array}{l}F(1,60868)=1.89 \\
\text { Prob }>F=0.1690\end{array}$ & $\begin{array}{l}F(1,31260)=2.17 \\
\text { Prob }>F=0.1408\end{array}$ \\
\hline $1995=1996$ & $\begin{array}{c}F(1,60868)=188.04 \\
\text { Prob }>F=0.0000\end{array}$ & $\begin{array}{c}F(1,31260)=131.22 \\
P r o b>F=0.0000\end{array}$ & $\mathrm{PFL}=\mathrm{PSDB}$ & $\begin{array}{c}F(1,60868)=37.39 \\
\text { Prob }>F=0.0000\end{array}$ & $\begin{array}{c}F(1,31260)=10.39 \\
\text { Prob }>F=0.0013\end{array}$ \\
\hline $1996=1997$ & $\begin{array}{c}F(1,60868)=78.88 \\
\text { Prob }>F=0.0000\end{array}$ & $\begin{array}{c}F(1,31260)=57.10 \\
\text { Prob }>F=0.0000\end{array}$ & $\mathrm{PFL}=\mathrm{PTB}$ & $\begin{array}{l}F(1,60868)=0.13 \\
\text { Prob > F = } 0.7200\end{array}$ & $\begin{array}{l}F(1,31260)=0.72 \\
\text { Prob }>F=0.3958\end{array}$ \\
\hline $1999=2000$ & $\begin{array}{l}F(1,60868)=9.76 \\
\text { Prob }>F=0.0018\end{array}$ & $\begin{array}{c}F(1,31260)=10.88 \\
\text { Prob }>F=0.0010\end{array}$ & PFL = OUTROS & $\begin{array}{l}F(1,60868)=0.87 \\
\text { Prob }>F=0.3517\end{array}$ & $\begin{array}{l}F(1,31260)=2.88 \\
\text { Prob }>F=0.0895\end{array}$ \\
\hline \multirow[t]{23}{*}{$2000=2001$} & $\begin{array}{l}F(1,60868)=3.83 \\
\text { Prob }>F=0.0504\end{array}$ & $\begin{array}{l}F(1,31260)=5.95 \\
\text { Prob }>F=0.0147\end{array}$ & $\mathrm{PFL}=\mathrm{PDT}$ & $\begin{array}{l}F(1,60868)=3.63 \\
\text { Prob }>F=0.0568\end{array}$ & $\begin{array}{l}F(1,31260)=3.45 \\
\text { Prob }>F=0.0634\end{array}$ \\
\hline & & & $P F L=P L$ & $\begin{array}{c}F(1,60868)=10.74 \\
\text { Prob }>F=0.0011\end{array}$ & $\begin{array}{l}F(1,31260)=1.99 \\
\text { Prob }>F=0.1582\end{array}$ \\
\hline & & & $\mathrm{PDS} / \mathrm{PPB}=\mathrm{PT}$ & $\begin{array}{l}F(1,60868)=0.23 \\
\text { Prob }>F=0.6316\end{array}$ & $\begin{array}{l}F(1,31260)=1.26 \\
\text { Prob }>F=0.2621\end{array}$ \\
\hline & & & PDS $/$ PPB = PSDB & $\begin{array}{c}F(1,60868)=47.19 \\
\text { Prob }>F=0.0000\end{array}$ & $\begin{array}{c}F(1,31260)=11.53 \\
\text { Prob }>F=0.0007\end{array}$ \\
\hline & & & $\mathrm{PDS} / \mathrm{PPB}=\mathrm{PTB}$ & $\begin{array}{l}F(1,60868)=2.87 \\
\text { Prob }>F=0.0904\end{array}$ & $\begin{array}{l}F(1,31260)=1.52 \\
\text { Prob }>F=0.2178\end{array}$ \\
\hline & & & PDS $/$ PPB $=$ OUTROS & $\begin{array}{l}F(1,60868)=5.62 \\
\text { Prob }>F=0.0178\end{array}$ & $\begin{array}{l}F(1,31260)=4.11 \\
\text { Prob }>F=0.0426\end{array}$ \\
\hline & & & PDS / PPB = PDT & $\begin{array}{c}F(1,60868)=10.30 \\
\text { Prob }>F=0.0013\end{array}$ & $\begin{array}{l}F(1,31260)=5.11 \\
\text { Prob }>F=0.0238\end{array}$ \\
\hline & & & $\mathrm{PDS} / \mathrm{PPB}=\mathrm{PL}$ & $\begin{array}{l}F(1,60868)=3.07 \\
\text { Prob }>F=0.0799\end{array}$ & $\begin{array}{l}F(1,31260)=2.90 \\
\text { Prob }>F=0.0885\end{array}$ \\
\hline & & & $\mathrm{PT}=\mathrm{PSDB}$ & $\begin{array}{c}F(1,60868)=23.48 \\
\text { Prob }>F=0.0000\end{array}$ & $\begin{array}{c}F(1,31260)=11.69 \\
\text { Prob }>F=0.0006\end{array}$ \\
\hline & & & $\mathrm{PT}=\mathrm{PTB}$ & $\begin{array}{l}F(1,60868)=2.22 \\
\text { Prob }>F=0.1360\end{array}$ & $\begin{array}{l}F(1,31260)=3.56 \\
\text { Prob }>F=0.0593\end{array}$ \\
\hline & & & PT $=$ OUTROS & $\begin{array}{l}F(1,60868)=3.19 \\
\text { Prob }>F=0.0743\end{array}$ & $\begin{array}{l}F(1,31260)=5.46 \\
P r o b>F=0.0195\end{array}$ \\
\hline & & & $\mathrm{PT}=\mathrm{PDT}$ & $\begin{array}{l}F(1,60868)=5.47 \\
\text { Prob }>F=0.0194\end{array}$ & $\begin{array}{l}F(1,31260)=6.11 \\
\text { Prob }>F=0.0135\end{array}$ \\
\hline & & & $\mathrm{PT}=\mathrm{PL}$ & $\begin{array}{l}F(1,60868)=0.48 \\
\text { Prob }>F=0.4894\end{array}$ & $\begin{array}{l}F(1,31260)=4.76 \\
\text { Prob }>F=0.0292\end{array}$ \\
\hline & & & PSDB = PTB & $\begin{array}{c}F(1,60868)=24.33 \\
\text { Prob }>F=0.0000\end{array}$ & $\begin{array}{l}F(1,31260)=4.55 \\
\text { Prob }>F=0.0330\end{array}$ \\
\hline & & & PSDB = OUTROS & $\begin{array}{c}F(1,60868)=24.92 \\
\text { Prob }>F=0.0000\end{array}$ & $\begin{array}{l}F(1,31260)=2.76 \\
\text { Prob }>F=0.0968\end{array}$ \\
\hline & & & $\mathrm{PSDB}=\mathrm{PDT}$ & $\begin{array}{c}F(1,60868)=13.04 \\
\text { Prob }>F=0.0003\end{array}$ & $\begin{array}{l}F(1,31260)=1.69 \\
\text { Prob }>F=0.1933\end{array}$ \\
\hline & & & $\mathrm{PSDB}=\mathrm{PL}$ & $\begin{array}{c}F(1,60868)=54.81 \\
\text { Prob }>F=0.0000\end{array}$ & $\begin{array}{l}F(1,31260)=1.61 \\
\text { Prob }>F=0.2045\end{array}$ \\
\hline & & & PDT = PTB & $\begin{array}{l}F(1,60868)=1.78 \\
\text { Prob }>F=0.1825\end{array}$ & $\begin{array}{l}F(1,31260)=0.78 \\
\text { Prob }>F=0.3766\end{array}$ \\
\hline & & & PDT = OUTROS & $\begin{array}{l}F(1,60868)=1.08 \\
\text { Prob }>F=0.2989\end{array}$ & $\begin{array}{l}F(1,31260)=0.08 \\
\text { Prob }>F=0.7726\end{array}$ \\
\hline & & & $\mathrm{PDT}=\mathrm{PL}$ & $\begin{array}{c}F(1,60868)=17.55 \\
\text { Prob }>F=0.0000\end{array}$ & $\begin{array}{l}F(1,31260)=0.02 \\
\text { Prob }>F=0.8994\end{array}$ \\
\hline & & & PTB $=$ OUTROS & $\begin{array}{l}F(1,60868)=0.17 \\
\text { Prob }>F=0.6787\end{array}$ & $\begin{array}{l}F(1,31260)=0.41 \\
\text { Prob }>F=0.5225\end{array}$ \\
\hline & & & PTB = PL & $\begin{array}{l}F(1,60868)=9.40 \\
\text { Prob }>F=0.0022\end{array}$ & $\begin{array}{l}F(1,31260)=0.39 \\
\text { Prob }>F=0.5331\end{array}$ \\
\hline & & & OUTROS = PL & $\begin{array}{c}F(1,60868)=13.69 \\
\text { Prob }>F=0.0002\end{array}$ & $\begin{array}{l}F(1,31260)=0.01 \\
\text { Prob }>F=0.9097\end{array}$ \\
\hline
\end{tabular}


Apêndice 1e.4 - Transferências correntes

\begin{tabular}{|c|c|c|c|c|c|}
\hline Hipótese & $\begin{array}{l}\text { Painel não } \\
\text { balanceado }\end{array}$ & $\begin{array}{c}\text { Painel } \\
\text { balanceado }\end{array}$ & Hipótese & $\begin{array}{c}\text { Painel } \\
\text { não balanceado }\end{array}$ & $\begin{array}{c}\text { Painel } \\
\text { balanceado }\end{array}$ \\
\hline $1991=1992$ & $\begin{array}{l}F(1,50814)=1.56 \\
\text { Prob }>F=0.2116\end{array}$ & $\begin{array}{l}F(1,26792)=3.49 \\
\text { Prob }>F=0.0616\end{array}$ & $\mathrm{PFL}=\mathrm{PDS} / \mathrm{PPB}$ & $\begin{array}{l}F(1,50814)=1.82 \\
\text { Prob }>F=0.1773\end{array}$ & $\begin{array}{l}F(1,26792)=0.36 \\
\text { Prob }>F=0.5480\end{array}$ \\
\hline $1992=1993$ & $\begin{array}{c}F(1,50814)=4544.82 \\
\text { Prob }>F=0.0000\end{array}$ & $\begin{array}{c}F(1,26792)=2815.63 \\
\text { Prob }>F=0.0000\end{array}$ & $\mathrm{PFL}=\mathrm{PT}$ & $\begin{array}{l}F(1,50814)=2.10 \\
\text { Prob }>F=0.1473\end{array}$ & $\begin{array}{l}F(1,26792)=0.94 \\
\text { Prob }>F=0.3312\end{array}$ \\
\hline $1995=1996$ & $\begin{array}{l}F(1,50814)=4.49 \\
\text { Prob }>F=0.0341\end{array}$ & $\begin{array}{l}F(1,26792)=5.64 \\
\text { Prob }>F=0.0176\end{array}$ & $\mathrm{PFL}=\mathrm{PSDB}$ & $\begin{array}{l}F(1,50814)=5.61 \\
\text { Prob }>F=0.0178\end{array}$ & $\begin{array}{l}F(1,26792)=4.95 \\
\text { Prob }>F=0.0261\end{array}$ \\
\hline $1996=1997$ & $\begin{array}{c}F(1,50814)=53.92 \\
\text { Prob }>F=0.0000\end{array}$ & $\begin{array}{c}F(1,26792)=17.96 \\
\text { Prob }>F=0.0000\end{array}$ & $\mathrm{PFL}=\mathrm{PTB}$ & $\begin{array}{l}F(1,50814)=4.32 \\
\text { Prob }>F=0.0376\end{array}$ & $\begin{array}{l}F(1,26792)=0.00 \\
\text { Prob }>F=0.9980\end{array}$ \\
\hline $1999=2000$ & $\begin{array}{c}F(1,50814)=62.82 \\
\text { Prob }>F=0.0000\end{array}$ & $\begin{array}{c}F(1,26792)=67.05 \\
\text { Prob }>F=0.0000\end{array}$ & PFL $=$ OUTROS & $\begin{array}{l}F(1,50814)=0.29 \\
\text { Prob }>F=0.5884\end{array}$ & $\begin{array}{l}F(1,26792)=1.15 \\
\text { Prob }>F=0.2834\end{array}$ \\
\hline \multirow[t]{23}{*}{$2000=2001$} & $\begin{array}{l}F(1,50814)=1.59 \\
\text { Prob }>F=0.2078\end{array}$ & $\begin{array}{l}F(1,26792)=0.04 \\
\text { Prob }>F=0.8429\end{array}$ & $\mathrm{PFL}=\mathrm{PDT}$ & $\begin{array}{l}F(1,50814)=0.95 \\
\text { Prob }>F=0.3308\end{array}$ & $\begin{array}{l}F(1,26792)=0.40 \\
\text { Prob }>F=0.5277\end{array}$ \\
\hline & & & $P F L=P L$ & $\begin{array}{l}F(1,50814)=0.23 \\
\text { Prob }>F=0.6341\end{array}$ & $\begin{array}{l}F(1,26792)=1.08 \\
\text { Prob }>F=0.2976\end{array}$ \\
\hline & & & $\mathrm{PDS} / \mathrm{PPB}=\mathrm{PT}$ & $\begin{array}{l}F(1,50814)=0.61 \\
\text { Prob }>F=0.4359\end{array}$ & $\begin{array}{l}F(1,26792)=1.58 \\
\text { Prob }>F=0.2086\end{array}$ \\
\hline & & & $\mathrm{PDS} / \mathrm{PPB}=\mathrm{PSDB}$ & $\begin{array}{l}F(1,50814)=1.46 \\
\text { Prob }>F=0.2264\end{array}$ & $\begin{array}{l}F(1,26792)=6.24 \\
\text { Prob }>F=0.0125\end{array}$ \\
\hline & & & $\mathrm{PDS} / \mathrm{PPB}=\mathrm{PTB}$ & $\begin{array}{l}F(1,50814)=0.58 \\
\text { Prob }>F=0.4465\end{array}$ & $\begin{array}{l}F(1,26792)=0.24 \\
\text { Prob }>F=0.6266\end{array}$ \\
\hline & & & PDS $/$ PPB = OUTROS & $\begin{array}{l}F(1,50814)=0.56 \\
\text { Prob }>F=0.4558\end{array}$ & $\begin{array}{l}F(1,26792)=2.21 \\
\text { Prob }>F=0.1374\end{array}$ \\
\hline & & & PDS / PPB = PDT & $\begin{array}{l}F(1,50814)=0.04 \\
\text { Prob }>F=0.8393\end{array}$ & $\begin{array}{l}F(1,26792)=0.01 \\
\text { Prob }>F=0.9392\end{array}$ \\
\hline & & & $\mathrm{PDS} / \mathrm{PPB}=\mathrm{PL}$ & $\begin{array}{l}F(1,50814)=0.27 \\
\text { Prob }>F=0.6023\end{array}$ & $\begin{array}{l}F(1,26792)=0.28 \\
\text { Prob }>F=0.5946\end{array}$ \\
\hline & & & $\mathrm{PT}=\mathrm{PSDB}$ & $\begin{array}{l}F(1,50814)=0.00 \\
\text { Prob }>F=0.9911\end{array}$ & $\begin{array}{l}F(1,26792)=0.22 \\
\text { Prob }>F=0.6396\end{array}$ \\
\hline & & & $\mathrm{PT}=\mathrm{PTB}$ & $\begin{array}{l}F(1,50814)=0.10 \\
\text { Prob }>F=0.7485\end{array}$ & $\begin{array}{l}F(1,26792)=0.86 \\
\text { Prob }>F=0.3547\end{array}$ \\
\hline & & & PT = OUTROS & $\begin{array}{l}F(1,50814)=1.36 \\
\text { Prob }>F=0.2429\end{array}$ & $\begin{array}{l}F(1,26792)=0.15 \\
\text { Prob }>F=0.6946\end{array}$ \\
\hline & & & $\mathrm{PT}=\mathrm{PDT}$ & $\begin{array}{l}F(1,50814)=0.76 \\
\text { Prob }>F=0.3843\end{array}$ & $\begin{array}{l}F(1,26792)=1.62 \\
\text { Prob }>F=0.2034\end{array}$ \\
\hline & & & $\mathrm{PT}=\mathrm{PL}$ & $\begin{array}{l}F(1,50814)=1.08 \\
\text { Prob }>F=0.2991\end{array}$ & $\begin{array}{l}F(1,26792)=2.22 \\
\text { Prob }>F=0.1361\end{array}$ \\
\hline & & & $\mathrm{PSDB}=\mathrm{PTB}$ & $\begin{array}{l}F(1,50814)=0.24 \\
\text { Prob }>F=0.6231\end{array}$ & $\begin{array}{l}F(1,26792)=3.87 \\
\text { Prob }>F=0.0492\end{array}$ \\
\hline & & & PSDB = OUTROS & $\begin{array}{l}F(1,50814)=3.38 \\
\text { Prob }>F=0.0660\end{array}$ & $\begin{array}{l}F(1,26792)=1.64 \\
\text { Prob }>F=0.2002\end{array}$ \\
\hline & & & $\mathrm{PSDB}=\mathrm{PDT}$ & $\begin{array}{l}F(1,50814)=1.70 \\
\text { Prob }>F=0.1922\end{array}$ & $\begin{array}{l}F(1,26792)=6.07 \\
\text { Prob }>F=0.0138\end{array}$ \\
\hline & & & $\mathrm{PSDB}=\mathrm{PL}$ & $\begin{array}{l}F(1,50814)=2.24 \\
\text { Prob }>F=0.1341\end{array}$ & $\begin{array}{l}F(1,26792)=6.79 \\
\text { Prob }>F=0.0092\end{array}$ \\
\hline & & & $\mathrm{PDT}=\mathrm{PTB}$ & $\begin{array}{l}F(1,50814)=0.82 \\
\text { Prob }>F=0.3651\end{array}$ & $\begin{array}{l}F(1,26792)=0.30 \\
\text { Prob }>F=0.5860\end{array}$ \\
\hline & & & PDT = OUTROS & $\begin{array}{l}F(1,50814)=0.23 \\
\text { Prob }>F=0.6349\end{array}$ & $\begin{array}{l}F(1,26792)=2.13 \\
\text { Prob }>F=0.1440\end{array}$ \\
\hline & & & $\mathrm{PDT}=\mathrm{PL}$ & $\begin{array}{l}F(1,50814)=0.11 \\
\text { Prob }>F=0.7438\end{array}$ & $\begin{array}{l}F(1,26792)=0.20 \\
\text { Prob }>F=0.6516\end{array}$ \\
\hline & & & PTB $=$ OUTROS & $\begin{array}{l}F(1,50814)=2.18 \\
\text { Prob }>F=0.1401\end{array}$ & $\begin{array}{l}F(1,26792)=0.78 \\
\text { Prob }>F=0.3771\end{array}$ \\
\hline & & & $\mathrm{PTB}=\mathrm{PL}$ & $\begin{array}{l}F(1,50814)=1.28 \\
\text { Prob }>F=0.2581\end{array}$ & $\begin{array}{l}F(1,26792)=0.83 \\
\text { Prob }>F=0.3626\end{array}$ \\
\hline & & & OUTROS = PL & $\begin{array}{l}F(1,50814)=0.00 \\
\text { Prob }>F=0.9488\end{array}$ & $\begin{array}{l}F(1,26792)=3.02 \\
\text { Prob }>F=0.0824\end{array}$ \\
\hline
\end{tabular}


Apêndice 1e.5-Despesa de investimento

\begin{tabular}{|c|c|c|c|c|c|}
\hline Hipótese & $\begin{array}{l}\text { Painel não } \\
\text { balanceado }\end{array}$ & $\begin{array}{c}\text { Painel } \\
\text { balanceado }\end{array}$ & Hipótese & $\begin{array}{c}\text { Painel } \\
\text { não balanceado }\end{array}$ & $\begin{array}{c}\text { Painel } \\
\text { balanceado }\end{array}$ \\
\hline $1991=1992$ & $\begin{array}{c}F(1,60868)=30.17 \\
\text { Prob }>F=0.0000\end{array}$ & $\begin{array}{c}F(1,31260)=28.23 \\
\text { Prob }>F=0.0000\end{array}$ & $\mathrm{PFL}=\mathrm{PDS} / \mathrm{PPB}$ & $\begin{array}{l}F(1,60868)=0.74 \\
\text { Prob }>F=0.3903\end{array}$ & $\begin{array}{l}F(1,31260)=5.78 \\
\text { Prob }>F=0.0162\end{array}$ \\
\hline $1992=1993$ & $\begin{array}{c}F(1,60868)=82.59 \\
\text { Prob }>F=0.0000\end{array}$ & $\begin{array}{c}F(1,31260)=158.79 \\
\text { Prob }>F=0.0000\end{array}$ & $P F L=P T$ & $\begin{array}{l}F(1,60868)=7.08 \\
\text { Prob }>F=0.0078\end{array}$ & $\begin{array}{c}F(1,31260)=19.60 \\
\text { Prob }>F=0.0000\end{array}$ \\
\hline $1995=1996$ & $\begin{array}{l}F(1,60868)=3.49 \\
\text { Prob }>F=0.0617\end{array}$ & $\begin{array}{l}F(1,31260)=7.58 \\
\text { Prob }>F=0.0059\end{array}$ & $\mathrm{PFL}=\mathrm{PSDB}$ & $\begin{array}{l}F(1,60868)=0.45 \\
\text { Prob }>F=0.5031\end{array}$ & $\begin{array}{l}F(1,31260)=1.65 \\
\text { Prob }>F=0.1996\end{array}$ \\
\hline $1996=1997$ & $\begin{array}{c}F(1,60868)=405.01 \\
\text { Prob }>F=0.0000\end{array}$ & $\begin{array}{c}F(1,31260)=430.05 \\
\text { Prob }>F=0.0000\end{array}$ & $\mathrm{PFL}=\mathrm{PTB}$ & $\begin{array}{l}F(1,60868)=0.04 \\
\text { Prob }>F=0.8453\end{array}$ & $\begin{array}{l}F(1,31260)=1.81 \\
\text { Prob }>F=0.1780\end{array}$ \\
\hline $1999=2000$ & $\begin{array}{l}F(1,60868)=3.14 \\
\text { Prob }>F=0.0762\end{array}$ & $\begin{array}{l}F(1,31260)=3.35 \\
\text { Prob }>F=0.0670\end{array}$ & PFL $=$ OUTROS & $\begin{array}{l}F(1,60868)=0.95 \\
\text { Prob }>F=0.3295\end{array}$ & $\begin{array}{l}F(1,31260)=0.08 \\
\text { Prob }>F=0.7734\end{array}$ \\
\hline \multirow[t]{23}{*}{$2000=2001$} & $\begin{array}{c}F(1,60868)=106.42 \\
P r o b>F=0.0000\end{array}$ & $\begin{array}{c}F(1,31260)=106.48 \\
P r o b>F=0.0000\end{array}$ & $\mathrm{PFL}=\mathrm{PDT}$ & $\begin{array}{l}F(1,60868)=0.04 \\
\text { Prob }>F=0.8332\end{array}$ & $\begin{array}{l}F(1,31260)=9.22 \\
\text { Prob }>F=0.0024\end{array}$ \\
\hline & & & $P F L=P L$ & $\begin{array}{l}F(1,60868)=6.69 \\
\text { Prob }>F=0.0097\end{array}$ & $\begin{array}{c}F(1,31260)=16.63 \\
\text { Prob }>F=0.0000\end{array}$ \\
\hline & & & $\mathrm{PDS} / \mathrm{PPB}=\mathrm{PT}$ & $\begin{array}{l}F(1,60868)=4.68 \\
\text { Prob }>F=0.0305\end{array}$ & $\begin{array}{l}F(1,31260)=9.05 \\
\text { Prob }>F=0.0026\end{array}$ \\
\hline & & & PDS $/ \mathrm{PPB}=\mathrm{PSDB}$ & $\begin{array}{l}F(1,60868)=0.00 \\
\text { Prob }>F=0.9639\end{array}$ & $\begin{array}{l}F(1,31260)=0.48 \\
\text { Prob }>F=0.4893\end{array}$ \\
\hline & & & PDS $/$ PPB = PTB & $\begin{array}{l}F(1,60868)=0.26 \\
\text { Prob }>F=0.6086\end{array}$ & $\begin{array}{l}F(1,31260)=0.60 \\
\text { Prob }>F=0.4373\end{array}$ \\
\hline & & & PDS $/$ PPB $=$ OUTROS & $\begin{array}{l}F(1,60868)=2.64 \\
P r o b>F=0.1043\end{array}$ & $\begin{array}{l}F(1,31260)=5.79 \\
\text { Prob }>F=0.0161\end{array}$ \\
\hline & & & $\mathrm{PDS} / \mathrm{PPB}=\mathrm{PDT}$ & $\begin{array}{l}F(1,60868)=0.26 \\
\text { Prob }>F=0.6121\end{array}$ & $\begin{array}{l}F(1,31260)=0.64 \\
\text { Prob }>F=0.4237\end{array}$ \\
\hline & & & $\mathrm{PDS} / \mathrm{PPB}=\mathrm{PL}$ & $\begin{array}{l}F(1,60868)=3.02 \\
\text { Prob }>F=0.0821\end{array}$ & $\begin{array}{l}F(1,31260)=4.24 \\
\text { Prob }>F=0.0395\end{array}$ \\
\hline & & & $\mathrm{PT}=\mathrm{PSDB}$ & $\begin{array}{l}F(1,60868)=4.56 \\
\text { Prob }>F=0.0327\end{array}$ & $\begin{array}{c}F(1,31260)=11.56 \\
\text { Prob }>F=0.0007\end{array}$ \\
\hline & & & $\mathrm{PT}=\mathrm{PTB}$ & $\begin{array}{l}F(1,60868)=5.80 \\
\text { Prob }>F=0.0160\end{array}$ & $\begin{array}{c}F(1,31260)=11.73 \\
\text { Prob }>F=0.0006\end{array}$ \\
\hline & & & $\mathrm{PT}=\mathrm{OUTROS}$ & $\begin{array}{l}F(1,60868)=9.34 \\
\text { Prob }>F=0.0022\end{array}$ & $\begin{array}{c}F(1,31260)=19.64 \\
\text { Prob }>F=0.0000\end{array}$ \\
\hline & & & $\mathrm{PT}=\mathrm{PDT}$ & $\begin{array}{l}F(1,60868)=5.67 \\
\text { Prob }>F=0.0172\end{array}$ & $\begin{array}{l}F(1,31260)=5.87 \\
P r o b>F=0.0154\end{array}$ \\
\hline & & & $\mathrm{PT}=\mathrm{PL}$ & $\begin{array}{l}F(1,60868)=0.72 \\
\text { Prob }>F=0.3957\end{array}$ & $\begin{array}{l}F(1,31260)=1.57 \\
\text { Prob }>F=0.2108\end{array}$ \\
\hline & & & $\mathrm{PSDB}=\mathrm{PTB}$ & $\begin{array}{l}F(1,60868)=0.17 \\
\text { Prob }>F=0.6769\end{array}$ & $\begin{array}{l}F(1,31260)=0.00 \\
\text { Prob }>F=0.9685\end{array}$ \\
\hline & & & PSDB = OUTROS & $\begin{array}{l}F(1,60868)=1.84 \\
\text { Prob }>F=0.1751\end{array}$ & $\begin{array}{l}F(1,31260)=2.00 \\
\text { Prob }>F=0.1574\end{array}$ \\
\hline & & & $\mathrm{PSDB}=\mathrm{PDT}$ & $\begin{array}{l}F(1,60868)=0.16 \\
\text { Prob }>F=0.6937\end{array}$ & $\begin{array}{l}F(1,31260)=1.80 \\
\text { Prob }>F=0.1803\end{array}$ \\
\hline & & & $P S D B=P L$ & $\begin{array}{l}F(1,60868)=2.64 \\
\text { Prob }>F=0.1039\end{array}$ & $\begin{array}{l}F(1,31260)=6.17 \\
\text { Prob }>F=0.0130\end{array}$ \\
\hline & & & $\mathrm{PDT}=\mathrm{PTB}$ & $\begin{array}{l}F(1,60868)=0.00 \\
\text { Prob }>F=0.9852\end{array}$ & $\begin{array}{l}F(1,31260)=2.20 \\
\text { Prob }>F=0.1384\end{array}$ \\
\hline & & & PDT = OUTROS & $\begin{array}{l}F(1,60868)=0.91 \\
\text { Prob }>F=0.3390\end{array}$ & $\begin{array}{l}F(1,31260)=9.01 \\
\text { Prob }>F=0.0027\end{array}$ \\
\hline & & & $\mathrm{PDT}=\mathrm{PL}$ & $\begin{array}{l}F(1,60868)=4.09 \\
\text { Prob }>F=0.0431\end{array}$ & $\begin{array}{l}F(1,31260)=1.80 \\
\text { Prob }>F=0.1801\end{array}$ \\
\hline & & & PTB $=$ OUTROS & $\begin{array}{l}F(1,60868)=0.92 \\
\text { Prob }>F=0.3386\end{array}$ & $\begin{array}{l}F(1,31260)=2.11 \\
\text { Prob }>F=0.1462\end{array}$ \\
\hline & & & $\mathrm{PTB}=\mathrm{PL}$ & $\begin{array}{l}F(1,60868)=4.28 \\
\text { Prob }>F=0.0385\end{array}$ & $\begin{array}{l}F(1,31260)=6.79 \\
\text { Prob }>F=0.0092\end{array}$ \\
\hline & & & OUTROS = PL & $\begin{array}{l}F(1,60868)=9.54 \\
\text { Prob }>F=0.0020\end{array}$ & $\begin{array}{c}F(1,31260)=16.09 \\
\text { Prob }>F=0.0001\end{array}$ \\
\hline
\end{tabular}


Apêndice 2

Apêndice 2.1 - Probabilidade de reeleição em função da despesa total (total dos quatro anos) - modelo logit - Pooled e efeitos aleatórios

\begin{tabular}{|c|c|c|c|c|c|c|}
\hline \multirow{2}{*}{$\begin{array}{c}\begin{array}{c}\text { Coeficiente } \\
\text { (desvio-padrão) }\end{array} \\
\text { Despesa Total }\end{array}$} & \multicolumn{3}{|c|}{ Pooled } & \multicolumn{3}{|c|}{ Efeitos aleatórios } \\
\hline & $\begin{array}{c}0.097 \\
(0.219)\end{array}$ & $\begin{array}{c}0.061 \\
(0.220)\end{array}$ & $\begin{array}{c}0.034 \\
(0.233)\end{array}$ & $\begin{array}{c}0.099 \\
(0.219)\end{array}$ & $\begin{array}{c}0.060 \\
(0.213)\end{array}$ & $\begin{array}{c}0.026 \\
(0.225)\end{array}$ \\
\hline PFL & & $\begin{array}{c}-0.262^{* * *} \\
(0.077)\end{array}$ & $\begin{array}{c}1.352 \\
(1.149)\end{array}$ & & $\begin{array}{c}-0.264^{* * *} \\
(0.080)\end{array}$ & $\begin{array}{c}1.319 \\
(1.166)\end{array}$ \\
\hline PTB & & $\begin{array}{c}-0.800^{* * *} \\
(0.121)\end{array}$ & $\begin{array}{c}-5.511^{\star * *} \\
(1.987)\end{array}$ & & $\begin{array}{c}-0.802^{\star * *} \\
(0.124)\end{array}$ & $\begin{array}{c}-5.622^{\star * *} \\
(2.130)\end{array}$ \\
\hline PSDB & & $\begin{array}{l}-1.059^{*} \\
(0.637)\end{array}$ & $\begin{array}{c}0.954 \\
(1.631)\end{array}$ & & $\begin{array}{l}-1.094 \\
(0.819) \\
\end{array}$ & $\begin{array}{c}0.926 \\
(1.784)\end{array}$ \\
\hline PDT & & $\begin{array}{c}-0.557^{* * *} \\
(0.112)\end{array}$ & $\begin{array}{l}-1.883 \\
(2.018)\end{array}$ & & $\begin{array}{c}-0.549^{* * *} \\
(0.114)\end{array}$ & $\begin{array}{l}-1.995 \\
(1.946)\end{array}$ \\
\hline PDS / PPB & & $\begin{array}{c}-0.437^{* * *} \\
(0.097)\end{array}$ & $\begin{array}{l}-1.936 \\
(1.719) \\
\end{array}$ & & $\begin{array}{c}-0.431^{\text {*** }} \\
(0.100)\end{array}$ & $\begin{array}{l}-2.067 \\
(1.683) \\
\end{array}$ \\
\hline PL & & $\begin{array}{c}-0.893^{* * *} \\
(0.154)\end{array}$ & $\begin{array}{c}-5.487^{\star *} \\
(2.459)\end{array}$ & & $\begin{array}{c}-0.893^{\star * *} \\
(0.158)\end{array}$ & $\begin{array}{c}-5.797^{\star *} \\
(2.408)\end{array}$ \\
\hline OUTROS & & $\begin{array}{c}-1.272^{* * *} \\
(0.128)\end{array}$ & $\begin{array}{c}-3.750^{\star *} \\
(1.738)\end{array}$ & & $\begin{array}{c}-1.264^{* * *} \\
(0.131)\end{array}$ & $\begin{array}{c}-3.904^{* *} \\
(1.883)\end{array}$ \\
\hline PT & & $\begin{array}{c}0.121 \\
(0.202)\end{array}$ & $\begin{array}{l}-2.985 \\
(3.776)\end{array}$ & & $\begin{array}{c}0.147 \\
(0.210)\end{array}$ & $\begin{array}{l}-2.982 \\
(3.786)\end{array}$ \\
\hline Despesa Total \& PFL & & & $\begin{array}{l}-0.208 \\
(0.147)\end{array}$ & & & $\begin{array}{l}-0.204 \\
(0.149)\end{array}$ \\
\hline Despesa Total \& PTB & & & $\begin{array}{l}0.593^{\star *} \\
(0.249)\end{array}$ & & & $\begin{array}{l}0.607^{* *} \\
(0.267)\end{array}$ \\
\hline Despesa Total \& PSDB & & & $\begin{array}{l}-0.269 \\
(0.200)\end{array}$ & & & $\begin{array}{l}-0.270 \\
(0.208)\end{array}$ \\
\hline Despesa Total \& PDT & & & $\begin{array}{c}0.169 \\
(0.255)\end{array}$ & & & $\begin{array}{c}0.184 \\
(0.246)\end{array}$ \\
\hline Despesa Total \& PDS / PPB & & & $\begin{array}{c}0.190 \\
(0.216)\end{array}$ & & & $\begin{array}{c}0.207 \\
(0.212) \\
\end{array}$ \\
\hline Despesa Total \& PL & & & $\begin{array}{l}0.591^{*} \\
(0.314)\end{array}$ & & & $\begin{array}{l}0.631^{\star *} \\
(0.308)\end{array}$ \\
\hline Despesa Total \& Outros & & & $\begin{array}{c}0.319 \\
(0.222)\end{array}$ & & & $\begin{array}{c}0.340 \\
(0.241)\end{array}$ \\
\hline Despe*sa Total \& PT & & & $\begin{array}{c}0.391 \\
(0.473)\end{array}$ & & & $\begin{array}{c}0.394 \\
(0.474)\end{array}$ \\
\hline Receita tributária & $\begin{array}{c}-0.114^{\star \star \star} \\
(0.036)\end{array}$ & $\begin{array}{c}-0.128^{* \star \star} \\
(0.037)\end{array}$ & $\begin{array}{c}-0.130^{\star \star \star} \\
(0.037)\end{array}$ & $\begin{array}{c}-0.116^{\star \star \star} \\
(0.040)\end{array}$ & $\begin{array}{c}-0.129^{\star \star \star} \\
(0.039)\end{array}$ & $\begin{array}{c}-0.131^{\star * *} \\
(0.039)\end{array}$ \\
\hline Receita de Transferências & $\begin{array}{l}0.472^{* *} \\
(0.211)\end{array}$ & $\begin{array}{l}0.517^{* *} \\
(0.213)\end{array}$ & $\begin{array}{l}0.494^{* *} \\
(0.215)\end{array}$ & $\begin{array}{l}0.518^{\star *} \\
(0.209)\end{array}$ & $\begin{array}{c}0.539^{\star \star \star} \\
(0.205)\end{array}$ & $\begin{array}{l}0.516^{\star *} \\
(0.206)\end{array}$ \\
\hline Prefeito \& Governador & $\begin{array}{c}0.290^{* * *} \\
(0.057)\end{array}$ & $\begin{array}{c}0.212^{* * *} \\
(0.060)\end{array}$ & $\begin{array}{c}0.224^{* * *} \\
(0.060)\end{array}$ & $\begin{array}{c}0.298^{* * *} \\
(0.060)\end{array}$ & $\begin{array}{c}0.218^{* * *} \\
(0.061)\end{array}$ & $\begin{array}{c}0.230^{* * *} \\
(0.061)\end{array}$ \\
\hline Prefeito \& Presidente & $\begin{array}{c}0.267^{\star \star \star} \\
(0.093)\end{array}$ & $\begin{array}{c}1.007 \\
(0.639)\end{array}$ & $\begin{array}{l}1.158^{*} \\
(0.654)\end{array}$ & $\begin{array}{c}0.330^{\star * *} \\
(0.099)\end{array}$ & $\begin{array}{c}1.069 \\
(0.822) \\
\end{array}$ & $\begin{array}{c}1.231 \\
(0.820)\end{array}$ \\
\hline Idosos & $\begin{array}{l}-0.036 \\
(0.023) \\
\end{array}$ & $\begin{array}{l}-0.037 \\
(0.024) \\
\end{array}$ & $\begin{array}{l}-0.040^{*} \\
(0.024)\end{array}$ & $\begin{array}{l}-0.049^{*} \\
(0.026)\end{array}$ & $\begin{array}{l}-0.043^{*} \\
(0.025)\end{array}$ & $\begin{array}{l}-0.046^{*} \\
(0.025)\end{array}$ \\
\hline Urbanização & $\begin{array}{c}-0.010^{* * *} \\
(0.002)\end{array}$ & $\begin{array}{c}-0.009^{* * *} \\
(0.002)\end{array}$ & $\begin{array}{c}-0.009^{\star * *} \\
(0.002)\end{array}$ & $\begin{array}{c}-0.011^{* * *} \\
(0.002)\end{array}$ & $\begin{array}{c}-0.009^{* * *} \\
(0.002)\end{array}$ & $\begin{array}{c}-0.009^{* * *} \\
(0.002)\end{array}$ \\
\hline Jovens & $\begin{array}{l}-0.006 \\
(0.010)\end{array}$ & $\begin{array}{l}-0.002 \\
(0.011)\end{array}$ & $\begin{array}{l}-0.004 \\
(0.011)\end{array}$ & $\begin{array}{l}-0.008 \\
(0.011)\end{array}$ & $\begin{array}{l}-0.003 \\
(0.011)\end{array}$ & $\begin{array}{l}-0.005 \\
(0.011)\end{array}$ \\
\hline População Total & $\begin{array}{c}0.109^{\star * *} \\
(0.040)\end{array}$ & $\begin{array}{c}0.128^{* * *} \\
(0.041)\end{array}$ & $\begin{array}{c}0.116^{\star \star *} \\
(0.041)\end{array}$ & $\begin{array}{c}0.117^{\star * *} \\
(0.043)\end{array}$ & $\begin{array}{c}0.131^{* * *} \\
(0.042)\end{array}$ & $\begin{array}{c}0.119^{\star * *} \\
(0.042)\end{array}$ \\
\hline Constante & $\begin{array}{c}-4.744^{* * *} \\
(1.133)\end{array}$ & $\begin{array}{c}-4.718^{* * *} \\
(1.148)\end{array}$ & $\begin{array}{c}-4.176^{* * *} \\
(1.275)\end{array}$ & $\begin{array}{c}-5.031^{* * *} \\
(1.237)\end{array}$ & $\begin{array}{c}-4.850^{* * *} \\
(1.189)\end{array}$ & $\begin{array}{c}-4.245^{* * *} \\
(1.320)\end{array}$ \\
\hline Observações & 6705 & 6705 & 6705 & 6705 & 6705 & 6705 \\
\hline
\end{tabular}


Apêndice 2.2 - Probabilidade de reeleição em função da despesa do ano eleitoral e da média dos três anos anteriores à eleição-modelo logit - Pooled e efeitos aleatórios

\begin{tabular}{|c|c|c|c|c|c|c|}
\hline $\begin{array}{c}\text { Coeficiente } \\
\text { (desvio-padrão) }\end{array}$ & \multicolumn{3}{|c|}{ Pooled } & \multicolumn{3}{|c|}{ Efeitos aleatórios } \\
\hline Despesa ano eleitoral & $\begin{array}{c}-0.730^{* * *} \\
(0.165)\end{array}$ & $\begin{array}{c}-0.717^{* * *} \\
(0.167)\end{array}$ & $\begin{array}{c}-0.997^{* * *} \\
(0.263)\end{array}$ & $\begin{array}{c}-0.826^{* * *} \\
(0.173)\end{array}$ & $\begin{array}{c}-0.769^{* * *} \\
(0.170)\end{array}$ & $\begin{array}{c}-1.076^{* * *} \\
(0.261)\end{array}$ \\
\hline Despesa média 3 anos & $\begin{array}{c}0.778^{\star \star *} \\
(0.207)\end{array}$ & $\begin{array}{c}0.729^{\star * *} \\
(0.209)\end{array}$ & $\begin{array}{c}0.997^{\star \star *} \\
(0.287)\end{array}$ & $\begin{array}{c}0.865^{\star \star \star} \\
(0.221)\end{array}$ & $\begin{array}{c}0.774^{\star \star *} \\
(0.217)\end{array}$ & $\begin{array}{c}1.063^{\star * *} \\
(0.295)\end{array}$ \\
\hline PFL & & $\begin{array}{c}-0.262^{* * *} \\
(0.077)\end{array}$ & $\begin{array}{c}0.843 \\
(0.947)\end{array}$ & & $\begin{array}{c}-0.265^{\star * *} \\
(0.081)\end{array}$ & $\begin{array}{c}0.809 \\
(0.974)\end{array}$ \\
\hline PTB & & $\begin{array}{c}-0.811^{\star * *} \\
(0.122)\end{array}$ & $\begin{array}{c}-4.756^{\star \star \star} \\
(1.658)\end{array}$ & & $\begin{array}{c}-0.814^{\star * *} \\
(0.125)\end{array}$ & $\begin{array}{c}-4.863^{\star \star \star} \\
(1.790)\end{array}$ \\
\hline PSDB & & $\begin{array}{l}-1.132^{*} \\
(0.621)\end{array}$ & $\begin{array}{c}0.459 \\
(1.403)\end{array}$ & & $\begin{array}{l}-1.186 \\
(0.815)\end{array}$ & $\begin{array}{c}0.425 \\
(1.556)\end{array}$ \\
\hline PDT & & $\begin{array}{c}-0.561^{* * *} \\
(0.112)\end{array}$ & $\begin{array}{l}-1.591 \\
(1.691)\end{array}$ & & $\begin{array}{c}-0.552^{* * *} \\
(0.115)\end{array}$ & $\begin{array}{l}-1.697 \\
(1.649)\end{array}$ \\
\hline PDS / PPB & & $\begin{array}{c}-0.448^{\star * *} \\
(0.097)\end{array}$ & $\begin{array}{l}-1.693 \\
(1.423)\end{array}$ & & $\begin{array}{c}-0.442^{\star * *} \\
(0.101)\end{array}$ & $\begin{array}{c}-1.831 \\
(1.410)\end{array}$ \\
\hline PL & & $\begin{array}{c}-0.900^{* * *} \\
(0.155)\end{array}$ & $\begin{array}{c}-5.036^{\star *} \\
(2.014)\end{array}$ & & $\begin{array}{c}-0.901^{* * *} \\
(0.159)\end{array}$ & $\begin{array}{c}-5.375^{\star * *} \\
(2.014)\end{array}$ \\
\hline OUTROS & & $\begin{array}{c}-1.252^{\star * *} \\
(0.128)\end{array}$ & $\begin{array}{l}-2.778^{*} \\
(1.451)\end{array}$ & & $\begin{array}{c}-1.241^{* * *} \\
(0.132)\end{array}$ & $\begin{array}{l}-2.932^{*} \\
(1.579)\end{array}$ \\
\hline PT & & $\begin{array}{c}0.119 \\
(0.201)\end{array}$ & $\begin{array}{l}-1.322 \\
(3.463)\end{array}$ & & $\begin{array}{c}0.150 \\
(0.212)\end{array}$ & $\begin{array}{l}-1.251 \\
(3.352)\end{array}$ \\
\hline Despesa ano eleitoral \& PFL & & & $\begin{array}{l}0.877^{\star *} \\
(0.413)\end{array}$ & & & $\begin{array}{l}0.904^{* *} \\
(0.419)\end{array}$ \\
\hline Despesa ano eleitoral \& PTB & & & $\begin{array}{c}0.875 \\
(0.725)\end{array}$ & & & $\begin{array}{c}0.910 \\
(0.707)\end{array}$ \\
\hline Despesa ano eleitoral \& PSDB & & & $\begin{array}{c}0.694 \\
(0.582)\end{array}$ & & & $\begin{array}{c}0.760 \\
(0.599)\end{array}$ \\
\hline Despesa ano eleitoral \& PDT & & & $\begin{array}{c}0.528 \\
(0.620)\end{array}$ & & & $\begin{array}{c}0.597 \\
(0.682)\end{array}$ \\
\hline Despesa ano eleitoral \& PDS / PPB & & & $\begin{array}{c}0.477 \\
(0.582) \\
\end{array}$ & & & $\begin{array}{c}0.547 \\
(0.605)\end{array}$ \\
\hline Despesa ano eleitoral \& PL & & & $\begin{array}{c}1.400^{*} \\
(0.777)\end{array}$ & & & $\begin{array}{l}1.514^{*} \\
(0.907)\end{array}$ \\
\hline Despesa ano eleitoral \& Outros & & & $\begin{array}{c}-1.786^{* *} \\
(0.708)\end{array}$ & & & $\begin{array}{c}-1.772^{* *} \\
(0.742)\end{array}$ \\
\hline Despesa ano eleitoral \& PT & & & $\begin{array}{l}-2.528^{*} \\
(1.429)\end{array}$ & & & $\begin{array}{l}-2.594^{*} \\
(1.480)\end{array}$ \\
\hline Despesa média 3 anos \& PFL & & & $\begin{array}{c}-1.065^{\star *} \\
(0.419)\end{array}$ & & & $\begin{array}{c}-1.089^{* * *} \\
(0.422)\end{array}$ \\
\hline Despesa média 3 anos \& PTB & & & $\begin{array}{l}-0.283 \\
(0.718)\end{array}$ & & & $\begin{array}{c}-0.303 \\
(0.700) \\
\end{array}$ \\
\hline Despesa média 3 anos \& PSDB & & & $\begin{array}{l}-0.959^{*} \\
(0.564)\end{array}$ & & & $\begin{array}{l}-1.029^{*} \\
(0.583)\end{array}$ \\
\hline Despesa média 3 anos \& PDT & & & $\begin{array}{l}-0.376 \\
(0.609) \\
\end{array}$ & & & $\begin{array}{c}-0.429 \\
(0.660) \\
\end{array}$ \\
\hline Despesa média 3 anos \& PDS / PPB & & & $\begin{array}{l}-0.293 \\
(0.591)\end{array}$ & & & $\begin{array}{l}-0.341 \\
(0.603)\end{array}$ \\
\hline Despesa média 3 anos \& PL & & & $\begin{array}{l}-0.772 \\
(0.804)\end{array}$ & & & $\begin{array}{l}-0.834 \\
(0.899)\end{array}$ \\
\hline Despesa média 3 anos \& Outros & & & $\begin{array}{c}2.057^{* * *} \\
(0.727)\end{array}$ & & & $\begin{array}{c}2.068^{* * *} \\
(0.747)\end{array}$ \\
\hline Despesa média 3 anos \& PT & & & $\begin{array}{l}2.779^{\star *} \\
(1.415)\end{array}$ & & & $\begin{array}{l}2.840^{*} \\
(1.454)\end{array}$ \\
\hline Receita tributária & $\begin{array}{c}-0.106^{\star * *} \\
(0.036)\end{array}$ & $\begin{array}{c}-0.121^{* * *} \\
(0.037)\end{array}$ & $\begin{array}{c}-0.121^{* * *} \\
(0.038)\end{array}$ & $\begin{array}{c}-0.106^{\star * *} \\
(0.040)\end{array}$ & $\begin{array}{c}-0.120^{* * *} \\
(0.039)\end{array}$ & $\begin{array}{c}-0.121^{* * *} \\
(0.040)\end{array}$ \\
\hline
\end{tabular}




\begin{tabular}{|c|c|c|c|c|c|c|}
\hline Receita de transferências & $\begin{array}{l}0.497^{* *} \\
(0.206)\end{array}$ & $\begin{array}{c}0.545^{\star * *} \\
(0.209)\end{array}$ & $\begin{array}{l}0.510^{* *} \\
(0.215)\end{array}$ & $\begin{array}{c}0.554^{* * *} \\
(0.213)\end{array}$ & $\begin{array}{c}0.576^{* * *} \\
(0.209)\end{array}$ & $\begin{array}{l}0.538^{* *} \\
(0.212)\end{array}$ \\
\hline Prefeito $=$ Governador & $\begin{array}{c}0.279^{* * *} \\
(0.057)\end{array}$ & $\begin{array}{c}0.202^{* * *} \\
(0.060)\end{array}$ & $\begin{array}{c}0.218^{* * *} \\
(0.061)\end{array}$ & $\begin{array}{c}0.286^{* * *} \\
(0.061)\end{array}$ & $\begin{array}{c}0.209^{* * *} \\
(0.061)\end{array}$ & $\begin{array}{c}0.225^{\star * *} \\
(0.062)\end{array}$ \\
\hline Prefeito $=$ Presidente & $\begin{array}{c}0.269^{* * *} \\
(0.094)\end{array}$ & $\begin{array}{l}1.080^{*} \\
(0.623)\end{array}$ & $\begin{array}{l}1.178^{*} \\
(0.649)\end{array}$ & $\begin{array}{c}0.338^{* * *} \\
(0.100)\end{array}$ & $\begin{array}{c}1.167 \\
(0.817)\end{array}$ & $\begin{array}{c}1.271 \\
(0.823)\end{array}$ \\
\hline Idosos & $\begin{array}{l}-0.024 \\
(0.024)\end{array}$ & $\begin{array}{l}-0.026 \\
(0.024)\end{array}$ & $\begin{array}{c}-0.029 \\
(0.024)\end{array}$ & $\begin{array}{l}-0.035 \\
(0.026)\end{array}$ & $\begin{array}{l}-0.031 \\
(0.025)\end{array}$ & $\begin{array}{l}-0.034 \\
(0.026)\end{array}$ \\
\hline Urbanização & $\begin{array}{c}-0.010^{\star * *} \\
(0.002)\end{array}$ & $\begin{array}{c}-0.009^{\star * *} \\
(0.002)\end{array}$ & $\begin{array}{c}-0.009^{\star * *} \\
(0.002)\end{array}$ & $\begin{array}{c}-0.011^{* * *} \\
(0.002)\end{array}$ & $\begin{array}{c}-0.010^{\star * *} \\
(0.002)\end{array}$ & $\begin{array}{c}-0.010^{\star * *} \\
(0.002)\end{array}$ \\
\hline Jovens & $\begin{array}{l}-0.003 \\
(0.010)\end{array}$ & $\begin{array}{c}0.000 \\
(0.011)\end{array}$ & $\begin{array}{l}-0.002 \\
(0.011)\end{array}$ & $\begin{array}{l}-0.005 \\
(0.011)\end{array}$ & $\begin{array}{l}-0.001 \\
(0.011)\end{array}$ & $\begin{array}{l}-0.002 \\
(0.011)\end{array}$ \\
\hline População Total & $\begin{array}{c}0.108^{* * *} \\
(0.040) \\
\end{array}$ & $\begin{array}{c}0.128^{* * *} \\
(0.041)\end{array}$ & $\begin{array}{c}0.116^{* * *} \\
(0.041) \\
\end{array}$ & $\begin{array}{c}0.116^{* * *} \\
(0.044)\end{array}$ & $\begin{array}{c}0.131^{* * *} \\
(0.043)\end{array}$ & $\begin{array}{c}0.120^{* * *} \\
(0.043) \\
\end{array}$ \\
\hline Constante & $\begin{array}{c}-4.560^{* * *} \\
(1.142)\end{array}$ & $\begin{array}{c}-4.617^{* * *} \\
(1.158)\end{array}$ & $\begin{array}{c}-4.068^{* * *} \\
(1.247)\end{array}$ & $\begin{array}{c}-4.887^{* * *} \\
(1.243)\end{array}$ & $\begin{array}{c}-4.787^{* * *} \\
(1.200)\end{array}$ & $\begin{array}{c}-4.176^{* * *} \\
(1.296)\end{array}$ \\
\hline Observações & 6705 & 6705 & 6705 & 6705 & 6705 & 6705 \\
\hline
\end{tabular}


Apêndice 2.3 - Testes de hipótese - estimação com despesa total-efeitos fixos

\begin{tabular}{|c|c|c|}
\hline Hipótese & Dummies de partido & Interações com despesa total \\
\hline $\mathrm{PFL}=\mathrm{PTB}$ & $\begin{array}{c}\text { chi2 }(1)=2.70 \\
\text { Prob }>\text { chi2 }=0.1005\end{array}$ & $\begin{array}{c}\text { chi2 }(1)=2.49 \\
\text { Prob }>\text { chi2 }=0.1145\end{array}$ \\
\hline$P F L=P S D B$ & $\begin{array}{c}\text { chi2 } 2(1)=0.59 \\
\text { Prob }>\text { chi2 }=0.4416\end{array}$ & $\begin{array}{c}\text { chi2 }(1)=0.00 \\
\text { Prob }>\text { chi2 }=0.9466\end{array}$ \\
\hline $\mathrm{PFL}=\mathrm{PDT}$ & $\begin{array}{c}\text { chi2 } 2(1)=1.95 \\
\text { Prob }>\text { chi2 }=0.1621\end{array}$ & $\begin{array}{c}\operatorname{chi} 2(1)=2.10 \\
\text { Prob }>\text { chi2 }=0.1475\end{array}$ \\
\hline$P F L=P D S / P P B$ & $\begin{array}{c}\text { chi2 }(1)=4.03 \\
\text { Prob }>\text { chi2 }=0.0446\end{array}$ & $\begin{array}{c}\text { chi2 }(1)=4.23 \\
\text { Prob }>\text { chi2 }=0.0397\end{array}$ \\
\hline$P F L=P L$ & $\begin{array}{c}\text { chi2 }(1)=9.75 \\
\text { Prob }>\text { chi2 }=0.0018\end{array}$ & $\begin{array}{c}\text { chi2 }(1)=9.21 \\
\text { Prob }>\text { chi2 }=0.0024\end{array}$ \\
\hline PFL = OUTROS & $\begin{array}{c}\text { chi2 }(1)=6.33 \\
\text { Prob }>\text { chi2 }=0.0119\end{array}$ & $\begin{array}{c}\text { chi2 }(1)=5.82 \\
\text { Prob }>\text { chi2 }=0.0159\end{array}$ \\
\hline $\mathrm{PFL}=\mathrm{PT}$ & $\begin{array}{c}\text { chi2 } 2(1)=0.59 \\
\text { Prob }>\text { chi2 }=0.4413\end{array}$ & $\begin{array}{c}\text { chi2 } 2(1)=0.86 \\
\text { Prob }>\text { chi2 }=0.3539\end{array}$ \\
\hline PTB = PSDB & $\begin{array}{c}\text { chi2 } 2(1)=0.76 \\
\text { Prob }>\text { chi2 }=0.3822\end{array}$ & $\begin{array}{c}\text { chi2 }(1)=2.23 \\
\text { Prob }>\text { chi2 }=0.1355\end{array}$ \\
\hline PTB = PDT & $\begin{array}{c}\text { chi2 } 2(1)=0.10 \\
\text { Prob }>\text { chi2 }=0.7467\end{array}$ & $\begin{array}{c}\text { chi2 } 2(1)=0.05 \\
\text { Prob }>\text { chi2 }=0.8189\end{array}$ \\
\hline $\mathrm{PTB}=\mathrm{PDS} / \mathrm{PPB}$ & $\begin{array}{c}\text { chi2 } 2(1)=0.00 \\
\text { Prob }>\text { chi2 }=0.9831\end{array}$ & $\begin{array}{c}\text { chi2 }(1)=0.01 \\
\text { Prob }>\text { chi2 }=0.9085\end{array}$ \\
\hline $\mathrm{PTB}=\mathrm{PL}$ & $\begin{array}{c}\text { chi2 } 2(1)=1.89 \\
\text { Prob }>\text { chi2 }=0.1693\end{array}$ & $\begin{array}{c}\text { chi2 } 2(1)=1.88 \\
\text { Prob }>\text { chi2 }=0.1706\end{array}$ \\
\hline PTB $=$ OUTROS & $\begin{aligned} \text { chi2 } 2(1) & =0.20 \\
\text { Prob }>\text { chi2 } & =0.6552\end{aligned}$ & $\begin{aligned} \text { chi2 } 2(1) & =0.20 \\
\text { Prob }>\text { chi2 } & =0.6539\end{aligned}$ \\
\hline $\mathrm{PTB}=\mathrm{PT}$ & $\begin{array}{c}\text { chi2 } 2(1)=0.04 \\
\text { Prob }>\text { chi2 }=0.8499\end{array}$ & $\begin{array}{c}\text { chi2 } 2(1)=0.00 \\
\text { Prob }>\text { chi2 }=0.9892\end{array}$ \\
\hline PSDB = PDT & $\begin{array}{c}\text { chi2 } 2(1)=0.33 \\
\text { Prob }>\text { chi2 }=0.5633\end{array}$ & $\begin{array}{c}\text { chi2 } 2(1)=1.77 \\
\text { Prob }>\text { chi2 }=0.1829\end{array}$ \\
\hline $\mathrm{PSDB}=\mathrm{PDS} / \mathrm{PPB}$ & $\begin{array}{c}\text { chi2 } 2(1)=1.06 \\
\text { Prob }>\text { chi2 }=0.3039\end{array}$ & $\begin{array}{c}\text { chi2 }(1)=3.51 \\
\text { Prob }>\text { chi2 }=0.0609\end{array}$ \\
\hline$P S D B=P L$ & $\begin{array}{c}\text { chi2 }(1)=5.54 \\
\text { Prob }>\text { chi2 }=0.0185\end{array}$ & $\begin{array}{c}\text { chi2 }(1)=8.31 \\
\text { Prob }>\text { chi2 }=0.0040\end{array}$ \\
\hline PSDB = OUTROS & $\begin{array}{c}\text { chi2 } 2(1)=2.24 \\
\text { Prob }>\text { chi2 }=0.1343\end{array}$ & $\begin{array}{c}\text { chi2 }(1)=4.94 \\
\text { Prob }>\text { chi2 }=0.0262\end{array}$ \\
\hline $\mathrm{PSDB}=\mathrm{PT}$ & $\begin{array}{c}\text { chi2 } 2(1)=0.14 \\
\text { Prob }>\text { chi2 }=0.7103\end{array}$ & $\begin{array}{c}\text { chi2 } 2(1)=0.87 \\
\text { Prob }>\text { chi2 }=0.3507\end{array}$ \\
\hline $\mathrm{PDT}=\mathrm{PDS} / \mathrm{PPB}$ & $\begin{array}{c}\text { chi2 } 2(1)=0.16 \\
\text { Prob }>\text { chi2 }=0.6919\end{array}$ & $\begin{array}{c}\text { chi2 } 2(1)=0.15 \\
\text { Prob }>\text { chi2 }=0.6943\end{array}$ \\
\hline $\mathrm{PDT}=\mathrm{PL}$ & $\begin{array}{c}\text { chi2 }(1)=2.94 \\
\text { Prob }>\text { chi2 }=0.0861\end{array}$ & $\begin{array}{c}\text { chi2 }(1)=2.63 \\
\text { Prob }>\text { chi2 }=0.1048\end{array}$ \\
\hline PDT = OUTROS & $\begin{array}{c}\text { chi2 } 2(1)=0.68 \\
\text { Prob }>\text { chi2 }=0.4086\end{array}$ & $\begin{array}{c}\text { chi2 }(1)=0.53 \\
\text { Prob }>\text { chi2 }=0.4687\end{array}$ \\
\hline $\mathrm{PDT}=\mathrm{PT}$ & $\begin{aligned} \text { chi2 } 2(1) & =0.00 \\
\text { Prob }>\text { chi2 } & =0.9860\end{aligned}$ & $\begin{array}{c}\text { chi2 } 2(1)=0.02 \\
\text { Prob }>\text { chi2 }=0.8913\end{array}$ \\
\hline $\mathrm{PDS} / \mathrm{PPB}=\mathrm{PL}$ & $\begin{array}{c}\text { chi2 } 2(1)=2.17 \\
\text { Prob }>\text { chi2 }=0.1409\end{array}$ & $\begin{array}{c}\operatorname{chi} 2(1)=1.90 \\
\text { Prob }>\text { chi2 }=0.1681\end{array}$ \\
\hline PDS / PPB = OUTROS & $\begin{array}{c}\text { chi2 } 2(1)=0.24 \\
\text { Prob }>\text { chi2 }=0.6276\end{array}$ & $\begin{array}{c}\text { chi2 } 2(1)=0.15 \\
\text { Prob }>\text { chi2 }=0.7018\end{array}$ \\
\hline $\mathrm{PDS} / \mathrm{PPB}=\mathrm{PT}$ & $\begin{array}{c}\text { chi2 } 2(1)=0.05 \\
\text { Prob }>\text { chi2 }=0.8310\end{array}$ & $\begin{array}{c}\text { chi2 } 2(1)=0.01 \\
\text { Prob }>\text { chi2 }=0.9289\end{array}$ \\
\hline $\mathrm{PL}=$ OUTROS & $\begin{array}{c}\text { chi2 } 2(1)=1.13 \\
\text { Prob }>\text { chi2 }=0.2879\end{array}$ & $\begin{array}{c}\text { chi2 } 2(1)=1.10 \\
\text { Prob }>\text { chi2 }=0.2940\end{array}$ \\
\hline $\mathrm{PL}=\mathrm{PT}$ & $\begin{array}{c}\text { chi2 } 2(1)=1.29 \\
\text { Prob }>\text { chi2 }=0.2552\end{array}$ & $\begin{array}{c}\operatorname{chi} 2(1)=0.94 \\
\text { Prob }>\text { chi2 }=0.3317\end{array}$ \\
\hline OUTROS = PT & $\begin{aligned} \text { chi2 } 2(1) & =0.23 \\
\text { Prob }>\text { chi2 } & =0.6292\end{aligned}$ & $\begin{array}{c}\operatorname{chi} 2(1)=0.09 \\
\text { Prob }>\text { chi2 }=0.7601\end{array}$ \\
\hline
\end{tabular}


Apêndice 2.4-Testes de hipótese - estimações com despesa do ano eleitoral e despesa média dos anos não eleitorais - efeitos fixos

\begin{tabular}{|c|c|c|c|}
\hline Hipótese & Dummies de partido & $\begin{array}{c}\text { Interações com despesa do } \\
\text { ano eleitoral }\end{array}$ & $\begin{array}{c}\text { Interações com despesa } \\
\text { media dos anos não eleitorais }\end{array}$ \\
\hline $\mathrm{PFL}=\mathrm{PTB}$ & $\begin{array}{c}\text { chi2 }(1)=2.21 \\
\text { Prob }>\text { chi2 }=0.1368\end{array}$ & $\begin{array}{c}\text { chi2 }(1)=0.00 \\
\text { Prob }>\text { chi2 }=0.9645\end{array}$ & $\begin{array}{c}\text { chi2 }(1)=0.41 \\
\text { Prob }>\text { chi2 }=0.5217\end{array}$ \\
\hline $\mathrm{PFL}=\mathrm{PSDB}$ & $\begin{array}{c}\text { chi2 } 2(1)=0.73 \\
\text { Prob }>\text { chi2 }=0.3921\end{array}$ & $\begin{array}{c}\text { chi2 }(1)=1.47 \\
\text { Prob }>\text { chi2 }=0.2258\end{array}$ & $\begin{array}{c}\text { chi2 }(1)=1.73 \\
\text { Prob }>\text { chi2 }=0.1879\end{array}$ \\
\hline $\mathrm{PFL}=\mathrm{PDT}$ & $\begin{array}{c}\text { chi2 }(1)=1.48 \\
\text { Prob }>\text { chi2 }=0.2238\end{array}$ & $\begin{array}{c}\text { chi2 } 2(1)=0.66 \\
\text { Prob }>\text { chi2 }=0.4168\end{array}$ & $\begin{array}{c}\text { chi2 }(1)=0.10 \\
\text { Prob }>\text { chi2 }=0.7504\end{array}$ \\
\hline $\mathrm{PFL}=\mathrm{PDS} / \mathrm{PPB}$ & $\begin{array}{c}\text { chi2 }(1)=3.60 \\
\text { Prob }>\text { chi2 }=0.0577\end{array}$ & $\begin{array}{c}\text { chi2 } 2(1)=0.88 \\
\text { Prob }>\text { chi2 }=0.3476\end{array}$ & $\begin{array}{c}\text { chi2 } 2(1)=0.02 \\
\text { Prob }>\text { chi2 }=0.8835\end{array}$ \\
\hline$P F L=P L$ & $\begin{array}{c}\text { chi2 }(1)=10.63 \\
\text { Prob }>\text { chi2 }=0.0011\end{array}$ & $\begin{array}{c}\text { chi2 }(1)=1.92 \\
\text { Prob }>\text { chi2 }=0.1657\end{array}$ & $\begin{array}{c}\text { chi2 } 2(1)=0.06 \\
\text { Prob }>\text { chi2 }=0.8044\end{array}$ \\
\hline PFL $=$ OUTROS & $\begin{array}{c}\text { chi2 }(1)=6.04 \\
\text { Prob }>\text { chi2 }=0.0140\end{array}$ & $\begin{array}{c}\text { chi2 }(1)=3.77 \\
\text { Prob }>\text { chi2 }=0.0521\end{array}$ & $\begin{array}{c}\text { chi2 }(1)=7.30 \\
\text { Prob }>\text { chi2 }=0.0069\end{array}$ \\
\hline $\mathrm{PFL}=\mathrm{PT}$ & $\begin{array}{c}\text { chi2 }(1)=0.00 \\
\text { Prob }>\text { chi2 }=0.9889\end{array}$ & $\begin{array}{c}\text { chi2 }(1)=2.24 \\
\text { Prob }>\text { chi2 }=0.1341\end{array}$ & $\begin{array}{c}\text { chi2 }(1)=2.95 \\
\text { Prob }>\text { chi2 }=0.0859\end{array}$ \\
\hline $\mathrm{PTB}=\mathrm{PSDB}$ & $\begin{array}{c}\text { chi2 }(1)=0.40 \\
\text { Prob }>\text { chi2 }=0.5271\end{array}$ & $\begin{array}{c}\text { chi2 } 2(1)=0.86 \\
\text { Prob }>\text { chi2 }=0.3545\end{array}$ & $\begin{array}{c}\text { chi2 }(1)=2.31 \\
\text { Prob }>\text { chi2 }=0.1285\end{array}$ \\
\hline PTB = PDT & $\begin{array}{c}\text { chi2 }(1)=0.11 \\
\text { Prob }>\text { chi2 }=0.7386\end{array}$ & $\begin{array}{c}\text { chi2 } 2(1)=0.42 \\
\text { Prob }>\text { chi2 }=0.5160\end{array}$ & $\begin{array}{c}\text { chi2 }(1)=0.61 \\
\text { Prob }>\text { chi2 }=0.4367\end{array}$ \\
\hline PTB $=$ PDS $/$ PPB & $\begin{array}{c}\text { chi2 } 2(1)=0.00 \\
\text { Prob }>\text { chi2 }=0.9526\end{array}$ & $\begin{array}{c}\text { chi2 }(1)=0.51 \\
\text { Prob }>\text { chi2 }=0.4752\end{array}$ & $\begin{array}{c}\operatorname{chi} 2(1)=0.44 \\
\text { Prob }>\text { chi2 }=0.5063\end{array}$ \\
\hline $\mathrm{PTB}=\mathrm{PL}$ & $\begin{array}{c}\text { chi2 }(1)=2.45 \\
\text { Prob }>\text { chi2 }=0.1175\end{array}$ & $\begin{array}{c}\text { chi2 }(1)=1.41 \\
\text { Prob }>\text { chi2 }=0.2347\end{array}$ & $\begin{array}{c}\text { chi2 }(1)=0.41 \\
\text { Prob }>\text { chi2 }=0.5222\end{array}$ \\
\hline PTB $=$ OUTROS & $\begin{array}{c}\text { chi2 }(1)=0.26 \\
\text { Prob }>\text { chi2 }=0.6118\end{array}$ & $\begin{array}{c}\text { chi2 } 2(1)=2.23 \\
\text { Prob }>\text { chi2 }=0.1354\end{array}$ & $\begin{array}{c}\text { chi2 }(1)=2.98 \\
\text { Prob }>\text { chi2 }=0.0842\end{array}$ \\
\hline $\mathrm{PTB}=\mathrm{PT}$ & $\begin{array}{c}\text { chi2 }(1)=0.59 \\
\text { Prob }>\text { chi2 }=0.4438\end{array}$ & $\begin{array}{c}\text { chi2 }(1)=1.86 \\
\text { Prob }>\text { chi2 }=0.1725\end{array}$ & $\begin{array}{c}\text { chi2 }(1)=1.64 \\
\text { Prob }>\text { chi2 }=0.2001\end{array}$ \\
\hline PSDB = PDT & $\begin{array}{c}\text { chi2 } 2(1)=0.10 \\
\text { Prob }>\text { chi2 }=0.7517\end{array}$ & $\begin{array}{c}\text { chi2 } 2(1)=0.08 \\
\text { Prob }>\text { chi2 }=0.7765\end{array}$ & $\begin{array}{c}\text { chi2 }(1)=0.60 \\
\text { Prob }>\text { chi2 }=0.4376\end{array}$ \\
\hline $\mathrm{PSDB}=\mathrm{PDS} / \mathrm{PPB}$ & $\begin{array}{c}\text { chi2 } 2(1)=0.63 \\
\text { Prob }>\text { chi2 }=0.4278\end{array}$ & $\begin{array}{c}\text { chi2 } 2(1)=0.08 \\
\text { Prob }>\text { chi2 }=0.7798\end{array}$ & $\begin{array}{c}\text { chi2 }(1)=0.97 \\
\text { Prob }>\text { chi2 }=0.3245\end{array}$ \\
\hline $\mathrm{PSDB}=\mathrm{PL}$ & $\begin{array}{c}\text { chi2 }(1)=5.39 \\
\text { Prob }>\text { chi2 }=0.0202\end{array}$ & $\begin{array}{c}\operatorname{chi} 2(1)=0.22 \\
\text { Prob }>\text { chi2 }=0.6353\end{array}$ & $\begin{array}{c}\operatorname{chi} 2(1)=0.33 \\
\text { Prob }>\text { chi2 }=0.5651\end{array}$ \\
\hline PSDB = OUTROS & $\begin{array}{c}\text { chi2 } 2(1)=1.64 \\
\text { Prob }>\text { chi2 }=0.2008\end{array}$ & $\begin{array}{c}\text { chi2 }(1)=6.35 \\
\text { Prob }>\text { chi2 }=0.0118\end{array}$ & $\begin{array}{c}\text { chi2 }(1)=10.55 \\
\text { Prob }>\text { chi2 }=0.0012\end{array}$ \\
\hline $\mathrm{PSDB}=\mathrm{PT}$ & $\begin{array}{c}\text { chi2 } 2(1)=0.16 \\
\text { Prob }>\text { chi2 }=0.6885\end{array}$ & $\begin{array}{c}\text { chi2 }(1)=3.65 \\
\text { Prob }>\text { chi2 }=0.0560\end{array}$ & $\begin{array}{c}\text { chi2 }(1)=4.79 \\
\text { Prob }>\text { chi2 }=0.0286\end{array}$ \\
\hline $\mathrm{PDT}=\mathrm{PDS} / \mathrm{PPB}$ & $\begin{array}{c}\text { chi2 } 2(1)=0.21 \\
\text { Prob }>\text { chi2 }=0.6479\end{array}$ & $\begin{array}{c}\operatorname{chi} 2(1)=0.00 \\
\text { Prob }>\text { chi2 }=0.9792\end{array}$ & $\begin{array}{c}\operatorname{chi} 2(1)=0.02 \\
\text { Prob }>\text { chi2 }=0.8781\end{array}$ \\
\hline $\mathrm{PDT}=\mathrm{PL}$ & $\begin{array}{c}\text { chi2 }(1)=3.74 \\
\text { Prob }>\text { chi2 }=0.0531\end{array}$ & $\begin{array}{c}\text { chi2 } 2(1)=0.47 \\
\text { Prob }>\text { chi2 }=0.4923\end{array}$ & $\begin{array}{c}\operatorname{chi} 2(1)=0.00 \\
\text { Prob }>\text { chi2 }=0.9871\end{array}$ \\
\hline PDT = OUTROS & $\begin{array}{c}\text { chi2 }(1)=0.83 \\
\text { Prob }>\text { chi2 }=0.3632\end{array}$ & $\begin{array}{c}\text { chi2 }(1)=4.86 \\
\text { Prob }>\text { chi2 }=0.0275\end{array}$ & $\begin{array}{c}\text { chi2 }(1)=6.28 \\
\text { Prob }>\text { chi2 }=0.0122\end{array}$ \\
\hline $\mathrm{PDT}=\mathrm{PT}$ & $\begin{array}{c}\text { chi2 } 2(1)=0.34 \\
\text { Prob }>\text { chi2 }=0.5584\end{array}$ & $\begin{array}{c}\text { chi2 }(1)=3.13 \\
\text { Prob }>\text { chi2 }=0.0770\end{array}$ & $\begin{array}{c}\text { chi2 }(1)=3.10 \\
\text { Prob }>\text { chi2 }=0.0782\end{array}$ \\
\hline$P D S / P P B=P L$ & $\begin{array}{c}\text { chi2 }(1)=2.76 \\
\text { Prob }>\text { chi2 }=0.0969\end{array}$ & $\begin{array}{c}\text { chi2 }(1)=0.49 \\
\text { Prob }>\text { chi2 }=0.4821\end{array}$ & $\begin{array}{c}\text { chi2 }(1)=0.02 \\
\text { Prob }>\text { chi2 }=0.8910\end{array}$ \\
\hline PDS $/$ PPB = OUTROS & $\begin{array}{c}\text { chi2 } 2(1)=0.27 \\
\text { Prob }>\text { chi2 }=0.6056\end{array}$ & $\begin{array}{c}\text { chi2 }(1)=5.62 \\
\text { Prob }>\text { chi2 }=0.0178\end{array}$ & $\begin{array}{c}\text { chi2 }(1)=6.15 \\
\text { Prob }>\text { chi2 }=0.0132\end{array}$ \\
\hline $\mathrm{PDS} / \mathrm{PPB}=\mathrm{PT}$ & $\begin{array}{c}\text { chi2 }(1)=0.71 \\
\text { Prob }>\text { chi2 }=0.4004\end{array}$ & $\begin{array}{c}\text { chi2 }(1)=3.25 \\
\text { Prob }>\text { chi2 }=0.0712\end{array}$ & $\begin{array}{c}\text { chi2 }(1)=2.91 \\
\text { Prob }>\text { chi2 }=0.0882\end{array}$ \\
\hline $\mathrm{PL}=$ OUTROS & $\begin{array}{c}\text { chi2 } 2(1)=1.52 \\
\text { Prob }>\text { chi2 }=0.2178\end{array}$ & $\begin{array}{c}\text { chi2 }(1)=6.13 \\
\text { Prob }>\text { chi2 }=0.0133\end{array}$ & $\begin{array}{c}\text { chi2 }(1)=4.38 \\
\text { Prob }>\text { chi2 }=0.0364\end{array}$ \\
\hline$P L=P T$ & $\begin{array}{c}\text { chi2 }(1)=3.09 \\
\text { Prob }>\text { chi2 }=0.0787\end{array}$ & $\begin{array}{c}\text { chi2 }(1)=4.18 \\
\text { Prob }>\text { chi2 }=0.0409\end{array}$ & $\begin{array}{c}\text { chi2 }(1)=2.63 \\
\text { Prob }>\text { chi2 }=0.1050\end{array}$ \\
\hline OUTROS = PT & $\begin{array}{c}\text { chi2 }(1)=1.19 \\
\text { Prob }>\text { chi2 }=0.2755\end{array}$ & $\begin{array}{c}\text { chi2 } 2(1)=0.23 \\
\text { Prob }>\text { chi2 }=0.6294\end{array}$ & $\begin{array}{c}\text { chi2 }(1)=0.03 \\
\text { Prob }>\text { chi2 }=0.8588\end{array}$ \\
\hline
\end{tabular}




\section{Apêndice 3}

\section{Apêndice 3.1 - Definições contidas na portaria 089/97 do Ministério da Fazenda}

Receitas Correntes - são as receitas tributária, de contribuições, patrimonial, industrial, de serviços e outras e, ainda, as provenientes de recursos financeiros recebidos de outras pessoas de direito público ou privado, quando destinadas a atender despesas classificáveis em Despesas Correntes;

Receitas de Capital - são as provenientes da realização de recursos financeiros oriundos de constituição de dívidas, da conversão em espécie de bens e direitos, dos recursos recebidos de outras pessoas de direito público ou privado destinados a atender despesas classificáveis em Despesas de Capital e, ainda, o superávit do Orçamento Corrente;

Despesas Correntes - constituem o grupo de despesas, da administração pública, para manutenção e o funcionamento dos serviços públicos em geral, por meio da administração direta, ou da administração indireta;

Despesas de Capital - constituem o grupo de despesas da administração pública, direta ou indireta, deste último referente à parcela custeada majoritariamente com receitas do Estado ou Município, destinados a adquirir ou constituir bens de capital que contribuirão para a produção ou geração de novos bens ou serviços e integrarão o patrimônio público;

Resultado Primário - é igual as receitas arrecadadas (RA), excluídas as receitas financeiras (RF), as operações de crédito (OC) e as alienações de bens (AB), menos as despesas liquidadas (DL) e restos a pagar não processados (NP), excluídos os serviços (SV) encargos e amortizações - das dívidas mobiliária e contratual, interna e externa; isto é: Resultado Primário = RA - $(\mathrm{RF}+\mathrm{OC}+\mathrm{AB})-(\mathrm{DL}+\mathrm{NP}-\mathrm{SV})$;

Necessidade de Financiamento Líquida - corresponde à diferença entre o Resultado Primário e as despesas financeiras líquidas (encargos das dívidas mobiliária, contratual e flutuante, de origem interna e externa, menos as receitas financeiras);

Necessidade de Financiamento Bruta - é igual à Necessidade de Financiamento Líquida mais as amortizações das dívidas mobiliária, contratual e flutuante, de origem interna e externa, menos as alienações de bens (AB); 
Apêndice 3.2: Regressões do resultado primário-OLS

\begin{tabular}{|c|c|c|c|}
\hline $\begin{array}{c}\text { Coeficiente } \\
\text { (desvio-padrão) }\end{array}$ & $\begin{array}{l}\text { Positivo e } \\
\text { negativo }\end{array}$ & Positivo & Negativo \\
\hline Pessoal / Receitas & $\begin{array}{c}-337.680^{* * *} \\
(40.554)\end{array}$ & $\begin{array}{c}-286.259^{* * *} \\
(70.344)\end{array}$ & $\begin{array}{c}125.810^{* * *} \\
(46.129)\end{array}$ \\
\hline Tributária / Receitas & $\begin{array}{l}-122.464 \\
(76.376)\end{array}$ & $\begin{array}{c}85.461 \\
(148.287)\end{array}$ & $\begin{array}{c}87.014 \\
(66.751)\end{array}$ \\
\hline PDS / PPB & $\begin{array}{c}33.197^{* * *} \\
(12.300)\end{array}$ & $\begin{array}{c}21.469 \\
(14.792) \\
\end{array}$ & $\begin{array}{l}-24.682^{*} \\
(13.859) \\
\end{array}$ \\
\hline PDT & $\begin{array}{l}32.891^{* *} \\
(14.359)\end{array}$ & $\begin{array}{c}15.418 \\
(13.837)\end{array}$ & $\begin{array}{l}-26.855 \\
(17.857)\end{array}$ \\
\hline$P L$ & $\begin{array}{l}23.494^{*} \\
(12.746)\end{array}$ & $\begin{array}{c}12.888 \\
(14.418)\end{array}$ & $\begin{array}{c}-2.241 \\
(13.614)\end{array}$ \\
\hline PSDB & $\begin{array}{c}31.850^{* * *} \\
(9.838)\end{array}$ & $\begin{array}{l}-16.933 \\
(11.780)\end{array}$ & $\begin{array}{c}-56.239^{\star * *} \\
(12.147)\end{array}$ \\
\hline PFL & $\begin{array}{l}25.948^{\star *} \\
(10.718)\end{array}$ & $\begin{array}{c}15.199 \\
(10.253)\end{array}$ & $\begin{array}{l}-10.984 \\
(13.516)\end{array}$ \\
\hline PTB & $\begin{array}{c}5.854 \\
(11.105)\end{array}$ & $\begin{array}{l}-14.001 \\
(10.078)\end{array}$ & $\begin{array}{c}-4.499 \\
(14.354)\end{array}$ \\
\hline PT & $\begin{array}{c}57.657^{\star \star *} \\
(14.780)\end{array}$ & $\begin{array}{c}10.042 \\
(16.433)\end{array}$ & $\begin{array}{c}-63.488^{* * *} \\
(17.627)\end{array}$ \\
\hline OUTROS & $\begin{array}{l}-17.403 \\
(15.117)\end{array}$ & $\begin{array}{c}-1.896 \\
(10.549)\end{array}$ & $\begin{array}{c}16.877 \\
(21.100)\end{array}$ \\
\hline Frac. Câmara & $\begin{array}{c}121.681^{* * *} \\
(35.460)\end{array}$ & $\begin{array}{c}-7.038 \\
(48.424)\end{array}$ & $\begin{array}{l}-57.811^{*} \\
(33.049)\end{array}$ \\
\hline Frac. Executivo & $\begin{array}{c}-155.622^{* * *} \\
(36.747)\end{array}$ & $\begin{array}{l}-55.737 \\
(39.076)\end{array}$ & $\begin{array}{c}42.346 \\
(47.889)\end{array}$ \\
\hline Prefeito \& Governador & $\begin{array}{c}7.209 \\
(11.669)\end{array}$ & $\begin{array}{c}21.562 \\
(14.077)\end{array}$ & $\begin{array}{c}12.663 \\
(13.217)\end{array}$ \\
\hline Idosos & $\begin{array}{l}-3.740 \\
(3.542)\end{array}$ & $\begin{array}{c}-13.231^{* * *} \\
(3.280)\end{array}$ & $\begin{array}{c}-28.676^{\star * *} \\
(5.479)\end{array}$ \\
\hline Urbanização & $\begin{array}{l}-0.510^{* *} \\
(0.245)\end{array}$ & $\begin{array}{l}0.548^{*} \\
(0.289)\end{array}$ & $\begin{array}{l}0.564^{* *} \\
(0.273)\end{array}$ \\
\hline Jovens & $\begin{array}{c}-6.756^{* * *} \\
(1.452)\end{array}$ & $\begin{array}{c}-3.695^{\star * *} \\
(1.418)\end{array}$ & $\begin{array}{c}-5.972^{* * *} \\
(2.297)\end{array}$ \\
\hline População & $\begin{array}{l}-0.825 \\
(4.515)\end{array}$ & $\begin{array}{c}-18.713^{* * *} \\
(7.297)\end{array}$ & $\begin{array}{c}-13.249^{* * *} \\
(4.337)\end{array}$ \\
\hline Constante & $\begin{array}{c}402.591^{* * *} \\
(86.520)\end{array}$ & $\begin{array}{c}545.658^{* * *} \\
(140.134)\end{array}$ & $\begin{array}{r}493.982^{* * *} \\
(105.936)\end{array}$ \\
\hline $\mathrm{R}^{2}$ & 0,1043 & 0,0924 & 0,0721 \\
\hline Observações & 2828 & 1235 & 1593 \\
\hline
\end{tabular}


Apêndice 3.3: Regressões do resultado primário - efeitos aleatórios

\begin{tabular}{|c|c|c|c|}
\hline $\begin{array}{c}\text { Coeficiente } \\
\text { (desvio-padrão) }\end{array}$ & $\begin{array}{c}\text { Positivo e } \\
\text { negativo }\end{array}$ & Positivo & Negativo \\
\hline Pessoal / Receitas & $\begin{array}{c}-377.723^{\star * *} \\
(30.245)\end{array}$ & $\begin{array}{c}-287.496^{* * *} \\
(37.032)\end{array}$ & $\begin{array}{c}153.616^{* * *} \\
(33.113)\end{array}$ \\
\hline Tributária / Receitas & $\begin{array}{c}-182.684^{* * *} \\
(47.323)\end{array}$ & $\begin{array}{l}84.670^{*} \\
(49.135)\end{array}$ & $\begin{array}{c}128.185^{\star *} \\
(56.904)\end{array}$ \\
\hline PDS / PPB & $\begin{array}{l}29.611^{* *} \\
(13.038)\end{array}$ & $\begin{array}{c}21.051 \\
(13.437)\end{array}$ & $\begin{array}{l}-27.042^{*} \\
(15.459)\end{array}$ \\
\hline PDT & $\begin{array}{c}22.066 \\
(17.460)\end{array}$ & $\begin{array}{c}15.598 \\
(18.898)\end{array}$ & $\begin{array}{l}-13.349 \\
(19.427)\end{array}$ \\
\hline $\mathrm{PL}$ & $\begin{array}{l}29.359^{*} \\
(15.488)\end{array}$ & $\begin{array}{c}12.849 \\
(16.844)\end{array}$ & $\begin{array}{l}-10.913 \\
(17.567)\end{array}$ \\
\hline PSDB & $\begin{array}{l}19.761^{*} \\
(11.118)\end{array}$ & $\begin{array}{l}-16.921 \\
(12.237)\end{array}$ & $\begin{array}{c}-37.113^{* * *} \\
(12.846)\end{array}$ \\
\hline PFL & $\begin{array}{c}18.307^{*} \\
(11.143)\end{array}$ & $\begin{array}{c}15.004 \\
(11.665)\end{array}$ & $\begin{array}{c}-2.131 \\
(12.906)\end{array}$ \\
\hline РTB & $\begin{array}{c}7.341 \\
(12.734)\end{array}$ & $\begin{array}{l}-13.943 \\
(13.721)\end{array}$ & $\begin{array}{c}-4.989 \\
(14.282)\end{array}$ \\
\hline PT & $\begin{array}{l}46.007^{* *} \\
(19.625)\end{array}$ & $\begin{array}{c}9.824 \\
(20.416)\end{array}$ & $\begin{array}{l}-42.774^{*} \\
(22.294)\end{array}$ \\
\hline OUTROS & $\begin{array}{l}-18.427 \\
(12.607)\end{array}$ & $\begin{array}{c}-1.853 \\
(13.908)\end{array}$ & $\begin{array}{c}14.425 \\
(13.992)\end{array}$ \\
\hline Frac. Câmara & $\begin{array}{c}142.337^{* * *} \\
(33.931)\end{array}$ & $\begin{array}{c}-6.754 \\
(34.275)\end{array}$ & $\begin{array}{c}-100.321^{* *} \\
(40.457)\end{array}$ \\
\hline Frac. Executivo & $\begin{array}{c}-182.358^{* * *} \\
(38.153)\end{array}$ & $\begin{array}{l}-55.038 \\
(38.835)\end{array}$ & $\begin{array}{c}104.172^{* *} \\
(45.381)\end{array}$ \\
\hline $\begin{array}{c}\text { Prefeito \& } \\
\text { Governador }\end{array}$ & $\begin{array}{c}11.901 \\
(10.224)\end{array}$ & $\begin{array}{l}21.544^{*} \\
(12.540)\end{array}$ & $\begin{array}{c}8.570 \\
(10.520)\end{array}$ \\
\hline Idosos & $\begin{array}{c}-9.536^{* * *} \\
(3.539)\end{array}$ & $\begin{array}{c}-13.132^{* * *} \\
(3.247)\end{array}$ & $\begin{array}{c}-15.120^{* * *} \\
(4.952)\end{array}$ \\
\hline Urbanização & $\begin{array}{l}-0.400 \\
(0.339)\end{array}$ & $\begin{array}{l}0.548^{*} \\
(0.301)\end{array}$ & $\begin{array}{c}0.642 \\
(0.451)\end{array}$ \\
\hline Jovens & $\begin{array}{c}-9.820^{\star \star \star} \\
(1.467)\end{array}$ & $\begin{array}{c}-3.677^{\star \star *} \\
(1.366)\end{array}$ & $\begin{array}{l}-0.320 \\
(2.036)\end{array}$ \\
\hline População & $\begin{array}{c}0.291 \\
(4.693)\end{array}$ & $\begin{array}{c}-18.697^{\star * *} \\
(4.130)\end{array}$ & $\begin{array}{c}-16.037^{* *} \\
(6.394)\end{array}$ \\
\hline Constante & $\begin{array}{c}538.114^{\star \star \star *} \\
(81.600)\end{array}$ & $\begin{array}{c}544.343^{* \star \star} \\
(76.511)\end{array}$ & $\begin{array}{l}230.434^{\star *} \\
(113.971)\end{array}$ \\
\hline $\mathrm{R}^{2}$ & 0,1015 & 0,0924 & 0,0593 \\
\hline Observações & 2828 & 1235 & 1593 \\
\hline
\end{tabular}


Apêndice 3.4 - Resultados dos probits (1989 - 2001), conforme Wooldridge (1995)

1989

probit crit_sup dpess_rcorr rtrib_rcorr pdsppb pdt pl psdb pfl ptb pt outros ver_frac pref_frac simil_gov prop_65m prop_urb prop 0014 lpoptot m0_dpess_rcorr m0_-̌rtrib_rcor $\bar{r}$ m0_pdsppb m0_pdt m0_pl m0_psdb m0_pfi m0_ptb m0_pt m0_outros m0_ver_férac m0_pref_frac m0_simil_gov m0_prop_65m m0_prop_urb m0_prop_o014 mo-lpoptot if àno==-1989, rōb

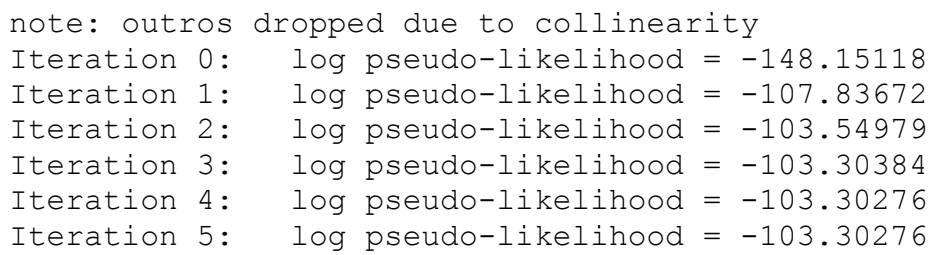

Probit estimates

\begin{tabular}{|c|c|c|c|c|c|c|c|}
\hline crit_sup & 1 & Coef & $\begin{array}{l}\text { Robust } \\
\text { Std Err }\end{array}$ & $\mathrm{z}$ & $\mathrm{P}>|\mathrm{z}|$ & {$[95 \%$} & ConfInterva \\
\hline dpess_rcorr & I & -8.982555 & 1.590181 & -5.65 & 0.000 & -12.09925 & -5.865857 \\
\hline rtrib_rcorr & | & -5.942455 & 3.121595 & -1.90 & 0.057 & -12.06067 & .1757589 \\
\hline$\overline{\mathrm{p}} \mathrm{d}$ sppb & 1 & .3780886 & .8929763 & 0.42 & 0.672 & -1.372113 & 2.12829 \\
\hline $\mathrm{pdt}$ & | & -2.16189 & 1.115302 & -1.94 & 0.053 & -4.347842 & .0240623 \\
\hline $\mathrm{pl}$ & | & .1045107 & .8811712 & 0.12 & 0.906 & -1.622553 & 1.831575 \\
\hline psdb & | & -.5199662 & .9739966 & -0.53 & 0.593 & -2.428964 & 1.389032 \\
\hline $\mathrm{pfl}$ & | & -.4042446 & .8054265 & -0.50 & 0.616 & -1.982851 & 1.174362 \\
\hline ptb & | & -.3552035 & .8755398 & -0.41 & 0.685 & -2.07123 & 1.360823 \\
\hline pt & 1 & .1041776 & 1.017502 & 0.10 & 0.918 & -1.89009 & 2.098445 \\
\hline ver frac & 1 & -2.172366 & 2.04559 & -1.06 & 0.288 & -6.181648 & 1.836916 \\
\hline pref_frac & | & 1.745713 & 2.246765 & 0.78 & 0.437 & -2.657864 & 6.149291 \\
\hline simil_gov & i & .8885186 & .8139073 & 1.09 & 0.275 & -.7067104 & 2.483748 \\
\hline prop_65m & 1 & -.7332832 & .3450222 & -2.13 & 0.034 & -1.409514 & -.0570521 \\
\hline prop_urb & | & .1120638 & .0335691 & 3.34 & 0.001 & .0462697 & .177858 \\
\hline prop_ono14 & i & -.2122305 & .1071623 & -1.98 & 0.048 & -.4222647 & -.0021963 \\
\hline lpoptot & i & 1.768444 & 1.474376 & 1.20 & 0.230 & -1.121279 & 4.658168 \\
\hline m0_dpess_r e & 1 & 5.416685 & 2.19617 & 2.47 & 0.014 & 1.112271 & 9.7211 \\
\hline $\mathrm{mo}^{-}$rtrib_r r & i & 4.786346 & 2.95601 & 1.62 & 0.105 & -1.007328 & 10.58002 \\
\hline m0_pdēsppb & | & -.7682238 & 1.004991 & -0.76 & 0.445 & -2.73797 & 1.201522 \\
\hline mo_pdt & 1 & 2.182619 & 1.48456 & 1.47 & 0.142 & -.7270646 & 5.092303 \\
\hline $\mathrm{m} \overline{0} \_\mathrm{pl}$ & i & -1.232623 & 1.170118 & -1.05 & 0.292 & -3.526012 & 1.060766 \\
\hline m0_ps $\bar{s}^{2} \mathrm{~b}$ & | & 1.698507 & .7419542 & 2.29 & 0.022 & .244303 & 3.15271 \\
\hline $\mathrm{m} \overline{0}_{-} \mathrm{pfl}$ & i & -.103779 & .8058042 & -0.13 & 0.898 & -1.683126 & 1.475568 \\
\hline mo_ptb & | & -.0690372 & 1.169322 & -0.06 & 0.953 & -2.360865 & 2.222791 \\
\hline $\mathrm{m} \overline{0} \_\mathrm{pt}$ & 1 & .317277 & 1.499212 & 0.21 & 0.832 & -2.621125 & 3.255679 \\
\hline mo_outros & i & -1.135651 & .8630079 & $-1 \cdot 32$ & 0.188 & -2.827116 & .555813 \\
\hline mo_vèr_frac & 1 & 4.216977 & 2.725731 & 1.55 & 0.122 & -1.125356 & 9.559311 \\
\hline mo_pref_frac & i & -2.153962 & 2.583704 & -0.83 & 0.404 & -7.217929 & 2.910005 \\
\hline mo_simil_gov & | & -1.917639 & .9659036 & -1.99 & 0.047 & -3.810776 & -.0245031 \\
\hline $\mathrm{m} \overline{0} \_$prop_65m & i & .5968037 & .3409003 & 1.75 & 0.080 & -.0713485 & 1.264956 \\
\hline m0_prop_urb & . & -.1367493 & .0388392 & -3.52 & 0.000 & -.2128729 & -.0606258 \\
\hline m0_prop_ō014 & | & .228234 & .1122766 & 2.03 & 0.042 & .008176 & .448292 \\
\hline m0_lpoptot & 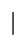 & -1.745107 & 1.512914 & -1.15 & 0.249 & -4.710364 & 1.22015 \\
\hline _cons & & 3.56361 & 3.614776 & 0.99 & 0.324 & -3.521221 & 10.64844 \\
\hline
\end{tabular}


1990

probit crit_sup dpess_rcorr rtrib_rcorr pdsppb pdt pl psdb pfl ptb pt outros ver_frac pref_frac simil_gov prop_65m prop_urb prop_0014 lpoptot m0_dpess_rcorr m0_rtrib_rcorr m0_pdsppb m0_pdt m0_pl m0_ps db m0_pfī m0_ptb m0_pt m0_outros m0_ver_frac m0_pref_frac m0_simil_gov m0_prop_65m m0_prop_urb m0_prop_o0014 mo-lpoptot if ano== 1990 , rob

note: outros $!=0$ predicts failure perfectly outros dropped and 7 obs not used

note: pt dropped due to collinearity

Iteration 0: $\quad \log$ pseudo-likelihood $=-113.0127$

Iteration 1: $\quad \log$ pseudo-likelihood $=-89.452344$

Iteration 2: $\quad$ og pseudo-likelihood $=-87.617938$

Iteration 3: $\quad \log$ pseudo-likelihood $=-87.565882$

Iteration 4: $\quad \log$ pseudo-likelihood $=-87.565816$

Probit estimates

Number of obs $=206$

Wald chi2(32) $=50.55$

Prob $>$ chi2 $=0.0197$

Log pseudo-likelihood $=-87.565816$

Pseudo R2 = 0.2252

\begin{tabular}{|c|c|c|c|c|c|c|c|}
\hline crit_sup & $\begin{array}{l}1 \\
1\end{array}$ & Coef & $\begin{array}{l}\text { Robust } \\
\text { Std Err }\end{array}$ & $\mathrm{z}$ & $P>|z|$ & {$[95 \%$} & ConfInterv \\
\hline dpess rcorr & 1 & -6.334886 & 1.88409 & -3.36 & 0.001 & -10.02763 & -2.642136 \\
\hline rtrib rcorr & 1 & -1.964562 & 3.054232 & -0.64 & 0.520 & -7.950747 & 4.021623 \\
\hline$\overline{\mathrm{p}} \mathrm{d}$ sppb & 1 & -1.852889 & .9664073 & -1.92 & 0.055 & -3.747012 & .0412348 \\
\hline pdt & | & -2.202805 & .9312483 & -2.37 & 0.018 & -4.028018 & -.3775917 \\
\hline pl & | & -.4227853 & .8936378 & -0.47 & 0.636 & -2.174283 & 1.328713 \\
\hline psdb & | & -2.944395 & 1.159137 & -2.54 & 0.01 & -5.216261 & -.6725283 \\
\hline$p f l$ & | & -2.46491 & .9466364 & -2.60 & 0.009 & -4.320283 & -.6095364 \\
\hline ptb & | & -1.881859 & .7903136 & -2.38 & 0.017 & -3.430845 & -.3328726 \\
\hline ver frac & 1 & 1.108346 & 2.066789 & 0.54 & 0.592 & -2.942485 & 5.159178 \\
\hline pref frac & | & -1.481179 & 2.601932 & -0.57 & 0.569 & -6.580873 & 3.618514 \\
\hline simī gov & | & -1.859931 & .8817161 & -2.11 & 0.0 & -3.588063 & -.1317994 \\
\hline prop $65 \mathrm{~m}$ & | & -.2905372 & .4519148 & -0.64 & 0.5 & -1.176274 & .5951995 \\
\hline prop_urb & | & .0120881 & .0302663 & 0.40 & 0.6 & -.0472328 & 409 \\
\hline prop_ō014 & | & -.3358852 & .1494662 & -2.25 & 0.0 & -.6288336 & -.0429368 \\
\hline lpoptot & | & -3.372686 & 2.090519 & -1.61 & 0.1 & -7.470028 & 554 \\
\hline m0 dpess r e & | & 4.715547 & 2.255451 & 2.09 & 0.0 & .2949434 & 3615 \\
\hline mortrib r r & | & 1.748473 & 3.252976 & 0.54 & 0.5 & -4.627243 & 8.124189 \\
\hline m0_pdsppb & | & -1.637913 & .9723717 & -1.68 & 0.0 & -3.543726 & 008 \\
\hline mo pdt & | & -2.47551 & 1.123096 & -2.20 & 0. & -4.676736 & -.2742827 \\
\hline $\mathrm{m} \overline{0} \mathrm{pl}$ & | & -4.649617 & 1.494183 & -3.11 & 0.0 & -7.578161 & -1.721072 \\
\hline m0_ps db & | & .9261679 & .9224899 & 1.00 & 0.3. & -.881879 & 2.734215 \\
\hline $\mathrm{m} \overline{0} \mathrm{pfl}$ & | & -1.417471 & .9549685 & -1.48 & 0.1 & -3.289175 & .4542326 \\
\hline mo ptb & | & -2.3725 & 1.122159 & -2.11 & 0.0 & -4.571891 & -.1731081 \\
\hline $\mathrm{m} \overline{0} \mathrm{pt}$ & | & -3.442897 & 1.314326 & -2.62 & 0. & -6.018928 & -.8668653 \\
\hline mo_outros & | & -.5642547 & .8604433 & -0.66 & 0.5 & -2.250692 & 1.122183 \\
\hline mo ver frac & | & -3.197279 & 2.64 & -1.21 & $0.2+2 \cdot x$ & -8.377851 & 1.983294 \\
\hline m0_pref_frac & | & 3.758511 & 3.227246 & 1.16 & 0.2 & -2.566774 & 10.0838 \\
\hline mo simil gov & | & -3.040209 & 1.059886 & -2.87 & 0.0 & -5.117547 & -.9628717 \\
\hline $\mathrm{m} \overline{0}$ prop_65m & | & .1412631 & .4672507 & 0.30 & 0.7 & -.7745314 & 1.057058 \\
\hline mo prop urb & | & -.0130039 & .0327487 & -0.40 & 0.6 & -.0771903 & .0511824 \\
\hline m0_prop_ō014 & | & .3144307 & .160098 & 1.96 & 0.050 & .0006444 & .628217 \\
\hline m0_lpoptot & | & 3.030475 & 2.105064 & 1.44 & 0.1 & -1.095374 & 7.156324 \\
\hline cons & & 8.939081 & 4.097641 & 2.18 & 0.029 & .9078521 & 16.97031 \\
\hline
\end{tabular}


1991

probit crit_sup dpess_rcorr rtrib_rcorr pdsppb pdt pl psdb pfl ptb pt outros ver_frac pref_frac simil_gov prop_65m prop_urb prop_0014 lpoptot m0_dpess_rcorr

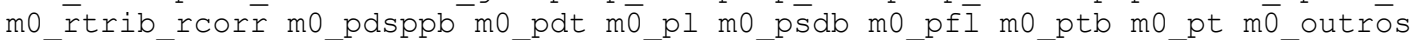
m0_ver_frac m0_pref_frac m0_simil_gov m0_prop_65m m0_prop_urb m0_prop_o0014 mo-lpoptot if ano== 1991 , rob

note: pdt $!=0$ predicts failure perfectly pdt dropped and 10 obs not used

note: psdb dropped due to collinearity

Iteration 0: log pseudo-likelihood $=-101.09309$

Iteration 1: $\quad \log$ pseudo-likelihood $=-79.674106$

Iteration 2: $\quad \log$ pseudo-likelihood $=-77.99697$

Iteration 3: $\quad \log$ pseudo-likelihood $=-77.937094$

Iteration 4: $\quad \log$ pseudo-likelihood $=-77.936899$

Iteration 5: $\quad \log$ pseudo-likelihood $=-77.936899$

Probit estimates

Number of obs $=188$

Wald chi2(32) $=54.53$

Prob $>$ chi2 $=0.0078$

Log pseudo-likelihood $=-77.936899$

Pseudo $\mathrm{R} 2 \quad=$

0.2291

\begin{tabular}{|c|c|c|c|c|c|c|c|}
\hline crit_sup & ! & Coef & $\begin{array}{l}\text { Robust } \\
\text { Std Err }\end{array}$ & $\mathrm{z}$ & $P>|z|$ & {$[95 \%$} & ConfInterva \\
\hline dpess rcorr & | & -4.58407 & 1.628108 & -2.82 & 0.005 & -7.775102 & -1.393038 \\
\hline rtrib_rcorr & | & .3096718 & 3.6659 & 0.08 & 0.933 & -6.875361 & 7.494704 \\
\hline$\overline{\mathrm{p}} \mathrm{dsppb}$ & | & .9815565 & .9766215 & 1.01 & 0.315 & -.9325864 & 2.895699 \\
\hline $\mathrm{pl}$ & 1 & 1.390094 & 1.014229 & 1.37 & 0.171 & -.5977592 & 3.377947 \\
\hline pfl & | & .4036836 & .8800696 & 0.46 & 0.646 & -1.321221 & 2.128588 \\
\hline ptb & 1 & .6521678 & .9464864 & 0.69 & 0.491 & -1.202911 & 2.507247 \\
\hline pt & 1 & .2793935 & 1.131557 & 0.25 & 0.805 & -1.938417 & 2.497204 \\
\hline outros & 1 & -.0383595 & 1.015941 & -0.04 & 0.970 & -2.029568 & 1.952848 \\
\hline ver_frac & 1 & 4.316722 & 2.202059 & 1.96 & 0.050 & .0007656 & 8.632678 \\
\hline pref-frac & 1 & 1.985588 & 2.28683 & 0.87 & 0.385 & -2.496517 & 6.467692 \\
\hline simil gov & 1 & 1.132866 & .9600509 & 1.18 & 0.238 & -.7487996 & 3.014531 \\
\hline prop_65m & 1 & .5478969 & .5956414 & 0.92 & 0.358 & -.6195387 & 1.715333 \\
\hline prop_urb & 1 & .138848 & .0603729 & 2.30 & 0.021 & .0205192 & .2571768 \\
\hline prop $\overline{0} 014$ & | & -.2413091 & .1676465 & -1.44 & 0.150 & -.5698902 & .0872719 \\
\hline lpoptot & 1 & 1.400633 & 2.917004 & 0.48 & 0.631 & -4.31659 & 7.117855 \\
\hline m0 dpess r e & 1 & 6.341647 & 2.617696 & 2.42 & 0.015 & 1.211058 & 11.47224 \\
\hline $\mathrm{mo}^{-}$rtrib $r \sim r$ & 1 & -5.573541 & 5.047093 & -1.10 & 0.269 & -15.46566 & 4.318579 \\
\hline${ }^{-}$m0_pdēspb & 1 & -1.567515 & 1.229005 & -1.28 & 0.202 & -3.97632 & .8412894 \\
\hline mo pdt & 1 & 1.608161 & 1.914762 & 0.84 & 0.401 & -2.144703 & 5.361026 \\
\hline $\mathrm{m}^{+} \mathrm{pl}$ & 1 & -1.811636 & 1.602002 & -1.13 & 0.258 & -4.951502 & 1.328229 \\
\hline mo ps $\bar{d} d b$ & 1 & 2.972241 & .9448338 & 3.15 & 0.002 & 1.120401 & 4.824081 \\
\hline $\mathrm{m}^{1} \mathrm{pfl}$ & 1 & -.6550001 & .9282692 & -0.71 & 0.480 & -2.474374 & 1.164374 \\
\hline mo ptb & 1 & -.6586961 & 1.142315 & -0.58 & 0.564 & -2.897593 & 1.580201 \\
\hline $\mathrm{m} \overline{0}^{+} \mathrm{pt}$ & 1 & -.7590749 & 1.629338 & -0.47 & 0.641 & -3.952519 & 2.434369 \\
\hline mo outros & i & -.279119 & .9893061 & -0.28 & 0.778 & -2.218123 & 1.659885 \\
\hline mo ver frac & i & -1.144894 & 2.72749 & -0.42 & 0.675 & -6.490675 & 4.200887 \\
\hline mo_preffrac & 1 & -5.026787 & 2.940521 & -1.71 & 0.087 & -10.7901 & .7365274 \\
\hline m0_simī__gov & i & -1.360193 & 1.038368 & -1.31 & 0.190 & -3.395357 & .6749706 \\
\hline $\mathrm{m} \overline{0}$ prop $65 \mathrm{~m}$ & 1 & -.7748547 & .6164605 & -1.26 & 0.209 & -1.983095 & .4333856 \\
\hline mo prop urb & 1 & -.1493226 & .0621453 & -2.40 & 0.016 & -.2711251 & -.02752 \\
\hline m0_prop_o014 & 1 & .1740587 & .1784069 & 0.98 & 0.329 & -.1756124 & .5237299 \\
\hline m0 lpoptot & 1 & -1.308397 & 2.950769 & -0.44 & 0.657 & -7.091798 & 4.475003 \\
\hline cons & I & 2.483101 & 3.842002 & 0.65 & 0.518 & -5.047084 & 10.01329 \\
\hline
\end{tabular}


1992

probit crit sup dpess rcorr rtrib rcorr pdsppb pdt pl psdb pfl ptb pt outros ver_frac pref_frac simil_gov prop_65m prop_urb prop_0014 lpoptot m0_dpess_rcorr

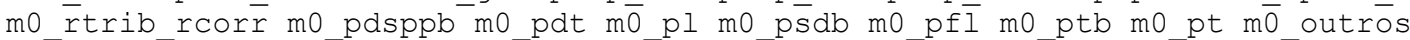
m0_ver_frac m0_pref_frac m0_simil_gov m0_prop_65m m0_prop_urb m0_prop_o_0014 mo-lpoptot if ano== 1992 , rob

note: psdb $!=0$ predicts failure perfectly psdb dropped and 3 obs not used

note: outros $!=0$ predicts failure perfectly outros dropped and 6 obs not used

note: pt dropped due to collinearity

Iteration 0: log pseudo-likelihood $=-56.775252$

Iteration 1: $\quad \log$ pseudo-likelihood $=-40.754285$

Iteration 2: log pseudo-likelihood $=-38.165277$

Iteration 3: $\log$ pseudo-likelihood $=-37.589588$

Iteration 4: $\quad$ log pseudo-likelihood $=-37.538761$

Iteration 5: $\quad \log$ pseudo-likelihood $=-37.538115$

Iteration 6: $\log$ pseudo-likelihood $=-37.538115$

Probit estimates

Number of obs = Wald chi2 (31)

185

Prob > chi2

60.03

Log pseudo-likelihood $=-37.538115$

Pseudo R2

$\begin{array}{ll}= & 0.0013 \\ = & 0.3388\end{array}$

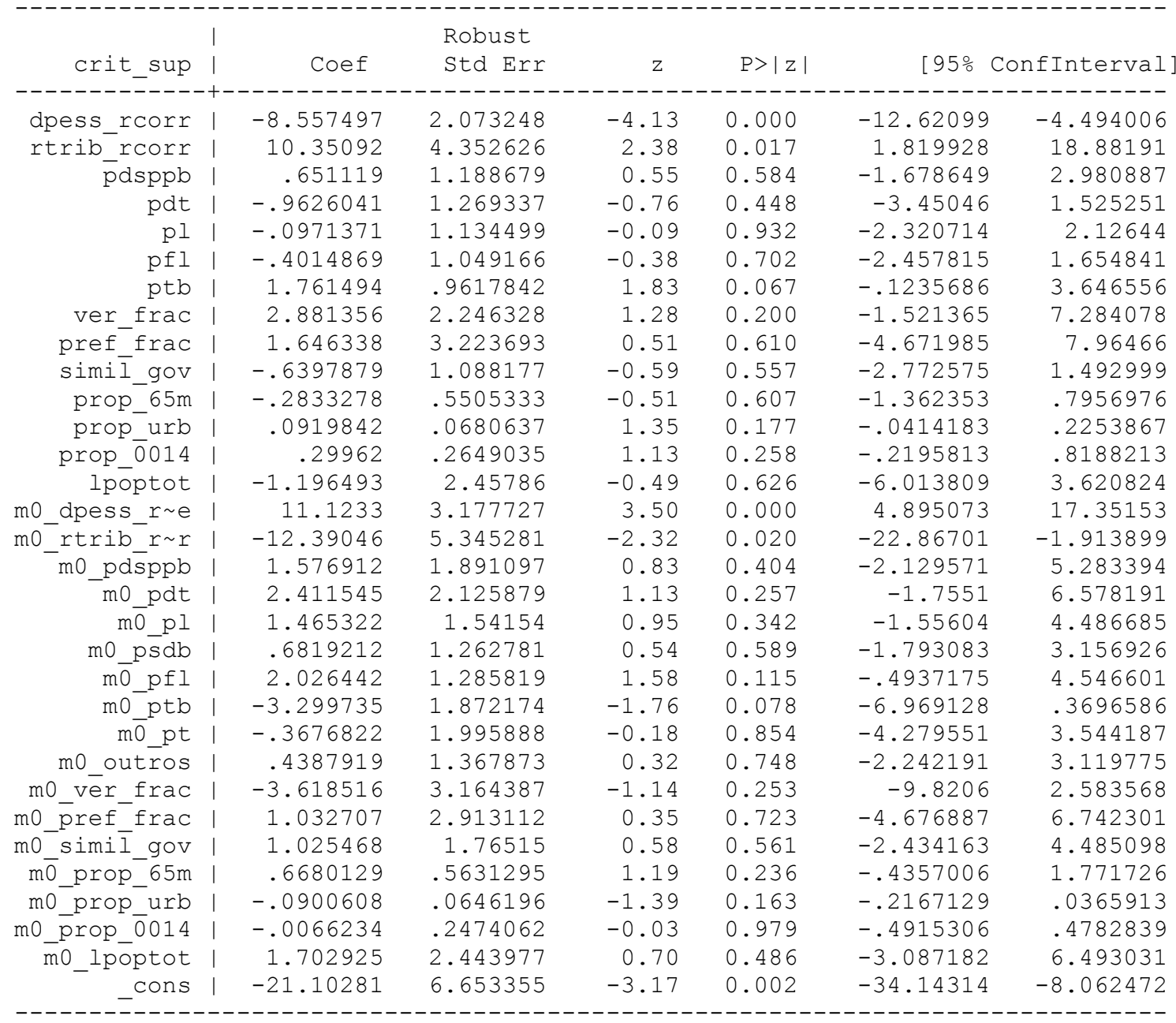


1993

probit crit_sup dpess_rcorr rtrib_rcorr pdsppb pdt pl psdb pfl ptb pt outros ver_frac pref_frac simil_gov prop_65m prop_urb prop_0014 lpoptot m0_dpess_rcorr m0_rtrib_rcorr m0_pdsppb m0_pdt m0_pl m0_ps db m0_pfī m0_ptb m0_pt m0_outros m0_ver_frac m0_pref_frac m0_simil_gov m0_prop_65m m0_prop_urb m0_prop_o0014 mo_lpoptot if $\overline{\text { ano }}==-1993$, rob

note: pdt $!=0$ predicts failure perfectly pdt dropped and 1 obs not used

note: pt dropped due to collinearity

Iteration 0: $\quad \log$ pseudo-likelihood $=-137.51136$

Iteration 1: $\quad \log$ pseudo-likelihood $=-93.014571$

Iteration 2: $\quad \log$ pseudo-likelihood $=-79.164138$

Iteration 3: $\quad \log$ pseudo-likelihood $=-75.649653$

Iteration 4: $\quad \log$ pseudo-likelihood $=-75.373097$

Iteration 5: log pseudo-likelihood $=-75.370929$

Iteration 6: $\quad \log$ pseudo-likelihood $=-75.370929$

Probit estimates

Number of obs $=199$

Wald chi2(32) $=83.17$

Prob $>$ chi2 $=0.0000$

Log pseudo-likelihood $=-75.370929$

Pseudo R2 = 0.4519

\begin{tabular}{|c|c|c|c|c|c|c|c|}
\hline \multirow{2}{*}{ crit_sup } & \multicolumn{2}{|l|}{ | } & \multicolumn{2}{|l|}{ Robust } & \multirow[b]{2}{*}{$P>|z|$} & \multirow[b]{2}{*}{$95 \%$} & \multirow[b]{2}{*}{ ConfInterval] } \\
\hline & & Coef & Std Err & z & & & \\
\hline dpess rcorr & 1 & -16.57048 & 2.990343 & -5.54 & 0.000 & -22.43144 & -10.70952 \\
\hline rtrib rcorr & i & -11.73791 & 3.835642 & -3.06 & 0.002 & -19.25563 & -4.220188 \\
\hline$\overline{\mathrm{p}} \mathrm{d}$ sppb & i & -1.884475 & 1.279294 & -1.47 & 0.141 & -4.391845 & .6228959 \\
\hline $\mathrm{pl}$ & | & .7393111 & 1.588695 & 0.47 & 0.642 & -2.374474 & 3.853097 \\
\hline psdb & 1 & -1.580735 & 1.23115 & -1.28 & 0.199 & -3.993745 & .8322746 \\
\hline $\mathrm{pfl}$ & 1 & .8041677 & 1.251091 & 0.64 & 0.520 & -1.647925 & 3.25626 \\
\hline ptb & | & -.451504 & 1.292875 & -0.35 & 0.727 & -2.985492 & 2.082484 \\
\hline outros & I & -.5085468 & 1.217079 & -0.42 & 0.676 & -2.893977 & 1.876884 \\
\hline ver frac & 1 & -2.606316 & 2.175225 & -1.20 & 0.231 & -6.869679 & 1.657047 \\
\hline pref_frac & i & 3.989593 & 2.289179 & 1.74 & 0.081 & -.4971153 & 8.476301 \\
\hline simī_gov & | & -.2291961 & 1.160567 & -0.20 & 0.843 & -2.503866 & 2.045473 \\
\hline prop $65 \mathrm{~m}$ & 1 & -.6479915 & .7783066 & -0.83 & 0.405 & -2.173444 & .8774614 \\
\hline prop urb & | & -.0328618 & .0563719 & -0.58 & 0.560 & -.1433486 & .0776251 \\
\hline prop $\overline{0} 014$ & I & -.2981701 & .220808 & -1.35 & 0.177 & -.7309458 & .1346056 \\
\hline lpoptot & 1 & -2.496073 & 3.215478 & -0.78 & 0.438 & -8.798294 & 149 \\
\hline m0 dpess r e & 1 & 13.18553 & 3.761757 & 3.51 & 0.000 & 5.812623 & 20.55844 \\
\hline mo rtrib $r \sim r$ & I & 5.801622 & 3.225635 & 1.80 & 0.072 & -.5205059 & 12.12375 \\
\hline m0_pdsppb & I & 1.982716 & 1.291769 & 1.53 & 0.125 & -.5491039 & 4.514537 \\
\hline $\mathrm{m} 0 \mathrm{pdt}$ & 1 & 2.918826 & 1.561182 & 1.87 & 0.062 & -.1410342 & 5.978687 \\
\hline $\mathrm{m} \overline{0} \_\mathrm{pl}$ & i & .0556218 & 1.322023 & 0.04 & 0.966 & -2.535496 & 2.646739 \\
\hline $\mathrm{m} 0 \mathrm{ps} \mathrm{db}$ & I & -.116574 & 1.053463 & -0.11 & 0.912 & -2.181323 & 1.948175 \\
\hline $\mathrm{m} \overline{0} \mathrm{pfl}$ & I & -.1424 & 1.165745 & -0.12 & 0.903 & -2.427218 & 2.142418 \\
\hline mo_ptb & | & .2010615 & 1.111321 & 0.18 & 0.856 & -1.977089 & 2.379211 \\
\hline $\mathrm{m} \overline{0} \_\mathrm{pt}$ & I & -1.630839 & 1.702612 & -0.96 & 0.338 & -4.967897 & 1.706218 \\
\hline mo outros & I & -1.280593 & 1.269118 & -1.01 & 0.313 & -3.768018 & 1.206832 \\
\hline mo ver frac & 1 & 3.436633 & 3.232796 & 1.06 & 0.288 & -2.899531 & 9.772797 \\
\hline m0_pref frac & I & -8.30837 & 3.403705 & -2.44 & 0.015 & -14.97951 & -1.637231 \\
\hline mo simil gov & I & 1.016854 & 1.154529 & 0.88 & 0.378 & -1.245981 & 3.279688 \\
\hline $\mathrm{m} \overline{0} \_$prop_65m & 1 & .535009 & .7900069 & 0.68 & 0.498 & -1.013376 & 2.083394 \\
\hline m0 propurb & I & .0077199 & .0589754 & 0.13 & 0.896 & -.1078697 & .1233094 \\
\hline m0_prop_o014 & I & .2159928 & .2348599 & 0.92 & 0.358 & -.2443242 & .6763098 \\
\hline m0 lpoptot & I & 2.728378 & 3.268183 & 0.83 & 0.404 & -3.677144 & 9.133899 \\
\hline cons & 1 & 7.143835 & 3.815017 & 1.87 & 0.061 & -.3334623 & 14.62113 \\
\hline
\end{tabular}




\section{4}

probit crit sup dpess rcorr rtrib rcorr pdsppb pdt pl psdb pfl ptb pt outros ver_frac pref_frac simil_gov prop_65m prop_urb prop_0014 lpoptot m0_dpess_rcorr

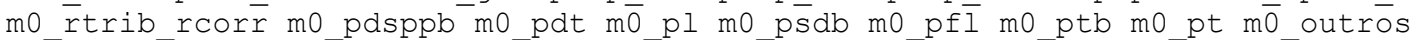
m0_ver_frac m0_pref_frac m0_simil_gov m0_prop_65m m0_prop_urb m0_prop_o0014 mo-lpoptot if ano== 1994 , rob

note: pdt $!=0$ predicts failure perfectly pdt dropped and 1 obs not used

note: pt $!=0$ predicts failure perfectly pt dropped and 5 obs not used

note: m0_pt $!=0$ predicts failure perfectly mo_pt dropped and 14 obs not used

note: pl dropped due to collinearity

Iteration 0: $\quad \log$ pseudo-likelihood $=-118.07966$

Iteration 1: $\quad \log$ pseudo-likelihood $=-95.644283$

Iteration 2: $\quad \log$ pseudo-likelihood $=-94.277598$

Iteration 3: $\log$ pseudo-likelihood $=-94.24458$

Iteration 4: $\quad \log$ pseudo-likelihood $=-94.24453$

Probit estimates

Number of obs $=191$

Wald chi2 $(30)=48.05$

Prob $>$ chi2 $=0.0196$

Log pseudo-likelihood $=-94.24453$

Pseudo R2=

0.2019

\begin{tabular}{|c|c|c|c|c|c|c|c|}
\hline \multirow{2}{*}{ crit_sup } & & \multicolumn{2}{|l|}{ Robust } & \multirow[b]{2}{*}{$\mathrm{P}>|\mathrm{z}|$} & \multirow[b]{2}{*}{$95 \%$} & \multirow[b]{2}{*}{ ConfInterval } \\
\hline & I & Coef & Std Err & z & & & \\
\hline dpess rcorr & | & -4.608771 & 1.94736 & -2.37 & 0.018 & -8.425526 & -.7920168 \\
\hline rtrib rcorr & | & 2.127899 & 3.54793 & 0.60 & 0.549 & -4.825916 & 9.081714 \\
\hline$\overline{\mathrm{p}} \mathrm{dsppb}$ & | & -.7044884 & .9702073 & -0.73 & 0.468 & -2.60606 & 1.197083 \\
\hline psdb & | & -2.048242 & .95438 & -2.15 & 0.032 & -3.918792 & -.1776912 \\
\hline$p f l$ & | & .0048174 & .9045201 & 0.01 & 0.996 & -1.768009 & 1.777644 \\
\hline ptb & | & .138937 & .9030406 & 0.15 & 0.878 & -1.63099 & 1.908864 \\
\hline outros & | & -.5983481 & .8450664 & -0.71 & 0.479 & -2.254648 & 1.057952 \\
\hline ver frac & | & -1.211784 & 1.710295 & -0.71 & 0.479 & -4.563901 & 2.140333 \\
\hline pref-frac & | & 1.273722 & 2.194296 & 0.58 & 0.562 & -3.027019 & 5.574463 \\
\hline simil gov & | & -.4187599 & .8160879 & -0.51 & 0.608 & -2.018263 & 1.180743 \\
\hline prop $65 \mathrm{~m}$ & 1 & .1600142 & .4188771 & 0.38 & 0.702 & -.6609699 & .9809982 \\
\hline prop urb & i & .0317142 & .0748138 & 0.42 & 0.672 & -.1149182 & .1783466 \\
\hline prop 0014 & | & .1765086 & .1880502 & 0.94 & 0.348 & -.1920631 & .5450803 \\
\hline lpoptot & i & -1.486266 & 4.383164 & -0.34 & 0.735 & -10.07711 & 7.104578 \\
\hline m0_dpess_r e & | & 3.568873 & 2.757645 & 1.29 & 0.196 & -1.836011 & 8.973758 \\
\hline $\mathrm{mo}^{-}$rtrib r r r & | & .8026109 & 4.231172 & 0.19 & 0.850 & -7.490333 & 9.095555 \\
\hline m0 pdēsppb & i & .2402673 & 1.041677 & 0.23 & 0.818 & -1.801382 & 2.281916 \\
\hline mo pdt & 1 & 1.369808 & 1.303078 & 1.05 & 0.293 & -1.184178 & 3.923794 \\
\hline $\mathrm{m} \overline{0} \mathrm{pl}$ & | & -.7600643 & 1.255172 & -0.61 & 0.545 & -3.220156 & 1.700028 \\
\hline mo_psdb & | & 1.603955 & .8566652 & 1.87 & 0.061 & -.0750783 & 3.282987 \\
\hline $\mathrm{mo}^{+} \mathrm{pfl}$ & i & -.7827636 & .9076766 & -0.86 & 0.388 & -2.561777 & .9962499 \\
\hline mo_ptb & | & -1.312909 & .9421526 & -1.39 & 0.163 & -3.159494 & .5336763 \\
\hline mo outros & | & -1.239512 & 1.292878 & -0.96 & 0.338 & -3.773507 & 1.294483 \\
\hline mo vèr frac & | & -.0982556 & 2.96335 & -0.03 & 0.974 & -5.906315 & 5.709803 \\
\hline mo pref-frac & 1 & .5650277 & 3.208757 & 0.18 & 0.860 & -5.724021 & 6.854076 \\
\hline mo-simil gov & | & -.4452965 & .9409981 & -0.47 & 0.636 & -2.289619 & 1.399026 \\
\hline$m \overline{0}$ prop $65 \mathrm{~m}$ & | & -.0542667 & .4206168 & -0.13 & 0.897 & -.8786604 & .770127 \\
\hline mo prop urb & i & -.0122328 & .0749612 & -0.16 & 0.870 & -.1591542 & .1346885 \\
\hline m0_prop_0014 & i & -.0410759 & .1947723 & -0.21 & 0.833 & -.4228225 & .3406707 \\
\hline m0 lpoptot & 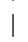 & .9918584 & 4.405082 & 0.23 & 0.822 & -7.641943 & 9.62566 \\
\hline cons & & -1.624861 & 3.330394 & -0.49 & 0.626 & -8.152313 & 4.902591 \\
\hline
\end{tabular}


1995

probit crit_sup dpess_rcorr rtrib_rcorr pdsppb pdt pl psdb pfl ptb pt outros ver_frac pref_frac simil_gov prop_65m prop_urb prop_0014 lpoptot m0_dpess_rcorr m0 r rtrib rcorr m0 pdsppb m0 pdt mo pl mo ps db m0 pfi mo ptb m0 pt mo outros m0_ver_frac m0_pref_frac m0_simil_gov m0_prop_65m m0_prop_urb m0_prop_o014 $\mathrm{mo}^{-}$lpoptot if $\mathrm{ano}^{-}={ }^{-}$1995, rob

note: pdt $!=0$ predicts failure perfectly pdt dropped and 1 obs not used

note: pt $!=0$ predicts failure perfectly pt dropped and 5 obs not used

note: simil_gov dropped due to collinearity Iteration 0: $\quad \log$ pseudo-likelihood $=-104.70998$ Iteration 1: $\quad \log$ pseudo-likelihood $=-86.565453$ Iteration 2: $\quad \log$ pseudo-likelihood $=-85.403527$ Iteration 3: $\log$ pseudo-likelihood $=-85.373679$ Iteration 4: $\quad \log$ pseudo-likelihood $=-85.373644$

Probit estimates

Number of obs= Wald chi2(31)

\begin{tabular}{|c|c|c|c|c|c|c|c|}
\hline crit_sup & 1 & Coef & $\begin{array}{l}\text { Robust } \\
\text { Std Err }\end{array}$ & $\mathrm{z}$ & $P>|z|$ & {$[95 \%$} & $\mathrm{Cc}$ \\
\hline dpess rcorr & 1 & -5.058733 & 2.26481 & -2.23 & 0.026 & -9.497679 & -.6197866 \\
\hline rtrib_rcorr & i & -4.629019 & 4.202625 & -1.10 & 0.271 & -12.86601 & 3.60797 \\
\hline$\overline{\mathrm{p}} \mathrm{dsppb}$ & 1 & .3005662 & .536984 & 0.56 & 0.576 & -.7519031 & 1.353035 \\
\hline $\mathrm{pl}$ & 1 & -.4735043 & .8138359 & -0.58 & 0.561 & -2.068593 & 1.12158 \\
\hline psdb & i & -.2531937 & .5527971 & -0.46 & 0.647 & -1.336656 & .830268 \\
\hline pfl & 1 & -1.362785 & .562 & -2.42 & 0 & -2.465384 & -.26 \\
\hline ptb & 1 & .0267827 & .6367879 & 0.04 & 0.966 & -1.221299 & 864 \\
\hline outros & | & -.5318962 & 356 & -0.94 & 0 . & -1.636 & 612 \\
\hline ver_frac & I & 1.627861 & 1.75235 & 0.93 & 0.3 & -1.806682 & 404 \\
\hline pref_frac & | & -.103724 & 2.069205 & -0.05 & 0.960 & -4.15929 & 3.951843 \\
\hline prop_ $65 \mathrm{~m}$ & 1 & .0669256 & .3856486 & 0.17 & 0.862 & -.6889 & 3 \\
\hline prop_urb & | & -.0027954 & .067 & -0.04 & 0. & -.1350 & .1294126 \\
\hline prop_o014 & । & .0626758 & .1606918 & 0.39 & 0. & -.2522744 & 7626 \\
\hline lpoptot & I & -.5676957 & 4.5 & -0.13 & 0 & -9.45 & 43 \\
\hline m0_dpess_r e & | & 4.228765 & 3.105222 & 1.36 & 0.173 & -1.857358 & 10.31489 \\
\hline m0_rtrib_r r & I & 4.014794 & 121 & 0.74 & 0.457 & -6.563369 & 14.59296 \\
\hline m0_pds̄ppb & | & 2.455064 & 1.169355 & 2.10 & 0. & .163 & 4.746957 \\
\hline mo_pdt & । & .9254817 & 1.345261 & 0.69 & 0.491 & -1.711182 & 3.562146 \\
\hline $\mathrm{m} \overline{0} \_\mathrm{pl}$ & | & 2.389555 & 1.408005 & 1.70 & 0.090 & -.3700843 & 5.149193 \\
\hline m0_psdb & I & -.5240959 & 1.093167 & -0.48 & 0.632 & -2.666664 & 1.618473 \\
\hline $\mathrm{m} \overline{0} \_\mathrm{pfl}$ & I & 2.617642 & 1.039657 & 2.52 & 0.012 & .5799524 & 4.65 \\
\hline mo_pto & | & 1.231546 & 1.200964 & 1.03 & 0.305 & -1.1223 & 3.585393 \\
\hline $\mathrm{m} \overline{0} \_\mathrm{pt}$ & । & 3.022021 & 1.417795 & 2.13 & 0.033 & .2431932 & 5.8 \\
\hline mo_outros & | & 1.596 & 676 & 1.03 & 0.305 & -1.454805 & 4.6 \\
\hline m0_ver_frac & I & -3.495833 & 3.092188 & -1.13 & 0.2 & -9.556 & 2.5 \\
\hline m0_pref_frac & I & -3.637548 & 3.065401 & -1.19 & 0.235 & -9.645624 & 2.370528 \\
\hline m0_simi ${ }_{-}$gov & । & 2.255679 & 1.147061 & 1.97 & 0.049 & .0074813 & 4.503876 \\
\hline m0_prop_65m & 1 & -.2900863 & .4122409 & -0.70 & 0.482 & -1.098064 & .517891 \\
\hline m0_prop_urb & I & .0104934 & .0691881 & 0.15 & 0.879 & -.1251128 & .1460997 \\
\hline m0_prop_0014 & I & -.1430758 & .1675411 & -0.85 & 0.393 & -.4714503 & .1852987 \\
\hline m0_lpoptot & I & .6624625 & 4.551327 & 0.15 & 0.884 & -8.257974 & 9.582899 \\
\hline cons & I & 3.805104 & 3.431178 & 1.11 & 0.267 & -2.91988 & 10.53009 \\
\hline
\end{tabular}


1996

probit crit sup dpess rcorr rtrib rcorr pdsppb pdt pl psdb pfl ptb pt outros ver_frac pref_frac simil_gov prop_65m prop_urb prop_0014 lpoptot m0_dpess_rcorr

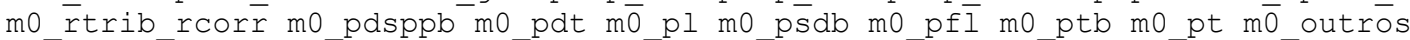
m0_ver_frac m0_pref_frac m0_simil_gov m0_prop_65m m0_prop_urb m0_prop_o_o014 mo-lpoptot if ano== 1996 , rob

note: pdt $!=0$ predicts success perfectly pdt dropped and 1 obs not used

note: simil gov dropped due to collinearity

Iteration 0: $\quad \log$ pseudo-likelihood $=-119.34652$

Iteration 1: $\quad \log$ pseudo-likelihood $=-99.506267$

Iteration 2: $\quad \log$ pseudo-likelihood $=-97.899608$

Iteration 3: $\quad \log$ pseudo-likelihood $=-97.843079$

Iteration 4: $\quad \log$ pseudo-likelihood $=-97.842975$

Probit estimates

Number of obs =

Wald chi2(32) =

Prob $>$ chi2 $=$

243

Log pseudo-likelihood $=-97.842975$

Pseudo R2

\begin{tabular}{|c|c|c|c|c|c|c|c|}
\hline crit_sup & 1 & Coef & $\begin{array}{l}\text { Robust } \\
\text { Std Err }\end{array}$ & z & $\mathrm{P}>|\mathrm{z}|$ & {$[95 \%$} & ConfInterva \\
\hline dpess_rcorr & I & -5.480821 & 2.034151 & -2.69 & 0.007 & -9.467684 & -1.493958 \\
\hline rtrib_rcorr & I & -4.823736 & 3.459946 & -1.39 & 0.163 & -11.60511 & 1.957634 \\
\hline$\overline{\mathrm{p}} \mathrm{dsppb}$ & | & .0481397 & .5050074 & 0.10 & 0.924 & -.9416566 & 1.037936 \\
\hline $\mathrm{pl}$ & 1 & .4247615 & .812738 & 0.52 & 0.601 & -1.168176 & 2.017699 \\
\hline psdb & | & .0906154 & .4462127 & 0.20 & 0.839 & -.7839454 & .9651763 \\
\hline$p f l$ & 1 & -.1928936 & .4274408 & -0.45 & 0 . & -1.030662 & 875 \\
\hline ptb & I & .5071869 & .5901589 & 0.86 & 0.390 & -.6495034 & 1.663877 \\
\hline pt & | & -.472525 & .8740911 & -0.54 & 0.589 & -2.185712 & 1.240662 \\
\hline outros & I & -.4696672 & .4947225 & -0.95 & 0. & -1.439305 & .499971 \\
\hline ver_frac & | & -1.900215 & 1.941446 & -0.98 & 0.328 & -5.705379 & 1.90495 \\
\hline pref_frac & I & 1.465377 & 2.262338 & 0.65 & 0.517 & -2.968725 & 5.899479 \\
\hline prop_65m & | & .4583342 & .292635 & 1.57 & 0.117 & -.1152199 & 1.031888 \\
\hline prop_urb & | & -.0019266 & .0483642 & -0.04 & 0.968 & -.0967186 & .0928654 \\
\hline prop_o014 & I & .3249472 & .1464726 & 2.22 & 0.027 & .0378661 & .6120282 \\
\hline lpoptot & | & 2.401222 & 1.851543 & 1.30 & 0.195 & -1.227735 & 0179 \\
\hline m0_dpess_r e & I & 5.240195 & 2.540517 & 2.06 & 0.039 & .2608725 & 10.21952 \\
\hline mo_rtrib_r r & I & 7.024448 & 4.39733 & 1.60 & 0.110 & -1.594162 & 15.64306 \\
\hline m0_pds̄sppo & । & -.276867 & .9113968 & -0.30 & 0.761 & -2.063172 & 1.509438 \\
\hline mo_pdt & | & -2.144168 & 1.282173 & -1.67 & 0.094 & -4.657182 & .368846 \\
\hline mo_pl & । & -1.120174 & 1.298317 & -0.86 & 0.388 & -3.664828 & 1.424481 \\
\hline m0_ps db & । & .9084792 & 1.011631 & 0.90 & 0.369 & -1.074281 & 2.891239 \\
\hline $\mathrm{m} \overline{0} \_\mathrm{pfl}$ & | & .7212958 & .8297908 & 0.87 & 0.385 & -.9050643 & 2.347656 \\
\hline mo_ptb & । & -.6104794 & .9083543 & -0.67 & 0.502 & -2.390821 & 1.169862 \\
\hline $\mathrm{m} \overline{0} \_\mathrm{pt}$ & I & 2.312896 & 1.278561 & 1.81 & 0.070 & -.1930378 & 4.81883 \\
\hline mo_outros & । & .5956168 & .9090943 & 0.66 & 0.512 & -1.186175 & 2.377409 \\
\hline m0_ver_frac & | & 1.318884 & 3.164789 & 0.42 & 0.677 & -4.883988 & 7.521756 \\
\hline m0_pref_frac & । & -.9361761 & 3.121393 & -0.30 & 0.764 & -7.053995 & 5.181642 \\
\hline m0_simil_gov & । & -.9824792 & 1.048289 & -0.94 & 0.349 & -3.037088 & 1.07213 \\
\hline $\mathrm{m} \overline{0} \_$prop_65m & । & -.291234 & .3258354 & -0.89 & 0.371 & -.9298596 & .3473916 \\
\hline mo_prop_urb & । & -.0157315 & .050393 & -0.31 & 0.755 & -.1145 & .083037 \\
\hline m0_prop_o014 & I & -.2870155 & .1578122 & -1.82 & 0.069 & -.5963217 & .0222906 \\
\hline m0_lpoptot & । & -2.469256 & 1.841524 & -1.34 & 0.180 & -6.078577 & 1.140066 \\
\hline cons & | & -.7751232 & 3.131401 & -0.25 & 0.804 & -6.912557 & 5.362311 \\
\hline
\end{tabular}


1997

probit crit_sup dpess_rcorr rtrib_rcorr pdsppb pdt pl psdb pfl ptb pt outros ver_frac pref_frac simil_gov prop_65m prop_urb prop_0014 lpoptot m0_dpess_rcorr m0 r rtrib rcorr m0 pdsppb m0 pdt mo pl mo ps db m0 pfi mo ptb m0 pt mo outros m0_ver_frac m0_pref_frac m0_simil_gov m0_prop_65m m0_prop_urb m0_prop_o014 $\mathrm{mo}^{-}$lpoptot if $\mathrm{ano}^{-}={ }^{-}$1997, rob

note: simil gov dropped due to collinearity

Iteration 0: $\quad$ log pseudo-likelihood $=-164.89339$

Iteration 1: $\quad$ log pseudo-likelihood $=-132.10181$

Iteration 2: $\quad \log$ pseudo-likelihood $=-129.6651$

Iteration 3: $\quad \log$ pseudo-likelihood $=-129.59329$

Iteration 4: $\quad$ log pseudo-likelihood $=-129.59322$

Probit estimates

Number of obs $=238$

Wald $\operatorname{chi2}(33)=62.83$

Prob $>$ chi2 $=0.0013$

Log pseudo-likelihood $=-129.59322$

Pseudo R2 $=0.2141$

\begin{tabular}{|c|c|c|c|c|c|c|c|}
\hline crit_sup & 1 & Coef & $\begin{array}{l}\text { Robust } \\
\text { Std Err }\end{array}$ & $\mathrm{z}$ & $\mathrm{P}>|\mathrm{z}|$ & {$[95 \%$} & ConfInterva \\
\hline dpess_rcorr & I & -10.29982 & 1.90276 & -5.41 & 0.000 & -14.02916 & -6.570479 \\
\hline rtrib rcorr & | & 6.93898 & 3.829967 & 1.81 & 0.070 & -.567617 & 14.44558 \\
\hline pdsppb & | & .3804241 & .5198755 & 0.73 & 0.464 & -.6385132 & 1.399361 \\
\hline$p d t$ & | & .3368894 & .7949705 & 0.42 & 0.672 & -1.221224 & 1.895003 \\
\hline $\mathrm{pl}$ & | & 2.186401 & .7223049 & 3.03 & 0.002 & .7707095 & 3.602093 \\
\hline psdb & | & 1.154995 & .47684 & 2.42 & 0.015 & .2204055 & 2.089584 \\
\hline$p f l$ & 1 & .8465693 & .5079413 & 1.67 & 0.096 & -.1489773 & 1.842116 \\
\hline ptb & I & .6693327 & .6005305 & 1.11 & 0.265 & -.5076855 & 1.846351 \\
\hline pt & 1 & .8025943 & .7805465 & 1.03 & 0.304 & -.7272487 & 2.332437 \\
\hline outros & | & .5102984 & .5363862 & 0.95 & 0.341 & -.5409992 & 1.561596 \\
\hline ver_frac & | & .7606562 & 1.675191 & 0.45 & 0.650 & -2.522659 & 4.043971 \\
\hline pref_frac & | & -3.351781 & 1.933943 & -1.73 & 0.083 & -7.14224 & .4386773 \\
\hline prop_65m & | & -.3032236 & .4531927 & -0.67 & 0.503 & -1.191465 & .5850178 \\
\hline prop_urb & 1 & -.0082785 & .0521863 & -0.16 & 0.874 & -.1105618 & .0940048 \\
\hline prop_o014 & | & -.0346428 & .1664707 & -0.21 & 0.835 & -.3609194 & .2916339 \\
\hline lpoptot & | & -1.627371 & 2.646757 & -0.61 & 0.539 & -6.81492 & 3.560178 \\
\hline m0_dpess_r e & | & 6.524326 & 2.152647 & 3.03 & 0.002 & 2.305214 & 10.74344 \\
\hline mo_rtrib_r r & | & -6.891564 & 4.357306 & -1.58 & 0.114 & -15.43173 & 1.648598 \\
\hline m0_pdsppb & | & -.263245 & .8031465 & -0.33 & 0.743 & -1.837383 & 1.310893 \\
\hline mo_pdt & 1 & -1.098295 & 1.727246 & -0.64 & 0.525 & -4.483635 & 2.287045 \\
\hline $\mathrm{m} \overline{0} \_\mathrm{pl}$ & 1 & -2.042418 & 1.125237 & -1.82 & 0.070 & -4.247842 & .1630053 \\
\hline m0_ps db & | & -.845334 & .6983722 & -1.21 & 0.226 & -2.214118 & .5234503 \\
\hline $\mathrm{m} \overline{0} \_\mathrm{pfl}$ & | & -1.198137 & .8642055 & -1.39 & 0.166 & -2.891948 & .4956748 \\
\hline mo_ptb & | & -2.148237 & .885813 & -2.43 & 0.015 & -3.884399 & -.4120757 \\
\hline $\mathrm{m} \overline{0} \_\mathrm{pt}$ & 1 & -.89944 & 1.192046 & -0.75 & 0.451 & -3.235806 & 1.436926 \\
\hline m0_outros & | & -.8627847 & .8702692 & -0.99 & 0.321 & -2.568481 & .8429116 \\
\hline m0_ver_frac & 1 & .9183106 & 1.750989 & 0.52 & 0.600 & -2.513564 & 4.350185 \\
\hline mo_pref_frac & | & 5.528876 & 2.671938 & 2.07 & 0.039 & .2919743 & 10.76578 \\
\hline m0_simil__gov & 1 & -1.677925 & .9373521 & -1.79 & 0.073 & -3.515102 & .1592511 \\
\hline $\mathrm{m} \overline{0} \_$prop_65m & | & .3233835 & .4789793 & 0.68 & 0.500 & -.6153986 & 1.262166 \\
\hline m0_prop_urb & | & -.0009773 & .0529872 & -0.02 & 0.985 & -.1048303 & .1028757 \\
\hline m0_prop_o014 & | & -.016134 & .1626544 & -0.10 & 0.921 & -.3349309 & .3026628 \\
\hline m0_lpoptot & | & 1.439151 & 2.637659 & 0.55 & 0.585 & -3.730566 & 6.608867 \\
\hline _cons & I & 3.818203 & 2.876818 & 1.33 & 0.184 & -1.820255 & 9.456662 \\
\hline
\end{tabular}




\section{8}

probit crit sup dpess rcorr rtrib rcorr pdsppb pdt pl psdb pfl ptb pt outros ver_frac pref_frac simil_gov prop_65m prop_urb prop_0014 lpoptot m0_dpess_rcorr m0 rtrib rcorr m0 pdsppb m0_pdt mo pl mo ps db m0 pfī m0 ptb m0 pt mo outros m0_ver_frac m0_pref_frac m0_simil_gov m0_prop_65m m0_prop_urb m0_prop_o_o014 mo-lpoptot if ano== 1998 , rōb

note: simil_gov dropped due to collinearity

Iteration 0: $\quad$ log pseudo-likelihood $=-162.89563$

Iteration 1: $\quad \log$ pseudo-likelihood $=-139.23921$

Iteration 2: $\quad$ log pseudo-likelihood $=-138.54054$

Iteration 3: $\quad \log$ pseudo-likelihood $=-138.53748$

Iteration 4: $\quad \log$ pseudo-likelihood $=-138.53748$

Probit estimates

Number of obs $=236$

Wald chi2(33) $=51.28$

Prob $>$ chi2 $=0.0222$

Log pseudo-likelihood $=-138.53748$

Pseudo R2 = 0.1495

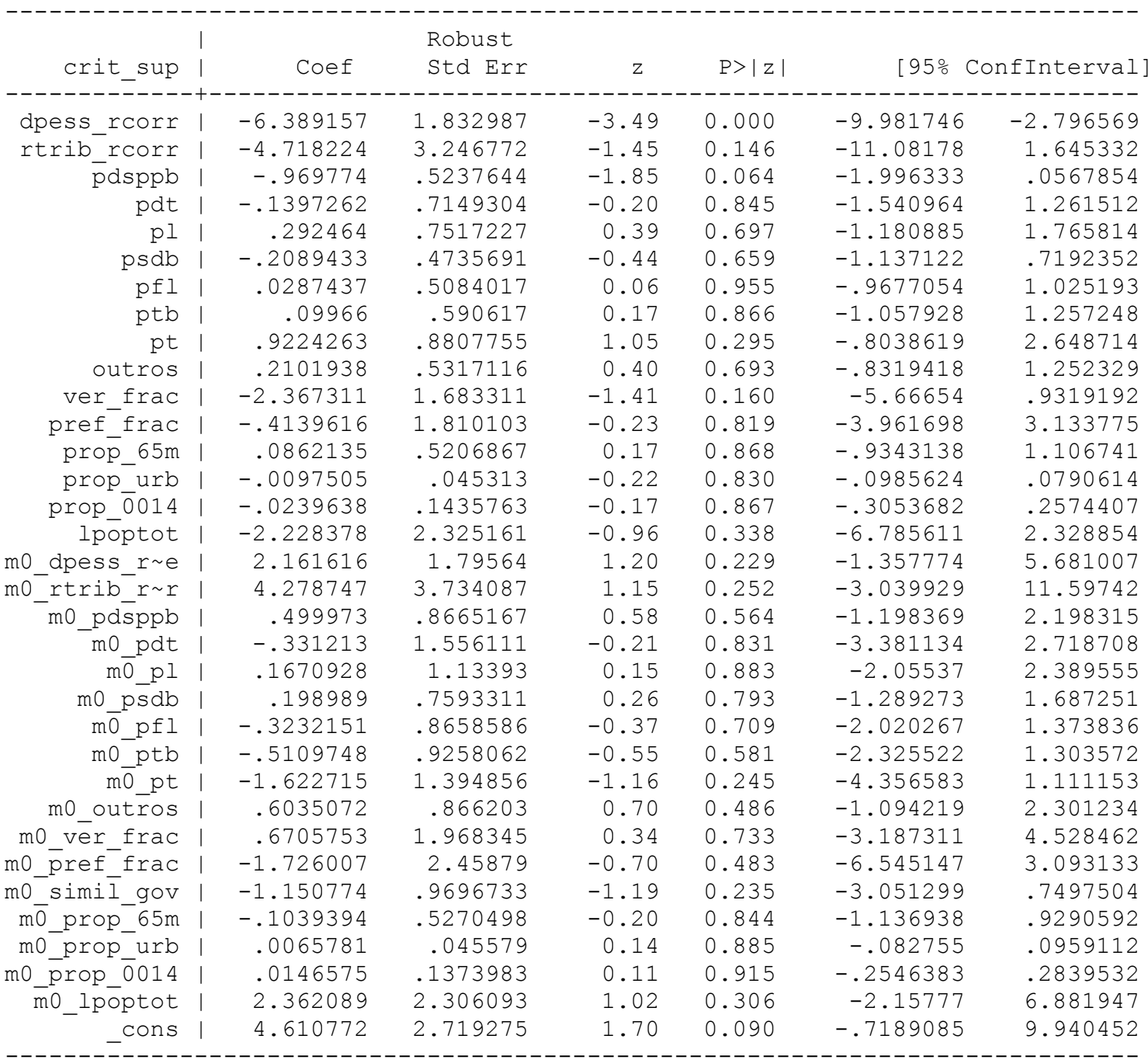


1999

probit crit sup dpess rcorr rtrib rcorr pdsppb pdt pl psdb pfl ptb pt outros ver_frac pref_frac simil_gov prop_65m prop_urb prop_0014 lpoptot m0_dpess_rcorr

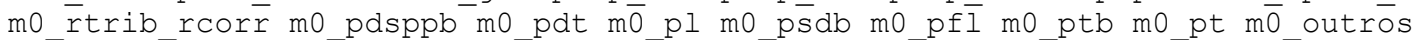
m0_ver_frac m0_pref_frac m0_simil_gov m0_prop_65m m0_prop_urb m0_prop_o014 $\mathrm{mo}^{-}$lpoptot if $\mathrm{ano}^{-}={ }^{-}$1999, rob

note: simil_gov dropped due to collinearity

Iteration 0: $\quad$ log pseudo-likelihood $=-146.24986$

Iteration 1: $\quad$ log pseudo-likelihood $=-122.49677$

Iteration 2: $\quad \log$ pseudo-likelihood $=-121.60195$

Iteration 3: $\quad \log$ pseudo-likelihood $=-121.59376$

Iteration 4: $\quad$ log pseudo-likelihood $=-121.59376$

Probit estimates

Number of obs=

Wald $\operatorname{chi2}(33)=50.15$

Log pseudo-likelihood $=-121.59376$

Prob $>$ chi2 $=0.0283$

Pseudo R2 $=0.1686$

\begin{tabular}{|c|c|c|c|c|c|c|c|}
\hline crit_sup & | & Coef & $\begin{array}{l}\text { Robust } \\
\text { Std Err }\end{array}$ & $z$ & $P>|z|$ & {$[95 \%$} & ConfInterval \\
\hline dpess rcorr & | & -8.275721 & 2.383438 & -3.47 & 0.001 & -12.94717 & -3.604268 \\
\hline rtrib rcorr & 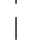 & 6.727931 & 3.557417 & 1.89 & 0.059 & -.2444775 & 13.70034 \\
\hline$\overline{\mathrm{p}} \mathrm{dsppb}$ & i & .456168 & .569034 & 0.80 & 0.423 & -.6591182 & 1.571454 \\
\hline pdt & 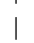 & -.3461981 & .7245955 & -0.48 & 0.633 & -1.766379 & 1.073983 \\
\hline $\mathrm{pl}$ & 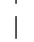 & -.1348589 & .7696138 & -0.18 & 0.861 & -1.643274 & 1.373556 \\
\hline psdb & 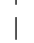 & .2208216 & .5213533 & 0.42 & 0.672 & -.8010121 & 1.242655 \\
\hline pfl & i & .7604718 & .5473969 & 1.39 & 0.165 & -.3124064 & 1.83335 \\
\hline ptb & 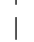 & .182181 & .6433179 & 0.28 & 0.777 & -1.078699 & 1.443061 \\
\hline pt & 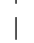 & -.0012442 & .9320035 & -0.00 & 0.999 & -1.827937 & 1.825449 \\
\hline outros & i & .3507821 & .5785817 & 0.61 & 0.544 & -.7832171 & 1.484781 \\
\hline ver frac & 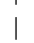 & -.6753526 & 1.788325 & -0.38 & 0.706 & -4.180406 & 2.829701 \\
\hline pref-frac & 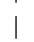 & -.0489816 & 1.954706 & -0.03 & 0.980 & -3.880135 & 3.782171 \\
\hline prop $65 \mathrm{~m}$ & 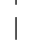 & -.3985253 & .3352369 & -1.19 & 0.235 & -1.055578 & .2585269 \\
\hline prop urb & i & -.0510648 & .0371378 & -1.38 & 0.169 & -.1238536 & .0217241 \\
\hline prop 0014 & | & -.4504649 & .12905 & -3.49 & 0.000 & -.7033983 & -.1975316 \\
\hline lpoptot & | & .1834724 & 1.68833 & 0.11 & 0.913 & -3.125594 & 3.492539 \\
\hline m0 dpess r e & i & 3.410369 & 2.060375 & 1.66 & 0.098 & -.6278924 & 7.44863 \\
\hline mo-rtrib r r & 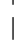 & -10.71108 & 3.845755 & -2.79 & 0.005 & -18.24862 & -3.173539 \\
\hline m0 pdsppb & 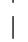 & -.5872405 & .9244989 & -0.64 & 0.525 & -2.399225 & 1.224744 \\
\hline mo pdt & | & 1.02521 & 1.412952 & 0.73 & 0.468 & -1.744126 & 3.794546 \\
\hline $\mathrm{m} 0 \mathrm{pl}$ & 1 & -.0733866 & 1.117592 & -0.07 & 0.948 & -2.263826 & 2.117053 \\
\hline mo ps db & | & .6704748 & .8390058 & 0.80 & 0.424 & -.9739463 & 2.314896 \\
\hline $\mathrm{m} \overline{0} \mathrm{pfl}$ & | & -1.054152 & .9118787 & -1.16 & 0.248 & -2.841402 & .7330971 \\
\hline mo pto & | & -.0092416 & 1.003811 & -0.01 & 0.993 & -1.976675 & 1.958192 \\
\hline $\mathrm{m} \overline{\mathrm{pt}}$ & | & .2344877 & 1.563334 & 0.15 & 0.881 & -2.82959 & 3.298565 \\
\hline mo outros & 1 & -1.288715 & .9563596 & -1.35 & 0.178 & -3.163146 & .585715 \\
\hline mo ver frac & 1 & 2.168061 & 1.850778 & 1.17 & 0.241 & -1.459398 & 5.795519 \\
\hline mo pref frac & | & -1.769814 & 2.55719 & -0.69 & 0.489 & -6.781815 & 3.242187 \\
\hline mo simil gov & 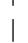 & -.7874296 & 1.111145 & -0.71 & 0.479 & -2.965234 & 1.390375 \\
\hline $\mathrm{m} \overline{0}$ prop $65 \mathrm{~m}$ & 1 & .3416669 & .3401946 & 1.00 & 0.315 & -.3251023 & 1.008436 \\
\hline mo prop urb & | & .0566499 & .0377581 & 1.50 & 0.134 & -.0173546 & .1306543 \\
\hline mo prop $\overline{0} 014$ & i & .4242202 & .131988 & 3.21 & 0.001 & .1655284 & .682912 \\
\hline m0 lpoptot & | & -.3148911 & 1.685489 & -0.19 & 0.852 & -3.618389 & 2.988607 \\
\hline cons & & 4.617033 & 2.760195 & 1.67 & 0.094 & -.7928501 & 10.02692 \\
\hline
\end{tabular}




\section{0}

probit crit_sup dpess_rcorr rtrib_rcorr pdsppb pdt pl psdb pfl ptb pt outros ver_frac pref_frac simil_gov prop_65m prop_urb prop_0014 lpoptot m0_dpess_rcorr m0_rtrib_rcorr m0_pdsppb m0_pdt m0_pl m0_ps db m0_pfī m0_ptb m0_pt m0_outros m0_ver_frac m0_pref_frac m0_simil_gov m0_prop_65m m0_prop_urb m0_prop_óp0014 mo-lpoptot if $\bar{a} \mathrm{no}==-2000$, rōb

note: simil_gov dropped due to collinearity

Iteration 0: $\quad$ log pseudo-likelihood $=-117.53789$

Iteration 1: $\quad \log$ pseudo-likelihood $=-97.267323$

Iteration 2: $\quad \log$ pseudo-likelihood $=-95.537948$

Iteration 3: $\quad \log$ pseudo-likelihood $=-95.371172$

Iteration 4: $\quad \log$ pseudo-likelihood $=-95.364928$

Iteration 5: $\quad$ log pseudo-likelihood $=-95.364909$

Probit estimates

Number of obs Wald chi2 (33)

Prob > chi2

Pseudo R2
210

47.31

0.0509

0.1886

Log pseudo-likelihood $=-95.364909$

Robust

\begin{tabular}{|c|c|c|c|c|c|c|c|}
\hline & | & & Robust & & & & \\
\hline crit_sup & i & Coef & Std Err & z & $\mathrm{P}>|\mathrm{z}|$ & {$[95 \%$} & ConfInterval] \\
\hline dpess_rcorr & | & -4.235521 & 1.620709 & -2.61 & 0.009 & -7.412052 & -1.058991 \\
\hline rtrib_rcorr & 1 & 3.311112 & 3.860547 & 0.86 & 0.391 & -4.25542 & 10.87764 \\
\hline$\overline{\mathrm{p}} \mathrm{dsppb}$ & 1 & -.3849246 & .6057247 & -0.64 & 0.525 & -1.572123 & .802274 \\
\hline pdt & i & -2.483926 & 1.041219 & -2.39 & 0.017 & -4.524678 & -.4431752 \\
\hline $\mathrm{pl}$ & | & -1.679541 & .7882729 & -2.13 & 0.033 & -3.224528 & -.1345547 \\
\hline psdb & i & -.8071668 & .6229728 & $-1 \cdot 30$ & 0.195 & -2.028171 & .4138374 \\
\hline $\mathrm{pfl}$ & 1 & .0522942 & .6758999 & 0.08 & 0.938 & -1.272445 & 1.377034 \\
\hline ptb & i & .0595558 & .7443107 & 0.08 & 0.936 & -1.399266 & 1.518378 \\
\hline pt & 1 & -.0980811 & .825378 & -0.12 & 0.905 & -1.715792 & 1.51963 \\
\hline outros & 1 & .7638337 & .7390102 & 1.03 & 0.301 & -.6845996 & 2.212267 \\
\hline ver_frac & । & -.6476513 & 1.824708 & -0.35 & 0.723 & -4.224014 & 2.928711 \\
\hline pref-frac & | & -3.737697 & 2.305991 & -1.62 & 0.105 & -8.257356 & .7819631 \\
\hline prop_ $65 \mathrm{~m}$ & i & -.2565211 & .2678487 & -0.96 & 0.338 & -.781495 & .2684527 \\
\hline prop_urb & । & .0198938 & .045952 & 0.43 & 0.665 & -.0701706 & .1099581 \\
\hline prop_ō014 & | & .0021006 & .1208639 & 0.02 & 0.986 & -.2347883 & .2389894 \\
\hline lpoptot & 1 & .2627012 & 1.319365 & 0.20 & 0.842 & -2.323207 & 2.848609 \\
\hline m0_dpess_r e & 1 & -.9089673 & 1.972637 & -0.46 & 0.645 & -4.775265 & 2.957331 \\
\hline mo_rtrib_r r & । & -2.237261 & 4.096866 & -0.55 & 0.585 & -10.26697 & 5.792449 \\
\hline m0_pds̄ppb & 1 & .6139155 & .9816528 & 0.63 & 0.532 & -1.310089 & 2.53792 \\
\hline m0_pdt & | & 6.925764 & 2.400367 & 2.89 & 0.004 & 2.221131 & 11.6304 \\
\hline $\mathrm{m} \overline{0} \_\mathrm{pl}$ & । & .8662551 & 1.17591 & 0.74 & 0.461 & -1.438487 & 3.170997 \\
\hline m0_ps db & । & .4265822 & .8750923 & 0.49 & 0.626 & -1.288567 & 2.141732 \\
\hline $\mathrm{m} \overline{0}_{-} \mathrm{pfl}$ & | & .6786425 & 1.008771 & 0.67 & 0.501 & -1.298512 & 2.655797 \\
\hline mo_ptb & । & .7378777 & 1.090458 & 0.68 & 0.499 & -1.399381 & 2.875136 \\
\hline $\mathrm{m} \overline{0} \_\mathrm{pt}$ & | & 1.327563 & 1.377603 & 0.96 & 0.335 & -1.37249 & 4.027616 \\
\hline m0_outros & 1 & 1.459668 & 1.084238 & 1.35 & 0.178 & -.6654008 & 3.584736 \\
\hline m0_ver_frac & । & .1226945 & 2.038693 & 0.06 & 0.952 & -3.87307 & 4.118459 \\
\hline m0_pref_frac & | & 3.197081 & 3.127566 & 1.02 & 0.307 & -2.932835 & 9.326998 \\
\hline m0_simi ${ }_{-}$gov & । & 1.608746 & 1.04295 & 1.54 & 0.123 & -.4353987 & 3.652892 \\
\hline $\mathrm{m} \overline{0} \_$prop_65m & | & .2084414 & .301555 & 0.69 & 0.489 & -.3825956 & .7994784 \\
\hline m0_prop_urb & । & -.0453593 & .0465835 & -0.97 & 0.330 & -.1366612 & .0459427 \\
\hline m0_prop_o014 & | & -.1322253 & .1313596 & -1.01 & 0.314 & -.3896853 & .1252348 \\
\hline m0_lpoptot & 1 & -.1882869 & 1.311964 & -0.14 & 0.886 & -2.759689 & 2.383115 \\
\hline cons & । & 8.183119 & 3.15631 & 2.59 & 0.010 & 1.996865 & 14.36937 \\
\hline
\end{tabular}


2001

probit crit_sup dpess_rcorr rtrib_rcorr pdsppb pdt pl psdb pfl ptb pt outros ver frac pref frac simil gov prop 65m prop urb prop 0014 lpoptot m0 dpess rcorr m0_rtrib_rcorr m0_pdsppb m0_pdt m0_pl mo_psdb m0_pfi m0_ptb m0_pt mo_outros m0_ver_frac m0_pref_frac m0_simil_gov m0_prop_65m m0_prop_urb m0_prop_0014 mo-lpoptot if $\mathrm{ano}==-2001$, rōo

note: pdsppb $!=0$ predicts success perfectly pdsppb dropped and 8 obs not used

note: pl != 0 predicts success perfectly pl dropped and 10 obs not used

note: ptb $!=0$ predicts success perfectly ptb dropped and 24 obs not used

note: m0 pdsppb $!=0$ predicts success perfectly m0_pdsppb dropped and 22 obs not used

note: simil_gov dropped due to collinearity

Iteration 0: $\quad \log$ pseudo-likelihood $=-51.373751$

Iteration 1: $\quad$ log pseudo-likelihood $=-37.537832$

Iteration 2: $\quad \log$ pseudo-likelihood $=-33.951226$

Iteration 3: $\quad$ log pseudo-likelihood $=-32.716477$

Iteration 4: $\log$ pseudo-likelihood $=-32.482158$

Iteration 5: $\quad \log$ pseudo-likelihood $=-32.467367$

Iteration 6: $\quad \log$ pseudo-likelihood $=-32.467284$

Iteration 7: $\log$ pseudo-likelihood $=-32.467284$

Probit estimates

Number of obs $=137$

Wald chi2(29) $=39.30$

Prob $>$ chi2 $=0.0960$

Log pseudo-likelihood $=-32.467284$

Pseudo R2=

0.3680

\begin{tabular}{|c|c|c|c|c|c|c|c|}
\hline \multirow{2}{*}{\multicolumn{2}{|c|}{ crit_sup }} & \multicolumn{6}{|c|}{ Robust } \\
\hline & i & Coef & Std Err & z & $\mathrm{P}>|\mathrm{z}|$ & {$[95 \%$} & ConfInterval \\
\hline ess rcorr & | & -5.580419 & 2.29063 & -2.44 & 0.015 & -10.06997 & -1.090866 \\
\hline rtrib rcorr & 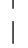 & -1.048841 & 6.175267 & -0.17 & 0.865 & -13.15214 & 11.05446 \\
\hline $\mathrm{pdt}$ & | & -1.786462 & .6795605 & -2.63 & 0.009 & -3.118376 & -.4545481 \\
\hline psdb & | & .0830862 & .512162 & 0.16 & 0.871 & -.9207328 & 1.086905 \\
\hline$p f l$ & i & -1.43995 & .6700327 & -2.15 & 0.032 & -2.753189 & -.1267096 \\
\hline pt & 1 & -1.830419 & .8510793 & -2.15 & 0.031 & -3.498504 & -.1623343 \\
\hline outros & 1 & -1.398727 & .6668058 & -2.10 & 0.036 & -2.705642 & -.0918115 \\
\hline ver frac & | & -3.866731 & 3.830643 & -1.01 & 0.313 & -11.37465 & 3.64119 \\
\hline pref_frac & 1 & 4.071068 & 2.966482 & 1.37 & 0.170 & -1.74313 & 9.885266 \\
\hline prop_ $65 \mathrm{~m}$ & 1 & .7038584 & .3559764 & 1.98 & 0.048 & .0061574 & 1.401559 \\
\hline prop_urb & 1 & -.13392 & .0694362 & -1.93 & 0.054 & -.2700126 & .0021725 \\
\hline prop 0014 & i & -.0727761 & .1450001 & -0.50 & 0.616 & -.356971 & .2114188 \\
\hline lpoptot & | & .5457805 & 3.05007 & 0.18 & 0.858 & -5.432246 & 6.523807 \\
\hline dpess r e & 1 & -1.150512 & 2.337888 & -0.49 & 0.623 & -5.732689 & 3.431664 \\
\hline mo rtrib r r & 1 & 13.58634 & 8.798091 & 1.54 & 0.123 & -3.657599 & 30.83028 \\
\hline mo_pdt & 1 & 1.424539 & 2.071086 & 0.69 & 0.492 & -2.634715 & 5.483793 \\
\hline $\mathrm{m} 0 \_\mathrm{pl}$ & 1 & -2.884229 & 1.575185 & -1.83 & 0.067 & -5.971535 & .2030764 \\
\hline m0_ps ${ }^{2} \mathrm{db}$ & 1 & -.467396 & 1.104 & -0.42 & 0.672 & -2.631196 & 1.696404 \\
\hline $\mathrm{m}^{1} \_\mathrm{pfl}$ & i & 4.675385 & 1.607611 & 2.91 & 0.004 & 1.524527 & 7.826244 \\
\hline mo_ptb & | & 3.806559 & 1.762188 & 2.16 & 0.031 & .3527344 & 7.260383 \\
\hline $\mathrm{m} \overline{0} \mathrm{pt}$ & 1 & 1.359148 & 1.818564 & 0.75 & 0.455 & -2.205172 & 4.923467 \\
\hline mo outros & | & 1.324955 & 1.334761 & 0.99 & 0.321 & -1.291128 & 3.941037 \\
\hline mo vèr frac & i & 3.543728 & 2.952772 & 1.20 & 0.230 & -2.243599 & 9.331055 \\
\hline mo_pref-frac & | & 8.547247 & 3.508363 & 2.44 & 0.015 & 1.670983 & 15.42351 \\
\hline mo-simil gov & 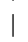 & -.1531021 & 1.292775 & -0.12 & 0.906 & -2.686894 & 2.38069 \\
\hline$m \overline{0}$ prop $65 \mathrm{~m}$ & | & -.9671024 & .4123963 & -2.35 & 0.019 & -1.775384 & -.1588205 \\
\hline m0_prop_urb & | & .1142511 & .0667191 & 1.71 & 0.087 & -.016516 & .2450182 \\
\hline m0_prop_o014 & | & -.0018873 & .1878677 & -0.01 & 0.992 & -.3701013 & .3663266 \\
\hline m0_lpoptot & | & -1.66498 & 3.002435 & -0.55 & 0.579 & -7.549645 & 4.219684 \\
\hline _cons & & 12.61018 & 5.61903 & 2.24 & 0.025 & 1.597085 & 23.62328 \\
\hline
\end{tabular}

